SZEGEDI TUDOMÁNYEGYETEM ÁLLAM- ÉS JOGTUDOMÁNYI KAR ÁLLAM- ÉS JOGTUDOMÁNYI DOKTORI ISKOLA

\author{
Molnár András
}

\title{
Alapjogi aktivizmus a Supreme Court gazdaságszabályozási tárgyú ügyeiben (1890-1936)
}

\section{PhD-értekezés}

A kézirat lezárásának időpontja: 2017. III. 24.

Témavezető:

Prof. Dr. Pokol Béla

Szeged, 2017 


\section{Tartalomjegyzék}

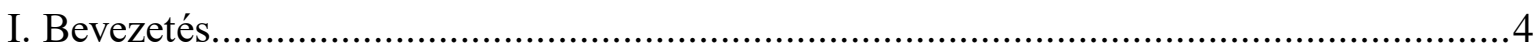

I.1. Problémafelvetés és előzetes megjegyzések ....................................................4

II. Az elméleti keretek kijelölése: szempontok a bírói „aktivizmus” definiálásához ............8

II.1. Normatív viszonyulások az alapjogi aktivizmushoz az alkotmányos normakontroll

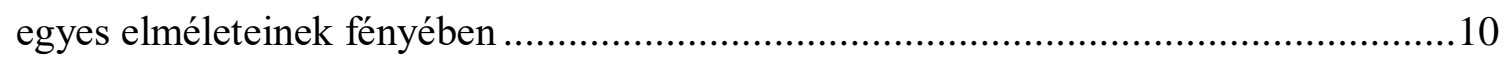

II.1.1. Álláspontok az alkotmányos normakontroll kiterjesztett szerepe mellett.........12

II.1.2. Álláspontok az alkotmányos normakontroll korlátozott szerepe mellett..........14

II.1.3. Kísérletek az aktivizmus fogalmának meghaladására .................................18

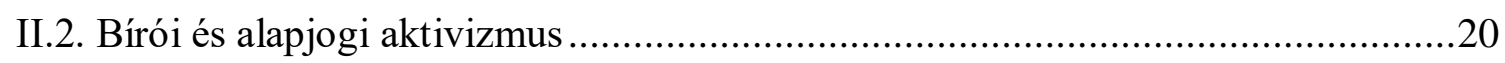

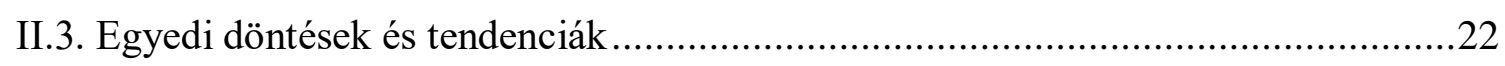

II.4. Az alkotmányos normakontroll természetének és terjedelmének időbeli változásai .22

II.5. Az aktivizmus definiálására tett jellemző kísérletek .........................................27

II.5.1. Döntéshozatal más hatalmi ágak helyett ..............................................28

II.5.1.1. A más hatalmi ágak indokolhatóan alkotmányos döntéseinek megvétózása

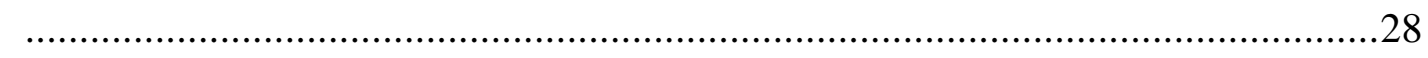

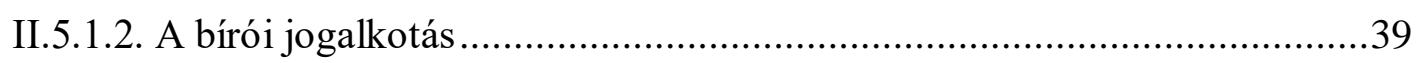

II.5.2. Az autoritatív szövegekhez való viszony megváltoztatása ...........................46

II.5.3. A bevett értelmezési módszerektől való eltérés............................................53

II.5.4. Az eredményorientált bíráskodás................................................................55

II.6. Az ismertetett megközelítések összegzése és állásfoglalás ...............................56

II.7. Dogmatikus és tudományos aktivizmus, illetve passzivizmus..............................58

II.8. Kitekintés: az Emberi Jogok Európai Bírósága, az Európai Unió Bírósága és a magyar Alkotmánybíróság az aktivizmusról szóló diskurzusban................................64

II.8.1. Az Emberi Jogok Európai Bírósága ...........................................................65

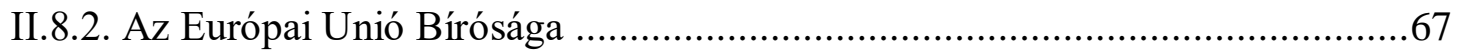

II.8.3. Az Alkotmánybíróság ...............................................................................69

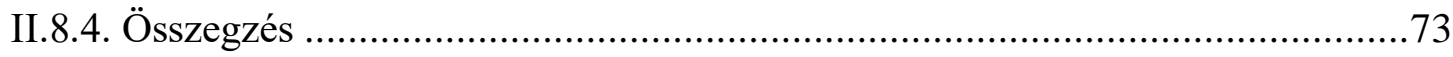

III. Tendenciák a Lochner-ítéletet és korának alkotmányértelmezési gyakorlatát értékelő szakirodalomban, valamint a jelen kutatás elhelyezése e megközelítésmódok között ........75 
III.1. A korabeli értékelések ..... . .76

III.1.1. A szociológiai mozgalom a jogban .76

III.1.2. A Supreme Court alkotmányértelmezési gyakorlatának korabeli megítélése..80

III.2. Értékelés 1937 után ..... 89

III.3. Jogpolitikai-ideológiai viták a Lochner-ítélet megítélésénél .98

III.3.1. A Lochner-ítélet mint a „többségellenesség” megtestesítője és negatív megítélésének egyéb megnyilvánulásai . .98

III.3.2. A Lochner-ügy revíziójának kísérletei 107

III.4. A Lochner-ítélet mint egy következetes alkotmányértelmezési gyakorlat része: Howard Gillman megközelítése. 112

III.5. Paul Kens és a Lochner-ítélet genezise 114

III.6. A jelen értekezés elhelyezése a téma korábbi kutatásainak kontextusában 117

IV. A Supreme Court „konzervatív aktivizmusa” a XX. század első évtizedeiben született precedensek tükrében 122

IV.1. A kutatás szempontjai 122

IV.2. A Supreme Court alkotmányértelmezési gyakorlatának releváns kulcsfogalmai 128

IV.2.1. A megfelelő eljárás fogalmának értelmezése. 128

IV.2.2. A police power 130

IV.3. A Supreme Court releváns gyakorlatának jellemzése. 131

IV.3.1. Általános észrevételek 131

IV.3.2. „Konzervatív aktivizmus” a pőre számok tükrében 133

IV.3.3. „Magától értetődő” szabályozási tárgyak: szeszesital-forgalmazás és egyéb „nyilvánvalóan káros” tevékenységek

IV.3.4. „Magától értetődő” szabályozási tárgyak: foglalkozások gyakorlására való alkalmasság.

IV.3.5. Állami beavatkozás a munkaviszonyba: munkáltatói felelősség az üzemi balesetekért, a tagállamok mérlegelési szabadsága és a fellow servant rule erodálódása 168

IV.3.6. Állami beavatkozás a munkaviszonyba: a munkaidő, a munkabér, és a munkaviszony egyéb feltételeinek szabályozása 190

V. Konklúzió 220

V.1. A Supreme Court XIX. század végi és XX. század eleji alkotmányértelmezési gyakorlatának jellemzése .... 220

V.2. A Lochner-ítélet helye a Supreme Court gyakorlatában 223 
Függelék

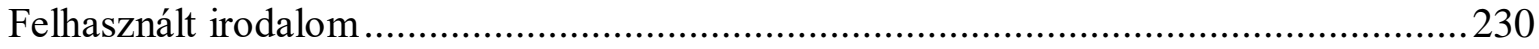

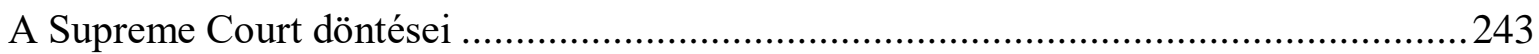

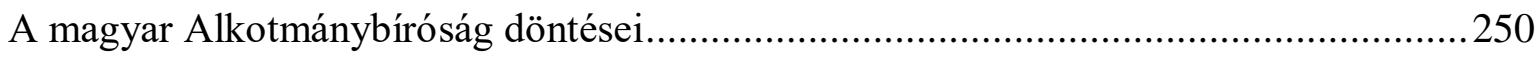

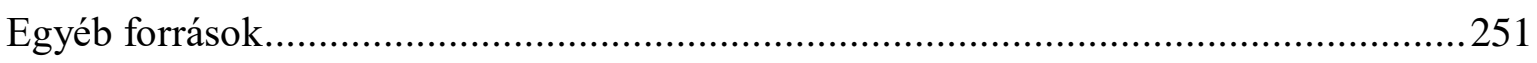




\section{Bevezetés}

\section{I.1. Problémafelvetés és előzetes megjegyzések}

Az Egyesült Államokban a XIX. század második felében végbement robbanásszerü gazdasági fejlődés árnyoldalainak hatására kialakult progresszív mozgalom követelései, ${ }^{1}$ valamint az ezek nyomán megindult törvényhozási tevékenység kapcsán kialakult társadalmi viták a korabeli joggyakorlaton és jogelméleten is rajta hagyták a nyomukat. A korszak az utókor számára - jogászi szemmel - elsősorban a Supreme Court ún. „konzervatív aktivizmusa” miatt ismeretes: a korszak fösodrú interpretációja értelmében amögött, hogy a Supreme Court a piaci versengés túlkapásainak megfékezésére irányuló jogszabályokat több ízben alkotmányellenessé nyilvánította, ideológiai okok húzódtak, a testület több tagja ugyanis a szabadversenyes piacgazdaság elkötelezett híve volt. A nagyjából a XIX. század utolsó évtizedétől 1937-ig tartó korszak emblematikus ítélete a Lochner v. New York-ügyben, 1905-ben hozott döntés volt, mely a pékek munkaidejét szabályozó New York állami törvényt alkotmányellenesnek nyilvánította azon az alapon, hogy sérti a szerződéses szabadság alkotmányos elvét. E döntés mindmáig a bírói visszaélés szinonimája, ${ }^{2}$ és a szakmai közvélemény szorosan összekapcsolja egy olyan korszakkal, amelyben az Egyesült Államok legfőbb bírói fóruma merev, idejétmúlt elvekre hivatkozva, ideológiai meggyőződésből gáncsot vetett a különféle társadalmi problémákat orvosolni kívánó törvényhozásnak. A korabeli szakirodalom jó része ezt a megközelítést vette át, és e nézet évtizedekig tartotta magát az 1937 utáni elemzésekben is. Az 1970-es80-as évekre tehető az újabb megközelítések felbukkanása, amikor is a jog gazdasági elméletének képviselői úgy ítélték meg, hogy össztársadalmi szempontból hasznos volt az állami beavatkozás megfékezése. Ennél valamivel később láttak napvilágot azok az elemzések, amelyek arra mutattak rá, hogy a Supreme Court többé-kevésbé következetes alkotmányértelmezési álláspontot képviselt döntéseiben, ezért alaptalan ideológiai ${ }^{3}$ elfogultsággal vádolni a testületet. A jelen tanulmány célja a korszak precedensanyagának

\footnotetext{
${ }^{1}$ Lásd pl. Link, Arthur S.: American Epoch - A History of the United States Since the 1890's. Alfred A. Knopf, New York, 1963, 68-72. o.

${ }^{2}$ Strauss sommás megállapítása szerint például ,[h]a manapság az ember az amerikai alkotmányjog fösodrához akar tartozni, el kell vetnie a Lochner-döntést.” (,You have to reject Lochner if you want to be in the mainstream of American constitutional law today.") Strauss, David A.: Why Was Lochner Wrong? In The University of Chicago Law Review, Vol. 70, 2003, 373 o.

${ }^{3}$ Ezekröl bővebb áttekintést a III. fejezetben adok.
} 
beható elemzése abból a szempontból, mennyire helytálló az említett „aktivizmusvád”, emellett egy sajátos tipológiának megfelelően igyekszem jellemezni a Supreme Court releváns gyakorlatát.

Alkotmányjogi szempontból a korszak kulcsfogalma a „megfelelő eljárás” (due process). Az Egyesült Államok Alkotmányának ötödik kiegészítése szerint „,egyetlen személy sem (...) fosztható meg életétől, szabadságától vagy tulajdonától megfelelő eljárás nélkül”, ${ }^{4}$ a tizennegyedik alkotmánykiegészítés értelmében pedig „,egyetlen tagállam sem foszthat meg senkit életétől, szabadságától vagy tulajdonától megfelelő eljárás nélkül”. 5 A Supreme Court kritikusai szerint a testület a megfelelő eljárás fogalmát tartalmi mérceként alkalmazta. A megfelelö eljárás követelménye eredetileg bizonyos nélkülözhetetlen eljárási garanciákat foglalt magába, mindenekelőtt az ügyben érintettek megfelelő értesítését, valamint az érdemi meghallgatás lehetőségét. A kritikák szerint ezt az értelmezést szigorúbb követelmények felállítása követte, melyek alapján a Supreme Court a támadott rendelkezések ésszerüségét is górcső alá vette, és amennyiben úgy találta, hogy a szabályozás indokolatlanul korlátozza az indítványozók szabadsághoz, illetve tulajdonhoz való jogát, alkotmányellenessé nyilvánította azt. ${ }^{6}$ A jelen értekezés azokra az esetekre fókuszál, amelyek az ötödik, illetve a tizennegyedik alkotmánykiegészítésben foglalt szabadsághoz, illetve tulajdonhoz való joggal állnak összefüggésben. ${ }^{7}$

A témafeldolgozás jogtörténeti, alkotmányjogi és jogelméleti vonatkozásokat is felmutat. A jogtörténeti és az alkotmányjogi vonatkozást az adja, hogy egy múltbeli korszak joggyakorlatára fókuszálok; az alkotmányjogi vonatkozás abban ragadható meg, hogy kifejezetten a Supreme Court alkotmányértelmezési gyakorlatára fókuszálok, méghozzá olyan rendelkezések értelmezésére, amelyek mind a mai napig meghatározóak a testület joggyakorlatában, ráadásul a társadalmilag legnagyobb hatású ítéletek is mindmáig gyakran ezen elöírások körül forognak. A dolgozat azonban nem redukálódik puszta alkotmánytörténetté; annak jogelméleti jellegét az adja, hogy egyrészt magát az aktivizmus fogalmát igyekszem elméleti igénnyel megragadni, másrészt a témakifejtés során

\footnotetext{
${ }^{4}$ „No person shall be ... deprived of life, liberty, or property, without due process of law”. A korlátozás a Kongresszusra vonatkozik.

${ }^{5}$ „No State shall ... deprive any person of life, liberty, or property, without due process of law”. Az 1868-ban ratifikált kiegészítés a fenti korlátozást a tagállamokra terjesztette ki.

${ }^{6}$ A „megfelelő eljárás” kifejezés több eltérő értelmet is kaphat. Victor Ramraj a nemzetközi gyakorlatban négy lehetséges jelentést különböztetett meg. Vö. Ramraj, Victor V.: Four models of due process. In International Journal of Constitutional Law, Vol. 2, 2004, 492-524. o.

$7 \mathrm{Az}$ élethez való jog ebben az összefüggésben lényegtelen: az értekezés kifejezetten a piac szabályozhatóságának kérdését érintő ítéletekkel foglalkozik. Az élethez való jog elsősorban büntetőjogi ügyekben, többnyire a halálbüntetés kapcsán merül fel, az ilyen esetek vizsgálata itt értelemszerüen fölösleges.
} 
bemutatott döntéseket azok érvelése szempontjából vizsgálom, és az előzetesen ismertetett fogalmi keretben igyekszem elhelyezni azokat.

Disszertációm tárgyát - a jelen bevezetéstől és a végkövetkeztetések levonásától eltekintve - három nagy egységre bontva, három fejezetben fejtem ki.

Az első fő tartalmi egységben (II. fejezet) a kutatásom alapjául szolgáló fogalmi kereteket vázolom fel. Azt, hogy mi tekinthető „bírói aktivizmusnak”, a szakirodalom egészen az elmúlt évtizedekig nem elemezte, annak ellenére, hogy a kifejezés az 1970-es80-as évektől kezdve már jelen volt az egyesült államokbeli szakmai közbeszédben, először az Earl Warren, majd Warren E. Burger által vezetett Supreme Court egyes jelentős alapjogkiterjesztő döntéseinek, később pedig a Reagan-korszak konzervatív fordulatának bírálataiban. E kölcsönös vádaskodások azonban olykor nem mentesek a politikai-ideológiai felhangoktól sem. A Supreme Court tevékenységének értékelése az „aktivizmus” kifejezés jelentéstartalmának behatárolását is szükségessé teszi. Erre tekintettel bemutatom az ,aktivizmus” fogalmának fontosabb megközelítéseit az amerikai és a hazai szakirodalom alapján, egyúttal kifejtem, mit tekintek „aktivizmusnak” a jelen értekezés keretei között. Ezután ismertetem azt a tipológiát, amely a jelen kutatás során vizsgált döntésanyag elemzésére szolgál. Ennek lényege az, hogy a Supreme Court ítélkezési gyakorlatát nem pusztán annak alapján jellemzem, hogy mekkora az alkotmányossá agy alkotmányellenessé nyilvánítás aránya, hanem aszerint is, hogy az indokolásokban mennyire található közvetlen hivatkozás tudományos szakirodalomra.

A második fö tartalmi egységben (III. fejezet) nagy vonalakban ismertetem azokat a főbb irányvonalakat, megközelítésmódokat amelyek a Supreme Court tevékenységének a jelen értekezésben vizsgált korszakában kirajzolódtak az idők folyamán, továbbá igyekszem elhelyezni saját kutatásomat e különböző kutatási irányok között. Arra mutatok rá ebben a fejezetben, hogy a Lochner-ügyet és korát vizsgáló elemzések között értelemszerüen találhatók olyanok, amelyek mögöttes premisszaként elfogadják azt a bevett elképzelést, hogy a Lochner-ítélet rossz döntés, a bírói visszaélés példája. Ez a meggyőződés már a XX. század korai évtizedeiben tetten érhető, ami a korszak politikai környezetét tekintve különösen érthető, hiszen erre az időszakra tehető a progresszív mozgalom térnyerése, a társadalmi problémák állami orvoslásának követelése; ugyanakkor ez a megítélés egészen napjainkig kitart. Emellett azonban már korán megjelentek a Supreme Court ítélkezési gyakorlatának kvantitatív jellegű értékelései, melyek során számszerüsítve demonstrálják egy vizsgált időszak alkotmányellenességet és alkotmányosságot megállapító döntéseinek egymáshoz való arányát; és hasonló elemzések 
később is megjelentek. Egy további megközelítésmód a Supreme Court egyes tagjai meggyőződésének vizsgálata. A XX. század utolsó harmadában erőre kapó gazdasági jogelmélet a Lochner-ítélet „rehabilitációját” eredményezte, amennyiben az irányzat által felkarolt neoliberális közgazdaságtan szerint az állami beavatkozás számos területen kimutatható, számszerüsíthető kárt eredményez. Végül rámutatok arra, hogy a viszonylag friss kutatások szerint a Supreme Court nem valamiféle ideológiai elhivatottságból hozta meg többségi döntését a Lochner-ügyben, hanem egy következetes, igaz, a kor társadalmi fejleményei által kikezdett alkotmányossági tesztnek megfelelően. E vonalon Howard Gillman kutatását emelem ki, aki azt mutatja be, hogy a Supreme Courtot egyfajta diszkriminációtilalmi megfontolás vezérelte, az a természetjogban gyökerező igazságossági követelmény, hogy a jogalkotó ne kivételezzen a - kor felfogása szerint hasonló helyzetü embercsoportok között. Saját kutatásaim részben igazolják Gillman következtetéseit, azonban megítélésem szerint az 1937-es fordulatot alátámasztó érvek valójában már korábban is jelen voltak a Supreme Court ítélkezési gyakorlatában, és épp hogy egyes alkotmányellenességet megállapító döntései tekinthetők elhajlásnak a vizsgált precedensek fényében.

E fejtegetéseket követi a Supreme Court korabeli gyakorlatának részletes elemzése a harmadik fö egységben (IV. fejezet). Itt igyekszem összefoglalni és összevetni az egyes precedensek indokolásának sarkalatos pontjait és az eredmény alátámasztásaként felhasznált érveket. Összességében arra a következtetésre jutok ebben a fejezetben, hogy az esetek túlnyomó részében a Supreme Court következetesen passzivista álláspontot képviselt a jogalkotói aktusok alkotmányosságának megítélése során, ugyanakkor bizonyos kérdésekben - az általánosságban megfigyelhető attitüdhöz képest - meglepő módon aktivista irányba ment el. Mindemellett arra is rámutatok, hogy a Supreme Court vizsgált gyakorlatában folyamatosan rendelkezésre álltak azok az elvek, amelyek ellenkező előjelü döntéshez vezettek volna, így az értekezésben levezetett álláspontom szerint a Supreme Court 1937 elötti alkotmányértelmezési koncepciója alkalmas volt a megváltozott társadalmi körülményekhez való alkalmazkodásra. Az alábbiakban részletesebben kifejtem a Supreme Court precedensanyagának szelekcióját vezérlő megfontolásokat. 


\section{Az elméleti keretek kijelölése: szempontok a bírói „aktivizmus" definiálásához}

A jogi normák jellemzése során visszatérő motívum a szabályok és az elvek megkülönböztetése: a szabályok viszonylag pontosan körülírt, konkrét értelemmel bíró rendelkezések, az elvek elvont, iránymutató jellegü előírások. ${ }^{8}$ Számos alkotmányos rendelkezés az utóbbi kategóriába sorolható, aminek következtében a rendes jognál szélesebb értelmezési lehetőségeket biztosítanak az azokat értelmező szervek számára. ${ }^{9} \mathrm{~A}$ magyar Alkotmánybíróság immáron bö két évtizede nap mint nap szembesül ezen értelmezési sokszínüség különféle nehézségeivel; a külföldi tapasztalatok pedig még ennél is régebbiek: a német Szövetségi Alkotmánybíróság (Bundesverfassungsgericht) például 1951-ben kezdte meg működését, az Egyesült Államok Legfelsőbb Bírósága (Supreme Court of the United States; az egyszerüség kedvéért a továbbiakban: Supreme Court) pedig 1803-ban testálta magára az alkotmányos normakontroll hatáskörét, ${ }^{10}$ ráadásul az

\footnotetext{
${ }^{8}$ A kérdéshez lásd pl. Sunstein, Cass R.: Problems with Rules. In California Law Review, Vol. 83, Issue 4, 1995, 953-1026. o.; Schauer, Frederick: Rules and the Rule of Law. In Harvard Journal of Law and Public Policy, Vol. 14, Issue 3, 1991, 645-694. o.

${ }^{9}$ Ez nem azt jelenti, hogy az alkotmányos alapjogok fogalmilag szélesebb értelmezési lehetőségeket rejtenek magukban, mint a rendes jog szabályai. A magánjogban is megfigyelhetők elvi jellegü rendelkezések, amelyek szintén sokrétủ tartalommal bírhatnak, és ha ez az idők során megszilárdult, az elsősorban nem a nyelvi konvencióknak, hanem a jogtudományi konszenzusnak, vagy adott esetben a hosszú hagyományokra visszatekintő bírói gyakorlatnak köszönhetö. Ezt példázza a német jogban a ,jóhiszeműség és tisztesség” elvének megfelelö Treu und Glaube elve, melynek tartalma a kereskedelmi forgalomban szokásos tisztességre szűkült. Vö. Pokol Béla: Autentikus jogelmélet. Dialóg Campus Kiadó, Budapest, 2010, 51-52. o.

${ }^{10}$ A Marbury v. Madison-ítéletben (5 U. S. /1 Cranch/ 137) a Supreme Court úgy határozott, hogy alkotmányellenes a bíróságokról szóló törvény azon rendelkezése, amely a writ of mandamus-ügyekben (vagyis olyan kereset esetén, melynek alapján a jogszabály szerint valamilyen cselekmény elvégzésére köteles szervet annak elmulasztása esetén a bíróság kötelezi az elvégzésére) a Supreme Court számára elsőfokú hatáskört biztosít, az alkotmány ugyanis taxatíve sorolja fel azokat a hatásköröket, amelyekben a testület első fokon járhat el, és a writ of mandamus-ügyek ebbe nem tartoznak bele. A szakirodalom többsége a Marbury-ügyet jóformán kritikátlanul az amerikai alkotmányos demokrácia és az alkotmány szupremáciája egyik alappillérének tekinti, ugyanakkor időnként megjelennek kritikus hangok is. Így például Sanford Levinson több szempontból bírálja az ítéletet. Szerinte kritikus pont, hogy maga az alapügy - William Marbury békebíróvá kinevezése - egyáltalán nem volt jelentős - ez az érv megítélésem szerint egyértelműen cáfolható, hiszen egy alkotmányjogi kérdésben született döntés jelentőségét nem maga az alapügy határozza meg, hanem az indokolásban lefektetett elvek. Másrészt Levinson szerint a Marbury-ügy indokolása is gyenge lábakon áll, ugyanis sem a kérdéses törvényhely, sem az alkotmány vonatkozó III. cikkének szövege olyan egyértelmü, mint ahogy azt John Marshall láttatni szerette volna. Vö. Levinson, Sanford: Why I Do Not Teach Marbury (Except to Eastern Europeans) and Why You Shouldn't Either. In Wake Forest Law Review, Vol. 38, 2003, 559., illetve 563-565. o. Levinson álláspontjának nyomán egy kisebb vita is támadt a Marbury v. Madison jelentőségét illetően. Lásd Segall, Eric J.: Why I Still Teach Marbury (and So Should You): A Response to Professor Levinson. In University of Pennsylvania Journal of Constitutional Law, Vol. 6, 2004, 573-587. o.; valamint Levinson, Sanford: Why I Still Won't Teach Marbury (Except in a Seminar). In University of Pennsylvania Law Review, Vol. 6, 2004, 588-603. o.
} 
Államokban az alkotmányos normakontroll eszméje és gyakorlata már e mérföldkőnek számító döntés előtt is létezett. ${ }^{11}$ A nehézségek egy része közvetlenül a feladat jellegéből fakad, elsősorban azért, mert az elvont rendelkezések határainak kijelölése, azok többékevésbé következetes rendszerbe foglalása komoly szellemi kihívást jelent. A nehézségek másik része az értelmezési tevékenység kíséröjelenségeként jelenik meg. E körben mindenekelőtt az „aktivizmus” vádját kell megemlíteni.

Miután az alkotmányos normakontrollt végző testületek döntései közvetlen befolyással bírnak a tételes jog anyagára, így közvetve a társadalompolitikai célkitűzésekre, azok megvalósításának lehetőségére, egyes ügyek eredménye nem közömbös az akadémiai szférán túl a szélesebb közönség számára sem. Az ilyen ügyek kapcsán a döntés kritikusai nem ritkán aktivizmust rónak fel a testületnek, amely leginkább az illegitim hatáskörtúllépéssel rokon értelmű. A kifejezéssel mind a laikus, mind a tudományos diskurzus során találkozhatni. Az első esetben a kifejezés alkalmazása csekély relevanciával bír a jogtudomány képviselői számára, a második esetben azonban érdekes módon kevés kísérlet figyelhető meg az aktivizmus mint jelenség vagy attitüd pontos meghatározására. Egy gyors kutatás a Google Ngram Viewer keresőjében demonstrálja, hogy a „bírói aktivizmus” (judicial activism) fogalmát - legalábbis a könyvekben - az 1950-es évektől kezdődően egyre gyakrabban használták, majd ez a gyakoriság az 1990-es években bekövetkező csúcs után enyhén mérséklődni kezdett. ${ }^{12}$

E hiányosság több szempontból is fájó. Egyrészt az alkotmánybírósági döntések értékelésénél megbízhatatlan mércét jelent egy olyan kifejezés, amely minden elemző számára más tartalommal bír. E sokrétüség különösen szembeszökő, ha tekintetbe vesszük, hogy az "aktivizmus" kifejezés nem csekély politikai felhanggal bír, ami könnyen az elemzés torzulásához vezet. Másrészt az empirikus vizsgálódásoknak a jogtudományban

\footnotetext{
${ }^{11}$ Az újabb kutatási eredmények közül lásd: Treanor, William Michael: Judicial Review Before Marbury. In Stanford Law Review Vol. 58, 2005, különösen 541-554. o.

${ }^{12}$ Lásd a Függelékben az 1. diagramot! A Google Ngram Viewer segítségével meghatározott időszakban pillanatnyilag 2008-cal bezárólag - meg lehet mérni, hogy a Google Books adatbázisában digitalizált könyvekben található összes szó vagy kifejezés közül arányosan hányszor fordul elő a keresőbe beírt szó vagy kifejezés, más szóval Ngram, azaz „N-gramma”, ahol a „gramma” a kifejezés tagját jelöli (ami bármely önálló, elválasztás nélküli karaktersor lehet), az „N” pedig azt, hogy hány grammából áll az adott N-gramma (így például a „bírói aktivizmus”, azaz judicial activism egy 2gram, vagyis 2-gramma, mert két önálló, elválasztás nélküli karaktersor alkotja). Ennek az eszköznek ugyan megvannak a maga hiányosságai, korlátai, azonban annak szemléltetésére maradéktalanul alkalmas, hogy a XX. század második felében relatíve mennyire felkapott lett a bírói aktivizmus mint téma az Egyesült Államokban. A 2-gramma előfordulási aránya látványos és viszonylag kiegensúlyozott emelkedést mutat az 1990-es évek elejéig, és utána is csak lassan csökken, hullámhegyek és hullámvölgyek kíséretében. Az 1. diagram az 1925 és 2008 közötti időszakot öleli fel. A kezdő évet azért 1925-ben jelöltem meg, hogy a kifejezés előfordulásáról teljesebb képet adjak: bár kétségtelen, hogy a XX. század második felében élte „,virágkorát”, érdekes módon elenyésző mértékben és elszigetelten, de megfigyelhető a felbukkanása az 1930-as évek környékén is.
} 
való szerepnövekedésével egy potenciális kutatási területet jelenthet egy alkotmánybíróság aktivizmusának mértéke. Ha egy ilyen vizsgálat alapfogalmát nem tisztázza a kutató, vállalkozása szükségképpen kudarcra kárhoztatott.

A jelen fejezet áttekintést nyújt a fontosabb definiálási lehetőségekről. Már e helyütt érdemes megemlíteni, hogy a tanulmány tárgya nem az aktivizmus eszközéül szolgáló normakontroll-hatáskör legitimációja, szükséges vagy szükségtelen volta. E kérdés vonatkozásában jóformán áttekinthetetlen terjedelemben áll rendelkezésre a szakirodalom, ${ }^{13}$ e helyütt azonban kizárólag arra a kérdésre kívánok szorítkozni, hogy a különböző megközelítések szerint milyen kritériumok alapján nevezhető aktivistának a normakontroll-hatáskör gyakorlása.

\section{II.1. Normatív viszonyulások az alapjogi aktivizmushoz az alkotmányos normakontroll egyes elméleteinek fényében}

Az alapjogi aktivizmus definiálása mellett a jogtudomány - magának az alkotmányos normakontrollnak a szerepével, indokoltságával, legitimációjával összefüggésben gyakran teszi fel azt a kérdést, mennyire kívánatos, illetve hasznos ez a jelenség. Az alábbiakban az ezzel kapcsolatos álláspontokra reflektálok röviden. Az alkotmányos normakontroll-hatáskör gyakorlása és a demokratikus többségi döntéshozatal közötti viszony kérdésében született állásfoglalások eltérő mértékben és vonatkozásban, illetve indokok miatt érvelnek az egyik vagy másik döntési forma meghatározott szerepe mellett. Fontos szem elött tartani, hogy a demokrácia és az alkotmánybíráskodás - minőségileg eltérő szerepük okán - nem egymást kizáró intézmények, ilyen álláspontot csak a többségi demokrácia szélsőséges, az alkotmánybíráskodás intézményét teljes egészében illegitimnek tekintő elméletei vallanak, az ilyen gondolatkör azonban marginálisnak tekinthető az alkotmányjog-tudományban. Mindazonáltal valóban létezik feszültség az alkotmánybíráskodás és a demokratikus felhatalmazás birtokában történő társadalomirányítás között, melynek forrása az alkotmánybíráskodás kontrollszerepe és az ún. „demokratikus deficit”, ami azonban kiegészítendő a következőkkel.

Akár az európai kontinentális, akár az egyesült államokbeli alkotmánybíráskodás intézményrendszerét vesszük szemügyre, a bírákat valamely demokratikus legitimációval

\footnotetext{
${ }^{13}$ Ehhez lásd pl., Levy, Leonard W.: Judicial Review, History, and Democracy: An Introduction. In Levy, Leonard W. (ed.): Judicial Review and the Supreme Court, Harper Torchbooks, New York, 1967, 1-42. o.,
} 
rendelkező személy vagy testület választja ki: Európában ez jellemzően a parlament, az Egyesült Államokban pedig az elnök (a Szenátus beleegyezésével és hozzájárulásával). Vagyis bizonyos mérvü demokratikus legitimáció megfigyelhető, a problémát az elszámoltathatóság ebből fakadó hiánya okozza, azonban kérdéses, hogy ez egyáltalán probléma-e, mert a bírói függetlenség fontos biztosítékáról beszélünk. Másfelől már Alexander Hamilton is kifejtette azt az álláspontot a The Federalist 78. számában, hogy az alkotmányos normakontroll intézménye valójában nem ellentétes a demokrácia eszményével, sőt, épp annak kiteljesítője, az alkotmány forrása ugyanis közvetlenül a nép, ilyenformán a benne foglaltak a népakarat közvetlen kifejezői. Az alkotmányos normakontroll gyakorlása ezért a valódi népakarat érvényesítése a nép meghatalmazottjainak akaratával szemben. ${ }^{14}$ Ezt a nézőpontot érdemes szem előtt tartani, részben történelmi okokból, hiszen a modern alkotmánybíráskodás kialakulásának folyamata során jelent meg, részben pedig azért, mert más fényben tünteti fel az alkotmánybíráskodás és a demokrácia problematikáját, amennyiben a kettő szervesen összekapcsolódik, és az előbbi az utóbbi egyik kifejeződési módjává válik. A kérdés ebben az esetben már nem az, hogy melyik döntési forma rendelkezik erősebb legitimációval, illetve melyiknek kell nagyobb teret hagyni a másikkal szemben, hanem az, hogy az alkotmánybíráskodás mennyiben lépi túl a népakarat által ráruházott hatáskört.

A demokrácia fogalma az alkotmányos normakontrollal és az alapjogi aktivizmussal összefüggésben a közösséget érintő döntések többségi elv szerint történő meghozatalát jelenti, azonban a vita résztvevői ezt a meghatározást jellemzően inkább evidenciaként, semmint reflektált álláspontként alkalmazzák. Egy friss kutatás a demokrácia hatféle koncepcióját különböztette meg, az ún. „elektorális” (electoral), a liberális (liberal), a többségi (majoritarian), a részvételi (participatory), a deliberatív (deliberative) és az egalitárius (egalitarian) demokráciát, ${ }^{15}$ melyek különböző, sajátos elvek szerint müködnek és különböző hangsúlyokkal alakítják ki intézményrendszereiket. E demokráciakoncepciók fényében az alkotmányos normakontroll is eltérő jelentőséget, funkciót kap. Pócza Kálmán ezeket az eltéréseket bemutatva arra a megállapításra jut, hogy az alkotmányos normakontroll erőssége alapján, a legerősebbtől a leggyengébbig haladva a hat koncepció a

\footnotetext{
${ }^{14}$ Hamilton, Alexander: The Federalist, 78. In Goldman, Lawrence (ed.): The Federalist Papers. Oxford University Press, Oxford, 2008, 382. o.

${ }^{15}$ Coppedge, Michael et al.: Conceptualizing and Measuring Democracy: A New Approach. In Perspectives on Politics, Vol. 9, 2011, 254. o.
} 
következőképpen állitható sorrendbe: liberális, elektorális (Póczánál „konszociális”), deliberatív, egalitárius, részvételi, többségi. ${ }^{16}$

Az alapjogi aktivizmus vitája kapcsán a fenti skála két szélső esete szolgál kiindulópontként. Természetesen nem a valóságban tiszta formában előforduló kategóriákról beszélünk: egy ország törvényhozása müködhet az erős többségi demokrácia elvén úgy, hogy egyúttal valamely független testület ellátja az alkotmányos normakontroll szerepét. Az aktivizmusvita azonban alapvetően a demokráciakoncepciók vitája, és ebben a vonatkozásban a fenti két szélső demokráciafelfogás bír a legnagyobb jelentőséggel részben azért, mert a téma tárgyalása során a kettő szembenállása rendszeresen megfigyelhető, részben pedig azért, mert a demokrácia e két típusa megtestesíti a politikai döntések régi dilemmáját, az egyéni, illetve a közösségi érdek közötti preferenciák mérlegelését is.

\section{II.1.1. Álláspontok az alkotmányos normakontroll kiterjesztett szerepe mellett}

A liberális demokrácia központi értéke az alkotmányosság, amelyből egyenesen következik az állami önkorlátozás követelménye, ezzel együtt az alapjogvédelem szilárd biztosítékrendszere, ennek pedig egyik kiemelt jelentőségű eleme az alkotmánybíráskodás. Az alkotmányos normakontroll hatáskör és a kiterjesztő alkotmányértelmezés pártfogói szemében jellemzően ez a megfontolás a legfőbb érv, amely indokot szolgáltat az alkotmánybíráskodást végző szerv fellépésére a demokratikus legitimációval rendelkező jogalkotó egyes döntéseivel szemben. Az alapjogok védelmének szükségessége megalapozható azzal, hogy az egyéni szabadságjogok önmagukban értékesek és érdemesek a védelemre; hogy védelmük a látszat ellenére - az első ránézésre megfigyelhetőnél bonyolultabb oksági láncolat következtében - a közérdeket szolgálja; ${ }^{17}$ avagy hogy az alapjogvédelem révén az alkotmánybíráskodást végző szerv egyfajta morális tanítást is nyújt az emberek számára. Ezek a megfontolások már korán megjelentek Rostow nagy

\footnotetext{
${ }^{16}$ Pócza Kálmán: Az alkotmánybíráskodás intézménye demokráciaelméleti szempontból. In Berkes Lilla Csink Lóránt (szerk.): Az ombudsmani rendszer és az alkotmánybíráskodás átalakulása. Tanulmányok az alapjogvédelem köréből. Pázmány Press, Budapest, 2015, 186. o.

17 Jól megfigyelhető az alapjogok mint „öncél”, illetve mint társadalomjobbítási eszköz védelmének párhuzama a véleménynyilvánítás szabadságának értékelésénél: a véleménynyilvánítás szabadsága védendő érték egyrészt mint önkifejezési forma, másrészt mint a minél inkluzívabb társadalmi diskurzus előmozdítója.
} 
hatású cikkében, ${ }^{18}$ majd később Swygertnél. $^{19}$ Más elképzelésekben az alkotmánybíráskodást végző szerv alkotmányossági felülvizsgálati tevékenysége kifejezetten összekapcsolódik a demokratikusan megválasztott döntéshozóéval, így Dahl szerint a Supreme Court szerepe abban áll, hogy a politikai döntéseket legitimációs többlettel ruházza fel, és ez a funkció onnét származtatható, hogy a testület a mesterséges látszat ellenére maga is politikai szerv, ilyenformán fölösleges és kontraproduktív elfedni ezt a társadalompolitikai döntésekben való részvételt. ${ }^{20}$

Az aktivizmus jelensége szempontjából is releváns annak kérdése, mennyiben korlátozódik ez az alkotmányos normakontroll gyakorlására. A problémát alább, a bírói és az alapjogi aktivizmus elhatárolása során is érinteni fogom, futólag utalva arra, hogy voltaképpen a kiterjesztő jogértelmezés egy válfajával állunk szemben, ami természetesen korántsem szükül az alkotmányjogra. Ennek nyomán kialakultak olyan álláspontok, amelyek érvelése szerint a kiterjesztő (jogfejlesztő) jogértelmezés más jogterületek egyes kérdéseiben - ilyen például a közrenddel ellentétes szerződések érvényre juttatásának megtagadása vagy a szigorú termékfelelősség bevezetése - megfigyelhető, ezért a felszíni különbségek dacára nincs nyomós oka annak, hogy az alkotmányértelmezésből kizárjuk ezt a lehetőséget. ${ }^{21} \mathrm{Az}$ ilyen álláspont erénye az, hogy szem előtt tartja a bírói értelmezés jelentőségét a jogfejlesztésben, ami az alkotmányos normakontroll és az aktivizmus problematikájában is megkerülhetetlen szempont, tekintve, hogy az alkotmánybíráskodás (különösen a konkrét normakontroll gyakorlása) természetét tekintve bírói művelet. Ugyanakkor fontos minőségi különbség a „rendes” kiterjesztő értelmezés, valamint az alkotmányértelmezés között, hogy utóbbi esetben a tét nem „csupán” annyi, hogy az anyagi jog milyen tartalmat nyer (kitöltve a jogalkotói szabályozás esetleges hiányosságait), hanem az, hogy a jogalkotónak marad-e lehetősége a megszületett döntéstől eltérő tartalmú szabályozás kialakítására. Ezért önmagában a bírói jogfejlesztés

\footnotetext{
${ }^{18}$ Rostow, Eugene V.: The Democratic Character of Judicial Review. In Levy, Leonard W. (ed.): Judicial Review and the Supreme Court, Harper Torchbooks, New York, 1967, 87-88. o.

${ }^{19}$ Lásd általában: Swygert, Luther M.: In Defense of Judicial Activism. In Valparaiso University Law Review, Vol. 16, 1982, különösen 439-458. o. Swygert az alapjogi aktivizmus melletti érvek széles választékát sorakoztatja fel a hivatkozott cikkben: rámutat a többségi és az alkotmányos demokrácia minőségi különbségeire, utal az alapítók alkotmányos normakontrollról és a bíróságok szerepéről alkotott felfogására, a Supreme Court alkotmányértelmezési primátusának fontosságára az ún. „departmentalism” elképzelésével szemben (melynek értelmében a három hatalmi ág alkotmányértelmezése egyenrangú és autonóm), továbbá konkrét szabályozási területek (gerrymandering, fogvatartotti jogok, szegregáció) példáján igazolja az aktivizmus egyes eseteinek morális, illetőleg össztársadalmilag kívánatos voltát (hozzátehető, hogy ezekben a példákban a morális vetület nagyobb hangsúlyt nyer).

${ }^{20}$ Dahl, Robert A.: Decision-Making in a Democracy: the Supreme Court as a National Policy-Maker. In Levy, Leonard W. (ed.): Judicial Review and the Supreme Court, Harper Torchbooks, New York, 1967, $106-$ 107. o.

${ }^{21}$ Johnson, Frank M.: In Defense of Judicial Activism. In Emory Law Journal Vol. 28, 1979, 906. o.
} 
létének ténye nem ruházza fel legitimációval az aktivista alkotmányértelmezési gyakorlatot.

\section{II.1.2. Álláspontok az alkotmányos normakontroll korlátozott szerepe mellett}

Az alkotmányos normakontrollal szembeni kritikus attitüdök jellemzően arra helyezik a hangsúlyt, hogy az intézmény helytelen gyakorlása - avagy ritkábban annak puszta léte - ellentétes a demokratikus döntéshozatal és felelősségvállalás értékeivel. Az alábbiakban ennek a gondolatkörnek egyes aspektusait tekintem át.

James Bradley Thayer az alkotmányos normakontroll korai kritikusai közé emelkedett mérvadó tanulmányával. Ennek konklúziójában távolról a jogi historizmust idéző álláspontot fejez ki, amikor úgy foglal állást, hogy a kiterjedt alkotmányos normakontroll csak felelötlenné teszi a törvényhozót, aki így könnyebben hoz rossz döntést arra tekintettel, hogy a bíróság azt majd úgyis korrigálja. Ezzel szemben az alkotmányos normakontroll szükítése megfontoltságra kényszeríti a legfőbb népképviseleti szervet. ${ }^{22} \mathrm{Ez}$ a meglátás nem csak az alkotmánybíráskodást végző szervekre vonatkozik, hanem magának az alkotmánynak a kiterjedtségére is. Vagyis elsősorban a törvényhozót megkötő tilalmak mennyisége számít, ellenben azok forrása, vagyis hogy egy kartális alkotmányban vannak-e lefektetve, avagy az alkotmány rendelkezéseit alkalmazó szerv, szervek döntésanyagában, másodlagos jelentőségűvé válik. Manapság ez az érv önmagában aligha bírna meggyőzőerővel, hiszen az alkotmánybíráskodást végző szervek fellépése olyan érzékeny problémaköröket érintett, amelyekről nem sokan mondanák azt, hogy elegendő, ha a nép „spontán tanulási folyamata” megoldja őket. A Brown v. Board of Educationítélet ezt kiválóan példázza: a Plessy v. Ferguson-ítélet és a teljes separate but equaldoktrína fényében azt a döntést nehéz lenne nem aktivistának tekinteni, ugyanakkor nehéz elképzelni, hogy a jogtudományban bárki azzal érvelne, hogy ott és akkor a Supreme Courtnak hagynia kellett volna, hogy az államok, a faji szegregáció szükségtelen és káros voltát egyenként belátva, azt eltöröljék. Egy ilyen elvárásnak valószínüleg nem is lett volna sok realitása.

A Supreme Court történetében előfordulnak döntések, amelyek negatív példaként maradnak meg az utókor emlékezetében, és egyfajta „ellenkánont” alkotnak, hivatkozási

\footnotetext{
${ }^{22}$ Thayer, James Bradley: The Origin and Scope of the American Doctrine of Constitutional Law. In Harvard Law Review, Vol. 7, 1893, 155-156. o.
} 
alapot arra, hogyan nem kellene az alkotmányos normakontrollt gyakorolni. ${ }^{23}$ Részben az ilyen döntések, részben más, nem olyan ismert, de negatív megítélésü döntések támasztják alá azokat a vélekedéseket, amelyek szerint az aktivista alkotmánybíráskodási stílus nemcsak több kárt okoz, mint amennyi hasznot hajt, de ráadásul épp a kritikus kérdésekben kifejezetten a „helytelen” végkifejletet támogatja. Erre az álláspontra helyezkedett már az aktivizmusról szóló viták korai éveiben Commager, aki azt a következtetést vonta le a Supreme Court történetének áttekintése során, hogy a testület fellépése nélkül az amerikai demokrácia semmivel sem tartana hátrébb, mint a korabeli tényleges állapotában. Commager érvei alátámasztására bemutat egy sor precedenst, melyekben a Supreme Court alkotmányellenesnek nyilvánít haladónak számító jogalkotói aktusokat: a precedensek nagyrészt piacszabályozási tárgyúak, de olyan emblematikus döntések is megtalálhatók közöttük, mint a Dred Scott-ítélet. ${ }^{24}$

Commager érvelésével nem önmagában az a probléma, hogy napjainkra különösen idejétmúltnak tekinthető, hiszen a cikk eredeti változata mindössze néhány évvel a Supreme Court 1937-es ,fordulata” után íródott, ${ }^{25}$ és még jóval azelőtt, hogy megjelent volna a Wolfe által modern bírói alkotmányos normakontrollnak nevezett döntési stílus. Az sokkal inkább problémás, hogy a példák kissé ötletszerüen vannak kiragadva, nem derül ki világosan sem az, milyen döntési körből, milyen okból lettek kiemelve, sem az, milyen ideálhoz képest minősülnek rossznak, illetve hogyan és miért kellett volna elbírálni őket. Továbbá ennél absztraktabb nézőpontból az is felvethető az okfejtéssel szemben, hogy önmagában annak ténye, hogy a Supreme Court hátráltatta a „haladó” jogalkotást, nem teszi szükségszerüvé azt a következtetést, hogy nincs is szükség a testületre, illetve az alkotmányos normakontroll intézményére, ehelyett ki lehetne jelölni a helyes hatáskörgyakorlás irányát. Erre azonban Commagernél nem kerül sor. Továbbá az általa kiemelt jogesetek némelyikével kapcsolatban téves maga a problémafelvetést. A Keller v. United States-ítélet ${ }^{26}$ ezek közé tartozik: ebben a viszonylag ismert döntésben a Supreme Court alkotmányellenessé nyilvánította azt a kongresszusi törvényt, amely büntetni rendelte a bevándorló, nem állampolgár nők prostituálását. A testület szerint ez a police power körébe tartozó aktus nem a Kongresszus, hanem a tagállamok hatáskörébe tartozik.

\footnotetext{
${ }^{23}$ Az alkotmányjogi „,kánon” és „ellenkánon” fogalmaihoz bővebben lásd a III.3.1. szakaszt!

${ }^{24}$ Commager, Henry Steele: Judicial Review and Democracy. In Levy, Leonard W. (ed.): Judicial Review and the Supreme Court, Harper Torchbooks, New York, 1967, 68-72. o.

${ }^{25}$ A hivatkozott tanulmány először a szerző 1943-as, Majority Rule and Minority Rights címủ kötetében jelent meg, vagyis a Supreme Courtnak a piacszabályozási törvényekhez, és közelebbről a New Dealhez való viszonyulásában bekövetkezett ,irányváltása" még friss élmény volt.

${ }^{26} 213$ U.S. 138 (1909)
} 
Azonban itt nem egyszerűen elvágták a jogalkotót annak lehetőségétől, hogy szabályozza a kérdéses életviszonyt, hanem csupán annyi lett kimondva, hogy erre nem a szövetségi szintü jogalkotónak van lehetősége a konkrét esetben. Vagyis a probléma nem redukálható pusztán egy jogalkotó és egy bírói testület szembenállására. Az ehhez hasonló ügyekben téves megközelítés az „antidemokratikus” müködést a Supreme Court terhére róni.

Commagerénél meggyőzőbb álláspontot dolgozott ki Ely, valamint az ő nyomdokain Waldron. Mindkét szerző processzualista álláspontot képviselt, ami alatt azt értem, hogy az alkotmányos normakontroll szerepét a demokratikus politikai akaratképzés folyamatának biztosításában jelölték meg. Ely ezt a funkciót azzal magyarázta, hogy magából az alkotmányszövegből rengeteg olyan érv olvasható ki, amelyek azt a célt szolgálják, hogy az emberek a demokratikus akaratképzés folyamataiban kifejezhessék a véleményüket, továbbá az ilyen párbeszéd minél teljesebb kiteljesedése érdekében az államhatalom köteles megóvni a különféle kisebbségeket a többség zsarnokságától. ${ }^{27}$ Megítélése szerint a bíróságok erre az ellenőrző feladatra több tényező folytán is alkalmasak. Az első tényező az alkotmány fentebb említett - Ely által demonstrált - processzusalista szemlélete. ${ }^{28} \mathrm{~A}$ második az, hogy a bíróságok a jogalkotónál alkalmasabbak arra, hogy az eljárási rendet és az emberek képviseletét megőrizzék. ${ }^{29}$ Harmadrészt pedig a bíró fellépésének akkor van helye, ha a népképviseleti rendszer rosszul müködik. ${ }^{30} \mathrm{Az}$ alkotmányos normakontrollt gyakorló szervek tehát főszabály szerint háttérbe húzódó „őrként” figyelik a demokratikus folyamatokat, és a választókra bízzák, hogy megállapodjanak, mely értékeket kívánják uralkodóvá tenni.

Hasonló, főszabályként önmegtartóztató alkotmányértelmezői koncepciót vázolt fel Waldron, akinek álláspontjának egyik fő sajátossága, hogy nem általánosságban „az” alkotmányos normakontrollról, illetve „a” demokráciáról ír a kettő kapcsolatának elemzésekor, hanem annak függvényében tartja indokoltnak az alkotmányos normakontroll intézményének meglétét és gyakorlati alkalmazását, hogy bizonyos előfeltevéseknek mennyiben felel meg valamely ország államszerkezete és társadalma. Waldron négy ilyen előfeltevést határoz meg. Az első a demokratikus államberendezkedés: a reprezentatív, politikailag felelős népképviseleti intézmények, ezek megfelelő müködése, a valódi

\footnotetext{
27 Ely, John Hart. Democracy and Distrust. A Theory of Judicial Review. Harvard University Press, Cambridge, 1980, 81-87. o.

${ }^{28}$ Ely 1980: 87. o.

${ }^{29}$ Ely 1980: 102. o.

${ }^{30}$ Ely 1980: 103. o.
} 
politikai pluralizmus és az általános választójog. ${ }^{31}$ A második előfeltevés a független bíróságok létezése, amelyek nem választott, illetve reprezentatív intézmények, továbbá hatáskörükben áll az alkotmányos normakontroll gyakorlása a végrehajtó és a törvényhozó hatalom irányában is. ${ }^{32} \mathrm{~A}$ harmadik előfeltevés a társadalom többségének alapjogtudatossága, az alapjogok iránti elköteleződése, az emberi jogokról világszerte kialakult konszenzus elfogadása. ${ }^{33}$ Végül a negyedik előfeltevés az, hogy az alapjogi diskurzusban nincs teljes egyetértés, az alapjogok elfogadott zsinórmértékének konkrét alkalmazása kapcsán eltérő álláspontok alakultak ki. ${ }^{34} \mathrm{Ha}$ ezek a feltételek fennállnak, akkor Waldron szerint nincs szükség a bírói alkotmányos normakontroll gyakorlására, egyrészt azért, mert nem szükségszerü az a következtetés, hogy a bíróságok hatékonyabban védik az alapjogokat a jogalkotónál, másrészt azért, mert az eljárásuk antidemokratikus lenne.

Ely és Waldron processzualista szemlélete felveti a kérdést, hogy mennyiben érdemes őket az alkotmányos normakontroll hatókörét szükre szabó elképzelések közé sorolni ahelyett, hogy az aktivizmus fogalmát meghaladó elméletek között kerülnének feltüntetésre, de ezt annyiból mégis indokoltabbnak látom, hogy a „főszabály” náluk a passzív bírói részvétel, és ehhez képest a rendhagyó állapotot jelenti az, ha az alkotmányos normakontrollért felelős bíróságnak fel kell lépnie meghatározott alapértékek védelmében. Az alkotmányos normakontroll egyik rendeltetése náluk voltaképpen az, hogy helyreálljon az a demokratikus társadalmi diskurzus, amelyet - ha rendesen funkcionál - egyébként magától a bírói aktivizmustól is óvni kell.

A demokratikus legitimáció problémája mellett az alapjogi aktivizmussal szembeni fő érvek közé tartoznak a jogbiztonsággal kapcsolatos aggályok. Ezek a megfontolások mutatkoznak meg például Leishman okfejtésében, aki a common law-ból ismert stare decisis elvének illegitim felrúgásaként értékelte az alapjogok kiterjesztő értelmezését, és úgy foglalt állást - a common law elméletének klasszikusai nyomán -, hogy a bírói jogfejlesztés csak lassú, fokozatos lépésekkel alakíthatja át a jogot. ${ }^{35}$

\footnotetext{
${ }^{31}$ Waldron, Jeremy: The Core of the Case Against Judicial Review. In The Yale Law Journal, Vol. 115, Issue 6, 2006, 1361-1362. o.

32 Waldron: i. m. 1363. o.

${ }^{33}$ Waldron: i. m. 1364-1365. o.

${ }^{34}$ Waldron: i. m. 1366-1367. o.

${ }^{35}$ Leishman, Rory: Against Judicial Activism - The Decline of Freedom and Democracy in Canada. McGillQueen's University Press, Montreal - Kingston, 2006, 26-29. o.
} 


\section{II.1.3. Kísérletek az aktivizmus fogalmának meghaladására}

Az aktivizmus fölötti szakirodalmi csatározások olyan közvetlen politikai és értékvonatkozásokkal bírnak, amelyek vonzóvá és kézenfekvővé teszik azt, hogy az elemző a számára felkínált bináris oppozíció egyik tagja mellett törjön lándzsát. Kevésbé szerencsés esetben ez közvetlen politikai-ideológiai értékválasztás eredménye, szerencsésebb helyzetben egy átfogóbb elméleti keret szerinti döntésből fakad. Viszonylag ritkább eset az olyan állásfoglalás, amely mindenestül felül akar emelkedni ezen a kettős kategorizáláson. Az ilyen törekvések fő megoldandó problémája megítélésem szerint az, hogy ez a meghaladás mennyiben lehet sikeres. Ugyanis míg egyfelől az aktivizmusról szóló vitát valóban eltorzíthatják a politikai-ideológiai ítéletek - melynek következtében a vita átcsaphat a másik oldal „túlkapásainak” felhánytorgatásába -, másfelől a problémakör természetéből adódóan nem nélkülözi a politikai vonatkozásokat, hiszen elválaszthatatlanul összefonódik a hatalomgyakorlás (mit tehet, mit nem tehet a legföbb népképviseleti szerv) és a közjó (mely szervek milyen eszközökkel járulhatnak hozzá a közjó előmozdításához) kérdéseivel. Ezért indokolt a meghaladási kísérleteket hasonló szkepszissel fogadni, mint az aktivizmus fogalmával nyíltan operáló megközelítéseket.

Epstein a korábban már hivatkozott tanulmányában arra mutat rá, hogy az alkotmány rendelkezéseinek egzaktabb vagy kevésbé egzakt jellege (konkrét példák gyanánt Epstein az elnökjelöltség korhatárát, illetve az első alkotmánykiegészítés szólásszabadságot védő elöírását hozza fel) meghatározza a bíró mozgásterét, és mivel a bírónak minden esetben kötelessége az elé kerülő norma alkalmazása, ezért tevékenységének az aktivizmusönkorlátozás dimenziójában való értékelése félrevezető. ${ }^{36}$ Hasonlóképp érvel Chemerinsky is, aki az alkotmányos normakontroll és a többségi akarat szembeállítását tartja helytelen kérdésfeltevésnek, ehelyett ő is az alkotmányos előírások eredendő értelmi bizonytalanságára helyezi a hangsúlyt. ${ }^{37}$ Csakhogy a kérdésfeltevés önmagában ezen a módon történő átformálása nem változtat magának a problémának a lényegén, ami viszont kétségtelenül az, hogy adott egy szűk grémium, amely a nyilvánvalóbb legitimációval ${ }^{38}$

\footnotetext{
${ }^{36}$ Epstein 2002: 86-88. o.

${ }^{37}$ Chemerinsky, Erwin: The Price of Asking the Wrong Question: An Essay on Constitutional Scholarship and Judicial Review. In Texas Law Review Vol. 62, 1984, 1211-1212. o.

38 A „nyilvánvalóbb legitimáció” alatt a jelen kontextusban azt értem, hogy a jogalkotó a többségi demokrácia elvének logikája miatt az átlagember számára magától értetődőbb legitimációval rendelkezik, mint az alkotmánybíráskodást végző szervek. Az előbbi tagjait ugyanis közvetlenül a választópolgárok választják, emiatt az ő döntéseik elfogadhatóbbak, mint az absztrakt értékek védelme érdekében létrehozott és működő alkotmánybíráskodást végz szervek. Meg kell azonban jegyezni, hogy a jogalkotó demokratikus
} 
rendelkező jogalkotói testület mozgásterét korlátozza, és meg kell határozni a kettő viszonyát, más kifejezésekkel élve: fel kell oldani a feszültséget a két végpont, a többségi demokrácia elve és az alkotmánybíráskodás között. Ezért álláspontom szerint nem szükségképpen a probléma újrafogalmazására kell törekedni, sokkal inkább azt kell tudatosítani, hogy amikor az alapjogi aktivizmus tematizálására kerül sor, akkor egy, a szakmai diskurzus érdekében és annak kontextusában depolitizált terminusról van szó, és e terminus alkalmazása meghaladja-meghaladhatja a politikai-ideológiai vádaskodásokat. Igaz ugyan, hogy az „aktivizmus” szó alkalmazása szükségképpen implikál bizonyos normatív tételeket a bírói szerepet illetően, ${ }^{39}$ ez azonban nem szükségszerüen jár, és nem is járhat az elfogulatlan szakmai diskurzus csorbulásával.

Mindemellett az aktivizmus-passzivizmus polarizáción túlmutató elméletek közül érdemes kiemelni Dyevre elképzelését. Dyevre kétféle hipotetikus szerződésen alapuló modellt vázol fel. A „megbízásos” (Principal-Agent) modell értelmében a normakontrollt végző szerv az alkotmányozó megbízottjaként juttatja érvényre az alkotmányban foglalt elöírásokat. A „vagyonkezelői” (Trustee) modell szerint a normakontrollért felelős szerv feladata annak biztosítása, hogy a jogalkotó a lehető legjobb, avagy legalább Paretooptimális eredményt érje el tevékenysége során. ${ }^{40}$ Ezekből az egyszerü és kézenfekvő hasonlatokból aztán az alkotmánybíráskodás egy sor különféle funkciója következtethető ki. A megbízásos modell esetében ez a feladat mindenekelött a normaalkalmazásban határozható meg, a vagyonkezelői modell esetében pedig a jogalkotás optimalizálásában. Ezek a funkciók természetükben eltérnek egymástól, és míg az első modell alapján a politikamentesség az egyik fő elvárás a norma alkalmazójával szemben, addig a második modell elfogadja, hogy ez tökéletesen soha nem valósulhat meg, ${ }^{41}$ és inkább arra törekszik, hogy a megfelelő irányba csatornázza a norma alkalmazójának társadalompolitikai meggyőződését. ${ }^{42}$ Vagyis Dyevre aktív politikai ágensként tekint az alkotmánybíráskodást végző szervekre, és nem szorítkozik mindenáron a teljesen „semleges”, „értékmentes” alkotmánybíráskodás eszméjéhez, ehelyett arra törekszik, hogy a jogalkalmazói meggyőződést valamiféle ésszerü mederbe csatornázza. Itt az alkotmánybíráskodás nem

\footnotetext{
legitimációjának e nyilvánvaló jellegét némiképp megkérdőjelezik azok a felmérések, amelyek szerint az alkotmánybíráskodást végző szervek jellemzően kimagasló mértékü bizalmat élveznek a lakosság részéröl.

${ }^{39}$ Roberts, Caprice L.: In Search of Judicial Activism: Dangers in Qualifying the Quantitative. In Tennesse Law Revire Vol. 74, 2007, 569-570. o.

${ }^{40}$ Dyevre, Arthur: Technocracy and distrust: Revisiting the rationale for constitutional review. In International Journal of Constitutional Law, Vol. 13, 2015, 32. o.

${ }^{41}$ Dyevre: i. m. 40 . o.

${ }^{42}$ Dyevre: i. m. 47 . o.
} 
azt az „éjjeliör"-funkciót tölti be, mint a fentebb bemutatott processzualista elképzeléseknél, hanem inkább egyfajta tevőleges partnerként jelenik meg.

\section{II.2. Bírói és alapjogi aktivizmus}

Az aktivizmusra leggyakrabban aggatott e két jelző tárgyalása mellett nem lehet szó nélkül elsiklani, meglátásom szerint ugyanis az eltérő jelzők eltérő jelentéstartományt ölelnek fel.

A „bírói aktivizmus” kifejezés különösen az Egyesült Államok irodalmában sürün használatos; releváns könyvek és tanulmányos egész sora e kifejezéssel jelöli meg vizsgálódása tárgyát. ${ }^{43}$ A tengerentúlon azonban ez más felhangokkal bír, mint a kontinentális jogi kultúrában. Az aktivizmus fogalma a napjaink jogtudományban óhatatlanul összekapcsolódott az alkotmánybíráskodással. Az Egyesült Államokban ez a rendes bírói szervezet hatáskörébe tartozik, míg Európában, így hazánkban is, a bírói szervezettől elkülönült, sui generisként felfogott ${ }^{44}$ testületébe. Az utóbbi esetben a "bírói aktivizmus" kifejezés a rendes bíróságok tevékenységének minősítését is magában foglalja, függetlenül attól, hogy azok a jogi lehetőség mellett ténylegesen mennyire veszik figyelembe az alkotmányos rendelkezéseket értelmezési tevékenységük során. ${ }^{45}$

A fentieken túl érdemes utalni arra, hogy amennyiben az ,aktivizmus” fogalmához a bíróságok „illegitim hatáskörtúllépését” társítjuk, a hosszabb távú hatással bíró, kiterjesztő jogértelmezést tartalmazó ítéletek, melyek valamely másik hatalmi ág cselekvési szabadságát korlátozzák, szintén beleesnek az „aktivizmus” fogalmi körébe.

\footnotetext{
${ }^{43}$ Lásd a tanulmányban meghivatkozott szakirodalmi müvek többségének címét.

${ }^{44}$ Vö. 1350/B/1992. AB határozat, ABH 1993, 619, 620. Hozzá kell tenni, hogy nálunk az Alaptörvény negyedik módosítása hatályon kívül helyezte a 2012 elötti alkotmánybírósági határozatokat, és az Alkotmánybíróság egyelöre nem foglalt állást jogi helyzetét illetően a 2012-t követő szabályozási környezetben, azonban tekintve, hogy megmaradt elkülönült intézménynek, nem valószínű, hogy ez a hitvallás megváltozott volna.

${ }^{45}$ A magyar bíróságokra például az Alaptörvény hatályba lépése elött jellemző volt, hogy noha nem volt kifejezett akadálya annak, hogy az alkotmányos rendelkezéseket beépítsék jogértelmező gyakorlatukba, azt mégsem tették. Vö. Pokol Béla: Jogelmélet. Századvég Kiadó, Budapest, 2005, 237-239. o., Bencze Mátyás: Díszítőelem, álcázóháló vagy tartóoszlop? - A büntetőbírói gyakorlat és az Alkotmány. In Fundamentum, 2007/3. szám, 18-19. o., Tóth J. Zoltán: Jogértelmezési módszerek a bírói gyakorlatban. In Jogelméleti Szemle, 2009/4. szám, http://jesz.ajk.elte.hu/tothj40.mht (2012. szeptember 14.). Ezzel szemben ismert, hogy a német Szövetségi Munkaügyi Bíróság 1957-ben egy ítéletében kifejezetten a Grundgesetz szabad házassághoz való jogot deklaráló rendelkezése alapján semmisített meg egy munkaszerződést; vagyis itt olyan, "aktivizmusként" jellemezhetö lépéssel állunk szemben, mely nem egy alkotmánybírósághoz köthető. Az esethez lásd: Pokol 2005: 83. o.
} 
Az „alapjogi aktivizmus” szűkebb fogalom, mely nem az aktivizmus alanyával, hanem annak tárgyával áll összefüggésben. Egy állam alkotmánya „kifejezi a társadalmi berendezkedés alapjait, meghatározza a társadalom és az állam viszonyát, megállapítja és biztosítja az alapjogokat, a jogegyenlőséget, szabályozza az államszervezet felépítését és müködését." ${ }^{46}$ A modern jogrendszerekben ezek a jogosultságok egyúttal alapjogi igényt is keletkeztetnek a sértett fél oldalán, aki - az érintettség bizonyos mértékü fennállása esetén - követelheti alkotmányos jogai sérelmének orvoslását. Meglátásom szerint két fő okra vezethető vissza, hogy az ilyen tárgyú beadványok elsősorban alapjogi jellegü rendelkezéseken alapulnak, s e körülmények egyúttal azt is megmagyarázzák, miért kézenfekvő az aktivizmust ,,alapjogiként” jellemezni.

Egyrészt az alapjogok értelmezése olyan terület, ahol a jogtudomány és a „külső” (például morálfilozófiai vagy gazdaságtani) megfontolások látványosan összefonódnak; másfelől pedig az alapjogokhoz kapcsolódó problémákkal könnyebb azonosulni, mint a mindennapi gondolkodástól távolabb eső államszervezeti problémákkal. Az átlagember nagyobb eséllyel fordul alkotmánybíráskodást végző fórumhoz azért, mert úgy érzi, egy konkrét jogszabályi rendelkezés alkotmányellenesen diszkriminálja őt más, hasonló helyzetű személyhez képest, vagy alkotmányellenes mértékben korlátozza a vallásszabadságát, mint azért, mert a kifogásolt jogszabályhely megsérti a hatalmi ágak elválasztásának vagy az alkotmányos szervek együttmüködésének követelményét.

Másrészt - ám a fentebb kifejtettektől nem függetlenül - az alapjogok kellően absztraktak ahhoz, hogy a legkülönfélébb jogvitákkal összefüggésbe hozzák őket a beadványozók. Nem igényel különösebben kimagasló jogászi leleményességet annak levezetése, hogy egy jogszabályi rendelkezés az emberi méltósághoz való jogba, a diszkrimináció tilalmába, vagy éppen a tisztességes eljáráshoz való jogba ütközik. Hazánkban az Alkotmánybírósághoz benyújtott beadványokban visszatérő elem az emberi méltósághoz való jogra, illetve a diszkrimináció tilalmára való hivatkozás, ${ }^{47}$ az Egyesült Államokban különösen a szólásszabadság, az élethez, szabadsághoz, tulajdonhoz való jog, valamint a diszkrimináció tilalma képezi számos, a Supreme Courthoz benyújtott beadvány

\footnotetext{
${ }^{46}$ Takács Imre: Az alkotmány és az alkotmányosság fogalma. In Kukorelli István (szerk.): Alkotmánytan I., Osiris Kiadó, Budapest, 2010, 23. o.

${ }^{47}$ Az emberi méltósághoz való jogot a 2011. december 31-ig az Alkotmányról szóló 1949. évi XX. törvény (Alkotmány) 54. § (1) bekezdése, 2012. január 1-jétől az Alaptörvény II. cikke biztosítja; a diszkrimináció tilalmát az Alkotmány 70/A. § (1) bekezdése, illetve az Alaptörvény XV. cikke, különösen a (2) bekezdés mondja ki.
} 
alapját. ${ }^{48} \mathrm{Az}$ érintett indítványozók tehát nagyobb eséllyel veszik igénybe az alapjogi rendelkezések nyújtotta lehetőségeket, mint például a kifejezetten államszervezeti kérdéseket szabályozó elöírásokat.

\section{II.3. Egyedi döntések és tendenciák}

Aktivistának nevezhető egy-egy egyedülálló döntés, de nevezhető annak egy adott bíróság is egy adott időszakban, mely utóbbi esetben azt állítjuk, hogy bizonyos kérdésekben ítélkezési gyakorlata szisztematikusan olyan jegyeket mutat, amelyek így vagy úgy aktivizmusra utalnak. Egy-egy specifikus döntés önmagában való kiemelése elhomályosítja a tágabb összefüggéseket, amelyek hozzátartoznak az aktivizmus jelenségéhez. Példának okáért az ilyen megközelítésmód semmit nem segít annak feltárásában, milyen hosszú távú hatásai vannak a kérdéses döntésnek, vagy milyen gyakorisággal születtek döntések hasonló eredménnyel és hasonló indokolással. A másik oldalon kizárólag az átfogó tendenciák szem előtt tartása téves nézőpontot eredményezhet, mely az aktivizmusprobléma kvantitatív aspektusait hangsúlyozza, például oly módon, hogy egy kutatás pusztán az alkotmányellenessé nyilvánító döntések statisztikai arányát mutatja ki, ám nem bocsátkozik az e döntésekben megjelenő érvelési sajátosságok mélyebb elemzésébe. Természetesen e két megközelítésmód szükségszerüen összefügg, és nem zárják ki kölcsönösen egymást, mi több, kifejezetten kedvezö, ha a kutató mindkettőt tekintetbe veszi, mindazonáltal indokoltnak gondolom ezt az analitikai különbségtételt, mert jelentőséggel bír az aktivizmus definiálására irányuló egyes kísérletek tárgyalásánál.

\section{II.4. Az alkotmányos normakontroll természetének és terjedelmének időbeli változásai}

Az aktivizmusdefinícióra tett kísérlet szempontjából nem elhanyagolható az időtényező, ami a jelen értekezés szempontjából kiemelt jelentőséggel bír, ugyanis a Supreme Courtnak a Lochner-ítélettel fémjelezhető korszaka két nagy periódus közé esik. Ezek a periódusok Christopher Wolfe elemzése nyomán kerülnek ismertetésre.

48 A szólásszabadságról az első, a többi felsorolt alapjogról a tizennegyedik alkotmánykiegészítés rendelkezik. 
Wolfe a bírói normakontroll három típusát különbözteti meg, melyek történetileg egymást követve jelentek meg az idők során. Korszakolása szerint a „tradicionális” (traditional) normakontroll az Egyesült Államok megalakulásától a XIX. század végéig tartott. E gyakorlat alkotmányszemléletét az jellemzi, hogy a jogrendszer alaptörvényét világosan meghatározható jelentéssel bíró, koherens egésznek tekinti, melynek értelme a szöveg, valamint az alkotmányozó ésszerűen feltételezhető szándéka alapján egyértelmüen meghatározható. Az alkotmány jelentésének elsődleges forrása az előbbi volt, az utóbbi források kiegészítésként jöhettek számításba, amennyiben a szöveg önmagában nem bizonyul kielégítőnek. Emellett a bírák az alkotmányt - részben írott jellegénél, részben a jogrendszerben betöltött szerepénél fogva - közvetlenül alkalmazandó jogszabálynak tekintették, melynek elsőbbsége természetét tekintve semmiben nem különbözik például egy törvénynek az alacsonyabb szintű rendelettel szembeni elsőbbségétöl. ${ }^{49}$

Az alapítás környékén még vita tárgya volt a bírói alkotmányos normakontroll létjogosultsága. Végső soron az a tábor került ki győztesen e vitából, amelyik a normakontroll legitim voltát hangsúlyozta, ám annak terjedelme meglehetősen korlátozottnak bizonyult. A Supreme Court ebben az időszakban jellemzően tartózkodott a jogszabályok alkotmányellenessé nyilvánításától, amit egyebek között John Marshallnak a McCulloch v. Maryland-ítélet indokolásában tett, unos-untalan idézett megjegyzése is alátámaszt. Amikor a Supreme Court akkori elnöke úgy fogalmazott, „egy alkotmány az, amit értelmezünk", ${ }^{50}$ akkor arra célzott, hogy az alkotmányértelmezésért elsősorban felelős testületnek megszorítóan kell értelmeznie az alapnorma rendelkezéseit, mert csak így érhető el az, hogy ne korlátozzák a jogalkotót a változó társadalmi problémák adekvát megoldásában. ${ }^{51}$

A tradicionális normakontrollt az ,átmeneti” (transitional) követte, melyet Wolfe a XX. század elejére datált, és lényegében a Supreme Court jellemzően konzervatív aktivizmusként felfogott időszakával azonosított. Ez a tizennegyedik alkotmánykiegészítés megszületésével, illetve a hozzá kapcsolódó alkotmányértelmezési gyakorlat megváltozásával hozható összefüggésbe. A megfelelő eljárás és az egyenlő törvényi védelem követelményét a tagállamok számára előíró, illetve az Egyesült Államok állampolgárai „kiváltságainak és előjogainak” (privileges and immunities) csorbítását

\footnotetext{
${ }^{49}$ Lásd: Wolfe, Cristopher: The Rise of Modern Judicial Review. From Constitutional Interpretation to Judge-Made Law. Basic Books, New York, 1986, 41-51. o.

$50,[I]$ t is a constitution we are expounding." 17 U. S. (4 Wheat.) 407

${ }^{51}$ Erre hívja fel a figyelmet például Scalia, amikor az „élő alkotmány” eszméjével szembehelyezkedve érvel az originalista alkotmányértelmezés mellett. Scalia, Antonin: Originalism: The Lesser Evil. In University of Cincinnati Law Review, Vol. 57, 1989, 852-853. o.
} 
nekik megtiltó módosítás eredeti célja a polgárháború után felszabadított rabszolgák bizonyos - jogainak védelme volt, ${ }^{52}$ általános megfogalmazása azonban lehetővé tette, hogy a faji szegregációval közvetlen összefüggésben nem álló élethelyzetekre is alkalmazzák, és különösen a megfelelő eljárási klauzula formális-eljárási jogosultságból szubsztantív alapjogvédelmi eszközzé váljon. A Supreme Court számára ezzel az értelmezésbeli váltással nyílt meg annak lehetősége, hogy a „szabadsághoz” - e vonatkozásban föként a szerződési szabadsághoz - és a tulajdonhoz való jog védelmére hivatkozva alkotmányellenesnek nyilvánítson egyes - elsősorban tagállami - jogszabályi rendelkezéseket. E bírói attitüd egy természetjogias gondolkodásban gyökerezett, amely előfeltételezett egy bizonyos „természetes igazságosságot”, ${ }^{33}$ és a Supreme Court ehhez mérte az előtte megtámadott rendelkezést. ${ }^{54}$

Wolfe tipológiájában a bírói normakontroll harmadik típusa a „modern” (modern) normakontroll, mely álláspontja szerint az 1950-es években elindult ,alapjogi forradalom” terméke. Ennek az időszaknak fö sajátossága az ,élő alkotmány” koncepciója, az az elképzelés, hogy az alkotmány elvont rendelkezéseit mindig annak a kornak a fényében kell értelmezni, amelyben alkalmazzák, a változó idők ugyanis változó alapjogsérelmeket szülnek, és ezek csak egy, az új kihívásokhoz folyamatosan alkalmazkodó értelmezési gyakorlattal orvosolhatók. A modern bírói normakontroll ennek megfelelően kiterjesztő alkotmányértelmezéssel párosul, amelynek forrása néhány magasabb szintű rendezőelvben jelölhető meg; ezek a rendezőelvek olykor az alkotmány írott szövegén kívüli elvek, értékek is lehetnek. ${ }^{55}$ Emellett a modern normakontrollnál megfigyelhető a perindítási jogok, az érintettség fogalmának kiterjesztése. ${ }^{56}$

\footnotetext{
${ }^{52}$ Wolfe: i.m. 125. o.

${ }^{53}$ Wolfe: i.m. 147. o.

${ }^{54}$ A szakirodalom többsége egyetért abban, hogy az amerikai alkotmányozás hátterében is - részben - az újkori természetjog eszméje - az elidegeníthetetlen alapjogok létének előfeltételezése - állt. Ez az eszme sarkallta az alkotmányozót az alapjogi katalógust tartalmazó Bill of Rights elfogadására is, melynek szükségességéről egyébként komoly viták folytak. A természetjog érvényesülésének módja azonban vitatott. Egyrészt maga az írott alkotmány, pontosabban annak alapjogi katalógusa a természetjogi eszme szülötte az alapvetöen erkölcsfilozófiai jellegü elvek az alkotmány szövegében pozitiválódtak -, ugyanakkor e pozitiválódás magában foglalja az alkotmányszöveg elégtelenségét, az alkotmányos joghézag lehetőségét is bizonyos sérelmek esetén, amire egy lehetséges válasz az alkotmányszövegen túli forrásokhoz való visszanyúlás. Egyes álláspontok szerint már az alkotmányozók koncepciója magában foglalta azt, hogy szükség esetén a bíróságok az alkotmányon kívüli forrásra alapozzák döntéseiket. Más áláspontok ezt vitatják. Vö. pl. Sherry, Suzanna: The Founders' Unwritten Constitution. In The University of Chicago Law Review, Vol. 54, 1987, 1127-1177. o.; valamint Michael, Helen K.: The Role of Natural Law in Early American Constitutionalism: Did the Founders Contemplate Judical Enforcement of "Unwritten" Individual Rights? In North Carolina Law Review, Vol. 69, 1991, 421-490. o.

55 Ennek példája Brennan párhuzamos indokolása a halálbüntetés alkotmányosságával kapcsolatos, a Supreme Courtot rendkívüli mértékben megosztó Furman v. Georgia-ítéletben. A „kegyetlen és szokatlan büntetések" (cruel and unusual punishments) kiszabását megtiltó nyolcadik alkotmánykiegészítés értelmezése során Brennan a rendelkezés alkalmazásának vezérfonalaként az emberi méltóság elvét jelölte
} 
Ebben a fogalmi keretben tulajdonképpen - Wolfe saját bevallása szerint is - az alkotmánybíráskodás, az alkotmányos normakontrollt végző szerv szerepfelfogásának két ellentétes pólusa érhető tetten. A tradicionális normakontroll a „bírói önmegtartóztatásnak”, a modern normakontroll a „bírói aktivizmusnak”, feleltetheto meg, ${ }^{57}$ avagy másképpen megfogalmazva az „aktivizmus-passzivizmus” kettősnek. E megközelítés szerint az önmegtartóztatás és az aktivizmus közötti különbségtétel nem is egyszerüen fokozati, hanem minőségbeli különbség, mert két teljesen eltérő hatalomfelfogást tükröznek.

Ugyanakkor a hármas korszakolás és e dichotómia összevetéséből látható, hogy vitás marad, hol helyezhető el az átmeneti normakontroll. Wolfe jellemzése alapján az a kép alakul ki, hogy egyfelől a tradicionális korszakot az alkotmányellenessé nyilvánítástól való tudatos tartózkodás jellemzi, másfelől a modern korszakot a bírói jogalkotás: „,[e] keretek között a bírói aktivizmus a „törvényhozó” hatalom bíróságok általi gyakorlása az alkotmányos ügyekben". ${ }^{58} \mathrm{Az}$ átmeneti korszak azonban a kettő valamiféle keveréke: egyrészt adott az a felfogás, hogy a bíró nem gyakorolhatja a törvényhozó jogait - ezt az érvet a XX. század első évtizedeiben még azokban a döntésekben is látványosan hangsúlyozta az előadó bíró, amelyek egyébként alkotmányellenessé nyilvánították a támadott rendelkezést -, másrészt viszont az alkotmányellenessé nyilvánításokkal mégis különösen a Roosevelt-érában - jelentős mértékben akadályozták a törvényhozó „társadalmi kísérletezéseit”. Vagyis a Supreme Court nem igyekezett a törvényhozó helyébe lépni, ugyanakkor tevékenységének számottevő gátjává vált. ${ }^{59}$

Részben tartom helytállónak azt is, hogy Wolfe a modern aktivizmust a „bírói jogalkotással" azonosítja. Tagadhatatlan, hogy a XX. század közepétől születtek olyan döntések, amelyek pozitív tartalmi szempontokat írnak elő a jogalkotó számára

meg, egy olyan elvet, amely nincs nevesítve az Egyesült Államok alkotmányában. Szerinte ebből négy további elv vezethető le a szóban forgó alkotmánykiegészítés vonatkozásában. 1. Bizonyos cselekményekért, állapotokért az emberek egyáltalán nem büntethetők, mert a büntetés, legyen bármilyen enyhe is, önmagában sérti az emberi méltóságot (ilyen eset például az, ha valakit azért sújtanak szankcióval, mert beteg). 2. A súlyos büntetések (severe punishments) nem alkalmazhatók önkényesen. 3. A súlyos büntetés nem lehet elfogadhatatlan a korabeli társadalom szemében - ezt az elfogadhatatlanságot Brennan objektív fogalomként kezeli, aminek nem szabad a bíró személyes belátásától függenie. 4. A súlyos büntetés nem lehet túlzó, vagyis nem irányulhat a szenvedés szükségtelen, öncélú okozására. Vö. 408 U. S. 270-282 (1972).

${ }^{56}$ Ehhez lásd bővebben az II.4. szakaszban a Roe v. Wade-ügy kapcsán elmondottakat!

${ }^{57}$ Wolfe, Christopher: Judicial Activism. Roman \& Littlefield Publishers, Lanham, 1997, 30. o.

58 „Judicial activism, in this framework, is the exercise of »legislative« power by courts in constitutional cases." Uo.

${ }^{59}$ Itt feltétlenül utalni kell rá, hogy Wolfe elemzéséből is a szakirodalom számottevő részére jellemző előfeltevés sejlik ki, miszerint a Supreme Court rendszeresen és következetesen hozott alkotmányellenessé nyilvánító döntéseket, annak ellenére, hogy a statisztikák ezt a feltevést nem támasztják alá. A „,konzervatív aktivizmus" lehetséges értelmezéseit, megközelítési módjait a következő fejezetben tárgyalom behatóbban, itt most magának az aktivizmus jelenségének a beazonosítási problémáira szeretném felhívni a figyelmet. 
alkotmányossági kritériumként. A Miranda-ítéletben a terhelt kihallgatásának alkotmányos szabályozásáról értekezett a Supreme Court, a Roe v. Wade-ügyben pedig a terhesség egyes trimesztereire vonatkozólag meghatározta, melyek azok a legitim indokok, amelyekre alapozva az állam korlátozhatja a várandós nő önrendelkezési szabadságát. Ugyanakkor Wolfe a Brown v. Board of Education-ügyet tekinti a bírói normakontroll modern korszaka kiindulópontjának. ${ }^{60}$ Márpedig a Brown-ítélet indokolásában nem található meg az a fajta szubsztantív kritériumállítás, ami egyes későbbi döntésekre jellemző volt. Megítélésem szerint a döntés nem tekinthető „bírói jogalkotásnak”, mert a Supreme Court pusztán annyit mondott ki, hogy az oktatásban a faji alapú szegregáció alkotmányellenes. Természetesen tagadhatatlan, hogy ez a döntés alapvető fordulatot jelentett mind az amerikai alkotmányjogban, mind az ország politikai életében - mint Wolf fogalmazott: a testület „megparancsolta” az integrációt. ${ }^{61}$ Ám ennek ellenére az alkotmányos korlát, melyet a Supreme Court felállít benne, nem határoz meg több tartalmi kritériumot a jogalkotó számára annál, ami egy alkotmányjogi tárgyú döntésben szükségszerűen benne rejlik (negatív módon), és ami a döntés precedensértékénél fogva szükségszerűen befolyásolja más, kapcsolódó tárgyú jogviták kimenetelét - vagyis bár a Brown-ítélet, az esetjogi szemléletnek megfelelően, a szegregáció alkotmányellenességét kifejezetten az oktatás vonatkozásában állapította meg, számítani lehet rá, hogy a döntés indokai alapján az más területeken, például a tömegközlekedésben sem fogja kiállni az alkotmányosság próbáját. ${ }^{62}$ A Brown-ítélet ennélfogva aligha tekinthető a Wolfe által definiált, és a bírói aktivizmussal azonosított modern bírói normakontroll esetének, jogelméleti jelentősége inkább az indokolás érvelésének természetében ragadható meg, amennyiben a társadalmi vélekedéshez való viszonya megváltozott a korábbi döntésekhez képest, és míg a korábbi felfogás szerint a bíró a jogot az élet passzív „követőjévé” teszi, és a mindennapi valósághoz igazítja, addig a Brown-ítéletben tetten érhető felfogás értelmében a jogot a közfelfogás aktívan alakítására használja. ${ }^{63}$

Másfelöl fel kell hívni a figyelmet arra, hogy ha a Miranda- és a Roe-ítéleteket a bennük megfigyelt kritériumállítás a „bírói jogalkotás” kategóriájába utalja, akkor hasonlót lehet elmondani az Adkins v. Children's Hospital-ítéletröl is. ${ }^{64}$ Ebben a döntésben a

\footnotetext{
${ }^{60}$ Wolfe: i.m. 23. o.

${ }^{61}$ Wolfe 1986: 263. o.

${ }^{62}$ Megjegyezhető, hogy konkrétan a tömegközlekedés vonatkozásában a Boynton v. Virginia-ítélet (364 U.S. 454 /1960/) állapította meg a szegregáció alkotmányellenességét.

${ }^{63}$ Nelson, William E.: Brown v. Board of Education and the Jurisprudence of Legal Realism. In Saint Louis University Law Journal, Vol. 48, 2004, 799. o.

${ }^{64} 261$ U. S. 525 (1923)
} 
Supreme Court egy tagállami minimálbér-törvényt nyilvánított alkotmányellenessé. Később ez az ítélet részletesebben elemzésre kerül, ${ }^{65}$ e helyütt azt kell kiemelni az indokolásából, hogy az előadó Sutherland négy pontba szedte a piacszabályozás eseteit, és általánosságban deklarálta, ezek közül melyekben alkotmányos az állami beavatkozás. E lépéssel Sutherland többet tett, mint hogy pusztán a konkrét eset vonatkozásában ítéletet mondott a szabályozás alkotmányossága fölött: hosszú távra meghatározta elöre, milyen tartalmú szabályozás tekinthető alkotmányosnak, illetve milyen nem. A döntés még magán viseli a tradicionális bírói normakontroll jellegzetességeit, amennyiben Sutherland indokolásának egyik fô sarokpontjává teszi azt az alapvetést, hogy az alkotmány szövegének jelentése kortól függetlenül mindig állandó marad, és ezt a jelentést a bíróságok csak kimondják. ${ }^{66}$ Ám tartalmában már a modern normakontrollt előlegezi meg.

\section{II.5. Az aktivizmus definiálására tett jellemző kísérletek}

Mind az aktivizmus definiálására, mind e kísérletek áttekintésére viszonylag későn került sor. Azt lehet mondani, hogy az amerikai szakirodalomban hamarabb került sor a mindenkori Supreme Court aktivizmusának kritikájára, mint az aktivizmus fogalmának a meghatározására. ${ }^{67}$ Keenan D. Kmiec az aktivizmus öt kurrens meghatározását különítette el: a más hatalmi ágak indokolhatóan alkotmányos döntéseinek megvétózását, a precedenstől való eltérést, a bírói jogalkotást, a bevett értelmezési módszerektől való eltérést, valamint az ún. eredményorientált bíráskodást. ${ }^{68} \mathrm{Az}$ alábbiakban jelentős mértékben erre a taxonómiára támaszkodok, amikor bemutatom a lehetséges aktivizmusdefiníciókat, valamint a hozzájuk kapcsolódó nehézségeket. Kmiec megközelítése rendkívül átfogó jellegén túl azért is jó kiindulópont, mert a szerző egyértelműen leíró, távolságtartó elemzést végzett, ami egybevág a jelen értekezés

\footnotetext{
${ }^{65}$ Lásd a $I V .3 .6$. szakaszt!

${ }^{66}$ Vö. 261 U. S. 544. Hozzátehetjük, hogy hasonló felfogás élt a klasszikus common law gondolkodásban is: eszerint a bíróságok csak „megtalálják” a hagyományokban és a józan észben mindig is ott rejlő helyes, méltányos megoldást.

${ }^{67}$ Vö. pl. Wright, J. Skelly: The Judicial Right and the Rhetoric of Restraint: A Defense of Judicial Activism in an Age of Conservative Judges. In Hastings Constitutional Law Quarterly, Vol. 14, Issue 3, 1987, 487523. o., Marshall, William P.: Conservatives and the Seven Sins of Judicial Activism. In University of Colorado Law Review, Vol. 73, Issue 4, 2002, 1217-1255. o.

${ }^{68}$ Kmiec, Keenan D.: The Origin and Current Meanings of "Judicial Activism”. In California Law Review, Vol. 92, Issue 5, 2004, 1463-1476. o.
} 
deklarált szemléletmódjával. Mindazonáltal Kmiec kategóriáit bizonyos pontokon helyénvalónak láttam módosítani. Az alábbi tipológia e módosítások nyomán született.

\section{II.5.1. Döntéshozatal más hatalmi ágak helyett}

Noha Kmiec a megvétózást és a bírói jogalkotást különálló fogalmakként kezelte, meglátásom szerint célszerü őket egy kategórián belül tárgyalni, ugyanis arról van szó, hogy az alkotmánybíráskodást végző szerv mindkét esetben korlátozza más hatalmi ágak a jelen tanulmány vizsgálódási körét tekintve kifejezetten a jogalkotó - döntési szabadságát, csak ennek iránya más: az egyik esetben negatív döntés születik, a jogalkotó bizonyos döntését alkotmányellenessé nyilvánítják, illetve megsemmisítik - ez a közismert kelseni „negatív jogalkotás” ${ }^{69}$-, a másik esetben egy hiányzó döntés pótlására kerül sor. Az említett két kritérium vizsgálatára ezért ennek megfelelően kerül sor.

\section{II.5.1.1. A más hatalmi ágak indokolhatóan alkotmányos döntéseinek megvétózása}

Az aktivizmusprobléma eredője a többségi demokrácia elve: a jelenség bírálói a demokratikus felhatalmazással rendelkező jogalkotó döntéseinek az alapvetően nem demokratikus úton pozícióhoz jutott - nem többségi szavazással választott, a nép felé közvetlenül nem elszámoltatható - bírák, alkotmánybírák általi felülbírálatát sérelmezik. Kmiec a meghatározást kiterjesztette a második klasszikus montesquieu-i hatalmi ágra, vagyis a végrehajtó hatalomra is, ${ }^{70}$ a jelen kontextusban azonban elegendő a törvényhozóval való konfliktusra összpontosítani.

Említést érdemel, hogy az „aktivizmus” nem keverendő össze a nyilvánvalóan alkotmányellenes döntések megvétózásával. Frank Easterbrook egy viszonylag friss tanulmányában - talán némi iróniát sem mellőzve - tulajdonképpen egy kalap alá vette az aktivizmus és a bárminemű megvétózás fogalmát, ${ }^{71}$ és egy ötven Supreme Court-döntésből

\footnotetext{
${ }^{69}$ Kelsen, Hans: General theory of Law and State. Harvard University Press, Cambridge, 1949, 268. o.

${ }^{70}$ Bizonyos esetekben az alkotmányossági felülvizsgálat élesen érintheti a végrehajtó hatalom hatáskörét is. Ilyen problémát érintett például az 1926-os Myers v. United States-ügy (272 U. S. 52), amelynek fö kérdése az volt, jogosult-e az elnök valamely jogalkotói testület jóváhagyása nélkül felmenteni a végrehajtó hatalom tisztviselőit.

${ }^{71}$ Easterbrook, Frank H.: Do Liberals and Conservatives Differ in Judicial Activism? In University of Colorado Law Review, Vol. 73, Issue 4, 2002, 1407. o.
} 
álló mintát alapul véve arra a következtetésre jutott, hogy a két nagy politikai-ideológiai oldal bírái nagyjából azonos arányban hajlanak az aktivizmusra. ${ }^{72}$ Meglátásom szerint azonban - és ezt Kmiec is kiemeli tanulmányában ${ }^{73}$ - az aktivizmus ilyetén fogalmi megközelítése egyoldalú és semmilyen szempontból nem célravezető. Egyrészt természetes dolog, hogy egy alkotmánybíráskodást végző szerv bizonyos esetekben alkotmányellenesnek ítéli az indítványozó által támadott jogszabályi rendelkezéseket, másrészt előfordulnak olyan esetek, amikor a kérdéses jogszabályhely nyilvánvalóan ellentétes a hivatkozott alkotmányos rendelkezéssel. Így például - hazai példával élve - ha egy közigazgatási tárgyú törvény valamelyik rendelkezése kizárja a másodfokú közigazgatási hatóság döntésével szembeni további jogorvoslat lehetőségét, az nyilvánvalóan ellentétes a régi Alkotmány 50. § (2) bekezdésével, illetve az Alaptörvény 25. cikk (2) bekezdés $b$ ) pontjával.

Vagyis ha a más hatalmi ág döntésének megvétózását tekintjük aktivizmusnak, tekintettel kell lenni a „könnyü” és a „nehéz” esetek létére is. Kmiec nyilván ez a szempontot is figyelembe véve alkalmazta az „indokolhatóan alkotmányos” kifejezést ezen aktivizmusdefiníció jellemzése során: a „megvétózás” akkor aktivista, ha az ügyben támadott jogszabályhely alkotmányossága mellett is felhozhatók bizonyos releváns érvek. E felfogás Oliver Wendell Holmesra vezethető vissza, aki Supreme Courton töltött évei során több többségi indokolásában, illetve különvéleményében kifejtette abbéli vélekedését, hogy a testület csak akkor nyilváníthat alkotmánysértőnek egy jogszabályhelyet, ha az egy racionálisan gondolkodó ember szerint is kétséget kizáróan ütközik az alkotmány valamely rendelkezésével. ${ }^{74}$

Ezzel a meghatározással kapcsolatban érdemes egy észrevételt tenni. Ehhez egy olyan ügyet hívok segítségül, melynek előadó bírója az imént hivatkozott Holmes volt. Az 1927-es Buck v. Bell-ügy tárgya egy virginiai eugenikai rendelkezés volt, amely bizonyos örökletesnek tartott mentális betegségben szenvedők kényszersterilizálását írta elő. Az indítványozók a tizennegyedik alkotmánykiegészítésre hivatkozva támadták e törvényt. A Supreme Court 8:1 arányban alkotmányosnak tartotta a szabályozást. ${ }^{75}$ Holmes úgy érvelt, hogy ha a társadalomnak saját fennmaradása érdekében jogában áll életerős, fiatal férfiakat megfosztani legfontosabb joguktól, az élethez való jogtól oly módon, hogy háborúba küldi

\footnotetext{
${ }^{72}$ Easterbrook: i. m. 1409-1410. o.

${ }^{73}$ Vö. Kmiec: i. m. 1464. o.

${ }^{74}$ Lásd pl. a Lochner v. New York-ügyhöz füzött különvéleményt: 198 U.S. 45, 75-76.

75 A többségi döntéssel ellentétesen egyedül a katolikus Pierce Butler szavazott. Lásd részletesebben: Leuchtenburg, William E.: The Supreme Court Reborn. Oxford University Press, New York, 1995, 14. o.
} 
őket, akkor a fortiori megteheti, hogy csekélyebb áldozatra kötelezi azokat a mentális sérülteket, aki egyébként is csak „elszívják az állam erejét”. ${ }^{76}$ Ezen indokolásban olvasható Holmesnak a mai közvélemény számára talán legsokkolóbb mondata: „[h]árom nemzedéknyi idióta éppen elég". 77 A jelen okfejtés szempontjából ez azért releváns, mert tükrözi, hogy Holmes nem pusztán a jogszabály létének egy racionális és alkotmányos indokát ismerteti, hanem tulajdonképpen nyíltan kifejezi egyetértését a szabályozással. Holmes szociáldarwinizmusa közismert az ő, valamint korának kutatói előtt. Az itt idézett indokolásban az látható, hogy Holmes olyan szabályozás elfogadhatósága mellett érvel, amelynek tartalma egybevág a saját világnézetével. Vagyis az e helyütt tárgyalt aktivizmuskritériummal éppen ellentétes helyzet áll fenn: az alkotmánybíráskodást végző szerv alkotmányosnak tartja a támadott rendelkezést, ám az a kép rajzolódik, hogy a döntés nemcsak hogy ideológiai tényezőkre is visszavezethető, de ezek a tényezők az előadó bíró meggyőződése miatt válnak perdöntővé.

Holmes esete szélsőséges példa, természetesen nem jellemző, hogy ennyire nyíltan felszínre kerüljön az előadó bíró személyes világnézeti álláspontja egy döntés indokolásában. A látensebb ideológiai mozgatórugók megléte azonban továbbra is foglalkoztatja az aktivizmus kutatóit. Különösen a Warren-bíróság ellenhatásaként megjelenő „konzervatív aktivizmus” kritizálói rónak fel egyfajta szelektív attitűdöt a Supreme Courtnak. Meglátásuk szerint a testület megengedőbb a konzervatív értékrenddel egyező szabályokkal, mint az azzal ellentétesekkel szemben.

Mindez azért érdemel említést, mert rámutatnak az aktivizmus más hatalmi ágak döntéseinek megvétózásával való azonosításának féloldalasságára. Ha egzakt definíciója vitás is, annyit nagy bizonyossággal leszögezhetünk, hogy ellenzői szerint akkor beszélhetünk aktivizmusról, ha a bíróság szereptévesztő módon von be eljárásába szubjektív értékeket. ${ }^{78}$ Mivel egy alkotmánybíráskodást végző szerv leglátványosabb intézkedése egy jogi rendelkezés alkotmányellenessé minősítése - hiszen a rendelkezés így kikerül az „élő” jogból -, kézenfekvő az aktivizmus fogalmát e kritériumra alapozni. Így

\footnotetext{
${ }^{76}$ „We have seen more than once that the public welfare may call upon the best citizens for their lives. It would be strange if it could not call upon those who already sap the strength of the State for these lesser sacrifices, often not felt to be such by those concerned, in order to prevent our being swamped with incompetence." 274 U.S. 200, 207

77 „Three generations of imbeciles are enough.” Uo.

${ }^{78}$ Mindez természetesen előfeltételezi az objektív, semleges értékek, elvek, zsinórmértékek létét. A semleges elvek alkotmányjogi alkalmazását szorgalmazza Wechsler, Herbert: Toward Neutral Principles of Constitutional Law. In Harvard Law Review, Vol. 73, Issue 1, 1959, különösen 10-20. o. Természetesen több tanulmány állítja, hogy értékítéletek nélkül képtelenség feloldani számos alkotmányjogi dilemmát. Lásd pl. Wright: i. m. 519-521. o.
} 
azonban elkerülik az elemző figyelmét azok az esetek, amikor a szubjektív meggyőződés a támadott jogszabály hatályban hagyásában realizálódik. Indokoltnak tünik tehát az alkotmányellenességet meg nem állapító döntéseket is bevonni a témával foglalkozó elemzésekbe.

Demokratikus államokban a jogalkotói döntések abból nyerik legitimációjukat, hogy egy többé-kevésbé mérvadó társadalmi többség választásokon kinyilvánított akarata áll mögöttük. Az amerikai ,alapjogi forradalom” számos mérvadó döntése e többség akaratával ellentétes. Bickel e feszültséget a „többségellenesség problémájának” (countermajoritarian difficulty) keresztelte el. ${ }^{79}$ A jelen fejezetben tárgyalt aktivizmusdefiníció egy speciális esete, amikor az alkotmánybíráskodást végző szerv olyan jogalkotói döntést nyilvánít alkotmányellenesnek, amely mögött - bírálói szerint - évszázados társadalmi meggyőződés áll.

Az 1992-es Planned Parenthood v. Casey-, ${ }^{80}$ valamint a 2003-as Lawrence v. Texasügyek $^{81}$ egyaránt olyan kérdésekkel foglalkoztak, amelyek éles vitákat generálnak a társadalomban. Az előbbi eset az abortusz kérdésével foglalkozott, revideálva a Roe v. Wade-ítéletben ${ }^{82}$ kifejtett trimeszterrendszerü abortuszszabályozási doktrínát, bevezetve helyette a rugalmasabb ,aránytalan teher” (undue burden) elvét. Az utóbbi ügyben a Supreme Court a magánszférához való jog (right to privacy) alapján bírálta felül az azonos neműek közötti konszenzuális kapcsolatok kriminalizálását alkotmányosnak tartó Bowers v. Hardwick-ítéletet. ${ }^{83}$

A Casey-ügyben Antonin Scalia különvéleményt fogalmazott meg. Álláspontja szerint az alkotmány nem teszi kötelezővé a tagállamok számára az abortusz engedélyezését, ebből következően nem nyilvánítható alkotmányellenesnek az abortuszkorlátozó szabályozás. ${ }^{84}$ Emellett az amerikai nép hosszú ideje élő hagyományai

\footnotetext{
${ }^{79}$ Bickel: i. m. 16-23. o.

${ }^{80} 505$ U.S. 833

81 539 U.S. 558

82 410 U.S. 113 (1973)

${ }^{83} 478$ U.S. 186 (1986)

${ }^{84}$ Scalia érvelése tartalmaz egy kísértetiesen Holmesra emlékeztető fordulatot. Megfogalmazása szerint „[e]gy tagállam választása két olyan álláspont között, amelyek kapcsán ésszerüen gondolkodó emberek között vita alakulhat ki, alkotmányos, akkor is, ha (mint az gyakran előfordul) sérti az abszolút értelemben vett »szabadságot«.” („A State's choice between two positions on which reasonable people can disagree is constitutional even when /as is often the case/ it intrudes upon a »liberty« in the absolute sense.") 505 U.S. 980. Holmes a következőképpen fogalmaz a Lochner-ügy különvéleményében: ,,[e]gy ésszerűen gondolkodó ember vélekedhet akként, hogy [a támadott rendelkezés] megfelelő egészségügyi intézkedés. Olyan emberek, akiket én semmi szín alatt nem neveznék ésszerütlenül gondolkodónak, fenntartanák, mint a munkaidő általános szabályozásának első állomása.” („A reasonable man might think it a proper measure on the score of health. Men whom I certainly could not pronounce unreasonable would uphold it as a first instalment of a general regulation of the hours of work.") 198 U.S. 76. A két gondolatmenet szerint tehát amennyiben
} 
szerint megengedhető az abortusz tiltása. ${ }^{85}$ Ugyanezzel az érvvel élt William H. Rehnquist is a saját különvéleményében. ${ }^{86}$ A két bíró ugyan nem használja az „aktivizmus” kifejezést, de a bírói önkorlátozást favorizáló álláspontjukból világosan következik, hogy a jogalkotó irányában megengedő bírói attitüdöt tekintik legitimnek, és ezzel szemben illegitimnek tartják a többségi ítéletben tetten érhető kiterjesztő értelmezést.

A hagyomány szerepe a Casey-ügyben egyértelmünek tünik, és kétségkívül a bírói önkorlátozás álláspontját alapozza meg. Nem ez azonban a helyzet a Lawrence v. Texasítélet esetében. A Kennedy bíró által jegyzett többségi indokolás második mondata a következő: „[h]agyományaink szerint az állami jelenlét otthon nem korlátlan." ${ }^{87} \mathrm{~A}$ szóhasználat természetesen felvet kérdőjeleket, hiszen a „hagyomány” utalhat a jogértelmezési hagyományra, bírói gyakorlatra is. Később azonban világossá válik, hogy nem csak erről van szó. A releváns szakirodalmat is felhasználó okfejtés szerint „[m]indenekelőtt meg kell jegyezni, hogy ebben az országban nincs hosszú története az önálló problémaként kezelt homoszexuális cselekmények ellen irányuló törvényeknek." ${ }^{88}$ Kennedy érvelése szerint a cél általában a gyermeknemzésre nem irányuló nemi aktusok visszaszorítása volt, nem kifejezetten a homoszexuális aktusok szankcionálása. Ráadásul a szóban forgó nemi aktusokat tiltó törvényeket sem érvényesítették az aktust kölcsönös beleegyezéssel, magánlakásban végző felnőttekkel szemben. ${ }^{89} \mathrm{Az}$ indokolás érdekes módon utal arra is, hogy a Roe-, illetve Casey-ügyek doktrínái fokozatosan erodálódtak, éppen azért, mert csak az ország hagyományaival összhangban álló alapjogok esetén alkalmazható szigorú alkotmányossági teszt. Egyúttal kiemeli, hogy - a szóban forgó esettel ellentétben a Roe- és a Casey-döntések ,az abortusz korlátozását fokozott szigorúságú vizsgálatnak vetették alá anélkül, hogy akár csak megkísérelték volna bizonyítani, hogy az abortusz szabadsága valóban a nemzet hagyományainak része." 90

Scalia különvéleményt fogalmazott meg az ügyben. Amellett érvelt, hogy az azonos nemü felnőttek közötti beleegyezéses, magánlakásban folytatott nemi aktusokat éppúgy

explicit alkotmányos tilalom nem található az adott kérdésben, az olyan szabályozás, amelyet egy józanul gondolkodó személy védhetőnek tart, alkotmányjogi indokok alapján nem tekinthető alkotmányellenesnek. 85505 U.S. 980

86 „Az amerikai nép történelmi hagyományai sem támasztják alá azt a nézetet, hogy a terhesség megszakításának joga »alapvető« jog." ("Nor do the historical traditions of the American people support the view that the right to terminate one's pregnancy is »fundamental.«") 505 U.S. 952.

87 „In our tradition the State is not omnipresent in the home.” 539 U.S. 562.

88 "At the outset it should be noted that there is no longstanding history in this country of laws directed at homosexual conduct as a distinct matter." 539 U.S. 568.

${ }^{89} 539$ U.S. 569

90 „Roe and Casey, of course, subjected the restriction of abortion to heightened scrutiny without even attempting to establish that the freedom to abort was rooted in this Nation's tradition." 539 U.S. 588. 
üldözték a hatóságok, mint bármely más, a törvény által tiltott cselekményt. ${ }^{91}$ Emellett kritizálta a többségi indokolás által használt „ébredő tudatosság” (emerging awareness) kifejezés alkalmazását is. A kifejezés alatt a többségi indokolás az azonos nemüek közötti nemi kapcsolat társadalmi elfogadásának fokozatos kialakulását érti. Scalia szerint az efféle tudatosság fokozatos kialakulása fogalmilag ellentétes azzal, ha mélyen benne gyökerezik az ország történelmében és hagyományaiban. ${ }^{92}$

A vita jól érzékelteti, hogy tartalmilag a „hagyomány” fogalma is vitatható. A jelen ítéletben mind a többség, mind Scalia hivatkozik az ország hagyományaira, évtizedesévszázados erkölcsi meggyőződésére. A „hagyomány” azonosításának e nehézsége bizonytalanná teszi a társadalmi többség meggyőződésével való szembenállásnak az aktivizmus fogalmi kritériumként való alkalmazását.

A „más hatalmi ágak indokolhatóan alkotmányos döntéseinek megvétózása” kategória egy variánsának tekinthető az aktivizmus Cross és Lindquist által azonosított megközelítési lehetőseinek egyike, melyben a többségi akarathoz, illetve az egyes kormányzati szereplők akaratához való viszony áll középpontban. ${ }^{93}$ Látni kell azt is, hogy itt a fogalom kiterjesztett jelentést nyer, ugyanis nem korlátozódik szigorúan a jogalkotó testülethez való viszonyra. A szerzőpáros ugyanakkor kritikus ezzel a megközelítéssel szemben, és az empirikus vizsgálatra alkalmatlannak találja, mert olyan pólusok rejlenek mögötte, amelyek nehezen azonosíthatók. Crossék a bírói „minimalizmus” és „maximalizmus” végleteit különítik el. Az előbbi olyan bírói attitűd, amely a fennálló doktrínák megkérdőjelezése nélkül vagy minél csekélyebb mértékü megkérdőjelezésével, fokról-fokra igyekszik azokat megváltoztatni, míg az utóbbit valló bíró nem riad vissza a radikális változtatásoktól sem, amennyiben a társadalmi körülmények változása megítélése szerint azt indokolttá teszi. Így például fentebb már vizsgált Brown-ítélet inkább a „maximalista” pólushoz áll közelebb, mert a Supreme Court radikálisan szakított a separate but equal-doktrínával. Mint Wolfe megjegyzi, a testületnek lehetőségében áll egyszerüen annak kimondása is, hogy a Topekában folyó szegregált oktatás nem biztosítja az egyenlő minőséget a különböző rasszok tagjainak, ezért alkotmánysértő a fennálló helyzet, ám ehelyett a doktrínának az oktatásban való általános alkalmazhatatlanságát deklarálta. ${ }^{94}$ Crossék szerint e dimenzió alapján nehéz behatárolni az aktivizmust, mert a

\footnotetext{
91539 U.S. 598

${ }^{92}$ Lásd uo.

${ }^{93}$ Lindquist, Stefanie A. - Cross, Frank B.: Measuring Judicial Activism. Oxford University Press, New York, 2009, 29-32. o.

${ }^{94}$ Wolfe 1986: 260. o.
} 
bíróság lépését az ügyben alperesként érintett hatóság várható viselkedése is meghatározza. Kritikájuk szerint egy szervvel vagy szervezettel (a konkrét példában egy iskolakerülettel) szemben nem alkalmazható az a szankció, ami az ítélet figyelmen kívül hagyásáért kiszabható, ez pedig a hatékony jogérvényesítés érdekében eltérő tartalmú ítélethez is vezethet a bíróságok részéröl. ${ }^{95}$

A magyar szakirodalomban Pokol Béla az alkotmánybíráskodás egyik legkorábbi elemzője és kritikusa, aki az alkotmánybíráskodás és a többségi demokrácia klasszikus dilemmájára fókuszált, így az ő elemzéseiben is a megvétózás az aktivizmus definitív attribútuma. Mindennek hátteréül azonban érdemes utalni Pokol átfogó jogelméletére, mely szerint a jog a luhmanni értelemben véve egy professzionális társadalmi alrendszer, bináris kódja pedig a jogos/jogtalan. ${ }^{96}$ A jog alrendszerén belül Pokol négy jogréteget különít el: a szövegréteget, a dogmatikai réteget, a bírói kazuisztika rétegét, és az - időben később megformálódott - alkotmányos alapjogok rétegét. ${ }^{97} \mathrm{~A}$ jelen értekezés témája szempontjából az alkotmányos alapjogok rétege releváns, mellyel kapcsolatban Pokol azt hozza fel problémaként, hogy a túlságosan tág alapjogi bíráskodás - az alapjogok természetüknél fogva nyitott, absztrakt jellegéböl következően - nyitottá teszi a jog összszerkezetét, $^{98}$ holott a modern jogrendszerrel szemben alapvető követelmény a (viszonylagos) kiszámíthatóság, másként fogalmazva a jog normarendszerének „egységes és ellentmondásmentes értelmi egésszé kell összeállnia." 99

Pokolnak az alkotmánybíráskodással kapcsolatos értékelése és kritikája ezen elméleti háttér mellett érthető meg mélyebben. Az aktivizmus problematikájához közelebb lépve Pokolnál két helyen találhatók olyan kategorizálások, amelyek az aktivizmus fogalmának

\footnotetext{
${ }^{95}$ Lindquist - Cross: i.m. 35. o.

${ }^{96}$ A társadalmi alrendszerek luhmanni elmélete szerint a modern társadalmakban végbemenő funkcionális differenciálódás eredményeként bizonyos fontos feladatok ellátására önálló alrendszerek alakultak ki, melyek valamilyen sajátos kommunikáció szerint szürik meg a társadalmi valóságból érkező sokszínủ információkat. Az alrendszerek elhatárolását e szürési szempontok alapozzák meg: az információk szürése egy-egy alrendszer-specifikus kategóriapáros, azaz bináris kód alapján történik. Pokol megfogalmazásában: „,[a] fontosabb társadalmi alapfunkciókat ellátó cselekvések, kommunikációk rögzített struktúrái egy-egy bináris kód szerinti szelektálást tesznek dominánssá az adott cselekvések, kommunikációk meghatározásánál, és a további értékszempontok szerinti szelekciókat már csak e saját univerzális értékduál prizmáján megtörve veszik figyelembe." Pokol Béla: Szociológiaelmélet. Századvég Kiadó, Budapest, 2004, 97. o. Fontos kiemelni, hogy ezt az elméletet Pokol annyiban pontosítja, hogy a bináris kódok működését és ennek alapján a társadalmi alrendszerek határainak megvonását a professzionális intézményrendszerek szintjére korlátozza, vagyis az olyan társadalmi szereplők kommunikációira, akik specializáltan végzik az adott tevékenységet, azaz olyan strukturális feltételek mellett, amelyek mellett már eleve az adott bináris kód szerint történik az adott alrendszer résztvevőjének rekrutációja, szocializációja, előmeneteli értékelése. Pokol 2004: 103. 0.

${ }^{97}$ Pokol 2005: 14-19. o.

${ }^{98}$ Pokol 2005: 89. o.

${ }^{99}$ Pokol 2005: 52. o.
} 
lehetséges megközelítéseit érintik, és mindkét esetben egy-egy hármas kategorizálással találkozhatunk.

Pokol egyrészt aszerint osztályozza az alkotmánybíráskodás típusait, hogy milyen szempontok dominálnak döntési gyakorlatában. Az első típus az ideológiai alkotmánybíráskodás, melyet Pokol „nagyobbrészt aktivistaként” jellemez, és sajátosságaként azt emeli ki, hogy annak - átfogó ideológiai elvek mentén kialakított gyakorlata a társadalmi viták hajtóerejévé, „az ideológiai szféra középpontjává” válik, vagyis a társadalmi szempontból nagy horderejü döntései egy-egy kérdésben komoly tábormegoszlásokat eredményez. Az alkotmánybíráskodást végző szerv e modell szerint egy szélesebb társadalmi diskurzus meghatározó résztvevője, melynek kommunikációja a társadalmi viták más résztvevőinek - mindenekelőtt a morális kérdésekben állást foglaló értelmiségi csoportok - nyelvén történik. Pokol mindemellett kiemeli, hogy ez a modell csak kivételes esetekben valósult meg tiszta vagy majdnem tiszta formában. ${ }^{100}$

A politikai alkotmánybíráskodás Pokol tipológiája szerint az alkotmánybíráskodás azon esete, amikor az alkotmánybíráskodást végző szerv a politikai-törvényhozási küzdelmek végső állomásává válik. Ez a típus elsősorban az olyan országokban jelenik meg, amelyekben az alkotmánybíráskodást végző szervhez csak a politikai élet szereplői fordulhatnak absztrakt normakontrollt kérve, a konkrét jogvitáikban alkotmányossági vizsgálatot kérő állampolgárok azonban nem. ${ }^{101}$

A jogászi alkotmánybíráskodás „,a morális-ideológiai diskurzusban kialakított emberi jogokat ötvözi a jogászi-jogdogmatikai tevékenység évszázadok alatt kifinomult

\footnotetext{
${ }^{100}$ Pokol 2005: 93. o. Pokol egész pontosan a következőt írja: „Az alkotmánybíróság egyes döntései utáni közvetlen ideológiai viták mindig újra meg újra provokálva, fokozatosan e döntések körül szerveződnek; a gyakorlati politikai szféra újabb impulzusokat kap absztrakt szintű, elvi politizálás mentén táborok kialakítására; a politizáló hajlamú közírók és művészeti körök egy része, mintegy alkotmányjogi szakértővé válva, tevékenységét e polémiáknak szenteli." Ez a megfogalmazás tulajdonképpen megfeleltethető az alkotmánybíráskodás diskurzuselméleti modelljének, melynek gondolatát a magyar szakirodalomban Sajó András vetette fel. Sajó az alkotmánybírósági eljárás mint nyilvános diskurzus sajátosságaként tekintett arra, hogy az állampolgárok alkotmányjogi panaszt kezdeményezhetnek, sőt, a tanulmány megírásakor még a actio popularis lehetösége is rendelkezésre állt. Az alkotmánybíróságon belüli diskurzus során „az információáramlás és az információkezelés nem akadályozott”, mivel az alkotmánybírák „mindenkitöl függetlenek és nem felelnek senkinek", ami az ideális kommunikációs közösségre jellemző vonás. Emellett az alkotmánybíróság határozataival üzen a jogalkotónak. Sajó András: Az alkotmánybíráskodás a diksurzuselmélet fényében. In Állam- és Jogtudomány, 36. évf., 1994, 32-33. o. Hozzá kell tenni, hogy Pokol a habermasi diskurzuselmélettel szemben általában véve is kritikus, részben a modern társadalmak fokozódó differenciálódása miatt (amiböl az következik, hogy egy átfogó ismeretekkel rendelkező értelmiséginek nincs és nem is lehet elmélyült tudása egy adott alrendszer, például a jog müködését illetően, pedig az egyes alrendszereket jellemző bonyolult ismerettömegek ez utóbbi tudásfajtát követelnék meg); részben pedig azért, mert a diskurzus általában véve illuzórikus, a kommunikációs folyamatokban közvetítőként résztvevő média ugyanis elfogult, az átlagemberek pedig napi tevékenységeik súlya alatt nem képesek elmélyedni és megalapozott véleményt nyilvánítani a szakértelmet igénylő morálfilozófiai kérdésekben. Ezekhez a kritikákhoz lásd Pokol 2005: 369-370. o., Pokol 2010: 60-61. o.

${ }^{101}$ Pokol 2005: 93-94. o.
} 
eljárásaival, s ez a korábbi szórványos és absztrakt viták helyett konkrét életbeli esetekkel szembesíti évről évre ezen alapjogokat." 102 Vagyis az alkotmánybíráskodásnak ez a típusa az ideológiai vitáknak kitett, ám jogi normává pozitiválódott alkotmányszöveget a fentebb említett ellentmondásmentességi követelménynek megfelelően igyekszik integrálni a jog átfogó összefüggéseibe.

Kicsivel később Pokol az „alapjogi bíráskodás jogkoncepcióiról” ír. Ezek közül az első a „parlamentitörvény-barát” koncepció, melynek képviselői illegitimnek tekintik az alapjogi bíráskodást annak demokráciadeficitjére hivatkozva, ${ }^{103}$ és csak a legszélső esetben, az alkotmányszöveggel való nyílt ütközés esetén hajlandók egy jogszabályhely alkotmányellenességét megállapítani.

Az alapjogi dogmatika koncepciója az alkotmánybíráskodás következetessége érdekében az alapjogok, alkotmányos előírások belső koherenciáját helyezi fókuszba; ${ }^{104}$ célja tehát egy kiszámítható ,,alapjogi dogmatika” megalkotása, mely a klasszikus jogágak fogalmi rendszerének megfelelően egy stabil, tartós, a szakemberek által elsajátítható támpontot ad az új és új esetek eldöntéséhez.

E hármas kategorizálásban az aktivista alapjogász koncepció kerül fedésbe az aktivizmus fogalmával: az ilyen felfogás számára az alkotmányértelmezés alapját a legelvontabb alapjogok képezik, melyeket a koncepció hívei igazságérzetüknek megfelelően értelmeznek, és adott esetben új alapjogok kiolvasztása révén nyilvánítják alkotmányellenessé, illetőleg semmisítik meg az ezen igazságérzettel ellentétes jogszabályokat, szükre szabva ezzel a jogalkotó mozgásterét. ${ }^{105}$

Pokol két kategorizálását vizsgálva és egybevetve az látható, hogy az „aktivista” és a „passzivista” végleteket azok eltérő - ám egymással szorosan összefüggő - aspektusaiban ragadja meg. Az alapjogi bíráskodás jogkoncepcióinál az alapjogi aktivista koncepció definiálásánál Pokol mintha arra helyezné a hangsúlyt, hogy az absztrakt alkotmányos alapjogokra támaszkodik, ami bizonytalan jelentéstartalmú normaszöveg. Az ideológiai alkotmánybíráskodás meghatározásánál a hangsúly arra esik, hogy átfogó ideológiai elvek határozzák meg az alkotmánybírósági gyakorlatot, és az alkotmánybíráskodás szervesen összefonódik a társadalmi vitákkal. Ezt a különbséget azért érdemes megfigyelni függetlenül attól, hogy a két kiemelt sajátosság jóformán kéz a kézben jár -, mert míg az első esetben a probléma a jogi hermeneutika síkjára tevődik (mivel a jogi szövegek

\footnotetext{
102 Pokol 2005: 94. o.

${ }^{103}$ Pokol 2005: 99. o.

104 Pokol 2005: 100. o.

${ }^{105}$ Uo.
} 
értelmezésével függ össze), addig az utóbbi esetben a jog egy meghatározott társadalomelméletének problémáját érinti (mivel arról van szó, milyen mértékben férkőzhetnek a jog alrendszerébe a rajta kívül álló, pl. eszmei-ideológiai, morális szempontok).

A Pokol-féle tipológiából a ,parlamentitörvény-barát” és az alapjogi aktivista szemléletmód szembeállítása érinti legközvetlenebbül az aktivizmusproblémát. Hasonló kettősséget észlel Jakab András is, aki a szövegpozitivista és az aktivista megközelítések között tesz különbséget - igaz, nála ez inkább távolságtartó, bemutató jelleggel történik, nem figyelhető meg az a határozott kritikai él, ami Pokol esetében. Jakab az aktivista alapjogi gondolkodás sajátosságaiként emeli ki az alkotmány egységes, összefüggő egészként való felfogását, a jövőorientált szemléletmódot - vagyis azt a törekvést, hogy az alapjogi tárgyú döntések a jövőbeli esetekre nézve is eligazítást tartalmazzanak -, a teleologikus szemléletmódot, adott esetben a szubsztantív érvekre támaszkodást, továbbá az alapjogi garanciákkal behatárolt államot középpontba helyező demokráciafelfogás. ${ }^{106}$

Az újabb magyar nyelvü szakirodalomból Varga Zs. András hasonló megközelítését érdemes kiemelni, mely bár elsősorban elsősorban a magyar Alkotmánybíróság tevékenységének értékelését célozza egy speciális történeti helyzetben, észrevételeiből kiszürhető egy sajátos aktivizmusfelfogás is.

Az 1989-es „,ideiglenes” Alkotmány, illetve a 2012-ben hatályba lépett Alaptörvény alapján müködő Alkotmánybíróság működését elemezve Varga Zs. arra a megállapításra jutott, hogy a korábbi Alkotmánybíróság működésének kezdetén a jogállamiság elvének központi jelentőséget tulajdonítva jóformán korlátlan ellenőrzési jogot hozott létre a törvényhozó aktusai fölött, ez pedig azért vált lehetségessé, mert a jogállamiság fogalmának nem volt olyan tartalmi korlátja, ami határozott irányt szabott volna az értelmezésének. ${ }^{107}$ Abban, hogy az Alkotmánybíróság ilyen jelentős szerephez juthatott a létrehozatalát követő első években, fontos szerepet játszott a rendszerváltás ténye, amennyiben az Alkotmánybíróságra hárult annak feladata, hogy a rendelkezésére álló

\footnotetext{
${ }^{106}$ Jakab András: Az Alkotmány kommentárjának feladata. In Uő. (szerk.): Az Alkotmány kommentárja I. Századvég Kiadó, Budapest, 2009, 46-47. o., illetve később Jakab András - Fröhlich Johanna: Alkotmányjogi érvelés az Alkotmánybíróság gyakorlatában. In Alkotmánybírósági Szemle, 2. szám, 2014, 83-86. o.

${ }^{107}$ Varga Zs. András: Eszményből bálvány? A joguralom dogmatikája. Századvég Kiadó, Budapest, 2015, 124-128. o. Varga Zs. az Alaptörvény hatályba lépésével orvosolhatónak tartja ezt az állapotot, részben azért, mert a Nemzeti Hitvallás mögöttes értéktartalommal látja el az alkotmányértelmezést, gátat szabva ezzel a parttalan alkotmánybírói önkénynek, részben pedig azért, mert az Alkotmánybíróság az Alaptörvény negyedik módosítása következtében köteles felülbírálni korábbi gyakorlatát az Alaptörvény rendelkezéseinek alkalmazása során. Varga Zs.: i. m. 131-135. o.
} 
eszközökkel gondoskodjon az elöző rendszerből fennmaradó jog Alkotmányhoz igazításáról. ${ }^{108}$ Vagyis megfigyelhető egyfajta kettősség: míg az Alkotmánybíróság Magyarország közjogi átrendeződése során kulcsfontosságú és elkerülhetetlen szerepet töltött be alkotmányértelmezésével, ez - a magyar alkotmányértelmezési hagyomány hiányában - egy kontroll nélküli túlhatalom kialakulásához vezetett.

Két dolgot érdemes kiemelni az aktivizmus e jellemzése kapcsán. Egyrészt megfigyelhető, hogy az aktivista gyakorlat alapjaként itt nem egy alapjogi rendelkezés jelenik meg, hanem egy alkotmányos érték, a jogállamiság: bár a jogállamiságból bizonyos esetekben alapjogi jellegü elöírások is következnek - a magyar gyakorlatban ilyen a visszaható hatály tilalma, valamint a kellő felkészülési idő -, az elsősorban nem alapjog, hanem az állammal szembeni követelmény. ${ }^{109} \mathrm{Ez}$ a megközelítés eltér attól a dimenziótól, amelyben az aktivizmus általában tematizálásra kerül. A magyar nyelvben az „,alapjogi aktivizmus" kifejezés már önmagában tükrözi, hogy az alkotmánybíráskodást végző szervek hatalmi túlsúlya gyakran valamilyen alapvető jogot megállapító rendelkezés kiterjesztő értelmezésében ragadható meg. Jól tetten érhető ez a megközelítés Pokol kritikájában, aki a Sólyom-bíróságot értékelve felhívta a figyelmet a 8/1990. (IV. 23.) AB határozat ${ }^{110}$ indokolásában az általános személyiségi jog „szubszidiárius alapjogként” való meghatározásának várható hosszú távú következményeire. Emellett az Egyesült Államok alkotmányértelmezési gyakorlatában is látható, hogy az aktivizmusról szóló szakmai viták tipikusan alapjogi jellegü elöírások körül forognak: mindenekelőtt az alapjogi színezettel bíró megfelelő eljárás követelménye, illetve az egyenlő törvényi védelem (diszkriminációtilalom) tartozik ide, ám ebbe a körbe sorolható a magánszférához (privacy) való jog, valamint a szakirodalomban csekélyebb mértékben tárgyalt, ám óriási lappangó potenciállal bíró kilencedik alkotmánykiegészítés is. ${ }^{111}$ Érdemes mindehhez

\footnotetext{
${ }^{108}$ Varga Zs.: i. m. 111-113. o. A szerző két további körülményként jelöli meg a jogállamiság normatív megjelenését, valamint Magyarországnak az Európa Tanács alapjogvédelmi rendszerébe való betagozódását, a jelen értekezés szempontjából azonban a rendszerváltást mint sajátos történelmi körülményt kell kiemelni.

${ }^{109}$ E helyütt csak jelzésszerűen kell utalni rá, hogy a magyarországi gyakorlatban például alkotmányjogi panasz föszabály szerint nem is alapítható a jogállamiság követelményére, annak sérelme ugyanis rendszerint nem eredményezi az Alaptörvényben biztosított jog sérelmét. E föszabály alól a visszaható hatály tilalma és a kellő felkészülési idő hiánya képez kivételt.

${ }^{110}$ ABH 1990, 42.

${ }^{111}$ Az Egyesült Államok alkotmányának kilencedik kiegészítése alapján az alkotmányban foglalt alapjogok nem értelmezhetők oly módon, hogy az korlátozza ,a nép által élvezett más jogokat” (rights retained by the people). A rendelkezés hagyományos értelmezése szerint „,a nép” kifejezés nem takar mást, mint az egyes tagállamokat, vagyis a kilencedik alkotmánykiegészítés célja az, hogy védje a tagállamok demokratikus önkormányzását a központi hatalom korlátozásaival szemben. Ezt a felfogást képviseli mindenekelőtt Berger, Raoul: The Ninth Amendment. In Cornell Law Review, Vol. 66, 1980, 1-26. o. Időközben azonban ennek a rendelkezésnek megjelent egy másik értelmezése is. Ennek első előfordulása a Griswold v. Connecticutítélet: a Supreme Court ezzel a döntésével a magánszférához való jog alapján a házastársak vonatkozásában
} 
hozzátenni, hogy az Egyesült Államok alkotmánya is tartalmaz olyan nem alapjogi jellegü rendelkezést, ami az aktivizmusviták kapcsán rendszeresen érintett: az ún. „kereskedelmi klauzula" (Commerce Clause) a kereskedelemnek a tagállami, illetve a szövetségi szintű jogalkotó általi szabályozási területeit határolja el egymástól, és ez a rendelkezés nem ritkán szerepel hivatkozási alapként a jelen értekezés által elemzett korszak bírósági döntéseiben is. Ugyanakkor látni kell, hogy míg a jogbiztonság követelménye rendelkezik egyfajta „alapjogi árnyalattal” - végső soron a jogbiztonság követelményét egy ésszerü és szükséges, ha úgy tetszik, joggá formált emberi elvárás, a jogrendszer kiszámíthatóságának és a jogszabályok megismerhetőségének az igénye hozta létre -, addig az amerikai kereskedelmi klauzula színtisztán hatásköri szabály.

Másrészt röviden érdemes említést tenni arról, hogy az elemzésben implicite benne van a történelmi-társadalmi körülmények jelentőségének elismerése: a rendszerváltás hatásának kiemelése rámutat arra, hogy az Alkotmánybíróság nem pusztán egy semleges jogalkalmazóként jelent meg, hanem menthetetlenül aktív társadalomalakító tényezővé vált.

\section{II.5.1.2. A birói jogalkotás}

A gondolat, miszerint a bíróságok nemcsak alkalmazzák, de alkotják is a jogot, már Benthamnek a common law-t kritizáló megjegyzéseiben, valamint kodifikációpártiságában tetten érhető, ${ }^{112}$ ám csak a német szabadjogi, ${ }^{113}$ valamint az amerikai jogi realista irányzatok térnyerésétől kezdve vált a jogelmélet egyik evidenciaszerü megállapításává. E megállapítást kezdetben - értelemszerüen - csak a rendes bíráskodásra vonatkoztatták, az

\footnotetext{
alkotmányellenessé nyilvánított egy olyan tagállami törvényt, amely korlátozta a fogamzásgátló beszerzésének lehetőségét. Az ügyben párhuzamos véleményt fogalmazott meg Goldberg bíró, aki szerint a kilencedik alkotmánykiegészítés nevesítetlen alanyi jogok forrása lehet. 381 U. S. $486-499$ (1965) Ez az értelmezés azóta sem nyert teret széles körben, azonban időnként megjelennek olyan javaslatok, amelyek e nevesítetlen alapjogi forrás-szereppel igyekszenek felruházni a szóban forgó rendelkezést. Vö. pl. Abramson, Paul R. - Pinkerton, Steven D. - Huppin - Mark: Sexual Rights in America. The Ninth Amendment and the Pursuit of Happiness. New York University Press, New York - London, 2003.

112 Vö. Plajos Rita: A bírák szerepe és a bírói jogalkotás William Blackstone és Jeremy Bentham elméletében. In Jogelméleti Szemle, 2009/3. szám, http://jesz.ajk.elte.hu/plajos39.mht (2012. szeptember 14.) ${ }^{113}$ Vö. pl. Nizsalovszky Endre: Fogalomkutató és érdekkutató jogtudomány, a szabad jogi iskola és a Tiszta Jogtan. In Uö.: Tanulmányok a jogról. Akadémiai Kiadó, Budapest, 1984, 13-39. o.
} 
alkotmányos normakontroll XX. századi elterjedésével ${ }^{114}$ azonban

alkotmánybíráskodást végző szervek vonatkozásában is felmerült.

A bírói jogalkotás bizonyos szempontból a jogalkotói döntés megvétózásának ellentéte: ez utóbbi esetben arról van szó, hogy a jogszabályi formában megjelenő jogalkotói döntés megszünik a jogrendszer részének lenni az alkotmánybíráskodást végző szerv döntésének következtében, a bírói jogalkotás ellenben valamilyen pozitív jogalkotói döntés hiányát pótolja.

Közhelyszerü elképzelés, hogy az alkotmányos normáknak kellően rugalmasnak kell lenniük ahhoz, hogy kiállják az idő próbáját, és a változó körülmények között se keletkezzen igény a megváltoztatásukra. John Marshall, a Supreme Court elnöke ezt a következőképpen fogalmazta meg a McCulloch v. Maryland-ítélet indokolásában: „[a]z alkotmány, ha aprólékosan leszabályozna minden részkérdést, melyre óriási hatóköre kiterjed, valamint a szabályok érvényesítésére szolgáló összes eszközt, egy kódex részletességével rendelkezne, és az emberi elme jóformán képtelenné válna a befogadására. A közönség valószínűleg soha nem értené meg. Természetéből adódóan szükséges tehát, hogy szabályai csak körvonalakat adjanak, a fontos célokat jelöljék ki, az e célokhoz vezető kisebb lépéseket pedig magából a célok természetéből kell dedukálni." ${ }^{115} \mathrm{Az}$ alkotmányjogban tehát elkerülhetetlen a többértelmű szabályozás, és e körülmény óhatatlanul teret biztosít a bírói jogalkotásnak, vagyis annak, hogy a bíró a nem konkluzív rendelkezésekből konkrét, számon kérhető jogi tartalmat nyerjen ki.

Az ilyen kreatív döntések nem ritkán a társadalom értékpreferenciáival ellentétes eredményt hoznak. Ezt példázza a szólásszabadság kapcsán a West Virginia State Board of Education v. Barnette-ítélet, ${ }^{116}$ a Brown v. Board of Education-ítélet, ${ }^{117}$ vagy a

\footnotetext{
${ }^{114}$ Vö. Cappelletti, Mauro - Cohen, William: Az alkotmánybíráskodás története és jelenkori elterjedése. In Paczolay Péter (szerk.): Alkotmánybíráskodás - alkotmányértelmezés. Rejtjel Kiadó, Budapest, 2003, 50. o.

115 „A constitution, to contain an accurate detail of all the subdivisions of which its great powers will admit, and of all the means by which they may be carried into execution, would partake of the prolixity of a legal code, and could scarcely be embraced by the human mind. It would probably never be understood by the public. Its nature, therefore, requires, that only its great outlines should be marked, its important objects designated, and the minor ingredients which compose those objects be deduced from the nature of the objects themselves." 17 U. S. 316, 407. Az ügyben az a kérdés merült fel, rendelkezik-e a Kongresszus hatáskörrel a szövetségi bank létrehozására. Marshall úgy érvelt, hogy igen, annak ellenére, hogy az alkotmány nem tartalmaz explicit rendelkezést erre vonatkozóan. A jogalkotó hatalomban ugyanis immanensen benne rejlik, hogy jogában áll az alkotmányban tételesen felsorolt feladatai ellátásához szükséges lépéseket is megtenni. Álláspontját az amerikai alkotmány I. cikk 8. szakasz 13. fordulatával támasztotta alá.

116319 U.S. 624 (1943). Az ítéletben a Supreme Court az első alkotmánykiegészítéssel ellentétesnek ítélte a tagállami elöírást, mely vallásra, világnézetre tekintet nélkül az amerikai zászló előtti tisztelgésre kötelezte az iskolásokat.

${ }_{117} 347$ U.S. 483 (1954)
} 
gyanúsítottak jogaival foglalkozó Miranda v. Arizona-ítélet. ${ }^{118}$ Ez utóbbival részletesebben is foglalkozok e helyütt.

A Miranda-döntés kimondja, hogy a gyanúsított rendöri kihallgatás során tett vallomása a bírósági tárgyaláson csak akkor fogadható el bizonyítékként, ha a kihallgatás elött közölték vele, hogy joga van ügyvédet fogadni, illetve nem kötelezhető olyan vallomás megtételére, amellyel saját magát büncselekmény elkövetésével vádolná. A döntés mérföldkőnek számít a büntető eljárásjog történetében, egyúttal a bírói jogalkotásnak is példája, hiszen arról van szó, hogy a konkrét jogvitában eljáró Supreme Court tételes feltételrendszert alakított ki a jogalkotó helyett, előre behatárolva ez utóbbi döntési szabadságát. ${ }^{119}$ A Miranda-ítélet alapja az ötödik alkotmánykiegészítésnek az önvádra kötelezés tilalmáról szóló rendelkezése. Az előadó bíró az indokolásban hosszasan taglalja azokat a fogvatartási és kihallgatási körülményeket, amelyek akkor is megengedhetetlen befolyást gyakorolnak a gyanúsítottra, ha nincs szó fizikai bántalmazásról. ${ }^{120}$

A Supreme Courtnak erre a kreatív alkotmányértelmezésére mindmáig a büntetőeljárási biztosítékok rendszerének sarkalatos pontjaként és az amerikai alkotmányosság fejlődésének mérföldköveként tekintenek. Ugyanakkor idővel felmerültek szempontok, amelyek megkérdőjelezik a Miranda-figyelmeztetések hatékonyságát, illetve az adott formában való alkalmazásuk kívánatosságát. Mint Elek Balázs írja, „[e]gyre több bizonyítékot vélnek felfedezni a Miranda káros hatásaira. Ilyen a Miranda hatályba lépését közvetlenül követő, a felderített bünügyek arányában hirtelen bekövetkező csökkenés, amiből arra a következtetésre jutnak, hogy a Miranda nagymértékben gátolja a rendőri eljárás hatásosságát”, továbbá „,[a]zt a lehetőséget, hogy a Miranda az ártatlanok kárára tartja vissza a bünözők vallomásait, valós megfigyelések támasztják alá." ${ }^{121}$ Richard Posner a kibővített terhelti jogoknak az 1960-as évektől kezdődő, felderítést gátló hatásai

\footnotetext{
118384 U.S. 436 (1966)

${ }^{119}$ Mindazonáltal megjegyezhető, hogy van példa a Miranda-ítéletnél sokkalta kirívóbb bírói jogalkotásra is, amely bizonyára jóval egyöntetübb megrökönyödést váltana ki a jogtudomány képviselőiből. Archibald Cox leír egy esetet, amelyben az eljáró szövetségi bíróság nem csupán kinyilvánította az elmegyógyintézetben ápoltak megfelelő ellátáshoz való jogát, de tételesen megszabott olyan ,alkotmányossági kritériumokat”, mint például a megfelelő mennyiségben biztosított melegvíz, a mosogatógép, valamint az ápolószemélyzet és a betegek megfelelő aránya. Az ilyen döntés vitán felül a bírói funkció túllépéseként értékelhető. Cox, Archibald: The Role of the Supreme Court in American Government. Oxford University Press, London, 1976, 96-98. o.

120384 U.S. 445-458

121 Elek Balázs: A hamis beismerő vallomást eredményező befolyásolás a büntetőeljárásban. In Debreceni Jogi Mühely, 2007/2. szám, http://www.debrecenijogimuhely.hu/archivum/2 2007/a hamis beismero_vallomast_eredmenyezo befolyas olas_a buntetoeljarasban/ (2012. szeptember 14.)
} 
kapcsán így fogalmaz: „a »Warren-bíróság« vakmerő büntetőeljárási döntéseit a bünözési mutatók látványos emelkedése követte, és noha az okozati összefüggés nagyon bizonytalan, van rá bizonyíték, hogy e döntések eredményezték ezt az emelkedést."122 Mindezek fényében kevéssé meglepö, hogy a Miranda-ítélet hatókörét idővel szükítették. ${ }^{123}$ az ötödik alkotmánykiegészítés csak annyit mond: „,senkit nem lehet arra kényszeríteni, hogy büntetöügyben saját maga ellen tanúskodjék". ${ }^{124}$ A rendelkezés lehetséges implikációinak kibontása óhatatlanul vitákat eredményez, amit illusztrál, hogy a Miranda-ügyben két különvélemény is született John Marshall Harlan, illetve Byron White bírók tollából.

A bírói jogalkotással tehát jelentős mértékű felelősség telepszik az alkotmányértelmező vállára. Nem meglepő, ha a kritikus elemzők bírálattal illetik azt a gyakorlatot, ha az alkotmányértelmezést végző szerv túl sok konkrét alkotmányos korlátot vezet le a jogalkotóra nézve a néha valóban bizonytalan jelentéstartalmú alkotmányi elöírásokból. Legyen szó az amerikai alkotmány megfelelő eljáráshoz való jogáról, a német Grundgesetznek a személyiség szabad kibontakoztatásához való jogáról, avagy Alaptörvényünkben az élethez és az emberi méltósághoz való jogról.

Győrfi is azonosít egy olyan jelentésváltozatot az aktivizmus esetében, amely a bírói jogalkotással azonosítható. Ennek kiindulópontja a harti „nehéz” és a „könnyu”” esetek elválasztása, ${ }^{125}$ pontosabban annak nehézsége: Győrfi különbséget tesz szabályozott, részlegesen szabályozott, valamint szabályozatlan esetek között: szabályozott az eset, ha annak ,általános szabály alá foglalását senki nem vitatja”, részlegesen szabályozott, ha „a nyelvi konvenciók bizonytalanok”, és szabályozatlan, ha „,a nyelvi konvenciók alapján nem sorolható az általános kategória alá.” ${ }^{126} \mathrm{Az}$ esetek e változatossága vezet ahhoz mindenekelőtt az alkotmányjogban -, hogy a jogalkalmazó szerveknek ún. nem konkluzív normákat kell alkalmazniuk, mely esetekben a bírónak „nem lehet nem kreatív munkát

\footnotetext{
122$, , $\mathrm{A}]$ great upsurge in crime rates accompanied the $»$ Warren court's $«$ adventurous rulings in criminal procedure, although the causality is deeply uncertain, there is some evidence that these rulings did cause crime rates to rise." Posner, Richard Allen: The Costs of Enforcing Legal Rights. In East European Constitutional Review, Vol. 4, Issue 3, 1995, 74. o. Az idézett szövegrész nem tartalmazza az eredetiben található.

${ }^{123}$ Tóth Mihály: A „,magyar Miranda” első néhány éve. In Erdei Árpád (szerk.): Tények és kilátások Tanulmányok Király Tibor tiszteletére. Közgazdasági és Jogi Könyvkiadó, Budapest, 1995, 64. o.

${ }^{124}$ „No person shall be ... compelled in any criminal case to be a witness against himself”.

${ }^{125}$ Hart, H. L. A.: A jog fogalma. Osiris Kiadó, Budapest, 1995, 149-152. o.

${ }^{126}$ Győrfi Tamás: Az alkotmánybíráskodás politikai karaktere. Értekezés a magyar Alkotmánybíróság első tíz évéröl. Indok, Budapest, 2001, 18-19. o.
} 
végeznie". ${ }^{127}$ Ilyenkor aktivista az a bíró, aki ezt a kreatív munkát felvállalja"128 Ugyanakkor Győrfi rámutat a bírói jogalkotás antidemokratikus természetére, ${ }^{129}$ továbbá kiemeli azokat a bírói és a jogalkotói tevékenység összehasonlításából származó, jól ismert aggályokat, miszerint a bíróságok nem rendelkeznek kellő mennyiségű információval a „jogalkotáshoz”, továbbá a bírói jogalkotás visszaható hatályú. ${ }^{130}$ Ezután a bírói (alkotmánybírói) jogalkotás több elképzelhető korlátozása vezérelvének felvázolását követően arra a következtetésre jut, hogy a „hogyan” kérdésére több plauzibilis álláspont alakítható ki, ezért az aktivizmus fogalma ebben az esetben nem használható. ${ }^{131}$ Ebben az esetben tehát tulajdonképpen Győrfi nem egy lehetséges aktivizmusdefiníciót ad, hanem a definíció céltalanságát és a jogbizonytalanság lehetséges feloldásainak egyenlő indokolhatóságát hangsúlyozza. Érdekes, hogy Győrfi a bemutatott két megfontolást, nevezetesen a jog mint szöveg eredendő bizonytalanságát és az ez által megkövetelt tudatos bírói kreativitást, illetve a „hogyanok”, vagyis a bizonytalan tartalmú szövegekből levezethető megoldások sokféleségét az aktivizmus két önálló aspektusaként elemezte, holott azok szervesen összetartoznak. Megítélésem szerint Győrfinek az aktivizmus fogalmának szükségtelenségére irányuló következtetése vezethető le a Peczenik-féle indeterminencia és a kreatív jogértelmezés elhatárolásának fentebb említett nehézségéből is.

A bírói jogalkotás problematikával összefüggésben érdemes utalni a joghézag kérdéskörére. A joghézag problémája kapcsán két fontos kérdés emelhető ki. Az első az, milyen joghézagtípusok különíthetők el. A jelen tanulmány témájára, valamint terjedelmi

127 Győrfi: i. m. 36. o. (kiemelés nélkül) Győrfi itt a szabályok és elvek Dworkin általi logikai megkülönböztetésére utal vissza. Dworkin szerint a szabályok a „mindent vagy semmit” logikája szerint alkalmazhatók, vagyis a bennük foglalt hipotézis megvalósulása esetén feltétlenül be kell állnia a jogkövetkezménynek; ehhez képest az elveket szempontként kell figyelembe vennie a jogalkalmazónak, amelyik a döntést valamilyen irányban elősegíti, azaz az elv írhat elő olyan feltételeket, amelyek elkerülhetetlenné teszik alkalmazását. Dworkin, Ronald: Vajon szabályok rendszeréből áll-e a jog? In Varga Csaba (szerk.): Jog és filozófia. Antológia a XX. század jogi gondolkodása köréből. Szent István Társulat, Budapest, 2001, 392., illetve 394. o. Győrfi ugyanakkor bírálja a distinkció ilyen alapra helyezését. Szerinte egyrészt „egy normának az általánossága, a kanonicitása és az ereje három különböző tulajdonsága”, másrészt a szabály és az elv fogalmát rendszerint nem a dworkini értelemben szoktuk használni. Győrfi: i. m. 34. o.

${ }^{128}$ Győrfi: i. m. 42. o.

${ }^{129}$ Győrfi: i. m. 46. o.

${ }^{130}$ Uo.

131 Győrfi: i. m. 64. o. A lehetséges korlátozások, vezérelvek között említi a szerző az alkotmányozó szándékának követését - ámbátor nem bocsátkozik annak részletes vizsgálatába, pontosan mit takar ez a szándék -, a processzuálius szemléletet - mely alapján az alkormánybírósági vizsgálat pusztán a törvényhozó eljárására szorítkozna, a tartalmi kérdéseket nem érintené -, az ún. „konszenzus-modellt” - vagyis a társadalmi értékítéletre való támaszkodást -, az ún. „koherencia-modellt” - ennek értelmében az alkotmánybíróság döntésének elsődleges szempontja az, hogy a felhasznált megfontolásoknak illeszkedniük kell az alkotmányszöveg összefüggéseibe -, valamint a ,helyettes törvényhozó” modellje - eszerint „,nincs minőségi különbség a törvényhozói és a nehéz eseteket eldöntő bírói döntéshozás között”. 
okokra tekintettel e helyütt a joghézag-tipizálásoknak még vázlatszerü ismertetésére sincs lehetőség, ${ }^{132}$ ezért csak Aleksander Peczenik - a téma szempontjából kézenfekvő klasszikus taxonómiáját mutatom be. Peczenik a joghézag négy fajtáját különböztethette meg. Inszuffienciáról beszélhetünk, ha a jog nem szabályoz ott, ahol kellene. Inkonzisztenciáról van szó, amikor a jog előírásai ellentmondásosak. Indeterminenciának nevezzük, ha a jogi szabályozás homályos. Végül axiológiai joghézaggal állunk szemben, ha a jog az erkölcsi paranccsal ellentétesen szabályoz. ${ }^{133}$

Az, hogy Peczenik beemelte taxonómiájába az inszuffiencia és az axiológiai joghézag fogalmait, jól szemlélteti a joghézag megragadhatóságának problematikus voltát. Azok a kérdések, hogy milyen életviszonyokat kellene szabályoznia az államnak, illetve milyen erkölcsi követelményekkel ellentétes a „hézagos” szabályozás, a végtelenségig húzódó morálfilozófiai, gazdaságtani, és egyéb természetü vitákat generálnak; megválaszolásuk előzetesen rögzített - és természetesen sokfelől vitatott - jogfilozófiai elképzelések fényében lehetséges. Napjaink világnézeti sokszínüségében pedig már az alapvetőnek tekintett, a társadalom egésze által vallott értékek is megkérdőjeleződni látszanak. $^{134}$

A Miranda-ítélethez kicsit visszakanyarodva, immár a joghézag-problematika kontextusában, lehet úgy érvelni, hogy inszuffienciáról van szó, vagyis az alkotmány nem is tartalmaz rendelkezést a kihallgatás során tanúsított hatósági nyomásgyakorlás kapcsán. White bíró különvéleményének egyik érve éppen az, hogy a szóban forgó rendelkezés nem jelent többet, mint hogy senki nem kötelezhető önmagára nézve terhelő vallomást tenni olyan büntetőeljárás során, melynek ő a terheltje. ${ }^{135}$ Ha pedig a vonatkozó alkotmánykiegészítés nem tartalmaz szabályozást olyan esetkörre, amelyre valamilyen oknál fogva kellene, vitatható, mennyiben jogosult, illetve köteles a bíróság pótolni a hiányosságot. A válasz természetesen az alapul vett elméletnek a függvénye, ebből azonban az is következik, hogy elméletenként változik, aktivistának tekinthetö-e az adott döntés, avagy sem. A Miranda-ügy példájánál maradva az, aki szerint a bíróság bizonyos

\footnotetext{
${ }^{132}$ Lásd bővebben Mezei Péter: A joghézag kérdése régen és ma. In Jogelméleti Szemle, 2002/2. szám, http://jesz.ajk.elte.hu/mezei10.html (2012. szeptember 14.).

${ }^{133}$ Peczenik, Aleksander: On Law and Reason. Springer, 2009, 18-20. o. Lásd még: Csink Lóránt - Paczolay Péter: A törvényhozói mulasztás problémái az alkotmánybíráskodásban. In Szabó Imre (szerk.): Ius et legitimatio - Tanulmányok Szilbereky Jenő 90. születésnapja tiszteletére. Pólay Elemér Alapítvány, Szeged, 2008, 185. o.

${ }^{134}$ Ezt példázza az amerikai bioetikus, Peter Singer sokat vitatott megállapítása arról, hogy bizonyos emberek nem tekinthetők személynek. Vö. „Provokatív nézeteim az életről és a halálról elgondolkodásra serkentik az embereket". Peter Singerrel, a Princeton University bioetika professzorával Halmai Gábor beszélget. In Fundamentum, 2001/1. szám, 2001, 61. o.

135384 U.S. 526-527
} 
esetekben pótolhatja a vázolt hiányosságot, valószínüleg könnyebben helyezkedik a többségi ítélethez hasonló álláspontra, és nem fogja „aktivistának” tekinteni az ilyen döntést, ezzel szemben aki elméletében korlátozottabb szerepet szán a bíróságoknak, nagyobb valószínűséggel érvel a többségi döntéssel ellentétes végeredmény mellett, egyúttal valószínübb az is, hogy a többségi döntést meghozó bíróság „aktivista” lesz a szemében.

Hasonlóképp inszuffienciaként is felfogható az a szabályozási hiányosság, amelyre végül a Katz v. United States-ítélet ${ }^{136}$ nyújtott megoldást: a negyedik alkotmánykiegészítésből nem következik az, hogy a terheltnek ésszerütlen házkutatás és motozás elleni védelmébe beletartozik az, ha a nyilvános telefonfülkében lehallgatott beszélgetésének tartalmát használják fel, elvégre a nyilvánosság számára rendelkezésre álló helyen tartózkodott. Ennek ellenére a Supreme Court úgy ítélte meg, hogy mivel a terhelt a felvétel időpontjában olyan helyen tartózkodott, ahol ésszerüen számíthatott a külvilágtól való elszigeteltségre, ezért a szóban forgó alapjog védelme alá esik. ${ }^{137} \mathrm{~A}$ joghézag kitöltése analógia útján történhet, ${ }^{138}$ ami nem más, mint olyan szabály keresése és alkalmazása, amely nem közvetlenül a konkrét, eldöntendő esetre ad iránymutatást, de ahhoz valamilyen szempontból hasonlóra, és e hasonlóság alapján a konkrét esetre is vonatkoztatható. A problémát természetesen az jelenti, hogy ki jogosult annak kinyilatkoztatására, hogy adott esetben hézagos a szabályozás, ami aztán legitimálja annak jogalkalmazói kiegészítését.

Adott rendelkezés jelentésének értelmezés útján való meghatározása és az indererminencia mint a joghézag egyik válfajának kitöltése között analitikai különbséget tenni roppant nehéz: ezt maga Peczenik is elismerte, ${ }^{139}$ márpedig épp az indeterminencia a joghézagok azon típusa, amelynek előfordulása az alkotmányértelmezés - és különösen az alapjogi bíráskodás - során a legvalószínűbb. Peczenik szerint az indeterminencia homályos (vague) vagy többértelmü (ambiguous) rendelkezések alkalmazása során merül fel. A homályos rendelkezés olyan szót vagy kifejezést tartalmaz, amelynek jelentése nem határozható meg egzakt módon, de a megfelelő kontextusban mégis egyértelművé válik (például nincs egzakt kritérium arra nézve, hogy hány fától számít erdőnek az erdő, de konkrét körülmények között mégis felismerjük). A többértelmű rendelkezés olyan szót

\footnotetext{
136389 U. S. 347 (1967)

${ }^{137}$ Vagyis a Supreme Court többsége ebben az ügyben a magánlakással analógiába állította a zárt telefonfülkét. 389 U. S. 353-354

${ }^{138}$ Pl. Jakab András: Az európai alkotmányjog nyelve. Nemzeti Közszolgálati Egyetem, Budapest, 2016, 3031. o.

${ }^{139}$ Peczenik: i. m. 19. o.
} 
vagy kifejezést tartalmaz, amely több érvényes jelentéstartalommal is rendelkezhet (például az „okoz” ige jelölhet olyan magatartást, amely szükséges feltétele egy adott eredménynek, és olyat is amely csak elegendő feltétele az eredménynek). ${ }^{140}$ Számos alkotmányi rendelkezés - mint fentebb erre már utaltam - tartalmaz efféle bizonytalanságot, ami szükségszerúen szabadon hagyja az utat a jogalkalmazó általi kiegészítés számára. Ha a bírói jogalkotást az aktivizmus egyik válfajaként fogjuk fel, akkor nyitva marad a kérdés, hogy ebben a konstellációban hol ér véget a rendes jogértelmezés és hol kezdődik az aktivizmus.

A Kmiec által felállított kategorizálás módosítása indokolt annyiban, hogy a megvétózást és a bírói jogalkotást egy fogalom két alesetének tekintsük, ugyanis mindkét esetben kifejezetten arról van szó, hogy olyan bírósági döntés születik, amelyet bírálói szerint csak a jogalkotónak lett volna szabad meghoznia. A különbség annyi, hogy egyik esetben a már meghozott döntést érvényteleníti az alkotmánybíráskodást végző szerv, a másik esetben pedig bizonyos jövőbeli döntések lehetőségét zárja ki, illetve a jogalkotó által meg nem hozott döntést pótolja.

\section{II.5.2. Az autoritatív szövegekhez való viszony megváltoztatása}

Az alkotmányos rendelkezések értelmezési lehetőségeinek sokfélesége a puszta normaszövegen túli zsinórmérték igénybevételét követeli meg az alkotmánybíráskodást végző testülettől. Az egyik ilyen zsinórmérték a precedenskövetés: ha a testület valamilyen módon eldöntött egy vitás kérdést, elvárható, hogy a hasonló ügyekben következetesen tartsa magát döntéséhez. Ez a következetesség több szempontból is előnyös. A legkézenfekvőbb a jogbiztonság követelménye, mely minden jogállam alapvető eleme kell legyen. A precedensekkel szembeni ezen elvárás már a Bentham által felvázolt „várakozások tézisében” is felszínre került. E tézis szerint a precedensek azért kötik a bíróságokat, mert az emberek elvárják, hogy a korábbi döntés alapjául szolgáló tényálláshoz hasonló tényállás esetén a bíróságok hasonló döntést hozzanak. ${ }^{141}$ Schauer a precedenshez kötöttség erényeit vizsgálva lényegében ugyanezt bontja két tényezőre, a

\footnotetext{
${ }^{140}$ Peczenik: i. m. 17-18. o.

${ }^{141}$ Ezen elvárásból egyúttal következik a bírói jogalkotás illegitim volta is, hiszen a már kialakult gyakorlat esetleges megváltoztatása tulajdonképpen visszaható hatályú jogalkotásnak minősülne. Vö. Plajos: i. m.
} 
tisztességesség (fairness) és a kiszámíthatóság (predictability) követelményeire, ${ }^{142}$ emellett kiemeli a későbbi döntéshozók döntéseinek hatékonyabbá tételét azáltal, hogy az eset tényeinek megállapítását követően elég a korábban született döntésre hagyatkoznia, valamint további előnyként könyveli el, hogy a precedenskövetéssel olyan döntési konzisztencia valósítható meg, amely erősíti a döntéshozó szerv tekintélyét. ${ }^{143}$

Amennyiben tehát egy adott kérdéskörben rendelkezésre áll irányadó precedens, az ettől való eltérés jó eséllyel éles visszhangot kelt az alkotmánybíráskodással foglalkozó szerv értékelői körében. Ez az aktivizmusdefiníció azonban szintén nem mentes a problémáktól.

Mindenekelőtt akkor merülhet fel probléma, ha maga a precedensértékü ítélet is aktivistának számít ugyanezen kritérium alapján. E problémát kiválóan illusztrálja a faji szegregációhoz kapcsolódó két legfontosabb amerikai precedens, a Plessy v. Ferguson-, ${ }^{144}$ valamint a Brown v. Board of Education-ügy viszonya. A Brown-döntés radikális szakítást jelentett az „elkülönítve, de egyenlően” (separate but equal) elvével és az azt alátámasztó precedensekkel, mindenekelőtt az elvet meghonosító Plessy v. Fergusonnal. ${ }^{145}$ Az ítélet mára szerves része az Egyesült Államok alkotmányjogának, és olyan alappontot jelent a törvény előtti egyenlőség kérdésében, amelytől a jelen körülmények között képtelenség visszalépni, a maga korában azonban szükségképpen aktivistának számított, hiszen egy közel hat évtizedes alkotmányértelmezési gyakorlattal fordult szembe. ${ }^{146}$

Hasonló probléma merülhet fel akkor is, ha a precedens más definíció alapján tekinthető aktivistának. E problémát talán az amerikai bírósági felülvizsgálatot megalapozó Marbury v. Madison-ítélettel lehet megfelelően illusztrálni. Ha ezt a döntést úgy fogjuk fel, mint „bírói jogalkotást”, akkor azt lehet mondani, hogy az amerikai alkotmánybíráskodás aktivista alapokon nyugszik. Egy ilyen megállapítás ingataggá tesz minden aktivizmuskritikát, hiszen ezek a kritikák az élő alkotmányjog gyökeres átalakítását implikálnák.

\footnotetext{
${ }^{142}$ Schauer, Frederick: Precedent. In Stanford Law Review, Vol. 39, Issue 3, 1987, 595-598. o.

${ }^{143}$ Schauer: i. m. 599-601. o.

144 163 U.S. 537 (1896)

${ }^{145}$ Hozzátehetjük, hogy a Supreme Court a Brown-döntésben nem jelentette ki explicite, hogy felülbírálja a Plessy-döntést, csak kimondta, hogy az „elkülönítve, de egyenlöen”-elvnek nincs helye a közoktatásban. Tény ugyanakkor, hogy az ítélet az elv gyors erodálásához vezetett a társadalom többi szegmensében is.

${ }^{146}$ Érdemes utalni rá, hogy XX. század második felédől kezdődően a szerzők ideológiai irányultságuktól függetlenül nem tekintik aktivistának a Brown-döntést, illetve nem vitatják a rendelkező rész helyességét. Amikor mégis ekként jellemzik a döntést, azt méltatólag teszik. Hozzátehetjük, hogy a jelenség más irányban is megfigyelhetö, így akadnak szerzők, akik a konzervatív aktivizmust találják kifejezetten kívánatosnak bizonyos szempontból. Vö. Wilkinson, Harvie J.: Is There a Distinctive Conservative Jurisprudence? In University of Colorado Law Review, Vol. 73, Issue 4, 2002, 1383-1400. o.
} 
A precedensek több szempont szerint osztályozhatók. Kmiec tanulmányában kétféle felosztással találkozhatunk. A szerzö különbséget tesz egyrészt a „vertikális”, vagyis a felettes bíróságok által hozott, illetve a „horizontális”, vagyis a bíróság által korábban hozott precedensek, másrészt az alkotmányjogi, a jogszabályértelmezési, illetve a common law precedensek között. ${ }^{147}$ A jelen tanulmány tárgyát tekintve a horizontális alkotmányértelmezési precedensek a legjelentősebbek, mivel jellemzően ilyen típusú precedensek születnek az alkotmánybíráskodást végző szerv alkotmányértelmezési tevékenysége során. Az európai jogrendszerekben megfigyelhető, a bírósági szervezettől elkülönült alkotmánybíráskodásra szintén e precedenstípusok jellemzőek, ami azzal magyarázható, hogy az alkotmánybíróságok sokszor nem avatkoznak bele a „rendes” bíróságok jogértelmezésébe.

Cross és Lindquist szintén azonosít egy hasonló kategóriát, ${ }^{148}$ mely azonban tágabb, mint a „precedenstől való eltérés” Kmiecnél, és a jogszabályszöveghez, az eredeti szándékhoz, illetőleg a jogalkotási előtörténethez való hüségen alapul. Ez az átfogó kategorizálás bizonyos szempontból előnyösebb, mint a precedensekre szükítés, mert kiemeli ezeknek a jogforrásoknak azt a közös sajátosságát, hogy objektivált alapot nyújtanak az alkalmazott jogi rendelkezés értelmezéséhez. Ez alól talán az „eredeti szándék" képez kivételt, hiszen e sokféleképpen értelmezhető fogalom konkretizálására nemcsak írott források állhatnak rendelkezésre: az ún. „hipotetikus intencionalizmus” a jogalkotó-alkotmányozó szubjektív szándékának feltárására törekvő azon irányzat, amely arra kérdez rá, hogy a szabály egykori megalkotója milyen szabályozást adna az alkalmazás idején felmerült problémákra, ${ }^{149}$ erre pedig szükségszerủen csak közvetett módon lehet következtetni. Mindazonáltal az esetek többségében rendelkezésre áll valamilyen szöveg, ami az értelmezés hiteles kiindulópontja. Ezek nem zárják ki egymást szükségszerüen, sőt, gyakran egymás kiegészítőjeként funkcionálnak. Jellemzően a szöveg értelmének pontosítását szolgálja a többi instrumentum, tipikusan ez a helyzet az alkotmányok szövege és az értelmező precedensek vagy az alkotmányozás során keletkezett, az alkotmányozó szándékát tükröző dokumentumok viszonylatában. Ez a viszony olykor megfordulhat, például akkor, ha az alkotmányszöveget értelmezni hivatott

\footnotetext{
${ }^{147}$ Kmiec: i. m. 1466-1467. o.

${ }^{148}$ Lásd: Lindquist - Cross: i.m. 36-37. o.

149 Tóth J. Zoltán: Dinamizmus, originalizmus, textualizmus, avagy az aktivista alapjogi bíráskodás és az arra adott neokonstrukcionista jogelméleti reakciók az Egyesült Államokban. In Jogtudományi Közlöny, 2007/4, 147-148. o.; Molnár András: Pragmatizmus és legalizmus - Richard Posner és Antonin Scalia a bírói szerepröl. In De iurisprudentia et iure publico, 2009/1, 48-49. o. http://www.dieip.hu/wpcontent/uploads/2009-1-szam.pdf (2014. január 15.)
} 
precedens elsőbbséget élvez magával a szöveggel szemben, és az alkotmánybíráskodást végző szerv pusztán a precedensanyagra támaszkodva távolodik el a szöveg eredeti jelentésétől. ${ }^{150}$

Azt, hogy nemcsak a precedensek, hanem a jogalkotó szándékát alátámasztó más anyagok vonatkozásában is megfigyelhető eltérés, jól szemlélteti Scalia ismert példája, amely szerint egy időben kialakult az a kongresszusi gyakorlat, hogy a jogszabályalkotás során a képviselők, szenátorok tudatosan tettek olyan nyilatkozatokat, amelyek a jegyzőkönyvbe kerülve később a ,jogalkotó szándékát” tükröző megnyilvánulásokként kezelhetők. ${ }^{151} \mathrm{Az}$ implikáció, ami a jelen okfejtés szempontjából fontos, az, hogy a bírónak, ha az így keletkezett „előtörténet” többféle, egymásnak ellentmondó ,jogalkotói szándkot" tartalmaz, akkor lehetősége van tetszőlegesen szelektálni közöttük, és adott esetben ,át is válthat” egyikről a másikra.

Összességében tehát arra a megállapításra lehet jutni, hogy Kmiec „precedenstől való eltérése” itt kibővíthető, és pusztán az „irányadó precedensektől való eltérés” helyett a rendszerint alkalmazott autoritatív szöveg alkalmazásában való változásról lehet beszélni. Az első esetben az alkotmánybíráskodást végző szerv valamely, a korábbi gyakorlatában rendszeresen alkalmazott autoritatív szöveg helyett más támpontokra hivatkozik döntései indokolásában; ennek példája lehet az, ha az adott testület az alkotmányértelmező precedensek helyett nagyobb jelentőséget kezd tulajdonítani az alkotmányozó addig elhanyagolt szubjektív - az alkotmányozás korában született dokumentumokból feltárható - vagy objektív - az alkotmány preambulumában vagy az értelmezés tekintetében irányadó deklarációiban megnyilvánuló - szándékának. Továbbá az autoritatív szövegek egymáshoz való viszonyának megváltoztatásáról példája az, amikor az alkotmányszöveg értelmezését szolgáló precedensek nagyobb jelentőségre tesznek szert, mint maga a szöveg. Itt tehát nem egyszerüen arról van szó, hogy az egyik autoritatív szöveg helyébe másik lép, hanem arról, hogy két, egymással szerves kapcsolatban álló autoritatív szöveg viszonyát fordítja visszájára az alkotmánybíráskodást végző szerv.

Érdemes e helyütt tárgyalni egy olyan kategóriát, amit szintén Cross és Lindquist vet fel: az „intézményi túlterjeszkedést” (institutional aggrandizement). Azok az esetek

\footnotetext{
${ }^{150}$ Mindazonáltal megjegyezhető, hogy az erre rámutató kritikáknak természetszerűleg előfeltételezniük szükséges azt, hogy az alkotmányszöveg rendelkezik egy bizonyossággal azonosítható, megváltoztathatatlan magjelentéssel, ami legitim és rendíthetetlen orientációs pontként szolgál a jogalkalmazó számára, és amelynek figyelmen kívül hagyása elkerülhetetlenül a döntés legitimációjának elvesztését eredményezi.

${ }^{151}$ Scalia, Antonin: Common-Law Courts in a Civil-Law System: The Role of United States Federal Courts in Interpreting the Constitution and Laws. In Uö.: A Matter of Interpretation. Federal Courts and the Law. Princeton University Press, Princeton, 1997, 34. o.
} 
tartoznak ide, amikor a bíróság olyan kérdéseket von vizsgálat alá, amelyek érdemi elbírálásától korábban valamilyen okból tartózkodott. ${ }^{152}$ Habár náluk az intézményi túlterjeszkedés önálló kategória, megítélésem szerint helyénvalóbb az autoritatív szövegekhez, azon belül is kifejezetten az irányadó precedensekhez való viszony speciális eseteként tárgyalni. A bíróságnak valamely esetekből való korábbi tartózkodása ugyanis nem „csak úgy történik”, hanem megmutatkozik valamilyen írásos, indokolt döntési formában. Ez a döntési forma pedig valamely precedens, méghozzá kifejezetten horizontális precedens lehet, hiszen csakis olyan döntési forma kerülhet szóba, amely fölött maga az érintett bíróság közvetlenül diszponálhat.

Technikailag az intézményi túlterjeszkedésnek több módja képzelhető el. A szerzőpáros a Baker v. Carr-ítéletet hozza fel példának. ${ }^{153}$ Ebben az ügyben néhány Tennessee állambeli polgár azért indított keresetet, mert a jogalkotó nem szabta át úgy az 1901-ben „önkényesen és szeszélyesen” (arbitrarily and capriciously) meghatározott választókerületeket, hogy a felosztás tekintettel legyen az állam egyes részeinek népsürüségére, illetve az abban bekövetkezett változásokra. A Supreme Court alkotmányellenesnek ítélte a szabályozást az egyenlő törvényi védelem klauzulája alapján. A döntés jelentősége abban áll, hogy e lépéssel a testület szakított azzal a következetes gyakorlatával, miszerint a hatalommegosztás elvére tekintettel tartózkodik a közvetlen politikai érintettségü ügyekbe való beavatkozástól (ez volt az ún. political questionsdoktrína). E gyakorlatot a tagállam képviselői a Colegrove v. Green-ítéletre hivatkozva támasztották alá, ${ }^{154}$ amelyben a Supreme Court egy hasonló kérdés érdemi elbírálását - bár a többségi indokolás a kifejezést nem tartalmazza - a political questions-doktrínára tekintettel megtagadta. ${ }^{155}$ A Supreme Court nem volt tekintettel erre a precedensre, ${ }^{156}$ és a döntés érdemben elbírálhatósága mellett érvelt, mondván, ,annak puszta ténye, hogy egy

\footnotetext{
${ }^{152}$ Lindquist - Cross: i.m. 37. o.

153369 U. S. 186 (1962)

154328 U. S. 549 (1946)

155328 U. S. 554-556

${ }^{156}$ Crossék úgy fogalmaznak, hogy a Baker v. Carr-ügyben a Supreme Court „,felülbírálta” (overruled) a Colegrove v. Green-döntést. Vö. Lindquist - Cross: i.m. 37. o. Ez azonban téves megállapítás. Az angolszász precedensjogban az overruling azt az esetet jelöli, amikor egy bíróság felülbírálja és elveti korábban alkalmazott precedensét. Itt a Supreme Court nem tett ilyen kijelentést a Baker v. Carr indokolásában. Természetesen ettől még a korábbi ügy kiveszett a gyakorlatból, „hivatalosan” azonban a Supreme Court nem nyilvánította ki annak alkalmazhatatlanságát. Hasonló nem ritkán megfigyelhető a testület gyakorlatában, példának okáért - mint később látható lesz -, a Lochner-ügy vonatkozásában is.
} 
perben valamely politikai jog védelmét kérik, nem jelenti azt, hogy politikai kérdés merült fel benne". 157

Az előadó bíró, William Brennan hivatkozott egy sor olyan precedensre, amelyekben a testület a Colegrove-döntés dacára érdemben foglalkozott a political questionsdoktrínát. ${ }^{158}$ E precedensek azonban kivétel nélkül ún. per curiam döntések, vagyis többnyire - a testület egyhangúlag elfogadja öket, és tömör, nem ritkán néhány mondatos indokolással látják el őket. A Baker v. Carr-ítélet indokolásának a szövetségi hatáskörrel foglalkozó szakaszában az e hatáskör alátámasztása végett hivatkozott precedensek mind rövid, néhány mondatos, a korábban eljárt bíróságok ítéletét helybenhagyó döntések. Ez alól két kivétel van. A South v. Peters-ítéletben ${ }^{159}$ szük egyoldalas indokolás született, melyben azonban egy szó sem esik arról, milyen mértékben foglalkozhatnak a szövetségi bíróságok a választójoggal kapcsolatos ügyekben felmerülő kérdéssel érdemben. ${ }^{160} \mathrm{~A}$ MacDougall v. Green-ügyből ${ }^{161}$ pedig egyértelműen kiderül, hogy az első fokon eljáró szövetségi bíróság hatáskör hiánya miatt visszautasította az indítványozók keresetét, és a Supreme Court, bár viszonylag hosszan, két és fél oldalon keresztül fejti ki azt, hogy a támadott szabályozás indokolható, ${ }^{162}$ végső soron az első fokon született visszautasító döntést hagyja helyben. Ennek fényében megalapozatlannak, de legalábbis ingatagnak tünik Brennan azon érve, miszerint a Supreme Court már a Baker v. Carr-ügy elött is érdemben befogadhatónak találta a választókerületek szabályozását támadó indítványokat, és valóban reális azt állítani, hogy az ítélet radikális fordulatot jelentett, továbbá nem alaptalan a Lindquist-Cross páros által felállított „intézményi túlterjeszkedés” kategória egyik példájaként tekinteni rá.

A Baker v. Carr-ügyben a Supreme Court a hatáskörét kiterjesztve vont magához olyan esetcsoportot, amellyel korábban nem foglalkozott. Máskor a testület más aspektusból bővítette hatáskörét. A Roe v. Wade-ügyben a többség elfogadta az

157 „Of course the mere fact that the suit seeks protection of a political right does not mean it presents a political question." 369 U. S. 209

158369 U. S. 202-203

159339 U. S. 276 (1950)

${ }^{160}$ Ebben a konkrét esetben a támadott georgiai törvény úgy rendelkezett, hogy a kormányzóválasztáson az egyes választókerületekben győző jelöltek számszerüen előre meghatározott „,pontértéket” szereznek: a nyolc legnépesebb választókerület győztese hatot, a többi választókerületé kettőt. Ezeket a ,pontokat” a választás végén összesítik, és a legtöbbet szerző jelölt nyeri magát a választást. Egyébként megjegyezhető, hogy bár a per curiam döntések többniyre egyhangúak, a jelen esetben Douglas és Reed különvéleményt nyújtott be.

161335 U. S. 281 (1948)

162 Ebben az ügyben a vita tárgyát képező illinois-i szabályozás ahhoz a feltételhez kötötte az új pártok megalakulását és azok jelöltállítását, hogy legalább 25000 választásra jogosult személy ajánlását beszerezzék, és ebből legalább 200-200 ajánlás a tagállam 50 különböző megyéjének lakosaitól származzon (összesen 102 megye volt). Az indítványozók sérelmezték, hogy a választópolgárok 52\%-a egyetlen megyében lakott, emellett 87\%-uk a 49 legnépesebb megyében, a maradék 13\% pedig a többi 53-ban. 
indítványozó nő perindítási jogát annak ellenére, hogy esete - Epstein kritikája szerint - a mootness (vagyis a vitás helyzet bírói beavatkozást szükségtelenné tevő rendeződése) tipikus példája, hiszen az indítványozó már megszülte gyermekét. A többségi indokolást megfogalmazó Blackmun bíró szerint a mootness megállapítása abszurd helyzetet eredményezne, hiszen egy terhesség kilenc hónapig tart, ám az, hogy egy ügy az első fokon eljáró bíróságtól a legfőbb bírói fórumig eljusson, évekbe telik. ${ }^{163}$ Hozzátehetjük, hogy a Supreme Court által alkalmazott kiterjesztés mellett ebben az esetben valóban nyomós érvek szólnak, hiszen amennyiben az indítványozótól elzárnák a Supreme Courthoz fordulás lehetőségét, akkor bizonyos törvényi rendelkezések legmagasabb fokon való alkotmányossági vizsgálata lehetetlenné válna. A súlyosabb dilemmát megítélésem szerint az jelenti, hogy vitatható az indítványozó érintettsége. A Roe v. Wade-ügyben támadott texasi jogszabály nem tartalmazott rendelkezést a terhes nőkre nézve, ehelyett a tiltott magzatelhajtást végrehajtó orvosokat fenyegette szankcióval. Szigorú értelemben véve a norma alkotmányosságának vizsgálatát kizárólag olyan orvosok kezdeményezhették, akik ellen tiltott magzatelhajtás miatt eljárás indult. Ennek kapcsán egyébként megjegyezhető, hogy a Roe v. Wade-ügyben volt egy ilyen indítványozó is, igaz, a szélesebb közönség számára inkább „Jane Roe”, azaz Norma McCorvey története ismert - és érdekes -, amit természetesen szívszaggató módon tálaltak a pro-choice aktivisták (ahogy általánosságban is jellemző, hogy kizárólag a testi önrendelkezéshez való jog oldaláról értékelik a fejleményeket). ${ }^{164}$

Fontos megjegyezni, hogy az autoritatív szöveghez való viszony megváltoztatása nem keverendő össze a következőkben tárgyalandó definíciós lehetőséggel, a bevett értelmezéi módszerektől való eltéréssel. A jelen esetben ugyanis arról van szó, hogy az alkotmánybíráskodást végző szerv ugyanahhoz (ugyanazokhoz) az autoritatív szöveghez (szövegekhez) folyamodik az értelmezés során. Ilyenkor a bevett értelmezési módszer nem változik, ezért ez az eset eltér attól, amikor az alkotmánybíráskodást végző szerv más szövegeket (vagy egyéb forrásokat, módszereket) kezd alkalmazni a korábbiak helyett (például az alkotmányozó „eredeti szándékát” kezdi el feltárni a normaszöveg hétköznapi jelentése helyett vagy azt kiegészítendő).

\footnotetext{
${ }^{163}$ Vö. 410 U. S. 125. Epstein kritikájához lásd: Epstein, Richard A.: Substantive Due Process by Any Other Name: The Abortion Cases. In The Supreme Court Review, 1973, 162. o.

${ }^{164}$ Vö. pl. Hitchcock, Susan Tyler: Roe v. Wade: Protecting a Woman's Right to Choose. Chelsea House Publishers, New York, 2007.
} 


\section{II.5.3. A bevett értelmezési módszerektöl való eltérés}

A jogértelmezés módszereinek szisztematikus vizsgálatának kezdete a XIX. században, a négy klasszikus értelmezési módszer Savigny általi felállításával vette kezdetét. ${ }^{165}$ Anélkül, hogy a jelen tanulmányban sor kerülne a jogértelmezés tudományos vizsgálata történetének áttekintő felvázolására, érdemes utalni arra, hogy a jogértelmezési módszerek legátfogóbb áttekintésére a Bielefeldi Kör által lebonyolított nemzetközi felmérés során került sor. A felmérés eredményét a kutatást vezető Robert S. Summers szerkesztésében megjelent kötet foglalja össze, melynek bevezető tanulmányában Summers tizenegy jogértelmezési módszert különít el. ${ }^{166} \mathrm{E}$ rendszerezéshez több korrekciót is füztek - egyebek között a magyar szakirodalomban is ${ }^{167}-$, mindamellett a

${ }^{165}$ Ez a négy módszer köztudott módon a nyelvtani, a logikai, a rendszertani, valamint a történeti értelmezés. Ez a négyes később a cél-, illetve érdekkutató jogtudomány nyomán a teleologikus, vagyis a jogszabály objektív céljára figyelő értelmezéssel egészült ki.

${ }^{166}$ Ezek: a hétköznapi jelentés szerinti értelmezés, a technikai (szakmai) jelentés szerinti értelmezés, a kontextuális értelmezés, a precedensek szerinti értelmezés, az analogikus értelmezés, a logikai-fogalmi értelmezés, az általános jogelvek szerinti értelmezés, a szokásjogi értelmezés, a jogszabály célja szerinti értelmezés, a szubsztantív értelmezés, valamint a jogalkotó szándéka szerinti értelmezés. Vö. Summers, Robert Samuel - Taruffo, Michele: Interpretation and Comparative Analysis. In McCormick, Donald Neil Summers, Robert Samuel (ed.): Interpreting Statutes. Dartmouth Publishing Co., Aldershot, 1991, 464-465. o.

${ }^{167}$ Pokol Béla több ponton módosította ezt a felosztást. Álláspontja szerint tizenkét értelmezési módszer között tehető különbség. Ezek: a hétköznapi szó szerinti értelmezés, a speciális-technikai szó szerinti értelmezés, a kontextuális értelmezés, a joglogikai értelmezés, a precedenseken nyugvó értelmezés, az analógia szerinti értelmezés, a doktrinális-jogdogmatikai értelmezés, a jogelvekre hivatkozó értelmezés, az alkotmányos alapjogok-alapelvek szerinti értelmezés, a jog mögötti etikai értékekre építö értelmezés, a jogszabály célját szem előtt tartó értelmezés, valamint a jogalkotó akarata, szándéka szerinti értelmezés. Vö. Pokol 2005: 218-231. o. Tóth J. Zoltán tizenhárom fő jogértelmezési módszert azonosít. Ezek: a nyelvtani értelmezés, a kontextuális értelmezés, a bírói jog szerinti értelmezés, az egyéb jogalkalmazói értelmezés, a logikai értelmezés, a teleologikus (a jogszabály objektív célján társadalmi rendeltetésén alapuló) értelmezés, a történeti (a jogalkotó szubjektív szándékán, alkotáskori akaratán alapuló) értelmezés, a jogtudományijogirodalmi értelmezés, az alkotmányos alapjogok, alapelvek, alkotmánybírósági határozatok alapján történő értelmezés, a nemzetközi egyezmények szerinti értelmezés, az összehasonlító jogi értelmezés, az általános jogelvek fényében történő értelmezés, valamint a szubsztantív (közvetlenül valamely bevett értékre hivatkozó) értelmezés. Tóth J. egyes értelmezési típusokat további altípusokra oszt, ez azonban a jelen vázlat szempontjából nem lényeges. Vö. Tóth J.: i. m. Az újabb szakirodalomból Szente Zoltán kategorizálását érdemes kiemelni, aki a következö értelmezéselméleteket azonosította: nyelvtani-logikai értelmezés, eredeti szándék szerinti értelmezés, kontextuális (rendszertani, strukturális) értelmezés, a norma célja szerinti értelmezés, morális és természetjogi értelmezés, jogi pragmatizmus, precedensek szerinti értelmezés, egyéb elméletek. Vö. Szente Zoltán: Érvelés és értelmezés az alkotmányjogban. Dialóg Campus Kiadó, Budapest Pécs, 2013, 139-190. o. Szente érdemét tekintve nem sokban tér el a korábban rögzített értelmezési módoktól, csak a besorolások változtak. Ami újdonság nála, az a jogi pragmatizmus önálló értelmezési elméletként való kiemelése, melynek lényege az ő megfogalmazásában az, hogy ,az interpretáció eredményének mindig tekintettel kell lennie az adott ügy - illetve a döntés - társadalmi következményeire is." Szente: i. m. 182. o. Szintén a legújabb szakirodalom köréből Jakab András a következő értelmezési módszerek között tett különbséget: a szavak hétköznapi vagy technikai jelentése, a rendszertani érvek (ezek között: az ún. „kontextuális harmonizációs” érvek, az értelmező precedensek, a doktrinális fogalmak és elvek, a hallgatáson alapuló érvek), az értékelő érvek (ezek körében az objektív és a szubjektív teleologikus érvek mellett találhatók a szubsztantív érvek is), valamint az „egyéb" érvek (szakirodalom, jogösszehasonlítás). Jakab 2016: 42-67. o. 
kötet megkerülhetetlen alapmủvé vált a jogértelmezéssel foglalkozó kutatók számára, egyúttal rávilágított az értelmezési technikák sokszínüségére is.

Ezt a meghatározási kísérletet látszólag vonzóvá teszi, hogy eltávolodik a politikai szempontoktól, és a jogtudomány, a jogértelmezés problematikája határain belül tartja a bírói aktivizmusról való diskurzust. Némi bizonytalanság azonban e definíció kapcsán is kimutatható. Két problémára érdekes rámutatni, amelyek korlátozzák a szóban forgó meghatározás használhatóságát.

Egyrészt a jogértelmezési módszerek közötti választás is végső soron jogfilozófia kérdése. Egy adott ország bevett jogászi gondolkodása kihat a jogi normák értelmezésére. Ugyanakkor adott jogértelmezési módszerek preferálása nem állandó. A jogtudományon belüli, valamint a jog szféráján kívüli tényezők egyaránt befolyásolják a jogásztársadalomnak a jog szerepéről alkotott elképzeléseit, módszertani preferenciáit. így például az Egyesült Államokban a XX. század első évtizedeiben felnövekvő jogászgeneráció úgy látta, a klasszikus természetjogi alapokon nyugvó alkotmányértelmezési gyakorlat alkalmatlan a kor gazdasági-társadalmi problémáival való megbirkózásra, az alkotmányhoz való új, visszafogott bírói viszonyulást szorgalmaztak. Idővel a Supreme Court többsége is magáévá tette ezt a preferenciát, és az 1940-es évektől kezdődően bevett alkotmányértelmezési doktrínává vált, hogy csak kirívó esetben bírálhatja felül a bíróság alkotmányos alapon a jogalkotói döntéseket. A szóban forgó kritérium alapján paradox módon aktivistának kellene tekinteni a jól ismert West Coast Hotel Co. v. Parrish-ügyben hozott ítéletet, ${ }^{168}$ mellyel a Legfelső Bíróság végett vetett annak a gyakorlatnak, hogy alkotmányellenessé nyilvánított több, a New Deal keretében megalkotott gazdaságszabályozó törvényt.

Kmiec azt írja tanulmányában - és ez a második probléma -, hogy nem alakult ki valódi szakmai konszenzus a megfelelő alkotmányértelmezési módszerekről. ${ }^{169} \mathrm{Ez}$ a megállapítás alapvetően igaz, ám két szempontból árnyalni kell. Egyfelől arra érdemes felhívni a figyelmet, hogy a megállapítás alapvetően az Egyesült Államokra vonatkoztatható, ahol nemcsak magas a társadalmi mobilitás, de emellett a jogászképzés és a jogászi karrier szerkezete olyan, hogy különböző társadalmi rétegekből származó személyek kerülhetnek akár a jogi szféra csúcsszerveibe is. Más országokról azonban ez csak korlátozott érvénnyel mondható el. Iskolapéldája ennek a brit ügyvédi kar, amely csak

\footnotetext{
168300 U.S. 379 (1937)

${ }^{169}$ Kmiec: i. m. 1474. o.
} 
az elmúlt években, évtizedekben kezdett nyitni az alsóbb osztályok és más társadalmi rétegek felé.

Másrészt azért is árnyalandó Kmiec kijelentése, mert bármilyen sokszínű is az egyesült államokbeli jogi gondolkodás, az ország legfőbb bírói fórumáról valószínüsíthető, hogy - ha más nem is, legalább az ideológiai megoszlás mentén - kialakít egy többékevésbé következetes értelmezési gyakorlatot. Ez a gyakorlat természetesen nem megváltoztathatatlan, de a személyi összetétel fokozatos megváltozása kell ahhoz, hogy a bíróság elvesse a bevett doktrínát.

Mindemellett azonban elmondható, hogy a „bevett értelmezési módszer” kritériuma szintén olyan bizonytalanságokkal terhelt, amelyek alkalmatlanná teszik arra, hogy az aktivizmus meghatározására szolgáljon.

\section{II.5.4. Az eredményorientált bíráskodás}

Kmiec szerint ez a kifejezés a legalkalmasabb meghatározási kísérlet. ${ }^{170}$ Ez a meghatározás pótolja azt a hiányosságot, amely a „megvétózás” kapcsán felmerült, nevezetesen azt, hogy rejtve maradnak azok az esetek, amikor a bíró a kívánt eredmény előmozdítása érdekében tartózkodik a támadott jogszabály alkotmányellenessé nyilvánításától.

Az eredményorientált bíráskodás kritériuma ugyanakkor természetszerüleg ki van téve annak a bizonytalanságnak, amelynek bármely más meghatározási kísérlet: a fogalom alkalmazhatósága függ az elemző jogi gondolkodásától. Példaként említhető Richard Epstein tanulmánya, aki az elvont normák rugalmas értelmezése mellett foglalt állást, anélkül, hogy ezt aktivizmusnak tekintette volna, jóllehet az ilyen jogértelmezés kétségkívül „eredményorientált”. ${ }^{171}$ Más elemző a józan észnek egyébként megfelelőként értékelhető értelmezést is tekintheti aktivizmusnak, amennyiben nyilvánvalónak tünik, hogy az adott döntést az alkotmánybíráskodást végző szerv következményorientált módon, de bizonyos korábban lefektetett értelmezési támpontok figyelmen kívül hagyásával hozta meg.

\footnotetext{
${ }^{170}$ Kmiec: i. m. 1476. o.

171 Epstein, Richard A.: Beyond Judicial Activism and Restraint. In The Georgetown Journal of Law \& Public Policy, Vol. 1, Issue 1, 2002, 87-89. o.
} 
Kérdésként merülhet fel, hogyan viszonyul az eredményorientált bíráskodás az objektív teleologikus értelmezéshez, tekintettel arra, hogy mindkét esetben az értelmezés valamilyen konkrét célhoz kötöttsége játszik központi szerepet. Álláspontom szerint az eredményorientált bíráskodás tágabb kategória. Az objektív teleologikus értelmezés során meghatározott cél „,vagy közvetlenül a szövegből (...) vezethető le, vagy közvetve, de annak alapján”. ${ }^{172} \mathrm{Az}$ eredményorientált bíráskodás viszont nem csupán ilyen rögzített célokra irányulhat, hanem olyan szubsztantív célokra való törekvésben is megnyilvánulhat, ami nem a normaszövegen, hanem a helyes társadalmi rend valamilyen elméletén alapul legyen szó gazdasági jogelméletről (avagy jogi pragmatizmusról), ${ }^{173}$ erényelméletről, ${ }^{174}$ feminizmusról ${ }^{175}$ vagy bármilyen más normatív elméletről.

\section{II.6. Az ismertetett megközelítések összegzése és állásfoglalás}

Mielőtt rátérnék a jelen értekezésben általam alkalmazott tipológiára, néhány összegző megjegyzést szeretnék tenni a bemutatott megközelítésekről. Mindenekelőtt arra érdemes felfigyelni, hogy míg könnyü az ,aktivizmus” bélyegét rásütni egy bíróságra,

\footnotetext{
172 Jakab 2016: 53. o.

${ }^{173}$ Posner, Richard A.: The Problematics of Moral and Legal Theory. The Belknap Press of Harvard University Press, Cambridge, 1999, 144-182. o. Posner könyvének ebben a szakaszában az általa jogi pragmatizmusnak is nevezett elmélet megfontolásait ülteti át az alkotmányjogba, amelynek tömör lényege abban foglalható össze, hogy az alkotmányértelmezést végzö bírónak körültekintőnek kell lennie az alapjogok értelmezése terén, ugyanis amennyiben nem tudhatja biztosan, hogy nem von-e maga után káros következményeket a döntése - például a bünözés esetleges emelkedését a túlzottan erös büntetőeljárási garanciák kiépítésével, avagy a hadseregben a vállaltan homoszexuális katonák beilleszkedési nehézségeit -, akkor érdemesebb önmegtartóztató álláspontra helyezkednie. Posner egyúttal élesen bírálja az alapjogok általa „fétisizmusnak” (fetishism) nevezett, eltúlzott tiszteletét. Voltaképp különösnek tünhet Posner elméletének felemlegetése a törzsszöveg kontextusában, föleg arra tekintettel, hogy ő is, mások is úgy foglaltak állást, hogy a pragmatizmus csekély valódi iránymutatással szolgálhat a joggyakorlat számára. Posner, Richard A.: What Has Pragmatism to Offer Law? In Southern California Law Review, Vol. 63, 1990, 1670. o.; Rosenfeld, Michel: Pragmatism, Pluralism and Legal Interpretation: Posner's and Rorty's Justice without Metaphysics Meets Hate Speech. In Dickstein, Morris (ed.): The Revival of Pragmatism. New Essays on Social Thought, Law, and Culture. Duke University Press, Durham, 1998, 340. o. Ugyanakkor ennek a pragmatikus távolságtartásnak a gyökere a metafizikai abszolútumoktól, dogmáktól függetlenített gyakorlati hasznosság, ebben pedig implicite benne rejlik annak lehetősége, hogy adott körülmények között a legcélszerübb döntés a bíró aktivista szerepvállalása.

${ }^{174}$ Cantu, Timothy: Virtue Jurisprudence and the American Constitution. In Notre Dame Law Review, Vol. 88, 2013, 1528-1535. o. Cantu itt azt mutatja be, hogy az alkotmányozás időpontjától eltávolodva az alkotmány egyre inkább akadályává vált annak, hogy az állam az erényes életvitelt elősegítő intézményeket támogassa.

${ }^{175}$ West, Robin: Re-Imagining Justice. In Yale Journal of Law and Feminism, Vol. 14, 2002, 333-344. o. West az általánosan elfogadott jogi gondolkodást bírálja annak három alappillérén, a joguralom (Rule of Law) eszméjén, az alapjogok (rights) eszméjén és a precedenskövetésben megmutatkozó formális igazságosságon keresztül.
} 
amelynek tevékenysége vagy adott döntése valamilyen szempontból kifogásolható az elemző számára, addig egy elmélyültebb kutatással feltárul a fogalom ambivalens jellege.

A különböző megközelítéseket összevetve láthatóvá válik, hogy akadnak bizonyos közös vonások. Különösen a Kmiec- és a Lindquist-Cross-féle felosztásra igaz ez. Az alkotmánybíráskodás létével menthetetlenül felmerülő „demokrácia vs. alapjogok” dilemmája mindegyik esetben tetten érhető, amennyiben valamilyen formában mindenhol az aktivizmus egy lehetséges meghatározásaként jelenik meg a jogalkotó mérlegelési szabadságának szükítése. Kmiecnél és a Lindquist-Cross párosnál egyaránt megjelenik az eredményorientált bíráskodás mint további kategória. Közös vonásként ki kell emelni továbbá a precedenstől való eltérést, ám itt jelezni kell azt is, hogy a Lindquist-Cross páros megközelítése szerencsésebb, ugyanis a precedensen túli autoritatív szövegekre is tekintettel volt. Sajátos lehetséges meghatározásként jelenik meg ugyanakkor Kmiecnél a bevett értelmezési módoktól való eltérés. A II.5.3. szakaszban észrevételezett problémákon túl az is megjegyezhetö, hogy ez a definíció részben feloldódik az autoritatív szövegtől való eltérésben, hiszen adott értelmezési mód egy-egy konkrét precedensben kerül kifejtésre, és az értelmezési módtól való eltérés jó eséllyel a precedens negligálását is maga után vonja. Emellett Lindquisték érdeméül kell betudni azt, hogy külön nevesítették az intézményi túlterjeszkedést, vagyis azokat az eseteket, amikor a bíróság a saját maga számára bővíti annak lehetőségét, hogy érdemben foglalkozzon az elé terjesztett üggyel.

A fentiek tanulságaként az vonható le, hogy pusztán egyetlen kritérium kiemelésével nem határozható meg az aktivizmus, ezért komplex megközelítés szükséges. Az megítélésem szerint vitathatatlan, hogy a jogalkotói döntések felülbírálata elengedhetetlen része a fogalomnak, ezt azonban mindenképpen korrigálni szükséges, hiszen az alkotmányellenessé nyilvánítás ténye önmagában nem mond semmit annak pontosabb indokairól. A precedenstől való eltérés nem alkalmas arra, hogy fogalmi elemmé váljon, ugyanis az, hogy az alkotmánybíráskodást végző szerv divergál korábbi gyakorlatától, legfeljebb az aktivizmus kísérőjelenségeként értékelhető. Crossék kiterjesztő megközelítése ebben a vonatkozásban több segítséggel szolgál. Az aktivizmus általuk azonosított egyik dimenziója lényegét tekintve az autoritatív szövegtől való eltérés.

A jelen disszertációban alkalmazott aktivizmusmeghatározás tulajdonképpen a legkézenfekvőbb megközelítéssel áll összhangban, azonban ezt igyekszem árnyalni. Álláspontom szerint a jogalkotói döntések korlátozása - amit a jelen értekezésben Kmiec tipológiáját némiképp korrigálva a „döntéshozatal más hatalmi ágak helyett” elnevezéssel illettem -, méghozzá szisztematikus és következetes korlátozása az aktivizmus első 
conditio sine qua nonjának tekinthető. Második nélkülözhetetlen elemként az alkotmányszöveg kiterjesztő értelmezése jelölhető meg. Vagyis e két feltétel együttes jelenléte esetén érdemes aktivizmusról beszélni: ilyen esetben nemcsak az alkotmányellenessé nyilvánítások gyakorisága relatíve nagy, hanem az indokolásokban is megmutatkozik egy olyan álláspont, ami ilyen tendenciák felé vezet. Az indokolásokra fókuszálással kiküszöbölhető annak dilemmája, vajon az „aktivista” precedens későbbi következetes szem elött tartása milyen nézőpontból tekinthető aktivizmusnak, és milyen szempontból nem, hiszen a kiterjesztő alkotmányértelmezéssel operáló döntés gondolati magva a precedenskövetés révén a későbbi döntésekben is manifesztálódik.

Nem lenne azonban teljes ez a definíció, ha nem reflektálnék arra a nehézségre, ami abból adódik, hogy az alkotmányos normakontrollt gyakorló szerv a támadott rendelkezés alkotmányosnak nyilvánításával is túllépheti a szerepét azáltal, hogy alig leplezetten azonosul a rendelkezés tartalmával. ${ }^{176}$ Paczolay egy tanulmányában egy bevett dichotómiát követ, amikor azt írja, hogy a kiterjesztő alkotmányértelmezést alkalmazó alkotmánybíróság aktivista, a megszorító alkotmányértelmezést alkalmazó pedig a bírói önkorlátozást támogatónak. ${ }^{177}$ Ezt a dichotómiát alkalmazom én is a jelen disszertációban, „passzivizmusnak” nevezve a bírói önkorlátozás képviseletét. Ugyanakkor azzal a megkötéssel teszem ezt, hogy az aktivizmus és a passzivizmus megkülönböztetését, valamint az érvelés ideológiai-világnézeti tartalmát két külön kérdésként kezelem. Az aktivizmus-passzivizmus dichotómia az alkotmányértelmezés terjedelmével függ össze, és ez egy viszonylag egzakt módon vizsgálható kérdés; ez áll a jelen vizsgálódás fókuszában is. A döntések ideológiai-világnézeti tartalmának, mögöttes mozgatóinak feltárása sokkal spekulatívabb feladat, hiszen aki erre rákérdez, az voltaképpen arra kérdez rá, hogyan viszonyult az indokolást megfogalmazó előadó bíró, valamint a testület többi tagja a konkrét rendelkezéshez, illetve az ahhoz kapcsolódó társadalmi problémához. Ez pedig nehezebben tehető szisztematikus vizsgálat tárgyává.

\section{II.7. Dogmatikus és tudományos aktivizmus, illetve passzivizmus}

\footnotetext{
${ }^{176}$ Lásd a II.5.1.1. szakaszban írottakat a Buck v. Bell kapcsán!

177 Paczolay Péter: Alkotmánybíráskodás a politika és jog határán. In Uö. (szerk.): Alkotmánybíráskodás alkotmányértelmezés. Budapest, Rejtjel Kiadó, 2003, 28. o.
} 
Az aktivizmus jelensége tehát egyrészt a szisztematikus alkotmányellenessé nyilvánításban (megsemmisítésben), másrészt az ezt megalapozó, kiterjesztő érvelésnek közvetlen vagy közvetett megjelenésében ragadható meg. Az aktivizmus azonban e jegyeken túlmenően is vizsgálható. A továbbiakban egy olyan tipológiát kívánok felvázolni, amely az alkotmányjogi tárgyú döntések indokolásának tartalmi elemzésén alapul.

Az alábbiakban (III.1.1.) bővebben fogom érinteni a „szociológiai mozgalom” jogban megfigyelhetö jelenségét a Lochner-döntésre tekintettel. E helyütt pusztán utalni szeretnék arra a tényre, hogy a jogi - és közelebbről az alkotmányjogi - érvelésnek a XX. század eleje óta integráns része a társadalomtudományi ismeretekre való támaszkodás is. Nem állítható, hogy ez kizárólagos vagy bármilyen formában domináns jelenség lenne, de a puszta léte vitathatatlan. Esetenként a társadalomtudományokra való támaszkodás nem egyszer kifejezetten a nagy horderejü kérdéseket érintő, megosztó döntésekben érhetö tetten. A Brown-ítélet ennek szemléletes példája: abban a Supreme Court nyíltan egy szociológiai elemzésre támaszkodott, amely szerint bizonyított, hogy a megkülönböztetés önmagában az érintett csoport szisztematikus marginalizálódásához vezet, és ezt a hivatkozott forrást vetette egybe azzal a közismertként bemutatott információval, miszerint az oktatás társadalmi jelentősége miatt újra kell gondolni a diszkrimináció létjogosultságát.

A fent bemutatott aktivizmusdefiníciók nem foglalkoznak az alkotmányjogi érvelésnek ezzel az aspektusával. Az aktivizmust így vagy úgy egy szereptúllépésként értelmezik, azonban megítélésem szerint nem szentelnek kellö figyelmet ennek a szereptúllépésnek a mikéntjére. A jogi érvelés autoritatív jellegü, azaz egy jogi álláspont meggyőző erejéhez szükség van arra, hogy azt valamilyen tekintély, autoritás alátámassza. A modern jogrendszerekben már követelmény az is, hogy ennek az autoritásnak hozzáférhetőnek kell lennie. Elsősorban természetesen magáról a jogszabályszövegről van itt szó, ${ }^{178}$ de ilyen autoritásként jön számításba a bírói gyakorlat (ami eseti döntésekben vagy egyéb normatív iránymutatásokban lelhető fel), a jogalkotó szubjektív szándékát alátámasztó dokumentumok, a jogirodalmi állásfoglalások. A jogi érvelésben azonban a világról szerzett ismeretek is efféle autoritásként jöhetnek számításba. Ismét a Brown v. Board of Education-ügy példájával élve: a Plessy v. Ferguson-ítélet a maga módján következetes és logikus volt, elvégre az equal protection of the laws kifejezés nem vonja szükségszerűen maga után a rasszok elkülönítésének tilalmát, pusztán azt, hogy hasonló

\footnotetext{
${ }^{178}$ E helyütt nem szándékozok kitérni a jogi norma érvényességének előzetes kérdésére, vagyis arra, hogy maga a jogi norma, melynek szövegére a jogalkalmazó támaszkodik, honnét nyeri autoritását.
} 
élethelyzetekben egyenlő elbánást kell nyújtani számukra - ennek a követelménynek a separate but equal-doktrína formálisan eleget is tett. Később azonban a testület ezen változtatott, és a megkülönböztetésnek elválaszthatatlan összetevőjeként tekintett az egyenlőtlenségre, és ennek során „külső”, azaz a jogtudományon kívüli szakirodalomra támaszkodott. Vagyis nemcsak hogy új ismereteket szerzett a társadalomról, de ennek az új ismeretnek a forrását jogi érvelése részévé tette azáltal, hogy a Brown-ítélet indokolásában hivatkozott rá.

Tipológiámat ennek megfelelően arra alapozom, hogy a vizsgált bírói döntés tartalmaz-e tudományos szakirodalomra hivatkozást. Az elemzés során elsősorban a társadalomtudományokra kézenfekvő gondolni, hiszen a nagy port kavaró ügyek jellemzően a társadalomtudományokat érintő kérdéseket érintenek (tipikusan ilyen a gazdaság szabályozásának, a szegregációnak, a terhességmegszakítás korlátozásának indokoltsága), ugyanakkor felmerülhetnek a természettudományokkal összefüggő problémák is (tipikusan e körbe vonható a környezetvédelem, de a müvi terhességmegszakítás is részben ilyen, hiszen a magzat testi fejlődése biológiaiorvostudományi kérdés). A jogalkotással szemben természetszerü elvárás, hogy igazodjon a valósághoz, és az alkotmánybíráskodást végző szervnek, amely a jogalkotó aktusainak alkotmányos kontrolljára hivatott, állást kell foglalnia abban, hogy ezt az elvárást érvényesíti-e a normakontroll-hatáskörén keresztül, és ha igen, milyen módon és terjedelemben. A szakirodalomban felmerül az az elvárás, hogy az alkotmánybíráskodást végző szerv érvényesítse a „racionális vagy tényeken alapuló jogalkotás” igényét. ${ }^{179} \mathrm{Ez}$ a problémakör indokolttá teszi annak vizsgálatát, hogy az alkotmánybírósági gyakorlat mennyire vonja be a kérdéses szabályozás által érintett terület tudományos szakirodalmát. Noha az ilyesmi nem jellemző, hiszen az alkotmánybíráskodást végző szervek mindenekelőtt alkotmányjogi érvekkel kell, hogy alátámasszák döntéseiket, a szaktudományi hivatkozások fontos legitimációs alapként jelennek meg néhány döntés indokolásában, mivel a döntéshozó testület jártasságát tükrözik a közönség felé. A Brown v. Board of Education-, vagy újabban az Obergefell v. Hodges-ügyek hivatkozott tudományos megállapításokat tartalmaznak alátámasztás gyanánt: az előbbi ügyben az Egyesült Államok közoktatásának történetét taglaló művekre történik hivatkozás, ${ }^{180}$ az utóbbiban a házasság történetének áttekintéséhez hívja segítségül az előadó bíró a

\footnotetext{
${ }^{179}$ Drinóczi Tímea: A racionális vagy tényeken alapuló jogalkotás és az Alkotmánybíróság. In Jogtudományi Közlöny, 70. évf., 5. szám, 2015, 240-241. o.

180347 U. S. 483, 489
} 
vonatkozó társadalomtörténeti szakirodalmat. ${ }^{181}$ Mindkét döntés kiemelkedő jelentőségű. Indokoltnak tủnik ezért egy olyan kategorizálás kialakítása, amelynek ez a jelenség a kiindulópontja.

Az általam javasolt kategorizálás szerint a döntések négy csoportra oszthatók. „Dogmatikus aktivistának” nevezhetők az olyan ítéletek, amelyek spekulatív természetű érveléssel kiterjesztik az alkalmazott alkotmányi rendelkezés jelentéstartományát, ezáltal szélesebb körű lehetőséget biztosítva az alkotmányellenesség megállapítására. Voltaképpen két összefüggő feltétel megvalósulása esetén érhető tetten e döntéstípus: egyrészt a döntést hozó alkotmánybíráskodást végző szerv hivatkozik valamilyen autoritatív szövegre, forrásra (legyen az jogszabályszöveg, precedens vagy bármi egyéb), másrészt azonban olyan releváns ténybeli körülményt is feltételez, amelyre a priori módon, a tudományos szakirodalom vizsgálata, az arra való hivatkozás nélkül következtet (például a ,józan észre” alapozva, avagy bizonyos „nyilvánvaló”, „közismert” körülményekre tekintettel). Ilyen körülmény lehet például a szerződési szabadság vonatkozásában a szerződő felek „ténybeli” egyenlősége (vagyis a formális egyenlőséghez kapcsolódó az a feltételezés, miszerint a felek, amennyiben józan ítélőképességük birtokában vannak, képesek szót emelni saját érdekeikért, és dönteni a számukra legkedvezőbb alternatíva mellett), vagy éppen ellenkezőleg, az a megfontolás, hogy az egyik fél potenciálisan visszaélhet előnyösebb helyzetével. „Dogmatikus passzivistának” ezzel szemben azokat a döntéseket nevezem, amelyek a fent ismertetett megfontolások alapulvételével megszorítóan értelmezik az alkalmazott alkotmányi rendelkezést, és ezzel tendenciózusan a támadott jogszabályi előírások alkotmányosságának megállapítását mozdítják elö.

„Tudományos aktivista” döntésnek azok a kiterjesztő alkotmányértelmezést tartalmazó döntések minősíthetők, amelyek a hagyományos jogi érvelés mellett az ügy tárgyához kapcsolódó kérdést illető szakirodalmi hivatkozást, szakirodalomra támaszkodó érvelést is tartalmaz; ehhez képest a „tudományos passzivista” döntések ilyen érvelés mellett értelmezik megszorítóan az alkalmazott alkotmányi elóírást. Mint fentebb említésre került, ez a szakirodalom társadalom- és természettudományi tárgyú egyaránt lehet. Emellett fontos kiemelni, hogy az alkalmazott érvelés tudományos szempontból nem kell, hogy kifogástalan legyen. A lényeg nem azon van, hogy az alkotmánybíráskodást végző szerv igazságot tesz egy más szaktudományra tartozó kérdésben, hanem azon, hogy ennek

${ }^{181} 135$ S. Ct. 2584, 2595 (2015) 
a szaktudománynak valamilyen meglátását bevonja álláspontja alátámasztására. Ebből következően az sem befolyásolja ezt a minősítést, hogy létezik-e tudományos konszenzus az ügy tárgyául szolgáló kérdésben vagy sem. A hangsúly ugyanis nem erre helyeződik, hanem arra, hogy az alkotmánybíráskodást végző szerv a döntésével és annak megindokolásával a nyilvánosság irányába is folytat kommunikációt, illetve döntései a nagyobb eséllyel tartanak számot a nyilvánosság érdeklődésére, és az ilyen irányú kommunikáció egyik összetevője a feltüntetett tudományos hivatkozás.

Ebben a kontextusban voltaképpen másodlagos az a kérdés, hogy az ilyen hivatkozás mennyiben tartozik hozzá az ügy „lényegéhez”. A jogalkalmazó szervek - ideértve az alkotmánybíráskodást végző szerveket is - jellemzően kérelemhez kötötten járnak el, vagyis meghatározott kérdésekre kell választ adniuk. A jogalkalmazó célja az, hogy döntése a közönség szemében logikusan felépített, szükségszerü és elkerülhetetlen következtetéshez vezető logikai láncként jelenjen meg. Ha így tekintünk a bírói döntésre, akkor valószínütlen, hogy az ügy „lényegéhez” nem tartozó kérdésben kerülne sor a tudományos hivatkozásra.

$\mathrm{Az}$, hogy a tudományos ismeretek befolyásolják a jogi döntéseket, olyan alapvetés, amit jóformán kimondani sem kellene. Ez több szinten történhet: egyrészt egy adott új ismeret értelemszerűen befolyásolja a bírónak a vilgáról alkotott képét, ami esetleg beépül a világképébe, és ezzel a „forgatókönyv” részévé válik másrészt ennél konkrétabban, egy aktuális ügy megoldásában a bíró igénybe vehet tudományos ismereteket is. Ez utóbbira szolgál példaként a fentebb említett Brown- és Obergefell-döntés. Egyúttal ez a változat az, ami a jelen kutatás számára érdekes. A nyílt hivatkozás jelentősége az alkotmánybíráskodást végző szervek elszámoltathatóságával, illetve annak hiányával hozható összefüggésbe. Ennek az ismert problémának a forrása az, hogy az alkotmánybíráskodást végző szerv a nála erősebb demokratikus legitimációval rendelkező szerv döntését érvényteleníti, és ezért bizonyos nagyon kivételes eseteket leszámítva mint amilyen az impeachment eljárás - nem vonhatók felelősségre - önmagában még negatív politikai, gazdasági vagy egyéb következmények esetén sem. Ilyen helyzet mellett kiemelten fontos a döntés nyomatékos alátámasztása. A jogalkalmazói döntés legitimációjának elsődleges forrása a megfelelő szabályok és elvek általi alátámasztás, azonban ezt a legitimációt erősíti a tények általi alátámasztás is, ami alatt a jelen kontextusban a társadalomról, illetve a természeti környezetről alkotott általános 
ismereteket értem. ${ }^{182}$ Ha úgy tetszik: amennyiben a jogalkalmazó szükségesnek tartja tájékoztatni a nyilvánosságot arról, milyennek kellene lennie a jognak, akkor ahhoz hozzátartozhat az is, hogy az ügy konkrét tényállásán túl a valóságról szerzett általánosabb ismereteket is tekintetbe veszi. ${ }^{183} \mathrm{~A}$ tudományos ismeretekre történő utalás legegyértelmübb és - ami itt talán még fontosabb - leginkább ellenőrizhető formája a közvetlen hivatkozás. Ezért helyezkedek arra az álláspontra, hogy az e helyütt kidolgozott tipológia „tudományos” kategória meghatározó tényezőjeként ezt kell számításba venni.

Ezeknek a kategóriáknak a kialakítását nem befolyásolja az, hogy melyikük fordul elő többször a gyakorlatban. Különösebben precíz adatok nélkül is sejthető, hogy a „tudományos” jellegü érvelés ritkább. Amikor azonban alkalmazásra kerül, jelentősége elvitathatatlan. Ismét érdemes a Brown- és az Obergefell-döntésekkel példálózni, hiszen mindkettő komoly fordulatott jelentett az alkotmányértelmezés gyakorlatában. Ezeket a döntéseket szem elött tartva akár az a hipotézis is megfogalmazható lenne, hogy az explicit szaktudományos alátámasztás nagyobb jelentőséggel bír az alkotmányértelmezési gyakorlat megváltoztatásában, mint a létező gyakorlat fenntartásában. Ennek igazolására vagy cáfolására mindazonáltal a jelen értekezés nem vállalkozik. Ami hangsúlyos, az az explicit hivatkozás ténye az indokolásban.

Felmerülhet kérdésként, hol helyezhetők el ebben a tipológiában a kifejezetten jogtudományi munkákra történő hivatkozások. Álláspontom szerint ha egy döntésben kizárólag jogtudományi elemzésre történik hivatkozás, az nem minősíthető tudományos aktivista vagy passzivista döntésnek, a minősítés alapja ugyanis kifejezetten a jogon kívüli tudományterületek bevonása.

1. táblázat: A tudományos, illetve dogmatikus aktivizmus, illetve passzivizmus szemléltetése példákkal

\begin{tabular}{|l||l|l|}
\hline \hline & Tudományos & Dogmatikus \\
\hline \hline Aktivista & Brown v. Board of Education & Lochner v. New York \\
& Támaszkodás és nyílt hivatkozás & A köztudomás szerint a pékek \\
\hline
\end{tabular}

182 Vagyis nem egy konkrét ügy konkrét történeti tényállásának megfelelő felderítettségét. Az alkotmánybíráskodás kontextusában első ránézésre ezt nem is szükséges különösebben hangsúlyozni, elvégre a jogalkalmazás ezen ága alapvetően absztrakt normák egybevetéséröl szól. A konkrét normakontroll tényleges lehetősége miatt - ami napjainkban az Egyesült Államokban és a kontinentális Európában egyaránt adott - érdemes utalni erre a körülményre.

${ }^{183}$ Rublin, Amy: The Role of Social Science in Judicial Decision Making: How Gay Rights Activists Can Learn from Integration and Capital Punishment Case Law. In Duke Journal of Gender Law \& Policy, Vol 19, 2011, 180. o. 


\begin{tabular}{|c|c|c|}
\hline & $\begin{array}{l}\text { valamilyen kortárs tudományos } \\
\text { ismeretre: empirikusan igazolt, } \\
\text { hogy az elkülönítés ténye } \\
\text { pszichésen káros az érintett } \\
\text { csoport tagjaira és rontja az } \\
\text { életesélyeiket, következésképp } \\
\text { érvényteleníteni kell ezt a } \\
\text { gyakorlatot }\end{array}$ & $\begin{array}{l}\text { szakmája lényegét tekintve nem } \\
\text { különbözik bármely más szakmától, } \\
\text { továbbá a szabályozás minden } \\
\text { látszat ellenére munkajogi, } \\
\text { következésképp ellentétes az } \\
\text { alkotmánnyal }\end{array}$ \\
\hline Passzivista & $\begin{array}{l}\text { Muller v. Oregon } \\
\text { Empirikus tények sora igazolja a } \\
\text { túlórázásnak a nőkre, és } \\
\text { közvetetten az egész társadalomra } \\
\text { gyakorolt káros hatását, } \\
\text { következésképp alkotmányosan } \\
\text { indokolt a korlátozó szabályozás }\end{array}$ & $\begin{array}{l}\text { West Coast Hotel v. Parrish } \\
\text { A józan ész számára egyértelmü } \\
\text { kapcsolat áll fenn a munkabér- } \\
\text { szabályozás és a közjó között, } \\
\text { következésképp a Supreme Court } \\
\text { nem bírálhatja felül a jogalkotó } \\
\text { értékelését }\end{array}$ \\
\hline
\end{tabular}

\section{II.8. Kitekintés: az Emberi Jogok Európai Bírósága, az Európai Unió Bírósága és a magyar Alkotmánybíróság az aktivizmusról szóló diskurzusban}

A fenti elemzés és példák, illetve a jelen disszertáció általában, alapvetően az Egyesült Államok legfőbb bírói fórumának gyakorlatán és a kapcsolódó szakirodalmi meglátásokon alapulnak, azonban a téma jelentősége túlmutat ennek körén. Az Egyesült Államokban az alkotmánybíráskodás, tágabban a magasabb szintű normákon alapuló normakontroll olyan sajátos jelenség volt, ami egy bő évszázadon keresztül egyedülállóként létezett a nyugati jogi kultúrában, hiszen ennyi időt - 117 évet - kellett várni, hogy Kelsen doktrínáinak nyomán 1920-ban létrehozzák az osztrák alkotmánybíróságot (egyúttal a gyakorlatban is megvalósuljon az alkotmánybíráskodás centralizált modellje). ${ }^{184}$ Napjainkban egy-egy ország jogalkotója és lakossága számára jóformán magától értetődő, hogy a törvények alá vannak vetve bizonyos, a jogforrási

${ }^{184}$ Az 1920-as csehszlovák alkotmány szintén rögzített egy alkotmánybíróságot, mely azonban ténylegesen csak később, 1921 novemberében kezdett el müködni. 
hierarchiában magasabb szintet elfoglaló jogi dokumentumoknak. Ilyen állapot mellett az alapjogi aktivizmus problémaköre nem csak azért különösen aktuális, mert több ilyen jogi dokumentum létezik, hanem azért is, mert ezek már túlmutatnak a demokratikus legitimációval bíró jogalkotó, valamint az alkotmányosság eszméjéből sarjadt alkotmánybíráskodás szembenállásán, és a kérdéskör további dimenziójaként felmerül a nemzeti szuverenitás és a nemzetközi kötelezettségek konfliktusa is.

\section{II.8.1. Az Emberi Jogok Európai Bírósága}

Bizonyos nézőpontból analógia állítható fel valamely nemzeti alkotmánybíráskodást végző szerv és az Emberi Jogok Európai Bírósága, illetve az Európai Unió Bírósága között is. Ennek alapja természetesen részben az emberi jogi alapon folytatott döntési hatáskör és gyakorlat. Másrészt viszont kifejezetten az Egyesült Államokban a Supreme Court által végzett alkotmányértelmezési gyakorlattal mutat párhuzamot az, hogy két szabályozási szint ütközik az adott bíróságok hatáskörgyakorlása során. Az Egyesült Államok föderatív állam, a létrehozatalakori koncepció szerint erős, de korlátozott központi (szövetségi), valamint széleskörü szabadsággal rendelkező tagállami hatalommal (mely utóbbinak első jelentős korlátozását a tizennegyedik alkotmánykiegészítés vezette be 1868-ban). Az Európa Tanács, illetve az Európai Unió nem államok, de a bíróságaik által alkalmazandó, illetve a nemzeti joganyag közötti kollízió kapcsán óhatatlanul felmerül a magasabb szintü jogforrás értelmezésének, alkalmazásának terjedelme, és ezzel együtt az aktivizmusprobléma is. Az Egyesült Államok alkotmányértelmezési gyakorlata, sőt, néha kifejezetten a Lochner-ítélet tanulságokkal szolgál a piac transznacionális szabályozására nézve a globalizálódó világban. ${ }^{185}$

Az Emberi Jogok Európai Bírósága és a Supreme Court mindenképpen párhuzamba állítható tevékenységük emberi jogi vonatkozása miatt, tekintve, hogy a Supreme Courtnak az aktivizmusról szóló vitát elindító gyakorlata emberi jogi vonatkozású volt. Ennek nyomán Paul Mahoney az Emberi Jogok Európai Bíróságát értékelve különbséget tett az aktivista és az önmegtartóztató stílusok között. Ugyanakkor eltért ezek hagyományos szembeállításától: a Bíróság aktivistaként, illetve önmegtartóztatóként jellemzett

${ }^{185}$ Zumbansen, Peer: Lochner Disembedded: The Anxieties of Law in a Global Context. In Indiana Journal of Global Legal Studies, Vol. 20, 2013, 65. o. Zumbansen Harlan bírónak a Lochner-ítéletben benyújtott különvéleményét állítja példaként, rámutatva arra, hogy az abban kifejtettek megelőlegezik napjaink bírájának a szakértői ismeretekre való ráutaltságát. 
jogértelmezési módszereit áttekintve arra a három következtetésre jutott - röviden összefoglalva -, hogy 1. a Bíróság csak empirikus bizonyíték alapján olvas új konnotációt a szövegbe, 2. a körülmény, hogy az értelmezett Egyezményt végső soron a részes államok érvényesítik, korlátozza a Bíróság befolyását, 3. a továbbfejlesztő értelmezésnek a Bíróság gyakorlatában csak akkor van helye, ha az szigorúan szükséges a konkrét ügyben. ${ }^{186}$ Később Popovic is észrevételezte, hogy a Bíróság az aktivista és önmegtartóztató megközelítést párhuzamosan alkalmazta, azonban arra a következtetésre jutott, hogy végső soron az előbbibe sorolható módszerek váltak dominánssá. ${ }^{187}$

A Mahoney-éhez hasonló álláspontok a modern emberi jogi bíráskodással összefüggésben más szerzőknél is megfigyelhetők, azonban ezekhez érdemes kritikusan közelíteni, épp úgy, mint fentebb, az alapjogi aktivizmus fogalmát meghaladni törekvő irányzatok esetében. A problémát abban látom, hogy Mahoney megközelítése végső soron nem segít eligazodni abban, hogy milyen egzakt szempontok alapján volna hely az Egyezmény aktivista, avagy önmegtartóztató értelmezésének. Annyit megállapítani, hogy bizonyos esetekben a kiterjesztő-továbbfejlesztő értelmezésnek van helye, nem elegendő, hiszen a „bizonyos esetek” köre továbbra is kényelmetlenül vitatható és képlékeny marad, és az értelmező preferenciájára van bízva azok azonosítása.

Az Emberi Jogok Európai Bírósága egy nemzetközi egyezmény alapján jött létre. Döntései ugyan kötelezők az egyedi ügyben érintett részes államokra nézve, azonban az e döntésekben foglalt iránymutatások követése alapvetően a részes államok jogérvényesítő mechanizmusainak függvénye, így például az Egyezménnyel esetlegesen ellentétes törvényt a részes állam jogalkotó testülete módosíthatja vagy helyezheti hatályon kívül, ${ }^{188}$ illetve a Bíróság által kidolgozott alapjog-értelmezést az állami bíróságoknak kell tekintetbe venniük. ${ }^{189}$ Ettől függetlenül a Bíróság döntéseinek van tényleges hatása és befolyása a részes államok jogrendszereire. A kialakult helyzet dilemmát eredményez: egyrészt szükséges az, hogy a döntések, amelyek kötelező erejének a szerződő államok

\footnotetext{
${ }^{186}$ Mahoney, Paul: Judicial Activism and Judicial Self-Restraint in the European Court of Human Rights: Two Sides of the Same Coin. In Human Rights Law Journal Vol. 11, 1990, 86-87. o.

${ }^{187}$ Popovic, Dragoljub: Prevailing of Judicial Activism over Self-Restraint in the Jurisprudence of the European Court of Human Rights. In Crighton Law Review Vol. 42, 2009, 395-396. o.

${ }_{188}$ Golsong, Heribert: The European Court of Human Rights and the national law-maker: some general reflections. In Matscher, Franz - Petzold, Herbert: Protecting Human Rights: The European Dimension. Carl Heymanns Verlag KG, Köln, 1990, 241. o.

${ }^{189}$ Utóbbihoz lásd pl.: Jennings, Robert: Human rights and domestic law and courts. In Matscher, Franz Petzold, Herbert: Protecting Human Rights: The European Dimension. Carl Heymanns Verlag KG, Köln, 1990, 299. o.
} 
alávetették magukat, ténylegesen érvényesüljenek. ${ }^{190}$ Másfelől azonban megjelentek olyan kritikus vélemények, amelyek a nemzetközi bíróság müködésének ellenőrizetlenségére, tévedéseinek korrigálhatatlanságára hívják fel a figyelmet. ${ }^{191}$

\section{II.8.2. Az Európai Unió Bírósága}

Az Európai Unió Bíróságának hatásköre az uniós jogforrások érvényesítése és értelmezése. E hatáskör gyakorlása is jelentőséggel bír az Unió arculatának kialakítása szempontjából. A Bíróság szerepének egyes funkcionalista megközelítései abból indulnak ki, hogy szükség volt arra, hogy az Unió sui generis joganyaga a puszta papírjognál nagyobb jelentőségre tegyen szert, ehhez pedig szükség volt a testületre. Az, hogy a Bíróság döntéshozatali tevékenysége során tartalommal töltötte fel ezt az elsődleges joganyagot, nem aktivizmus és pláne nem illegitim, ellenkezőleg: szükséges lépés az elsődleges jogforrások tényleges érvényesüléséhez. ${ }^{192}$ Ezt a célt szem előtt tartva egyes álláspontok szerint az Unió Bírósága tendenciózusan önmegtartóztató gyakorlatot folytatott a másodlagos és az elsődleges jogforrások viszonyát illetően, ${ }^{193}$ a tagállami és az uniós jog viszonyát illetően pedig az értékek sokszínűségének elvét követi. ${ }^{194}$ Más álláspontokból ennél sokkal nagyobb távlatú szerep tükröződik a Bíróságot illetően: ezek szerint a testület jogértelmező tevékenységével egy szupranacionális alkotmány megszületését segíti elő. ${ }^{195}$

$\mathrm{Az}$ újabb kritika az Európai Unió Bíróságának alapjogi gyakorlatának egyes területeit illetően észlelte az aktivista attitűd megjelenését, így például a transznemüek jogainak a diszkrimináció tilalmának fényében történő interpretálása ebbe a körbe

\footnotetext{
${ }^{190}$ Az Emberi Jogok Európai Egyezménye 46. cikk 1. szakasz szerint „[a] Magas Szerződő Felek vállalják, hogy magukra nézve kötelezőnek tekintik a Bíróság végleges ítéletét minden ügyben, amelyben félként szerepelnek." Ez a szöveg tehát alapvetően az egyedi ügyekre vonatkozik, amikor az államra nézve a Bíróság konkrét jogokat és kötelezettségeket állapít meg az őt perelő személy viszonylatában. Mindemellett - és ez a jelenség megfigyelhető Magyarországon is - a Bíróság döntései az Alkotmánybíróság döntéshozatali tevékenységén keresztül kifejezésre jutnak a magyar jogrendszerben.

${ }^{191}$ Varga Zs., András: Constitutional identity and the judgments of the ECtHR. In Pázmány Law Working Papers, No. 16, 2016. http://plwp.eu/evfolyamok/2016/174-2016-16 (2017. február 16.)

${ }^{192}$ Grimmel, Andreas: 'This is not Life as it is Lived Here': The Court of Justice of the EU and the Myth of Judicial Activism in the Foundational Period of Integration through Law. In European Journal of Legal Studies Vol. 7, 2014, 68-70. o.

${ }^{193}$ Lenaerts, Koen: The Court's Outer and Inner Selves: Exploring the External and Internal Legitimacy of the European Court of Justice. In Adams, Maurice et al. (ed.): Judging Europe's Judges. The Legitimacy of the Case Law of the European Court of Justice. Hart Publishing, Oxford, 2013, 18. o.

${ }^{194}$ Lenaerts: i. m. 29. o.

${ }^{195}$ Pl. Sweet, Alec Stone: Governing with Judges. Constitutional Politics in Europe. Oxford University Press, Oxford, 2000, 153-193. o.
} 
tartozik, ${ }^{196}$ habár egy másik, hasonló természetủ kérdést, az azonos nemü párok jogi helyzetének megítélését szemügyre véve árnyaltabb kép nyerhető, itt ugyanis a Bíróság gyakorlata mérsékeltebb. ${ }^{197}$

Az Európai Unió kiterjedt jogforrásanyagát nem pusztán absztrakt, elvi jellegü iránymutatások alkotják, hanem a legkülönfélébb szakterületek időnként minuciózusan körülírt szabályozása. E szupranacionális joganyag jóformán felmérhetetlen tárgyi sokfélesége a konkrét ügyekben óhatatlanul maga után vonja a szaktudományos ismeretek iránti igény problémáját egy adott kérdés helyes megoldása érdekében. A „tudományos”, illetve „dogmatikus” döntési kategóriák alkalmazása ezért indokolttá teszi, hogy az Európai Unió Bíróságának gyakorlatáról is essen néhány szó.

A szaktudományos ismeretek és a bírói aktivizmus viszonyáról kiváló áttekintést ad Vos, aki felvázolja a frissen kitapintható tendenciákat is: megfigyelése szerint míg az Európai Unió Bíróságának korai tevékenységét a passzivista, tartózkodó (deferential) megközelítés jellemezte, addig ez napjainkra átfordult egy aktivistább megközelítésbe. ${ }^{198}$ Ez a megközelítés azonban némiképp eltért az aktivizmusnak attól a válfajától, amit a szakirodalom rendszerint feltételez. Arról van szó ugyanis, hogy az Európai Unió Bírósága „információs katalizátorként” (informational catalyst) müködik, vagyis nem kategorikusan foglal állást, hanem azt ellenőrzi, hogy a kérdéses szabályozás kellő információ birtokában született-e. ${ }^{199}$ Ez a jelenség a habermasi diskurzuselmélet sajátos megvalósulására emlékeztet hasonlóképpen ahhoz, ahogyan azt például Sajó felvázolta kifejezetten az alkotmánybíráskodás vonatkozásában - igaz, itt nem az alkotmánybíráskodás intézményei és a civil társadalom, hanem az uniós jogalkotó és a Bíróság között zajlik ez a diskurzus. Egy szempontból azonban „feje tetejére áll” a jogalkotó és az igazságszolgáltatás viszonya. A szakirodalomban - és e megfontolások a dolog természetéből adódóan jellemzően az alkotmányos normakontroll témakörében kerültek kifejtésre - visszatérő álláspont az, hogy valamely életviszony szabályozásában a jogalkotásért felelős szerv - a demokratikus felhatalmazáson túl - azért is nagyobb kompetenciával rendelkezik, mert rendelkezésére állnak olyan források és intézmények, amelyekkel a bírói szervek - feladatkörükből adódóan - nem rendelkeznek. Az ilyen megfontolás rendszerint a normakontroll-

\footnotetext{
${ }^{196}$ De Waele, Henri - van der Vleuten, Anna: Judicial Activism in the European Court of Justice-The Case of LGBT Rights. In Michigan State Journal of International Law Vol. 19, 2011, 655. o.

${ }^{197}$ De Waele - van der Vleuten: i. m. 657. o.

${ }^{198}$ Vos, Ellen: The European Court of Justice in the face of scientific uncertainty and complexity. In Dawson, Mark et al. (ed.): Judicial Activism at the European Court of Justice. Edward Elgar Publishing Ltd., Cheltenham, 2013, 165. o.

${ }^{199}$ Vos i. m. 152-153. o.
} 
hatáskörrel rendelkező bíróságok önmegtartóztató hatáskörgyakorlását támasztja alá. Ám Vos elemzésének fényében ez a szereposztás megfordul, és az Európai Unió Bírósága egyfajta „szaktudományos szürővé” válik.

\section{II.8.3. Az Alkotmánybíróság}

Noha tartalmát tekintve az Alaptörvény túlnyomórészt egyezik a hatályon kívül helyezett Alkotmánnyal, a hatályba lépésével jelentős változás történt a magyar alkotmányos berendezkedésben és ily módon az alkotmánybíráskodás alapjaiban is. Az Alkotmánybíróságnak az Alaptörvény hatálya alatt követett gyakorlata számos vitát generált, ami részben az új alapnorma hatályosulására vezethető vissza, részben pedig arra, hogy az elmúlt években számos politikailag érzékeny alkotmányjogi kérdésben kellett az Alkotmánybíróságnak állást foglalnia.

A jelen értekezésben ismertetett kategorizálás alkalmazása talán a 43/2012. (XII. 20.) $\mathrm{AB}$ határozat által felvetett egyes dilemmákkal szemléltethető. Ebben a határozatában az Alkotmánybíróság az alapvető jogok biztosának indítványára megsemmisítette a családok védelméről szóló 2011. évi CCXI. törvény (a továbbiakban: Csvt.) 7. és 8. §-át. A kérdéses rendelkezések a családot a házasság Alaptörvény szerinti - vagyis kizárólag férfi és nő között fennálló - fogalmára alapozták, ${ }^{200}$ illetve rögzítették az ebböl eredő öröklési jogi következményeket. ${ }^{201}$ A döntés jogalapja a Csvt. 7. §-a vonatkozásában az Alaptörvény L) cikke, a törvény 8 . §-a vonatkozásában pedig a B) cikk (1) bekezdése. A jelen okfejtés szempontjából az előbbi rendelkezés megítélése releváns. A Csvt. 7. §-ának alaptörvényellenességét az Alkotmánybíróság azon az alapon állapította meg, hogy az Alaptörvény L) cikke által védeni rendelt család fogalmának a törvényalkotó olyan leszükítő értelmet

\footnotetext{
200 „7. § (1) A család a természetes személyek érzelmi és gazdasági közösségét megvalósító olyan kapcsolatrendszer, amelynek alapja egy férfi és egy nő házassága vagy egyenesági rokoni kapcsolat, vagy a családbafogadó gyámság.

(2) Egyenesági rokoni kapcsolat leszármazással vagy örökbefogadással jön létre.”

201 „8. § (1) Végintézkedés hiányában történő öröklés (a továbbiakban: törvényes öröklés) esetében öröklésre elsősorban törvényben meghatározott rokonsági fokig az egymással egyenesági vagy oldalági rokonságban, illetve az örökbefogadási kapcsolatban állók és a házastárs jogosult.

(2) Az állam és más személyek törvényes öröklésének csak az (1) bekezdésben említett személyek hiányában lehet helye.

(3) Az örökhagyó házastársát külön törvényben szabályozottak szerint özvegyi jog illeti meg.

(4) Kötelesrész illeti meg az örökhagyó leszármazóját, házastársát, továbbá szülöjét, ha az öröklés megnyíltakor az örökhagyó törvényes örököse vagy végintézkedés hiányában az lenne. A kötelesrész mértékét, alapját, számítását, kiadását, továbbá a kötelesrészből való kitagadás részletes szabályait külön törvény tartalmazza."
} 
adott, ami nem következne a szóban forgó alaptörvényi elöírásból. A törvény a család fogalmát a házassági életközösséghez kötötte, ami az Alaptörvényből következően fogalmilag csak nő és férfi között állhat fenn, ám ezzel - az Alkotmánybíróság érvelése szerint - nem tett eleget az állami intézményvédelmi kötelezettségnek. A határozatban olvasható megfogalmazás szerint „,[a]z Alaptörvény L) cikkéből (...) nem következik az, hogy például az egymás gyermekeiről gondoskodó, és őket felnevelő élettársak, a közös gyermeket nem vállaló, vagy olyan különnemü élettársak, akiknek egyéb körülmények miatt közös gyermeke nem lehet (így például az idősebb vagy meddö, egymással életközösségben élő személyek), az özvegyek, a testvérükről vagy testvérük, esetleg más rokonuk gyermekéről gondoskodó személyek, az unokájukat felnevelő nagyszülők, a nem egyenesági idősebb rokonaikról gondoskodó személyek, és számos más, a tágabb, dinamikusabb szociológiai család-fogalomba beletartozó, azonos célra irányuló, kölcsönös gondoskodáson alapuló, tartós érzelmi és gazdasági életközösségekre ne vonatkozna ugyanúgy az állam objektív intézményvédelmi kötelezettsége, nevezze ezeket bárhogyan is a törvényhozó." ${ }^{202}$ Ehhez a megfontoláshoz kapcsolta az Alkotmánybíróság a meglévő védelem szintjének követelményét: „ha a jogalkotó a családokra nézve kíván jogokat és kötelességeket megállapítani, akkor azoktól a személyektől, akik a családalapítást a házasságkötést megelőző vagy mellőző más - a jogalkotó által legalább egyes elemeiben szabályozott és elismert - tartós érzelmi és gazdasági életközösségben kívánják megvalósítani, a már megadottakhoz képest jogokat nem vonhat vissza, a társkapcsolati forma meglévő védelmi szintjét nem csökkentheti, és különösen a gyermekek mindenek felett álló érdeke szempontjából az intézményvédelmi kötelezettségét azonos módon kell érvényre juttatnia." ${ }^{203}$ A Csvt. 7. §-ának megsemmisítéséhez vezető döntést ennek a két szempontnak az egymásra vetítése alapozta meg. A határozat vitás megítélését tükrözi a két párhuzamos indokolás, és még inkább a három különvélemény megfogalmazásának ténye: ez utóbbiak részben abból az okból kifogásolták a megsemmisítést, hogy önmagában a kifogásolt szabályozás szúkítő tartalmából nem következik, hogy a család más típusai ne nyerhetnének védelmet más szabályozásban, ${ }^{204}$ részben pedig amiatt, mert az Alkotmánybíróság téves alapra helyezte a döntését azzal, hogy újragondolás nélkül átvette az Alkotmány elöírásai alapján kialakított gyakorlatát az Alaptörvény

\footnotetext{
202 43/2012. (XII. 20.) AB határozat, Indokolás [43]

203 43/2012. (XII. 20.) AB határozat, Indokolás [45]

${ }^{204}$ Lásd Balsai István és Dienes-Oehm Egon különvéleményeit: 43/2012. (XII. 20.) AB határozat, Indokolás [87], illetve [101]-[102]!
} 
értelmezéséhez is. ${ }^{205} \mathrm{Az}$ ügy politikailag érzékeny jellegéhez a puszta tárgyán túl hozzájárult az is, hogy az alkotmányozó/alkotmánymódosító hatalom ${ }^{206}$ az Alaptörvény negyedik módosításával az L) cikk (1) bekezdésébe beiktatta azt a mondatot, hogy „,[a] családi kapcsolat alapja a házasság, illetve a szülő-gyermek viszony”, és ezáltal szembehelyezkedett az Alkotmánybíróság döntésével.

A Csvt.-ben alkalmazott, leszükítő családfogalom a nem házasságon alapuló családok kirekesztése miatt vált kritikussá, ami az azonos nemű párok esetében kétszeres hátrányt is jelentett, mivel számukra fogalmilag nem is volt megadatott a házasság lehetősége. Az ügy a társadalmi érzékenység érintése mellett jelentős szociológiai problémát is érint, hiszen az elmúlt évtizedekben a család és a házasság fogalma egyaránt radikális átalakuláson ment keresztül. Az Alkotmánybíróság a határozatában csak érintőlegesen tett említést a család fogalmának társadalmi sokszínűségéről, mindemellett nem tett kísérletet annak meghatározására, mit tekint a család szociológiai fogalmának, csupán utalt annak dinamikus jellegére. ${ }^{207} \mathrm{Az}$ ebből fakadó dilemmát a „család” szó használatának jogi kontextusa révén oldja fel, amikor utal arra, hogy a jogági környezetben ez a szó más értelmet kap, mint a Csvt.-ben. ${ }^{208}$ A család fogalmának szociológiai összefüggéseire való legrészletesebb utalást Pokol Béla tette a különvéleményében, amikor az élettársi kapcsolatot „a szociológiai tapasztalatok szerint is kisebb gyerekszámot eredményező" viszonynak nevezi, ${ }^{209}$ azonban az ő érvelésének magva is egyértelmüen dogmatikai természetü, jelesül a testület többsége által alapul vett dogmatika helyébe javasol egy másikat.

Összességében tehát a 43/2012. (XII. 20.) AB határozat érvelése dogmatikusnak nevezhető. További kérdés az, mennyiben tekinthető Csvt. 7. §-át érintő érvelés aktivistának. E kérdés megválaszolásához a kulcs a többségi indokolás azon megállapítása, miszerint ,[a] más jogági normákban kifejeződő jogvédelmi (intézményvédelmi) szintet a jogalkotó nem szállíthatja le (burkoltan sem) olyan módon, hogy megadja az Alaptörvényben is szereplő család általános, ez esetben erősen leszükített fogalmát.”210

\footnotetext{
${ }^{205}$ Ez Pokol Béla álláspontja: 43/2012. (XII. 20.) AB határozat, Indokolás [110].

${ }^{206}$ Ehhez a distinkcióhoz lásd: Chronowski Nóra et al.: Túl az alkotmányon... Az alkotmányvédelem elméleti és európai kontextusa, továbbá magyar gyakorlata 2010-ben, avagy felülvizsgálható-e az alkotmánymódosító törvény az Alkotmánybíróság által. In Közjogi Szemle, 4. szám, 2010, 2. o.

207 A családfogalom dinamikus jellegének az Alkotmánybíróság határozatával összefüggésben való ismmertetéséhez lásd még: Bojnár Katinka: Az Alkotmánybíróság határozata a család fogalmáról. A családfogalom szúkítő értelmezésének elfogadhatósága. In Jogesetek Magyarázata 4. évf., 1. szám, 2013, 2426. 0 .

${ }^{208}$ 43/2012. (XII. 20.) AB határozat, Indokolás [43]-[44]

209 43/2012. (XII. 20.) AB határozat, Indokolás [110]

210 43/2012. (XII. 20.) AB határozat, Indokolás [43]
} 
Ebből a tételből ugyanis két álláspontra lehet következtetni. Egyrészt az Alkotmánybíróság többsége nem tartotta járhatónak azt az utat, hogy a jogalkotó korlátozó jellegü általános definícióval illesse a családot, másrészt ugyanakkor az intézményvédelmi kötelezettség mércéjéül a más jogági normák összességét tette. Az indokolás alapján kérdéses maradt, hogy az Alkotmánybíróság mögöttesen feltételezi-e azt, hogy az Alaptörvényben szereplő „család” szónak olyan sajátos jelentése van, ami független a jogalkotó általi jogszabályi konkretizálástól. A jogszabályi környezetre való utalással mindenesetre a döntéshozó többség bevonta álláspontja megalapozásába a hatályos jogszabályi kontextust, és arra utalással tekintette az Alaptörvénybe ütköző módon leszükítőnek a Csvt. kérdéses rendelkezését. Erre tekintettel álláspontom szerint az Alkotmánybíróság elemzett határozata a megsemmisítés ellenére is passzivistának tekinthető. A határozat egyrészt meghagyott bizonyos kérdőjeleket a család pontos definícióját illetően, ${ }^{211}$ ezzel ugyanakkor további mérlegelési teret hagyott a jogalkotó számára.

Csak kitekintő jelleggel érdemes utalni a 43/2012. (XII. 20.) AB határozat ismert „utóéletére”: az alkotmányozó/alkotmánymódosító hatalom az Alaptörvény számos elöírását érintő negyedik alaptörvény-módosítással megszüntette a döntés alkotmányos jogalapját azzal, hogy fogalmilag összekapcsolta a családot és a házasságot. Ez a lépés természetszerüleg bírálatot vont maga után az aktuálpolitikai felhangok miatt, ${ }^{212}$ továbbá azért is, mert a módosított L) cikk inkoherenciát okoz az Alaptörvény szerkezetében, és ily módon felvetődik e módosítás alkotmányellenességének lehetősége. ${ }^{213}$ Ez utóbbi aggály az alkotmányellenes alkotmánymódosítások elméleteinek általam „koherenciaelméletnek” nevezett kategóriájába sorolható, ${ }^{214}$ mivel az Alaptörvény belső összhangja okán tartja reálisnak a módosítás alkotmányellenességének (alaptörvény-ellenességének) veszélyét, illetve legitimnek az alkotmányellenesség kimondását. Az ilyen érvekkel összefüggésben felvethető, hogy az Alaptörvény magjának bizonytalansága ${ }^{215}$ ismeretében mi az az elvárható koherencia, amely alatt az Alkotmánybíróság megállapíthatja az

\footnotetext{
${ }^{211}$ Dombos Tamás - Polgári Eszter: Zavaros progresszió: Az Alkotmánybíróság a családok védelméről szóló törvényröl. In Fundamentum 17. évf., 1. szám, 2013, 59-60. o.

${ }^{212}$ Sonnevend, Pál - Jakab, András - Csink, Lóránt: The Constitution as an Instrument of Everyday Party Politics: The Basic Law of Hungary. In von Bogdandy, Armin - Sonnevend, Pál (ed.): Constitutional Crisis in the European Constitutional Area. Theory, Law and Politics in Hungary and Romania. Hart Publishing, Oregon, 2015, 58., valamint 85-86. o.

${ }^{213}$ Drinóczi Tímea: Ismét az alkotmányozó, az alkotmánymódosító hatalomról és az alkotmányellenes alkotmánymódosításról - az Alaptörvény alapján. In Jogtudományi Közlöny, 70. évf., 7-8. szám, 2015, 369. o.

${ }^{214}$ Molnár András: Adalékok az 'alkotmányellenes alkotmánymódosítás' problémájához. In Balogh Elemér (szerk.): Számadás az Alaptörvényről. Magyar Közlöny Lap- és Könyvkiadó, 2016, 252. o.

${ }^{215}$ Varga Zs. András: A jogrendszer és a jogalkalmazás határozatlansága és nem-teljessége. In Jogtudományi Közlöny, 68. évf., 3. szám, 2013, 113-115. o.
} 
alkotmánymódosítás alkotmányellenességét. Továbbá felvetődik annak problémája, hogy egyáltalán rendelkezik-e az Alkotmánybíróság legitimációval arra, hogy az alkotmányozó/alkotmánymódosító hatalom aktusait bármilyen módon felülbírálja. Voltaképpen olyan rendkívüli esettel állunk itt szemben, amely túllépi az aktivizmus mint a legitim alkotmányértelmezési tartomány egyik végletének kereteit, és az illegitim, contra legem alkotmányértelmezés és -alkalmazás tartományába csúszik át.

Később az Alaptörvény módosított L) cikke és egyes családpolitikai intézkedések közötti ellentmondás időnként további feszültségeket eredményezett. A dilemma lényege az, hogy mennyiben alkalmazhat megkülönböztetést a jogalkotó akkor, ha alkotmányi szinten kiemelte a házasságon alapuló család jelentőségét. E feszültség egy ilyen megnyilvánulása volt a 14/2014. (V. 13.) AB határozat, amelyben az Alkotmánybíróság mulasztásban megnyilvánuló alaptörvény-ellenességet állapított meg azért, mert a jogalkotó nem gondoskodott róla, hogy a családi pótlék mértéke a közös háztartásban, együtt nevelt gyermekek után azonos mértékü legyen a szülők együttélési formájától függetlenül. Meglátásom szerint ebben az - erős megoszlást generáló - ügyben is megfigyelhető a hatályos jogszabályi kontextus bevonása, melyből a testület többsége arra következtetett, hogy ,a szabályozás szempontjából a gyermekek tartoznak azonos csoportba, nem pedig a szülők által választott társkapcsolati formák”, ${ }^{216}$ és ez továbbra is a dogmatikus passzivista irányba mozdítja el az Alkotmánybíróság tevékenységét e téren. Ugyanakkor észlelhető az is, hogy problémás maradt a viszony a házasságnak a családpolitika szempontjából való privilegizálása, illetve más alkotmányossági követelmények, így a diszkriminációtilalom között.

\section{II.8.4. Összegzés}

A fenti szemléltetések két megállapítást tesznek lehetővé. Egyrészt az aktivizmusvita korántsem csak a nemzeti alkotmánybíráskodás értékelése során merülhet fel, másrészt a II.7. szakaszban ismertetett tipológia releváns a nemzeti alkotmánybíráskodáson túli ítélkező szervek tevékenységének értékelése során is. Ez elsősorban az Európai Unió Bíróságával, valamint a magyar Alkotmánybírósággal összefüggésben rajzolódik ki jól. Az Unió Bírósága kifejezetten felveti nem pusztán az aktivizmus kérdését, de ítélkezési

216 14/2014. (V. 13.) AB határozat, Indokolás [43] 
gyakorlatának szaktudományos alapokra támaszkodását is, és az erről szóló elemzések tanúsága alapján e gyakorlat révén létezik egyfajta tudományos alapú párbeszéd a Bíróság és az Unió más szervei között. A magyar Alkotmánybíróság aktivizmusa lényegében a testület fennállása óta vita tárgya. Ezek a viták csak felerösödtek az Alaptörvény hatályba lépésével és az azt követő egyes jogalkotói és alkotmányozói lépésekkel. A fentebb szemléltetett példával a dogmatikus passzivizmus egy esetét elemeztem. 


\section{Tendenciák a Lochner-ítéletet és korának alkotmányértelmezési gyakorlatát értékelő szakirodalomban, valamint a jelen kutatás elhelyezése e megközelítésmódok között}

Habár a szakmai közvélemény a Lochner v. New York-ítéletet, valamint az amerikai Supreme Court korabeli gyakorlatát egy erőteljes konzervatív aktivizmussal kapcsolja össze, a korszakkal behatóbban foglalkozó szakirodalom árnyaltabban közelíti meg a kérdést, és vitába száll ezzel az általánosítással. A Supreme Courtnak a XX. század első harmadában folytatott joggyakorlata fontos adalékokat nyújt a bírói szerep meghatározásához, valamint az alkotmányértelmezés és a „demokratikus deficit” dilemmájához, elvégre a testület müködésének ezen időszaka az első olyan ismert eset, amikor az ideológiai elfogultság és a dogmatikus megrögzöttség indíttatására való ítélkezés vádjával illették. A jelen fejezet arra igyekszik rávilágítani, milyen megítélés alá esett a Supreme Court tevékenysége az azt elemző vagy bíráló szakirodalomban, valamint arra, hogy ezekben az elemzésekben milyen főbb csapásirányok mutathatók ki.

Már elöljáróban leszögezhető, hogy az álláspontok meglehetősen vegyesek. A kérdéses időszakban a bíráló hangok voltak a legerősebbek - különösen Holmes, Brandeis, valamint Frankfurter tekintélyének, valamint a szabadversenyes kapitalizmus 1929-es világválság miatti tekintélyvesztésének köszönhetően -, ám már ekkor is megjelentek olyan elemzések, amelyek a Supreme Court markáns önmérsékletét igazolják. A Lochneritéletet és az azzal összefüggésbe hozott joggyakorlatot negatívan megítélő vélemények később is domináltak, ami feltehetően összhangban áll a jóléti állam eszméjének az 1930astól az 1970-es évekig tartó virágzásával. Azonban ez alatt az idő alatt is születtek alternatív álláspontok, melyek vitatják a „konzervatív bíróság” képét. Időben későbbre tehető egy olyan vonulat, amely egyetértőleg viszonyul a Supreme Court gyakorlatához. Alapvetően olyan szerzők sorolhatók ide, akik közgazdaságtani érvekkel támasztják alá az állami szabályozás indokolatlanságát, és ezzel együtt a szabadságjogok - így a tulajdonhoz való jog - erősebb védelme mellett szállnak síkra. Végül megfigyelhető egy „kiegyensúlyozott” tábor. Az ebbe tartozó szerzők elsősorban annak kimutatására törekszenek, hogy a Supreme Court - bárhogy is minősítse ezt a külső szemlélő - a maga módján következetes gyakorlatot érvényesített. Ennek a gyakorlatnak lehetnek ideológiai 
gyökerei, amelyek akár egészen az alapításig is visszanyúlhatnak, de a Supreme Court döntései semmi esetre sem tekinthetök önkényesnek.

\section{III.1. A korabeli értékelések}

Az Egyesült Államokban a XIX. század második felében beindult, majd a századfordulóra beérett gazdasági-társadalmi változások a jogról való gondolkodás változását is maguk után vonták, hiszen - nem kis részben európai befolyásra ${ }^{217}$ - ekkortájt bukkantak fel az első olyan elméleti irányzatok, amelyek a jog társadalomtudományos vizsgálatának fontosságát hangsúlyozták. Azok, akik fogékonyak voltak az új gondolatokra, nem ritkán kritikával illették az absztrakt fogalmakra építő langdelliánus jogszemléletet és joggyakorlatot, és abban a korban - kimagasló társadalmi jelentőségére tekintettel - megkülönböztetett figyelemben részesültek a piac visszásságainak korlátozására irányuló vagy a társadalom jobbítását célzó jogszabályok alkotmányosságával kapcsolatos döntések. Ezért a Lochner-korszak megítélésének vizsgálatához elengedhetetlen némi kitekintés a jogtudományi életben akkortájt fellendülő szociológiai mozgalomra.

\section{III.1.1. A szociológiai mozgalom a jogban}

Amikor a szociológiai szemléletmódnak az amerikai jogtudományban való megjelenéséről esik szó, óhatatlanul az ifjabb Oliver Wendell Holmes fellépésével kell kezdeni a vizsgálódást. A fösodrú felfogás szerint Holmes volt az, aki megalapozta az amerikai progresszív jogelméletet azáltal, hogy fontosabb mủveiben felhívta a figyelmet a társadalmi valóság figyelembevételének jelentőségére a jogrendszer müködésében. Ilyenkor legtöbbször Holmes Common Law címü monográfiájának egyik bevezető mondata kerül elő, mely szerint a ,jog élete nem a logika: a tapasztalat volt" ${ }^{218}$ Később hasonló gondolatok jelentek meg a Path of the Law címü írásában is, melyben Holmes

\footnotetext{
${ }^{217}$ Az európai szociológiaelmélet és szociológiai jogelmélet tengerentúli befolyásához lásd különösen Nagy Zsolt: Szociológiai jogelmélet vagy jogszociológia? Jhering hatása Amerikában. In Frivaldszky János Pokol Béla (szerk.): Rudolf von Jhering és jogelméletének hatása. PPKE JÁK, Budapest, 2011, 193-209. o. 218 „The life of the law has not been logic: it has been experience.” Holmes, Oliver Wendell: The Common Law. Little, Brown, and Company, Boston, 1881, 1. o.
} 
szerint ,[1]ehet, hogy a jog racionális tanulmányozását ma a betük embere végzi, de a jövőben a statisztikák embere, a gazdaságtan ismerője fogja”. ${ }^{219}$ Holmes itt - bírálva, de nem gyökerestül elvetve a történeti jogi iskola tanait - arra mutat rá, hogy kizárólag a múlt tanulmányozásával nem alkotható megfelelő szabályozás a jelen viszonyaira nézve, ezért a múlt tanulmányozása, az adott életviszonyra kialakított régi szabályozás okainak, rációjának megismerése mellett szükség van azok mindenkori kritikai felülbírálatára, ez pedig társadalomtudományos ismereteket követel. ${ }^{220}$ Konkrét példaként a büntetés elméletét hozza fel, és a büntetés rendeltetését a bünözést kiváltó okok (veleszületett hajlam, környezettől való tanulás) függvényében határozza meg. ${ }^{221}$ Egy másik tanulmányában hasonlót szorgalmaz: a jog tanulmányozása nem merülhet ki a dogmatikában és a logikában, a múltban kialakított szabályok életszerüségét újra meg újra felül kell vizsgálni tudományos alapon. ${ }^{222}$

Ugyanakkor meg kell jegyezni, hogy a Holmes munkásságával foglalkozó későbbi szerzők megkérdőjelezik a fősodratú narratívát. Így például White arra mutat rá, hogy Holmes Common Law címü kötete módszertanában erősen emlékeztet Langdell munkásságára, Holmes méltatói pedig egyoldalúan emelték ki munkásságának egy részét, jelentős figyelmet tulajdonítva a társadalomtudományok hasznosításának, a jog való élethez való közelítésére irányuló szólamaira, ugyanakkor hajlamosak voltak megfeledkezni munkásságának egyéb elemeiről. ${ }^{223}$ Mások arra hívják fel a figyelmet, hogy ha Holmes munkásságát kora jogtudományának kontextusában vizsgáljuk, akkor azt láthatjuk, hogy ő elsősorban a természetjog individuumközpontú, morális felróhatóságon alapuló felelősségi elképzeléseivel fordult szembe, és az „objektív”, külsődleges mércék (external standards) révén a modernizálódó, egyre összetettebbé váló társadalom számára megfelelőbb felelősségi rendszert kínál. ${ }^{224}$ Megint mások azt mutatták ki, hogy amikor Holmes a német jogtudományt a beszűkült formalizmussal azonosítja, akkor voltaképpen hanyagul és féloldalasan jár el, mert a német jogtudománynak csak a saját álláspontját

\footnotetext{
${ }^{219}$ Holmes, Oliver Wendell: The Path of the Law. In Harvard Law Review Vol. 10, 1897, 469. o.

220 Vagyis Holmes azt a jogszociológiára jellemző gondolatot juttatta kifejezésre, amit Selznick történetiségnek nevezett. Selznick, Philip: Jogszociológia. In Sajó András (szerk.): Jog és szociológia. Válogatott tanulmányok. Közgazdasági és Jogi Könyvkiadó, Budapest, 1979, 66. o.

${ }^{221}$ Holmes 1897: 470-471. o.

${ }^{222}$ Holmes, Oliver Wendell: Law in Science and Science in Law. In Harvard Law Review Vol. 12, 1899, 452. o.

${ }^{223}$ White, G. Edward: Justice Oliver Wendell Holmes: Law and the Inner Self. Oxford University Press, New York, 1993, 170-171. o.

${ }^{224}$ Horwitz, Morton J.: The Place of Justice Holmes in American Legal Thought. In Gordon, Robert W. (ed.): The Legacy of Oliver Wendell Holmes, Jr. Stanford University Press, Stanford, 1992, 34-35. o. Holmes objektív mércéinek ismertetéséhez lásd még Molnár András: Oliver Wendell Holmes jogi gondolkodása. In Jogelméleti Szemle, 2011/4. szám, http://jesz.ajk.elte.hu/molnar48.pdf (2014. augusztus 27.).
} 
megerősítő vonásait hangsúlyozza, s ezáltal erősíti az önmagáról alkotott ,,antiformalista tudós" képet, holott tüzetes elemzéssel kiviláglik, hogy egyes német jogtudósok nézetei is komoly átfedéseket mutatnak az övéivel. ${ }^{225}$ Kelley egyenesen azt állítja, hogy mind Langdellnél, mind Holmesnál tetten érhető egyfajta erőteljes formalizmus, és ezek csupán megalapozásukban térnek el egymástól. Holmes szerint ugyanis a jog egy adott társadalompolitikai cél megvalósítására irányul, és a bírónak - mivel a lehetséges célok között nem lehet tudományos alapokon választani - nincs más dolga, mint a törvényhozási többség által követett célt érvényesíteni. Langdell ehhez képest a jog önállóságából és más területektől való szigorú elválasztásából indult ki. ${ }^{226}$ Holmes nézete bírói tevékenységében is megmutatkozott: számos ítéleti indokolásában, különvéleményében látható, hogy nem hivatkozott az adott problémát érintő szakirodalomra - ebben látványosan elütött követőjétől és kollégájától, Louis Brandeistól -, hanem deklarálta, hogy bíróként nem tiszte állást foglalni olyan kérdésben, amelyben hozzáértő, értelmes emberek között sincs egyetértés. Holmes „szociológiai jogelmélete” tehát elsősorban a jogalkotói mérlegelés érintetlenül hagyását, egy rendkívül passzív bírói funkció elméleti megalapozását szolgálta.

A szociológiai mozgalom elindítása igazán Roscoe Pound nevéhez füződik, aki tanulmányok és monográfiák egész sorában fejtette ki álláspontját a szociológia és a jogtudomány összekapcsolásáról. Ugyan Hunt felhívja rá a figyelmet, hogy Pound tulajdonképpen nem alkotott egyetlen koherens elméletet, mert nem egységes jelentést tulajdonított az általa használt fogalmaknak, bizonyos mértékig az időben egymást követő tézisei is utólagos feloldás nélküli ellentmondásba kerültek, a szociológiára pedig tetszőlegesen hivatkozik, ${ }^{227}$ ennek ellenére Poundnak a jogi doktrínák és a társadalmi valóság közelítésében játszott jelentős tengerentúli szerepe nem tagadható. Aligha állítható, hogy Pound nélkül - aki számára természetesen, ezt hangsúlyozni kell, komoly szellemi forrást jelentett az európai jogirodalom - nem léptek volna színre az övéhez hasonló nézetek, az viszont tény marad, hogy ő a jog és a szociológia összekapcsolására irányuló amerikai törekvések ikonikus alakja.

Pound - voltaképpen Holmes nyomdokain járva - bírálta korának hazai jogi gondolkodását, amiért az túlságosan „történeti és analitikus” (historical and analytical), ${ }^{228}$

\footnotetext{
${ }^{225}$ Reimann, Mathias W.: Holmes's Common Law and German Legal Science. In Gordon, Robert W. (ed.): The Legacy of Oliver Wendell Holmes, Jr. Stanford University Press, Stanford, 1992, 104-105. o.

${ }^{226}$ Kelley, Patrick J.: Holmes, Langdell and Formalism. In Ratio Juris, Vol. 15, 2002, 48-49. o.

${ }^{227}$ Hunt, Alan: The Sociological Movement in Law. The Macmillan Press Ltd., London, 1978, 34. o.

${ }^{228}$ Pound, Roscoe: Law in Books and Law in Action. In American Law Review Vol. 44, 1910, 25. o.
} 
és észrevételezi, hogy korának jogrendszere egy sor olyan esetet produkál, amikor az írott jog, illetve a bevett jogi doktrínák összeütközésbe kerülnek a valósággal. Emellett kritikusan jegyzi meg, hogy az amerikai jogi gondolkodás túlságosan individualista és ezzel összefüggésben az emberek túlságosan nagy bizalmat fektetnek a személytelen, mechanikus igazságszolgáltatásba. Pound ezt a gondolkodásmódot idejétmúltnak tartja, és a törvényhozó általi társadalomalakítást pártfogolja. ${ }^{229}$ Hasonló gondolatok jelennek meg egy másik tanulmányában, amelyben amellett érvel, hogy a bírói jogalkotás történelmi körülményei elmúltak, és - legalábbis az Egyesült Államokban - a központi jogalkotás alkalmasabb a társadalmi problémák megoldására. ${ }^{230}$

Már az eddigiekből is sejthető, hogy Pound alapvetően a jogalkotó vonatkozásában hangoztatja a társadalomtudományok jelentőségét. Ez a vonás még erőteljesebben megfigyelhető abban a hat pontban, melyben a „szociológiai jogtudomány” (sociological jurisprudence) feladatait foglalja össze. Nézete szerint az irányzat képviselőinek a következő feladatokra kell fókuszálnia: a jogintézmények és jogi doktrínák társadalomra gyakorolt tényleges hatásának vizsgálata, szociológiai kutatás valamely jogszabály megalkotását megelőzően, a jogérvényesítés lehetőségeinek tanulmányozása, a múltbeli jogintézmények társadalmi hatása, az egyedi esetek ésszerű és méltányos megoldása lehetőségének vizsgálata, valamint a jog céljainak hatékonyabb megvalósítására való törekvés. $^{231}$

A jog kiszámíthatatlanságának tézisével és a jog, illetve a társadalomtudományok kapcsolatának hangoztatásával Holmes és különösen Pound megelőlegezte a jogi realisták 1930-as években kibontakozó elképzeléseit. E nézetek azzal a természetjogi gyökerü általános felfogással helyezkedtek szembe, miszerint valamely élethelyzetre a racionális gondolkodás, a józan ész segítségével a priori helyes és objektíve igazolható szabályozás alakítható ki. Kifejlődésének óriási löketet adott az a körülmény, hogy a jogfelfogás és a társadalmi valóság többé-kevésbé eltávolodott egymástól. A jelen tanulmányban ennek alkotmányjogi vetülete - a Supreme Courtnak a piac szabályozására irányuló jogszabályokhoz való viszonya - kerül középpontba, azonban meg kell jegyezni, hogy a probléma a jogrendszer egészét átjárta. Ezt példázzák a kártérítési jogi gondolkodás változásai: míg korábban a bíróságok abból indultak, ki, hogy az okozati összefüggés

\footnotetext{
${ }^{229}$ Pound: i. m. 35. o. Érdekes módon annak ellenére ez a végkövetkeztetés, hogy magának Poundnak a figyelme sem siklik át a törvényhozás egyes hátrányai fölött. Vö. Pound: i. m. 34. o.

${ }^{230}$ Pound, Roscoe: Common Law and Legislation. In Harvard Law Review Vol. 21, 1908, 403. o.

${ }^{231}$ Pound, Roscoe: The Scope and Purpose of Sociological Jurisprudence. In Harvard Law Review, Vol. 25, 1912, 512-515. o.
} 
feltárása során szilárd támpontok segítségével megbízhatóan különböztethetők meg a releváns és az irreleváns elemek. Mint Horwitz bemutatja, különösen az 1920-as évektől ezt a felfogást heves bírálat alá vették a korai jogi realisták, mondván, a határ megvonása bírói szeszély kérdése. ${ }^{232}$ Amit itt látni kell, az az, hogy a Supreme Court korabeli tevékenysége szoros összefüggésben áll egy mélyreható jogelméleti paradigmaváltással.

\section{III.1.2. A Supreme Court alkotmányértelmezési gyakorlatának korabeli megítélése}

A korabeli kritikákat áttekintve talán a leginkább az a szembeötlő, hogy már a vizsgált korszakban is megjelentek a „pro” és „kontra” álláspontok a tekintetben, mennyire minősíthető „bírói visszaélésnek” a tizennegyedik alkotmánykiegészítés Supreme Court általi értelmezése. Ha nem számítjuk Holmest, aki olykor különvéleményeiben fogalmazott meg egészen éles - nem egyszer fájóan tömör - kritikát, akkor Poundot tekinthetjük a kritikus hozzáállásúak legbefolyásosabb képviselőjének. Legtöbbször idézett tanulmányában általános tézise illusztrációjaként hozza fel a Supreme Court alkotmányértelmezési tevékenységét. Szerinte nemcsak a bíróságok, de a jogalkotók is többnyire $a$ priori elképzelésekből indulnak ki, ahelyett, hogy tudományosan elemeznék a szabályozandó problémakört. ${ }^{233}$ Az ötödik, illetve a tizennegyedik alkotmánykiegészítéssel

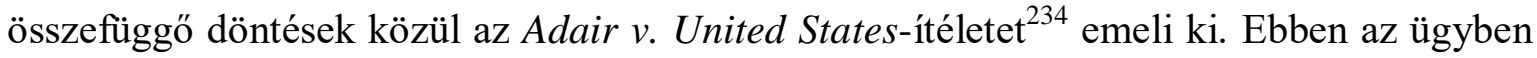
a Supreme Court az ötödik alkotmánykiegészítés alapján a szerződési szabadsággal ellentétesnek, és ezért alkotmányellenesnek nyilvánított egy szövetségi törvényt, amely megtiltotta, hogy a munkáltatók a szakszervezeti tagság miatt bocsássák el alkalmazottaikat. Pound szerint a szerződési szabadság fogalma nem egyéb, mint logikai dedukció, melyet anélkül alakított ki a bírói gyakorlat, hogy tekintettel lett volna a gyakorlati alkalmazás várható következményeire. ${ }^{235}$

Ezzel az érveléssel kapcsolatban annyit célszerü megjegyezni, hogy sommás ítéletalkotása során Pound nem foglalkozik a Supreme Court döntéseinek tendenciájával. A későbbiekben ki fogok térni az ezzel kapcsolatos empirikus felmérésekre, ugyanakkor a

\footnotetext{
232 Ehhez lásd különösen: Horwitz, Morton J.: The Transformation of American Law 1870-1960. Oxford University Press, Oxford, 1992, 51-63. o.

${ }^{233}$ Pound, Roscoe: Mechanical Jurisprudence. In Columbia Law Review, Vol. 8, 1908a, 613-614. o.

234208 U. S. 161 (1908)

${ }^{235}$ Pound 1908a: 616. o.
} 
saját e témában végzett kutatásaim is alátámasztani látszanak azon álláspontot, miszerint a piacszabályozás terén a Supreme Court gyakorlatára összességében inkább az jellemző, hogy alkotmányosnak találta a támadott jogszabályhelyeket, még akkor is, ha tevékenységében mutatkoznak irracionális elemek, így például kérdéses, a testület miért éppen a munkaidö-maximálás és a minimálbér rögzítése között vonta meg az alkotmányosság határát. ${ }^{236}$ Persze lehet amellett érvelni, hogy a Pound által kiemelt Adairdöntés minden tendenciától függetlenül valóban okot ad a Pound nézeteiből fakadó kritikára, hiszen a Supreme Court itt egy olyan politikai célkitüzés megvalósításának szab gátat, amit egyébként bármely ésszerüen gondolkodó ember kézenfekvőnek találhat. Mégis érdemes tekintettel lenni arra, hogy az ilyen eset fordult elö ritkábban, és noha a Supreme Court rendszerint nem bocsátkozott a szabályozási tárggyal kapcsolatos empirikus felmérések elemzésébe, „mechanikus” gyakorlata során rendszerint teret adott a jogalkotói elképzeléseknek. Ez pedig némileg enyhíti Pound kritikájának élét.

Pound egy tanulmányt kifejezetten a szerződési szabadság korabeli értelmezése bírálatának szentel. Ebben eszme- és jogfilozófia-történeti kontextusban értékeli a fogalom jogrendszerbeli helyét. Szerinte az egyesült államokbeli jogi gondolkodás túlságosan az újkori természetjogi alapokra helyezkedik, ami problematikus, mert megváltoztathatatlannak tekintik az alapjogokat, és nincsenek tekintettel sem azok eredeti, történelmi rendeltetésére, sem a társadalmak folyamatos változására. ${ }^{237}$ Hét okot - a fentebb ismertetettekből részben ismerős - okot sorol fel, amelyek ahhoz vezettek, hogy az Egyesült Államok jogásztársadalma jelentős mértékben eltávolodott a társadalmi valóságtól. Ezek: az individualista, az egyéni érdeket a közérdek elé helyező gondolkodás, a jogalkalmazás logikai dedukcióként való felfogása, az állam, a gazdaság és a politika kizárólag jogászi felfogása, a jogászok tizennyolcadik századi filozófián való nevelkedése, az alapjogok természetjogi megalapozása, ami csak akkor müködhet, ha minden ember azonos morális és gazdasági nézeteket vall, az a fejlemény, hogy a korai munkajogi törvények felkészületlenül érték az akkori társadalmat, valamint a jogrendszer azon minősége, hogy az alkotmányosság jogi kérdés, ezért a jogszabályok alkotmányosságát nem hatékonyságuk, hanem müvi kritériumok, fogalmak alapján ítélik meg. ${ }^{238}$

\footnotetext{
${ }^{236}$ Ehhez lásd például Molnár András: Az amerikai Supreme Court „konzervatív aktivizmusa” a XX. század első évtizedeiben született precedensek tükrében. In Jogelméleti Szemle, 2013/4. szám, http://jesz.ajk.elte.hu/molnar56.pdf (2014. augusztus 27.).

${ }^{237}$ Pound, Roscoe: Liberty of Contract. In Yale Law Journal, Vol. 18, 1909, 455-457. o.

${ }^{238}$ Pound: i. m. 457-458. o.
} 
Tanulmányában Pound több bírósági döntést kritizál; ezek között található a Lochner-ügy is. Ennek kapcsán megjegyzi azt, hogy a szerződési szabadság definíciójából nem következne szükségszerüen az, hogy a New York-i törvény azzal ellentétes. A Supreme Court két ténybeli előfeltevésre alapozta döntését: egyrészt nem számít közügynek az, mennyit dolgoznak a pékek, mert az nem függ össze a munka eredményével; másrészt ez a munka nem káros az egészségre - Pound szerint mindkét előfeltevés téves. ${ }^{239}$

Pound első megjegyzésével kapcsolatban érdemes felhívni a figyelmet arra, hogy annak alapján két szempontból is problematikusnak tartja a Supreme Court döntését. Egyrészt a testület egy sokjelentésü fogalommal operált, ami Pound szerint - a szabálypontosságú rendelkezések alkalmazásával egyetemben - nem kívánatos módja a jogalkalmazásnak, szerinte ugyanis célszerübb az olyan jogelvekhez folyamodni, amelyekből az esetek egy meghatározott csoportjára nézve lefektethető valamilyen szabály, ám a körülmények megváltozásával új, azokhoz igazodó szabály vezethető le ugyanabból az elvből. Követendő példaként Pound a német polgári törvénykönyvet jelöli meg. ${ }^{240}$ Sajnos Pound nem részletezi, pontosan miben tartja eltérőnek a „méltányossági alapú jogalkalmazás laza módszereit" (lax methods of equitable application), a kettő ugyanis abban mindenképpen hasonlít, hogy viszonylag széles mozgásteret hagynak a bírónak. Másrészt nyilvánvalóan azért is volt kritikus Pound a Lochner-döntéssel szemben, mert a Supreme Court nem volt tekintettel a valós társadalmi tényekre. Összességében tehát a testület egy, a bíróságok számára széles mozgásteret biztosító eszközt helytelenül használt fel.

A Pound által képviselt gondolati vonalat viszi tovább Felix Frankfurter egy 1916-os tanulmányában, amelyben kifejezetten a munkaidő-korlátozás alkotmányosságával kapcsolatos tagállami és szövetségi felsőbírósági döntéseket veszi szemügyre. Frankfurter kézenfekvő módon három kategóriára osztotta a vizsgált döntéseket: az első csoportba kerültek azok, amelyek a nők vagy a gyermekek védelmével összefüggő jogszabályok alkotmányosságát érintették, a másodikba azok, amelyek a veszélyes munkakörülményekhez kapcsolódtak, a harmadikba azok, amelyek az elöbbi körön kívül eső, általánosságban a munkaidőt szabályozó jogszabályokkal foglalkoztak. A tanulmányból az világlik ki, hogy az első két kategóriában az eljáró bíróság túlnyomórészt alkotmányosnak találta a szabályozást, míg a harmadik kategóriába sorolható jogszabályok

\footnotetext{
${ }^{239}$ Pound: i. m. 479-480. o.

${ }^{240}$ Pound 1908a: 613. o.
} 
megítélése vegyesnek bizonyult. Megítélése szerint egy kardinális változás figyelhető meg a gyakorlatban, ami az 1908-as Muller v. Oregon-döntéshez köthető. ${ }^{241}$ Itt fordult elő elsőként, hogy a Supreme Court tudományos alapon végezte el az elé tárt kérdés vizsgálatát - amelynek eldöntésében, mint ismert, az akkor még ügyvédként fellépő Louis Brandeis terjedelmes kutatási anyaga jelentős szerepet játszott -, addig ugyanis a testület $a$ priori alapon döntött egy szabályozás ésszerüségéről és az alkotmánynak való megfelelőségéröl. ${ }^{242}$

Frankfurter a Lochner-ítéletet az általános munkaidő-szabályozással kapcsolatos ügyek között helyezte el, ${ }^{243}$ majd később a konklúziók között megjegyzi, hogy e döntés rációját meghaladta a gyakorlat, ugyanis míg ott a közfelfogásra hivatkoztak a többségi álláspontot képviselő bírák, addig az újabb esetekben a döntés megalapozásához tudományos ismeretek szükségesek. Ezzel kapcsolatban érdemes megjegyezni két dolgot.

Az elkövetkező évek rácáfoltak Frankfurter 1916-ban megfogalmazott reményeire legalábbis a szövetségi döntések vonatkozásában, amelyeket nekem is módomban állt elemezni. A Supreme Court 1937-ig hozott fontosabb döntéseiben egyértelmüen alkotmányellenesnek minősítette a munkabér megengedett legalacsonyabb értékének jogszabályi rögzítését. ${ }^{244}$

Másrészt elmondható, hogy a Supreme Court 1937-et követő gyakorlata sem igazolta Frankfurter bizakodását, ugyanis az figyelhető meg, hogy a testület éppúgy a priori alapon foglalt állást az alkotmánynak való megfelelés, mint korábban az alkotmányellenesség mellett. ${ }^{245}$ És ez az attitűd, ha kisebbségben is, de már korábban megfigyelhető volt a Supreme Court tagságánál. Frankfurter, Holmes rendíthetetlen méltatója és követője ${ }^{246}$ a Lochner-ítélet ismertetése során hosszabban idézi Holmes különvéleményét (furcsamód a

\footnotetext{
${ }^{241} 208$ U. S. 412 (1908)

${ }^{242}$ Frankfurter, Felix: Hours of Labor and Realism in Constitutional Law. In Harvard Law Review, Vol. 29, 1916, 363-364. o.

${ }^{243}$ Frankfurter: i. m. 359-360. o.

${ }^{244}$ Ehhez lásd: Molnár 2013.

${ }^{245}$ A West Coast-döntésben például nincs hivatkozás olyan gazdasági szakirodalomra, amely indokolhatóvá, indokolttá tenné a támadott törvényhelyet, a Supreme Court többsége egyszerüen csak - a megerösítő precedensek szokásos felsorolása mellett - kinyilvánítja, hogy a „tagállami törvényhozó vitán felül jogosult volt arra, hogy tekintetbe vegye az alkalmazásban lévő nők helyzetét, annak tényét, hogy a legcsekélyebb mértékü bérezésben részesüló osztályba tartoznak, azt, hogy viszonylag alacsony az alkuképességük, és hogy könnyen áldozatul esnek azoknak, akik hasznot húznának szükségszerüen előállott körülményeikböl.” „The legislature of the State was clearly entitled to consider the situation of women in employment, the fact that they are in the class receiving the least pay, that their bargaining power is relatively weak, and that they are the ready victims of those who would take advantage of their necessitous circumstances." West Coast Hotel Co. v. Parrish, 300 U. S. 379, 398 (1937).

${ }^{246}$ Vö. pl. Frankfurter, Felix: The Constitutional Opinions of Justice Holmes. In Harvard Law Review Vol. 29, 1916, 683-702. o.; Frankfurter, Felix: Mr. Justice Holmes and the Constitution. In Harvard Law Review Vol. 41, 1927, 121-173. o.
} 
Harlan bíró által megfogalmazott különvéleményről épp csak említést tesz). Érdekes módon azonban az okfejtés, amellyel azonosul, szintén csupán a priori jelleggel nyilatkozik a támadott rendelkezés alkotmányosságáról: „[e]gy ésszerüen gondolkodó ember helyénvaló egészségügyi szabályozásnak vélheti [a kifogásolt munkaidőkorlátozást]." ${ }^{247}$ Holmes ritkán elemezte - ha egyáltalán - részletekbe menően a vizsgált kérdések társadalomtudományos vonatkozásait; alapelve rendszerint az volt, hogy elképzelhető olyan ésszerü álláspont, amelynek fényében alkotmányosan indokolható a kérdéses szabályozás. Ezt azonban nem tudományos felmérésekkel támasztotta alá, hanem in abstracto kijelentette. ${ }^{248}$

Ray Brown is azt a tendenciát vélte megfigyelni, hogy a Supreme Court behatóbban vizsgálja az esetekhez kapcsolódó tényeket. ${ }^{249}$ Ugyanakkor ő felhívja a figyelmet arra, hogy a tudományos megközelítés sem mindig nyújt egyértelmű iránymutatást, vannak ugyanis olyan esetek, amelyekben nem lehet egyértelmüen meghatározni, hogy a szóban forgó jelenség káros-e vagy sem - így például noha a korabeli megítélés szerint a margarin káros az egészségre, annyi előnnyel jár a forgalmazása, hogy az emberek olcsóbban jutnak élelmiszerhez. ${ }^{250}$ Brown szerint a megfelelő eljárás követelményének értelmezése menthetetlenül együtt jár a támadott rendelkezés tartalmi értékelésével, és úgy ítéli meg, hogy a Supreme Court több esetben is visszaélésszerüen értelmezte az alkotmány rendelkezéseit.

Az eddigiek alapján az látható, hogy több szerző azt az álláspontot képviselte a Supreme Court alkotmányértelmezése kapcsán, amelyet „fósodrúnak” nevezhetünk - ezek arra helyezték a hangsúlyt, hogy a testület több esetben a demokratikus akarat kinyilvánításának „,kerékkötőjeként” járt el. Ugyanakkor már a vizsgált időszakban készült olyan átfogó vizsgálat, amely széles körben vizsgálta a Supreme Court döntéseit. 1913-as tanulmányában Warren a Supreme Court 24 évnyi - 1887-től 1911-ig terjedő - döntési anyagát vizsgálta meg. Röviden összefoglalva arra a következtetésre jutott, hogy a

\footnotetext{
${ }^{247}$ „A reasonable man might think it a proper measure on the score of health.” 198 U. S. 76, idézi: Frankfurter 1916, 360. o.

${ }^{248}$ Ehhez képest Frankfurternél helyenként megfigyelhető, hogy kifejezetten a vonatkozó szakirodalomra támaszkodva alakítja ki álláspontját. Erre példa a vallásszabadsággal összefüggő, meglehetősen nagy publicitást kapott Gobitis-ügy. Vö. Minersville School District v. Gobitis, 310 U. S. 586, 597 (1940), 4. lábjegyzet.

${ }^{249}$ Brown, Ray A.: Due Process of Law, Police Power, and the Supreme Court. In Harvard Law Review Vol. 40, 1927, 960. o.

${ }^{250}$ Brown: i. m. 961. o.
} 
figyelembe vett több mint 560 döntésből - ideértve a Lochner-ítéletet is - a testület összesen háromban állapítja meg valamely tagállami jogszabály alkotmányellenességét. ${ }^{251}$

Warren megállapításával szemben olyan kifogás támasztható, ami a későbbi empirikus vizsgálatok vonatkozásában is többször fel fog merülni. A problémát abban látom, hogy Warren differenciálatlanul vont egyetlen nagy halmazba olyan döntéseket, amelyek között a téma szempontjából jelentős különbségek vannak. Megítélésem szerint félrevezető egy kategóriába sorolni a piac szabályozására irányuló jogszabályokat az olyan jogszabályokkal, amelyek például bizonyos közszolgáltatások tarifáját határozzák meg, közfejlesztéseket foganatosítottak, vagy éppen adónemeket határoztak meg. Csak e három esetkörnél maradva megállapítható, hogy közszolgáltatások tarifájának szabályozását a Supreme Court meglehetősen tág keretek között tette lehetővé. Itt ugyanis magától értetődőnek számított az, hogy a közszolgáltatás nyújtásában részt vevő vállalatok tulajdonhoz való joga a köz érdekében jelentős mértékben korlátozható. Az alkotmányosság mércéjét a „kisajátító” (confiscatory) mértékü jövedelemkorlátozás jelentette, ez pedig abban az esetben valósult meg, ha a kifogásolt tarifacsökkentés révén az állam megtagadta a szolgáltatótól azt a „méltányos kompenzációt” (just compensation), amelyre igényt tarthatnak annak okán, hogy tulajdonukat a közszolgáltatás nyújtására fordítják. ${ }^{252}$ Másutt a Supreme Court úgy fogalmaz, önmagában a bevételcsökkenés, nem eredményezi az alkotmány sérelmét, még akkor sem, ha az túlzó, csak akkor, ha ezzel a szolgáltató elesik a „tisztességes megtérüléstől” (fair return). ${ }^{253}$ Emellett a Supreme Court társadalompolitikai szempontból kritikus döntései rendszerint - noha a tizennegyedik alkotmánykiegészítéssel függenek össze - a police power fogalmának tartalmához kapcsolódtak, azonban a közszolgáltatási tarifák szabályozásáról ugyanez nem mondható el. Néhány kivételtől eltekintve ${ }^{254}$ az a jellemző, hogy a közszolgáltatási tarifákkal kapcsolatos döntések indokolásában egyáltalán nem is szerepel a police power kifejezés, a Supreme Court az ilyen ügyekben sokkal inkább esetről-esetre vizsgálja a jogszabályban előírt tarifa ésszerüségét. ${ }^{255} \mathrm{Az}$ is bevett doktrína volt, hogy ha a szolgáltató szerződésre

\footnotetext{
${ }^{251}$ Warren, Charles: The Progressiveness of the United States Supreme Court. In Columbia Law Review Vol. 13, 1913, 295. o.

${ }^{252}$ Vö. pl. Missouri Rate Cases, 230 U. S. 474, 497 (1913).

${ }^{253}$ Vö. pl. Louisville and Nashville Railroad Co. v. Garrett, 231 U. S. 298, 315 (1913).

${ }^{254}$ Vö. pl. Lake Shore and Michigan Southern Railway Co. v. Smith, 173 U. S. 684, 688-689 (1899).

${ }^{255}$ E körbe sorolható mindenekelőtt a tarifák szabályozásában meghatározó jelentőségű Ex parte Young-ítélet (209 U. S. $123 / 1908 /$ ), de a vizsgált időszak különböző szakaszaiban is megfigyelhető volt ez a tendencia. Vö. pl. Home Telephone and Telegraph Co. v. Los Angeles, 227 U. S. 278 (1913); Chicago, Milwaukee \& St. Paul Railway Co. v. Public Utilities Commission of the State of Idaho, 274 U. S. 344 (1927).
} 
lépett az állammal, akkor az esetleges tarifacsökkentést - természetesen amíg az a „kisajátító” mértéket el nem érte - hallgatólagosan elfogadta.

A közfejlesztéssel kapcsolatos ügyekben a vita tárgyát túlnyomórészt az képezte, hogy egy helyi önkormányzat oly módon rendezte valamilyen közfejlesztés - tipikusan utcaburkolás, csatornázás - költségeit, hogy speciális ,,adót” vetett ki azokra, akiknek az adott fejlesztésből előnye származhat (például a leburkolt utcára nyíló vagy a csatornával érintett ingatlanok tulajdonosai). Ilyenkor a Supreme Court a kérdéses előnnyel való érintettséget vizsgálta, azt ugyanis egyáltalán nem vitatta, hogy az államnak jogában áll a végrehajtott fejlesztések költségét célirányosan a kedvezményezettekre terhelni.

Az adóügyek vonatkozásában ${ }^{256}$ hasonló megállapítások tehetők. A Supreme Court meglehetősen kiterjesztően fogta fel az állam adóztatási szabadságát, és csak bizonyos szélső esetekben nyilvánított alkotmányellenesnek valamilyen adót megállapító jogszabályt. Ezért például a testület vonatkozó döntéseinek, visszatérö érvelési fordulata, hogy a tizennegyedik alkotmánykiegészítés egyenlö törvényi védelmet elöíró rendelkezése nem kényszeríti a tagállamot valamiféle „egyenlö adóztatási vasszabály” (iron rule of equal taxation) elfogadására. ${ }^{257} \mathrm{Az}$ adóztatáshoz kapcsolódó egyéb kérdésekben a Supreme Court szintén alapvetően passzív attitüdöt tanúsított, így például nem ütközött alkotmányos követelménybe az, hogy az adómegállapítás tekintetében a vasúttársaságokat csak egyszeri meghallgatási jog illette meg az adóhatóság előtt, míg másokat kétszeres. ${ }^{258}$ Ugyanígy elmondható, hogy rendszerint a különböző tevékenységek eltérő adóztatása sem minősült alkotmányellenesnek. ${ }^{259}$ Vagyis az adóügyek esetében is az látható, hogy a police power fogalma - kevés kivételtől eltekintve - meglehetősen irreleváns volt.

Megítélésem szerint fontos rámutatni arra is, hogy a progresszív szellemü törvényhozás által érintett élethelyzetek természetüket tekintve is mások - legalábbis abban a korban más megítélés alá estek -, mint az itt felsoroltak. A szociális törvényhozás

\footnotetext{
${ }^{256}$ Itt indokolt tenni egy distinkciót. A közfejlesztések finanszírozására szedett bevételek szintén „adónak” minősültek. Ugyanakkor ezeket az ,adókat” mindig egy konkrét fejlesztéssel összefüggésben szedték be, és mindig az érintettektől, vagyis időben és alanyi kört tekintve is specifikus adókról beszélhetünk. Ettől a kategóriától élesen megkülönböztethetők az általánosan meghatározott személyi kört érintő, időben nem meghatározott adók (például a meghatározott ügyleteket vagy tevékenységet terhelő adók). Az „adóügyként” aposztrofált esetek ezt a kategóriát ölelik fel.

${ }^{257}$ Vö. pl. Bell's Gap Railroad Co. v. Pennsylvania, 134 U. S. 232, 237 (1890); Adams Express Co. v. Ohio State Auditor, 165 U. S. 194, 228 (1897); Magoun v. Illinois Trust \& Savings Bank, 170 U. S. 283, 295 (1898). Lásd még: Armour Packing Co. v. Lacy, 200 U. S. 226, 236 (1906); Michigan Central Railroad Co. v. Powers, 201 U. S. 245, 281, valamint 283 (1906).

${ }^{258}$ Vö. pl. Pittsburgh, Cincinnati, Chicago and St. Louis Railway Co. v. Backus, 154 U. S. 421, 427 (1894).

${ }^{259}$ Vö. pl. Nashville, Chattanooga \& St. Louis Railway Co. v. Wallace, 288 U. S. 249, 268 (1933). Ebben az ügyben a Supreme Court alkotmányosnak minősítette azt a szabályozást, miszerint a vasúti és a közúti áruszállítás eltérő adózás alá esik.
} 
esetében a szabályozott élethelyzet szereplői mellérendelt személyek: jellemzően a munkáltatók és a munkavállalók, vagy a vállalatok és a fogyasztók. Ebbe a viszonyba külső szereplőként szól bele az állam, e beavatkozás azonban egyáltalán nem szükségszerü. Az imént említett viszonyokban azonban az állam meghatározó, olykor egyenesen fogalmilag elengedhetetlen szerepet játszik. Ez az adóügyek esetében a legnyilvánvalóbb, hiszen az adójogviszonyoknak - az adóalanyok mellett - kifejezetten alanya az állam. A közfejlesztések finanszírozásának meghatározása esetében az állam ugyancsak egy - igaz, speciális - adójogviszony alanyaként jár el. A közszolgáltatási tarifák szabályozása esetében az állam kevésbé közvetlen, ugyanakkor nem elhanyagolható szerepet játszik: olyan szolgáltatás tarifájának szab határokat közé, amelyek széles körben való hozzáférhetősége közérdek. A Supreme Court a Munn-ügyben már 1877-ben lefektette azt a tételt, miszerint ,[a]mikor (...) valaki a tulajdonát oly módon hasznosítja, hogy az a köznek is érdeke, voltaképpen érdekeltséget keletkeztet a köz számára ama használat vonatkozásában, ezért a közjó érdekében alá kell vetnie magát a köz általi szabályozásnak az általa létrehozott érdekeltség mértékéig." ${ }^{260}$ Ezt az elvet a testület a Budd-ügyben 1892-ben megerősítette. ${ }^{261}$ Ugyan a doktrína ezekben az években még nem nyert osztatlan támogatást a Supreme Court bírái körében, ${ }^{262}$ a testület gyakorlatába szervesen beépült. E doktrína azonban ebben a formában nem jelenik meg a szociális törvényhozással kapcsolatos ítéletek indokolásában. Ezekben az ügyekben a közérdekkel kapcsolatba hozható elv szerint az alkotmányos alapjogok korlátozhatók, amennyiben a korlátozást bizonyos értékek - rendszerint a közjólét, közerkölcs, közegészség, közbiztonság (public welfare, morals, health, safety) - indokolják. Ez ránézésre párhuzamba állítható a Munn-doktrínával, megfigyelésem szerint azonban a kettő mégis eltérő területen került alkalmazásra. A Munn-doktrína által érintett helyzetekben a szabályozás kifejezetten a címzett vállalkozásokat érinti. A kedvezményezettek körére

260 „When, therefore, one devotes his property to a use in which the public has an interest, he, in effect, grants to the public an interest in that use, and must submit to be controlled by the public for the common good, to the extent of the interest he has thus created." Munn v. Illinois, 94 U. S. 113, 126 (1877). A doktrína eredete ugyanakkor a XIX. századnál régebbre nyúlik vissza; Morrison Remick Waite, az ügy előadó bírája az angol Matthew Hale De Portibus Maris címü müvére hivatkozik. Vö. uo.

${ }^{261}$ Budd v. New York, 143 U. S. 517, 544-545 (1892)

${ }^{262}$ A Munn-ügyben Stephen Johnson Field bíró fogalmazott meg különvéleményt, melyet a klasszikus liberalizmus gazdasági elveivel támasztott alá - még Adam Smithre is hivatkozott benne -; e különvéleményhez William Strong bíró is csatlakozott. A Budd-ügyben Brewer bíró fogalmazott meg különvéleményt, ehhez Field és Brown is csatlakozott. Érdekességképpen megjegyezhető, hogy Rufus Peckham, a Lochner-ítélet indokolásának megfogalmazója ekkor annak a New York-i felsőbíróságnak a tagja volt, amellyel szemben az indítványozók a Supreme Courthoz fordultak, és ennek apropóján született meg a Budd-ítélet. A New York Court of Appeals szerint megállapítható volt, hogy az indítványozó a törvényben rögzítettnél magasabb áron hordta a gabonaelevátor tövébe a gabonát. Peckham - a Budd-ítélet ügyismertetése alapján - csatlakozott Gray különvéleményéhez. 143 U. S. 520. 
ugyan lehet következtetni, azonban a szabályozás nem tartalmaz rájuk utalást, a jogszabályok ugyanis ilyenkor csak annyit írnak elő, hogy a címzett szolgáltató csak bizonyos áron értékesítheti szolgáltatását, mely bármely fizetőképes ügyfél számára esetleg bizonyos általános feltételek mellett - hozzáférhető - így például bárkinek a gabonája továbbítható, ha azt kifizetik, a vasutat bárki igénybe veheti. A progresszív törvényhozás esetében némileg más a helyzet: itt a kedvezményezettek köre is többkevesebb pontossággal meghatározható: a szabályozási körbe tartozó munkáltatók munkavállalói. És ezeket a munkavállalókat gyakran iparág szerint azonosította egy-egy jogszabály: így találhatunk rendelkezést a bányászokról, ${ }^{263}$ a pékekről és cukrászokról, ${ }^{264}$ vagy éppen a gépesített létesítmények, gyárak, mosodák női dolgozóiról. ${ }^{265}$

Végső soron tehát az mondható el, hogy Warren felmérése, noha fontos összesített észrevételeket tartalmaz a Supreme Court tevékenységéről, egyúttal olyan különbségeket figyelmen kívül hagy, amelyek a vizsgált korszakban folytatott ítélkezési tevékenység pontos értékelésében komoly jelentőséggel bírnak.

Nehéz magyarázatot találni arra, hogy az 1920-as években miért esett olyan szigorú alkotmányos megítélés alá a minimálbér-szabályozás, mindenesetre tényként állapítható meg, hogy vonatkozó döntéseiben a Supreme Court 1937 előtt rendre alkotmányellenesnek minősítette az ilyen tárgyú jogszabályokat. Ezt az irányultságot élesen bírálta Thomas Powell, aki mind a tagállami, mind a szövetségi bíráskodás szintjén áttekintette a vonatkozó gyakorlatot. A jelen tanulmány témája szempontjából az Adkins-ítélet ${ }^{266}$ többségi indokolásában kifejtett gondolatmenet kritikája releváns. Powell megítélése szerint, noha az előadó Sutherland bíró megkérdőjelezhetetlenséget sugalló szavakkal rögzítette, hogy a Supreme Court nem tehet egyebet, mint hogy kimondja, ha egy jogszabály alkotmányellenes, ezt az alkotmányellenességet nem támasztotta alá kétséget kizáróan. Szerinte Sutherland tévedett, amikor úgy fogalmazott, hogy a szerződési szabadság a föszabály, annak korlátozása pedig a kivétel, ugyanis az alkotmány szövegéből nem olvasható ki ez a doktrína. ${ }^{267}$ Ezután rámutat arra, hogy Sutherland tévesen állapította meg azt, hogy nincs irányadó precedens a támadott jogszabály alkotmányossága mellett. Powell szerint Sutherland nem vette figyelembe a Bunting-

\footnotetext{
${ }^{263}$ Holden v. Hardy, 169 U. S. 366 (1898)

${ }^{264}$ Lochner v. New York

${ }^{265}$ Muller v. Oregon, 208 U. S. 416

${ }^{266}$ Adkins v. Children's Hospital, 261 U. S. 525 (1923)

${ }^{267}$ Powell, Thomas Reed: The Judiciality of Minimum-Wage Legislation. In Harvard Law Review Vol. 37, 1924, 555. o.
} 
ítéletet, ${ }^{268}$ amelyben a támadott rendelkezés - bár munkaidő-maximumot szabott meg általános hatályú volt, épp úgy, mint az Adkins-ügyben támadott minimálbérszabályozás. ${ }^{269}$ Emellett - lényegében a Holmes különvéleményében foglalt gondolatokat visszhangozva - megkérdőjelezi Sutherland azon érvét, miszerint a szavazójogot a nőkre kiterjesztő tizenkilencedik alkotmánykiegészítés elfogadásával megindult egyfajta egyenlősítő tendencia a nők és a férfiak között, ezért a minimálbér kizárólag nők esetében való elöírása sem menthető az alkotmány alapján. ${ }^{270}$

\section{III.2. Értékelés 1937 után}

Érdekes tény, hogy noha a West Coast-ügyben a Supreme Court lényegében egy szúkítő alkotmányértelmezési gyakorlatot alapoz meg - mely szerint csak a legszélsőbb esetben vezethet egy alapjogi korlátozás alkotmánysérelemhez -, és a döntést a Lochnerítélet által fémjelzett korszakkal való szakításként szokás értékelni, a Supreme Court tulajdonképpen nem veti el a Lochner-ügyben (is) megfigyelhető érvelést. Az indokolásban ugyanis egyenesen hivatkozás található a Lochner-döntésre: az előadó Charles Evans Hughes annak alátámasztásaként említi meg az ítéletet egy lábjegyzetben, hogy a Supreme Court hosszú idő óta tartotta magát az elvhez, miszerint, noha a tizennegyedik alkotmánykiegészítésben szereplő „szabadság” kitételbe a szerződési szabadság beletartozik, ez a szabadság alávethető bizonyos ésszerü korlátoknak. Az indokolásban ugyan Hughes a McGuire-ügyet idézi hosszabban, ${ }^{271}$ azonban az idézett rész az Allgeyer- ${ }^{272}$ és a Lochner-ítéletekre utal vissza. ${ }^{273}$ Ezzel Hughes tulajdonképpen úgy alapoz meg egy, a gazdasági alapjogok terén szükítő alkotmányértelmezési gyakorlatot, hogy közben az ezen irányvonallal ellentétes döntést is implicite az alkotmányértelmezési kánon részének tekinti.

A Supreme Court attitüdjét jól tükrözi az ezzel összefüggésben sűrün idézett Ferguson v. Skrupa-ítélet, amelyben a testület nyíltan bírálja a XX. század első három évtizedének vitatott, alkotmányellenességet megállapító döntéseit. Az indokolást olvasva

\footnotetext{
${ }^{268}$ Bunting v. Oregon, 243 U. S. 426 (1917)

${ }^{269}$ Powell: i. m. 557. o.

${ }^{270}$ Powell: i. m. 559. o.

${ }^{271}$ Chicago, Burlington and Quincy Railroad Co. v. McGuire, 219 U. S. 549 (1911). Az idézethez lásd: 300 U. S. 392.

${ }^{272}$ Allgeyer v. Louisiana, 165 U. S. 578 (1897)

${ }^{273}$ Vö. 219 U. S. 566-567.
} 
annak a jelenségnek lehetünk tanúi, hogy a kisebbségi álláspont többségivé válik: az előadó Hugo Black bíró a „a bírák részéről a törvényhozói értékítéletek birodalmába való beavatkozásként" (intrusion by the judiciary into the realm of legislative value judgments) minősítette a kiemelt döntéseket, ${ }^{274}$ Holmesnak a Tyson \& Brother v. Banton-ügyben megfogalmazott különvéleményét idézi hosszan, ${ }^{275}$ mely szerint a Supreme Court az alkotmány értelmezése során nem nyúlhat túl a benne található tilalmak nyilvánvaló jelentésén (obvious meaning), ${ }^{276}$ és kimondja, hogy a kiemelt döntések filozófiáját a gyakorlat régóta meghaladta.

Érdemes e helyütt röviden említést tenni arról, hogy Holmes különvéleménye némileg hiányosan - kis túlzással azt mondhatnánk, megtévesztő módon - kerül idézésre a döntés szövegében, elvi álláspontjának egy fontos vonatkozása ugyanis kimarad. Holmes azzal kezdi különvéleményét, hogy rámutat arra, hogy valamely, a közjó nevében meghozott jogszabályt rendszerint a police power fogalmával vagy azzal próbálnak indokolni, hogy a szabályozás alanya a köz rendelkezésére bocsátotta tulajdonát. Holmes szerint az ilyen ,apológiáknak” (apologies) nincs helye - ezzel összefüggésben jelentette ki azt, hogy a jogalkotót csak az alkotmány szövegének nyilvánvaló értelme korlátozhatja. ${ }^{277}$ Vagyis Holmes egy radikálisan megszorító alkotmányértelmezés mellett tört lándzsát, ez azonban explicit módon nem jelent meg a Ferguson v. Skrupa-ítélet indokolásában.

Grier Stephenson az 1898 és 1906 közötti korszak bírói attitüdjeit elemezte. Mivel a jelzett időszakban mindössze két személycsere történt a Supreme Court tagságában, ${ }^{278}$ ezért itt az egyes bírák szavazási tendenciái is bemutathatók. Stephenson két halmazra osztotta a vizsgált korszak döntéseit: külön vizsgálta az 1898-tól 1902-ig, illetve az 1903tól 1906-ig terjedő szakaszokat. Az elválasztás alapja a két bírócsere éve. Stephenson négy táblázatot rajzolt fel, ezekben egyrészt az egyes időintervallumokra lebontva ábrázolta azt, hogy a Supreme Court egyes tagjai a vizsgált döntésekben - melyek kivétel nélkül az alkotmányosság megállapításában végződtek - milyen arányban szavaztak a támadott jogszabályok alkotmányossága, illetve alkotmányellenessége mellett. Az egyes időintervallumokban egyrészt általában a tagállamok jogalkotási szabadságának terjedelmével kapcsolatos ügyeket figyelte, másrészt e körön belül a tulajdonhoz való

\footnotetext{
${ }^{274}$ Ferguson v. Skrupa, 372 U. S. 726, 729 (1963)

275273 U. S. 418 (1927)

276273 U. S. 446

277273 U. S. 445-446

${ }^{278}$ Stephenson, D. Grier: The Supreme Court and Constitutional Change: Lochner v. New York Revisited. In Villanova Law Review Vol. 21, 1976, 233. o.
} 
joggal, illetve a szerződési szabadsággal összefüggő ügyeket. A tanulmány talán legérdekesebb megállapítása az, hogy úgy az 1898 és 1902, mint az 1903 és 1906 közötti években a police powerral kapcsolatos ügyben Brewer és Peckham bírák egyaránt látványosan vezettek az alkotmányellenessé nyilvánítás terén. Ez a megállapítás összhangban áll azzal a „fősodrú” narratívával, amely szerint a századforduló évtizedeiben e két bíró volt a „konzervatív aktivizmus” éllovasa. Hozzájuk képest például Henry Billings Brown is - aki bizonyos esetekben konzervatív álláspontra helyezkedett, így például a Lochner-ügyben is a többség oldalára állt - a „középmezőnyben” foglal helyet. A másik oldalról azonban szintén a „fösodrú” állásponttal van összhangban az a megállapítás, hogy az 1903 és 1906 közötti időszakban Holmes - aki 1902-ben lépett be a Supreme Courtba, és az 1903. január 5-én elbírált Otis v. Parker-ítélet ${ }^{279}$ volt az első, amelyben előadóként járt el - vezet az „önmegtartóztató” bírák között. ${ }^{280}$

A „Lochner-korszak” alkotmányértelmezését vizsgáló kutató néha akarvaakaratlanul is úgy érzi, mintha egy ,jók a rosszak ellen” típusú narratívába csöppent volna. A szereposztás kézenfekvő: a ,jó fiúk” táborának oszlopos tagjai Holmes és Brandeis, ezzel szemben a „rossz fiúk” oldalát az 1890-estől az 1910-es évekig Brewer és Peckham, az 1920-as és 1930-as években pedig a konzervatív tábor négy személyisége, Van Devanter, McReynolds, Sutherland és Butler erösíti. Ez valamelyest megmutatkozik abban is, hogy az egyes „szereplők” mennyi tudományos figyelmet kapnak. Ennek mértékéről könnyü benyomást szerezni már pusztán azzal, ha az ember megnézi, hány találat jön ki a HeinOnline keresőrendszerében a ,justice holmes” keresőszavakra - 2014. július 9-én ez a szám 157 volt -, és hány - példának okáért - a ,justice sutherland” keresőszavakra - az említett napon ez a szám 15 volt. ${ }^{281}$ Elvétve ugyanakkor akadnak olyan tanulmányok, amelyek a „negatív” oldal képviselői szakmai álláspontjának mélyebb megértésére törekednek. Az ilyen vizsgálódások nem feltétlenül változtatják meg alapjaiban a korszakról alkotott képet, azonban segítenek elvonatkoztatni attól a könnyen kialakuló képtől, hogy az egyik oldalon olyan bírák álltak akik az alkotmány rendelkezéseivel visszaélve ráerőltették világnézetüket a jogalkotóra, illetve a jogalkotó által képviselt demokratikus többségre, velük szemben pedig azok a „,progresszívek” álltak, akik a

\footnotetext{
279187 U. S. 606

${ }^{280}$ Stephenson: i. m. 234-235.

281 Azért épp Sutherlandet választottam e hevenyészett példa bemutatása során a Holmesszal való szembeállításhoz, mert a kora XX. századi Supreme Court konzervatív tagjai közül ő az, aki teoretikusként is a legelismertebb volt.
} 
társadalmi problémák hatékony, tudományos alapú - ennélfogva implicite igazságos megoldásának igényét az alkotmányjogi terminológiába transzformálják.

Brewer bíró esete ennek jó példája. Az, hogy meggyőződéses konzervatív volt, tagadhatatlan, miként az is, hogy e meggyőződése kifejezésre jutott Supreme Court-bírói állásfoglalásaiban is. Ahogy Gamer fogalmaz, „[a] konzervativizmus időszaka volt ez, Brewer pedig konzervatív volt a maga korában." ${ }^{282}$ Mindemellett érdemes kicsit árnyaltabb módon szemügyre venni Brewer nézeteit. Gamer rámutat arra, hogy Brewer konzervativizmusának egyik stabil fundamentuma szilárd kereszténysége volt, amiből egyebek között a „harácsoló” kapitalizmus éles kritikája következett. A XIX. század második fele az Egyesült Államokban az óriási tőkefelhalmozások időszaka volt, amikor az óriásvállalatok vezetői a gazdasági hatalom mellett - azzal összefüggésben - komoly politikai befolyást is szereztek - a közvéleményben a pejoratív „rablóbáró” (robber baron) kifejezést alkalmazták ezekre a vezetőkre. Brewer ezt bíráló nézete jól tetten érhető az ún. „granger-mozgalommal” szemben megfogalmazott egyik ellenvetésében. ${ }^{283}$ Egyrészt ugyanis elítéli a mozgalmat, mondván, a „puszta számok erejével igyekszik elhalványítani a magántulajdon védelmét." ${ }^{284}$ Másrészt ugyanakkor nincs szó arról, hogy teljes egészében elvetette volna a mozgalom célkitüzéseit. „A munkásszervezetek a tőkés szervezetek szükséges és megfelelő kiegészítői”, ${ }^{285}$ fogalmaz. Szerinte az ilyen szervezetek kiegyenlítik a rosszabb alkupozícióban lévő dolgozók piaci hátrányát, és ezáltal megakadályozzák, hogy a tőkeerős munkáltatók visszaéljenek helyzeti előnyükkel. A veszélyt abban látta, hogy az állam esetleg túlzásokba esik a szabályozással, ugyanis a tulajdonhoz való jogot csak kivételes esetekben tartotta korlátozhatónak. Brewer hitt az elidegeníthetetlen jogok eszméjében, ezzel összefüggésben markáns individualista volt, aki szerint az állam elsődleges feladata az egyének védelme. ${ }^{286} \mathrm{Az}$ individuális szabadság védelmét azonban a túlzott hatalmat koncentráló óriásvállalatokkal szemben épp úgy fontosnak tartotta, mint az állammal szemben. Említést érdemel az is, hogy noha Brewer

\footnotetext{
282 „This was an age of conservatism, and Brewer was a conservative in his age.” Gamer, Robert E.: Justice Brewer and Substantive Due Process: A Conservative Court Revisited. In Vanderbilt Law Review Vol. 18, 1965, 641. o.

283 A granger-mozgalom egy, az 1860-as években született szerveződés volt, mely a polgárháború után elszegényedett mezőgazdasági termelők érdekvédelmét volt hivatott ellátni. A mozgalom egyik jelentős eredménye volt a gabonatárolás és -szállítás tarifájának törvényi szabályozása, amivel a farmerek számára hátrányos díjszabások mértékének csökkentésére törekedtek. A fentebb szóba került Munn v. Illinois-ügy alapügye is egy ilyen rendelkezés alkalmazása volt.

284 „I wish rather to notice that movement which may be denominated the movement of »coercion, « and which by the mere force of numbers seeks to diminish protection to private property." Idézi: Gamer: i. m. 622. o.

285 „Labor organizations are the needed and proper complements of capital organizations.” Idézi: uo.

${ }^{286}$ Gamer: i. m. 623. o.
} 
jellemzően nem látott alkotmányos indokot a piacszabályozó jogszabályok megalkotására, ez alól jelentős kivételt képezett a nők munkakörülményeinek szabályozása, amit látványosan példáz, hogy ő volt a Muller v. Oregon-ügy előadó bírája. Természetesen a késő XX. századi feminista jogkritika képviselőiből minden bizonnyal súlyos bírálatot váltanak ki az olyan meglátások, melyek szerint „,[a]z, hogy a nő testi felépítése és anyai rendeltetésének betöltése hátrányba hozza őt a létfenntartásért folytatott küzdelemben, nyilvánvaló”, illetve „az egészséges anyák nélkülözhetetlenek az életerős utódokhoz”, ${ }^{287}$ témánk szempontjából azonban az bír jelentőséggel, hogy bizonyos kérdésekben - az egyébként a női szavazójog mellett is kiálló - Brewer a „progresszív” tábort erősítette. ${ }^{288}$

Brewer tehát egy „emberarcú” kapitalizmusban hitt, amelyben a tisztességes verseny feltételei valóban érvényesülnek, az egyének elidegeníthetetlen szabadságjogai a lehető legteljesebb mértékben biztosítva vannak; az állam funkciója pedig e feltételek biztosításában kimerül. Ha hihetünk Gamer megállapításának, akkor Brewer - noha fiatalkorában annak befolyása alatt állt - nem a korában virágzó spenceri szociáldarwinizmus könyörtelen élethalálharcában hitt, hanem egy olyan humánus világban, ahol az egyén céljainak megvalósításához a jog a legteljesebb mértékben biztosítja az intézményi feltételeket. ${ }^{289}$

Nem ítélhető meg egyértelműen az, hogy ez az elképzelés mennyire volt összhangban a kor társadalmi valóságával. Az mindenesetre az évek múlásával egyre világosabban látszik, hogy a felmerült társadalmi feszültségeket az állam - szövetségi és tagállami szinten egyaránt - korlátozó rendelkezésekkel igyekezett orvosolni, és Brewer társadalomfilozófiája korának törvényhozásában háttérbe szorult. Egyes esetek mindazonáltal arra engednek következtetni, hogy Brewer elképzelései meghaladottá váltak. A szakszervezeti tagsági záradékot - melynek értelmében a munkavállaló szakszervezetbe történő belépése felmondási okot képez - tartalmazó szerződéseket tiltó törvények jól példázzák, hogy Brewer idealisztikus elképzelései megkérdőjelezhető talapzaton állnak. Az Adair v. United States-ügyben Brewer csatlakozott az ilyen tárgyú szövetségi törvényt alkotmányellenesnek tekintő többséghez. Az indokolás szerzője nem ő volt, ugyanakkor feltételezhetö, hogy a konkrét esetben úgy ítélte meg, hogy a szabályozás ésszerütlenül korlátozza az egyéni szabadságjogokat. Ugyanakkor ezen állásfoglalása óhatatlanul maga

\footnotetext{
287 „That woman's physical structure and the performance of maternal functions place her at a disadvantage in the struggle for subsistence is obvious.” , „[H] ealthy mothers are essential to vigorous offspring[.]" $208 \mathrm{U}$. S. 421

${ }^{288}$ Mindehhez lásd még Bergan, Francis: Mr. Justice Brewer: Perspective of a Century. In Albany Law Review Vol. 25, 1961, 201. o.

${ }^{289}$ Gamer: i. m. 632. o.
} 
után von egy ellentmondást. Egyrészt kétségtelen, hogy az állam a törvénnyel egy alkotmányos jogot korlátoz. Másrészt azonban a szóban forgó kikötést szerződésbe foglaló munkáltatók is korlátozzák alkalmazottaik szabadságát, hiszen megnehezítik számukra a szervezett érdekérvényesítést. Annak ellenére, hogy - mint fentebb látható volt - Brewer maga is legitimnek - sőt, szükségesnek - tartotta a munkavállalók önszerveződését, most tulajdonképpen ennek ellehetetlenítése előtt nyitotta meg az utat.

Különös, és bizonyos iróniát nem nélkülöző ellentmondás fedezhető fel, ha Brewer imént ismertetett nézeteit összevetjük a bírói önmegtartóztatás elvének legfőbb korai képviselőjeként számon tartott Holmeséval. Brewer egy alapvetően humánus világképből kiindulva érvelt az állami beavatkozás minimálisra szorítása mellett, és ezért menthetetlenül a konzervatív táborba sorolódott. Holmest pályafutása alatt, valamint a halálát követő években a progresszív oldal „hőseként” méltatták, aki a bírói önkény visszaszorítása és a demokratikus akaratképzés kiteljesedése mellett tört lándzsát. Személyes világképében ugyanakkor Holmes a szociáldarwinizmus lelkes híve volt, aki tagadta azt az eszmét, hogy az embert pusztán ebbéli minősége miatt bárminemü elidegeníthetetlen jogok illetnék meg, és úgy vélte, a társadalmat a pőre érdekküzdelmek határozzák meg. Ezt a nézetet juttatta kifejezésre még a massachusettsi legfóbb bírói fórum bírájaként a Vegelahn v. Güntner-ítélethez benyújtott különvéleményében, ezen álláspontja miatt figyelt fel rá Theodore Roosevelt elnök, majd nevezte ki a Supreme Court tagjává 1902-ben, és néhány híres szakmai megnyilvánulása mögött is ez a filozófia húzódik meg. Ha a munkásszervezetek példájánál maradunk, akkor az látható, hogy míg Brewer szemében ezek egy igazságosabb társadalom lehetőségét hordozzák magukban azáltal, hogy a szabadpiaci kapitalizmus egyes visszásságait ellensúlyozzák, addig Holmes szemében csupán az örökös társadalmi harcok konkrét megnyilvánulásai.

A - komoly politikai visszhangot kiváltó - Northern Securities-ítélet jól illusztrálja Brewer nézőpontját. Az ügyben az 1890-es trösztellenes törvényt (Sherman Act) kellett alkalmazni két nagyvállalat fúziója kapcsán. A többségi álláspont szerint a trösztellenes törvény versenyt korlátozó összehangolt működést tilalmazó rendelkezése a konkrét esetben alkalmazható, a fúzióra jogellenesen került sor. Brewer párhuzamos indokolást fogalmazott meg, amelyben azt hangsúlyozta, hogy a kifogásolt fúzió vitathatatlanul versenykorlátozó hatású, nincs ésszerü indoka, és a monopólium lehetősége miatt ellentétes a közérdekkel. ${ }^{290}$

${ }^{290}$ Northern Securities Co. v. United States, 193 U. S. 360-363 (1904) 
Holmes ebben az ügyben különvéleményt fogalmazott meg, ${ }^{291}$ melyet az alkalmazott jogszabályi rendelkezés szó szerinti értelmezésére alapozott. Holmes arra mutatott rá, hogy a törvényszöveg két büntetendő magatartást különít el: a kereskedelem korlátozására irányuló szerződések (contracts in restraint of trade) megkötését, valamint a kereskedelem korlátozására irányuló összefogásokat vagy összeesküvéseket (combinations or conspiracies in restraint of trade). Szerinte az első kategóriába azok az esetek tartoznak, amikor a szerződéskötő fél olyan idegen személlyel köt szerződést, aki tőle eltérő tevékenységet folytat, és a szerződéskötő fél a saját gazdasági tevékenységét korlátozza ezzel. A második kategória azokat az eseteket öleli fel, amikor az egyezségre lépő felek harmadik személyeknek a gazdasági tevékenységből való kizárására törekednek. ${ }^{292}$ Holmes szerint a konkrét ügyben ezen esetek egyike sem valósult meg, a két vállalat, melyek fúziójából a perben részt vevő Northern Securities Company megalakult, nem azért egyezett meg egymással, hogy gazdasági tevékenységüket korlátozzák, a fúzió bekövetkezéséből pedig nem következik, hogy a felek a gazdasági versenyt akarták korlátozni, és ez önmagában még nem is vezet a verseny korlátozásához, a többség ezért igen távoli okozati összefüggésre alapozta döntését. A döntés rációjának elfogadása ahhoz a képtelen és nem kívánatos eredményhez vezet - a jogszabály következetes érvényesítése esetén -, hogy ha bármely két gazdasági szereplő, akik korábban riválisok voltak - legyen szó akár két nagyvállalatról, akár két helyi kiskereskedőről -, az egyesülés mellett döntenek, azzal szükségképpen jogsértést követnek el. ${ }^{293}$

Holmesnak ez az állásfoglalása csalódást jelentett az őt jelölő Theodore Roosevelt elnök számára, elvégre egy szigorú - mi több, megszorító, egyébként a common law gyakorlatára hivatkozó $^{294}$ - szó szerinti értelmezés által szembehelyezkedett a Sherman Act nyilvánvaló társadalompolitikai céljával, nevezetesen az óriásvállalatok gazdasági hatalmának visszaszorításának igényével. ${ }^{295} \mathrm{Ez}$ önmagában pusztán a tételes jog

\footnotetext{
${ }^{291}$ A döntés indokolását Harlan fogalmazta meg, amelyhez rajta kívül hárman csatlakoztak; Brewer önálló párhozamos indokolást írt. Az ügyben két különvélemény született, az elsőt White fogalmazta meg, a második Holmes szerzeménye. A rendelkező résszel egyet nem értő négy bíró mindkét különvéleményhez csatlakozott, White-on és Holmeson kívül Peckham, valamint a Supreme Court akkori elnöke, Fuller osztotta a különvéleményekben kifejtett álláspontokat.

292193 U. S. $403-404$

${ }^{293} 193$ U. S. 405-411. Ezzel összefüggésben - talán a monopóliumok visszaszorításának hiábavalóságát illusztrálandó - meglehetösen kétes érvelést is felvonultat: eszerint tulajdonképpen minden vállalkozás, legyen az kicsi vagy nagy volumenű, „monopolhelyzetben” van a saját tevékenységi körét illetően. Voltaképpen minden vasúttársaság „monopolizálja” a gazdasági tevékenység bizonyos területét. Ha a jogszabályt nem megszorítóan alkalmazzák, akkor jóformán bármely vállalkozást folytató személyek ellen eljárás indulhatna. Vö. 193 U. S. 406-407.

${ }^{294} 193$ U. S. 404

${ }^{295}$ Holmes maga is pontosan tisztában volt ezzel a céllal. Vö. 193 U. S. 407.
} 
értelmezésének kérdésének tekinthető: Holmes a jogalkotó szubjektív célja szerinti értelmezés helyett a szó szerinti értelmezést választotta, méghozzá annak speciális változatát, hiszen a „kereskedelem korlátozására irányuló szerződés” kifejezésnek speciális, a common law által meghatározott értelmet tulajdonított. Egyes kritikus kutatók ugyanakkor rámutattak arra, hogy Holmes alkotmányjogi érvelésének hátterében a közvélemény számára meglehetősen vitatott meggyőződés állt. Holmes nimbuszát először a második világháború idején és az azt követő években kezdték ki, abszolút értékeket nem feltételező nézetei elsősorban a totalitárius Németországgal való hadviselés folytán váltak, hiszen az ottani korlátlan, visszaélésekre hajlamos politikai hatalomra könnyen lehetett úgy tekinteni, mint annak egyenes következményére, ha értéktételezés nélküli elvek érvényesülnek a jogban. ${ }^{296}$ Később - immár a közvetlen politikai feszültségek nélkül nemcsak azt mutatták ki, hogy a Holmes döntései mögötti premisszák híján vannak minden értékelvüségnek, hanem azt is, hogy ezáltal Holmes bírói tevékenységének van egy „negatív” oldala is. Rogat szerint Holmes egy nyers hatalomelméletet képviselt, amelynek értelmében a társadalmi erők állandó harcában a mindenkor domináns csoportok akarata minősül jognak, és a bíróságoknak az alkalmazott normaszöveg keretei között kötelessége teret adni ezen akarat kiteljesedésének. ${ }^{297}$ Az alkotmányos alapjogokat pedig jóformán nem létezőnek tekintette. ${ }^{298} \mathrm{Ez}$ a nézete egy sor - úgy a tizennegyedik alkotmánykiegészítéssel, mint az alkotmány egyéb rendelkezéseivel kapcsolatos - esetben alapjogkorlátozó eredményhez vezetett. ${ }^{299}$ Rogat szerint a tizennegyedik alkotmánykiegészítés esetében ez a faji szegregáció alkotmányosságában nyilvánult meg. ${ }^{300}$ Természetesen a különféle következmények társadalmilag kívánatos vagy nem kívánatos voltának megállapítása mellett arra is fel kell hívni a figyelmet, hogy Holmes kritizált nézetei ettől még egy következetes álláspontot képeznek. Pusztán arról van szó, hogy az adott korszakban, az adott vonatkozásban - a XX. század első harmadában, a piac szabályozhatóságának kérdéskörében - Holmes álláspontja a „haladást” képviselte sokak számára, más esetekben ugyanez az elvi álláspont „maradinak” bélyegezhető. Az ugyanakkor mára kétségtelenül leszögezhető, hogy Holmes érvelése mögött a jogban rejlő

\footnotetext{
${ }^{296}$ Ehhez lásd különösen Palmer, Ben W.: Hobbes, Holmes and Hitler. In American Bar Association Journal Vol. 31, 1945, 569-573. o.

${ }^{297}$ Rogat, Yosal: Mr. Justice Holmes: A Dissenting Opinion. In Stanford Law Review Vol. 15, 1962, 11. o.

${ }^{298}$ Rogat: i. m. 37. o.

${ }^{299}$ A konkrét ügycsoportok tárgyalásához lásd Rogat, Yosal: Mr. Justice Holmes: A Dissenting Opinion. In Stanford Law Review Vol. 15, 1963, 254-308. o.

${ }^{300}$ Rogat 1963: 255-261. o.
} 
immanens értékeket tagadó, ${ }^{301}$ a jogot a társadalmi erők függvényeként ábrázoló elmélet húzódik.

Más kutatások arra utalnak, hogy Holmes korántsem volt olyan következetes a tizennegyedik alkotmánykiegészítés megszorító értelmezésében, és bár látszólag a bírói önmegtartóztatás következetes képviselője volt, valójában ő maga is tartalmi értelmezést adott a megfelelő eljárás követelményének, illetve olykor maga is az alkotmány kiterjesztő értelmezése mellett foglalt állást. Phillips arra a megfigyelésre jut, hogy Holmes a róla kialakított mítosz dacára számos esetben a támadott jogszabály alkotmányellenessége mellett foglalt állást - akár előadó bíróként, akár a többségi indokoláshoz csatlakozva. Ennek több elképzelhető okát sorolta fel: 1. Holmes progresszív meggyőződésű volt, 2. Holmes elvetette az olyan törvényeket, amelyek egy adott társadalmi osztály számára kedveznek, 3. Holmes eltérően ítélte meg a szabadság, illetve a tulajdon korlátozását. ${ }^{302}$ Phillips ugyanakkor úgy véli, hogy ezek a feltevések önmagukban nem rendelkeznek kellő magyarázóerővel, ezért kiegészíti őket azzal, hogy Holmes jól ismert relativizmusa és a társadalmi többség akaratával szembeni engedékenysége állhatott a progresszív törekvések iránti elfogadó attitűdje mögött. ${ }^{303}$ Vagyis a politikailag nagy jelentőségű ügyekben, ahol világosan kitapintható volt a többség akarata, Holmes okkal vélekedhetett úgy, hogy a támadott jogszabályban a társadalmilag domináns csoport akarata nyilvánul meg, amelyet csak egyértelmü esetben korlátozhat az alkotmány.

Phillips cikkéhez célszerü hozzáfüzni egy észrevételt. Holmes relativizmusával összefüggésben említést kell tenni a jogértelmezéssel kapcsolatban kifejtett álláspontjáról, amelyre megítélésem szerint Phillips nem helyez kellő hangsúlyt. Holmes ugyanis úgy vélekedett, hogy a jogalkalmazásban segítséget nyújtó distinkciók valójában meglehetősen bizonytalanok, és néhány egyértelmü végletet leszámítva a bírói mérlegelés terméke az, hogy egy eset milyen megítélés alá esik. Így például ha valaki személygépkocsijával sík terepen, ahol semmi nem akadályozza a látást, körülnézés nélkül átkel, és elüti öt a vonat, a vasúttársaságot egyértelműen nem terheli kártérítési felelősség, hiszen minden adott volt ahhoz, hogy a károsult felismerje az átkeléssel járó veszélyt, ennek hiányában a káresetben

\footnotetext{
301 A természetjogot kritizáló tanulmányában Holmes az igazság végletes szubjektivitása mellett érvel; szerinte az igazság nem egyéb, mint az ember intellektuális korlátainak rendszere, vagyis azért fogadunk el igaznak egy állítást, mert az adott kor adott közegének mércéje szerint megfelel az igazság kritériumainak. Ez a szubjektivizmus igaz a természetjogra is, ami ennek következtében nem más, mint egy szubjektív értékpreferencia objektívként való feltüntetése. Holmes, Oliver Wendell: Natural Law. In Harvard Law Review Vol. 32, 1918, 40-42. o.

${ }^{302}$ Phillips, Michael J.: The Substantive Due Process Decisions of Mr. Justice Holmes. In American Business Law Journal Vol. 36, 1999, 472-473. o.

${ }^{303}$ Phillips: i. m. 475. o.
} 
való közremüködése miatt elesik a kártérítési igénytől. Ám ha olyan körülmények merülnek fel, amelyek fennállása esetén nem várható el a körültekintés (például a vonat takarásban van, esetleg a zaját is elnyomják a környezet tárgyai, és nincs semmilyen jelzés, ami arra utalna, hogy vonat közlekedik a síneken), akkor már felmerül a vasúttársaság

kárfelelőssége is, ami esetről-esetre állapítható meg. ${ }^{304}$ A bíróságok mindig a konkrét esetekben határozzák meg, hogy mennyiben megalapozott a kártérítési igény, illetve az milyen mértékben zárható ki, és ha kellő számú döntés születik, abból kirajzolódik egy viszonylag egzakt határvonal. Ez azonban sosem lehet teljesen szilárd, hiszen egyrészt idővel változhat, másrészt kialakulását is meglehetősen sok esetlegesség befolyásolja.

Holmes ezeket a gondolatokat eredetileg a magánjogi jogalkalmazást jellemezve fejtette ki, és persze felsejlik mögöttük a bírói jogalkotásnak a common lawjogrendszerekbeli magától értetődősége. Az elmélet azonban éppúgy alkalmazható az alkotmánybíráskodásra is. Az, hogy egy piacszabályozási rendelkezés legitim módon korlátozza-e a címzettek alapjogait, széleskörü mérlegelés függvénye. Phillips szerint Holmes relativizmusa a bírói önmegtartóztatást éppúgy megalapozza, mint egy aktivista álláspontot. Elképzelhető, hogy a Holmes álláspontjában megmutatkozó ellentmondások az e határok kijelölésére való törekvés eredményei.

\section{III.3. Jogpolitikai-ideológiai viták a Lochner-ítélet megítélésénél}

\section{III.3.1. A Lochner-ítélet mint a „többségellenesség” megtestesítője és negatív megítélésének egyéb megnyilvánulásai}

A Lochner-ügy és kora egészen napjainkig vissza-visszatér az amerikai szakmai diskurzusban. Az ehhez kapcsolódó kutatások között vannak deskriptív jellegűek, amelyek egy adott szempontból elemzik a Supreme Court korabeli tevékenységét. Más elemzések ugyanakkor erősebb hangsúlyt fektetnek az értékelő megközelítésre. Ilyenkor tipikusan a negatív szimbólummá vált döntés érvelési módszerének továbbélését bírálják, vagy magának a döntésnek a helyességét vizsgálják.

${ }^{304}$ Holmes 1899: 457-458. o. 
Az Egyesült Államokban az alkotmányjog-történeti értekezésekben rendre visszaköszön az a narratíva, miszerint a Supreme Court a XX. század elején a gazdasági vonatkozású alkotmányos rendelkezéseket alkalmazta aktivista módon, majd később, a század derekától a polgári szabadságjogokat. Ez a narratíva meglehetősen egyszerü és kézenfekvő fejlődési ívet vázol fel, ám pontosításra szorul, hiszen egyes alapjogok, amelyeket a Supreme Court a XX. század közepén vagy azt követően érvényre juttatott, még a századforduló környékén, vagy az azt követő évtizedekben körvonalazódtak. Ennek legismertebb példája a magánszférához való jog, amely szó szerint nincs nevesítve az alkotmányban, ugyanakkor már a XIX. század végén megjelentek olyan döntések, amelyek a magánszférához való jog által védett érték fontosságát hangsúlyozták, ${ }^{305}$ a XX. század elejéről pedig a Meyer v. Nebraska-ítélet ${ }^{306}$ számít ezen alapjog fö fundamentumának. Ettől függetlenül a XX. század második felében több kritikus azért bírálta a Supreme Court alapjog-kiterjesztő gyakorlatát, mert szerintük a testület épp azt teszi liberális színekben, mint amit nem sok évtizeddel korábban tett konzervatív színekben.

Ennek egy erőteljes kifejeződése John Hart Ely elemzése. Ely a magánszférához való jogot a mủvi terhességmegszakítás szabadsága kapcsán kiterjesztő Roe v. Wade-ítéletet ${ }^{307}$ aprólékosan bírálva jut arra a következtetésre, hogy e döntés kétségkívül párhuzamba állítható a Lochner-ítélettel, ami a bírói aktivizmust illeti, ugyanakkor két különbség kimutatható a kettő között, és végső soron a Roe-ítélet veszélyesebb precedenst jelent, mint a közel 70 évvel elötte született Lochner.

Az első különbség az, hogy míg a Lochner-ítéletben ésszerü (rational) indokolást vártak el a jogalkotótól, amellyel egy alkotmányos alapjogot korlátozása meggyőzően magyarázható, addig a Roe-ítélet mércéje alapján kényszerítő (compelling) okot kell felmutatni a müvi terhességmegszakítás jogának korlátozásához.

A második különbség ahhoz kapcsolódik, miért nem találta a Supreme Court az alkotmánynak megfelelőnek az egyes esetekben támadott rendelkezéseket. A Lochner-

\footnotetext{
${ }^{305}$ Vö. Boyd v. United States (116 U. S. 616 /1886/); Union Pacific Railway Co. v. Botsford (141 U. S. 250 /1891/). Az első ügyben a Supreme Court alkotmányellenessé nyilvánított egy olyan eljárási rendelkezést, amelynek értelmében a büntetóeljárás kivételével a csempészettel kapcsolatos eljárásokban az eljárás alá vont személy köteles benyújtani a gyanú szerint a birtokában lévő dokumentumokat, ellenkező esetben az eljáró ügyész beadványában állítottakat a vallomása részének tekintik. A második ügyben a Supreme Court azt mondta ki, hogy kártéritési ügyekben az alperes kérelmére a felperes nem kötelezhető orvosi vizsgálaton való részvételre. Lásd még Molnár András: A magánszférához való jog az amerikai Legfelsőbb Bíróság gyakorlatában. In De iurisprudentia et iure publico, 2011/2. szám, http://dieip.hu/wp-content/uploads/2011-211.pdf (2014. augusztus 27.)

${ }^{306} 262$ U. S. 390. Ebben az ügyben a Supreme Court alkotmányellenesnek minősítette azt a tagállami törvényt, amely megtiltotta, hogy az általános iskolákban az angolon kívül más nyelvet oktassanak.

307410 U. S. 113 (1973)
} 
ítélet idején Ely meglátása szerint két okból bizonyulhatott alkotmányellenesnek egy alapjogkorlátozó szabályozás: vagy maga a cél ellentétes az alkotmánnyal, vagy nincs megfelelő okozati összefüggés a cél és a korlátozás között. Ezzel szemben a Roe-ítéletben a Supreme Court többsége úgy foglalt állást, hogy a magzat védelme nem kellően fontos ahhoz, hogy a szabályozás alkotmányossága megállapítható legyen. ${ }^{308}$

Hasonló észrevételeket tett az alkotmányjog számos területén a burke-i minimalizmust követő Sunstein. A burke-i minimalizmus Edmund Burke-nek a forradalmak nemkívánatos voltával és a lassú, lépésről-lépésre haladó, organikus társadalmi változások előnyösségével kapcsolatos nézeteinek az alkotmányértelmezésre történő alkalmazása. Sunstein szerint ,az alkotmányos elveket fokozatosan, analogikus úton kell kiépíteni, szoros tekintettel a régóta fennálló gyakorlatra", ${ }^{309}$ és mindeközben kerülni kell bármiféle önálló morális vagy politikai érv felhasználását. Sunstein szerint a Lochner-ítélet nem pusztán az agresszív bírói szerepet jelképezi, hanem „olyan megközelítést, amely az alkotmányjogi semlegesség követelményét írja elő, és a kifejezés alatt a javak és a jogosítványok létező elosztási rendjének a common law elvei mentén történő megőrzését érti.” ${ }^{110}$ Sunstein úgy ítélte meg, hogy a Lochner-bíróság „bűne” egyfajta formalizmus volt, melynek alapján pártosnak minősítette a valamely társadalmi csoport érdekét előmozdító törvényeket akkor is, ha az adott csoport hátrányos helyzetü volt. ${ }^{311}$ Megfigyelése szerint hasonló jogalkalmazási szemlélet kora alkotmányjogi gyakorlatában is tetten érhető, nemcsak a tizennegyedik alkotmánykiegészítés, de számos más alkotmányos rendelkezés értelmezése kapcsán is.

Barry Friedman az alapjogi bíráskodás és a többségi akarat közötti konfliktus, az ún. „többségellenességi probléma” (countermajoritarian difficulty) történetét áttekintő ötrészes tanulmánysorozatában külön fejezetet szentel a Lochner-ügynek. Az ő konklúziója az,

\footnotetext{
${ }^{308}$ Lásd mindehhez Ely, John Hart: The Wages of Crying Wolf: A Comment on Roe v. Wade. In The Yale Law Journal, Vol. 82, 1973, 940-942. o. Epstein a Roe v. Wade-ítélet értékelésénél célzást tesz arra, hogy a többség nem alkalmazta a Holmes-doktrínát, amikor nem az ő nézetük került törvénybe. Epstein 1973: 168. o. Az ezredforduló környékén aztán a vád ismét a konzervatívok ellen irányult, vö. pl. Krotoszynski, Ronald J.: The Wages of Crying Wolf Revisited: The Essential Consanguinity of Lochner, Roe, and Eastern Enterprises. In The Georgetown Journal of Law \& Public Policy, Vol. 1, 2002, 133-147. o.

309 „Burkean minimalists believe that constitutional principles must be built incrementally and by analogy, with close reference to long-standing practices." Sunstein, Cass R.: Burkean Minimalism. In Michigan Law Review, Vol. 105, 2006, 356. o.; valamint Sunstein, Cass R.: A Constitution of Many Minds. Why the Founding Document Doesn't Mean What It Meant Before. Princeton University Press, Princeton, 2009, 36. O.

310, ,T] he case should be taken to symbolize not merely an aggressive judicial role, but an approach that imposes a constitutional requirement of neutrality, and understands the term to refer to preservation of the existing destribution of wealth and entitlements under the baseline of the common law." Sunstein, Cass R.: Lochner's Legacy. In Columbia Law Review, Vol. 87, 1987, 875. o.

${ }^{311}$ Sunstein 1987: 882. o.
} 
hogy a Lochner-ítélet és kora elemzése során a fő kérdés az, milyen kapcsolatban van a jogi és a társadalmi legitimitás. Friedman arra mutat rá, hogy a Lochner-ítélet intenzív bírálatához kora éles társadalmi ellentétei is hozzájárultak. Az ügy tényállásának jogi megítélése kétes volt, ez pedig ahhoz vezetett, hogy a döntés jogi legitimitását is kétségbe vonták. $^{312}$ Szerinte a korszak revizionista elemzői, azok, akik a Lochner-korszak alkotmányértelmezési gyakorlatát magyarázhatónak és következetesnek, vagy épp egyenesen indokolhatónak tartják, tévedésben esnek akkor, amikor kizárólag a Lochnerítélet jogi indokolhatóságát tartják szem előtt, ilyenkor ugyanis figyelmen kívül hagyják azt a súlyos társadalmi felháborodást, ami a döntést kísérte.

Friedman elemzésének fontos erényeként könyvelhető el az, hogy nem kizárólag a „számokkal foglalkozik” - mint ahogy arra Warren, valamint Stephenson tanulmányainál felhívtam a figyelmet -, hanem tekintettel van arra is, hogy egyes ügyek mekkora jelentőséggel bírtak a maguk korában. Amint hangsúlyozza, kimutatható különbség van az amerikai polgárháborút követő, illetve a századforduló utáni évtizedek között az alkotmányellenessé nyilvánítás gyakorisága vonatkozásában, és az utóbbi időszakban a Supreme Court kevesebb törvény alkotmányellenességét állapította meg; ugyanakkor „[m]ég a számok tekintetében beállott változás sem árul el semmit a Supreme Court által alkotmányellenessé nyilvánított törvények természetéről és jelentőségéről." 313 Ám noha Friedman problémafelvetésével egyet lehet érteni, megítélésem szerint az további árnyalásra szorul. Amikor ő a vitatott jogszabályok jelentőségére utal, kétségkívül azok társadalmi jelentőségére gondol, arra, milyen széles személyi kört érintenek az adott rendelkezések, milyen csoportok érdekeit befolyásolják, vagy éppen milyen hatást gyakorolnak a fennálló társadalmi-gazdasági rendre. Emellett azonban nem hagyható figyelmen kívül egy támadott jogszabály által generált jogtudományi probléma jelentősége sem. A kettő nem feltétlenül függ össze egymással; egy alkotmányjogi kérdés jogtudományi jelentősége, valamint az annak apropójául szolgáló kérdés társadalmi jelentősége nem szükségszerüen áll párhuzamban. ${ }^{314}$ Talán - ahogyan Friedman is utal rá -

\footnotetext{
${ }^{312}$ Friedman, Barry: The History of the Countermajoritarian Difficulty, Part Three: The Lesson of Lochner. In New York University Law Review Vol. 76, 2001, 1454. o.

${ }^{313}$ „Of course, even the change in numbers says nothing about the nature and significance of legislation athat the Court struck down." Friedman: i. m. 1449. o.

314 Erre hívja fel a figyelmet a friss, magyar nyelvü szakirodalomban Pokol Béla, amikor az alkotmánybírósági döntések „kettős jellegéröl” ír. Vö. Pokol Béla: Alkotmánybíráskodás - Szociológiai, politológiai és jogelméleti megközelítésekben. Kairosz Kiadó, Budapest, 2014, 16-21. o. Pokol a probléma azon aspektusát emeli ki, hogy egyrészt az alkotmánybírósági döntés rendelkező része tartalmazza a támadott jogszabály alkotmányosságáról való állásfoglalást, és ez az, ami a szélesebb nyilvánosság érdeklődésére jobban számot tarthat; ugyanakkor azok a normatív támpontok, amelyek hozzú távra meghatározhatják egy
} 
valóban olyan társadalmi jelentőséggel bírt a Lochner-ítélet, hogy komoly kérdőjelek merültek fel annak társadalmi legitimitását illetően, azonban legalább ilyen súlyú volt az általa felvetett elméleti probléma is. A döntés ugyanis komoly kérdéseket vet fel a bírói szerep terjedelmet illetően, és legalább kettő, de talán három álláspont realizálódik a többségi indokolásban, illetve a különvéleményekben. Ezek az állásfoglalások pedig legalább akkora súllyal bírnak a döntés jogtudományi vonatkozásában, mint amekkorával a döntés eredménye az általa érintett társadalmi erőviszonyok vonatkozásában.

Mindemellett kérdéses az is, hogy mekkora volt a Lochner-döntés társadalmi jelentősége. Paul Kens arra mutat rá, hogy noha a progresszív mozgalom sajtója - érthető módon - kritikusan fogadta a döntést, korántsem volt szó arról, hogy „vészharangot kongattak" volna; nem fogadták szenvedélyesen negatív visszhanggal a döntést, és az elégedetlenség ellenére nem került sor tevőleges ellenállásra, valószínüleg azért, mert korábban már kialakult némi szkepszis az iránt, mennyire tudja a munkásmozgalom megvalósítani a céljait a törvényhozás útján. ${ }^{315}$ Kens is arra helyezi a hangsúlyt, ami fentebb említésre került, nevezetesen, hogy a Lochner-ítélet jelentőségét nem annak szűken vett tárgya adja, hanem a benne ütköző általános elvek. ${ }^{316}$ Ráadásul nemcsak a támadott törvény társadalmi jelentősége vitatható, hanem egyes szerzők azt is kétségbe vonják, hogy a nagy többség ellenezte a századforduló környékén domináló laissez-faire felfogást. Ha ez igaz, akkor Friedmannek a társadalmi legitimitás hiányáról alkotott megállapítása bizonytalan lábakon áll.

Meg kell jegyezni, hogy a Lochner-ítélet újabb elemzései eltávolodnak a többségellenesség vonalától és másképp igyekeznek megragadni annak az ítéletnek, illetve korának sarkalatos pontjait. Ennek oka az „alapjogi forradalomban” (rights revolution) keresendő, vagyis a Supreme Court mélyreható társadalmi változásokat eredményező, kiterjesztő alkotmányértelmezési gyakorlatában, amit a leginkább Earl Warren neve fémjelez. A probléma az, hogy a többségellenesség az új - de legalábbis időben közelebbi - gyakorlat és annak vívmányai fényében alkalmatlanná válik a Supreme Court korábbi gyakorlatának bírálatára: ha a demokratikus többség akaratának illegitim korlátozása a bírálat alapja, akkor a Lochner-ítélettel jellemzett korszak és a XX. század második felében született ítéletek egyaránt kifogásolhatók, ideértve a több mint fél évszázados, megszilárdult és következetes gyakorlatot néhány év alatt megingató deszegregációs

alkotmánybíráskodást végző szerv gyakorlatának irányát, az indokolásban kerülnek lefektetésre, ezért ez az a rész, ami valóban fontossággal bír.

${ }^{315}$ Kens, Paul: i. m. 143-146. o.

${ }^{316}$ Kens: i. m. 147. o. 
döntéseket, a terheltek jogainak rögzítését, mindenekelőtt a Miranda-ítéletet, valamint a reprodukciós jogoknak a Warren-éra utáni elismerését. Ebben a helyzetben olyan magyarázat válik kézenfekvővé, ami eltekint a többségi elv prioritásától. Sajátos megoldást nyújt Barnett, aki egyfajta rendszerszemléletü originalizmusra támaszkodva véli tarthatatlannak a Lochner-döntést. Szerinte a Supreme Court akkor követett el alapvető hibát, amikor a Slaughter-House Casesben ${ }^{317}$ megbolygatta a tizennegyedik alkotmánykiegészítés rendszerét és eredeti értelmét. Ezen alkotmánykiegészítés kapcsán a joggyakorlat és a jogtudomány egyaránt a megfelelö eljárás és az egyenlö törvényi védelem követelményeire fókuszál, holott ez az egység más rendelkezéseket is tartalmaz, többek között az „elöjogok vagy kiváltságok” klauzuláját (Privileges or Immunities Clause), melynek értelmében a tagállamoknak tilos olyan törvényt alkotniuk vagy végrehajtaniuk, amely az Egyesült Államok polgárainak előjogait vagy kiváltságait csorbítaná. Barnett álláspontja szerint a tizennegyedik alkotmánykiegészítés első szakaszának egyes rendelkezéseinek címzettjei a három nagy hatalmi ág képviselői: az előjogok vagy kiváltságok klauzulájának címzettje a törvényhozó, a megfelelő eljárás klauzulájáé az igazságszolgáltatás, az egyenlö törvényi védelem klauzulájáé pedig - noha ez a jelen értekezés tárgya szempontjából kevésbé releváns - a végrehajtó. ${ }^{318} \mathrm{Ez}$ a tipológia egyszerre „menti meg” a megfelelő eljárás követelményének régi tartalmát és hagyja érintetlenül az alapjogi forradalom vívmányait, hiszen a megfelelő eljárást annak formális értelmére szükíti, ${ }^{319}$ ugyanakkor biztosítja a legitimációt a modern Supreme Court alkotmányértelmezése számára is.

Vagyis ebben az értelmezésben nem is magán a Lochner-ítéleten van a hangsúly, hanem azon a kifogásolt tradíción, ami Barnett szerint a Slaughter-House Cases elbírálásával kezdődött. Az ő kritikája ezért valójában technikai jellegü. Nem foglal állást abban a kérdésben, hogy a Lochner-ítélet tartalmát tekintve mennyiben problematikus vagyis mennyiben legitimálható a szerződési szabadságnak az ítéletben megfogalmazott védelme -, ehelyett a tizennegyedik alkotmánykiegészítés feltételezett eredeti rendeltetése fényében a Supreme Court gyakorlatának jogalapját javasolja módosítani. Nem Barnett az első, aki a megfelelő eljárási klauzulát bizonyos minimális eljárási tisztességesség követelményeire törekszik szükíteni, azonban az ő megközelítése szélesebb spektrumú, ugyanis átfogóbb rendszerbe foglalja a tizennegyedik alkotmánykiegészítés elöírásait. Ez

\footnotetext{
31783 U. S. (16 Wall.) 36 (1873)

${ }^{318}$ Barnett, Randy E.: Foreword: What's so Wicked About Lochner? In New York University Journal of Law \& Liberty, Vol. 1, 2005, 331. o.

${ }^{319}$ Ehhez lásd lentebb a IV.2.1. szakaszt!
} 
az erény azonban másfelől nézve az elképzelés hibája is, mert figyelmen kívül hagy egy még tágabb kontextust: azt az alkotmányértelmezési hagyományt, amit a Supreme Court müködésének kezdetén fektetett le John Marshall vezetésével, mindenekelött a McCulloch v. Maryland-ügyben. Ez a koncepció ugyanis a bíróságok megszorító alkotmányértelmezésére épült, valamint arra, hogy a jogalkotónak széles mérlegelési teret kell hagyni, és nem ismerte a nevesítetlen jogoknak azt a védelmét, amit Barnett javasol. ${ }^{320}$

A Supreme Court gyakorlatában a valamilyen szempontból meghatározó jelentőségü, és ennek okán piedesztálra emelt ügyek mellett természetszerüleg születtek olyanok is, amelyeket az utókor „szégyenfoltként” idéz fel. ${ }^{321}$ Az előbbieket Balkin és Levinson az alkotmányjog „kánonjába”, az utóbbiakat pedig az ellenkánonba tartozónak tekinti. ${ }^{322}$ A „kánon” szó - ha túllépünk az egyházjogi eredeten - az irodalomból lehet ismerős: itt a kánon azokat a szövegeket jelöli, amelyek meghatározóak, mérvadóak az utókor szerzői és olvasói számára. ${ }^{323}$ Az alkotmányjogi kánon sajátossága az, hogy kapcsolódik hozzá egy ellenkánon is. Míg az irodalomoktatásban nem cél az, hogy megismertessék a tanulókat a rossz irodalommal, addig a jogtudományban a jogi érvelés rossz példáit is bemutatják. Balkin és Levinson szerint ennek magyarázata abban keresendő, hogy a jog az autoritásra támaszkodik, ennek igazolása során pedig azokra a példákra is ki kell térni, amikor erre az autoritásra hibásan támaszkodtak. ${ }^{324}$ Ahogy Jamal Greene fogalmaz: az ellenkánonba

\footnotetext{
${ }^{320}$ Barnett: i. m. 333. o.

${ }^{321}$ Az, hogy miért válik egy ítélet pozitív vagy negatív megítélésűvé, többféle körülménytől függ: adott esetben az államberendezkedés formálódásához való hozzájárulás válik ilyen szemponttá - a Marbury v. Madison kétségkívül ebbe a kategóriába tartozik -, más esetben a döntés tényleges kimenetele - mint például a rabszolgaságot a polgárháború hajnalán megerősítő Dred Scott v. Sandford.

${ }^{322}$ Lásd általában: Balkin, Jack M. - Levinson, Sanford: The Canons of Constitutional Law. In Harvard Law Review, Vol. 111, 1998, 964-1022. o. Balkin és Levinson az alkotmányjogi kánonnak több típusát küönböztette meg a kánon definíciója és közönsége alapján. Eszerint az alkotmányjogi kánon meghatározható annak alapján, milyen eseteket és joganyagot szükséges tanítani a leendő jogászok számára; ez az ún. „pedagósiai kánon” (pedagogical canon). Másrészt a kánon részét képezhetik azok az esetek és joganyagok, amelyeket a müvelt embernek ismernie kell ahhoz, hogy részt vehessen az alkotmányjogról folyó diskurzusban; ez az ún. „kulturális írástudási kánon” (cultural literacy canon). Végül beszélhetünk az ún. „,akadémikus elméleti kánonról” (academic theory canon), vagyis arról a korpuszról, amit a jogtudományi viták résztvevőinek szükséges figyelembe venniük. Balkin - Levinson: i. m. 975. o.

${ }^{323}$ Harold Bloom nagy visszhangot kiváltó elmélete szerint az irodalmi (,nyugati”) kánonba azok a művek tartoznak, amelyek a szövegek közötti versengésböl gyöztesen kerültek ki, és amelyekhez a későbbi korok szerzői magukat mérik, illetve azokhoz képest eredetit kívánnak alkotni. Bloom, Harold: The Western Canon: The Books and School of the Ages. Harcourt, Brace \& Company, New York, 1994, 20. o. A kánon, kanonicitás Bloomnál elsősorban esztétikai kategória, ez különösen azért hangsúlyozandó, mert Bloom a könyvében visszatérően bírálja a kánont ideológiai alapon bíráló vagy eltörölni kívánó elméleteket, és arra mutat rá, hogy a kánonba tartozó müvek olyan esztétikai minőséget mutattak fel, ami indokolttá teszi kanonizált státuszukat, és ennek megingatására az ideológiai alapú kritika önmagában alkalmatlan. Vö. Bloom: i. m. 24-25. o. A kánonvitáról a ,jog és irodalom” irányzat kontextusában magyar nyelven kiváló összefoglalót ad Nagy Tamás: Josef K. nyomában - jogról és irodalomról -. Attraktor, Máriabesnyő Gödöllő, 2010, 26-29. o.

${ }^{324}$ Balkin - Levinson: i. m. 982. o.
} 
tartozó döntések olyan rosszul lettek eldöntve, hogy a hibáikat „nem hagynánk szándékosan elhalni". 325

E modell szerint a Lochner-ítélet megítélésének változása felvázolható olyan folyamatként, amelynek során a döntés fokozatosan elveszítette ellenkánoni jellegét. Ez persze nem jelenti azt, hogy átkerült a kánonba, de mint arra Balkin rámutat, a tudományos közösség számára már nem egyértelmü, hogy az ítélet a saját korában is téves volt. ${ }^{326}$ Balkin szerint az ilyen változások a kánont övező narratívák változásaival magyarázhatók. Egy-egy kanonikus - avagy „antikanonikus” - esethez mindig kapcsolódik egy történet, amelyből megismerhetők az ügy szereplői, valamint a konfliktus természete, és e narratíva tartalma befolyásolja a problémakör bevett megítélését. ${ }^{327}$ A Lochner-ügy esetében az idő múlásával veszített aktualitásából az ügy tétjét jelentő gazdaságpolitikai kérdés, így lehetőség nyílt az ügy távolságtartóbb és az „,antikanonikus narratívától” különböző, sőt, olykor homlokegyenest szembenálló elemzésére. ${ }^{328}$

Balkin Mark Tushnet végletes historicista álláspontját vitatva érvel amellett, hogy a Lochner-ügy a jelenlegi, ,élét vesztett” formájában is rossz döntésként fogható fel, azért, mert a korabeli jogi kultúra képes volt létrehozni a tényleges végeredménytől eltérő alternatívákat (Balkin itt Harlan bíró különvéleményét emeli ki), ebből kifolyólag a kor „jól szocializálódott jogászainak” (well-socialized lawyers) lehetőségében állt másként dönteni. ${ }^{329}$ Megítélésem szerint azonban ez a kiindulópont is téves alap a bírálatra. Mindenekelőtt arra kell rámutatni, hogy Balkin kissé felszínesen mutatja be Tushnet álláspontját, ugyanis nem hangsúlyozza kellőképpen, hogy mit takar nála a ,jól szocializálódott jogász" alakja: nem egyszerüen a kor követelményei szerint jó szakmai képesítésben részesült személyről van szó, hanem olyasvalakiről, aki a kor által támasztott legkülönfélébb szerepkövetelményeket interiorizálta, így nemcsak professzionális életében, hanem az élet más területein is a kor standardjei által formált. ${ }^{330}$ Vagyis olyan sokrétủen determinált, hogy életszerütlen azt feltételezni vagy visszamenőlegesen elvárni, hogy az

\footnotetext{
325, ,The anticanon] is the set of legal materials so wrongly decided that their errors ... we would not willingly let die." Greene, Jamal: The Anticanon. In Harvard Law Review, Vol. 125, 2011, 386. o. Greene itt Harold Bloomot parafrazeálja.

${ }^{326}$ Balkin, Jack M.: "Wrong the Day It Was Decided": Lochner and Constitutional Historicism. In Boston University Law Review Vol. 85, 2005, 684. o.

${ }^{327}$ Vö. Balkin - Levinson: i. m. 986-991. o.

${ }^{328}$ Balkin: i. m. 688. o. Hasonló érveléshez és következtetéshez lásd: Gillman, Howard: De-Lochnerizing Lochner. In Boston University Law Review Vol. 85, 2005, különösen 865. o. Gillman a friss elemzésekre támaszkodva fejti ki azt, hogy a Lochner-ítélet környezetéről, jogi megalapozottságáról szerzett ismeretek megváltoztak, és így velük együtt változott a döntés közmegegyezéses „státusza” is - ebböl kifolyólag ideje letenni a bírói visszaéléssel való társításáról.

${ }^{329}$ Balkin: i. m. 724-725. o.

${ }^{330}$ Tushnet, Mark: Self-Historicism. In Tulsa Law Review, Vol. 38, 2003, 775. o.
} 
ilyen személy - nemcsak jogászi, de teljes, sokoldalú társadalmi meghatározottságában - a „helyesnek” tartott, de legalábbis a „helytelentől” eltérő álláspontra helyezkedjen.

A Lochner-ítélet ,antikanonikus”, illetve hibásan elbírált jellegének tárgyalásánál e döntést a Supreme Court történetének más „szégyenteljes pillanataival” kontextusban tárgyalják. Ebből a kontextusból mindenekelőtt a rabszolgasággal, illetve a faji szegregációval kapcsolatos, mérföldkő jellegü döntések emelendők ki: a Dred Scott v. Sanford, valamint a Plessy v. Ferguson. Az előbbi - polgárháború előtti - döntésben a Supreme Court megállapította, hogy a rabszolga - aki a jog szerint dolognak minősül nem szabadul fel akkor, ha a rabszolgaságot el nem ismerő állam vagy territórium területére lép, ellenkező esetben ugyanis sérülne a tulajdonosnak a tulajdonhoz való alkotmányos alapjoga. Az utóbbi a separate but equal-doktrínát meghonosítva nem vélte alkotmánysértő diszkriminációnak az eltérő bőrszínű személyek elkülönített vasúti kocsikba rendelését a tömegközlekedés igénybevétele során. Mai szemmel természetesen ezek a döntések és indokolásaik vérlázítónak és a civilizált erkölccsel homlokegyenest ellenkezőnek minősülnek, ${ }^{331}$ ám még ebben az esetben is kérdéses, sújthatja-e az utókor negatív ítéletével azok szerzőit, illetve a bennük alkalmazott érvelést, elvégre a kor ,jól szocializálódott jogásza" könnyen találkozhatott olyan társadalmi nézetekkel, amelyek összhangban álltak az ítéletekkel. De még ha a válasz igen is, ezekben az ügyekben nyílt faji diszkrimináció történt, ami sokkal egyértelmübben méltánytalan és indokolhatatlan, mint az abban a kérdésben való állásfoglalás, hogy a jogalkotó milyen mértékben határozhatja meg a versenyszféra résztvevőinek szerződési szabadságát, ez utóbbi esetben ugyanis felvethetők legitim érvek úgy az egyik, mint a másik oldalon. A Dred Scottal és a Plessyvel egy kategóriába kerülés méltánytalan történeti esetlegesség a Lochner vonatkozásában.

\footnotetext{
${ }^{331}$ A Dred Scott-ügy indokolásának egyik sarokpontja az volt, hogy az alkotmány létrehozói soha nem gondoltak a feketékre államalkotó tényezöként, amikor az alkotmányszöveg utal rájuk, akkor rabszolgaminőségben említi öket, és az egyes államok különböző törvényei is világosan megerösítik azt az össznépi meggyőződést, mely szerint a feketék alacsonyabb rendűek az Egyesült Âllamokat létrehozó fehéreknél. A Plessy-ügy konkrét tényállása szerint az indítványozót, egy nyolcadrészben fekete származású személyt azért bírságoltak meg, mert nem a feketéknek fenntartott kocsiba szállt. A tény, hogy bár az illető csak csekély arányban volt fekete származású, mégis a feketéknek fenntartott kocsiban kellett volna utaznia, azt az értékítéletet sejteti, hogy a fehéreket védeni kell a nem fehérektől, és a mégoly csekély arányú nem fehér származás is olyan „,szennyeződés”, ami miatt az érintetteknek el kell különíteni a fehérektől. Ez a körülmény azért érdemel említést, mert látható, hogy a Supreme Court többsége a saját, meglehetősen kifordított módon értelmezett formális egyenlőségi mércéjéhez sem tartotta magát.
} 


\section{III.3.2. A Lochner-ügy revíziójának kísérletei}

A neoliberális gazdaságfilozófiának az 1970-es években való elterjedése nem hagyta érintetlenül a jogtudományt sem. Az irányzat még az 1960-as években tette meg kezdő lépéseit, $^{332}$ majd a rá következő évtizedben befolyásos és megkerülhetetlen szemléletmóddá erősödött. Az irányzat „kodifikálása” Richard Posner nevéhez köthető, akinek 1973-ban megjelent, azóta több kiadást megélt, Economic Analysis of Law címü műve a jog gazdasági elméletének mérföldkövévé vált. Posner ebben a könyvében a jognak csaknem minden területét átértékeli közgazdaságtani szempontból, ideértve a Lochner-korszak szempontjából jelentős szabályozási területeket is.

Posner kifejezetten a minimálbér kapcsán arra mutat rá, hogy a szabályozás valójában a munkavállalóknak okoz hátrányt, azon kézenfekvő oknál fogva, miszerint a munkáltató valószínűleg inkább elbocsátja azokat az alkalmazottakat, akinek munkáját kevesebbre értékeli az előirt minimálbérnél - és akinek a szabályozás hatályba lépése előtt értelemszerüen kevesebbet fizetett. ${ }^{333}$ Érdekes tény, hogy a Supreme Court érvkészletében ez a megfontolás nem szerepelt. A Lochner-éra minimálbérrel foglalkozó legfontosabb döntése vitathatatlanul az Adkins-ügy, amelyben a testület elöször foglalkozott nem átmeneti jellegü minimálbér-szabályozással. Tulajdonképpen maga az eljárás tipikusan olyan helyzet miatt indult, amelyre tekintettel a közgazdászok vitatják az ilyen jellegü szabályok hatékonyságát: az egyik indítványozó egy szállodai liftkezelő volt, akit épp azért bocsátottak el, mert a törvény által felállított bizottság magasabb bért határozott meg számára. ${ }^{334}$ Ennek ellenére ez a hatékonysági megfontolás nem található meg a többségi indokolás szövegében. Helyette az előadó Sutherland a minimálbért eseti jelleggel megállapító bizottság által mérlegelendő szempontok bizonytalanságát emeli ki, ${ }^{335}$ valamint morális érvekre támaszkodik, mondván, a szabályozás révén igazságtalanul

\footnotetext{
${ }^{332}$ Vö. Coase, Ronald: The Problem of Social Cost. In Journal of Law and Economics Vol. 3, 1960, 1-44. o.; Calabresi, Guido: Some Thoughts on Risk Distribution and the Law of Torts. In The Yale Law Journal Vol. 70, 1961, 499-553.; Becker, Gary. S.: Crime and Punishment: An Economic Approach. In Journal of Political Economy Vol. 76, 1968, 169-217. o.

${ }^{333}$ Posner, Richard A.: Economic Analysis of Law. Aspen Law \& Business, New York, 1998, 361. o.

${ }^{334} 261$ U. S. 542. Annyi azért megjegyezhető, hogy rendszerint a munkáltatók közül kerültek ki az efféle ügyek indítványozói. Az olyan esetek ,archetípusa”, amelyekben a munkavállaló elégedetlen az első ránézésre az ő javát szolgáló szabályozással, egy New York tagállami döntés, az In re Jacobs-ítélet, amelyben egy dohánytermékek előállításával foglalkozó kisvállalkozás alkalmazottja támadta a szabályozást; a laissez-faire pártolói erre az esetre mutathattak, amennyiben azt akarták alátámasztani, hogy a munkaviszonyba való jogalkotói beavatkozás valójában szabad és nagyjából hasonló alkupozíciójú személyek egyezkedésének önkényes megzavarása.

335261 U. S. 555-556
} 
terhelik a társadalmat, amely végső soron azért köteles elszenvedni a dráguló szolgáltatások miatti többletköltségeket, mert a jogalkotó akaratából értékén felül kell megfizetni az alkalmazott munkaerőt. ${ }^{336}$ Ugyan nem a minimálbér, hanem a munkaidőkorlátozás kapcsán, de a Lochner-itélet többségi indokolásában egyetlen félmondat erejéig tetten érhető egy Posneréhez hasonló hatékonysági érv: Peckham reductio ad absurdumot alkalmazva érzékelteti, milyen veszélyes lenne, ha a jogalkotó hatalom alkotmányos korlátok nélkül korlátozhatná a munkaidőt bármely szakmában, és ennek során jegyzi meg, hogy az ilyen intézkedések súlyosan megnehezítik a dolgozó számára önmaga és családja eltartását. ${ }^{337}$ A hangsúly ugyanakkor nem erre, hanem a szabályozás igazságtalanságára, alapjog-korlátozó jellegére helyeződik.

A Supreme Courttól adott esetben nem volt idegen a jog gazdasági elméletét idéző érvelés, ${ }^{338}$ az összkép azonban az, hogy a Lochner-éra meghatározó precedensei nem tükröznek ehhez hasonló szemléletmódot. A Supreme Court retorikája inkább igazságosság- és alapjogcentrikus volt; ebben az esetben ez a gondolati irány történetesen egybevágott a jog gazdasági elméletének képviselői által kívánatosnak tartott eredménnyel. Elsősorban azonban a morálfilozófiai-alkotmányjogi megfontolások domináltak.

A munkavédelmi szabályozással kapcsolatban Posner nem kevésbé szkeptikus: megítélése szerint a munkáltatónak érdeke a munkavállalók optimális szintű biztonságának garantálása a munkavégzés során, hiszen az utóbbiak így képesek a legnagyobb hasznot termelni. Ha a jogszabály által elöírt munkavédelmi követelmények teljesítése költségesebb a munkáltató számára, mintha maga szavatolná alkalmazottai biztonságát, akkor a különbözetet a bérekből fogja lefaragni, hogy a jogszabálynak való megfelelésből származó veszteségét kompenzálja. ${ }^{339}$ Ugyanakkor az ilyen tárgyú jogszabályokat a Supreme Court rendszerint alkotmányosnak ítélte. A kulcsszó a „biztonság” védelme: az emberek fizikai veszélytől való megóvása legitim alkotmányos célnak számított; ehhez a Supreme Court következetesen tartotta magát. A Lochner-ítélettel ellentétben a munkavédelmi elöírások esetében nem is merült fel kétség a szabályozás és a biztonság mint alkotmányosan védhető érték között. Ebben az esetben tehát az látható, hogy az

\footnotetext{
${ }^{336} 261$ U. S. 557-558

337198 U. S. 59

338 Erre példa az 1894-es Lawton v. Steele-ítélet (152 U. S. 133) indokolásában kifejtett gondolatmenet, melynek értelmében a támadott tagállami halászatkorlátozó szabályozásban nem indokolt az a rendelkezés, hogy a jogellenes halászat elleni fellépés során elkobzott hálókat meg kell semmisíteni, ugyanis ez sokkal hatékonyabb módszer, mint bonyolult adminisztrációs úton visszajuttatni azokat tulajdonosaiknak, ehhez képest a háló csekély értékü, így a jogellenesen halászókat ezzel összevetve nem éri súlyos veszteség.

${ }^{339}$ Posner: i. m. 363. o.
} 
alkotmányjogi doktrína ellentétben állt a közgazdaságtani megfontolásokkal, és a Supreme Court az előbbi mellett foglalt állást.

Posner - egy rövid kitérőtől eltekintve ${ }^{340}$ - általánosságban foglalkozott a piacszabályozás gazdasági vonatkozásaival. Michael J. Phillips kifejezetten a Lochnerkorszakra összpontosította figyelmét. Elemzésében vitatja azt az érvet, amely a Supreme Court döntéseiben, valamint a korabeli és kései kritikákban egyaránt visszatérő jelleggel felbukkant, nevezetesen hogy a nagyvállalatok aránytalanul magas alkupozícióval rendelkeztek, és a Supreme Court, valahányszor egy piacszabályozó törvény alkotmányellenességét állapította meg, figyelmen kívül hagyta ezt a körülményt. Phillips négy pontra bontva cáfolja ezt az érvet. Először arra mutat rá, hogy noha sürün hivatkoztak a méret és az alkupozíció összefüggésére, valójában alaptalan az állítás, miszerint a nagyvállalatok nagy méretüknek köszönhetően bírtak jobb alkupozícióval a kiszolgáltatott dolgozóknál. Másodszor cáfolja azt az érvet, hogy az egyik oldal erőfölénye miatt a munkaszerződések megkötése során nem került sor valódi, egyenlő alkura. Phillips erre azzal válaszol, hogy a kritikusok szerint a munkáltatók azonos feltételeket kínáltak a munkavállalóknak, ez azonban valójában annak a jele, hogy a munkáltatók versengtek a munkavállalókért, amiből az következik, hogy volt helye a valódi, kölcsönös alkunak. Harmadszor Phillips vitába száll azzal az érvvel, hogy a munkáltatók kihasználták a munkavállalók függő helyzetét; szerinte a puszta tény, hogy a munkavállalók az adott feltételek mellett munkába álltak, azt mutatja, hogy a munkavállalást megelőző helyzetük még rosszabb volt. Végül ugyanezt az ellenvetést állítja szembe azzal az érvvel, hogy a szükségben lévő munkavállalók tulajdonképpen nem tekinthetők szabad embernek. ${ }^{341}$

Ezt a kritikai vonalat képviselte Ellen Frankel Paul is, aki Holmes különvéleménye apropóján értékelte a Lochner-ítélet alkotmányos alapjainak helytállóságát. Holmes, mint ismeretes, egyebek között az alkotmány világnézeti semlegességére hivatkozva bírálta azt, hogy a többség egy konkrét gazdaságfilozófiát olvas bele az alkotmány - megítélése szerint - ideológiailag neutrálisnak szánt előírásaiba. Paul ezzel az észrevétellel vitázva hívja fel a figyelmet arra, hogy az alkotmányozók osztották Locke gazdaságfilozófiáját, ez a meggyőződésük ott állt az alkotmányozás hátterében, és annak szövegében is megjelenik. ${ }^{342}$ Emellett rámutat arra, amivel fentebb én is foglalkoztam, nevezetesen, hogy

\footnotetext{
${ }^{340}$ Ehhez lásd Posner: i. m. 685-691. o.

${ }^{341}$ Phillips, Michael J.: The Lochner Court, Myth and Reality, Substantive Due Process from the 1890s to the 1930s. Praeger Publishers, Westport, 2001, 130-134. o.

${ }^{342}$ Paul, Ellen Frankel: Freedom of Contract and the „Political Economy” of Lochner v. New York. In New York University Journal of Law \& Liberty Vol. 1, 2005, 528-529. o.
} 
a „konzervatív aktivista” bíróknak is voltak olyan nézeteik, amelyek a progresszív célkitűzésekkel álltak összhangban. ${ }^{343}$ Álláspontja szerint az a teszt, amelyet a Supreme Court a Lochner-ügyben alkalmazott, elsősorban bizonytalan alkalmazhatósága miatt nem állja meg minden tekintetben a helyét, és védhetőbb lett volna, ha nyíltan ideológiai alapon foglalt volna állást, és kiemelten védendő értékként helyezte volna középpontba a szerződési szabadságot, ez ugyanis összhangban állt volna az alapítók gondolkodásával és az alkotmány eredeti filozófiájával. ${ }^{344}$

Paul okfejtése azért érdemel figyelmet, mert olyan originalista álláspontot képvisel, amely nyíltan felvállal és indokolhatónak tart egy, a szakmai közvélemény által élesen elítélt döntést. Az originalizmus egy fő dilemmája a múltra való apellálás miatt épp az, hogyan határolódjon el az utókor által diszkreditált ítéletektől. Az olyan döntések, mint a Dred Scott ${ }^{345}$ vagy a Plessy v. Ferguson ${ }^{346}$ a releváns rendelkezések „eredeti jelentésének” alkalmazásával születtek, ez pedig nagy támadási felületet hagy az irányzat bírálóinak. A tizennegyedik alkotmánykiegészítés értelmezése hasonlóan problematikus kérdést jelent az originalisták számára, és különböző szerzők különböző megoldásokkal álltak elő. Raoul Berger egy komplett kötetben tekintette át az alkotmánykiegészítés életet, szabadságot, illetve tulajdont védő rendelkezésének értelmezését, és arra a megállapításra jutott, hogy eredetileg a szabadság védelme csak a fizikai szabadság biztosítására vonatkozott, vagyis az amerikai bíróságok az eredeti jelentéstől eltérően terjesztették ki a rendelkezést, amikor a „szabadság” fogalmába tartozónak tekintették a szerződési szabadságot is. ${ }^{347} \mathrm{Az}$ ő esetében tehát elhatárolódásnak lehetünk tanúi. Paul originalista érvelése ezzel szemben felvállalja a Lochner-ítélet által közvetített ideológiát; szerinte a döntés és a benne alapul vett alkotmányos rendelkezés a szabadpiaci kapitalizmus morálfilozófiai bázisán nyugszik.

A Warren-bíróság kiterjesztő gyakorlatának évtizedeitől a liberálisok és a konzervatívok egymást váltva vádolják a Supreme Courtot a másik oldalt szolgáló aktivizmussal. A jog gazdasági elméletének képviselői sem kivételek e tendencia alól. Horwitz meglátása szerint ez az irányzat, azáltal, hogy a javak egyenlőtlen elosztásának apológiájaként kezdett funkcionálni, elveszítette tudományos nimbuszát, és egy

\footnotetext{
${ }^{343}$ Paul: i. m. 546. o.

344 Paul: i. m. 567. o.

${ }^{345}$ Dred Scott v. Sandford, 60 U.S. 393 (1857)

346163 U. S. 537 (1896)

${ }^{347}$ Vö. Berger, Raoul: Government by Judiciary: The Transformation of the Fourteenth Amendment. Harvard University Press, Cambridge, 1977.
} 
ideológiává vált a sok közül, amellyel egész jogelméleti irányzatokat alapoznak meg. ${ }^{348} \mathrm{Ez}$ az észrevétel annyiban egészítendő ki, hogy különböző irányzatok különböző diszciplínák előtérbe helyezésével alakítják ki eltérő hangsúlyaikat is; így például arra a klasszikus kérdésre, kicsikarható-e kínzással az elfogott terroristából az ezrek életét fenyegető időzített bomba holléte, más választ adhat olyasvalaki, aki egy, az emberi méltóságot középpontba helyező morálfilozófia talaján áll, mint az, aki az utilitárius megfontolásoknak tulajdonít nagyobb jelentőséget. Az adott diszciplína fogalmi keretei között, illetve módszertana szerint egy válasz lehet helyes, mégis homlokegyenest ellentétes egy másik diszciplína fogalmi kerete és módszertana révén megadott válasszal. Ez a kiegészítés azonban nem változtat azon, hogy ha a különböző nézőpontok, nézetrendszerek fölé emelkedve vesszük szemügyre a különféle elméleti irányzatok közötti intellektuális csatározásokat, akkor óhatatlanul ideológiailag elfogult résztvevőket láthatunk mindkét oldalon. A jog gazdasági elmélete nem képes ezen a nehézségen túllépni, hiszen a közgazdasági nézőpont csak egy a sok nézőpont közül. Ha azonban ezt az állítást elfogadjuk, abból az következik, hogy az irányzat képviselői ingoványos terepen járnak, amikor elképzeléseik bíróságok általi implementálását szorgalmazzák.

A jog gazdasági elmélete által többnyire favorizált deregulációval való azonosulása miatt e szakaszban érdemes tárgyalni David Bernstein észrevételeit. Az amerikai alkotmányértelmezési elmélet és gyakorlat körében megfigyelhetők olyan törekvések, amelyek nevesítetlen alapjogokra támaszkodva igyekeznek bővíteni az egyéni szabadságjogok lehetséges körét. Maga a Lochner-ítélet körüli vita is részben arra összpontosul, hogy mit volt, illetve nem lett volna szabad a Supreme Courtnak levezetnie az alkotmányra hivatkozással (avagy az alkotmány tételes rendelkezései mire adtak lehetőséget). A magánszférához való jog vitás megítélése hasonlóképpen erre a dilemmára vezethető vissza. ${ }^{349}$ Egyes újabb kutatók a kilencedik alkotmánykiegészítés alapján

\footnotetext{
${ }^{348}$ Horwitz, Morton J.: Law and Economics: Science or Politics? In Hofstra Law Review Vol. 8, 1980, 912. o.

${ }^{349}$ Hozzátehető, hogy egyes, viszonylag új szakirodalmi álláspontok szerint már nem beszélhetünk a magánszférához való jogról, annak doktrínáját ugyanis felváltotta a szabadságra (liberty) történő hivatkozás. Greene, Jamal: The So-Called Right to Privacy. University of California, Davis Law Review, Vol. 43, 715 748. o. Talán Greene következtetését támasztja alá a tény, hogy a 2015-ben eldöntött Obergefell v. Hodgesügy (135 S. Ct. 2584) többségi indokolásában a privacy szóra egyetlenegyszer történik utalás, és ebből az érvelésből Roberts bíró „hámozza ki” a privacy-magot a különvéleményében. Ugyancsak ebbe az irányba látszik mutatni az is, hogy egy még későbbi ítélet, a Whole Woman's Health v. Hellerstedt [
} 
törekszenek új utakat nyitni e téren. Ebben az elméleti vonulatban helyezhető el Bernstein is, aki általánosságban szembehelyezkedik a szabadságjogok mindennemü korlátozásával, ${ }^{350}$ és ennek során történeti érvelésre támaszkodik, amely szerint az Egyesült Államok alkotmányos kultúrájában a nevesítetlen szabadságjogok kiolvasztása és védelme régóta jelen van. A Lochner-ügy szempontjából ez azért jelentős, mert Bernstein ezt az ítéletet is a nevesítetlen szabadságjogok effajta érvényre juttatásának korai példájaként mutatja be, ${ }^{351}$ továbbá rámutatott néhány olyan körülményre, amelyek a Bakeshop Act gazdaságtalanságát, illetve piactorzító hatását jelzik. ${ }^{352}$ Bernstein elemzése alapos szintézise a Lochner-ítéletről és koráról alkotott nézeteknek, mindazonáltal az általa előadott tézis különösebben nagy újdonságerővel nem hat. Ami az ő megközelítését újszerüvé teszi, az az, hogy a nevesítetlen alapjogok elméletét általánosságban kiterjeszti, és minden élethelyzetre alkalmazandónak tartja. Vagyis Bernstein meghaladja azt a túl sokszor észlelhető és az aktivizmusról folyó szakmai diskurzust elakasztó megosztottságot, miszerint mindig a „másik oldal aktivizmusa” a „rossz”, és persze mindig a „másik oldal” nézetei szerinti alkotmányértelmezési gyakorlat hasonlítható a Lochner-ügyhöz. Ennek a fajta ,jogtudományi pártoskodásnak” a szerző véget vet azzal, hogy a kérdéses döntést pozitív példaként mutatja be, és ilyen minőségében helyezi a Supreme Court más, a szabadságjogokat kiterjesztően értelmező döntések mellé, továbbá mindemellett az „ellenséget” a társadalom különféle szegmenseinek szabályozásában látja.

\section{III.4. A Lochner-ítélet mint egy következetes alkotmányértelmezési gyakorlat része: Howard Gillman megközelítése}

Az eddigiekből látható volt, hogy a Lochner-ügy és kora megítélését könnyen átjárhatják különféle ideológiai megfontolások. Széleskörü, és mondhatni, dogmatikus elutasítottságának mintegy ellenpólusát képezi az az álláspont, amely szerint a döntés helyes gazdasági-társadalomelméleti premisszákból levont helyes konklúzió. Bármely

579 U. S. (2016)] többségi indokolásában a privacy szó már egyáltalán nem is található meg, jóllehet az érvelés a Planned Parenthood v. Casey-döntés által bevezetett undue burden mércéjére támaszkodik.

350 Lásd pl. Bernstein, David E.: You Can’t Say That! The Growing Threat to Civil Liberties from Antidiscrimination Laws. Cato Institute, Washington, 2003.

${ }^{351}$ Bernstein, David E.: Rehabilitating Lochner. Defending Individual Rights against Progressive Reform. University of Chicago Press, Chicago, 2011, 23-39., különösen 33-35. o.

${ }^{352}$ Bernstein 2011: 24-25. o. 
álláspontot is tartjuk azonban szem előtt, mögöttes prekoncepciókat fedezhetünk fel, amelyek az ítélet és annak joggyakorlati kontextusa torz megítélését eredményezték.

Ezt a torz megítélést kívánta meghaladni Howard Gillman, aki nem pusztán magára a Lochner-ügyre fókuszált elemzésében, hanem annak szélesebb szellemi-szakmai környezetét vizsgálta. Vagyis bár kérdésfeltevésének apropóját szükségszerűen a Lochnerítélet körüli viták inspirálták, ő nem ragad le ennél a konkrét döntésnél, hanem azt egy viszonylag koherens, következetes bírósági gyakorlat része, mely csak e kontextusában értelmezhető megfelelőképpen.

Gillman két pontban summázza a Lochner-ügy bevett megítélését: meglátása szerint a szakmai közvélemény egyrészt azért bírálja ezt az ítéletet, mert állást foglalt egy politikai kérdésben, másrészt azért, mert a jogalkotást egy ésszerüségi tesztnek vetette alá. ${ }^{353}$ Gillman ezzel a vélekedéssel szemben azt demonstrálta könyvében, hogy a Lochner-ítélet többségi indokolásában tetten érhető megközelítés jellemző volt a Supreme Court korabeli gyakorlatára, sőt, e megfontolásokkal voltaképpen az alapítók szellemi örökségét vitték tovább. ${ }^{354}$ A probléma gyökere az, hogy az újkori természetjog eszméit az alkotmányba belefoglaló alapítók nem készültek fel a modern termelési viszonyok sebes elterjedésére és az ebből fakadó egyenlőtlenségek, társadalmi feszültségek okozta új kihívásokra. ${ }^{355}$ Gillman úgy érvel, hogy a Supreme Court alapvetően az „osztálypolitikával”, vagyis egyes társadalmi csoportok kiváltságos helyzetbe helyezésének gyakorlatával helyezkedett szembe. Vagyis gyakorlata nem a szabadpiaci kapitalizmus nyílt propagálására irányult, hanem egyfajta egyenlőségkoncepció érvényre juttatására, amely koncepció egy olyan kor szülötte, amelyet nem jellemzett az emberek egymástól való tömeges függése. ${ }^{356} \mathrm{E}$ tekintetben pedig viszonylag következetes joggyakorlatot folytatott, mint azt Gillman számos precedens bemutatásával demonstrálja is.

Ami magát a Lochner-ügyet illeti, Gillman rámutat két további körülményre, amelyek megalapozták annak indokolását. ${ }^{357}$ Egyrészt a XIX. század közepén megváltozott a tagállami törvények alkotmányos felülbírálatának alapja: 1868-ban elfogadták a tizennegyedik alkotmánykiegészítést, ami az alkotmány szövetségi és

\footnotetext{
353 Gillman, Howard: The Constitution Besieged. The Rise and Demise of Lochner Era Police Powers Jurisprudence. Duke University Press, Durham, 1993, 19. o.

${ }^{354}$ Gillman: i. m. 20. o.

${ }^{355}$ Gillman: i. m. 21. o.

${ }^{356}$ Gillman: i. m. 61. o.

357 E helyütt célszerü az „indokolás”, és nem az „eredmény” szót alkalmazni. Lentebb, a Lochner-ügy részletes ismertetésénél majd látható lesz, hogy ugyanazzal az elméleti alappal két ellentétes álláspont, a kérdéses törvény alkotmányossága és alkotmányellenessége is alátámasztható - ez esetben történetesen az alkotmányellenességet hangoztató oldal került többségbe.
} 
tagállami jogalkotói hatásköröket meghatározó I., illetve a szövetségi jognak a jogforrási hierarchiában való elsőbbségét kimondó VI. cikke mellett a tagállami jogalkotás újabb korlátját jelentette. Másrészt éretté váltak a kapitalista termelési formák, végbementek az ezzel együtt járó társadalmi változások, mindenekelőtt a bérből élők számának drasztikus növekedése, valamint a ciklikus gazdasági válságok. ${ }^{358}$

Gillman fő tézise tehát a következőkben foglalható össze. A Lochner-ítéletet meghozó Supreme Court nem önkényes szeszélyből vagy ideológiai elfogultságból hozta meg döntését, hanem egy kimunkált, dogmatikailag megalapozott gyakorlatot követett, ez a gyakorlat pedig olyan teszt elé állította a jogvitában támadott szabályozást, amelynek az nem tudott megfelelni. Ez a gyakorlat és alkotmányossági teszt azonban olyan eszmei és társadalmi környezet szülötte, amely természeténél fogva idegen volt attól az iparosított kapitalista társadalomtól, amelynek új kihívásait a Supreme Court sem tudta megkerülni. Mint ilyen, előbb-utóbb menthetetlenül konfliktusba került a korabeli társadalmi valósággal. Gillman meglátása szerint ez a konfliktus mindenekelött a minimálbér előírásának alkotmányosságával kapcsolatos vitákban vált tetten érhetővé. Gillman e meglátásai tulajdonképpen részben nem tekinthetők novumnak, hiszen a Supreme Court kora XX. századi alkotmányértelmezési elveinek elavultságát már annak progresszív kritikusai is hangoztatták. Gillman azonban ezt bőséges mennyiségü konkrét példával, ítélettel is alátámasztva szisztematikusan levezeti, így a régtől fogva hangoztatott állítás szilárdabb megalapozást nyert.

\section{III.5. Paul Kens és a Lochner-ítélet genezise}

Paul Kens Lochner v. New York: Economic Regulation on Trial címü könyvének megközelítésmódja bizonyos szempontból eltér a fentebb ismertetettektöl. A Supreme Court gyakorlatát illetően a szerző arra a megállapításra jut, hogy a testület abban az időben bizonyos, már-már taxatív jelleggel felsorolt alkotmányos célok, illetve a velük fennálló ésszerü cél-eszköz viszony megléte esetén minősítette alkotmányosnak a támadott szabályozást. Kötetének legjava azonban nem a Supreme Court szélesebb körü gyakorlatával, hanem a Lochner-ítéletben vizsgált Bakeshop Act születésének társadalmi körülményeivel, valamint a Lochner-ügy folyamatával foglalkozik behatóan.

${ }^{358}$ Gillman: i. m. 62-63. o. 
Következtetései közül az ez utóbbi tárgykörre vonatkozók a jelentősebbek, ezért elsősorban ezeket kívánom e helyütt felvillantani.

Kens legfontosabb megállapításai a következők voltak. Az eset szükebb spektrumát a sütőipar helyzetét - illetően arra mutat rá, hogy a sütőipar - annak is a gyorsan romló késztermékeket előállító ága - a századforduló környékének óriási léptékű iparosodása dacára többségében legfeljebb négy föt foglalkoztató kisvállalkozások kezén maradt. ${ }^{359}$ Ezek a vállalkozások egyrészt viszonylag csekély költségráfordítással müködtek, viszont másfelöl nem is hoztak magas profitot, és ha a költségekböl le kellett faragni, azt alapvetően két területen lehetett megtenni: a munkabéreken és a munkakörülményeken. ${ }^{360}$ Ez a kiélezett verseny körülményei között ahhoz vezetett, hogy a pékek alkalmanként abszurd mértékü munkaidőben dolgoztak meglehetősen igénytelen körülmények között ideértve az elégtelen világítást, a szellőzés és a higiénia hiányát. ${ }^{361}$ Ugyanakkor érdemes hozzátenni, hogy ez a helyzet egyáltalán nem jellemezhető a naiv „kizsákmányolt alkalmazottak kontra kizsákmányoló munkáltatók" sémával: Kens rámutat arra, hogy e kisvállalkozások vezetői maguk is alaposan kivették a részüket a munkából. ${ }^{362}$

Ezek a körülmények az 1890-es években, a társasházak általános állapotának tematizálásával kerültek napvilágra. Itt mindenekelőtt az ún. „muckrakerek” fő alakja, ${ }^{363}$ Jacob Riis How the Other Half Lives címü, először 1890-ben kiadott tényfeltáró írását kell megemlíteni, amely nagymértékben hozzájárult ahhoz, hogy a New York zsúfolt, szegényebb negyedeiben uralkodó állapotok tematizálásra kerüljenek a szélesebb közönség elött. Riis ebben a könyvében mintegy idegenvezetőként „kalauzolja végig” az olvasót New York City különböző régióin. E „kalauzolás” vezérelve nagyrészt az etnikum (Riis egyebek között külön fejezetet szentel az olaszoknak, a kínaiaknak, a zsidóknak, vagy éppen a feketéknek), illetve az egyéb társadalmi rétegekhez való tartozás (Riis foglalkozik például a gyermekek és a dolgozó nők helyzetével). Riis laza szerkezetủ áttekintése életközeli képet igyekszik adni a nagyvárosi életről, mely meglehetős nyíltsággal mutat rá korának olyan létező társadalmi problémáira, mint a túlzsúfoltság, a társasházi szobák

\footnotetext{
${ }^{359}$ Kens, Paul: Lochner v. New York. Economic Regulation on Trial. Kansas University Press, Kansas, 1998, 7. o.

360 Kens: i. m. 8. o.

${ }^{361}$ Kens: i. m. 8-9., illetve 13. o.

${ }^{362}$ Kens: i. m. 7. o.

363 A „,muckraker” kifejezés az Egyesült Államokban a századforduló környékének reformista, tényfeltáró újságíróit jelöli, akik „felrázták” a közvéleményt és a döntéshozókat a városi élet és az iparosodás árnyoldalait illetően.
} 
kivilágítatlansága és levegőtlensége, ${ }^{364}$ a higiénia hiánya, ${ }^{365}$ a gyermekszegénység és bűnözés veszélye, ${ }^{366}$ a dolgozó nők és gyereklányok kiszolgáltatottsága. ${ }^{367}$

Riis vizsgálata az urbanizáció problematikájának igen széles spektrumát elemzi. Mellette meg kell említeni egy, a Lochner-ítélet szempontjából közvetlenebbül releváns vizsgálatot is, mely 1894-ben zajlott le az ún. „Gilder-bizottság” vezetésével. Ennek során három témával foglalkoztak: a rossz állapotú épületekben fennálló betegség- és halálveszéllyel, a túlzsúfoltság problémájával és a parkok, játszóterek meglétével, illetve hiányával. ${ }^{368}$ Ezek közül az első érintette a péküzemek helyzetét is, mivel azokat - az alacsony bérleti díj miatt - gyakran társasházak pincéiben alakították ki. A vizsgálat eredményeképp mérsékelt szabályozási javaslat született, mely arra irányult, hogy a pékségek épületeinek tüzállónak kell lennie.

A pékek ügyét felkaroló Edward Marshall, a New York Press szerkesztője - egyúttal a Gilder-bizottság tagja - azonban nem elégedett meg ennyivel, és személyesen járt utána kifejezetten a péküzemekben uralkodó körülményeknek. Megfigyeléseit hatásvadász cikkekben tette közzé, melyekben bemutatta - fényképek kíséretében -, milyen higiéniátlan körülmények között készül a kenyér, amit az emberek tömegei nap mint nap fogyasztanak. ${ }^{369}$ E cikkek nem maradtak visszhangtalanul az olvasóközönség előtt, és csakhamar több ezer levél érkezettbe az állam törvényhozó testületéhez, melyben a problémát kezelő törvény meghozatalát sürgették. ${ }^{370}$ A kezdeti nehézségek után végül a jogalkotó szerv mindkét kamarája ellenszavazat nélkül elfogadta a Bakeshop Actet. ${ }^{371}$

\footnotetext{
${ }^{364}$ Lásd elsősorban Riis, Jacob: How The Other Half Lives. Hill and Wang, New York, 1957, 11-15. o. A szobák szellőzésének életveszélyes hiányát Riis annak tudja be, hogy a régi társasházak eredetileg nagyobb méretủ szobáit a tulajdonos-bérbeadók több kisebb szobára választották szét, és ezt minden tiltakozás nélkül megtehették, a nagy tömegek ugyanis e szük, kivilágítatlan-levegőtlen szobák számára is megfelelő keresletet biztosítottak. Vö. Riis: i. m. 6. o.

${ }^{365}$ Lásd pl. Riis: i. m. 25. o.

${ }^{366}$ Riis: i. m. 136. o.

${ }^{367}$ Riis: i. m. 176-183. o. Könyvének 20. fejezetében Riis a Dolgozó Nők Társasága (Working Women’s Society) egy tagjának egy nyilvános gyülésen elhangzott panaszát idézi: „Ismert tény, hogy a férfiak bére nem eshet létfenntartásuk határa alá, ellenben a nő bérének nincs határa, mert számára mindig nyitva áll a gyalázat ösvénye.” (,It is a known fact that men's wages cannot fall below a limit upon which they can exist, but woman's wages have no limit, since the paths of shame are always open to her.") Riis: i. m. 176-177. o. Riis ugyan az egész fejezetben nem mondja ki nyíltan, de feltételezhetö, hogy a „gyalázat ösvénye” a prostitúciót vagy egyéb, a kor szemében erkölcstelen foglalkozást jelentette. Érdekesség, hogy a fejezet végén optimistán megjegyzi: a New York-i nők csak a legritkább esetben ,züllenek el”, mert mint osztály, erényesek. Riis: i. m. 183. o.

${ }^{368}$ Kens: i. m. 56. o.

369 Kens: i. m. 57. o.

370 Kens: i. m. 60. o.

371 Kens: i. m. 64. o.
} 


\section{III.6. A jelen értekezés elhelyezése a téma korábbi kutatásainak kontextusában}

Kevés olyan jogeset létezik, amelyet a szakirodalom többet boncolgatott, mint a Lochner-ügyet. A döntés jogtudományi ${ }^{372}$ jelentősége megítélésem szerint a bírói szerepről alkotott felfogások ütközésében, és a domináló szerepfelfogásnak a vélt vagy valós társadalmi helyzettel való ellentétében rejlik. A Lochner-ítélet előtt talán nem volt döntés, amely ilyen nyíltsággal reprezentálta volna azokat a dilemmákat, amelyek a rendes jogszabályok alkotmányhoz mérésével előállnak. Ezt szem előtt tartva kevéssé meglepő, hogy a döntés jóformán mind a mai napig foglalkoztatja a szakmai közvéleményt.

A döntést és a korszakot elemző müvek megközelítésmódjaik alapján jól körülhatárolható csoportokra oszthatók. Mindenekelőtt érdemes az ideológiai-politikai alapú elemzéseket, kritikákat elkülöníteni. Ezekre alapvetően az jellemző, hogy bírálat alá vonták a Supreme Court „konzervatív elhajlását”, „átpolitizáltságát”, mindezt azonban olyan háttérrel tették, hogy maguknak a bírálatoknak a társadalmi-ideológiai küzdelmektől való távolsága sem tűnt magától értetődőnek. Itt mindenekelőtt a Lochner-ügy és általában a Supreme Court XX. század eleji kritikáiról kell szót ejteni, melyek részben a zabolátlan, iparosított kapitalista gazdasági rend vadhajtásait visszametszeni igyekvő progresszív mozgalommal álltak összefüggésben: a jogi gondolkodásban megjelenő „szociológiai mozgalom" olyan elméletet alkotott, amelynek egyik fó tézise az életviszonyokba való állami beavatkozás széleskörü legitimitása, e tézisböl pedig - többek között - az a következtetés vonható le, hogy az alkotmányossági tesztet, a legitim célok körét, illetve a cél-eszköz viszony ésszerűségét a törvényalkotó javára kell értelmezni, melyet részben a demokratikus legitimáció indokol, részben pedig a folyvást változó társadalomban felmerülő problémák újszerüsége. ${ }^{373} \mathrm{Ez}$ a jogfelfogás messzemenően összhangban állt azokkal a társadalompolitikai törekvésekkel, amelyek a régi ideológia és az ennek

\footnotetext{
${ }^{372}$ Megfigyelésem szerint a döntés történelmi jelentősége csekély, az általam vizsgált történettudományi müvek meglehetősen változó gyakorisággal tettek említést a Lochner-ügyről, és ha igen, akkor is csak példálózó jelleggel utaltak rá, mint olyan esetre, amikor a testület meghiúsította a progresszív társadalompolitikai törekvéseket. Történelmi szempontból sokkal nagyobb jelentőséggel bírnak a New Deal egyes törvényeinek alkotmányosságát firtató ítéletek.

${ }^{373}$ A jog szociológiai megközelítésének egyesült államokbeli „alapító atyjai” közül Holmes gondolkodását elsősorban az első megfontolás jellemezte - ez később követője, Felix Frankfurter jogfelfogásában is megjelenik -, Pound gondolkodását pedig elsősorban a második.
} 
megfelelő társadalmi rend felváltásáért szálltak síkra. A korabeli jogelméleti irányzatok e társadalmi viták fényében mélyebben megérthetők.

Az ilyen gyökerü kritikák mellett viszonylag korán megjelentek azok a hangok, amelyek a Supreme Court gyakorlatának mennyiségi jellegű elemzésével vizsgálták a bírálatok igazolhatóságát. Az ilyen felmérések egy meghatározott időintervallum tárgy, illetve alkalmazott alkotmányos rendelkezés alapján szelektált döntéseinek végeredményét summázták, és ebből tágabb rálátást nyújtottak a Supreme Court gyakorlatának tendenciáira. E kutatások gyermekbetegsége volt azonban, hogy kizárólag a kvantitatív szempontokat tartották szem előtt, vagyis meggyőzőnek tartották azokat a következtetéseket, amelyeket pusztán a támadott jogszabályhelyeket alkotmányosnak, illetve alkotmányellenesnek nyilvánító döntések arányából le lehetett vonni. A XX. század második felében végbement hasonló kutatások többé-kevésbé túlléptek ezeken a kezdeti nehézségeken, azonban a kvantitatív szempontok szem előtt tartása továbbra is általánosságban jellemezte ezeket a megközelítésmódokat.

A vízválasztó 1937-es évet követően a Lochner-ítélet az ideológiai megfontolásból eredő bírói visszaélés, önkény szinonimája lett. Ez a helyzet különösen akkor vált pikánssá, amikor - a Warren-bíróság színre lépésével - a gazdasági jellegü szabadságjogok szűk védelmével párhuzamosan a polgári szabadságjogok védelme erőteljes hangsúlyt kapott; innét kezdődően ugyanis a konzervatívok és a liberálisok kölcsönösen, egymás rovására vádolhatták a Supreme Courtot azzal, hogy feléleszti a Lochner-korszakot. Ugyanakkor a XX. század második felében újfent megjelentek azok a tanulmányok, amelyek elrugaszkodni törekednek a hagyományos képtől.

Végül különösen a XX. század utolsó harmadában mutatkoztak törekvések a Lochner-ítélet „rehabilitálására”. Az 1929-es gazdasági világválságot és a New Dealt követően a szabadpiaci kapitalizmus tanai az 1970-es években leltek ismét széles körben kedvező fogadtatásra, ami a jogtudományban a jog gazdasági elméletének térnyerésében csapódott le, ennek a folyamatnak pedig - az 1960-as évekbeli előzményeket követően mérföldköve volt Posner először 1973-ban kiadott, Economic Analysis of Law címü kötete. Az ebben és más közgazdaságtani nézőpontú elemzésen kijelölt csapásirányon haladva sor került bizonyos bevett jogi meggyőződések felülbírálata is; ezek közé tartozott a Lochnerügynek és korának újraértékelése. A közgazdaságtan fényében a Supreme Court alkotmányellenessé nyilvánító - mindenekelőtt a munkaidőt és munkabért szabályozó rendelkezéseket érintő - döntései kedvező megítélést nyertek. A neoliberális gazdaságfelfogás szerint a piac szabályozása kontraproduktív, ezért hatékonysági 
szempontból hátrányos. Az ilyen értékelés esetében megállapítható, hogy új alapokra helyezik a döntés indokolását, a Lochner-ítélet gerincét ugyanis morálfilozófiai megfontolások alkották, nem közgazdaságtani felmérések. Azonban találhatunk olyan rehabilitáló álláspontokat is, amelyek az Egyesült Államok alkotmányának locke-i - és így természetjogi - gyökereire, a tulajdonvédelem kiemelt jelentőségére apellálva tartják indokolhatónak a döntést. A jog gazdasági elmélete ily módokon revideálta a „konzervatív Supreme Courtot".

A Supreme Court ugyanakkor egy testület, amely emberekböl áll; így müködésének értékelése tovább árnyalható egyes prominens tagjainak szakmai attitüdjét vizsgálva. Az ilyen irányú kutatásokból kiderül, hogy a „rossz” oldalon álló bírák sem burkolt vagy nyílt elfogultságból döntöttek egy adott álláspont mellett, hanem választásukat többé-kevésbé következetes szakmai érvek támasztották alá. Ennek kiemelése és szem előtt tartása különösen célszerü az olyan vitatott ítéletek, korszakok elemzésénél, amelyek résztvevői könnyen polarizálhatók ,jó”, illetve „rossz” oldal szerint. Az ilyen polarizáció iskolapéldája a Dred Scott-ügy megítélése, melyet a rabszolgaság öröksége különösen kényessé tesz, de nem áll messze ettől a Lochner-ítélet sem. A jelen értekezésben különösen a Holmes és Brewer szakmai elvei és világnézete közötti harsogó különbségek felvillantását tekintettem kellően szemléltető erejünek.

Azon megközelítések közül, amelyek abból a megfontolásból indultak ki, hogy a Lochner-ítélet nem önmagában vizsgálandó, más döntésekkel való összevetése pedig nem alapulhat pusztán a döntések végeredményének összevetésében, hanem egy következetes gyakorlat megnyilvánulásaként kell tekinteni rá, Howard Gillman elemzése tekinthető mérvadónak. Gillman szerint a Supreme Court doktrínájának középpontjában az „osztályigazságszolgáltatásnak" a - voltaképpen az osztó igazságosságon alapuló - elkerülése állt, vagyis az arra való törekvés, hogy a jogalkotó ne nyújtson privilégiumokat olyan társadalmi csoportoknak, melyek nem rendelkeznek az erre indokot adó differentia specificával. A Supreme Court századfordulós gyakorlata egyfelől egy viszonylag friss helyzetre adott reakcióból eredt, hiszen a tagállamok jogalkotási szabadságát korábban nem létező határok közé záró tizennegyedik alkotmánykiegészítést csak 1868-ban fogadták el; másfelől pedig e gyakorlat az alapítók szellemiségét követte, és épp ez eredményezte a problémát, tekintve, hogy az alapítók nem látták, nem láthatták előre a gépesített ipari termelésből eredő gazdasági-társadalmi változásokat, és nem ezeket szem előtt tartva fogalmazták meg az alkotmány rendelkezéseit. 
A jelen értekezésnek az ismertetett megközelítésmódokhoz való viszonya a következőképpen vázolható fel. Mindenekelött azt tartom fontosnak kiemelni, hogy nem osztom azokat az elutasító nézeteket, amelyek akár a Supreme Court korabeli általános gyakorlatát, akár szükebben a Lochner-döntést a bírói visszaélés szinonimájaként kezelik, már-már „démonizálva” azokat. Az első vonatkozásában az elutasítás nyilvánvaló: a Supreme Court számtalan esetben hagyott szabad teret a jogalkotói mérlegelésnek Másfelől azonban a jog gazdasági elméletével azonosulók meglátásaiból sem kívánok kiindulni: a jelen vizsgálódás tárgyát egyáltalán nem képezi az, hogy a jogvitákban kérdéses szabályozási megoldások közgazdaságtani szemmel nézve mennyire hatékonyak vagy nem hatékonyak. A kutatás elsősorban a vizsgált döntések indokolásaiban tetten érhető érvelést veszi górcső alá, ehhez pedig nincs szükség a hatékonyságot illetően állást foglalni. Hasonlóképpen nem célom a Supreme Courtban a kérdéses időszakban megfordult bírák életútjának, világnézetének, illetőleg szakmai hitvallásának részletes boncolgatása. Az ilyen irányú vizsgálódások létjogosultsága vitathatatlan, hiszen árnyalják a Supreme Courtról mint testületröl alkotott képet, és mélyebb rálátást biztosítanak arra, milyen nézetek ütköztek azoknak a döntéseknek a megvitatása, meghozatala során, amelyek végül is meghatározták egy-egy rendelkezés alkotmányosságát. A jelen kutatás keretei között azonban ezek részletes elemzésére nincs szükség, azt a kutatás fókusza nem indokolja.

Vizsgálódásomban elsősorban Gillman elemzésére kívánok támaszkodni, illetve az ő meglátásaira kívánok reflektálni. Kutatásom eredménye részben alátámasztja Gillman megállapításait, részben azonban eltérö következtetésekre jutok, amelyekkel szerintem egyes észrevételei korrigálhatóak. Természetesen már önmagában némi különbözőséget eredményez az, hogy én más fogalmi keretben elemzem az Egyesült Államok legfőbb bírói testületének a kijelölt időszakban folytatott munkásságát. Ennél azonban fontosabb, hogy egyfelől én is arra a következtetésre jutok, hogy a Supreme Court egy többé-kevésbé következetes gyakorlathoz tartotta magát, és például maga a Lochner-ítélet is ennek eredményeképp jött létre, másfelől azonban árnyalni kívánom a tézist, miszerint a Supreme Court mércéje nem állta ki a próbát a késő XIX. és a kora XX. század által támasztott új társadalmi-gazdasági kihívásokkal szemben. Ha a Lochner-ügyet vizsgáljuk, akkor azt láthatjuk, hogy az abban támadott szabályozás tárgyát következetlenül választotta meg a jogalkotó. A szabályozás személyi hatályának kizárólag a pékekre (valamint, a pontosság kedvéért, a cukrászipari dolgozókra) való kiterjesztése tényleg szokatlannak és indokolatlannak tünik, és tulajdonképpen nem meglepö, hogy a Supreme Court 
érvénytelenné nyilvánította a kifogásolt elöírásokat. Ugyanakkor megítélésem szerint téves az a konklúzió, miszerint a Supreme Court gyakorlata alkalmatlan volt az új társadalmigazdasági kihívások kezelésére. Az én álláspontom az, hogy a Supreme Court releváns gyakorlata tartalmazza azokat az érveket, megfontolásokat, amelyek lehetővé teszik a széleskörü jogalkotói mérlegelést. Gillman helyesen emeli ki, hogy a testület mindenekelőtt a minimálbért érintő szabályozást nyilvánította következetesen alkotmányellenesnek. Ugyanakkor meglátásom szerint - a Supreme Court tágabb gyakorlatának fényében - ez egyfajta elhajlásként értékelhető. A West Coast Hotel v. Parrish-ügyben a testület tulajdonképpen nem tett mást, mint visszatért ahhoz a gyakorlathoz, melyet egy sor egyéb tárgyú ügyben addig is következetesen érvényre juttatott. Az alább következő fejtegetések reményeim szerint alátámasztják ezt a megelőlegezett konklúziót. 


\section{A Supreme Court „,konzervatív aktivizmusa” a XX. század első évtizedeiben született precedensek tükrében}

\section{IV.1. A kutatás szempontjai}

A vizsgálódás elvégzéséhez a Supreme Court döntésanyagának a testület 1890-es, illetve 1936-os ítélkezési évei közötti intervallumba eső részét használtam fel elsődleges forrásként. Egy ítélkezési év egy adott év októberétől a következő év októberéig tartott, ami azt jelenti, hogy az adott ítélkezési évbe sorolt döntések valójában sokszor csak a következő évben születtek meg. Így fordulhatott elő, hogy például maga a Lochner-ítélet is, noha az 1904-es ítélkezési évbe sorolják, valójában 1905-ben született meg. A fósodrú felfogás 1937-re datálja a fordulatot, melynek során a Supreme Court szakított az állítólagos konzervatív elhajlásával. Ebben az évben született meg a West Coast Hotel Co. v. Parrish-ügyben hozott itélet, ${ }^{374}$ amely alkotmányosnak nyilvánított egy tagállami minimálbér-törvényt annak ellenére, hogy mindössze egy évvel korábban egy hasonló rendelkezést alkotmányellenesnek minősített. ${ }^{375}$ Miután a West Coast-döntés az 1936-os ítélkezési évbe tartozik, fölöslegesnek tartottam az 1937-es ítélkezési évet is áttekinteni.

A kutatáshoz a HeinOnline internetes adatbázis keresőrendszerét hívtam segítségül. Tekintettel arra, hogy a „megfelelő eljárás” klauzulája, valamint a tizennegyedik alkotmánykiegészítés kulcsfontosságú a korszak gyakorlatának értékelésénél, a due process, illetve a fourteenth amendment kifejezéseket alternatív lehetőségekként írtam be a keresőbe. $^{376} \mathrm{Az}$ így talált döntések aztán erős szelekción mentek keresztül. Célom

\footnotetext{
374300 U. S. 379

${ }^{375}$ Morehead v. New York ex rel. Tipaldo, 298 U. S. 587

${ }^{376}$ Felvetődhet a kérdés, miért nem írtam be a fifth amendment kifejezést is, hiszen a megfelelő eljárás klauzuláját - a Kongresszus hatáskörére vonatkozóan - e rendelkezés is tartalmazza. A jogos kifogásra a következő válasz adható. A piacszabályozás alkotmányossága elsősorban a tagállami jogalkotás problémája volt, a tagállami jogalkotó testületek ugyanis szélesebb mérlegelési jogkörrel rendelkeznek, mint a Kongresszus. A tagállamok a saját területükön folyó gazdasági tevékenységek szabályozására kizárólagos hatáskörrel rendelkeznek. A Kongresszus hatásköre ehhez képest az alkotmány I. cikk 8. szakasz 3. fordulata alapján a tagállamok közötti kereskedelemre korlátozódik (ugyanezen fordulat jogosítja fel a Kongresszust az indián törzsekkel, valamint az idegen nemzetekkel folytatott kereskedelem szabályozására, ami azonban a téma szempontjából kevésbé releváns). A szövetségi és tagállami szint közötti eme hatáskörmegoszlás azt eredményezte, hogy az indítványozók túlnyomó többsége valamilyen tagállami szintủ jogszabályt támadott, amit a tizennegyedik alkotmánykiegészítés alapján tehetett meg. A másik ok, amiért a fifth amendment kifejezést kihagytam a keresési szempontokból, az, hogy míg a tizennegyedik alkotmánykiegészítés legsürübben hivatkozott rendelkezése éppen a megfelelő eljárás klauzulája, addig az ötödik alkotmánykiegészítés több más olyan rendelkezést is tartalmaz, amelyek szintén sürủ hivatkozási alapot jelentenek az indítványozók számára - a legfontosabb ezek közül talán az önvádra kötelezés tilalma. Ilyen
} 
kifejezetten olyan döntések kiválogatása volt, amelyeknek a tárgya valamely, a piac szabályozására irányuló jogszabály alkotmányossága volt. Ez a szelekció számos ügycsoport kizárását eredményezte. Mindenekelőtt értelemszerüen kizártam azokat az ítéleteket, amelyek kifejezetten csak egy alsóbb szintü bírói döntés alkotmánysértő jellegével foglalkoznak, anélkül, hogy az indítványozók valamely jogszabály normakontrollját kérték volna a Supreme Courttól. Az Egyesült Államok jogrendszerében a Supreme Court egyszerre látja el a bírósági hierarchia csúcsszervének, valamint a legfőbb alkotmányértelmező szervnek a szerepét, és a testület az alkotmányt a jogrend alapjaként nevesítette, amellyel ellentétes jogszabályokat a bíróságok nem alkalmazhatnak. ${ }^{377}$ Miután a Lochner-ítélet, valamint a korszak alkotmányértelmezési gyakorlata elsősorban a jogalkotás és az alkotmánybíráskodás konfliktusát, illetve ez utóbbi „demokratikus deficitjének” problémáját veti fel, a csupán alsóbírósági döntésekkel, nem pedig a jogszabályok alkotmányosságával foglalkozó döntések irrelevánsnak tekinthetők.

Ugyancsak kézenfekvő módon megakadtak a szürőn a büntető anyagi vagy eljárásjogi, illetve szabálysértési rendelkezések normakontrolljával kapcsolatos döntések. Néhány esetben az indítványozók a szabadsághoz való joguk sérelmére hivatkozva támadtak a Supreme Court előtt egyes szabadságvesztéssel fenyegető büntetőjogi tényállásokat. A mérce az volt, mennyiben függ össze az adott tényállás a piac szabályozásával: az olyan döntéseket, amelyekben a kettő között nem állt fenn érdemi

körülmények között a kutatást jelentösen megnehezítette volna, ha a vizsgált idöszakban minden, az ötödik alkotmánykiegészítést is megemlítő Supreme Court-döntést is vizsgálni kellett volna, és ez az energiaráfordítás valószínủleg nem térült volna meg, hiszen ha az indítványozó a megfelelő eljárás klauzulája alapján támad egy szövetségi szintű jogszabályt, akkor jó eséllyel számítani lehet arra, hogy a fifth amendment mellett a due process kifejezés is felbukkan valahol a döntés szövegében.

377 Ezt az alapvetést John Marshall, a Supreme Court akkori elnöke rögzítette az 1803-as Marbury v. Madison-ítéletben, amelyben kifejtette, hogy abszurd lenne az alkotmánnyal ellentétes törvényt érvényre juttatni a nyilvánvalóan magasabb rendủ alkotmánnyal szemben, ráadásul ésszerüen az sem feltételezhető, hogy az alapítók semmilyen hatályt nem szántak az alkotmánynak. Vö. 5 U. S. (1 Cranch) 174-180. A textuális felhatalmazás nélküli normakontroll-hatáskör gyakorlás legitimitása visszatérő vitatéma a szakirodalomban. Míg ugyanis tény, hogy az alkotmány kifejezett rendelkezést nem tartalmaz a jogszabályok alkotmányosságának bírósági vizsgálata vonatkozásában, egyes szerzők rámutatnak arra, hogy a korlátozott szuverén eszméje már a Marbury-döntés előtt is jelen volt az Egyesült Államok jogi-politikai kultúrájában, sőt, olykor a gyakorlatban is kifejezésre jutott. Vö. pl. Corwin, Edward S.: Marbury v. Madison and the Doctrine of Judicial Review. In Michigan Law Review, Vol. 12, 1913-1914, különösen 553-567. o.; valamint Plucknett, Theodore F. T.: Bonham's Case and Judicial Review. In Harvard Law Review, Vol. 40, 19261927, különösen 61-68. o. Később a korlátozott szuverén eszméjének jelenlétére támaszkodva legitimálja a bírósági alkotmányos normakontrollt az originalista Berger is. Vö. Berger, Raoul: Congress v. The Supreme Court. Harvard University Press, Cambridge, 1974. Alexander Bickel, mindeme körülmények dacára, híres könyvében kritizálja a Marbury-döntést, érvelése szerint ugyanis a Marshall által hivatkozott alkotmányos rendelkezések (nevezetesen a bírói hatalmi ágról rendelkező III., valamint az alkotmány és a szövetségi törvények elsőbbségét deklaráló VI. cikk) nem vezettek szükségszerủen a Supreme Court által egyhangúlag elfogadott eredményre. Vö. Bickel, Alexander: The Least Dangerous Branch - The Supreme Court at the Bar of Politics. Yale University Press, 1986, 1-14. o. 
kapcsolat, nem vettem tekintetbe a vizsgálódás során, amennyiben azonban a szabályozás egyes piaci visszásságok büntetőjogi vagy szabálysértési eszközökkel való kiegyenlítésére irányult, a szóban forgó döntést bevontam a vizsgált anyagok körébe. ${ }^{378}$

A keresés eredményeképpen számos olyan ügy került felszínre, amelyben az indítványozók a tulajdon szabadságára hivatkozva támadtak meg olyan önkormányzati vagy törvényhozói aktust, amelynek lényege az, hogy bizonyos fejlesztések (pl. járdaburkolás, csatornázás) költségeit részben vagy egészben olyan személyekre terhelik, akiknek a fejlesztésből valamilyen haszna származik (például értékesebbé válik a kapcsolódó ingatlanja). Az ilyen ügyeket több okból különítettem el a vizsgált döntéshalmaztól. Egyrészt, noha a jogalkotó törvényi vagy önkormányzati rendeleti úton intézkedett az adott fejlesztésről, az intézkedés mindig egy konkrét fejlesztésre vonatkozott, ezért nem tekinthető abban az értelemben általános jogszabálynak, ahogyan akár a klasszikus jogágak normái, akár például a kor munkabiztonságot, munkakörülményeket szabályozó elöírásai. Másrészt ez az ügycsoport a lehető legtávolabb állt azoktól az ideológiai és jogtudományi csatáktól, amelyek a progresszív eszme által ihletett jogszabályokat kísérték: nem vetett fel olyan kérdéseket, amelyek a bírói alkotmányértelmező szerep határainak átgondolását igénylik, és ilyen tárgyú okfejtések nem is találhatók az indokolásokban.

Jelentős mennyiséget képeztek az adójogszabályok alkotmányosságával kapcsolatos döntések is, amelyek jellemzően szintén a tulajdon szabadsága körül forogtak. Ezt az ügycsoportot - a fentihez hasonlóan - azon az alapon zártam ki a vizsgált döntésanyagból, hogy távol áll azoktól a vitás kérdésektől, amelyek a Supreme Courtot érö aktivizmusvádak során jellemzően felmerülnek. Ez esetben azonban be kellett iktatni néhány kivételt. Az adójogszabályok alkotmányosságának vizsgálata kapcsán a Supreme Court általában abból az előfeltevésből indult ki, hogy azok célja az állami bevételek gyarapítása, és e téren többnyire igen széles mérlegelési szabadságot biztosított a jogalkotó számára. ${ }^{379}$ Olykor azonban észrevételezte, hogy az adójogszabályok a társadalompolitikai célok megvalósításának eszközeiként is szolgálhatnak ${ }^{380}$ - például azokban az esetekben,

\footnotetext{
${ }^{378}$ Vö. pl. Collins v. Texas, 223 U. S. 288 (1912).

${ }^{379}$ Ami azt illeti, a Supreme Court helyenként - mondhatni, originalista érvelést alkalmazva - azt is rögzítette, hogy a tizennegyedik alkotmánykiegészítést nem az adóztató hatalom korlátozása végett alkották meg. Vö. pl. Southwestern Oil Co. v. Texas, 217 U. S. 114, 119 (1910). Más esetekben azt állapította meg, hogy az adóztatás terén a tagállamokat szélesebb mérlegelési szabadság illeti meg, mint a jogalkotás egyéb területein. Vö. pl. Citizens' Telephone Co. v. Fuller, 229, 322,329 (1913). Lásd még Magnano Co. v. Hamilton, 292 U. S. 40, 44 (1934), illetve III.3.2.

${ }^{380}$ Vö. pl. Gundling v. Chicago, 177 U. S. 183, 189 (1900); McCray v. United States, 195 U. S. 27 (1904); Bradley v. Richmond, 227 U. S. 477, 480 (1913).
} 
amikor a jogalkotó bizonyos típusú vállalatokat azért sújt nagyobb adóteherrel, hogy velük szemben előnyösebb helyzetbe hozza az általa favorizált vállalattípusokat. Amennyiben a testület egy adótörvényt mint társadalompolitikai eszközt vizsgálta, és a vizsgálat alapja a tizennegyedik vagy az ötödik alkotmánykiegészítés volt, úgy a döntést bevontam a vizsgált anyagok körébe.

Megjegyezhető továbbá, hogy következetesen kizártam bizonyos „egyéb” kategóriába sorolható ügyek elemzését, amelyek, bár az indítványozók a tizennegyedik vagy az ötödik alkotmánykiegészítésre hivatkoztak, távol álltak a kutatás alapproblémájától. E körbe sorolhatók az amerikai öslakosok helyzetével összefüggő döntések: az őslakosok speciális társadalmi csoportot képeztek, melynek problémái eltértek az iparosodás, a növekvő gazdaság és a szociális, illetve piaci etikai szempontok konfliktusától. Nem egy olyan döntés került elö, amelynek tárgya valamilyen puerto ricói jogszabály. Tekintettel arra, hogy Puerto Rico soha nem tartozott az Egyesült Államok elismert tagállamai közé, az ott megalkotott jogszabályok fölötti alkotmányos normakontroll némileg más kérdéseket vet fel, mint az elismert tagállami jogszabályok fölötti, ugyanis ez utóbbi esetben a föderalizmus, a tagállami és a szövetségi szint közötti hatáskörmegoszlás problémája is felvetődik, ami a tagállamoktól eltérő egyéb képződmények esetében nem mondható el. Emellett természetesen különválasztottam az olyan, a téma szempontjából nyilvánvalóan irreleváns eseteket, mint az esküdtszékek müködésével kapcsolatos kérdések (az esküdtszéki eljáráshoz való jog, az esküdtek kiválasztásának folyamata), a faji diszkrimináció, a szólásszabadság mint a liberty egyik esete a tagállami szabályozással összefüggésben, valamint a bevándorlás szabályozása. Ugyancsak elkülönítettem az olyan eseteket, amelyekben nem természetes személy vagy gazdálkodó szervezet hivatkozott alkotmányos alapjogokra (például egy települési önkormányzat), ${ }^{381}$ valamint azokat, amelyekben az indítványozó által támadott jogszabály nem általános hatályú, hanem egyetlen konkrét jogalany számára állapít meg jogokat vagy kötelezettségeket (például müködési engedélyt ad egy vállalat számára, vagy viadukt építésére kötelezi a vasúttársaságot). ${ }^{382}$ Meg kell még említeni, hogy az érdemi vizsgálatot mellőző, visszautasító döntéseket is kizártam a vizsgálat köréből, és csak azokat vontam be, amelyekben a Supreme Court érdemben foglalkozott az elé terjesztett kérdéssel.

\footnotetext{
${ }^{381}$ Vö. pl. Chicago v. Sturges, 222 U. S. 313 (1911).

${ }^{382}$ Vö. pl. Owensboro v. Cumberland Telephone \& Telegraph Co., 230 U. S. 58 (1913); Missouri Pacific Railway Co. v. Omaha, 235 U. S. 121 (1914).
} 
Végül szót kell ejteni arról, hogy a tagállami felsőbíróságok, legfelsőbb bíróságok, valamint a szövetségi fellebbviteli bíróságok vonatkozó döntéseivel szintén nem foglalkoztam. Tekintettel az ehhez kapcsolódó roppant anyagmennyiségre, valamint a források beszerezhetőségének nehézségére, úgy gondolom, ez a szükítés érthető.

Összességében tehát a Supreme Court mint az Egyesült Államok bírósági szervezetrendszerének csúcsszerve és az alkotmányos normakontroll terén messze kimagasló szerepet játszó testület azon, az indítványozók által felvetett alkotmányos kifogásokra érdemben reagáló döntéseire igyekeztem kiterjeszteni a vizsgálódást, amelyek tárgya olyan jogszabály - szövetségi, illetve tagállami törvény vagy önkormányzati rendelet -, amely a piac szabályozására irányul, általános rendelkezéseket tartalmaz, és amelyben az indítványozók az ötödik vagy a tizennegyedik alkotmánykiegészítés megfelelő eljárási klauzulájára, avagy a tizennegyedik alkotmánykiegészítés egyenlő törvényi védelmi klauzulájára ${ }^{383}$ hivatkozva kértek normakontrollt a testülettől.

A tartalmi oldalt tekintve négy tárgykörre szükítettem az elemzett döntésanyagot, mindegyik tárgykör valamilyen formában a piac müködésével és a szerződés, illetve a tulajdon szabadságával áll összefüggésben. Először foglalkoztam bizonyos nyilvánvalóan káros tevékenységek szabályozásával, ide mindenekelőtt a szeszesital forgalmazása tartozik, de egyéb tárgykörök is; ez a szakasz megfelelő áttekintést ad azokról a problémakörökről, amelyekre a korabeli közvélemény tradicionálisan úgy tekintett, mint ami aggálytalanul az állami szabályozás tárgya lehet. Ennek a tárgykörnek a kiemelése azért indokolt és hasznos, mert jó kontrasztot nyújt abban a tekintetben, hogy hogyan viszonyult az alkotmányértelmezési gyakorlat az olyan élethelyzetekhez és viszonyokhoz, amelyek esetében a közfelfogás szerint indokolt vagy érthető valamilyen tiltó, illetve korlátozó jogszabályi előírás a közjó érdekében. Tekintve, hogy a témakörben kiemelt figyelmet kapott Lochner-ügy „határesetnek” bizonyult a gazdasági tevékenység szabályozását érintő ügyekben, ez a minta jó képet ad arról, hogy milyen körben számított természetesnek az állami beavatkozás.

Másodszor foglalkoztam a foglalkozások gyakorlására való alkalmasság problémáját érintő szabályozással; ennek relevanciája abban határozható meg, hogy miként a Lochnerügy és a hasonszőrü, szociális-progresszív indíttatásból született jogszabályok alkotmányosságával foglalkozó döntések, az e tárgykörrel kapcsolatos döntések is a munkaviszonyhoz, munkaszerződéshez kötődnek, azok létesítésének, módosításának,

383 „No State shall ... deny to any person within its jurisdiction the equal protection of the laws.” 
megszüntetésének lehetséges korlátait feszegetik. Továbbá ez az esetcsoport is nyújt egy viszonyítási pontot azzal, hogy általa szemléltethető a munkaviszony „,személyi oldalának” egy aspektusa. Ez azért fontos, mert a Lochner-ítéletnek is volt egy személyi vonatkozása, amennyiben felmerült benne a kérdés, hogy nincs-e a törvén által indokolatlanul korlátozva bármely félnek a szerződési szabadsága. Ezzel az esetkörrel a munkaszerződésbe való belépés szabályozásának alkotmányossági megítélése szemléltethető.

Harmadszor foglalkoztam egy speciális kárfelelősségi alakzat, az ún. fellow servant rule $^{384}$ érvényesülését érintő döntésekkel. E tárgykör kapcsán megfigyelhető, hogy a jogalkotó tendenciózusan igyekszik visszaszorítani ennek az elvnek az érvényesülését azért, hogy a munkáltató a másik munkavállaló vétkességére való hivatkozással ne tagadhassa meg a kompenzációt a károsult munkavállalótól. Az ilyen szabályozás szociális indíttatása meglehetősen egyértelmü, továbbá ez esetben is annak lehetünk tanúi, hogy a jogalkotó a munkaviszony jól behatárolható aspektusára nézve alakít ki szabályokat. Ez az esetkör arra is rálátást nyújt, hogy a common law nagy tiszteletben tartott elöírásainak jogalkotói módosítására hogyan reagált a Supreme Court. A Lochner-ügyben tárgyalthoz hasonló szabályozás minden elterjedtsége mellett viszonylag újkeletű volt, és ez elmondható a common law-t érintő jogalkotói beavatkozásról is. Ezért ez a harmadik ügycsoport a testületnek az újfajta szabályozáshoz való viszonyáról is szélesebb képet nyújt.

Végül negyedszer áttekintem azokat a döntéseket, amelyek a munkakörülményeket valamilyen formában szabályozó jogszabályokat érintenek. A Lochner-ítélet kétségkívül ebbe a kategóriába esik, ezért kézenfekvő, sőt, elkerülhetetlen volt a leginkább hasonló tárgyú jogszabályokat érintő egyéb döntéseket is megvizsgálni.

Összességében tehát a bemutatott négy kategória olyan szabályozási tárgyköröket ölel fel, amelyek alkotmányossági megítélésének bemutatásával közelebb kerülhetünk ahhoz, hogy átlássuk a Lochner-ítélet precedenskontextusát, és ezek áttekintésével körültekintőbb ítéletet alkothatunk arról, hogy ez a konkrét döntés mennyiben tér el a környezetétől. A mintaválasztásból látható, hogy az egyes ügycsoportokban meglehetősen hasonló tárgyú esetek találhatók. Ezek elbírálásának áttekintésével nyomon követhető az, hogy változott-e egy adott ügytípus megítélése az idők során. Ez az aspektus fontos a jelen vizsgálódás esetében, mert a Lochner-ügyhöz hasonló esetekben - amint az a IV.3.

\footnotetext{
${ }^{384}$ Ennek az elvnek az a lényege, hogy a munkahelyen a munkavállalót a munkavégzéssel összefüggésben érő károsodás esetén a munkáltató mentesül a felelősség alól, amennyiben bizonyítható, hogy a károsodás bekövetkezése valamely másik munkavállaló gondatlan magatartásának következménye.
} 
szakaszban kifejtettek alapján megfigyelhető lesz - több alkalommal előfordult, hogy a hasonló alkotmányossági kérdések rövid időközön belül eltérő megítélést nyertek.

\section{IV.2. A Supreme Court alkotmányértelmezési gyakorlatának releváns kulcsfogalmai}

\section{IV.2.1. A megfelelö eljárás fogalmának értelmezése}

A megfelelő eljárás követelménye egészen az 1215-ös Magna Chartáig visszavezethető, és az angol jog egyik alappillére lévén utat talált magának az Egyesült Államok alkotmányába is: mind az ötödik, mind a tizennegyedik alkotmánykiegészítésben megtalálható, ráadásul a kifejezés szük kontextusa mindkét rendelkezésben azonos. A kifejezés értelmét először az ötödik alkotmánykiegészítés vonatkozásában határozta meg a Supreme Court. ${ }^{385}$ Értelmezésének változásai szorosan összekapcsolódnak a testület konzervatív elhajlását felhánytorgató kritikákkal. Ez azzal magyarázható, hogy a megfelelő eljárást a Supreme Court már a XIX. századtól kezdődően lényegében kétféleképpen értelmezte. Az első értelmezést nevezhetjük a kifejezés formális vagy eljárási értelmezésének. Eszerint egy alapjogkorlátozó rendelkezés megfelel az alkotmánynak, ha bizonyos eljárási garanciák érvényesülnek. A Supreme Court rendszerint két követelményt nevesített ezzel összefüggésben: egyrészt az eljárás érintettjének szabályszerü idézést kell kapnia (notice), másrészt pedig lehetőséget kell biztosítani számára, hogy előadja saját érveit, illetve előterjessze bizonyítékait (hearing). Általában ha ez a két feltétel teljesült, a Supreme Court nem állított fel további követelményeket. Így például nem értékelte alkotmánysértőnek, ha az adott eljárási jogszabály nem biztosítja a többszöri meghallgatást vagy a jogorvoslat lehetőségét, ${ }^{386}$ emellett nem támasztott különösebb kritériumokat az eljáró fórum jellegével szemben sem: ha az említett két követelmény teljesült, az indítványozók az alkotmány alapján nem kifogásolhatták, ha nem bíróság, hanem egyéb szerv jár el ügyükben. ${ }^{387}$

\footnotetext{
${ }^{385}$ Vö. Murray's Lessee v. Hoboken Land \& Improvement Co., 59 U.S. 272 (1855)

${ }^{386}$ Vö. pl. Pittsburgh, Cincinnati, Chicago and St. Louis Railway Co. v. Backus, 154 U. S. 421, 427 (1894)

${ }^{387}$ Vö. pl. Lawton v. Steele, 152 U. S. 133, 141 (1894), Reetz v. Michigan, 188 U. S. 505, 507 (1903), Public Clearing House v. Coyne, 194 U. S. 497, 508-509 (1904)
} 
A megfelelő eljárás szubsztantív értelmezése (substantive due process) a személyeket megillető elidegeníthetetlen jogokra fókuszál. Ennek értelmében az alapjogok korlátozása egy, lényegében az általunk is ismert szükségesség-arányosság tesztnek megfelelő tartalmi szürőn kell, hogy átessen: a korlátozás csak legitim cél által indokolható, és alkalmasnak kell lennie a cél elérésére. A kulcsszó az ésszerűség volt: a cél legitimitását az adta, hogy a jogalkotó egy valós problémára keresett olyan megoldást, ami a problémával ésszerü kapcsolatban állt.

A megfelelö eljárás ezen értelmezését a kései szakirodalom nem egyszer kifejezetten a Lochner-korszakkal társítja, ${ }^{388}$ és azt lehet mondani, hogy a tizennegyedik alkotmánykiegészítés elfogadása után élte „virágkorát”. Ugyanakkor érdemes utalni rá, hogy alkalmazása már a tizennegyedik alkotmánykiegészítés előtt is tetten érhető. Egyes kutatók szerint a formális mellett a szubsztantív értelmezés is részét képezhette a jogi gondolkodásnak már az új köztársaság korai éveiben. Robert E. Riggs szerint a szubsztantív értelmezés helyenként az angol jogi értekezésekben is körvonalazódott, és ez az amerikai gyakorlatban is éreztette hatását. ${ }^{389}$ Más kutatók arra mutatnak rá, hogy a megfelelő eljárás tartalmi értelmezésének egyik korai megnyilvánulása figyelhető meg az 1857-ben meghozott Dred Scott v. Sandford-döntésben. ${ }^{390}$ A döntést ma már egyként sorolja az Egyesült Államok jogtörténetének fekete lapjaira az akadémikus közvélemény: az eldöntendő kérdés az volt, elnyeri-e szabadságát az a színesbőrű rabszolga, aki olyan területre lép, ahol nem létezik a rabszolgaság intézménye. Roger B. Taney, a Supreme Court akkori elnöke, egyben az ügy előadó bírája úgy fogalmazott, nem, a rabszolga ugyanis dolog, és mint ilyen, tulajdonjog tárgya akkor is, ha tulajdonosa - akit megillet a tulajdonhoz való alkotmányos jog - a rabszolgaságot el nem ismerő területre lép. ${ }^{391}$ A testület ennek következtében alkotmányellenessé nyilvánította az ún. Missouri

\footnotetext{
${ }^{388}$ Vö. pl. Chemerinsky, Erwin: Substantive Due Process. In Touro Law Review, Vol. 15, 1999, 1509. o.

${ }^{389}$ Riggs, Robert E.: Substantive Due Process in 1791. In Wisconsin Law Review, 1990, különösen 973 984.,valamint 995-999. o.

39060 U. S. 393. Az állitáshoz lásd Sunstein, Cass R.: Constitutional Myth-Making: Lessons from the Dred Scott Case. In Occasional Papers of the Law School of the University of Chicago, Vol. 37, 1996, 2. o.; valamint Balkin, Jack M. - Levinson, Sanford: Thirteen Ways of Looking at Dred Scott. In Chicago-Kent Law Review, Vol. 82, 2007, 73. o.

${ }^{391} 60$ U. S. 450-451. Manapság a döntést, eredményére tekintettel, kivétel nélkül elítélik a szakmában, de a technikai érveknél talán még inkább ellenkezik a korszellemmel az indokolás első fele, melyben Taney mintegy szociológiai tényként rögzíti, hogy a színesbörủeket az Egyesült Államokban másodrendü polgárként ismerik el, és az alkotmány szövegéből, az alkotmányozók eredeti szándékából, valamint egyes, a faji megkülönböztetést nyíltan alkalmazó jogszabályokból azt vezeti le, hogy az amerikai nép soha nem is kívánta öket egyenrangú állampolgárként elismerni. A késő XX. századi amerikai jogtudományi vitákban a döntés az originalizmus kritikusainak ,aduásza” lett, hiszen elrettentő példaként hozhatták fel, hogy az alkotmányozók eredeti szándékának komolyan vétele a színesbőrüek alávetettségét legitimálja. Ezzel szemben az originalisták természetesen nem győznek elhatárolódni a döntéstöl, és demonstrálni, hogy egy ilyen ítélet nem hozható összhangba alkotmányértelmezési elképzeléseikkel.
} 
Kompromisszumot, amely az Egyesült Államok nyugati territóriumainak egyes életviszonyait rendezte, és egyebek között a jogszabályban kijelölt határvonaltól északra eső territóriumokon tiltotta a rabszolgaságot. ${ }^{392}$ Vagyis a Supreme Court a tulajdonhoz való jogot mint önmagában álló alkotmányos alapjogot védte meg, nem a korlátozásával együtt járó eljárást vette górcső alá.

Míg a XIX. század második felében a szubsztantív értelmezés csak ritkán jellemezte a Supreme Court gyakorlatát, a korabeli szakirodalom alapján a XX. század első évtizedeire a megfelelő eljárás szubsztantív értelmezése éppúgy részét képezte az alkotmányjogi gyakorlatnak, mint a formális. ${ }^{393} \mathrm{Ez}$ mutatkozott meg a piaci folyamatok szabályozására irányuló jogszabályi rendelkezésekben is. A szubsztantív értelmezés később, miután a Supreme Court kifejezetten önmegtartóztató álláspontot vett fel a gazdasági élet szabályozására irányuló jogszabályok alkotmányosságának megítélése kapcsán, a polgári szabadságjogok kiterjesztő értelmezésében kapott fontos szerepet. A testület XX. század második felében folytatott tevékenységének kritikusai nem is mulasztják el, hogy rámutassanak az alkotmányértelmezés szubsztantív jellegére. ${ }^{394}$

\section{IV.2.2. A police power}

A nehezen magyarítható police power kifejezés a tagállamok jogalkotó hatalmát jelöli. Roger B. Taney 1847-es, sokat idézett meghatározása szerint ez nem egyéb, mint „a kormányzás hatalma, mely a saját területén minden szuverén természetes része. Akár karanténtörvényt alkot a tagállam, akár büntető rendelkezést, akár bíróságokat hoz létre, akár bizonyos adatok jegyzőkönyvbe vételét rendeli el, akár a kereskedelmet szabályozza a határain belül, mindegyik esetben egyazon hatalmat gyakorolja: nevezetesen a szuverén hatalmát, azon hatalmat, hogy saját területén rendelkezzék a személyek és a dolgok felett. E hatalomból eredően alkot törvényt, a kereskedelem szabályozására irányuló hatásköre

\footnotetext{
39260 U. S. 452

${ }^{393}$ Vö. pl. McGehee, Lucius Polk.: Due Process of Law under the Federal Constituiton. Edward Thompson Company, Northport, 1906, 73-84., valamint 138-145. o.; továbbá Taylor, Hannis: Due Process of Law and the Equal Protection of the Laws, Callaghan and Company, Chicago, 1917, 286-297., valamint 403-404. o.

${ }^{394}$ Vö. pl. Epstein 1973: 180. o. Megjegyezhető, hogy már a XX. század első harmadából is akad példa a polgári szabadságjogok kiterjesztő értelmezésére. Vö. pl. Meyer v. Nebraska, 262 U. S. 390 (1923). Ebben az ügyben az előadó James McReynolds bíró alkotmányellenesnek ítélte a tagállami törvényt, amely tiltotta az angolon kívül más nyelv oktatását. Álláspontját azzal indokolta, hogy a tizennegyedik alkotmánykiegészítésben szereplö szabadság fogalma túlmutat a puszta testi szabadságon, és számos egyéb helyzetben való döntési szabadságot foglal magába.
} 
pedig éppoly kizárólagos, mint az egészségügyi törvények alkotására irányuló hatalma, $\mathrm{s}$ ennek csupán az Egyesült Államok Alkotmánya szabhat gátat." ${ }^{395}$ Ennél pontosabb megfogalmazással nem találkozhatunk, a Supreme Court jellemzően tartózkodott a kifejezés pontos, aprólékos definiálásától, inkább az esetről esetre való körülírást preferálta. A szakirodalom a gyakorlatból azt emelte ki, hogy a tagállamoknak hatalmukban áll minden olyan jogszabály megalkotása, amellyel a biztonságos és gördülékeny együttélést segítik elő a társadalomban. Taylor a Barbier v. Connolly-ügyet ${ }^{396}$ idézve mutat rá arra, hogy e hatalom birtokában a tagállamok szabályozás útján előmozdíthatják az emberek egészségét, nyugalmát, erkölcseit, müveltségét, a helyes rendet, emellett bővíthetik iparukat, erőforrásaikat, fokozhatják bőségüket, jólétüket. ${ }^{397}$ McGehee különbséget tesz a kifejezés szükebb és tágabb értelme között, az előbbi a rend, nyugalom, egészség, erkölcs, biztonság védelmét öleli fel, az utóbbi a társadalom gazdasági és intellektuális jólétének elősegítését is. ${ }^{398}$ Összességében azt lehet mondani, hogy a fogalom a jogalkotó mérlegelési szabadságának egy meghatározott aspektusát jelöli, azon esetek összességét, amikor valamilyen társadalmi probléma indokolttá teszi a jogalkotó alapjog-korlátozó cselekvését. Felvetődhet a kérdés, vajon ez alatt az indokoltság alatt kifejezetten kényszerítő indokok felmerülését kell-e érteni, avagy pusztán a probléma és a rá adott válasz között fennálló ésszerü összefüggést. Meglátásom szerint - amit remélhetőleg az alább részletesen ismertetett precedensanyag is alátámaszt - a jelen értekezésben vizsgált gyakorlat az utóbbi felfogást tükrözi.

\section{IV.3. A Supreme Court releváns gyakorlatának jellemzése}

\section{IV.3.1. Altalános észrevételek}

\footnotetext{
395, ,T]he powers of government inherent in every sovereignty to the extent of its dominions. And whether a state passes a quarantine law, or a law to punish offenses, or to establish courts of justice, or requiring certain instruments to be recorded, or to regulate commerce within its own limits, in every case it exercises the same powers -- that is to say, the power of sovereignty, the power to govern men and things within the limits of its dominion. It is by virtue of this power that it legislates, and its authority to make regulations of commerce is as absolute as its power to pass health laws except insofar as it has been restricted by the Constitution of the United States." Licence Cases, 46 U. S. (5 How.) 504, 583 (1847)

${ }^{396} 113$ U. S. 27

${ }^{397}$ Taylor: i. m. 398. o.

${ }^{398}$ McGehee: i. m. 301. o.
} 
A II. fejezetben az aktivizmusnak két meghatározó ismérvét különítettem el: a jogalkotó döntéseinek szisztematikus alkotmányellenessé nyilvánítását, valamint az indokolásokban fellelhető, illetve - közvetlenül vagy közvetetten - visszatérő jelleggel alkalmazott kiterjesztő alkotmányértelmezést. Ezen kívül különbséget tettem az aktivizmus, illetve a passzivizmus „tudományos” és „dogmatikus” válfaja között. A továbbiakban ezt a fogalmi keretet alkalmazom a Supreme Court 1890 és 1937 közötti gyakorlatára. A vizsgálódást a következőképpen végzem el. Mindenekelőtt áttekintő jelleggel ismertetem, hogy a IV.1. szakaszban bemutatott szempontok alapján kiválasztott ügyek közül a testület mennyiben találta alkotmányosnak, és mennyiben alkotmányellenesnek a támadott rendelkezést. Ezt követően egyes ügycsoportok elbírálási szempontjainak részletes kifejtésére kerül sor.

A részletes vizsgálódás során négy olyan ügycsoportot veszek alaposan górcső alá, amelyek elemzésével megítélésem szerint reprezentatívan érzékeltethetők a Supreme Court gyakorlatának tendenciái. Ezt a négy ügycsoportot tárgyuk alapján választottam ki. Valamilyen formában mindegyikük tárgya egy olyan jogszabály alkotmányossága, amely a gazdaság müködését korlátozza. Bizonyos tevékenységek szabályozását, korlátozását a korszellem magától értetődőnek tartotta. A szeszforgalmazás szabályozásának, sőt, tiltásának kérdése az erre szolgáló legeklatánsabb példa, de más termékek forgalmazásának szabályozása is sokszor hasonló megítélés alá esett, mi több, egyes esetekben a Supreme Court úgy nyilatkozott, hogy a szabályozás egyenesen kötelessége a jogalkotónak. ${ }^{399}$ Emellett e körbe sorolhatók bizonyos egyéb, veszélyesnek ítélt szórakozási formák korlátozásával kapcsolatos döntések is. Kézenfekvő, hogy a Supreme Court teljesen egyhangú döntéseket hozott e kérdéskörökben. Más esetkörökben nem alakulhatott ki az eligazodást segítő konszenzus. A munkaviszony valamiféle szabályozására irányuló jogszabályok látszólag ide tartoznak, hiszen a rendszeres munkaviszony viszonylag újkeletű jelenség volt a századfordulón. Első ránézésre azt lehetne várni, hogy ezen esetekben komoly nézetkülönbségek mutatkoznak a Supreme Court tagjai között. Ennek ellenére csak az esetek csekély hányadában lehet ilyesmit megfigyelni.

Az első csoportban érintett elöírások bizonyos károsnak tartott termékek forgalmát, tevékenységek folytatását szabályozzák. A második csoportban érintett rendelkezések bizonyos foglalkozások gyakorlását kötik valamilyen kritériumhoz. E két csoport közös vonása, hogy olyan tárgykört érintenek, amelyeknél az állami szabályozás lehetőségét

\footnotetext{
${ }^{399}$ Vö. pl. Williams v. Walsh, 222 U. S. 415, 424 (1912). A konkrét ügy tárgya a puskapor forgalmazásának szabályozása volt.
} 
magától értetődőnek tekintették. Ezek az ügyek jól illeszkednek abba a sémába, amely szerint valamely alapjogkorlátozás alkotmányosságának előfeltétele bizonyos véges számú cékitűzések követése - jellemzően ilyen cél a közerkölcs, a közegészség, a „közjólét”, a közbiztonság -; a szóban forgó esetek többnyire a közegészséggel állnak összefüggésben. Ismertetésük azért is szükséges, mert ezáltal képet kaphatunk arról, milyen viszonyokban tartották hagyományosan indokolhatónak, sőt, kívánatosnak az állami beavatkozást, és így a Lochner-ítélet, illetve a hozzá kapcsolt bírói attitűd átfogóbb kontextusban válik értelmezhetővé.

A második két ügycsoportot azok az esetek alkotják, amelyek kifejezetten munkajogi vonatkozásúak. Az előző két csoport által nyújtott szélesebb kontextus mellett értelemszerüen szükséges az is, hogy sor kerüljön a tárgyukban a Lochner-üggyel rokonítható döntések elemzésére. A második két ügycsoport vizsgálatával ezt a feladatot teljesítem. Ezek közül az első halmazt egy speciális norma alkotja: a common law-ban fellow servant rule-ként ismert szabály, illetve az azt hatályon kívül helyezö törvényi elöírások. Ez a tárgykör azért releváns, mert itt a jogalkotó tudatosan igyekszik kiiktatni egy olyan szabályt, amely - bár viszonylag friss kialakulású - abban a korban szerves részét képezte az angolszász jogrendszernek. Végül pedig a negyedik ügycsoportba a Lochner-üggyel leginkább rokonítható ügyek tartoznak: azok, amelyekben az indítványozó a munkaszerződés tartalmát korlátozó - valamilyen módon a munkakörülményekre vonatkozó - jogszabályi elöírásokat támad meg.

\section{IV.3.2. „Konzervatív aktivizmus” a pöre számok tükrében}

A puszta számok alapján a következő mondható el. A 114 vizsgált ügyből 100 elutasítással végződött, és a Supreme Court a maradék 13-ban állapította meg, hogy a támadott törvény ellentétes az alkotmány hivatkozott rendelkezéseivel. Ebből az állapítható meg, hogy a testület a vizsgálódás tárgyául szolgáló 46 éves intervallumban, a jelen értekezésben elemzett ügyekben körülbelül ötször annyi esetben ítélte a jogalkotó döntését alkotmányosnak, mint ahányszor alkotmányellenesnek. Ezek a számok azonban önmagukban keveset mondanak az ügyek természetéről, valamint az indokolásokban figyelembe vett szempontokról, ismertetésük pusztán a részletekbe menő fejtegetések felvezetéseként szolgálhat. 


\section{IV.3.3. „Magától értetődo” szabályozási tárgyak: szeszesital-forgalmazás és egyéb „nyilvánvalóan káros” tevékenységek}

A testület korán lefektette, hogy a tagállam mérlegelési szabadsága vitathatatlanul magában foglalja az alkoholtartalmú italok kereskedelmének megregulázását, egyúttal azt is megállapította, hogy a szeszesitalok készítésének és forgalmazásának joga nem tartozik az Egyesült Államok polgárának állampolgárságából fakadó, a tizennegyedik alkotmánykiegészítés által védett jogok közé. A vizsgált időszakban a legkorábbi ilyen eset az 1890-ben elbírált Crowley v. Christensen, ${ }^{400}$ amelyben a testület egy san franciscói önkormányzati rendelet alkotmányosságát vizsgálta, melynek értelmében a kiskereskedők csak akkor kaphatnak engedélyt szeszesital fogalmazására, ha egy e célból létrehozott bizottság többsége beleegyezik. A döntés indokolásában Field bíró a sic utere tuo... maximájából vezette le a tagállamok azon jogosítványát, hogy a különböző foglalkozásokat ésszerü módon, a fentebb a police power kapcsán említett „legitim célok” elérése érdekében szabályozzák. Megítélése szerint a szeszesitalok fogyasztása nem csupán a fogyasztóra lehet káros hatással, de környezetére is, ebböl következően indokolt lehet, hogy a tagállamok korlátozzák forgalmazásukat. Egyúttal azt is megjegyzi, hogy a szabályozás a legváltozatosabb formákat öltheti: meghatározható a lehetséges vásárlók köre vagy az üzletek nyitvatartási ideje, de a teljes tiltás sem zárható ki. ${ }^{401}$

Ugyanezeket az alapvetéseket rögzítette a Supreme Court három évvel később, a Giozza v. Tiernan-döntésben. ${ }^{402}$ Ebben az ügyben azt vizsgálta a testület, alkotmányos-e a szeszesitalt forgalmazó személyekre kivetett különadó. Az igenlő választ roppant rövid indokolással támasztotta alá az előadó Fuller bíró, aki az alapjogjogkorlátozó tagállami jogalkotás megengedett céljainak felsorolása után megállapítja, hogy sem a megfelelő eljárást, sem az egyenlő törvényi védelmet előíró klauzulák nem sérültek. ${ }^{403}$ Ami az előbbit illeti, ennek kapcsán megállapítja, hogy a törvén mindenkire egyformán vonatkozik, és az egyén nincs kiszolgáltatva az önkényes hatalomgyakorlásnak. Az utóbbi vonatkozásában

\footnotetext{
${ }^{400} 137$ U. S. 86

401137 U. S. 91

402148 U. S. 657 (1893). A két döntés között, 1891-ben a Supreme Court elbírálta az In re Rahrer-ügyet, mely szintén a szeszesital-forgalmazással áll összefüggésben, itt azonban a fô kérdés az volt, megfelel-e a kereskedelmi klauzulának a Wagner Act, melyben a Kongresszus kifejezetten felhatalmazta a tagállamokat arra, hogy saját területükön szabályozzák az importált szeszesitalok forgalmazását. A testületnek tehát itt kifejezetten hatásköri kérdést kellett megválaszolnia ebben a jogvitában. Vö. 140 U. S. 545.

403 148 U. S. 662
} 
arra érdemes felhívni a figyelmet, hogy a testület a tagállami adóztatási szabadság iránti tipikusan megengedő attitűdöt tanúsítja: kimondja, hogy az egyenlő törvényi védelem klauzulája nem törekszik az egyenlöség valamiféle „vastörvényének” (iron rule of equality) kikényszerítésére, ellenkezőleg, a tagállamok szabadon osztályozhatják a vagyontárgyakat az adóztatás szempontjából. A vitatott törvény a „kettős természetü” jogszabályok körébe sorolható: egyfelöl adójellegű, másfelől azonban társadalompolitikai célok előmozdítására irányul. Ezzel összhangban áll, hogy alkotmányossága is kettős alapon nyugszik: egyrészt legitim célra irányul, másrészt azonban némileg absztraktabb síkon a széleskörü adóztatási szabadság is a jogszabály érintetlenül hagyását indokolja.

A kérdéskörhöz kapcsolódó többi döntés részben csak egy-két oldalas ismétlése az eddig elmondottaknak, ${ }^{404}$ részben egyes részletkérdések tisztázása a rögzített alapvetések elfogadása mellett. Érdemes kiemelni az Ohio ex rel. Lloyd v. Dollison-esetet, ${ }^{405}$ melynek tárgya egy tagállami törvény, amely felhatalmazza a helyi önkormányzatokat, hogy tetszésük szerint szabályozzák a szeszesitalok kereskedelmét. A törvényt a Supreme Court egyhangúlag alkotmányosnak találta, és az indokolás tartalmaz egy bírói önmérsékletre utaló fordulatot, nevezetesen azt, hogy a testület a kevésbé nyilvánvaló törvényi megkülönböztetéseket sem bírálja felül. ${ }^{406}$ Egy másik döntés, a Purity Extract and Tonic Co. v. Lynch $^{407}$ indokolásában a testület az a tételt erősíti meg a szeszesital-forgalmazással összefüggésben, hogy a legitim cél érvényesítése érdekében a tagállam tilthatja az önmagukban veszélytelen termékek kereskedelmét is ${ }^{408}$ - a konkrét ügyben a tagállam a szeszesitalok árusítását tiltotta meg, s e tilalom alá esett egy csekély malátatartalmú termék.

A Cox v. Texas-eset ${ }^{409}$ arról tanúskodik, hogy a tagállamok szabályozási szabadságának tiszteletben tartása előnyt élvez egyéb esetleges alkotmányos aggályokkal szemben. A konkrét ügyben az indítványozó a tizennegyedik alkotmánykiegészítés egyenlő törvényi védelmi klauzulájára hivatkozva támadott meg egy tagállami törvényt, amely kivonta az adózás alól azokat a termelöi borokat, amelyeket a tagállam területén termesztett szőlőből készítettek. Az előadó bíró, Holmes precedenshivatkozások nélkül állapítja meg, hogy a tagállamokat nem korlátozzák alkotmányos akadályok, ha elő

\footnotetext{
${ }^{404}$ Lásd: Cronin v. Adams, 192 U. S. 108 (1904), Cronin v. Denver, 192 U. S. 115 (1904), Rippey v. Texas, 193 U. S. 504 (1904), Thompson v. Kentucky, 209 U. S. 340 (1908), valamint Eberle v. Michigan, 232 U. S. 700 (1914).

405 194 U. S. $445(1904)$

406194 U. S. 448

${ }^{407} 226$ U. S. 192 (1912)

408226 U. S. 201-202

409202 U. S. 446 (1906)
} 
kívánják mozdítani a hazai termelést, vagy óvni akarják a borok tisztaságát. ${ }^{410}$ Álláspontja szerint nincs szó az indítványozó által hangoztatott, a különféle alkoholtartalmú italok forgalmazói közötti megkülönböztetésről, mivel nincs olyan, hogy egyes eladók kizárólag házi készítésű bort árulnak, mások pedig egyéb szeszesitalokat. ${ }^{411}$ Ezt a nézetet Harlan bíró vitatta egy bekezdésnyi különvéleményben, szerinte ugyanis a jogalkotó különböző csoportok között alkalmazott indokolatlan megkülönböztetést. ${ }^{412}$

Ugyancsak véleménykülönbség sejlik fel a Clark Distilling Co. v. Western Maryland Railway Co. and State of West Virginia-ügyben. ${ }^{413}$ Itt egy többszintü szabályozás alkotmányosságával foglalkozott a Supreme Court. Egyrészt West Virginia megtiltotta a bódító hatású italok behozatalát, másrészt ennek a jogszabálynak egy kongresszusi törvény, a Webb-Kenyon Act szerzett érvényt. Az indítványozó mind a két jogszabályt támadta a tizennegyedik, illetve az ötödik alkotmánykiegészítés kapcsán, a Supreme Court pedig mindkét esetben elutasította az indítványokat. Álláspontja szerint ,[n]incs helye vitának a tekintetben, hogy a [tagállami] kormányzat a megfelelő eljárás követelményének megfelelően tilthatja a szeszesitalok előállítását és eladását, valamint szabályozhatja azok kereskedelmét; s ugyancsak vitathatatlan, hogy e hatalommal együtt jár az annak érvényesítésére irányuló korlátlan hatáskör is". ${ }^{414}$ Ami pedig a Kongresszus szabályozási szabadságát illeti, a testület a tizennegyedik alkotmánykiegészítés alapján elmondottakat ebben az összefüggésben is irányadónak tartja, ${ }^{415}$ emellett kifejtette, hogy mivel a törvény rendelkezései egyformán vonatkoznak minden tagállamra, ezért nem támasztható velük szemben az alkotmányra alapozott kifogás. ${ }^{416}$ A többségi döntéssel szemben két bíró foglalt állást, ők azonban indokolás csatolása nélkül jelezték ellenkezésüket.

Az ezt követő néhány esetben a megfelelő eljárás követelménye jelentéktelenné válik, hiszen 1919-ben hatályba lépett a szesztilalomról rendelkező tizennyolcadik alkotmánykiegészítés, amellyel a szeszesitalok forgalmazásának tilalma alkotmányos szintre emelkedett. ${ }^{417}$ Ezután már csak a Van Oster v. Kansas-ügy ${ }^{418}$ emelendő ki,

\footnotetext{
410202 U. S. 451

411202 U. S. 450

412202 U. S. 452. A különvéleményhez Brewer és Brown bírók is csatlakoztak.

413242 U. S. 311 (1917)

414 ,That government can, consistently with the due process clause, forbid the manufacture and sale of liquor and regulate its traffic, is not open to controversy; and that there goes along with this power full police authority to make it effective, is also not open." 242 U. S. 320

${ }^{415} 242$ U. S. 332

416242 U. S. 327

${ }^{417}$ Ezt tükrözi például a Corneli v. Moore-ügy, amelynek indokolásában a megfelelő eljárás követelménye csak a legutolsó oldalon kerül elő néhány mondat erejéig. Vö. 257 U. S. 491, 498 (1922). A Supreme Court
} 
amelyben a Supreme Court az állapította meg, hogy a tagállam alkotmányosan kobozhatja el a jogellenes célra - a jelen esetben szeszesital szállítására - használt személygépkocsit. Mint az indokolásban áll, ,a dolgok bizonyos fajta felhasználása annyira nemkívánatosnak tekinthető, hogy tulajdonosuk csak saját kockázatára bocsáthatja őket mások rendelkezésére. Ily módon a jog másodlagos védelmet hoz létre a tiltott használat ellen, és kiküszöböli a visszaélésszerü joggyakorlást azáltal, hogy megszünteti a jogellenesen cselekvő, valamint az állítólagosan vétlen tulajdonos közötti összefonódással kapcsolatos bírói vizsgálódás szükségességét". ${ }^{419}$ A Supreme Court itt kiterjeszti a társadalmilag káros tevékenységek megengedhetőségére vonatkozó doktrínáját a tiltott cselekmény eszközéül használt idegen dolgokra, és azt lehet mondani, hogy az egyéni érdekeket újabb vonatkozásban rendeli a közösség érdekei alá.

Az egyéb károsnak tartott tevékenységek közül kiemelkednek a különféle szerencsejátékok. Az 1903-ban elbírált Lottery Case $^{420}$ az első a vizsgált időszakban, amely az efféle tevékenységek szabályozásának alkotmányosságát vizsgálja. Első ránézésre úgy tünhet, az eset cáfolja a tárgykör szabályozásának vitathatatlanságáról fentebb kifejtett elképzelést, az alábbiakban azonban kiderül, hogy ez az ellentmondás csak látszólagos.

$\mathrm{Az}$ indítványozó egy kongresszusi törvényt támadott, amely egyebek mellett a lottószelvények tagállamok közötti szállítását rendelte büntetni; indítványát a kereskedelmi klauzulára, ${ }^{421}$ valamint a megfelelő eljárás követelményére, alapozta arra hivatkozással, hogy a lottószelvények önmagukban nem rendelkeznek vagyoni értékkel, ezért kereskedelmi forgalom tárgyai sem lehetnek, s így egyrészt a kereskedelmi klauzula által biztosított felhatalmazás a lottószelvények szállítására nem terjed ki, másrészt e szabályozás révén az indítványozót megfelelő eljárás nélkül fosztották meg szerződési szabadságától. A Supreme Court többsége nem fogadta el ezt az érvelést. A John Marshall Harlan által megfogalmazott indokolás kiindulópontja az, hogy az alkotmány nem

azt is egyértelmüsítette, hogy a tizennyolcadik alkotmánykiegészítésben foglalt tilalmak a hatálybalépését megelözően létrejött jogviszonyokra is kiterjednek. Vö. National Prohibition Cases, 253 U.S. 350 (1920). 418272 U. S. 465 (1926)

419 ,[C]ertain uses of property may be regarded as so undesirable that the owner surrenders his control at his peril. The law thus builds a secondary defense against a forbidden use and precludes evasions by dispensing with the necessity of judicial inquiry as to collusion between the wrongdoer and the alleged innocent owner." 272 U. S. 467-468

${ }^{420} 188$ U. S. 321

${ }^{421}$ Az ún. „kereskedelmi klauzula“ (Commerce Clause) a következőképpen hangzik: “[A Kongresszus jogosult] az idegen nemzetekkel történő, az államok egymás közötti, valamint az indián törzsekkel történő kereskedelem szabályozására[.]” (,[The Congress shall have power] to regulate commerce with foreign nations, and among the several states, and with the Indian tribes[.]") 
határozza meg a kereskedelem fogalmát. Harlan gondolatmenete szerint azonban az kétségbevonhatatlan, hogy a vagyoni értékkel bíró dolgok szállítása annak minősül, ebből pedig kikövetkeztethető, hogy azon szelvények szállítása is kereskedelemnek tekinthető, amelyek birtokosukat meghatározott összegü pénz követelésére jogosítják fel. ${ }^{422} \mathrm{~A}$ lottószelvények árucikk-jellegét támasztja alá az is, hogy adott esetben adásvétel tárgyai lehetnek. ${ }^{423} \mathrm{Az}$ indokolásban feltüntetett precedensek sokaságából és az alkotmány szükszavú megfogalmazásából is arra lehet következtetni, hogy a Kongresszus komoly diszkrécióval rendelkezik a tagállamok közötti kereskedelem szabályozása terén, erre tekintettel a lottószelvények szállításának tiltása sem zárható ki ebböl a körből. A tagállamok részére biztosított szabályozási jogosítványokat szemügyre véve Harlan úgy vélte, hogy ha azok széles körben alkothatnak szabályokat a saját határaikon belül folyó gazdasági tevékenység tekintetében, akkor a tagállamok közötti tevékenység szabályozása kapcsán éppoly széles mérlegelési szabadság illeti meg a Kongresszust. ${ }^{424}$ Egyúttal azt is leszögezi, hogy alaptalan az indítványozó azon érve, miszerint a Kongresszus visszaélhet e széles hatáskörével, a visszaélés absztrakt lehetősége ugyanis önmagában nem érv valamely hatáskör gyakorlásának alkotmányosságával szemben. ${ }^{425}$

A tény, hogy összesen négy bíró jelezte ellenérzését a többségi indokolással szemben, azt mutatja, hogy olykor a látszólag könnyű esetek is nehézzé válhatnak. A konkrét ügyben Melville Fuller, a Supreme Court akkori elnöke fogalmazott meg különvéleményt, melyhez három kollégája csatlakozott. ${ }^{426}$ Ebben egyrészt kifogásolta, hogy a többség szerint a Kongresszust a saját hatáskörében - a tagállamok közötti kereskedelem szabályozásában - éppúgy megilleti a police power, mint a tagállamokat a magukéban - vagyis a saját területükön folyó kereskedelem szabályozásában. Álláspontja szerint ez ellentétes a tizedik alkotmánykiegészítés előírásával. ${ }^{427}$ A szóban forgó állításból ugyanis az következne, hogy a Kongresszus bizonyos „,bennrejlo”, az alkotmány által kifejezetten nem biztosított hatáskörökkel is rendelkezik, márpedig a tizedik alkotmánykiegészítés értelmében az ilyen hatáskörök a tagállamokat vagy a népet illetik. ${ }^{428}$ Fuller egyúttal vitatja azt is, hogy a lottószelvény árucikknek minősülne: ennek kapcsán arra mutat rá, hogy a Supreme Court más esetben, a biztosítási szerződések kapcsán már

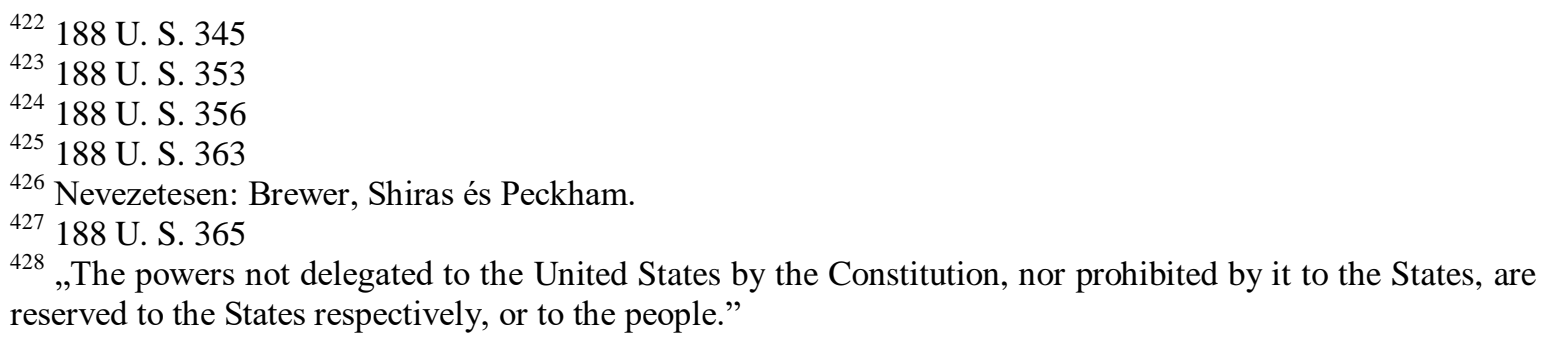


kimondta, hogy azok nem árucikkek, a szerződéseket ugyanis a felek a tagállam területén, a tagállami jognak megfelelően írják alá; az okirat esetleges átszállítása egyik tagállamból a másikba nem abból a célból történik, hogy azokat eladják. ${ }^{429}$

Az ítélet kapcsán a következőkre érdemes felhívni a figyelmet. Először is annak ellenére, hogy a Supreme Court 5:4 arányban hozta meg döntését, ez a megosztottság nem a szabályozási tárgy szabályozhatóságának kérdése körül forog, legalábbis nem abban az értelemben, ahogyan az a jelen tanulmányban értendő. A különvéleményben sehol nincs állásfoglalás a tekintetben, hogy a lottószelvények forgalmazása nem lehet káros a társadalomra nézve, és tiltásának nincs semmiféle alkotmányos indoka. Meglátásom szerint ezt támasztja alá az is, hogy a különvélemény szerzője nem állít olyasmit, hogy a többségi döntés a szerződési szabadság alkotmányos jogát sértené. A vita középpontjában a Kongresszus hatáskörének természete áll, és kétségtelennek tủnik, hogy a Supreme Court egy nehezen feloldható jogkérdésbe botlott. Míg ugyanis egyfelől a kereskedelmi klauzula valóban teljeskörü hatalmat biztosít a Kongresszus számára a tagállamok közötti kereskedelem szabályozására, másfelől azonban Fuller észrevétele, miszerint a tizedik alkotmánykiegészítésből következően nem emlegethető egy lapon a tagállamok és a Kongresszus szabályozó hatalma, szintén helytálló. A többségi indokolás ugyan hivatkozik a McCulloch v. Maryland-ügyre, ${ }^{430}$ alátámasztandó, hogy a legitim cél érdekében az alkotmányba foglalt hatáskörök változatos módokon gyakorolhatók, ám ezen érv meggyőző ereje az imént említett vitás kérdés eldöntésének függvénye. A McCullochügyben a Supreme Court az alkotmány I. cikk 8. szakasz 18. fordulatára alapozva rögzítette, hogy a Kongresszus taxatíve felsorolt hatáskörei nem értelmezhetők megszorítóan. E rendelkezés értelmében a szövetségi jogalkotó szerv jogosult mindazon szabályok meghozatalára, amelyek szükségesek és megfelelőek az explicit hatáskörök gyakorlása szempontjából. ${ }^{431}$ A jelen esetben azonban épp az a vita tárgya, hogy a lottószelvények szállításának tiltása belefér-e a tagállamok közötti kereskedelem szabályozásába. Végül ugyancsak okkal alakult ki vita a Supreme Court tagjai között a lottószelvény árucikk-jellegét illetően, hiszen éppúgy állítható az, hogy van esély arra, hogy adásvétel tárgya legyen - amint azt a többségi indokolás is jelezte -, mint az, hogy a szelvény önmagában csupán egy jövőbeli szerződés lehetőségét hordozza magában.

\footnotetext{
${ }^{429} 188$ U. S. $367-368$

${ }^{430} 17$ U. S. (4 Wheat.) 316 (1819)

431 „The Congress shall have Power ... To make all Laws which shall be necessary and proper for carrying into Execution the foregoing Powers, and all other Powers vested by this Constitution in the Government of the United States, or in any Department or Officer thereof."
} 
A fentiekből világosan látható, hogy a Supreme Court nyitott kimenetelü esettel került szembe, amelyet a megfelelő indokok felhasználásával bármelyik irányba eldönthetett. A testület a jogalkotói hatalom kiterjesztésének lehetőségét választotta annak ellenére, hogy megalapozott aggályok merültek fel választásával kapcsolatban. Meglátásom szerint a döntés a bírói önmegtartóztatás eklatáns példájának tekinthető. Az a tény pedig, hogy a testületen belül egyik oldal sem adott hangot olyan nézetnek, mely szerint a lottószelvények szállításának tiltása a szerződési szabadságba ütközne, azt mutatja, hogy a Supreme Court korabeli tevékenységének elemzése során nem téveszthető szem elől az, hogy míg bizonyos - az aktivizmus bírálói által tipikusan felhozott döntések valóban a megfelelő eljárás követelménye körül forogtak, mások sokkal inkább technikai jellegü kérdéseket érintettek, és a Lottery Case ez utóbbiak közé sorolandó.

Az időben soron következő döntés az 1905-ben elbírált Marvin v. Trout-ügyben ${ }^{432}$ született. Az ügy tárgya egy ohiói törvény alkotmányossága, amelynek értelmében a szerencsejáték vesztese hat hónapon belül bíróság elött visszakövetelhette az elvesztett összeget. A Supreme Court egyhangú döntésével alkotmányosnak minősítette a törvényt. Az ügy előadó bírája Rufus Wheeler Peckham volt, aki az indokolásban megerösítette a police power terjedelmére vonatkozó doktrínát, melynek értelmében a tagállam alkotmányosan korlátozhatja azokat a tevékenységeket, amelyek a bevett vélekedés szerint veszélyesek a köz erkölcseire és jólétére. ${ }^{433}$

Az ügy érdekességét azonban nem önmagában e doktrína alkalmazása adja, hanem a tény, hogy a Supreme Court egyáltalán érdemben foglalkozott az üggyel. Az indokolásból világosan kiderül, hogy az indítvány nem felelt meg az érdemi vizsgálat kritériumainak. A befogadás feltétele nemcsak az, hogy az indítványozó megjelöljön valamilyen szövetségi jogi kérdést, amely a szövetségi bíróság eljárását indokolja, de azt is bizonyítani kell, hogy az indítványozó már a megelőző eljárásban hivatkozott ilyen kérdésre. A Supreme Court gyakorlatából látható, hogy ha a szövetségi jogi kérdést csak az előtte folyó eljárásban terjesztik elő, akkor visszautasításnak van helye. A testület a konkrét ügy indokolásában rámutat arra, hogy az indítványozó csak egy utólag kiállított igazolást nyújtott be, amelyben az eljárt tagállami bíróság megerősíti, hogy az eljárás során szövetségi kérdés is felmerült, ebből pedig nem állapítható meg a Supreme Court hatásköre. ${ }^{434}$ Ennek ellenére a Supreme Court, ha csak röviden is, de a támadott törvény alkotmányossága mellett szóló,

\footnotetext{
432199 U. S. 212

433199 U. S. 224

434199 U. S. 222-223
} 
érdemi érveket ismertet. Ez az okfejtés tulajdonképpen teljesen fölöslegesnek tekinthető: még csak különösebben szigorú álláspontra sem szükséges helyezkedni a bírói szerepet illetően ahhoz, hogy azt mondja az elemző, a be nem fogadható kérdések érdemi vizsgálatának nincs helye. A Supreme Court furcsa módon túllépett önnön hatáskörén, és ennek során a tagállam döntésének alkotmányossága, nem alkotmányellenessége mellett foglalt állást.

Két, szintén 1905-ben elbírált eset, a Cook v. Marshall County-és a Hodge v. Muscatine County-ügy ${ }^{435}$ a cigarettaforgalmazással áll összefüggésben. Az indítványozók mindkét esetben ugyanazt a tagállami törvényt támadták. A törvény egyfajta „büntetőadót” vetett ki a cigarettát árusító személyekre, valamint azokra, akiknek az ingatlanján cigarettaárusítás folyik. A Cook-ügyben az indítványozó az egyenlő törvényi védelem sérelme miatt kérte a törvény alkotmányellenessé nyilvánítását, az ugyanis nem vonatkozott azokra a kereskedőkre, akik nagykereskedelmi áron, a tagállamon kívüli vevőknek adták el az árut. A Hodge-ügyben az indítványozó a megfelelő eljárás sérelmét vélte megállapíthatónak, amiért a fix összegü adót külön értesítés nélkül rója ki rá az állam. A Supreme Court mindkét indítványt elutasította. Az első ügyben úgy érvelt, hogy a tagállamon belüli viszonteladók, illetve a nagykereskedelmi áron a tagállamon kívüli vevők részére eladó kereskedők közötti különbség valós, a megkülönböztetés ezért indokolt. Az előadó bíró, Brown kiemeli, hogy az adóztatás terén a tagállamok a szokásosnál szélesebb mérlegelési szabadságot élveznek. ${ }^{436}$ A második ügyben - melyben, mint megfigyelhető, a megfelelő eljárás követelményének csak formális, nem szubsztantív értelmezése merül fel - az előadó bíró úgy fogalmaz, az adózóknak lehetőséget biztosít a törvény arra, hogy az adó megállapítása ellen egy felügyelöbizottsághoz, annak döntése ellen pedig a bírósághoz folyamodjanak, ez pedig az alkotmány szempontjából elégséges szintű garancia. ${ }^{437}$ Mindkét ügyben három bíró, Fuller, Brewer és Peckham különvéleményt nyújtott be, ám indokolást nem füztek hozzá, így az ellentét okára nem derül fény.

A Murphy v. California-esetben ${ }^{438}$ a Supreme Court egy önkormányzati rendelet alkotmányosságát vizsgálta, amely minden személy számára megtiltotta a biliárdtermek üzemeltetését, e rendelkezések hatálya alól azonban kivonta a huszonöt vagy több szobával rendelkező szállodák tulajdonosait. Az indítványozó a tizennegyedik alkotmánykiegészítés

\footnotetext{
435196 U. S. 261, illetve 196 U. S. 276

436196 U. S. 274

${ }^{437} 196$ U. S. 281

438225 U. S. 623 (1912)
} 
megfelelő eljárási és egyenlő törvényi védelmi klauzulája alapján is támadta a rendelkezést. A Supreme Court mindkét indítványi elemet meglehetősen szükszavúan bírálta el egyhangú határozatában. Az első indítványi elemet illetően sommásan megállapította, hogy ,[a]z, hogy a biliárdtermek üzemeltetése káros tendenciákkal jár, bizonyítást nem igénylő tény, $\mathrm{s}$ ezt nem cáfolja az indítványozó vallomása, miszerint gazdasági tevékenységét jogszerüen végezte, s az mentes volt a szerencsejátéktól, valamint minden egyébtől, ami hatással lehet a közösség vagy a vendégek erkölcsére." ${ }^{439} \mathrm{Az}$ önmagukban veszélytelen tevékenységek tendenciájukban veszélyesek lehetnek a társadalomra, ez pedig alkotmányos alapot ad az állami cselekvésre. Ami az egyenlő törvényi védelmet illeti, a Supreme Court az indítványozói jogosultság hiányát állapította meg, az indítványozó ugyanis csak egy szobát bérelt, amelyet biliárdteremmé alakított, és nem volt szállodatulajdonos, a támadott fordulat pedig kifejezetten a szállodatulajdonosok között tett különbséget. ${ }^{440}$

A szintén egyhangú döntéssel zárult Packer Corporation v. Utah-ügy ${ }^{441}$ tárgya egy tagállami törvény volt, amely tiltotta a dohánytermékek bizonyos módokon (óriásplakáton, jelzőtáblán, transzparensen) történő reklámozását, ugyanakkor az újságokban, folyóiratokban történő reklámozást megengedte. A Supreme Court két dologra mutatott rá a jogszabály alkotmányosságát megállapító döntése indokolásában. Egyrészt a tagállam azért alkalmazta az ismertetett distinkciót, hogy a kereskedelmi klauzula követelményének megfeleljen: a folyóiratokat több tagállam területén is terjeszthetik, így tartalmuk korlátozása a tagállamok közötti kereskedelem korlátozása is egyben, ezzel szemben a tilalom alá eső reklámfelületek mindig a tagállam területén maradnak.

Bizonyos alapvető élelmiszerek forgalmának szabályozása szintén olyan kérdés volt, amelyben a vizsgált precedensek tanúsága szerint a Supreme Court meglehetősen széles körü diszkréciót ismert el a jogalkotó oldalán. Tárgyát tekintve itt különösen a margarin forgalmazásának a vaj javára történő korlátozása szembeszökő, de akadtak egyéb előírások is, amelyek valamilyen módon az élelmiszerbiztonsággal álltak összefüggésben. Az ilyen tárgyú jogvitákra általában jellemző, hogy a Supreme Court a szabályozást a közegészség megóvására irányulóként fogta fel, mely ennek következtében a legitim célú jogalkotás

\footnotetext{
439 „That the keeping of a billiard hall has a harmful tendency is a fact requiring no proof, and incapable of being controverted by the testimony of the plaintiff that his business was lawfully conducted, free from gaming or anything which could affect the morality of the community or of his patrons." 225 U. S. 629

440225 U. S. 630-631

441285 U. S. 105 (1932)
} 
körébe tartozott, s mint ilyen, nagyobb eséllyel számíthatott alkotmányosságának elismerésére.

Ebben a kérdéskörben a vizsgált időszak vonatkozásában az egyik legkorábbi döntés 1894-ben, a Plumley v. Massachusetts-ügyben született. ${ }^{442}$ Az ítélet összetett kérdéskörrel foglalkozik, jelentős részének a Kongresszus és a tagállamok közötti jogalkotási hatáskörelválasztás a tárgya, ugyanakkor érinti a tagállami jogalkotó mérlegelési szabadságát is.

Az ügyben egy tagállami törvényt támadott az indítványozó, amely megtiltotta az olyan, tiszta tejtermékek utánzása céljából, „,egészben vagy részben bármilyen zsírból, olajból, olajtartalmú anyagból vagy azok összetevőjéböl" (wholly or partly out of any fat, oil or oleaginous substance or compound thereof) előállított termékek forgalmazását, amelyeket a vajhoz hasonlatossá színeznek. A törvény nyilvánvalóan a margarin forgalmazásának szabályozására irányult. Abban az időben a szegényebb rétegek számára megfizethető, a vajat helyettesítő margarinra sokszor gyanakodva tekintettek, és számos törekvés figyelhető meg, ami kereskedelmének korlátozására irányul, elsősorban abból a célból, hogy a valódi tejtermékek számára ne jelentsenek konkurenciát, és a fogyasztók ne téveszthessék össze a kétféle terméket. ${ }^{443}$ A szóban forgó törvény ez utóbbi célt szolgálta, azzal a kifejezett kikötéssel, hogy nem adható neki olyan értelmezés, amelynek értelmében a margarin forgalmazása megtiltható akkor is, ha világosan megkülönböztethető a vajtól. A Supreme Court többsége arra az álláspontra helyezkedett, hogy a vásárlók csalárdságtól való megóvása olyan tárgykör, amelynek tekintetében a tagállamokat vitathatatlanul teljeskörü mérlegelési szabadság illeti meg. ${ }^{444}$ Ezt az álláspontot hárman vitatták, a különvéleményt megfogalmazó Fuller szerint - akinek érveléséhez Field és Brewer csatlakozott - pusztán az, hogy a margarin forgalmazói terméküket átszínezik azért, hogy vonzóbbá váljon a fogyasztók számára, nem ad jogalapot a beavatkozásra, és a szabályozás indokolhatatlan korlátozásokhoz is vezet amiatt, hogy nem csak a csalárd szándékú átszínezésre terjed ki. ${ }^{445}$

A döntés - a jelen tanulmányban vizsgált időszakon kívül eső - előzménye a Powell v. Pennsylvania-ügyben hozott ítélet, ${ }^{446}$ melyben a testület a margarin csalárd szándékkal történő forgalmazását tiltó jogszabály alkotmányosságát mondta ki. A csalárdság elleni

\footnotetext{
${ }^{442} 155$ U. S. 461

${ }^{443}$ Megjegyezhető, hogy a „vaj-margarin-vita” manapság is él. Abban az időben azonban a margarin valószínüleg tényleg egészségtelenebb összetevőkből állt; napjainkra előállításának módja jelentős mértékben megváltozott, ami egészségesebbé válásához is vezetett.

${ }^{444} 155$ U. S. 472

445155 U. S. $480-481$

${ }^{446} 127$ U. S. $678(1888)$
} 
védekezés mint legitimáló körülmény az 1916-os Seven Cases of Eckman's Alternative v. United States-ügyben ${ }^{447}$ is felmerült, melyben a Supreme Court alkotmányosnak ítélte azt a kongresszusi törvényt, amely szankcionálni rendelte a tagállamok közötti kereskedelemben az élelmiszerek vagy gyógyszerek megtévesztő elnevezését. Itt azonban a vásárlók megtévesztésére irányuló piaci magatartások nyilvánvaló veszélye mellett nagyobb súllyal esett latba az az információs aszimmetria is, amely különösen a gyógyászati termékek kereskedelmében jelen van. ${ }^{448}$

A Powell v. Pennsylvania-ügy kapcsán érdemes megemlíteni a Hammond Packing Co. v. Montana-ügyben hozott döntést. ${ }^{449}$ Ez utóbbi döntésben a Supreme Court egyhangúlag alkotmányosnak minősített egy tagállami különadót, ami kifejezetten a margarin forgalmazását sújtotta. Ezt kifogásolta az indítványozó a megkülönböztetés indokoltságát vitatva. Az elöadó Holmes roppant tömören, nagyjából egy oldal terjedelemben intézi el az ügyet, gyakorlatilag pusztán a precedensekre hivatkozik, egyebek között a Powell-ítéletre. Ez azért kiemelendő, mert abban az ügyben a Supreme Court eredetileg azt állapította meg, hogy a szabályozás alkotmányosságát a vásárlók megtévesztésével szembeni fellépés mint legitim cél alapozta meg. Ehhez képest a Hammond Packing Co. v. Montana-döntésben már csak annyi kerül kiemelésre az ügy lényegeként, hogy a jogalkotó akár ,a gyártást is teljes egészében megtilthatja”. ${ }^{450} \mathrm{~A}$ testület tehát kiterjesztőleg értelmezte önnön gyakorlatát, mégpedig a jogalkotói mérlegelési szabadságot kiszélesítve.

Csak érintőlegesen említendő meg a Capital City Dairy Co. v. Ohio-ügy. ${ }^{451}$ Ebben a kérdéses tagállami törvényt a kereskedelmi klauzula, továbbá az ötödik, valamint a tizennegyedik alkotmánykiegészítés alapján támadta az indítványozó. A jelen vizsgálódás szempontjából csak annyi relevanciával bír az ügy, hogy a Supreme Court megerősítette a fentebb ismertetett precedensek érvényét. Az alkotmányos kifogások elsősorban a kereskedelmi klauzulára, valamint - mint az indokolás rámutatott, tévesen - az ötödik alkotmánykiegészítésre irányult; a - tagállami szabályozás szintjén irányadó tizennegyedik alkotmánykiegészítéssel való ütközés vizsgálatát azzal utasította vissza a testület, hogy a tagállami eljárásban nem került kifejtésre az ezzel való ütközés az

\footnotetext{
447239 U. S. 510 (1916)

448 Vö. 239 U. S. 517-518

449233 U. S. 331 (1914)

450 „It even may forbid the manufacture altogether." 233 U. S. 333

451183 U. S. 238 (1902)
} 
iratokban. ${ }^{452}$ Ez annyiban érdemel kiemelést, hogy más esetekben a testület szabadelvübb alkotmányértelmezést alkalmazva úgy foglalt állást, hogy ha valaki az ötödik alkotmánykiegészítésre hivatkozik, noha a támadott törvényt egy tagállam hozta, akkor úgy tekinti, mintha a tizennegyedik alkotmánykiegészítésre hivatkoztak volna - tekintve, hogy a megfelelő eljárás klauzulája mindkettőben azonos megfogalmazást kapott.

A New York ex rel. Lieberman v. Van de Carr-ítéletben ${ }^{453}$ a Supreme Court egy olyan önkormányzati rendelettel foglalkozott, amelynek értelmében New York város területén tej nem tartható árusítás céljából, csak egy bizottság előzetes írásbeli engedélye alapján, és akkor, ha egyébként a bizottság által létrehozott egészségügyi elöírásoknak megfelel. Az indokolás szóhasználata alapján világosan megállapítható, hogy a testület vitathatatlannak találta a tagállamnak azt a szabadságát, hogy közigazgatási úton szabályozza bizonyos tevékenységek gyakorlását: „Ahhoz nem férkőzhet kétség, hogy e bíróság nem fog közbeavatkozni amiatt, mert a tagállamok helyénvalónak találják azt, hogy helyi bizottságok adminisztratív diszkrecionális hatáskörébe utalják azt, hogy olyan kereskedelmi tevékenységet vagy foglalkozást üzzenek, illetve végrehajtsanak olyan cselekvéseket, amelyek megfelelő módon szabályozhatók a nép egészségének és biztonságának védelme érdekében a tagállamok számára fenntartott hatáskör gyakorlása során”. ${ }^{454}$ A Supreme Court az ítélet egy korábbi szakaszában már tett olyan megjegyzést, ami mindegy előfeltételezi az idézett megállapítást, ám abban a szakaszban a hangsúly azon volt, hogy a jogvita elbírálására irányadó elvek szilárdan rögzítésre kerültek egy sor precedensben, vagyis a múltbeli döntések puszta súlya és mennyisége alapján eldönthetö lenne az ügy. ${ }^{455} \mathrm{Az}$ idézett passzusban viszont explicit módon hangsúlyozza a testület azt, hogy az indítvány rég eldöntött kérdéseket feszeget.

A Lieberman-ítéletre támaszkodik a Supreme Court az Adams v. Milwaukeeítéletben ${ }^{456}$ egy olyan önkormányzati rendeletet vizsgálva, amelynek értelmében az adott város határain kívül előállított tej forgalmazására más szabályok vonatkoznak, mint a város határain belül elöállítottéra. A rendelet egyebek között előírta, hogy a jogsértő árus termékét meg kell semmisíteni. A Supreme Court egyhangú véleménye szerint ez az elóírás nem ellentétes a tizennegyedik alkotmánykiegészítéssel, mivel az eltérő

\footnotetext{
452183 U. S. 248

${ }^{453} 199$ U. S. $552(1905)$

${ }^{454}$ „That this court will not interfere because the States have seen fit to give administrative discretion to local boards to grant or withhold licenses or permits to carry on trades or occupations, or perform acts which are properly the subject of regulation in the exercise of the reserved power of the States to protect the health and safety of its people there can be no doubt." 199 U. S. 560

${ }^{455}$ Vö. 199 U. S. 558

${ }^{456} 228$ U. S. 572 (1913)
} 
szabályozás előírása a fennálló helyzetet tekintve megfelelő és célszerü, a veszélyesnek bizonyult termék megsemmisítése pedig az „egyetlen rendelkezésre álló és hatékony” szankció a rendelet megsértéséért. ${ }^{457}$

A St. John v. New York-ügy ${ }^{458}$ nem vet fel a jelen értekezés szempontjából releváns kérdéseket, tárgya miatt azonban szükséges említést tenni róla. Az indítványozó egy olyan tagállami szabályozást kifogásolt, amelynek értelmében a tej minőségének ellenőrzése során azoknak az eladóknak, akik maguk állítják elő a terméket, lehetőségük van igazolni, hogy a tej olyan összetételü, mint a fejéskor volt, míg azok számára, akik nem maguk állítják elő a terméket, ez a lehetőség nem volt biztosítva. A támadott szabályozást olvasva látható, hogy itt nem maga a jogalkotói cél alkotmányossága lett vita tárgya, hanem egy járulékos megkülönböztetés. A Supreme Court rövid, egyhangú indokolásában elutasította a megkülönböztetés indokolatlanságára való hivatkozást, mondván, az ésszerü, hiszen a termelő eladó esetében könnyü meggyőződni a tej összetételéről, míg erre a nem termelő eladó esetében nincs mód. A szabályozás célja a mesterségesen módosított összetételü tej forgalmának korlátozása volt, mellyel kapcsolatban annyit érdemes észrevételezni, hogy a törvény kifejezetten a tej összetételének módosítását szankcionálta, vagyis ha a nem megfelelő minőségű tej már a fejéskor olyan volt, akkor a (termelö) eladó mentesült a szankció alól. Ez gyakorlatilag azt eredményezte, hogy a termelő eladó - mentesülése esetén - hátrányos következmények nélkül forgalmazhatott olyan tejet, amelynek forgalmazásáért a nem termelő eladónak mindenképpen szankcióval kellett számolnia. A Supreme Court megfontolása természetesen nagyon is gyakorlatias, hiszen tény, hogy a nem termelő eladó esetén jóformán képtelenség a tej eredeti állapotáról meggyőződni, mégis azt látjuk, hogy a törvény eltérően ítéli meg adott esetben a hasonló összetételü termék forgalmazását. Megítélésem szerint a Supreme Court ebben az esetben passzivista módon járt el.

A North American Cold Storage Co. v. Chicago-ügy ${ }^{459}$ központi kérdése a megfelelő eljárás követelménye formális értelmezésének terjedelme. Chicago városa önkormányzati rendeletben írta elő az emberi fogyasztásra alkalmatlan baromfi elpusztítását, amit az indítványozó sérelmezett. Panaszában azt kifogásolta, hogy a jogszabály szerint az ilyen intézkedésről nem kell értesítést küldeni a tulajdonosnak, ami egyébként a megfelelö

\footnotetext{
457 ,[T]he destruction of the milk was the only available and efficient penalty[.]” 228 U. S. 584

458 201 U. S. 633 (1906)

459211 U. S. 306 (1908)
} 
eljárás egyik alapvető követelménye a meghallgatás mellett. ${ }^{460}$ A testület azonban nem fogadta el érvelését, és saját álláspontját a jogalkotó arra irányuló kötelezettségével támasztotta alá, hogy megóvja polgárainak egészségét. A kötelezettség ebben az esetben az egészségre ártalmas áru megsemmisítésében nyilvánult meg, és tekintve, hogy amíg az áru létezik, addig fennáll eladásának veszélye, ezért az állami kötelezettség elsőbbséget élvezett az indítványozó tulajdonának védelménél, mely utóbbival összefüggésben bekövetkezett sérelmek orvoslása végett egyébként a baromfi elpusztítása után is felléphet az érintett. ${ }^{461} \mathrm{Az}$ eset jól példázza, hogy a Supreme Court nem igyekezett egyfajta „dogmatikus ketrecbe” zárkózni: a szóban forgó ügyben nem helyezte mindenek fölé az értesítés követelményét, hanem azt összevetette a praktikus követelményekkel, és így szabta meg az elv alkalmazhatóságának határait. ${ }^{462}$

1915-ben a Price v. Illinois-ítéletben ${ }^{463}$ a Supreme Court egyhangúlag alkotmányosnak ítélet egy tagállami törvényt, amely a bórsavat tartalmazó tartósítószerek forgalmazását tiltotta meg. A döntés gyakorlatilag kritikátlanul továbbviszi azt az érvelési vonalat, miszerint bizonyos tárgykörök szabályozásának joga evidens módon megilleti a jogalkotót. ${ }^{464} \mathrm{Az}$ indokolás szerint „,[a]z indítványozó állításának csak akkor lehetne helyt adni, ha úgy tünne, hogy a vélemények egybeesése alapján a tartósítószer megkérdőjelezhetetlenül veszélytelen a szóban forgó használat vonatkozásában, vagyis kétséget kizáróan egészséges kereskedelmi cikként osztályozható, ami szándékolt felhasználása során olyannyira ártalmatlan, és olyannyira nem függ össze semmiféle, a közegészséget fenyegető lehetséges veszéllyel, hogy a szabályozást a polgárok tulajdonának és szabadságának pusztán önkényes akadályaként kell felfogni." ${ }^{465}$ Ebből a gondolatból két elemet szükséges kiemelni.

Az első a „vélemények egybeesésére” (consensus of opinion) történő hivatkozás, melynek kapcsán azt kell látni, hogy a testület nem határozza meg közelebbröl, miféle véleményeknek kell egybeesnie a szabályozás önkényessé minősüléséhez. Legalább

${ }^{460}$ Vagyis ebben az esetben sem magát a szabályozás legitimitását vitatja. Ezt a legitimitást egyébként a Supreme Court - mint azt a szóban forgó ügyben megerősíti - korábbi, részben hasonló - a hulladékgazdálkodás egyes szabályaival összefüggő - precedenseiben is rögzítette. Vö. California Reduction Co. v. Sanitary Reduction Works, 199 U. S. 306 (1905); Gardner v. Michigan, 199 U. S. 325 (1905).

461211 U. S. 315-316

${ }^{462}$ Ebben az ügyben egyedül Brewer bíró szavazott a többség ellenében.

463238 U. S. 446

464238 U. S. 452

465 ,The contention of the plaintiff in error could be granted only if it appeared that by a consensus of opinion the preservative was unquestionably harmless with respect to its contemplated uses, that is, that it indubitably must be classed as a wholesome article of commerce so innocuous in its designed use and so unrelated in any way to any possible danger to the public health that the enactment must be considered as a merely arbitrary interference with the property and liberty of the citizen." Uo. 
háromféle vélemény releváns lehet itt. Egyrészt beszélhetünk az általános közvéleményröl, amely a mindennapok tapasztalataiból indul ki - eszerint ha a mindennapokban azt tapasztalják a fogyasztók, hogy az adott tartósítószer ártalmatlan, akkor szükségtelenné és alkotmányosan tarthatatlanná válik forgalmának korlátozása. Másrészt elképzelhető egy szakmai konszenzus is, ebben az esetben a hozzáértő vegyészek általános egyetértése vezet az említett következményhez. Harmadrészt nem zárható ki a bírói konszenzus feltételként szabása sem. Ennek megkülönböztethető egy szükebb és egy tágabb válfaja: a szükebb esetben csak a Supreme Court tagjainak egyetértése, illetve egységes ítélkezési gyakorlata releváns, a tágabb esetben pedig a testület tekintetbe veszi a tagállamok felsőbíróságainak vonatkozó álláspontját is. ${ }^{466} \mathrm{E}$ háromféle konszenzus nem szigetelhető el hermetikusan, hiszen folyamatos kapcsolatban állnak, befolyást gyakorolnak egymásra. Nem mindegy azonban, melyikük számít perdöntőnek egy bírósági ítélet indokolásában.

A szóban forgó ítélet szövegét tanulmányozva nem derül ki egyértelmüen, milyen konszenzusra történik utalás. A szakmai konszenzus jó eséllyel kizárható, hiszen a meglehetősen rövid indokolásban ${ }^{467}$ nem esik szó a vonatkozó tudományos álláspontokról. Az általános közvéleményre való támaszkodás felvet egy dilemmát. Egyfelől ezáltal gyakorlatilag felszínessé válna az ítélkezés, hiszen az, hogy egy álláspontot a puszta közvélemény alátámaszt, nem teszi azt sem helyessé, sem igazzá. Másfelől azonban ha az emberek tényleg rendszeresen használják valamilyen célra az adott terméket, és a tapasztalat szerint ez nem eredményez károsodást, az csakugyan megkérdőjelezi a szabályozás szükségességét, és ezáltal alkotmányos alapját. A dilemma e második aspektusa ugyanakkor további dilemmához vezet: ilyen esetben ugyanis azzal a helyzettel találjuk szembe magunkat, hogy a többség vélhető szándékával összhangban áll a többség képviselői által megalkotott norma alkotmányellenessé nyilvánítása. Az ilyen felállás az alkotmánybíráskodásnak a többségellenesség dilemmája alapján történő kritikájának sémáiba nehezen illeszthető be, inkább azzal a - már az alapítók által is vallott koncepcióval fér össze, miszerint az írott alkotmány a szuverén nép legvégső akaratának

\footnotetext{
${ }^{466}$ Természetesen a Supreme Courtot mint az Egyesült Államok bírói szervezetének csúcsszervét semmilyen módon nem köti, kötötte a tagállami felsőbíróságok, illetve legföbb bírói fórumok jogértelmezési gyakorlata, azért megjegyezhető, hogy a testület gyakran támaszkodott a tagállami ítélkezésre. Ez elsősorban a támadott tagállami rendelkezések értelmezésében mutatkozott meg: a Supreme Court számos alkalommal lefektette és megerősítette azt az elvet, hogy egy jogszabályi előírás autentikus értelmének megállapítása során abból a jelentésböl indul ki - a nyilvánvaló abszurditások és önellentmondások eseteit leszámítva -, amelyet a tagállami bíróságok tulajdonítanak neki.

${ }^{467} \mathrm{Az}$ indokolás szük kilenc oldalt tesz ki, ennek legjavát azonban a tényállás és a szembenálló érvek ismertetése teszi ki, a bíróság álláspontjának rögzítése az utolsó két-három oldalra szorul úgy, hogy a jelen okfejtésben releváns megfelelö eljárási követelmény mellett itt veszik számba az egyenlö törvényi védelemre, valamint a kereskedelmi klauzulára való indítványozói hivatkozásokat is.
} 
dokumentuma. Végül a bírói konszenzus optimális esetben az előző kettő valamelyikének folyománya, máskülönben felvetődik a bírói önkény vagy a bírói gyakorlat idejétmúltságának, negatív értelemben vett dogmatikusságának gyanúja.

Az ítélet indokolásának magvát képező gondolatból másodikként azt kell kiemelni, hogy a szabályozott termék kétséget kizáróan veszélytelen voltának igazolását várta el ahhoz, hogy a korlátozás alkotmányellenesnek legyen tekinthető. A Supreme Court ezzel nem egyszerűen az indítványozóra hárítja az alkotmányellenesség bizonyításának terhét ami önmagában természetes és kézenfekvő -, de ráadásul szigorú mércét támaszt vele szemben, hiszen az indítványozónak gyakorlatilag ki kell zárnia azokat az ésszerüen elképzelhető alternatívákat, amelyek a szabályozást legitimálhatják. A testület ezzel az alkotmányosság vélelmének elvét erősítette meg újból.

A Schmidinger v. Chicago-ügyben ${ }^{468}$ a testület elé kerülő önkormányzati rendeleti szabályozás a Chicago területén kereskedelmi forgalomba kerülő kenyér méretét szabályozta, ami az indítványozó szerint a megfelelő eljáráshoz és az egyenlő törvényi védelemhez való jogát is sértette. Az egyhangú ítélet indokolása nyíltan érinti a szerződési szabadság és a police power alkotmányos terjedelmét - az előadó Day bíró következtetése szerint nem sérült semmilyen alkotmányos előírás, az önkormányzat legitim célból alkotott megfelelő szabályozást. Érvelésének a jelen kontextusban releváns eleme az, hogy az indokolás szerint a szabályozott tárgykör ebben az esetben is nyilvánvalóan a jogalkotó mérlegelési szabadságának a körébe vonható. ${ }^{469}$ Arra az indítványi elemre, mely szerint a szabályozás, még ha a célja legitim is, aránytalan, a testület úgy reagál, hogy a helyi viszonyokat elsősorban a helyi hatóságok, nem a bíróságok tudják megítélni, ezért tartózkodik a felülbírálattól. ${ }^{470}$ Ezt az érvelési vonalat követte a két évtizeddel később született - szintén egyhangú - P. F. Petersen Baking Co. v. Bryan-ítélet ${ }^{471}$ is egy hasonló tartalmú szabályozás vonatkozásában.

Az Armour \& Co. v. North Dakota-ítélet ${ }^{472}$ indokolása iskolapéldája lehetne annak az érvelési stílusnak, amelyet az első fejezetben „dogmatikus passzivizmusnak” neveztem. A Supreme Court ugyanis meglehetősen távolságtartó módon azzal utasítja el az indítványozó panaszát, hogy „ha valamely veszélyről való meggyőződés nem önkényes,

\footnotetext{
468226 U. S. 578 (1913)

469226 U. S. 587

470226 U. S. $587-588$

471290 U. S. 570 (1934)

472240 U. S. $510(1916)$
} 
annak mértékét nem becsülhetjük fel a törvényhozó becslése ellenében”. ${ }^{473}$ Más szavakkal: ha a külső szemlélő számára az adott veszély ésszerüen elképzelhető - pontosabban szólva annak tünik-, akkor a szabályozásnak nincs alkotmányos akadálya.

Figyelmet érdemel továbbá az, hogy a testület nyíltan eltekintett az indítványozó által felhozott azon érvektől, melyek szerint a szabályozás rontja az érintett területen dolgozó szervezetek hatékonyságát, és úgy fogalmazott, a jogalkotói cél - a piaci megtévesztés megakadályozása ${ }^{474}$ - előbbre való ezeknél a megfontolásoknál: „,[e]z [ti. a jogszabály elöírásainak való megfelelés] együtt járhat a csomagolásnak a társaság általi megváltoztatásával, valamint e változtatások költségének viselésével, ez azonban olyan áldozat, amelyet a törvény elvárhat annak érdekében, hogy védelmet nyújtson a régi módszerből adódó megtévesztéstől." ${ }^{475}$ Úgy tűnhet, ebben az attitűdben implicite tetten érhető az a megfontolás, hogy az alkotmányjogi szempontok függetlenek a gazdaságihatékonysági szempontoktól, és bizonyosan feltehető, hogy ennek a distinkciónak a Supreme Court is a legteljesebb mértékben tudatában volt. Ugyanakkor úgy tünik, az Armour \& Co. v. North Dakota-ítélet indokolásának szerzője nem erre a megkülönböztetésre helyezi a hangsúlyt, hanem arra, hogy a jogszabály követése tényleges előnyökkel is jár. ${ }^{476}$ Vagyis a Supreme Court itt szubsztantív érvvel támogatta meg döntését, és ennek alapján tartózkodott a jogalkotó megfontolásának felülbírálatától.

A Hebe Co. v. Shaw-ítélet ${ }^{477}$ indokolásának érdemi része tulajdonképpen nem egyéb, mint a korábbi precedensek következetes alkalmazása. A Price v. Illinois-ügyben meghatározó alkotmányossági vélelem ebben az ügyben is irányadónak bizonyult a megfelelő eljárás vonatkozásában. ${ }^{478}$ Két érvelési elem érdemel külön kiemelést: egyrészt attól, hogy az elöírt tilalom körébe eshetnek olyan dolgok is, amelyek forgalmának korlátozása indokolatlan, a rendelkezés még nem lesz alkotmányellenes; másrészt amennyiben a korlátozás alá eső dolog ártalmassága vagy ártalmatlansága vitatható, úgy a

\footnotetext{
473 ,[I]f a belief of evils is not arbitrary we cannot measure their extent against the estimate of the legislature[.]" 240 U. S. 513

${ }^{474}$ A támadott törvény értelmében a disznózsírt meghatározott ürtartalmú, egyúttal meghatározott tömegü zsír tárolására alkalmas vödrökben lehetett forgalmazni. A jogalkotó ezzel kívánta elejét venni annak, hogy az eladók a tárolóeszköz tömegét is számításba véve az áru nettó tömegének áránál drágábban adják el a terméküket.

475 „This may involve a change of packing by the company and the cost of that change, but this is a sacrifice the law can require to protect from the deception of the old method." 240 U. S. 516

${ }^{476}$ Vö. uo.

477248 U. S. 297 (1919)

${ }^{478} \mathrm{Az}$ indítványozó egyéb alkotmányi elöírásokra hivatkozva is támadta a kérdéses jogszabályhelyet, e vizsgálódás szempontjából azonban csak a megfelelő eljárás klauzulája bír jelentőséggel.
} 
jogalkotó saját mérlegelési körében dönthet forgalmának korlátozásáról. ${ }^{479}$ Ez az álláspont egyértelműen összhangban áll a Supreme Court korábbi ítélkezési gyakorlatával. ${ }^{480}$

A Corn Products Refining Co. v. Eddy-ítélet ${ }^{481}$ indokolásának középpontjában a szabályozott termék összetevőinek titokban maradásához füződő érdek és a közérdek ütközése áll. A Supreme Court egyhangúlag az utóbbi javára voksolt: a fentebb ismertetett döntések nyomán leszögezi, hogy a gyártóknak, eladóknak a titokhoz való joga a tagállam szabályozási hatáskörének van alávetve - abból a célból, hogy a fogyasztók tájékozódhassanak a részükre felkínált termék valódi mibenlétét illetően -, és ezt a megállapítást magától értetődő alapvetésként kezelte. ${ }^{482}$

A mindeddig megfigyelhető egyhangúságot a Jay Burns Baking Co. v. Bryan-ítélet ${ }^{483}$ bontotta meg. Ebben az ügyben a Supreme Court többsége azzal a fó indokkal nyilvánította alkotmányellenesnek a támadott tagállami szabályozást - mely meghatározta a forgalomba hozható kenyér minimális egységnyi, illetve átlagos tömegét, valamint az attól való maximálisan megengedhető eltérést ${ }^{484}$-, hogy az annak való megfelelés ésszerűen nem elvárható, a kenyér végső súlyának kialakulását ugyanis számos tényező befolyásolhatja, és a szabályozást megalkotó tagállam - Nebraska - természeti körülményei között a kenyér kész állapotában jelentős mértékü súlyt veszíthet az elkészítés folyamatában fennálló állapothoz képest. ${ }^{485}$

A többség álláspontjával Brandeis helyezkedett szembe; különvéleményéhez Holmes is csatlakozott. Szerinte tévedés a szóban forgó esetett kivonni a Schmidinger-ügy hatóköre alól, itt ugyanis a szabályozás csak részben szigorúbb a korábbi vitához képest, más vonatkozásokban épp hogy enyhébb. ${ }^{486}$ A többség nem volt tekintettel azokra a - nagyon is ésszerü - szempontokra, amelyeket a tagállam szem előtt tartott. ${ }^{487}$ Erre vonatkozó érveit három pontban foglalta össze. Egyrészt az átlagos tömeg el nem érésének szankcionálása

\footnotetext{
479 248 U. S. 303

${ }^{480}$ Említést érdemel az, hogy a Hebe Co. v. Shaw-ügyben született egy különvélemény Day bíró tollából, melyhez ketten (Van Devanter és Brandeis) csatlakoztak, ez azonban az alkotmányértelmezés vonatkozásában nem tanúskodik koncepcionális eltérésröl: a véleménykülönbség a támadott jogszabály értelmezésével kapcsolatos, a kisebbségi álláspontot felkaroló bírák szerint ugyanis az eljáró bíróságoknak nem lett volna szabad a törvény hatálya alá vonni a konkrét ügyben érintett terméket.

481249 U. S. 427 (1919)

482249 U. S. $431-432$

483264 U. S. 504 (1924)

${ }^{484}$ A törvény egész pontosan a következőt írta elő. Az egyes kenyérveknik tömege fél font, egy font, másfél font, illetve az egy font valamely egész szorzata lehet. Emellett a veknik standard tömegétől legfeljebb két unciával lehet bármely irányba eltérni. Ez az átlagos tömeg legalább huszonöt vekni standard tömegének átlagolásával állapítható meg, amit huszonnégy órával a sütés után kell megállapítani.

${ }^{485} 264$ U. S. $514-516$

486264 U. S. 518

487264 U. S. 520
} 
mellett (ami első belegondolásra a legkézenfekvőbb, hiszen a cél az, hogy a könnyebb veknit ne árusítsák áron felül) az átlag meghaladása adminisztratív szükségszerüség miatt szankcionálandó. ${ }^{488}$ Másrészt Brandeis megítélése szerint a szabályozás alkalmas arra, hogy - legitim - célját megfelelően betöltse. ${ }^{489}$ Harmadrészt pedig a szabályozás nem jelent aránytalan terhet a sütőiparra. ${ }^{490}$

Ez a döntés egyike azoknak, amikor a „mindennapos tapasztalat” és az „ésszerüség” mellett nyílt hivatkozás olvasható valamilyen szakmai álláspontra az indokolásban, ${ }^{491}$ igaz, ez a különvéleményben sokkal markánsabban megfigyelhetö, mivel Brandeis rengeteg különféle forrást idéz meggyőződése alátámasztására. A Supreme Court többsége bevallottan a nebraskai sajátos természeti állapotok figyelembevételével hozta meg döntését, amihez a következő megjegyzések tehetők. Ennek kifejezésre juttatása implicite magában hordozza azt, hogy bizonyos esetekben, amikor a speciális helyi körülmények nem indokolják, akkor nem állapítható meg szükségszerüen a szabályozás alkotmányellenessége. Másrészt azonban az előadó bíró úgy fogalmaz, hogy a Supreme Court feladata - egyebek között - az, hogy megállapítsa, van-e ésszerü kapcsolat a szabályozás és annak deklarált célja között, valamint hogy a szabályozás „rendszerint valóban betölti-e azt a rendeltetést, amely végett megalkották”. ${ }^{492}$ Megítélésem szerint ezzel a megfogalmazással a Supreme Court ellentmondásba került egy másik, gyakran hangoztatott elvvel, miszerint a bíróságoknak nem feladata az, hogy a támadott jogszabály „bölcsességét” (wisdom), azaz hatékonyságát, eredményességét firtassa. Természetesen ez utóbbi követelménynek soha nem tud egészen megfeleni, hiszen az általa alkalmazott szükségesség-arányosság teszt menthetetlenül a jogszabály tartalmi vizsgálatához vezet. $\mathrm{Az}$ alapjogkorlátozás akkor alkotmányos a testület gyakorlata szerint, ha létezik valamilyen valós körülmény, ami azt indokolttá tette, és a céllal arányban áll a szabályozás - márpedig ha a szabályozás nem, vagy csak korlátozott mértékben mozdítja elő az egyébként valós probléma megoldását, akkor az vagy szükségtelen, vagy aránytalan. A Jay Burns Baking Co. v. Bryan-ügyben ez az ellentmondás jól tetten érhető. Az indokolásban

\footnotetext{
488 Uo. Brandeis nem részletezi explicit módon, mi ez az adminisztratív szükségszerűség, véleményem szerint arra gondolhatott, hogy a jogalkotó törekedett az ár-érték arány fenntartására, vagyis el akarta kerülni - példának okáért - azt, hogy az adott egységnyi tömeget meghaladó vekniket arányaiban sokkal magasabb áron értékesítsék.

489264 U. S. 527

490264 U. S. 530

${ }^{491}$ Vö. 264 U. S. 514

$492,[\mathrm{I}] \mathrm{t}$ is the duty of the court to determine whether the challenged provision has reasonable relation to the protection of purchasers of bread against fraud by short weights and really tends to accomplish the purpose for which it was enacted." 264 U. S. 513
} 
foglalt érvelés, miszerint a természeti körülmények jóformán lehetetlenné teszik az elöírások betartását, meggyőző, akkor is, ha Brandeis szerint a megengedett tömegtől fölfelé való eltérés maximálását „adminisztratív szükségszerüség” indokolja - ezt a szükségszerüséget egyébként nem részletezi különvéleményében, azonban a testület ezzel túllépte a saját maga számára megállapított hatásköri korlátozást.

A United States v. Shreveport Grain \& Elevator Co.-ügy ${ }^{493}$ jelentőségét a benne megerősített értelmezési elv adja. Ebben az ügyben egy kongresszusi törvény alkotmányosságát kérdőjelezték meg az indítványozók, amely büntetni rendelte a hamisan megjelölt áruk forgalmazását (értelemszerüen csak a tagállamok közötti, valamint az idegen országokkal való kereskedelemben). Az ügyben explicit módon tulajdonképpen csak érintőlegesen esik szó a tulajdon vagy a (szerződési) szabadság védelméről, az indokolás gondolatmenete a jogbiztonság és a hatalommegosztás köré épült, és mivel ezek közül az előbbit a Supreme Court olykor összefüggésbe hozta a megfelelő eljárás követelményével - miszerint a klauzulában felsorolt jogok sérelmét eredményezi, ha azokat homályos szövegü jogszabállyal korlátozzák -, ezért nem tünik célszerütlennek itt említést tenni erről az ítéletről. Az indítványnak a jogbizonytalanságra alapított részét a Supreme Court azzal utasította el, hogy amennyiben a támadott jogszabálynak ésszerü keretek között tulajdonítható alkotmányos értelmezés, akkor ezt kell irányadónak tekinteni. ${ }^{494} \mathrm{Ez}$ az elv rendszeresen visszaköszön a Supreme Court korabeli érvelésében még olyan döntések indokolásában is, amelyekben a testület alkotmányellenességet állapított meg -, és a Wolfe tradicionális normakontrolljára jellemző bírói önmegtartóztatást tükrözi. A jelen esetben az indítványozó nem azzal érvelt, hogy a szabályozás alkotmányellenes célra - vagy alkotmányos cél alkotmányellenes megvalósítására - irányul, hanem azzal, hogy a jogszabály értelmezhetetlensége eredményez alkotmányellenességet. Itt tehát nem merül fel annak kérdése, mennyire „nyilvánvaló” az adott életviszony szabályozhatósága, az alkotmánykonform értelmezés elve azonban enélkül is lezárja a vitát.

Az alkotmánykonform értelmezést ebben az ítéletben a Supreme Court bizonyos szempontból túl is hajszolta azáltal, hogy deklarálta: az ilyen jelentés felkutatásának nem akadálya a jogszabályszövegben alkalmazott központozás. Az indokolásban a következő gondolat olvasható. „Az írásjelek nem részei a törvénynek. A törvény értelmezése során a bíróság a jog szándékának meghatározása érdekében figyelmen kívül hagyja a

\footnotetext{
493287 U. S. 77 (1932)

494287 U. S. 82
} 
központozást, avagy szükség esetén megváltoztatja azt avégböl, hogy az alkalmazott szavak természetes jelentéséhez eljusson. " ${ }^{495}$ A nyelvtani értelmezés egyik alapvetése az, hogy a jogszabályszövegben minden apró írásjelnek döntő jelentősége lehet. A Supreme Court ezt a megfontolást nyíltan félrehajította azért, hogy a jogalkotó feltehető szándékát megállapítva az alkotmánnyal összhangban álló jelentést tulajdonítson a vizsgált jogszabálynak. Másként - és sarkosabban - fogalmazva: ebben az ügyben a testület amellett kötelezte el magát, hogy szükség esetén akár a jogértelmezés legalapvetőbb szabályait is megszegje annak érdekében, hogy a vizsgált jogszabályt megfeleltethesse az alkotmány előírásainak. Az indokolás szóhasználatából ítélve meglátásom szerint ez a törekvés túlmutat azon a praktikus elven, miszerint a nyilvánvaló elírások, a nyilvánvalóan téves szóhasználat nem részei a jogszabály jelentésének, azokat a bíróságok figyelmen kívül hagyhatják (ilyen eset például az, ha olyan helyen szerepel a „nem” szócska, ahová nyilvánvalóan nem szánták, és vice versa). ${ }^{496}$

A Magnano Co. v. Hamilton-ítélet ${ }^{497}$ indokolása az „önmegtartóztató” érvek egész tárházát vonultatja fel. Ebben az esetben a Supreme Court egy Washington tagállami törvénnyel foglalkozott, amely különadóval sújtotta a vajpótló anyagokat forgalmazó személyeket - ami elsősorban a margarin kereskedelmét érintette. Az indokolást elemezve látható, hogy a testület következetesen tartotta magát azon érveléséhez, miszerint bizonyos tárgykörök „nyilvánvalóan” beletartoznak a tagállam szabályozási hatáskörébe: ez esetben a vaj és a margarin összetétele közötti eltérés alapozta meg ezt az álláspontot. ${ }^{498} \mathrm{~A}$ támadott törvény alkotmányossága mellett szóló további érv volt az, hogy az adónak tulajdonított hosszú távú hatás túlságosan spekulatív, ${ }^{499}$ valamint az, hogy a jogalkotó esetleges mellékes szándéka a törvényt illetően irreleváns a bíróság számára. ${ }^{500}$

Ugyancsak jelentős a döntés vizsgálata szempontjából az, hogy adójogszabályról van szó. A Supreme Court megállapította, hogy a megfelelő eljárási klauzulák - legyen szó akár az ötödik, akár a tizennegyedik alkotmánykiegészítésről - a jogalkotó adóztatási szabadságát nem korlátozzák. ${ }^{501} \mathrm{Az}$ adóztatás elsődleges célja bizonyos közcélok

\footnotetext{
495 „Punctuation marks are no part of an act. To determine the intent of the law, the court, in construing a statute, will disregard the punctuation, or will repunctuate, if that be necessary, in order to arrive at the natural meaning of the words employed." 287 U. S. 82-83

${ }^{496}$ Ehhez az elvhez lásd pl. Siegel, Jonathan R.: What Statutory Drafting Errors Teach Us About Statutory Interpretation. In George Washington Law Review, Vol. 69, 2001, különösen 313. o.

497292 U. S. 40 (1934).

498292 U. S. 43

${ }^{499}$ Uo.

500292 U. S. 44

${ }^{501}$ Uo. Lásd még a 379. lábjegyzetet és a hozzá tartozó szöveget!
} 
finanszírozási forrásainak biztosítása a közterhek megfelelő kirovása által. A jelen esetben azonban a jogalkotó közvetlen társadalompolitikai - közelebbről: egészségpolitikai - cél megvalósítására is törekedett: az egészségtelennek tekintett margarin helyett az egészségesnek tartott vaj fogyasztását szorgalmazta. Érvelésével a Supreme Court tulajdonképpen egy látszólagos „kiskaput” hozott létre a jogalkotó számára azáltal, hogy a megfelelő eljárás követelménye alól kivonta az adójogszabályokat, és ha ezt összevetjük az imént említett elvvel, miszerint nem a bíróságra tartozik a jogalkotó mellékes szándékainak vizsgálata, akkor arra a következtetésre juthatnánk, hogy az adóztatás álarca mögött egy sor olyan szabályozás születhetne, ami, ha nem adó kivetésére irányulna, akkor alkotmányellenesnek bizonyulna (ennek példája lenne az, ha a jelen esetben megállapított célt a jogalkotó hatósági úton igyekezne elérni, például közvetlen közigazgatási szankció kilátásba helyezésével). Hozzá kell tenni: a gyakorlatban a Supreme Court elzárta ezt a „kiskaput”. Azonban a széles adóztatási szabadság és a nyílt bírói önmegtartóztatás hangsúlyozása és következetes érvényesítése ellentétben állt volna a testület ténylegesen követett gyakorlatával. Ezt szemléletesen példázza maga a Lochner-ítélet is - melynek precedenskörnyezetében való, részletes ismertetésére a III.3.4. szakaszban kerül sor -: ebben az indokolás egyik fö érve az volt, hogy a jogalkotó munkaügyi szabályozást alkotott az egészségügyi szabályozás leple alatt. A Lochner-ügyben a feltételezhető jogalkotói szándék (tegyük hozzá: más megfontolások mellett) a jogszabály alkotmányellenességét eredményezte, a Magnano-ügyben azonban a testület egyszerüen nem vette ezt figyelembe. Az ellentmondás kiváltképp szembeszökő, tekintettel arra, hogy az utóbb ügy előadó bírája a konzervativizmusáról is ismert Sutherland volt.

A gyógyszerek kereskedelmének a közegészséggel való kapcsolata nyilvánvaló tény. A Supreme Court gyakorlatából ez a belátás egyértelmüen kiviláglik. A Baccus v. Louisiana-ítélet $^{502}$ ezt kihangsúlyozva nyilvánította alkotmányossá a támadott törvényhelyet - amely megtiltotta a házaló árusoknak a gyógyszerek árusítását. Az egyetlen bő oldalt kitevő indokolás szerint már a testület korábbi gyakorlatából is nyilvánvalóan következik az, hogy el kell ismerni a jogalkotó döntési szabadságát ebben a vonatkozásban, hiszen korábban már alkotmányosnak bizonyult egy olyan törvény, amely a házalók tevékenységét szabályozta. ${ }^{503}$ Ennél fontosabb azonban, hogy a szabályozás a gyógyszerek kereskedelmét érintette: ,a hatalom, amely a tagállami kormányzatot avégből megillette, hogy osztályozza és szabályozza a vándorárusokat vagy házalókat, és amely a

\footnotetext{
502232 U. S. 334 (1914)

${ }^{503}$ Vö. Emert v. Missouri, 156 U. S. 296 (1895)
} 
szóban forgó törvényben megnyilvánul, halmozottan fennáll, és ha lehet, még nyilvánvalóbban jogszerü ama tény következtében, hogy a kérdéses szabályozás a gyógyszereknek vagy gyógyszerösszetevőknek a vándorárusok vagy házalók általi eladásával foglalkozik, olyan tárgyakkal, amelyek egyértelműen beletartoznak a kormányzat szabályozási hatalmába." ${ }^{504}$ Tehát találkozhatunk egy precedensre támaszkodó argumentummal, valamint a szabályozás és annak tárgya közötti összefüggés kiemelésével. Megítélésem szerint csakis egyetérteni lehet ez utóbbinak az érvelésbe való bevonásával, hiszen önmagában a precedensre való hivatkozás nem lenne kellően meggyőző, elvégre pusztán annak megállapításából, hogy a jogalkotó szabályozhat bizonyos tevékenységi kört, nem következik az, hogy azt bármilyen módon szabályozhatja. A szabályozási tárgy relevanciája és a szabályozás indokoltsága meggyőzőbben igazolja a szabályozás alkotmányosságát. Emellett az, hogy a Supreme Court mindössze egy oldalt szentelt a döntés indokainak kifejtésére, jól szemlélteti, mennyire vitathatatlannak tekintette a jogalkotó kizárólagos kompetenciáját az adott kérdésben.

Hasonló határozottsággal járt el a testület egy olyan tagállami törvény kapcsán, amely orvosi rendelvényhez kötötte a morfium és egyéb narkotikus hatású szerek vásárlását. A Whipple v. Martinson-ügy indokolása szerint „,[n]em férhet kétség ahhoz, hogy a tagállamnak hatáskörében áll a police powert gyakorolni avégből, hogy szabályozza a törvényben is nevesített, veszélyes és függőséget okozó gyógyszerek adminisztrációját, adásvételét, felírását és használatát. E hatalomnak a közegészség és -jólét érdekében való gyakorlásának joga olyannyira nyilvánvaló, hogy szükségtelen lenne fejtegetésekbe bocsátkozni annak kijelentésén túlmenően, hogy e megfontolás szilárdan rögzült, ezért eredményesen nem kérdőjelezhető meg." 505 Figyelmet érdemel, hogy a testület semmilyen irányadó precedenst nem említ álláspontja alátámasztására, csupán ex cathedra megállapítja, hogy az indítványozó érvei minden jogalapot nélkülöznek. Az indokolás szövegének tanúsága alapján annyira magától értetődőnek tekintették a kifejtett

\footnotetext{
504 „[T] $[$ he power which the state Government possessed to classify and regulate itinerant vendors or peddlers exerted in the statute under consideration is cumulatively sustained and made if possible more obviously lawful by the fact that the regulation in question deals with the selling by itinerant vendors or peddlers of drugs or medicinal compounds, objects plainly within the power of government to regulate." 232 U. S. 338 505 „There can be no question of the authority of the State in the exercise of its police power to regulate the administration, sale, prescription and use of dangerous and habit-forming drugs, such as are named in the statute. The right to exercise this power is so manifest in the interest of the public health and welfare, that it is unnecessary to enter upon a discussion of it beyond saying that it is too firmly established to be successfully called in question." 256 U. S. 41, 45 (1921)
} 
álláspontot, hogy még csak azoknak a forrásoknak a meghivatkozását sem tartották szükségesnek, amelyek igazolják annak ,szilárdan rögzült” voltát. ${ }^{506}$

A fentebb ismertetett ítéletekből az tünik ki, hogy a Supreme Court a közegészség védelme okán a jogalkotói beavatkozás lehetőségeinek meglehetősen széles skáláját ismerte el, méghozzá a „mindennapi józan észre” támaszkodva, vagyis a jelen tanulmány fogalmi rendszerében a „dogmatikus passzivizmus” gyakorlatát követve. Ám ennek az attitüdnek is megvoltak a határai, melyeket a Weaver v. Palmer Brothers Co.-ügyben ${ }^{507}$ a többség megítélése szerint a jogalkotó túllépett. A támadott tagállami törvény teljeskörűen megtiltotta a hulladékanyagból (shoddy) készített ágynemü forgalmazását közegészségügyi megfontolásokra hivatkozva. A Supreme Court ezeket a megfontolásokat nem tartotta meggyőzőnek. Indokolásában elvetette azt az érvet, hogy a Powell v. Pennsylvania-ügy irányadó lenne a jelen esetben is, szerinte ugyanis míg a korábbi ítéletben megállapításra került, hogy a margarin tartalmaz vagy tartalmazhat káros összetevöket, amelyek forgalmának korlátozását legitimálják, addig a szóban forgó ügyben bizonyítást nyert az, hogy a fertőtlenítéssel az alapanyag már nem veszélyes az egészségre, ezért felhasználásának korlátozása indokolatlan és alkotmányellenes. ${ }^{508} \mathrm{Az}$ indokolás szövegében nem található hivatkozás olyan forrásra, amely ezt az álláspontot megalapozza, így feltételezhető, hogy az indítvány tartalmazott ilyen anyagot. A Supreme Court itt dogmatikus jellegü érvelést alkalmazott, méghozzá az érintett törvényhely rovására. Ehhez képest Holmes különvéleménye - melyhez Brandeis és Stone csatlakozott - képviseli a „dogmatikus passzivista” álláspontot, miszerint elképzelhető olyan veszély, amelynek elhárítására a jogalkotó indokolhatóan hozta létre a kérdéses szabályozást. ${ }^{509}$ A nehézség abban rejlik, hogy egyfelől az iratok alapján úgy tủnik, a fertőtlenítés bizonyítottan megszünteti a felhasznált anyag miatti fertőzésveszélyt, másfelől azonban a szabályozás egy, a hétköznapi gondolkodás számára magától értetődő összefüggést tükröz, melynek értelmében a szennyes közegből származó, eldobott alapanyagból készült termék potenciális forrása lehet az egészségügyi problémáknak. Ezt szem előtt tartva azt lehet mondani, hogy a Supreme Court fölöttébb ingoványos talajon járt ennek a jogvitának az elbírálása során, ugyanis egyáltalán nem egyértelmü, mennyire alkalmazható az általa felállított szükségesség-arányosság teszt, illetve fennáll-e olyan ésszerü cél-eszköz viszony

\footnotetext{
${ }^{506}$ A támadott törvényhely és a tizennegyedik alkotmánykiegészítés ellentétének kérdését a Supreme Court ebben az egy bekezdésben intézte el. Az indokolás további része a tagállami törvény és egy kongresszusi rendelkezés ütközését vizsgálja; ez az indítványi elem szintén eredménytelennek bizonyult.

${ }^{507} 270$ U. S. 402 (1926)

508270 U. S. 414

509270 U. S. 415
} 
a szabályozás és annak célja között, ami alapján az előbbi alkotmányosnak ítélhető. A Supreme Courtnak a fertőzésveszély kizártságára alapított álláspontja meggyőző, de egyáltalán nem szükségszerűen következik.

Összegzésképpen a következő megállapítások tehetők az e szakaszban tárgyalt döntések vonatkozásában. 39 ítélettel foglalkoztam, ezek közül mindössze kettőben állapította meg a Supreme Court a támadott rendelkezés alkotmányellenességét, ${ }^{510}$ és mindkét esetben fellépett véleménymegoszlás a Supreme Court tagjai között. A maradék 37, a támadott szabályozás alkotmányosságát kimondó döntésböl kilenc esetben merült fel eltérés. ${ }^{511}$ A Supreme Court egészének vagy többségének érvelését jellemezve elmondható, hogy annak középpontjában állt a jogalkotói mérlegelési szabadság messzemenő tisztelete. A Price v. Illinois-ügy ezt érzékletesen példázza azzal, hogy a Supreme Court hangsúlyozta, hogy az alkotmányellenességet kétséget kizáróan kell bizonyítani, szélső esetként pedig a United States v. Shreveport Grain \& Elevator Co.-ítélet említhetö meg, amelyben a testület a központozás tudatos figyelmen kívül hagyásával jutott el végső következtetésére.

Az alkoholforgalommal összefüggő, a jelen szakaszban elemzett 13 ügyből a testület minden esetben alkotmányosnak ítélte a támadott szabályozást, ezen belül három esetben figyelhető meg véleménykülönbség, ${ }^{512}$ e háromból pedig kettőben született szöveges különvélemény. E kettőből a Cox v. Texas-ítélethez fúzött különvélemény tekinthető relevánsnak, mert ebben közvetlenül a tagállami szabályozás terjedelméről esik szó a tizennegyedik alkotmánykiegészítés alapján; a Corneli v. Moore elbírálásakor már a tizennyolcadik alkotmánykiegészítés hatálybalépése miatt nem volt kérdés az alkoholforgalom és -birtoklás korlátozásának terjedelme - függetlenül McReynolds különvéleményétől, melyhez senki más nem csatlakozott. Az egyéb „hagyományosan” károsnak tekintett tevékenységek szabályozásánál az egyhangú és nem egyhangú döntések aránya $3: 3,{ }^{513}$ ugyanakkor csak a Lottery Case-ben született szöveges különvélemény, mely a Kongresszus jogalkotó hatáskörének a Kereskedelmi Klauzula alapján meghatározható terjedelme körül forgott, a szerencsejáték megítélése tehát nem volt vitatott. Ami a harmadik jelentős csoportot illeti, az élelmiszerforgalom biztonságával

\footnotetext{
${ }^{510}$ Ez a két döntés: Jay Burns Baking Co. v. Bryan, Weaver v. Palmer Brothers Co.

${ }^{511}$ Nevezetesen a következö ügyekben: Plumley v. Massachusetts, Lottery Case, Cook v. Marshall County, Hodge v. Muscatine County, Cox v. Texas, North American Cold Storage Co. v. Chicago, Clark Distilling Co. v. Western Maryland Railway Co. and State of West Virginia, Hebe Co. v. Shaw, Corneli v. Moore.

${ }^{512}$ Ezek a következö ügyek: Cox v. Texas, Clark Distilling Co. v. Western Maryland Railway Co. and State of West Virginia, Corneli v. Moore.

${ }^{513}$ Véleménykülönbség mutatkozott a Lottery Case, Cook v. Marshall County, Hodge v. Muscatine Countyügyekben.
} 
kapcsolatos szabályozás esetében 16 esetből egy esetben született alkotmányellenességet kimondó döntés, ${ }^{514}$ és négy esetben alakult ki véleménykülönbség. ${ }^{515}$ E négyből egy nem tartozik a jelen vizsgálódás tárgyához, egy csak a megfelelő eljárás formális értelmezését érinti, egy esetben a különvélemény épp az alkotmányellenessé nyilvánítást vitatja, így végső soron egy olyan eset marad, ahol az alkotmányosság megállapítását érdemben vitatja a testület egy csoportja. A gyógyszerforgalmazással kapcsolatos két vizsgált eset pedig mind egyhangú lett. Mindez azt mutatja, hogy a Supreme Courtban született ugyan némi véleménykülönbség a vizsgált tárgykört illetően, ám ez csupán elenyészö esetben került kibontásra; az alkotmányosság mellett szavazó többségi állásponttal szembehelyezkedők csak ritkán tartották fontosnak, hogy álláspontjukat részletesen ismertessék kollégáik és a széles nyilvánosság előtt.

Érvelését tekintve a legtöbb döntés mögött meghúzódik egy bevett, a priori meggyőződés arról, hogy a szabályozott probléma (potenciálisan) veszélyt jelent(het) a társadalomra, ezért van alkotmányos indoka a kérdéses rendelkezéseknek. Az itt vizsgált ügyeknél ez nem igényel különösebb magyarázatot; az alkohol és a cigaretta káros egészségügyi és társadalmi hatásai régen is, ma is köztudomás tárgyát képezték-képezik, ezért egy ilyen tárgykörben hozott szabályozás alkotmányjogilag legitim mivolta veti fel a legkevesebb kérdőjelet, és hasonló mondható el a gyógyszerek forgalmáról is. Az élelmiszerek forgalma esetében a vaj-margarin vita vált a szembenállás forrásává, mivel itt a jogalkotó két hasonló küllemü és funkciójú termék közül diszkriminálta az egyiket, a megtévesztés kiküszöbölése azonban kellő alkotmányos alapot nyújtott a szabályozás számára. Látható az is, hogy a Supreme Court nem törekedett a jogviták által érintett általánosabb ténykérdések kategorikus eldöntésére, hanem azokban az esetekben, amikor úgy ítélte meg, hogy azokra nem egyértelmű a válasz, a jogalkotói mérlegelési szabadság mellett tette le a voksát; ennek markáns példája a Price v. Illinois-ítélet és az abban emlegetett „vélemények egybeesése”. Ráadásul számos esetben támadtak olyan szabályozást, ami meglehetősen paternalistának vagy protekcionistának tűnik, ilyen szabályok például azok, amelyek a kenyér méretét szabályozzák vagy valamilyen terméket különadóval sújtanak, a Supreme Court mégis - nemritkán egyhangúlag - alkotmányosnak minősítette azokat. Ez a tény azt a megállapítást erősíti, hogy a Supreme Court gyakorlatát nem a laissez-faire eszméjében való mögöttes meggyőződés vezérelte.

\footnotetext{
${ }^{514}$ Ez az eset a Jay Burns Baking Co. v. Bryan volt.

${ }^{515}$ A Jay Burns-ügy mellett a Plumley v. Massachusetts-, North American Cold Storage Co. v. Chicago- és a Hebe Co. v. Shaw-ügyekben.
} 
A fentieken túl rá kell mutatni arra, hogy a ,józan észen” alapuló gondolatmenet egyértelmủen tetten érhető a Supreme Court gyakorlatában, így elmondható, hogy e döntéscsoport tendenciáját tekintve a „dogmatikus passzivista” kategóriába sorolható.

\section{IV.3.4. „Magától értetődő” szabályozási tárgyak: foglalkozások gyakorlására való alkalmasság}

A piac szabályozását célzó rendelkezések között találhatók olyanok, amelyek bizonyos foglalkozások gyakorlásának feltételeit határozták meg. A Supreme Courtnak az ilyen elöírások alkotmányosságát kétségbe vonó indítványokat elbíráló döntései alapján úgy tünik, hogy a testület ezt a tárgykört is a magától értetődően szabályozható viszonyok körébe sorolta.

Az e tárgykörben született legkorábbi döntések egyike a Hawker v. New York, ${ }^{516}$ amelynek relevanciája azonban a jelen vizsgálódás vonatkozásában megkérdőjelezhető. Az ebben az ügyben felmerült konkrét probléma tulajdonképpen nem tartozik szorosan a tárgyhoz, és az alkotmányossági kifogást sem a tizennegyedik alkotmánykiegészítésre alapították, precedensként a későbbi döntésekre gyakorolt hatása miatt azonban szükséges elemezni. Az indítványozó ugyanis egy olyan jogszabály alkotmányosságát vitatta, amely megtiltotta, hogy büntetett előéletü személyek orvosi tevékenységet végezzenek. A Supreme Court érdekes módon nem egyhangúlag fogadta el a szabályozás alkotmányosságát megállapító döntést. A hatfős többség Brewer által előadott álláspontja szerint az orvosi hivatás a szakismeretek mellett a megfelelő jellemet is megköveteli, ezért a szabályozás indokolt. ${ }^{517} \mathrm{Az}$ indítványozó az alkotmány I. cikk 10. szakaszára hivatkozott, amely a tagállamok számára megtiltja a visszaható hatályú törvények (ex post facto laws) alkotását, mindazonáltal a többség a police power dimenziójában tárgyalta a kérdést - a korábbi, irányadónak tekintett precedensek nyomdokain. Ez az értelmezési irány szolgáltatta a törésvonalat a testületen belül, a különvéleményt megfogalmazó Harlan szerint ugyanis a törvény visszaható hatályú: visszaható hatályú az olyan elöírás, amelyik a büncselekménnyel vagy annak következményeivel kapcsolatban valamely személy hátrányára változtatja meg a fennálló helyzetet. ${ }^{518} \mathrm{~A}$ támadott előírás beleesik ebbe a

\footnotetext{
516170 U. S. 189 (1898)

${ }^{517} 170$ U. S. 194

${ }^{518}$ Vö. 170 U. S. 202
} 
definícióba, ebből kifolyólag a vita nem dönthető el a police power terjedelmének meghatározásával, és a hivatkozott precedensek sem irányadók, ugyanis az azok által érintett szabályozás a jövőre irányulóan határozta meg bizonyos foglalkozások kvalifikációs feltételeit, a jogalkotói cél pedig az alkalmasság biztosítása és a megtévesztés elhárítása volt. $^{519}$

A Hawker-ügy e dilemmáját vizsgálva két megállapítás tehető. Egyrészt le kell szögezni, hogy a testületen belül nem volt vita azzal kapcsolatosan, hogy szabadságában áll-e a jogalkotónak bizonyos foglalkozások gyakorlását törvényi feltételekhez kötni. Az ítélet indokolásából és a különvéleményekből is megfigyelhető, hogy a válasz egyértelmüen igen. A különvélemény ennek az álláspontnak a hallgatólagos elfogadása mellett hívta fel a figyelmet arra, hogy a kérdéses törvény visszamenőlegesen súlyosbítja a büncselekmények jogkövetkezményeit, és ez a tulajdonság - nem pedig a foglalkozás gyakorlásának szabályozása - eredményezi - legalábbis a kisebbséget alkotó három bíró szerint - az alkotmányellenességet.

Másodsorban azt kell látni, hogy a Supreme Court többsége még e szembenállás mellett is a jogszabály alkotmányossága mellett foglalt állást, tartózkodva a jogalkotói akarat felülbírálatától. Megítélésem szerint a kisebbségben maradt bírák tévedtek és indokolatlanul kiterjesztő értelmezést alkalmaztak akkor, amikor összekapcsolták a büncselekmény miatti büntetőjogi szankciót és a professzió jogalkotó általi büntetlen előélethez kötését, és ez utóbbit a büntetőjogi szankció fokozásaként értékelték. A jogalkotó a szabályozással ugyanis nem a büncselekmény elkövetőjét akarja további büntetéssel sújtani, hanem a büncselekményre való hajlandóságot, a közösségnek való ártást értékelte olyan morális állapotnak, amely az adott személyt alkalmatlanná teszi bizonyos foglalkozások betöltésére. A kétféle értékelés nem ugyanaz, a kisebbségbe került bírák azonban figyelmen kívül hagyják ezt a distinkciót. ${ }^{520}$ Egy aktivistább bíráság adott esetben felkarolhatta volna a kisebbségi álláspontot, és a visszaható hatályú jogalkotás

\footnotetext{
519170 U. S. $202-204$

${ }^{520}$ Ezzel az okfejtéssel nem akarom azt állítani, hogy a felhozott érvek a mai alkotmányjogi-emberi jogi diskurzusban okvetlenül megállnák a helyüket - miként azt sem, hogy nem. A büntetett elöélet természetesen hátrányt jelent a munkaerőpiacon, ám az, hogy az állam jogszabályban rögzítheti-e a büntetett elő́letűek kizárását bizonyos foglalkozások gyakorlásából - leszámítva értelemszerüen az igazságszolgáltatásban, a rendvédelemben dolgozókat, valamint egyéb állami alkalmazottakat -, vitatható, hiszen önmagában az, hogy valaki elkövetett egy büncselekményt, nem teszi őt alkalmatlanná egy foglalkozás gyakorlására, az pedig, hogy a közvélemény természetszerüleg gyanúval viseltet a büntetett elöéletủ személyekkel szemben, nem szükségszerüen legitimálja az állami beavatkozást. Azt azonban nem szabad szem elöl téveszteni, hogy a vizsgált korban sokkal magától értetődőbbnek számított az erkölcsi állapot és a munkára való alkalmasság közötti összefüggés, ráadásul a büntetőpolitikai közfelfogás sokkal represszívebb volt, így nem számított különlegesnek az, hogy a büntetett elöéletủeket kizárhatónak tartották valamely szakma gyakorlásából különösen ha az olyan jelentős és bizalmas munkakör volt, mint az orvosi.
} 
tilalma alapján alkotmányellenesnek nyilváníthatta volna a támadott törvény helyett. A többség azonban nem tartózkodott ettől a lépéstől.

Akárhogy is, a megfelelő eljárást illetően nem merült fel vita a Supreme Courton belül, és ez az álláspont élt tovább a Reetz v. Michigan-ügyben, ${ }^{521}$ amelyben a támadott törvényhely az orvosi praktizálást egy erre létrehozott bizottság által alkalmassá nyilvánításhoz kötötte. ${ }^{522} \mathrm{Az}$ indítványozó a tizennegyedik alkotmánykiegészítésre és az alkotmány fentebb említett I. cikk 10. szakaszára hivatkozva támadta ezt a rendelkezést, mindkét vonatkozásban eredménytelenül, és a testület mindkét kérdésben a Hawker-ítéletre is támaszkodik. ${ }^{523} \mathrm{~A}$ megfelelő eljárás vonatkozásában az indokolás rögzítettnek és vitathatatlannak tekinti a jogalkotó széles mérlegelési szabadságát az orvosi hivatás gyakorlási feltételeinek meghatározása kapcsán. ${ }^{524}$ 1910-ben a testület az egyenlő törvényi védelem vonatkozásában is megerősítette a fenti formulákat, megállapítva, hogy az elv, miszerint a jogalkotó különösen az egészségüggyel kapcsolatos foglalkozásokat széles körben szabályozhatja, „túlságosan szilárdan le van fektetve, semhogy részletezni kelljen". 525 És habár ez a probléma a leggyakrabban az orvoslás mesterségével összefüggésben merült fel, ${ }^{526}$ a testület egyéb szakmák vonatkozásában is kiterjesztette e

\footnotetext{
${ }^{521}$ Lásd a 387. lábjegyzetet!

${ }^{522}$ Megemlíthető még e körben a Collins v. Texas-ítélet is - lásd a 378. lábjegyzetet -, azonban ebben az ügyben a Supreme Court lényegében az indítványozó érintettségének hiányát állapította meg. Vö. 223 U. S. 295-296

${ }^{523} 188$ U. S. 506, illetve 510

${ }^{524}$ Ami a visszaható hatályú jogalkotás tilalmát illeti, az előadó bíró a Hawker-ügyre támaszkodva a fortiori megállapítja, hogy ha abban az ügyben a büntetett elöélet kizárási okként való megjelölése alkotmányosan elfogadható volt, akkor még kevésbé kifogásolható az, ha a korábbi felelősségre vonástól függetlenül, szigorúbban szakmai érvek alapján történik az alkalmasság megállapítása. 188 U. S. 510. Itt jegyezhető meg, hogy Harlan bíró párhuzamos álláspontjának adott hangot, ám párhuzamos indokolást nem fejtett ki. Csak valószínüsíthető, hogy e megnyilvánulást azért tette, mert a Hawker-ügyet illegitim hivatkozási alapnak tekintette.

525 „It is too well settled to require discussion at this day that the police power of the States extends to the regulation of certain trades and callings, particularly those which closely concern the public health." Watson v. Maryland, 218 U. S. 173, 176. A támadott törvényhely az orvosi hivatás gyakorlását előzetes nyilvántartásba vételhez kötötte, amely alól kivételt képeztek azok, akik a törvény hatálybalépét megelőző egy éven belül legalább tizenkét beteggel foglalkoztak; ezt vélte az indítványozó alkotmánysértő megkülönböztetésnek.

${ }^{526}$ Az orvoslás gyakorlására való alkalmasság jogszabályi kikötését a Supreme Court a vizsgált korszakban végig a lehető legkevésbé vitatható problémák között tartotta számon; ezt tanúsítja a Douglas v. Noble-, valamint a Graves v. Minnesota-ítélet. Lásd 261 U. S. 165 (1923), valamint 272 U. S. 425 (1926).
} 
gyakorlatát Olsen v. Smith-, ${ }^{527}$ illetve a Lehmann v. State Board of Public Accountancyügyben. ${ }^{528}$

A Bradley v. Richmond-ügy ítélete ${ }^{529}$ két vonatkozásban érdemel kiemelést. Egyrészt a szabályozás itt sem az orvoslással és az egészségüggyel függ össze, amely esetben a Supreme Court a leginkább magától értetődőnek tartja az állami beavatkozás lehetőségét. Másrészt a jogalkotó a társadalompolitikai célokat adókivetés útján kívánta elérni a támadott szabályozás révén, vagyis „kevert” szabályozás született, amely két alkotmányértelmezési elv alapján is elbírálható. ${ }^{530}$ A támadott szabályozás értelmében bizonyos foglalkozások gyakorlásának előfeltétele egy meghatározott összegü adó befizetése. Látható, hogy itt már nincs szó arról, hogy a köz védelme érdekében bizonyos szakmai vagy erkölcsi kompetenciák, képesítések jogszabályi szinten megkövetelhetők az adott szakmát gyakorolni kívánóktól: a jogalkotó a megjelölt szakmák gyakorlásának feltételeként pusztán egy adott pénzösszeg kifizetését várta el. A Supreme Court nem talált alkotmányos kifogást az ilyen előírásban: álláspontja szerint - szemben az indítványozó állításával - a szabályozás nem ruházza fel annak alkalmazóját az önkényes megkülönböztetések alkalmazásának lehetőségével, ${ }^{531}$ annak tekintetében pedig, hogy a jogalkotó mely foglalkozásokat vonja a szóban forgó adózási kötelezettség alá, a jogalkotót az alkotmányos keretek között jóformán korlátlan mérlegelési szabadság illeti meg ${ }^{532}$ feltéve, hogy e kategóriákon belül az alanyokat azonos mértékű adó terheli. ${ }^{533}$ A jogalkotó szabályozási szabadsága tehát tovább bővült, és ennek alátámasztását az adóztatás terjedelmével kapcsolatos érvkészlet szolgáltatja.

\footnotetext{
527195 U. S. 332 (1904). A támadott rendelkezésekben a jogalkotó a hajófuvarozással kapcsolatban határozott meg bizonyos körülményeket, egyebek között egy bizottságot hozott létre a szállítási szolgáltatást nyújtók képesítésének, munkájának felügyeletére. Arra mindazonáltal fel kell hívni a figyelmet, hogy ennek az ítéletnek az indokolása homályos, ugyanis nem derül ki az, hogy az indítványozó a tizennegyedik alkotmánykiegészítésnek melyik előírására alapozta indítványát, és csupán a szembenálló felek érveinek ismertetéséből lehet valószínüsíteni, hogy a megfelelő eljárás követelménye szolgáltatta érvelése alapját.

${ }^{528} 263$ U. S. 394 (1923). A közjegyzöként dolgozó indítványozó azt sérelmezte, hogy a szakma felügyeletére rendelt bizottság visszavonta müködési engedélyét, és e cselekményt a törvény nem köti egzakt feltételek fennállásához; ennek során a megfelelő eljárás klauzulájára, valamint a visszaható hatály tilalmára alapította érvelését. Az ítélet indokolásából egyértelmüen a Reetz v. Michigan-ítélet köszön vissza, a testület azonban a lentebb tárgyalandó Douglas v. Noble-ügyre támaszkodott a tagállam jogalkotói mérlegelési szabadságát rögzítve.

${ }_{529}^{102}$ Lásd a 380. lábjegyzetet!

${ }^{530}$ Ehhez lásd a Giozza v. Tiernan-, a Cook v. Marshall County-, valamint a Hodge v. Muscatine Countyítéleteket a IV.3.3. szakaszban!

${ }^{531} \mathrm{Az}$ alkotmányellenes negatív diszkriminációnak a korszakban is legtöbbet idézett példája a Yick Wo v. Hopkins-ügy, melyben a Supreme Court megállapította, hogy alkotmánysértő az a jogszabály, amely a mosodák felügyeletéről rendelkezik, ugyanis a szabályait alkalmazni hivatott szervet implicite felhatalmazza a szisztematikus hátrányos megkülönböztetés gyakorlására, és e lehetőséggel a szerv - a bevándorló kínaiak rovására - élt is. Vö. 118 U. S. 356 (1886).

532227 U. S. 481

533227 U. S. 482-484
} 
Megemlítendő még, hogy az ügyben különvélemény nem született; Lamar bíró - a döntés eredményével egyetértve - nem csatlakozott a többségi indokoláshoz, ám álláspontját nem indokolta részletesen.

A Crane v. Johnson-ítéletet ${ }^{534}$ olvasva a leginkább az szembeszökő, hogy mennyire csekély figyelmet szentel az indokolás az ügy érdemét eldöntő körülménynek. A támadott tagállami törvény regisztrációhoz köti az orvoslás gyakorolhatóságát, ideértve a „nem gyógyszeres” kezelést nyújtó személyek tevékenységét is; ez utóbbi kategóriából azonban nyíltan kivonja az imádságot, amit az indítványozó alkotmánysértő megkülönböztetésként értékelt. Indítványa egyhangú elutasításba ütközött, és a Supreme Court mindössze annyit jelöl meg az alkotmányosság okaként, hogy ,[n]em mondhatjuk azt, hogy a foglalkozásoknak és azok különbségeinek tagállamok általi meghatározása önkényes lenne, és ezért kívül esne a kormányzat hatalmán." ${ }^{535}$ Ezt a megjegyzést leszámítva az indokolás jóformán semmi érdemit nem szól a jogvitát kiváltó helyzetről. Ha tüzetesebben szemügyre vesszük a fennálló helyzetet, az két, egymással ütköző nézőpontból értékelhető. Egyrészt a törvény különbséget tesz a gyógyszeres és a nem gyógyszerek kezelések között, mely utóbbi kategóriába az irracionális kezelések sora is beletartozott, így például maga az indítványozó - mint arra az indokolás szövege utal - saját bevallása szerint a „hitet, a reményt, a mentális szuggesztió és a mentális adaptáció folyamatait" alkalmazta eljárásai során. ${ }^{536}$ Vagyis olyan módszerekhez folyamodott az indítványozó, amelyek a tudomány szemében éppúgy irracionálisnak minősülnek, mint az ima. Másrészt azonban a törvény az irracionális kezelés ez utóbbi válfajait is megkülönböztette, és csak az első esetben társított szankciót a regisztráció elmulasztásához. Természetesen könnyen kimutatható az irracionális gyógykezelés két módja közötti különbség: az ima esetében a vallásgyakorlás egy megnyilvánulási formájáról van szó: az adott vallás egy követője vagy a vallási tevékenységet hivatásszerüen folytató személy (pap, lelkész, stb.) a vallási dogmák szerinti legfőbb hatalomhoz folyamodik a beteg személy érdekében. Az ilyen tevékenység a vallásszabadság körébe sorolható. A szóban forgó rendelkezés esetben azonban a jogalkotó minden bizonnyal az üzletszerü gyógyítási tevékenységet végzők müködését kívánta bizonyos minimális szakmai feltételekhez kötni. Nyilvánvaló, hogy az előadó bíró is ezt a megfontolást tartotta szem előtt az indokolás megfogalmazása során, azonban erre csupán

\footnotetext{
${ }^{534} 242$ U. S. 339 (1917)

${ }^{535}$ „We cannot say that the State's estimate of the practices and of their differences is arbitrary and therefore beyond the power of government." 242 U. S. 344

${ }_{536}$ „He has ... charged ... that he does employ faith, hope and the processes of mental suggestion and mental adaptation.” 242 U. S. 343
} 
minimális utalás történik. Az indokolás szövegéből kiderül: a jogalkotó autentikus értelmezés gyanánt beiktatta azt a rendelkezést, hogy a törvény alkalmazása nem irányulhat egyrészt az orvoslási iskolák közötti diszkriminációra, másrészt a vallásgyakorlás akadályozására. ${ }^{537}$ Később a testület tulajdonképpen ezt az értelmezést szentesíti részletezés nélkül, az indokolás zöme a tényállás, a kérdéses jogszabály, valamint az indítványozó kifogásainak ismertetésére irányul.

A Crane-ügyben benyújtott indítvány mellett a Supreme Court egy másik hasonló indítványt is elbírált; az ebben támadott törvény a gyógyszeres és nem gyógyszeres szemészeti kezelések között tett különbséget; az indítványozó kifogásaival szemben a testület pusztán arra mutatott rá, hogy az általa végzett és a törvényben megjelölt tevékenység különböző elnevezése önmagában nem alkotmányellenességi ok. ${ }^{538}$

Az eddig ismertetett gyakorlat a szakmai alkalmasság feltételeihez kapcsolódott, és ezek a feltételek jellemzően az adott - szinte kivétel nélkül valamilyen gyógyító - szakma megfelelő színvonalon való gyakorlásához szükséges ismeretek birtoklására irányultak, vagyis szervesen kapcsolódtak magához az adott tevékenységhez. A közegészség védelméhez füződő érdek kiemelt alkotmányos jelentőségén túl ez a szoros összefüggés is hozzájárult ahhoz, hogy a Supreme Court jellemzően alkotmányosnak tekintette az ilyen tárgyú szabályozást.

Ezt a gyakorlatot terjesztette ki a - továbbra is egyhangú - La Tourette v. McMasterügy. ${ }^{539}$ A támadott törvényhely itt azt írta elő, hogy a törvényt megalkotó tagállamban Dél-Karolinában - az tevékenykedhet biztosítási brókerként, aki a tagállam bejelentett lakosa és legalább két éve biztosítási ügynök. Az indítványozó a tizennegyedik alkotmánykiegészítés megfelelő eljárási, valamint egyenlő törvényi védelmi klauzulája alapján is támadta a rendelkezést. Az első indítványi elemet a Supreme Court meglehetősen sommásan bírálta el. Az irányadó doktrína ebben az esetben a közérdekkel érintettség elve, melyet a testület a Munn v. Illinois-ügyben fektetett le, ${ }^{540}$ ebben az ügyben azonban a German Alliance Insurance Co. v. Lewis-ítélettel ${ }^{541}$ támasztott alá. A közérdeket a testület abban látta, hogy „rátermett és megbízható” (competent and trustworthy) személyek folytassák a szóban forgó tevékenységet, ami egyszerübben valósítható meg

\footnotetext{
${ }^{537}$ Vö. 242 U. S. 342

${ }^{538}$ McNaughton v. Johnson, 242 U. S. 344 (1917)

539248 U. S. 465 (1919)

${ }^{540}$ Lásd a 260. lábjegyzetet, valamint a hozzá kapcsolódó szöveget!

541233 U. S. 389 (1914). A Supreme Court ebben az ügyben 6:3 arányban állapította meg, hogy a biztosítási tevékenység kellő mértékben érinti a közérdeket ahhoz, hogy legitim szabályozás tárgya lehessen. Különvéleményt Lamar bíró fogalmazott meg, melyhez Fuller és Van Devanter csatlakoztak.
} 
akkor, ha az engedélyt csak helyi lakosok kaphatják meg. ${ }^{542}$ Ez az álláspont annyival lett megtoldva, hogy a Supreme Court rögzítette: nem feladata a jogalkotó céljainak megismerése. $^{543}$

$\mathrm{Az}$ idegen tagállam lakosával szembeni hátrányos megkülönböztetésre való hivatkozást a testület annyival intézte el, hogy a kérdéses törvényi feltételek az idegen tagállam polgáraira is ugyanúgy érvényesek. ${ }^{544}$

A Bratton v. Chandler-ítélet ${ }^{545}$ azért érdemel kiemelést, mert a Supreme Court megváltoztatta az alapügyben eljárt bíróság ítéletét, amely eredetileg alkotmányellenesnek nyilvánította a támadott tagállami rendelkezést. Ennek alapján a tagállam felállított egy bizottságot, amely az ingatlanügyi brókerek és az ingatlankereskedök müködési engedélye fölött diszponál, felhatalmazva azt (egyebek között) arra, hogy bizonyítékokat „kérjen és szerezzen” (require and procure) az engedélyt kérő személy egyes tulajdonságait illetően. A bizottság titokban járt utána az indítványozó bizonyos tulajdonságainak, mire a bíróság, mely elött az indítványozó megtámadta a bizottság döntését, alkotmányellenesnek nyilvánította a támadott rendelkezést, mondván, a „szerezzen” (procure) kifejezés a titkos adatgyüjtésre is felhatalmazza a bizottságot, ami - mivel így az érintettnek nincs lehetősége védekezni - alkotmánysértő. Az ügyet eldöntő fö érv a jogrendszer kíméletének elve, illetve az alkotmánykonform értelmezés követelménye. A Supreme Court álláspontja szerint adható olyan értelmezés a kérdéses kifejezésnek, mely szerint az érintett személy részére a titkos adatszerzés esetén is lehetőséget kell biztosítani saját álláspontja előadására. $^{546}$

A Smith v. Cahoon-ügy ${ }^{547}$ tulajdonképpen mellékesen érinti a jelen szakasz tárgyát. A támadott törvényhely azt írta elő, hogy a gépjármü általi szállítást vállaló személyek tevékenységük megkezdése előtt kötelesek beszerezni egy bizottság hozzájárulását, melyben a bizottság rögzíti, hogy az adott személy tevékenysége fontos és indokolt, ezért engedélyezhető. Az ügy azért „kakukktojás” a jelen kontextusban, mert noha bizonyos tevékenység folytatásának feltételeivel kapcsolatos - s ez indokolja, hogy e helyütt említést tegyek róla -, ez a feltétel nem a kérelmező alkalmasságára irányul, hanem meghatározott közérdek füződik hozzá: a közutak tehermentesítése, a vizsgálat elsődleges szempontja ezért nem az, hogy a kérelmező bármilyen vélt vagy valós okból alkalmas-e az adott

\footnotetext{
${ }^{542} 248$ U. S. 468

543 Uo.

${ }^{544} 248$ U. S. $469-470$

${ }^{545} 260$ U. S. $110(1922)$

${ }^{546} 260$ U. S. $114-115$

${ }^{547} 283$ U. S. $553(1931)$
} 
tevékenység végzésére, hanem az, hogy tevékenysége nem károsítja - a bizottság álláspontja szerint - indokolatlanul az utakat.

A Supreme Court egyhangúlag alkotmányellenesnek ítélte a támadott rendelkezést, méghozzá több indok miatt. A törvény rendelkezett egyrészt a szállítási tevékenységet közszolgáltatási jelleggel végző személyekről (common carriers), másrészt az ugyanezen tevékenységet magánvállalkozás keretei között üzők (private carriers) között, ugyanakkor nem derül ki az, hogy mely rendelkezései irányadók az egyik, és melyek a másik csoportra. A Supreme Court álláspontja szerint ez ellentétes a jogszabályok egyértelmü megszövegezésének követelményével, hiszen büntetőjogi fenyegetés terhe mellett várja el a magánszemélyektől, hogy kiismerjék magukat a szabályozásban. ${ }^{548}$

A második kifogás az volt, hogy a jogalkotó a magánszemélyek között is indokolatlanul különbséget tett, ugyanis bizonyos termékek szállítóit kivonta a törvény hatálya alól, noha ez a kivételezés nem áll értékelhető összefüggésben a szabályozás céljával. ${ }^{549}$ Úgy tünik, a Supreme Court ezen álláspontjának kialakítása során nem merült fel semmilyen vita - legalábbis ilyennek nem maradt nyoma -, ugyanakkor érdemes megjegyezni, hogy az indokolásban nem merül fel annak eshetősége, hogy a jogalkotó méltányolható okból, a helyi gazdaság fellendítése végett alkalmazta a kérdéses megkülönböztetést. A szabályozás alól kivont tevékenységek közé tartozik az agrártermékek, illetve a hal-, kagyló- és rákfélék szállítása, Nem zárható ki az, hogy ezek fontos szegmensét képezték a helyi gazdaságnak, és a jogalkotó nem akarta ezen a téren megnehezíteni a vállalkozások dolgát. Ez az érv megítélésem szerint több puszta spekulációnál: egyrészt a szabályozás a tengerparti Floridában született, ahol kézenfekvő feltételezés, hogy a halászat fontos szerepet tölt be a gazdaságban, másrészt többször is előfordult, hogy a Supreme Court kifejezetten tekintettel volt a helyi viszonyokra. Mindezek fényében különösnek tünik, hogy ez a szempont még csak fel sem merült a szóban forgó ügyben, holott a Supreme Court által lefektetett érvkészlet alapján is relevanciával bírhatott volna.

Az e fejezetben tárgyalt ügycsoportok közül a jelen szakaszban ismertetett halmaz tartalmazza a legkisebb számú ügyet, ezért ennek reprezentativitása a legcsekélyebb. Mindenesetre ezen ügycsoport vonatkozásában egyrészt az mondható el, hogy 12 ügyből mindössze egyben született alkotmányellenességet megállapító döntés, másrészt pedig az,

\footnotetext{
548283 U. S. 565

549283 U. S. $566-567$
} 
hogy az ide tartozó döntések kivétel nélkül egyhangúak. ${ }^{550} \mathrm{Az}$ egyetlen alkotmányellenességet megállapító döntés ${ }^{551}$ pedig részben a jogbizonytalansághoz kapcsolódott, nem önmagában ahhoz, mennyiben ésszerü vagy indokolt az adott megkülönböztetés, részben pedig a vitatott megkülönböztetés alkotmányellenességére vonatkozó érv is kétségbe vonható. Ezeknek az adatoknak a fényében egyértelmü, hogy a Supreme Court nem törekedett arra, hogy a szabályozott foglalkozások tekintetében a piac szürje ki az alkalmatlanokat, a laissez-faire mint mögöttes mozgatóeszme ebben az esetben is kizárható.

A vitatott szabályozás alkotmányosságát alátámasztó fó érv az adott foglalkozásnak a közegészséghez vagy egyéb közérdekhez való kapcsolata, azonban a Supreme Court ezen is túllépett, amikor alkotmányosnak ítélte azt, hogy a jogalkotó a közérdekre való tekintet nélkül, pusztán egy foglalkozás gyakorlásának feltételeként szabott ki különadót. Ugyancsak megfigyelhető az alkotmánykonform értelmezés jelenléte a Supreme Court gyakorlatának ebben az ágában.

\section{IV.3.5. Állami beavatkozás a munkaviszonyba: munkáltatói felelösség az üzemi balesetekért, a tagállamok mérlegelési szabadsága és a fellow servant rule erodálódása}

Meglátásom szerint a munkajogi viszonyok szabályozásával összefüggő Supreme Court-döntések két nagy kategóriára oszthatók. Egyrészt elkülöníthetjük azokat a döntéseket, amelyek a - mai magyar szakkifejezéssel élve - üzemi balesetek miatt a munkavállalókat ért károkért való felelősséget szabályozó - és jellemzően a munkáltatóra terhelő - törvények alkotmányosságát vizsgálták. A másik kategória a munkáltatók és a munkavállalók közötti alkufolyamatok, valamint a munkakörülmények szabályozásával kapcsolatos döntéseket foglalja magába.

$\mathrm{Az}$ első kategória önállóságát részben az idetartozó döntések nagy száma is indokolja, ennél fontosabbak azonban az elkülönítés doktrinális indokai. Amikor a

\footnotetext{
550 Ebbe az összegzésbe nem vettem bele a Hawker v. New York-ügyet, mivel - ahogy arra korábban rámutattam - annak tárgya nem a tizennegyedik alkotmánykiegészítés; a szakasz elején való tárgyalását precedensként való jelentősége indokolta.

${ }^{551} \mathrm{Ez}$ az egy döntés az utolsóként elemzett Smith v. Cahoon.
} 
tagállamok $^{552}$ a munkavállalókat ért, üzemi balesetből eredő károkért való felelősséget szabályozták, a common law akkorra már bevetté vált elvét kérdőjelezték meg. Az úgynevezett fellow servant rule a respondeat superior elvének kivételeként jelent meg. $\mathrm{E}$ szabály értelmében a munkavállalót a munkavégzéssel összefüggésben ért károsodás miatt nem terheli felelősség a munkáltatót, ha a károsodás egy másik alkalmazott gondatlan magatartásának következménye. A fellow servant rule-t Nagy-Britanniában 1837-ben alkalmazták először. Az Egyesült Államokban Lemuel Shaw, a massachusettsi legföbb bírói fórum elnöke vette át először egy 1842-es jogesetben. A szabály hamar az ország kötelmi jogának meghatározó részévé vált. Egyes kutatók szerint a XIX. század végére olyan mélyen beivódott a jogi kultúrába, hogy a jogtudósok óva intették a jogalkotókat és a bíróságokat attól, hogy az „évszázadok bölcsességén és precedensein” alapuló common law-szabályt félreállítsák. ${ }^{553}$

$\mathrm{Az}$ intelmek ellenére a századfordulóra a doktrína törvényhozási szintű visszaszorítását tapasztalhatták az elemzők. ${ }^{554}$ A megfigyelt esetek alapján az mondható, hogy alkotmányértelmezésével a Supreme Court jelentős mértékben asszisztált e változásokhoz. Elöljáróban az az általános észrevétel tehető, hogy az objektív munkáltatói felelösséget korlátozó törvényeknek a tizennegyedik alkotmánykiegészítéssel való összhangja vizsgálata kapcsán két vissza-visszatérő érv jelenik meg: egyrészt a common law-hagyományoktól való elszakadás veszélye, másrészt az egy-egy tevékenységre kiterjedő szabályozás diszkriminatív volta.

A Chicago, Kansas and Western Railroad Co. v. Pontius-ügyben, ${ }^{555}$ mely a vizsgált korszak első releváns esete, a Supreme Court csak megerősített egy korábban hozott döntést, ${ }^{556}$ és a konkrét ügyben jóformán evidensnek vette a megkülönböztetés alkotmányosságát azon az alapon, hogy a ,jellegét tekintve speciális törvény nem es[ik] szükségszerüen az alkotmányos tilalom alá, amennyiben azonos körülmények és feltételek között ugyanazon szabály kerül alkalmazásra”. ${ }^{557}$ Néhány évvel később, 1899-ben, a Tullis

\footnotetext{
${ }^{552}$ Ebben a kérdéskörben szinte kivétel nélkül tagállami szabályozással találkozhatunk, mivel a tagállamokon belül folyó gazdasági tevékenység szabályozása kizárólagos tagállami hatáskörbe tartozik.

${ }^{553}$ Vö. The Creation of a Common Law Rule: The Fellow Servant Rule, 1837-1860. In University of Pennsylvania Law Review, Vol. 132, 1984, 579. o.

${ }^{554}$ Vö. pl. Dabney, Arch'd D.: Abrogation of the Fellow-Servant Doctrine with Reference to Railroad Employees. In Virginia Law Register, Vol. 8, 1902, 245-254. o.

555 157 U. S. 209 (1895)

${ }_{556}^{55}$ Missouri Pacific Railway Co. v. Mackey, 127 U. S. 205 (1888)

${ }^{557}$ „As to the objection that the law deprived railroad companies of the equal protection of the laws, and so infringed the Fourteenth Amendment, this court held that legislation which was special in its character was not necessarily within the constitutional inhibition, if the same rule was applied under the same circumstances and conditions[.]" 157 U. S. 210
} 
v. Lake Erie and Western Railroad Co.-ügyben ${ }^{558}$ ugyanarra az ügyre hivatkozva erösítette meg a Supreme Court egy indianai törvény alkotmányosságát, amely a munkavállalóikat ért üzemi baleseti károsodás bizonyos eseteire megállapítani rendelte a „,vasúttársaságok és egyéb gazdasági társaságok" kárfelelősségét. A Supreme Court ebben az ügyben is magától értetődőnek vette a tagállamok mérlegelési szabadságát e téren, és jóformán nem is foglalkozik a konkrét esettel, helyette precedensek egész sorát idézi, amelyekben az eljárt bíróságok a megkülönböztetés különböző típusait alkotmányossá nyilvánítják. ${ }^{559}$

A Wilmington Star Mining Co. v. Fulton-ügyben ${ }^{560}$ a fentebb említett előzetes észrevételek mindegyike megerősítést nyer. Az indítványozó egy bányászati törvény rendelkezéseit támadta, amelyek értelmében a bányatulajdonosok csak engedéllyel rendelkező bányakezelőket és bányavizsgálókat alkalmazhattak, és a tulajdonosokat kártérítési felelősség terhelte, amennyiben ezen alkalmazottak szándékosan nem biztosítják a dolgozók számára az ésszerüen biztonságos munkaterületet. Az ügy apropója az volt, hogy egy bányász sújtólégrobbanásban életét vesztette, özvegye pedig kártérítésért perelte a bánya tulajdonosát. A jogvita több kérdést érint; a jelen tanulmány témája szempontjából releváns problémát a Supreme Court röviden elbírálta: álláspontja szerint noha a felelősségnek a bányatulajdonosra való terhelése ,nem állt összhangban a common lawnak a megbízó és megbízott viszonyára alkalmazható elveivel, tekintve, hogy a tagállam rendelkezett hatáskörrel ezen elvek társadalompolitikájának megfelelő alakítására és módosítására, nem juthatunk arra a következtetésre, hogy a bányatulajdonosoknak mint külön osztálynak a felelősség megállapítása szempontjából való kiemelése tisztán önkényes volt, és minden indokot nélkülözött.. ${ }^{561}$ Ezen érv mind a megfelelő eljárás, mind az egyenlő törvényi védelem követelményei vonatkozásában irányadó. Ha ezt a döntést a Tullis-üggyel összevetjük, láthatóvá válik, hogy a Supreme Court nem pusztán a jogi és a természetes személyek közötti megkülönböztetést tartotta alkotmányosnak - mint az a korábbi döntésben történt -, de a jogi személyek közötti - tevékenység, nem típus alapján történő - különbségtételnek is szabad utat biztosított.

${ }_{558} 175$ U. S. 348

559 175 U. S. $351-353$

560205 U. S. $60(1907)$

561 „And even although the liability imposed upon the mine owner to respond in damages for the willful failure of the mine manager and mine examiner to comply with the requirements of the statute. was not in harmony, With the principles of the common law applicable to the relation of master and servant it being competent for the State to change and modify those principles in accord with its conceptions of public policy, we cannot infer that the selection of mine owners as a class upon which to impose the liability in question was purely arbitrary and without reason." 205. U. S. 74. Mellékesen jegyezhető meg, hogy egyébként a konkrét anyagi jogi kérdésben a Supreme Court a bányatulajdonos javára döntött, a bányakezelő magatartása és a munkavállaló halála közötti kauzális összefüggést ugyanis nem találta bizonyítottnak. 
Egy későbbi ügyben az indítványozó kifejezetten azt kifogásolta a támadott jogszabályban, hogy az kizárólag a vasúttársaságok alkalmazottaira vonatkozik. A Louisville \& Nashville Railroad Co. v. Melton-ügyben ${ }^{562}$ hozott egyhangú ítélet indokolása értelmében a vasúti dolgozókat érő üzemi balesetek miatti kárfelelősséget a vasúttársaságokra hárító törvény nem ellentétes a tizennegyedik alkotmánykiegészítés egyenlő törvényi védelmi klauzulájával. A Supreme Court meglehetősen szubsztantív érvelése szerint a szóban forgó rendelkezés nem korlátozza a „kormányzati hatalom rendes gyakorlását”, csupán a „,visszaélést”, és önmagában az, hogy a legitim hatalomgyakorlás folytán némi egyenlőtlenség keletkezik, nem oka az alkotmányellenesség megállapításának. ${ }^{563}$ Ebből következően nem alkotmánysértő a vasúttársaságok kárfelelősségét megállapító törvény azért, mert az csak a vasúti munkával együtt járó, speciális kockázatoknak kitett munkavállalókra terjesztette ki kárfelelősségi rendelkezéseit. $^{564}$

Még mielőtt a következő, az eddigiektől némiképp eltérő problémát felvető jogeset tárgyalására sor kerülne, érdemes e helyütt szót ejteni a Jeffrey Manufacturing Co. v. Blagg-ítéletet, ${ }^{565}$ amely tovább erősíti az eddig ismertetett gyakorlatot. Ebben az ügyben a megkülönböztetés alapja az alkalmazottak létszáma volt, és a Supreme Court egyhangúlag alkotmányosnak ítélte azt, ha a tagállami törvény az öt vagy annál több föt foglalkoztató vállalkozások számára azt írja elő, hogy amennyiben nem vetik alá magukat a benne foglalt - a kompenzációval kapcsolatos - elöírásoknak - melyek a munkáltatók számára egy állami biztosítási alapba való befizetés lehetőségét kínálták -, akkor üzemi baleset esetén nem hivatkozhatnak kimentési okként a gondatlan munkavállaló vétkességére. Az indokolás szerint az, hogy a nagyobb létszámú üzemekben a munkatárs gondatlansága miatti baleset bekövetkezésének nagyobb az esélye, mint a kisebb létszámúakban, nyilvánvaló, ezért részletesebb kifejtést nem is igényel. ${ }^{566}$ A gondolatmenetből egy kétszintü logikára látszik támaszkodni: az első szint annak az alapvető összefüggésnek a leszögezése, miszerint a kisebb létszámú üzemek dolgozói kisebb eséllyel tudnak balesetet okozni. A második szint az, hogy az esetleges kapcsolódó jogalkotás során el kell határolni egymástól a „nagyobb” és a „kisebb” létszámú vállalatokat. Mivel e határkijelölés

\footnotetext{
562218 U. S. 36 (1910)

563, ,T]he equal protection of the law clause does not restrain the normal exercise of governmental power, but only abuse in the exertion of such authority, therefore that clause is not offended against simply because as the result of the exercise of the power to classify some inequality may be occasioned." 218 U. S. 52

${ }^{564} 218$ U. S. $53-54$

565235 U. S. $571(1915)$

566 235 U. S. $575-576$
} 
vitathatatlanul jogalkotói kompetencia, ezért a bírósági beavatkozás ebben az esetben szükségképpen kizárandó.

Meglátásom szerint ugyanakkor a testület e bennrejlő logika kézenfekvősége ellenére meglehetősen nagyvonalúan, hovatovább összecsapott módon intézte el a kérdést, hiszen az ilyen balesetek temérdek okból bekövetkezhetnek. Így például nem a munkavállalók létszámának függvénye az, hogy a munkáltató rosszabb minőségű, balesetveszélyesebb munkagépet szerez be, vagy éppen valamelyik alkalmazott ittas állapotban megy be dolgozni. Sőt, adott esetben úgy is lehet érvelni, hogy a kisebb létszámú vállalkozások esetében nagyobb a baleset kockázata, hiszen az ilyen vállalkozások kevésbé tőkeerősek, így - gépek használata esetén - olcsóbb munkagépek beszerzésére törekszenek a költséghatékonyság érdekében, az alacsonyabb ár azonban rosszabb minőséggel is jár(hat), ez pedig növelheti a balesetek esélyét. Jómagam a kutatás során nem találkoztam ilyen vagy ehhez hasonló konkrét esettel, mindenesetre érdemes belegondolni, vajon milyen következtetésre jutott volna a Supreme Court egy ilyen szabályozás alkotmányosságát illetően. Akárhogy is, az egyértelmüen kiviláglik, hogy a Jeffrey-ügyben a testület igen markánsan kifejezésre juttat egyfajta „dogmatikus passzivista” megközelítést; az indokolás gondolatmenetében ugyanis prima facie meggyőző, vagy legalábbis kézenfekvő, racionálisan elképzelhető összefüggések alapján hozta meg döntését.

A fentiek mellett fontos rámutatni arra, hogy a testület az ítéletben tartotta magát a jelen kutatás alapján következetesnek mondható ahhoz a gyakorlatához, miszerint csak a panaszos vonatkozásában felmerült alkotmányos kifogásokat bírálja el érdemben. Ebben az esetben a Supreme Court, tekintettel arra, hogy munkavállalók az ügyben nem éltek alkotmányossági kifogással a törvény vonatkozó elöírásával szemben, nem foglalkozott a munkavállalókat esetlegesen érő, potenciális alapjogi sérelmekkel. ${ }^{567}$

A fenti esetekkel ellentétes probléma merült fel a Mobile, Jackson \& Kansas City Railroad Co. v. Turnipseed-ügyben, ${ }^{568}$ ahol is az indítványozó éppen abban látta az egyenlöség sérelmét, hogy a tagállami törvény disztingválás nélkül vonatkozott minden munkavállalóra. A Supreme Court vitát nem engedő módon tartózkodott attól, hogy felülbírálja a jogalkotó mérlegelését: „,á]m ez a bíróság soha nem értelmezte olyképpen a tizennegyedik alkotmánykiegészítés által a tagállamok meghatározott munkaviszonyokkal kapcsolatos törvényhozási tevékenységére vonatkozó korlátozását, hogy amiatt érvénytelenítse a nyilvánvaló társadalompolitikai elveken nyugvó általános osztályozást,

\footnotetext{
${ }^{567} 235$ U. S. 576

568 219. U. S. 35 (1910)
} 
mert előfordulhat, hogy az osztályozás a nem azonos mértékü veszélynek kitett személyeket is magában foglalja."

Az indítványozó másik kifogása az volt, hogy a törvényhozó önálló csoportként kezelte a vasúttársaságokat, és negatív diszkriminációt alkalmazott velük szemben. A szabályozás értelmében ha a közlekedő vonat dologi vagy személyi kárt okoz, az megdönthető vélelmet keletkeztet arra nézve, hogy a vasúttársaság alkalmazottja nem rendelkezett megfelelő képzettséggel, illetve nem a tőle elvárható gondossággal járt el. Ennek következményeként a vasúttársaságra hárul az ellenkező bizonyításának terhe, a bizonyítási teher ilyetén megfordítása azonban más vállalatok esetében nem merül fel. Erre azonban a Supreme Court azt válaszolta, hogy a bizonyítás szabályai között temérdek vélelem található, és a jogalkotót semmi nem akadályozza ezek kialakításában; mindössze annyi megkötésnek kell érvényesülnie, hogy valamiféle ésszerü kapcsolat álljon fenn a vélelmezö és a vélelmezett tény között. ${ }^{570}$

Az, hogy a Supreme Court ehhez hasonló önmegtartóztató álláspontot juttat érvényre, egyáltalán nem ritka a korabeli gyakorlatban. Arra mindazonáltal érdemes felhívni a figyelmet, hogy a második indítványi elemre a testület tulajdonképpen nem válaszol. Az indítványozó azt kifogásolta, hogy a vasúttársaságok felelősségére külön szabályok vonatkoznak, mint más vállalatokéra, ez pedig indokolatlan megkülönböztetést eredményez. Ehhez képest a Supreme Court a vélelmek felállításának alkotmányosságával foglalkozott, vagyis tulajdonképpen arra a kérdésre adott választ, alkotmányosan elfogadható szabályozás-e a valamely fél számára terhelő tények törvényi (és megdönthető) vélelmezése. Ez a kérdés azonban elsősorban nem az egyenlő elbánással, hanem az eljárás tisztességességével, „megfelelőségével” hozható összefüggésbe. Habár egy ilyen téves indokolásból túlságosan messzemenő következtetéseket nem lehet levonni, mindazonáltal meglátásom szerint ez a felületesség tükröz valamit abból, hogy a Supreme Court úgy tekintett az indítványozó által felvetett problémára, mint amelyet megnyugtatóan sikerült rendezni, és amely nem vet fel további kérdéseket.

A bírói önmegtartóztatás újabb példájával találkozhatunk az Aluminium Company of America v. Ramsey-ügyben. ${ }^{571} \mathrm{Itt}$ a támadott tagállami jogszabály személyi hatálya ismét a vasúttársaságokra terjedt ki, ugyanakkor a természetes személyekre nem, és az

\footnotetext{
569 „But this court has never so construed the limitation imposed by the Fourteenth Amendment upon the power of the State to legislate with reference to particular employments as to render ineffectual a general classification resting upon obvious principles of public policy because it may happen that the classification includes persons not subject to a uniform degree of danger." 219 U. S. 40

570219 U. S. 42-43

571222 U. S. 251 (1911)
} 
indítványozó ezt kifogásolta benne. A Supreme Court az indítványozó ellenvetéseit tömören elvetette; döntésének indokolása szerint ez a különbségtétel pusztán a hasonló tárgyban korábban született precedensek erejénél fogva nem ellentétes a tizennegyedik alkotmánykiegészítéssel. ${ }^{572}$

Rövidsége ellenére több szempontból figyelemreméltó megfontolásokat tartalmaz a döntvénytárakban csak Second Employers' Liability Cases címmel illetett esetcsoport, mely kivételesen egy kongresszusi törvény alkotmányosságát érinti. ${ }^{573} \mathrm{E}$ törvény értelmében a tagállamok vagy territóriumok közötti forgalmat bonyolító vasúttársaságok felelösek az alkalmazottaikat a munkaviszonnyal összefüggésben érő károkért, kivéve ha a károsultak saját gondatlansága is hozzájárult a kár bekövetkezéséhez. Az indítványozó a törvényt a kereskedelmi klauzulával és az ötödik alkotmánykiegészítéssel találta ellentétesnek. Az első kifogást a Supreme Court azzal az érvvel hárította el, hogy a Kongresszus az alkotmány által ráruházott hatáskör gyakorlása során azokat az élethelyzeteket is szabályozhatja, amelyek a tagállamok közötti kereskedelemmel „valós vagy lényegi” összefüggésben (real or substantial relation) állnak. Mivel a tagállamok közötti vasútvonalakon alkalmazott személyeket ért üzemi balesetek miatti felelősség ilyen jellegünek tekinthető, hatásköri alapon nem támasztható velük szemben alkotmányossági kifogás. ${ }^{574}$

Jóllehet fentebb utaltam rá, hogy a jelen tanulmány a tizennegyedik alkotmánykiegészítés alapján hozott döntéseket állítja középpontba, érdemes egy kicsit foglalkozni az imént ismertetett érveléssel. 1918-ban a Supreme Court hozott egy döntést, mely ha nem is vált olyan közkeletủen hírhedtté, mint a Lochner-ítélet, majdnem annyira elrettentő példája a szakmai köztudatban a Supreme Court állítólagos konzervatívkapitalista elhajlásának. A Hammer v. Dagenhart-döntés ${ }^{575}$ értelmében a kereskedelmi klauzulával ellentétes az a kongresszusi törvény, amely bizonyos, kiskorúak

\footnotetext{
572222 U. S. 256

573223 U. S. 1 (1912). A döntés összesen négy jogvita elbírálását tartalmazza, melyeket a bennük felmerült kérdések hasonlósága miatt egyesített a Supreme Court. Mellékesen érdemes utalni rá, hogy az „első” Employers' Liability Casest a Supreme Court 1908-ban bírálta el (207 U. S. 463). Abban az ügyben a kongresszusi rendelkezést kizárólag a kereskedelmi klauzula alapján támadta az indítványozó, és a Supreme Court helyt adott az alkotmányossági kifogásoknak. A többségi döntés ellen több bíró különvéleményben foglalt állást. Így Moody egy leszükítő, alkotmánykonform értelmezést javasolt, amely révén az alkotmányellenessé nyilvánítás elkerülhető, Harlan és McKenna a jogszabálynak a Kongresszus eredeti szándéka szerinti értelmezése mellett foglalt, amely álláspontjuk szerint az alkotmányos határok közé szorította volna a támadott rendelkezések hatókörét, Holmes pedig elvi éllel fogalmazta meg, hogy ha több értelmezési lehetőség adódott, és ezek között volt alkotmánykonform, akkor a testületnek ebből kellett volna kiindulnia.

574 223 U. S. 47

575 247 U. S. 251
} 
munkaerejének igénybevételével készült termékek tagállamközi forgalmát tiltotta. ${ }^{576} \mathrm{Az}$ 5:4 arányban meghozott döntés indokolása szerint a termékek elöállítása nem minősül kereskedelemnek, ezért nem vonható a kereskedelmi klauzula tárgyi hatálya alá. ${ }^{577} \mathrm{Az}$ elóírást nem legitimálja a célja sem, a kereskedelmi klauzulát ugyanis nem azzal a szándékkal alkották meg, hogy a tagállamok közötti gazdasági feltételeket kiegyenlítse. ${ }^{578}$ Ráadásul míg más, korábbi esetekben a tiltás alkotmányosságát megalapozta a termék káros jellege, a konkrét esetben ilyesmiről nem lehet beszélni, mert egy termék káros jellegét nem az határozza meg, milyen munkaerő alkalmazásával állították elő. ${ }^{579}$

Meglátásom szerint a két jogesetben két elv ütközik egymással, és ezek a Hammerügyben eltérő eredményre vezetnének, a Supreme Court pedig azt alkalmazta, amelynek fényében alkotmányellenesnek kell tekinteni a kérdéses jogszabályt. A Second Employers' Liability Cases indokolásában a kereskedelemmel való valós vagy lényegi összefüggés alapozta meg a szabályozás alkotmányosságát. A Hammer v. Dagenhart indokolásának középpontjában két kérdés áll: egyrészt az, milyen tevékenység eshet a kereskedelem határain kívülre vagy belülre, másrészt az, ártalmas-e a közre az adott termék. Ugyanakkor az első elv alkalmazható lenne az utóbbi ügyben is, hiszen a gyártási folyamatról éppúgy elmondható, hogy „valós vagy lényegi” összefüggésben áll a tagállamok közötti kereskedelemmel, mint az alkalmazottak esetleges kárainak megtérülése. Úgy tűnhet, a jogalkotó mérlegelési szabadságát illetően itt következetlenül járt el a Supreme Court. Ugyanakkor több magyarázat is adható erre az eltérésre. Egyrészt elképzelhető, hogy a Hammer-ügyben a Supreme Court többsége valóban ,aktivista” módon járt el. Ezen „aktivizmus” legnyersebb interpretációja természetesen az, hogy az alkotmányellenesség mellett érvelők pusztán a laissez-faire gazdaságpolitika melletti elköteleződésükre hallgattak. Másrészt azonban elképzelhető az is, hogy a többségi indokolás pártján állók határt akartak vonni a tagállami és kongresszusi hatáskörök mögött. A két ismertetett ügyet összehasonlítva jól érzékelhetővé válik, mennyire nehéz elválasztani ezeket a hatásköröket, hiszen gyakorlatilag arról van szó, hogy a tagállamban zajló - és tagállami szabályozás alá eső - tevékenység egy ponton ,átfolyik” a tagállamok közötti kereskedelembe, és a kettő

\footnotetext{
${ }^{576}$ A törvény értelmében tilos volt a tagállamok közötti kereskedelmi forgalomba hozatal céljából szállítani bármely terméket, ha a gyárból történő elszállításuk elött harminc napon belül bizonyos korosztályú munkavállalókat alkalmaztak. A törvény két korosztályt különböztet meg. A tizennégy éven aluliak alkalmazását a munkaidőre tekintet nélkül tiltja, ezzel szemben a tizennégy és tizenhat év közötti kiskorúak esetében csak a napi nyolc órát, illetve heti hat napot meghaladó munkaidőben való, vagy az este hét és reggel hat óra közötti munkavégzést.

577247 U. S. 272

578247 U. S. 273

579247 U. S. 271
} 
között fennálló szerves kapcsolat képlékennyé teszi azt a pontot. Ebből a szempontból nézve azt lehet mondani, hogy a többség tulajdonképpen egy zsinórmértékszerüen alkalmazható distinkció kialakítására törekedett, és ha ezt a kézenfekvő igyekezetet tekintetbe vesszük, akkor enyhíthetünk a kritikák élén. Howard Gillman egy lábjegyzetben említést tesz arról, hogy a Hammer v. Dagenhart-döntés egy tendencia része volt: a Kongresszus a XIX. század végén olyan területeket is szabályozás alá vont, amelyeket hagyományosan nem tekintettek a tagállamok közötti kereskedelem fogalma alá tartozónak, és a Supreme Court mintegy erre reagálva nyilvánította alkotmányellenessé a túlzásnak tartott törvényeket. ${ }^{580}$ Úgy gondolom, a Second Employers' Liability Cases árnyalja ezt a megállapítást, ugyanis kiviláglik belőle, hogy a Supreme Court által a Hammer-ügyben alkalmazott érvelés némileg bizonytalan alapokon nyugszik. ${ }^{581}$

A Second Employers' Liability Cases indokolásának másik része az ötödik alkotmánykiegészítés megfelelő eljárási klauzulája körül forgott. Az indítványozó e rendelkezés sérelmeként értékelte, hogy a törvényben meghatározott felelősség csak a vasúttársaságokat terhelte, más, a tagállamok közötti áruszállítással foglalkozó más társaságokat nem. A Supreme Court ide vonatkozó gondolatmenete azért érdekes, mert, ha csak teoretikus jelleggel is, de felveti annak lehetőségét, hogy az ötödik alkotmánykiegészítésben foglalt megfelelő eljárási klauzula és a tizennegyedik alkotmánykiegészítés egyenlő törvényi védelemről szóló rendelkezése közé egyenlőségjel tehető. A Supreme Court ezt az indítványi elemet is elutasította a Kongresszus széles

\footnotetext{
${ }^{580}$ Gillman 1993: 202. o., 14. lábjegyzet.

${ }^{581}$ Az már csak járulékosan jegyezhető meg, hogy a többségi indokolás fundamentumát képező másik érv, a káros termékek kereskedelme tiltásának legitimitása némi kiterjesztéssel szintén az indokolás ellen fordítható. Lényegében Holmes is ezt tette, amikor úgy érvelt különvéleményében, hogy a civilizált országok között egyetértés áll fenn a gyermekmunka káros mivoltával kapcsolatban. Ugyanakkor érdemes figyelmesen olvasni a különvéleményt, mert annak fö pillére az az elv, hogy a bíróságoknak nincs semmilyen hatásköre a jogalkotó döntéseinek morális meggyőződésük alapján való felülbírálatára, ha azonban a Supreme Court tagjai mégis erre hajlamosak, akkor épp a gyermekmunka tilalma az, amelynek alkotmányosságát - az említett nemzetközi konszenzusra tekintettel - nem kellene megkérdőjelezniük. Holmes ezen érvelésében nehéz nem észrevenni némi cinizmust, mindenesetre látni kell azt is, hogy a többségi indokolással szembeni kritikája azon alapul, hogy a Supreme Court bírái hajlamosak értékítéletüket is bevonni az ítélkezésbe, noha ezt kerülniük kellene, és ha már így tesznek, akkor nem egy olyan jelenség elleni fellépést kellene alkotmányellenessé nyilvánítaniuk, amelynek káros mivolta jóformán közismert. Holmes tömör érvelésével igen élesen rávilágított arra, hogy a piacszabályozás alkotmányosságának megítélése nem egyszer puszta értékítélet függvénye. A többségi indokolással azonban a benne felvázolt fogalmi keret révén is lehet vitatkozni, hiszen megalapozottan lehetett volna oly módon érvelni, hogy noha a gyermekmunkával készített termékek önmagukban nem feltétlenül jelentenek veszélyt az emberekre nézve, mégis szorosan hozzájuk kapcsolódik az a negatív társadalmi hatás, amelyet a fiatal korban végzett munka eredményez, ezért létezik olyan kapcsolat a termék és a káros hatás között, ami a forgalom tiltását alkotmányosan indokolhatja. Azonban még így is probléma marad, hogy Holmes figyelmen kívül hagyta a többségnek a tagállamok közötti kereskedelem fogalmával kapcsolatos okfejtését, így különvéleménye tulajdonképpen nem veszi figyelembe az indokolás minden pontját. Holmes különvéleményének releváns szakaszához lásd 247 U. S. 280 .
} 
mérlegelési szabadságára hivatkozva, ám emellett nem zárta ki kategorikusan a két alkotmányi elöírás közös nevezőre hozását. ${ }^{582}$ Erre azért érdemes felfigyelni, mert noha a megfelelő eljárás követelménye mind az ötödik, mind a tizennegyedik alkotmánykiegészítésben megtalálható, az egyenlő törvényi védelem csak az utóbbiban. Ha a Supreme Court azokat az alkotmányossági kifogásokat, amelyek tagállami vonatkozásban az egyenlö bánásmód követelménye alapján merülnek fel, szövetségi vonatkozásban a megfelelő eljárás követelményének fényében tárgyalja, ezzel abba a technikai hibába esik, hogy nyelvtanilag nem azonos szöveghelyeket azonos szempontok alapján értelmez, és ezáltal azonos jelentést tulajdonít nekik. A jelen esetben a Supreme Court felvetésének nem volt gyakorlati jelentősége, mivel nyitva hagyta a tartalmi azonosság kérdését, ám évtizedekkel később egy hasonló probléma nagyon is aktuálissá vált, a testület ugyanis fokozatosan a tizennegyedik alkotmánykiegészítés által védett „szabadság” körébe vont egyes, a Bill of Rightsban található, eredetileg csak a Kongresszus hatalma ellen védő alapjogokat, melyek ezáltal a tagállami jogalkotás elé is korlátot állítottak. Ennek következtében az a különös helyzet állt elö, hogy míg a Kongresszust két külön rendelkezés tartja vissza például a sajtószabadság megkurtításától, valamint a megfelelő eljárás nélküli szabadságkorlátozástól, addig a tagállamokkal szemben ugyanezen két tilalmat egyetlen rendelkezés tartalmazza. Ugyan a XX. század első harmadában a Supreme Court gyakorlatát ez a fajta alapjog-kiterjesztés nem jellemezte, érdemes megfigyelni, hogy a probléma nyomokban már ekkor is megjelent.

A Second Employers' Liability Casest több kevésbé jelentős döntés követte. Egy ízben a Supreme Court azt állapította meg, hogy az ügy tárgyául szolgáló sérülés keletkezésekor hatályos tagállami jogszabály nem alkotmánysértő, mert abban az időpontban még nem volt hatályban a hasonló esetekre irányadó kongresszusi törvény, mely normakollízió esetén elsőbbséget élvezne; ${ }^{583}$ egy másik esetben a Tullis- és a Meltonügyekben tárgyalt indianai törvény alkotmányosságát erősítette meg azon az alapon, hogy a tagállami legföbb bírói fórum értelmezése szerint a törvény csak a fokozott veszélynek kitett alkalmazottak vonatkozásában írja elő a munkáltató kárfelelősségét, ami az alkotmányossági kifogásokat alaptalanná teszi. ${ }^{584}$ Mindkét esetben egyhangú döntés született.

\footnotetext{
${ }^{582}$ Vö. 223 U. S. 53

${ }^{583}$ Missouri Pacific Railway Co. v. Castle, 224 U. S. 541 (1912)

${ }^{584}$ Chicago, Indianapolis \& Louisville Railway Co. v. Hackett, 228 U. S. 559, 562 (1913)
} 
A New York Central Railroad Co. v. White-ügyben ${ }^{585}$ a Supreme Court New York állam kiterjedt és részletes munkáltatói kárfelelősségi rendszerének alkotmányosságával foglalkozott. A törvény objektív felelősséget rótt minden munkáltatóra a munkavállalókat munkavégzés közben ért károkért, amennyiben az utóbbiak nem szándékosan vagy ittas állapotban okoztak maguknak sérülést. A törvény aprólékosan kiporciózta a fizetendő kártérítés mértékét, az eltartottakat is feljogosította annak követelésére, és lehetőséget biztosított a közigazgatási úton megállapított összeg bírósági felülvizsgálatára. Az indítványozó vasúttársaság szerint a törvény megfelelő eljárás nélkül fosztja meg őt tulajdonától az objektív felelősség miatt, a munkavállalók jogait azért sérti, mert a számítási rendszer alapján nem mindig a károsodással azonos mértékü kártérítés jár nekik, végül pedig mindkét fél szerződési szabadsága sérül, mert nem saját tetszésük szerint határozhatják meg a munkaszerződésben előírt feltételeket. ${ }^{58}$ Pitney, az előadó bíró a kifogásokra válaszképpen ismét rögzítette, hogy a common law szabályai nem módosíthatatlanok, valamint azt, hogy - noha a munkáltatók és munkavállalók közötti felelősségi viszonyok szabályai szoros kapcsolatban állnak a szabadsághoz és a tulajdonhoz való alapjoggal - senkinek nincs elidegeníthetetlen joga ahhoz, hogy bizonyos, reá nézve kedvező rendelkezések változatlanok maradjanak. ${ }^{587}$ Ennek kapcsán arra is rámutat, hogy a fellow servant rule viszonylag új jogintézménynek számít, mely arra a belátásra vezethető vissza, hogy a gondatlan munkatárs által okozott kár a munkavégzéssel járó olyan természetes kockázat, melyet a munkavállalók tudatosan vállalnak. Ugyancsak új keletü a kockázatvállalás általános doktrínája, és mindkettőtől eltekinthetnek a tagállamok. ${ }^{588}$ Az okfejtést a releváns precedensek utalásszerủ felsorolása erősíti meg. ${ }^{589}$

Ezt követően a testület szubsztantív vizsgálódásba bocsátkozik, és a „természetes igazságosság” (natural justice) fényében értékeli a jogszabályt. Ennek során érdekes gondolatmenettel találkozhatunk. Az indokolás mindenekelőtt rögzíti, hogy a törvény a munkaképtelenséget okozó vagy halálos sérülések esetén rendeli el a kártérítés fizetését. Ezután megállapítja, hogy a munkavállalók által elszenvedett sérüléseket a munkafolyamat során fellépő veszteségnek kell tekinteni, éppúgy, mint a gépek tönkremenetelét, vagy az egyéb felmerülő költségeket. Ebből az a következtetés vonható le, hogy a „természetes igazságosság” felől szemlélve nem tekinthető ésszerütlennek, ha - az egyéb járulékos

\footnotetext{
585243 U. S. 188 (1917)

586243 U. S. $196-197$

587243 U. S. $197-198$

588243 U. S. 198-200

589243 U. S. 200
} 
veszteségekhez hasonlóan - a munkavállalót ért súlyos sérülések kockázatát a munkáltatónak kell viselnie. ${ }^{590}$

Ennek a gondolatmenetnek az érdekessége meglátásom szerint abban áll, hogy azt a távolságtartó hangnemet üti meg, amely Holmes érvelésében is gyakran megfigyelhető. Holmes némelyik közismert és sokszor méltatott különvéleményében olyan társadalom képét vázolta fel, amelyben a különbözö érdekcsoportok küzdenek egymással, és ha valamelyikük álláspontja elnyeri a széles választói tömegek rokonszenvét, azzal szemben a bíróságok csak akkor léphetnek fel, ha az adott álláspont nyíltan alkotmányos rendelkezésbe ütközik. ${ }^{591}$ Ez vezetett oda, hogy több ízben kritikusan viszonyult egy adott jogszabályhelyet alkotmányellenessé nyilvánító többségi döntéshez, és elvetette a megfelelő eljárási klauzula szubsztantív értelmezését. ${ }^{592}$ Pitney egész pontosan a következőképpen fogalmaz: „[v]ilágos, hogy a természetes igazságosság talaján állva nem ésszerütlen a tagállam részéröl, hogy míg mentesíti a munkáltatót a common law mércéje alapján megállapításra került kárfelelősség alól, amely őt csak abban az esetben terheli, ha ő maga vagy azon személy, akinek magatartásáért felelősséggel tartozik, vétkesnek bizonyul, megköveteli tőle azt, hogy megfelelő és pontos mértékrendszer szerint számszerüsített, ésszerü összeggel járuljon hozzá a keresőképességben a közös vállalkozás során szerzett sérülés folytán beállott csökkenés jóvátételéhez, tekintet nélkül a gondatlanság kérdésére, ahelyett, hogy hagyná, hogy azon fél viselje a teljes csökkenés következményeit, akinél azok felmerültek - nevezetesen a sérülést elszenvedett munkavállaló vagy eltartottjai." ${ }^{, 593}$ Az idézett szövegrészből az a mögöttes előfeltevés sejlik ki, hogy a szóban forgó probléma megoldására több lehetőség is adott - jelen esetben vagy az, hogy vagy a munkáltató viseli a meghatározott kárért való felelősséget, vagy az érintett munkavállaló viseli a következményeket. Vagyis a tagállamok széles cselekvési szabadsággal rendelkeznek, és a bíróságok csak egy absztrakt, objektív mérce alapján értékelik döntéseiket. Ahogyan Holmesnál az ésszerüség kritériuma egy olyan elvont

\footnotetext{
${ }^{590} 243$ U. S. 205

591 Ennek rövid áttekintéséhez lásd Molnár András: Oliver Wendell Holmes jogi gondolkodása. In Jogelméleti Szemle, 2011/4. szám, http://jesz.ajk.elte.hu/molnar48.pdf (2013. november 29.)

${ }^{592}$ A jelen tanulmány nem Holmes bíróként vallott nézeteire fókuszál, de mellékesen érdemes utalni arra, hogy egyes kutatók, áttekintve Holmes kapcsolódó állásfoglalásait, vitatják a szubsztantív értelmezéssel való szembehelyezkedésének következetességét.

${ }^{593}$ „It is plain that, on grounds of natural justice, it is not unreasonable for the State, while relieving the employer from responsibility for damages measured by common-law standards and payable in cases where he or those for whose conduct he is answerable are found to be at fault, to require him to contribute a reasonable amount, and according to a reasonable and definite scale, by way of compensation for the loss of earning power incurred in the common enterprise, irrespective of the question of negligence, instead of leaving the entire loss to rest where it may chance to fall-that is, upon the injured employee or his dependents." 243 U. S. 203-204
} 
fogalommá vált, ami egyáltalán nem esik egybe a „hasznosság” vagy a „helyesség” elvárásaival, úgy a szóban forgó ügyben is az ésszerüség fogalmának ez a sajátossága domborodik ki. Nem mellékesen arra is érdemes felfigyelni, hogy noha a Supreme Court deklaráltan a „természetes igazságosságra”, egy alapvetően szubsztantív mércére támaszkodik, az idézett szövegrészből kiolvasható távolságtartó attitüd enyhíti az ilyen értelmezés kapcsán természetszerüleg felmerülő aggályokat.

A Supreme Court a White-döntést a közvetlenül utána elbírál két esetben is irányadónak mondta ki. A Hawkins v. Bleakly-ügyben ${ }^{594}$ vizsgált törvény sajátossága az volt, hogy diszpozitív szabályozást alakított ki a munkaügyi kapcsolatokra, a támadott rendelkezés ugyanakkor kikötötte, hogy az üzemi balesetekből eredő munkavállalói károsodásért a munkáltatókat akkor is a törvényben rögzített objektív felelősség terheli, ha egyébként a felek nem a törvényben leírtak szerint rendezik a munkaviszonyt. A White-ügy alapulvétele mellett érdekességként emelhető ki az az érvelés, amely szerint a munkáltatók és a munkavállalók önálló csoportokat alkotnak, ezért megkülönböztetésük alkotmányosan elfogadható, és mindaddig az is marad, amíg az egyes csoportokba tartozó személyek azonos elbánásban részesülnek. A támadott törvény esetében ez a követelmény teljesült, ezért az alkotmányos kifogásoknak nincs helye. ${ }^{595}$

A Mountain Timber Co. v. Washington-ügyben ${ }^{596}$ támadott törvény arra kötelezett bizonyos iparágakban tevékenykedő vállalatokat, hogy meghatározott összeget fizessenek be egy alapba, amelyből az üzemi baleset miatti elhalálozásért vagy munkaképességcsökkenésért kompenzációt fizetnek a károsult munkavállalóknak. A törvény két kategóriába sorolta a munkahelyeket: az egyikbe tartoztak azok, amelyek nem szükségképpen veszélyesek, a másikba azok, amelyek „fokozottan kockázatosak” (extrahazardous), ennélfogva az ezekben dolgozók fokozott veszélynek vannak kitéve. Ez utóbbi kategória a munkahelyek, tevékenységek széles körét ölelte fel, egyebek között az olyan gyárakat, üzemeket, amelyekben gépet használnak, a bányákat, a különböző közlekedési eszközöket, a víz- és gázműveket, emellett lehetővé tette azt is, hogy egyéb, hasonlóan veszélyes munkahelyeket a törvény hatálya alá vonjanak. ${ }^{597}$ A Supreme Court a „természetes igazságosságnak” való megfelelésre tekintettel alkotmányosnak nyilvánította ezt a törvényt is. ${ }^{598}$ Emellett az indítványozók túlzónak tartották a kompenzáció mértékét,

\footnotetext{
594243 U. S. 210 (1917)

595243 U. S. 218

596243 U. S. 219 (1917)

597243 U. S. 229

598243 U. S. 239
} 
valamint a költségek elosztásának módját, ezeket az indítványi elemeket azonban a Supreme Court azzal utasította el, hogy az indítványozók nem hoztak fel elegendő indokot állításaik alátámasztására. ${ }^{599}$ Ugyanakkor érdekes módon a Mountain Timber-döntéssel és csak azzal - szemben négy bíró is jelezte ellenkezését. Mivel álláspontjukhoz nem füztek indokolást, nem derül ki, mely pontokon és milyen okból nem értettek egyet a többségi döntéssel. Ez az ügy annyiban eltér az előző kettőtől, hogy itt a törvény nem pusztán a munkáltatók felelősségét állapítja meg bizonyos esetekben, hanem a konkrét balesetektől függetlenül hoz létre egy alapot, amelybe a munkáltatóknak rendszeresen be kell fizetniük az elöírt hozzájárulást. Nem zárható ki, hogy a kisebbség ezt a körülményt tartotta alkotmányellenes mértékü korlátozásnak, de az is elképzelhető, hogy a többségi állásponttal szemben ők kielégítő részletességünek és alaposnak ítélték a kompenzáció mértékét vagy a költségek elosztásának módját támadó indítványi elemeket.

A Middleton v. Texas Power \& Light Co.-üggyel ${ }^{600}$ folytatódik azon döntések sora, melyekben a Supreme Court egyhangúlag megerősítette egy munkaügyi felelősséget szabályozó törvény alkotmányosságát. Ebben az ügyben ismét egy komplex szabályozási módszerrel lehet találkozni: a támadott törvény egy munkáltatói biztosítási társulást hozott létre, melybe a munkáltatók szabad döntésük alapján léphettek be. Ha beléptek, a munkavállalók, illetve hozzátartozóik nem követelhettek üzemi baleset miatti munkaképesség-csökkenésre vagy elhalálozásra hivatkozva kártérítést, hanem a tagok által fenntartott alapból fizették ki őket. Ha a munkáltató a belépés mellett döntött, erről írásban értesítenie kellett munkavállalóit, akik dönthettek arról, fenntartják-e a megváltozott feltételek mellett a munkaviszonyt, vagy kilépnek. A törvény a szabályozás alól kivont bizonyos munkavállalói csoportokat, egyebek között a házicselédeket, a mezőgazdasági dolgozókat és a vasúttársaságok egy meghatározott körét, továbbá azon munkáltatók munkavállalóit, akik öt főnél nem több alkalmazottat foglalkoztatnak.

Ebben az ügyben ismét előkerült az alkotmányellenes megkülönböztetés érve, melyet a Supreme Court tömör tartózkodással utasított el, és már-már formulaszerủen hivatkozott arra az elvre, hogy az egyenlő törvényi védelem követelménye nem azonosítható azzal az elvárással, miszerint egyetlen jogszabályban kell leszabályozni az adott tárgykör minden szegmensét. Bizonyos csoportoknak a szabályozásból való kihagyása nem fogadható el alkotmányossági kifogásként. ${ }^{601}$ A Supreme Court, noha leszögezi, hogy erre nincs

\footnotetext{
${ }^{599}$ Vö. 243 U. S. $240-242$

${ }^{600} 249$ U. S. $152(1919)$

${ }^{601} 249$ U. S. $157-158$
} 
szükség, mert az alkotmánysértés bizonyításának terhe az indítványozóra hárul, röviden még fel is hoz néhány kézenfekvő indokot az adott szabályozásra. ${ }^{602}$ Az indokolás másik sarkalatos pontja a szabad akarat hangsúlyozása: a Supreme Court kiemelte, hogy a megfelelő vonatkozásokban mind a munkáltatók, mint a munkavállalók rendelkeznek döntési szabadsággal, hiszen az elöbbiek szabadon határozhatják el, hogy belépnek a rendszerbe vagy sem, az utóbbiak pedig maguk dönthetik el, megmaradnak-e munkáltatójuknál az új rendszerben, vagy új munkahelyet keresnek. ${ }^{603}$ Végül a testület arra is rámutatott, hogy nem tekinthető alkotmányos jognak az az igény, hogy egy adott szabályozás változatlan maradjon, ezért alkotmányos alapokon nincs helye kifogásnak, ha az üzemi balesetek során szerzett sérülésekért való felelősség rendezésére a jogalkotó új szabályokat vezet be. ${ }^{604}$

A fentiekből jól látható, hogy a Supreme Court a munkáltatók objektív felelösségének kérdésében következetesen tartózkodott a törvényhozói döntések felülbírálatától. Ez mind a döntések érdemében, mind az indokolások retorikájában markánsan tetten érhetö. Ugyanakkor még a Middleton-döntés évében, 1919-ben született egy olyan ítélet, amely komoly ellentéteket hozott a felszínre. Az Arizona Employers' Liability Cases $^{605}$ cím alatt egyesített ügyek közös vonása, hogy az indítványozók Arizona államnak a munkáltatók üzemi baleset miatti kárfelelősségéről szóló törvényét támadták a tizennegyedik alkotmánykiegészítés alapján. A jogszabály bizonyos foglalkozásokat „kockázatosnak” (hazardous) minősített, és elrendelte, hogy amennyiben az e foglalkozásokat üzők balesetet szenvednek a munkavégzés folyamán, úgy munkáltatójuk kártérítéssel tartozik, feltéve, hogy a sérülés nem a károsult gondatlanságának tudható be. Egy másik törvény a kártérítés mértékéről rendelkezett, melyet az átlagkeresethez igazított, ugyanakkor 4000 \$-ban maximált. E törvények megalkotására a tagállami alkotmány kifejezett felhatalmazást tartalmazott, egyúttal annak XVIII. cikk 4. szakasza kimondta a fellow servant rule eltörlését is.

Pitney, az ügy előadó bírája tulajdonképpen ismerős érvekkel hárítja el az ismerős indítványozói kifogásokat, $\mathrm{s}$ a fentebb ismertetett precedensek immár stabil alapot szolgáltattak neki. ${ }^{606} \mathrm{Az}$ indokolás megerősíti a tételt, miszerint senkinek sincs alanyi joga

\footnotetext{
602249 U. S. $158-159$

603249 U. S. 160,162

604249 U. S. 163

605250 U. S. 400

${ }^{606}$ Vö. 250 U. S. 419
} 
ahhoz, hogy valamely életviszonyt rendező jogszabályokat ne módosítson a jogalkotó. ${ }^{607}$ Ezután megismétli a gazdasági kockázatokról szóló, a White-ügyben kifejtett álláspontját: ennek értelmében nem kifogásolható, hogy a törvény bizonyos veszélyek viselésének pénzbeli kockázatát a jogalkotó a munkáltatóra hárítja. ${ }^{608} \mathrm{~A}$ White-ügy a továbbiakban is meghatározónak bizonyul, mivel Pitney lényegében annak rációjára alapozva támasztja alá, hogy a támadott törvény a közérdeket szolgálja, hiszen a balesetet szenvedett munkavállalók keresőképességének védelmével az elszegényedéstől és az azzal együtt járó bünözési hajlandóságtól is védi az egyént, illetve a társadalmat. ${ }^{609}$

Pitney álláspontja voltaképpen nem más, mint egy ésszerüségi teszt laza alkalmazása: lényege abban áll, hogy a gazdasági tevékenység során bizonyos kockázatok elkerülhetetlenül felmerülnek, és a jogalkotó szabadságában áll meghatározni, melyik fél viselje azokat. A White-ügyben ezt a szemlélet osztatlan egyetértést nyert. Az Arizona Employers' Liability Casesben Holmes olyan párhuzamos indokolást nyújtott be, amely túllépett ezeken a kereteken: „ha azt tekintik a társadalompolitika irányvonalának, hogy bizonyos szabad elhatározásból végrehajtott cselekvések kockázatát a cselekvő viselje, akár a biztonság érdekében, akár gazdasági vagy egyéb okokból, semmit nem tudok felhozni ennek akadályaként. Aki alkalmazottat fogad, vállalja azon magatartás kockázatát, melyet az alkalmazott a munkaviszony folyamán tanúsít, és semmi nem szerepel az alkotmányban, ami az elvet a jelen esetre szükítené."610 A köz által fogyasztott termékek vagy igénybevett szolgáltatások költségébe belekalkulálhatók az előállítással együtt járó személyi sérülések is. Ha közvetlenül a munkáltató viseli az ilyen sérülések anyagi kockázatát, azt a munkáltató hosszú távon áthárítja a fogyasztókra, márpedig e logikai láncot tekintetbe véve nem állítható, hogy ésszerütlen lenne a fogyasztókon számon kérni a termékek, szolgáltatások költségét. ${ }^{611}$ Itt tehát már nemcsak arról van szó, hogy a munkafolyamatban közvetlenül érintett személyek - a munkavállaló és a munkáltató valamelyike kényszerül viselni a kockázatot, és a jogalkotó szabadon kötelezheti erre bármelyiküket, hanem a kapcsolat kiterjed egy olyan személyi körre is, amely nem közvetlenül érintett a munkafolyamatban: a végső fogyasztókra. Holmes tulajdonképpen

\footnotetext{
${ }^{607} 250$ U. S. 420

${ }^{608} 250$ U. S. $420-421$

${ }^{609} 250$ U. S. 424

610, ,[I]f it is thought to be public policy to put certain voluntary conduct at the peril of those pursuing it, whether in the interest of safety or upon economic or other grounds, I know of nothing to hinder. A man employs a servant at the peril of what that servant may do in the course of his employment and there is nothing in the Constitution to limit the principle to that instance." 250 U. S. 432. Holmes párhuzamos indokolásához Brandeis és Clarke bírók is csatlakoztak.

${ }^{611}$ Vö. 250 U. S. 433
} 
szélesebb kontextusba, társadalmi-gazdasági összefüggéseibe helyez egy alkotmányjogi kérdést, nevezetesen a törvényi rendelkezések által érintett munkáltatók alkotmány által biztosított jogai korlátozásának terjedelmét, és azáltal, hogy egy ésszerü kapcsolatot tételez a költségek fogyasztókra hárítása, valamint az alapjogkorlátozás között, voltaképpen azt mondja ki, hogy a következmény - a költségek áthárítása - méltányos, ezért a korlátozás is megengedhető. Végső soron tehát hangsúlyeltolódásának lehetünk tanúi: a kérdést a várható következmény döntötte el Holmes számára, nem a korlátozás önmagában vett értékelése.

A többségi indokolással szemben két bíró élt a különvélemény megfogalmazásának lehetőségével. Az első közülük Joseph McKenna volt, a második James Clarke McReynolds. ${ }^{612} \mathrm{Az}$ előbbi különvéleményéből talán nem is elsősorban maga az érdemi állásfoglalás bír a legnagyobb jelentőséggel, hanem az a gondolat, amellyel okfejtését felvezeti. McKenna voltaképpen elismeri, hogy a többségi döntés beillik a Supreme Court korábbi, hasonló ügyekben meghozott precedenseinek sorába. ${ }^{613}$ Ennek ellenére kritikus álláspontot fogalmaz meg, méghozzá kifejezetten konzekvencialista alapon: „kiterjedésüket [a korábbi döntések kiterjedését] - legalábbis szerintem - nem lehetett előre megjósolni, ezért számomra a jelen ügy túlterjeszkedik azok határain." ${ }^{\text {614 }}$ Szerinte a törvény nemcsak diszkriminál a munkáltatók és a munkavállalók között pusztán e minőségük alapján, ${ }^{615}$ de súlyos alkalmazási bizonytalanságok is felmerülnek vele kapcsolatban, amennyiben a „gyártás” (manufacturing) mint veszélyesnek minősített tevékenység fogalma nincs benne pontosabban kifejtve. ${ }^{616}$ McKenna bírálattal illeti Holmes álláspontját is, szerinte ugyanis az oda vezet, hogy bármilyen jogkorlátozás megengedhető. ${ }^{617}$

A különvéleménye elejét tett megjegyzéssel McKenna lényegében elismerte, hogy szélmalomharcot vív a többséggel, hiszen az általa kritizált elveket, intézményeket - a vétkesség nélküli felelősséget, a munkáltatók és munkavállalók mint csoportok közötti lényeges különbségeket - a Supreme Court kétségkívül alkotmányosként fogadta el. Okfejtésében vitatható pont a jogbizonytalanságra való hivatkozás is. Míg ugyanis egyfelől igaz, hogy a Supreme Court gyakorlatában megfigyelhető az alkotmányellenesség

${ }^{612}$ Megjegyezhető, hogy mindketten csatlakoztak egymás különvéleményéhez, emellett mindkét különvéleményhez csatlakozott White, a Supreme Court akkori elnöke, valamint Van Devanter.

${ }_{613} 250$ U. S. 434

614, „[T]here was, at least to me, no prophecy of their extent, and therefore to me the present case is a step beyond them." Uo.

${ }^{615} 250$ U. S. 435

616 250 U. S. 437

617 250 U. S 439 
megállapítása, amennyiben a támadott rendelkezés valóban annyira homályos kifejezést tartalmaz, hogy a címzettektől ésszerüen nem várható el a jogkövető magatartás, a testület számos esetben elutasította az indítványt, amennyiben úgy ítélte meg, hogy a kifogásolt kifejezés értelmezhető a joggyakorlatban. A jelen esetben megítélésem szerint nem kifogásolható a Supreme Courttól, hogy a „gyártás” szót nem ítélte az alkotmányellenesség mértékét elérően homályosnak.

Az Arizona Employers' Liability Casesben a legmarkánsabb szembenállás McKenna és Holmes véleménye között fedezhető fel, méghozzá a fentebb kifejtett szempontok mentén. McKenna nemcsak a munkáltatói objektív felelősséggel szemben elutasító, de azzal a nézettel szemben is, hogy bizonyos méltányosként vagy igazságosként titulálható következmények előreláthatósága alkotmányossá teszi az alapjogkorlátozást. Holmesszal szemben ő a korlátozás alanyára helyezi a hangsúlyt elemzésében: „a munkáltató és a munkavállaló helyzete közötti különbség, tekintetbe véve, hogy az utóbbiak gazdaságilag kiszolgáltatottabbak, nem igazolja az előbbiek jogainak megsértését, és az egyéni jogok nem tolhatók félre az emberbarátság javára". ${ }^{618}$

McReynolds különvéleményének első fele a nálunk „élő jog”-doktrínaként ismert megközelítésmódot alkalmazza: a tagállami bíróságok értelmezéséből indul ki, amikor a támadott törvény jelentését értelmezi. ${ }^{619}$ Az általa ismertetettekből arra a következtetésre jut, hogy a törvény cizellálás nélkül minden munkáltatóra nézve kötelezö, függetlenül azok méretétől, vagy attól, természetes vagy jogi személyek-e. Szerinte ugyanakkor a törvény el is tér a korábbi esetekben tárgyaltaktól: a törvény semmilyen esetben nem menti fel a munkáltatót a felelősség alól, a common law-beli felelősség helyébe nem lépett másik, ésszerü felelősségi forma (reasonably just substitute), ${ }^{620}$ a foglalkozással rendszerint együtt járó kockázatok veszélyét is a munkáltató viseli, és a felelősség a pénzügyi veszteségeken túl a fizikai és mentális károsodásra is kiterjed.

A White-ügyben vizsgált New York-i törvény alkotmányosságát nem sokkal később ismét támadták. A NewYork Central Railroad Co. v. Bianc-ügy ${ }^{621}$ alapja tulajdonképpen

\footnotetext{
618 ,[T]he difference between the position of employer and employee, simply considering the latter as economically weaker, is not a justification for the violation of the rights of the former, and that individual rights cannot be made to yield to philanthropy[.]" 250 U. S. 437

619250 U. S. 447-449

${ }^{620}$ Mc Reynolds a White- és a Mountain Timber-ügyekre hivatkozva adja elő álláspontját. Ennek kapcsán megjegyezhető, hogy a White-ügyben az „ésszerű helyettesítés” követelménye csak az említés szintjén jelenik meg: az előadó bíró utal rá, hogy annak hiánya nem merült fel az ügyben, ezért szükségtelen foglalkozni vele. Vö. 243 U. S. 201. Ebben természetesen implicite benne rejlik, hogy e követelmény valóban létezik, mindenesetre McReynolds utalása dacára érdemben nem fejtik ki a mibenlétét. A Mountain Timber-ügyben még az utalás szintjén sem merül fel ez a kérdés.
}

${ }^{621} 250$ U. S. 596 (1919) 
egy részletkérdés volt - egy konkrét sérüléstípus bekövetkezése esetén fizetendő kártérítés, illetve annak felső határának alkotmányossága -, és a Supreme Court rövid úton elutasította az indítványt, alkotmányosnak nyilvánítva a törvényt. McReynolds ebben az esetben is szembehelyezkedett a többség álláspontjával, azonban nem fogalmazott meg különvéleményt. Az eset elsősorban azért szolgál érdekességgel számunkra, mert arra mutat rá, hogy McReynolds a Mountain Timber-ügy után markánsabban ad hangot a vitatott törvények alkotmányossága ellen szóló meggyőződésének.

1922-ben a Ward \& Gow v. Krinsky-ítélet ${ }^{622}$ különös ellentétet hozott felszínre. A támadott jogszabály értelmezési lehetőségeit a Supreme Court már-már megdöbbentő mértékig szélesítette. New York állam korábban is vizsgált törvényét a jogalkotó kiterjesztette minden olyan esetre, amikor a munkáltatóval négy vagy több munkás (workmen or operatives) áll tartós munkaviszonyban. A tagállami bíróságok ezt a kiterjesztést úgy értelmezték, hogy akkor is helyt kell adni a kártérítési követelésnek, ha az ilyen munkáltatók egy olyan alkalmazottja szerez sérülést, aki nem tartozik a „munkás” kategóriába. A konkrét ügyben az indítványozónak dolgozó újságárus szerzett maradandó sérülést, amikor a földalatti - melynek állomásán végezte a munkáját - elcsapja a fejét. A Supreme Court megerősítette a tagállami bíróságok álláspontját. Az érvelés középpontjában ezúttal az állt, hogy megfelelő szabályozás hiányában az alkalmazottnak kellene viselnie az üzemi baleset minden következményét, holott ő maga csak épp annyira láthatja ezt előre, mint a munkáltatója, ugyanakkor ez utóbbinál kevesebb lehetősége van intézkedni ellene. ${ }^{623}$ Emellett a felelősség kiterjesztését azért is indokolhatónak tartotta, mert elképzelhető az, hogy a munkáltató egy helyen dolgoztatja az eltérö veszélyességi fokú munkákat végző alkalmazottait, vagy az, hogy a tapasztalatok arra mutattak, a tevékenység típusától függetlenül bármelyik munkavállaló bármikor üzemi baleset áldozata lehet. ${ }^{624} \mathrm{Az}$ indokolás tartalmaz egyéb okokat is, azonban a kiemelt gondolatok bírnak különös jelentőséggel, mert a Supreme Court egy igen absztrakt vélelemre támaszkodott. Korabeli gyakorlatának, érvelési módszerének szerves részét képezte az a megfontolás, hogy egy jogszabály alkotmányosságának vizsgálatánál abból a megdönthető vélelemből kell kiindulni, hogy a jogalkotónak volt ésszerü, alkotmányos indoka a

\footnotetext{
${ }^{622} 259$ U. S. 503. Csak mellékesen érdemes megjegyezni, hogy ezen ügy előtt a Supreme Court elbírált egy szintén a témába vágó jogvitát, ez azonban kétségkívül a „könnyư” esetek közé sorolható, a testület mindössze néhány oldalnyi indokolásban fejti ki, hogy a kérdéses törvényben elöírt munkáltatói felelősségi rendszer kizárólag szénbányászatban való alkalmazása nem alkotmánysértő, tekintettel a szénbányászat más iparágaktól való lényeges eltérésére. Vö. Lower Vein Coal Co. v. Industrial Board of Indiana, 255 U. S. 144 (1921).

${ }_{623} 259$ U. S. $515-516$

${ }^{624} 259$ U. S. 524
} 
szabályozás létrehozására. A jelen esetben a Supreme Court ezt a vélelmet terjesztette ki a végsőkig azáltal, hogy pusztán feltételezett indokokat felsorolva elfogadhatónak ítélt egy jogszabályt, és ennek során teljesen figyelmen kívül hagyta azon - mind az indítványozó, mind McReynolds és McKenna által különvéleményükben felkarolt - ellenérvet, hogy a jogszabály alkalmazása - a tagállami bíróságok jogértelmezési gyakorlata alapján abszurd eredményre vezet, amennyiben a veszéllyel nem járó munkát végzőkre is kiterjed a törvény hatálya a feltételek teljesítése esetén.

A Supreme Court az üzemi balesetekért való felelősség kérdésében számos más irányba is széles mérlegelési lehetőséget hagyott a jogalkotónak. Így alkotmányosnak ítélte azt, hogy a károsult tagállamon kívüli eltartottjainak is fizetnie kell a munkáltatónak, megállapítva, hogy „nincs olyan alkotmányos rendelkezés, amely elöírná, hogy az ilyen típusú törvényi megoldásokból fakadó előnyök kizárólag a tagállam polgáraira vagy lakosaira korlátozódjon." ${ }^{625}$ A Cudahy-ügyben ${ }^{626}$ alkotmányosnak bizonyult az a tagállami rendelkezés, amelynek értelmében a munkáltató kártérítéssel tartozik, amennyiben a munkaviszony a balesethez jelentősen hozzájáruló ok (substantially contributory cause) volt. A Supreme Court - az előadó Sutherland bíró indokolásán keresztül - kifejtette, hogy amennyiben a baleset és a munkaviszony között semmilyen kapcsolat nem mutatható ki, az alkotmányellenességhez nem férhet kétség, ám ha bárminemű összefüggés kimutatható, a testületnek fokozott óvatossággal kell eljárnia, ${ }^{627}$ és ezt figyelembe véve úgy döntött, nem alkotmánysértő, ha a támadott törvény alapján megítélhető a kártérítés annak az alkalmazottnak a javára, akit a munkahelyére vezető legrövidebb úton halálra gázolt a vonat. Ugyancsak alkotmányosnak bizonyult az a szabályozási megoldás, amelynek értelmében a munkáltató, ha az érdekkörébe tartozó balesetben elhunyt munkavállalónak nincsenek eltartottjai, egy alapba köteles egy meghatározott összeget befizetni. ${ }^{628} \mathrm{E}$ döntések azt mutatják, hogy zömmel konszenzus volt a testület tagjai között, egyedül a Cudahy-ügyben történt, hogy három bíró (McKenna, McReynolds, Butler) a többség ellenében szavazott. ${ }^{629}$ Mivel álláspontjukat nem fejtették ki, csak feltételezhető, hogy

\footnotetext{
625, ,[T] here is no constitutional provision requiring that the benefits of such legislative scheme be limited to citizens or residents of the State." Madera Sugar Pine Co. v. Industrial Accident Commission of the State of California, 262 U. S. 499, 503 (1923)

${ }^{626}$ Cudahy Packing Co. of Nebraska v. Parramore, 263 U. S. 418 (1923)

${ }^{627} 263$ U. S. 423

${ }^{628}$ R. E. Sheehan Co. v. Shuler, 265 U. S. 371 (1924), valamint New York State Railways v. Shuler, 265 U. S. 379 (1924)

${ }^{629}$ Mellékesen jegyezhető meg, hogy a Supreme Court egy kapcsolódó tárgyú kongresszusi rendelkezést is alkotmányosnak nyilvánított a Panama Railroad Co. v. Johnson-ügyben, ez azonban a téma szempontjából kevéssé jelentős, mert az ügy középpontjában annak kérdése állt, meddig terjed a Kongresszus tengeri jogot (maritime law) szabályozó alkotmányos hatásköre. Az ötödik alkotmánykiegészítés csak részkérdésként
} 
döntésüket a White-ügyben kifejtett, a tagállamok túl széles beavatkozásától óvó megfontolások motiválták.

A Supreme Court későbbi gyakorlata is egyértelmüen azt a képet mutatja, hogy a testület tagjai között nem merült fel vita. Egyszerü esetként dőlt el, hogy nem éri alkotmányellenes sérelem a munkáltatót, amely az általa opcionálisan elfogadott törvényi rendelkezéseket támadja; ${ }^{630}$ nem bizonyult alkotmányellenesnek a munkavégzés során bekövetkezett haláleset miatt megállapítható, a munkáltatót terhelő büntető kártérítés, mert az emberéletek gondatlan kockáztatásának visszaszorítása legitim állami cél; ${ }^{631}$ a Cudahyügyben alkalmazott doktrína pedig változatlanul továbbélt. ${ }^{632}$ Ugyancsak továbbvitte a Supreme Court a Sheehan Co. v. Shuler-ügyben kifejtett doktrínáját, és egyhangúlag megállapította, hogy a harmadik személy által okozott, munkavégzés közben bekövetkezett halálesetért a törvény alapján perelheti a munkáltató és a felelősségbiztosító a halált okozó személyt. ${ }^{633}$ Meglátásom szerint a Supreme Court passzív gyakorlata a vizsgált időszak végéig nem is változott. Három jelentéktelen esetet leszámítva ${ }^{634}$ csak az 1936-ban elbírált Phillips Petroleum Co. v. Jenkins-ítélet ${ }^{635}$ érdemel említést, az is elsősorban azért, mert a testület fenntartotta azon doktrínáját, miszerint a tagállamok széles mérlegelési szabadsággal rendelkeznek a jogalanyok csoportosítása vonatkozásában, ebből kifolyólag nem alkotmánysértő, ha a törvény csak a jogi személyekre terjeszti ki az üzemi balesetért való munkáltatói felelősségről szóló törvény hatályát, míg a természetes személyek közötti, munkavégzésre irányuló jogviszonyok esetében a fellow servant rule marad az irányadó.

A fentieket összefoglalva a következő mondható el. Az üzemi balesetekért való munkáltatói felelősség kérdésében a vizsgált korszak harmincegy vizsgált ítéletében a

került elő: a Supreme Court egyhangúlag elutasította azon indítványi elemet, hogy a megfelelő eljárás követelményébe ütközik az a rendelkezés, amelynek értelmében az üzemi balesetben megsérült tengerészek több kereseti forma közül választhattak. Vö. 264 U. S. 375, 392 (1924)

${ }^{630}$ Booth Fisheries Co. v. Industrial Commission of Wisconsin, 271 U. S. 208 (1926)

${ }^{631}$ Louis Pizitz Dry Goods Co. v. Yeldell, 274 U. S. 112 (1927)

${ }^{632}$ Bountiful Brick Co. v. Giles, 276 U. S. 154 (1928)

${ }^{633}$ Staten Island Rapid Transit Railway Co. v. Phoenix Indemnity Co., 281 U. S. 98 (1930)

${ }^{634}$ A Crowell v. Benson-ügyben, hasonlóan a Panama Railroad Co. v. Johnson-ügyhöz, a kongresszusi törvény és az ötödik alkotmánykiegészítés viszonya csak részletkérdés volt. A Mattson v. Department of Labor and Industries of Washington-ügyben az volt a kérdés, alkotmányos-e, hogy a jogalkotó egy törvénymódosítással lerövidítette a munkavállalók számára nyitva álló igényérvényesítési határidőt, és a Supreme Court az ésszerüségi tesztet alkalmazva úgy foglalt állást, nem. Az Alaska Packers Association v. Industrial Accident Commission of California-ügyben a testület megállapította, hogy akkor sem alkotmányellenes a munkáltatói kárfelelősség törvényi szabályozása, ha a felek egy másik tagállam törvényének a hatályát ismerték el magukra nézve kötelezőnek, mivel ez utóbbi tagállam volt a munkavégzés tényleges helyszíne. Vö. 285 U. S. 22 (1932), 293 U. S. 151 (1934), 294 U. S. 532 (1935).

635297 U. S. 629 
Supreme Court kivétel nélkül alkotmányosnak ítélte a támadott jogszabályokat. ${ }^{636}$ Noha az indítványozók számos esetben felvetették, hogy a kérdéses jogszabály nincs összhangban a common law-ban bevezetett fellow servant rule-lal, a Supreme Court ezt az érvet egyetlen alkalommal sem fogadta el. Természetesen az indítványozók ezen érve elkönyvelhető közönséges ügyvédi fogásként is, hiszen könnyen megeshet, hogy jogi képviselőik egyszerüen csak felhasználtak minden kézre eső érvet, bármilyen reménytelennek tünhetett is azok alkalmazása. Ugyanakkor némi jelentőséggel bír az a tény, hogy a Supreme Court kimondta a common law szabályainak a jogalkotó által való felülbírálhatóságát. A fellow servant rule ugyan csak viszonylag késön került be a common law anyagába, ám mégiscsak részét képezte annak, az pedig közismert, hogy a common law egyfajta természetjogi jelleggel bírt, hiszen követői olyan normatömegként tekintettek rá, amelynek normáról normára való létrehozatala során a bíróságok csak kimondták az adott helyzetre a dolgok természetéből és a józan észből fakadóan irányadó szabályt. Ennek ellenére a Supreme Court nem e tradicionális státusú normatömeg elsőbbségét deklarálta, és nem is azzal hárította el a fellow servant rule-ra való hivatkozást, hogy ez a szabály csak későn lett a common law része, ezért a jogalkotó félretolhatja azt az adott élethelyzet szabályozása során - szemben például egyéb, több évszázad alatt megerősített szabállyal -, hanem kifejezetten a jogalkotó mérlegelési szabadságára hivatkozott, és egy igen laza ésszerüségi tesztre hagyatkozott.

Figyelmet érdemel az is, hogy a 31 ítéletből 25 egyhangúnak bizonyult, ${ }^{637}$ ehhez képest hat esetben történt, hogy a testület megoszlott az adott kérdés megítélését illetően, ${ }^{638}$ ám írásos különvélemény ezen eseteknek csak egy részében, három alkalommal

\footnotetext{
${ }^{636}$ Mellékesen megemlíthető, hogy egy, a vizsgálódás tárgyával összefüggő ügyben a Supreme Court megállapította a támadott szabályozás alkotmányellenességét, azonban az összefüggés csak felületes, ugyanis a kérdéses rendelkezés nem a munkáltató és a munkavállaló viszonyára vonatkozott, hanem a harmadik személyeknek okozott károk vonatkozásában vélelmezte a kárfelelősség fennállását. Vö. Western \& Atlantic Railroad v. Henderson, 279 U. S. 639 (1929)

${ }^{637}$ Ezek a következök: Chicago, Kansas and Western Railroad Co. v. Pontius, Tullis v. Lake Erie and Western Railroad Co., Wilmington Star Mining Co. v. Fulton, Louisville \& Nashville Railroad Co. v. Melton, Mobile, Jackson \& Kansas City Railroad Co. v. Turnipseed, Aluminium Company of America v. Ramsey, Second Employers' Liability Cases, Missouri Pacific Railway Co. v. Castle, Chicago, Indianapolis \& Louisville Railway Co. v. Hackett, Jeffrey Manufacturing Co. v. Blagg, New York Central Railroad Co. v. White, Hawkins v. Bleakly, Middleton v. Texas Power \& Light Co., Lower Vein Coal Co. v. Industrial Board of Indiana, Madera Sugar Pine Co. v. Industrial Accident Commission of the State of California, Panama Railroad Co. v. Johnson, R. E. Sheehan Co. v. Shuler, New York State Railways v. Shuler, Booth Fisheries Co. v. Industrial Commission of Wisconsin, Louis Pizitz Dry Goods Co. v. Yeldell, Bountiful Brick Co. v. Giles, Staten Island Rapid Transit Railway Co. v. Phoenix Indemnity Co., Mattson v. Department of Labor and Industries of Washington, Alaska Packers Association v. Industrial Accident Commission of California, Phillips Petroleum Co. v. Jenkins.

${ }^{638}$ Ezek a következök: Mountain Timber Co. v. Washington, Arizona Employers' Liability Cases, New York Central Railroad Co. v. Bianc, Ward \& Gow v. Krinsky, Cudahy Packing Co. of Nebraska v. Parramore, Crowell v. Benson.
} 
született. ${ }^{639}$ Ennél is fontosabb, hogy nem figyelhető meg az a tipikus törésvonal a Supreme Court tagjai között, amelyet a szakirodalom oly sürün emleget. Jól példázza ezt, hogy a Bountiful Brick-ügy előadó bírája Sutherland volt, akit pedig nemcsak a szélsőséges konzervatív táborba sorolnak, de az ide tartozók közül az elméletileg legfelkészültebbnek is ismernek el. Sutherland itt egy olyan doktrína alkotmányosságát erősítette meg, amelyet korábban, a Cudahy-ügyben a „szélsőséges konzervatív” tábor két tagja elvetett - igaz, írásos különvélemény nélkül. Az látható tehát, hogy a piac állami szabályozásának eme szegmense fölött a Supreme Court csak igen laza alkotmányossági ellenörzést gyakorolt.

Megfigyelhető, hogy a Supreme Court nem igyekezett a kézenfekvő és a józan ész számára hozzáférhető megfontolások mögé hatolni. Ha a testület szubsztantív érvelésbe bocsátkozott, azzal is csak a kérdéses szabályozás alkotmányosságát támasztotta alá. Az is látható, hogy azok az elképzelhető veszélyhelyzetek, amelyek valamilyen jogalkotói beavatkozást igényelnek, illetve annak legitimitását megalapozták, igen széles kört öleltek fel. A Supreme Court nem támasztott szigorú mércét a jogszabályok címzettjeinek kategorizálásával szemben sem. Ebben az ügycsoportban a Supreme Court részéről tipikusan a „dogmatikus passzivista” attitűd érhető tetten.

\section{IV.3.6. Allami beavatkozás a munkaviszonyba: a munkaidö, a munkabér, és a munkaviszony egyéb feltételeinek szabályozása}

Az üzemi balesetek miatti kárfelelősség, jóllehet számos eset merült fel vele kapcsolatban, csak egy olyan szegmense a munkaügyi kapcsolatoknak, amelyekbe a jogalkotó tudatosan beavatkozott. Emellett egy sor egyéb szabályozás is született, melyek közös sajátossága az, hogy valamilyen módon kifejezetten a munkaszerződésben foglaltak teljesítésével állnak összefüggésben - míg a fentebb tárgyalt ügyeknél a szabályozás a munkavállalót a munkavégzés során ért károsodás miatti felelősségre irányult. Ezek elemzése során a legkézenfekvőbb a munkaidővel és a munkabérrel kapcsolatos ügyekre gondolni, elvégre a leghíresebb-leghírhedtebb döntések ilyen tárgyú rendelkezésekkel

\footnotetext{
${ }^{639}$ Nevezetesen az Arizona Employers' Liability Casesben, illetve a Ward \& Gow v. Krinsky-, valamint a Crowell v. Benson-ügyekben.
} 
foglalkoztak. Ám rengeteg egyéb szabályozás is a Supreme Court elé került alkotmányossági vizsgálatra. Az alábbiakban ezek ismertetése következik. ${ }^{640}$

Utah állam 1896-os törvénye napi nyolc órában maximálta a bányászok, olvasztómunkások munkaidejét, kivéve, ha az életet vagy a tulajdont közvetlen veszély fenyegeti. A törvény alkotmányosságát a tizennegyedik alkotmánykiegészítés megfelelő eljárási és egyenlő törvényi védelmi klauzulái alapján egyaránt támadták, a Supreme Court azonban a Holden v. Hardy-döntésben ${ }^{641}$ elutasította e felülvizsgálati kérelmeket. Érvelésének központi eleme az volt, hogy a változó társadalom változó igényekkel bír, melyekre - a természetes részét képező police power következtében - a jogalkotó megfelelő választ adhat. Jóllehet az Egyesült Államok agrárius korszakában alig volt szükség szabályozásra, az iparosodás és a városiasodás új és új kihívásokat támaszt. Az ezekre való válasz együtt járhat - egyebek közt - a szerződési szabadság vagy a tulajdonjog korlátozásával. ${ }^{642}$ Mivel sem a szerződési szabadság, sem a tulajdonjog nem abszolút, csak az a szabály bizonyulna vitán felül alkotmányellenesnek, amely egy az egyben, kártalanítás és a meghallgatás lehetősége nélkül megfosztja ezektől a polgárokat. ${ }^{643}$

A Supreme Court legitim célnak ítélte a közegészség és a közerkölcsök védelmét célzó szabályozást, ${ }^{644}$ és érdekes módon megjelenik a kor reformpárti retorikájának egy visszatérő eleme is: annak hangoztatása, hogy a kiszolgáltatottabb helyzetű munkás nem valódi érdekei, hanem az éhenhalás fenyegetése alatt bocsátkozik számára prima facie elönytelen munkaviszonyba. ${ }^{645}$

\footnotetext{
${ }^{640}$ A vizsgált időszakban született döntésekkel jóval szűkebb spektrumban már egy korábbi tanulmányban foglalkoztam. Vö. Molnár András: Érvelési minták a „Lochner-bíróság” munkaidő- és minimálbérszabályozás alkotmányosságát vizsgáló döntéseiben. In Jogelméleti Szemle 2009/4. szám, http://jesz.ajk.elte.hu/molnar40.mht (2013. november 29.). Az ott leírtakat e helyütt is felhasználom, a meglátások körét azonban bővítem. A témával korábban is foglalkozott Nagyné Szegvári Katalin egy 2005ös tanulmányában, ő azonban nagyobb hangsúlyt helyezett a New Deal keretében szültetett törvények alkotmányosságával kapcsolatos vitákra, emellett elsősorban jogtörténeti aspektusból vizsgálta az általa elemzett ítéleteket, és nem tett különbséget a vizsgált döntések között aszerint, hogy a ötödik, illetve tizennegyedik alkotmánykiegészítés, vagy a kereskedelmi klauzula állt-e azok középpontjában. Vö. Nagyné Szegvári Katalin: Munkajogi szabályozás és a Legfelső Bíróság joggyakorlata Amerikában. In Béli Gábor Kajtár István - Szekeres Róbert (szerk.): Jogtörténeti tanulmányok VIII. PTE ÁJK, Pécs, 2005, 371-387. o. ${ }_{641} 169$ U. S. $366(1898)$

${ }^{642} 169$ U. S. $392-393$

${ }^{643} 169$ U. S. $390-391$

${ }^{644}$ „De ha a törvényhozó hatalmában áll efféle intézkedéseket tenni polgárai életének védelme érdekében[, hogy ti. a tíznél több embert foglalkoztató szénbányák vezetöit részletes üzemtérkép biztosítására kötelezze], nehéz belátni, miért ne tehetne óvintézkedéseket azok egészségének és erkölcseinek védelmében.” („,But if it be within the power of the legislature to adopt such means for the protection of the lives of its citizens, it is difficult to see why precautions may not also be adopted for the protection of their health and morals.") 169 U. S. 395

${ }^{645}$ Vö. 169 U. S. 397
} 
A Holden-ítélet indokolásában kifejtett megfontolások számos későbbi döntésben visszaköszönnek. Ezek egyik korai példája a Knoxville Iron Co. v. Harbison-döntés, ${ }^{646}$ amelyben a Supreme Court megállapította, hogy nem alkotmányellenes azt elöírni, hogy a munkáltatók szénutalványok helyett - a munkavállaló kérésére - készpénzben fizessék ki az esedékes munkabért. Álláspontja szerint a törvény a munkaszerződésben részt vevő felekre kivételezés nélkül vonatkozik, ezért az egyenlő törvényi védelem követelménye nem sérül. ${ }^{647} \mathrm{Az}$ indokolásban újfent előkerül a felek alkupozíciójában mutatkozó különbségek érve, s ezt a testület azzal erősítette meg, hogy a jogalkotónak szabadságában áll olyan szabályozást alkotni, amely az érdekellentétekből eredő heves összecsapások elkerülését célozza. ${ }^{648}$ A Supreme Court ugyanekkor egy másik ügyet is elbírált az ismertetett megfontolás alapján. ${ }^{649}$ Peckham és Brewer itt is a többségi döntés ellenében szavazott.

A St. Louis Consolidated Coal Co. v. Illinois-ügyben ${ }^{650}$ a Supreme Court olyan tagállami törvény alkotmányosságát vizsgálta, amely egy felügyeleti rendszert hozott létre az ötnél több alkalmazottat foglalkoztató bányák fölött. Ennek értelmében a kormányzó egy bizottság javaslatára bányafelügyelőket nevez ki, akik a törvényben előírt határok közé szorított díjazásra jogosultak minden bányavizsgálatot követően, és a díjat a vizsgált bánya tulajdonosának kell megtérítenie. A Supreme Court úgy ítélte meg, hogy a különböző létszámú bányák közötti megkülönböztetés ésszerü alapokon nyugszik, mert ahol több alkalmazottra van szükség, ott jellemzően veszélyesebb munka folyik, és ezért indokoltabb a szakmai felügyelet. ${ }^{651} \mathrm{Az}$ indítványozók kifogásolták azt is, hogy a felügyelők maguk állapítják meg a vizsgálati díj mértékét, valamint a vizsgálatok gyakoriságát, ezeket a kifogásokat azonban a testület azzal utasította el, hogy nem szabályozható minden apró részlet törvényben, ezért indokolt, hogy az elöre nem látható helyzetekben a felügyelők rendelkeznek döntési szabadsággal. ${ }^{652}$ A döntést a Supreme Court egyhangúlag hozta meg.

Érdemes ezt az ítéletet összevetni egy másikkal, mely azonos ítélkezési évben született, és a döntéshozatal során az imént ismertetettekhez hasonló megfontolások vezették a testületet, ám az ügy végül ellentétes kimenetellel zárult. Az esetre a St. Louis Consolidated Coal-ügyben is hivatkoztak az indítványozók. A Cotting v. Kansas City

\footnotetext{
${ }^{646} 183$ U. S. 13 (1901)

647183 U. S. 19

648183 U. S. $20-21$

${ }^{649}$ Dayton Coal and Iron Co. v. Barton, 183 U. S. 23 (1901)

${ }^{650} 185$ U. S. 203 (1902)

651185 U. S. 208

652185 U. S. 209
} 
Stock Yards Co. and the State of Kansas-ügy ${ }^{653}$ tárgyául szolgáló jogszabály értelmében a száz vagy annál több élőállatot fogató istállótelep nyilvános istállótelepnek (public stock yard) minősül, és ezekre bizonyos vonatkozásokban szigorúbb előírások érvényesek. A Supreme Court alkotmányellenesnek találta a megkülönböztetést, elsősorban azért, mert kivételező jogszabálynak vélte: a hátrányos rendelkezések kizárólag a Kansas Cityben található istállótelepekre voltak alkalmazhatók. ${ }^{654}$ Emellett egy hosszas fejtegetést követően azt is megállapította, hogy az árszabályozó rendelkezések megsértésének aránytalanul súlyos szankcionálása azért alkotmánysértő, mert lényegében elrettenti a potenciális indítványozókat attól, hogy alkotmányossági teszt elé állítsák a törvényt. ${ }^{655}$ Ugyancsak az alkotmányellenességet alátámasztó indokok között szerepelt az a megfontolás, miszerint nem állítható, hogy a 99, illetve a 101 élőállatot tartó istállótelepek különböző tevékenységet folytatnának, ezzel pedig hiányzik a distinkció alapja. ${ }^{656}$ Ebben az ügyben tehát a Supreme Court érvelése két pilléren nyugodott: a konkrét körülményeken és az elvi megfontolásokon. A nyilvánvalóan diszkriminatív szándék kimutatása mellett az elöadó bíró, Brewer fontosnak tartotta, hogy elvi szinten is megszilárdítsa álláspontját. Ez az elvi mérce ugyanaz volt, mint amit a Supreme Court a St. Louis Consolidated Coal-ügyben is alkalmazott: a megítélés attól függött, ránézésre létezhet-e olyan megfontolás, ami a megkülönböztetés számára alapot nyújthat. A St. Louis Consolidated Coal-ügyben a testület evidensnek tekinti, hogy a kevés emberrel müködő bányák természetüknél fogva csekélyebb mértékü felügyeletet igényelnek. A Cottingügyben ellenben nem talált ilyen nyilvánvaló okot, és ennek hiánya el is döntötte a vitát; a testület nem bocsátkozott mélyebb vizsgálódásba a tekintetben, nem léteznek-e olyan lokális okok, amelyek indokolttá teszik a tagállami szabályozást.

Érdemes rámutatni arra, hogy a Cotting-ügy indokolásában megjelennek a liberális kapitalizmus alapvető elvei is. A Supreme Court felteszi a retorikai kérdést, engedhető-e, hogy egy személy profitját pusztán azon az alapon korlátozza a jogalkotó, hogy az túlságosan magas, és e kérdésre nemleges választ ad. ${ }^{657}$ Megítélésem szerint e gondolatok megjelenése összefüggésben áll a két összehasonlított ügy eltérő megítélésével: a St. Louis Consolidated Coal-ügyben nem volt szó a saját keresmény korlátozásáról, csupán egy kötelező biztonsági ellenőrzésről. A Cotting-ügyben viszont közvetlen vagyonelvételre

\footnotetext{
${ }^{653} 183$ U. S. 79 (1901)

${ }^{654} 183$ U. S. 103

655183 U. S. 102

656183 U. S. 112

${ }^{657} 183$ U. S. 105
} 
került sor. Itt a Supreme Court könnyebben juthatott olyan álláspontra, hogy az állam cselekvése az alkotmányba ütközik.

Végül megjegyezhető, hogy ez utóbbi ügyben felszínre kerül némi bizonytalanság, ugyanis két bírói szerepfelfogás versengése érhető tetten. Brewer terjedelmes okfejtésében egy stabil, hosszú távra szóló elvi alapot dolgoz ki, értelemszerủen azzal a célzattal, hogy az a jövőben is zsinórmértékként szolgáljon a jogalkotói döntések alkotmányossági megítéléséhez. Ezzel szemben a Supreme Court hat bírája egy bekezdésnyi párhuzamos indokolásban azon álláspontját fejtette ki, hogy elegendő lenne pusztán arra hivatkozással alkotmányellenessé nyilvánítani a kérdéses jogszabályt, hogy nyílt diszkriminációt kíván megvalósítani. Itt kétféle bírói megközelítésmód ütközik egymással. A párhuzamos indokolásban egy önmegtartóztató nézet jut kifejezésre, mely szerint elegendő csupán a legnyilvánvalóbban alkotmánysértő körülményre hivatkozni. Ezen érv mögött implicite ott rejlik az a megfontolás, hogy tartózkodni kell az átfogó elvek lefektetésétől, mert nem látható előre, milyen új esetek merülnek, fel, amikor ezek az elvek vagy módosításra szorulnak, vagy az újabb társadalmi problémák újszerü megoldását gátolják. Tulajdonképpen a Sunstein munkásságában részletesen kidolgozott „burke-i minimalizmus" kristálytiszta megnyilvánulásával találkozhatunk itt, ${ }^{658}$ még ha ennek teoretikus kifejtése értelemszerüen nem található meg az egyetlen bekezdésnyi párhuzamos indokolásban. Noha meglehetősen paradox helyzetet eredményezett, hogy a testület többsége párhuzamos indokolást fogalmazott meg, a jelen tanulmány témája szempontjából jelentős körülmény, hogy a Supreme Court többsége ezt az önmegtartóztató, esetről-esetre haladó attitüdöt tette magáévá.

Szót kell ejteni arról, hogy a St. Louis Consolidated Coal-ügyben kifejtett doktrínát a Supreme Court továbbvitte más, későbbi precedensekben, így a McLean v. Arkansas-, ${ }^{659}$ valamint a Booth v. Indiana-ügyekben. ${ }^{660}$ A jogalkotó mindkét esetben az alkalmazotti létszámtól tette függővé az adott szabályozás hatályát; a korábbi esetben a tíz vagy több bányászt foglalkoztató bányák tulajdonosai számára tilos volt bérfizetés előtt átvizsgáltatni a bányászott szenet, és levonni a bérből a fölösleges anyag arányát; a második esetben a húsz vagy több főt alkalmazó bányák tulajdonosai kötelesek voltak mosdót létesíteni a dolgozók számára. Megítélésem szerint a Supreme Court kiterjesztette a St. Louis Consolidated Coal-ügyben alapul vett elvet egyfajta mechanikus precedensalkalmazással.

\footnotetext{
${ }^{658}$ Vö. Sunstein, Cass R.: Burkean Minimalism. In Michigan Law Review, Vol. 105, 2006, 362-386. o. ${ }^{659} 211$ U. S. 539, 551-552 (1909)

${ }^{660} 237$ U. S. 391, 397 (1915)
} 
A szóban forgó döntés indokolásában az előadó bíró a dolgozói létszám és a bánya mélysége, illetve biztonságossága közötti összefüggéseket ecsetelte, és mivel reális összefüggést vélt felfedezni, alkotmányosnak ítélte a szabályozást. A később elbírált két ügyben már csak hivatkozás történik a St. Louis Consolidated Coal-, illetve a McLeanügyekre, és mindkét esetben a kérdést rövidre zárva kijelentik, hogy a hasonló osztályozás egyszer már alkotmányosnak ítéltetett, ezért a konkrét esetben is ezt kell megállapítani. Észre kell venni azonban, hogy ezekben az ügyekben nem alaptalan amellett érvelni, hogy a szabályozás és a létszám között lazább az összefüggés. Ez különösen a McLean-ügyben mutatkozik meg igen erőteljesen: a támadott törvény célja, mint a Supreme Court megállapította, a csalárd elbánás kiküszöbölése a bérszámítás során, ez pedig legitim cél. ${ }^{661}$ Egy szigorúbb alkotmányértelmezési megközelítést követve azonban úgy is lehetne érvelni, hogy még ha legitim is a cél, azzal a megkülönböztető rendelkezés nem áll összefüggésben, hiszen ha a csalárd elbánás kiküszöbölése a cél, akkor érthetetlen, miért járnának el a kevesebb alkalmazottat foglalkoztató munkáltatók kevésbé csalárdul, mint a több alkalmazottat foglalkoztatók. A Supreme Court nem ezt az utat választotta - és noha Brewer és Peckham a többségi ítélet ellen szavazott, különvéleményt nem fogalmaztak meg, ezért nem ismerhetjük meg álláspontjukat teljes bizonyossággal -, ez pedig ellentmond a „konzervatív aktivizmus” sztereotípiájának.

1903-ban két kevéssé jelentős ügy született, melyek mindazonáltal a munkaviszony szabályozásával állnak összefüggésben. A Patterson v. Bark Eudora-eset ${ }^{662}$ a Kongresszus hatáskörét érintette, és az volt az eldöntendő kérdés, megtiltható-e alkotmányosan az, hogy a tengerészek bérét elöre kifizessék. A jogvitában hatásköri kérdések is felmerültek, melyek kapcsán a Supreme Court úgy foglalt állást, hogy ha a munkáltató által folytatott kereskedelem több tagállam területére terjed ki, akkor a Kongresszus jogosult az ilyen tevékenységet szabályozni. Ennél fontosabb azonban a megfelelő eljárási klauzulára ${ }^{663}$ alapozott indítványi elem elbírálása: a testület itt köztudomású tényként kezelte azokat a visszaéléseket, amelyekre a tengerészek bérének előre történő kifizetése lehetőséget nyújt, ${ }^{664}$ ezért a szerződési szabadság korlátozását indokoltnak tartotta. Az Atkin v. Kansasügyben ${ }^{665}$ vizsgált törvénye az állam által közmunkára alkalmazott dolgozók munkaidejét

\footnotetext{
${ }^{661}$ Vö. 211 U. S. 550

662190 U. S. 169

663 Érdekes módon az indítványozó itt a tizennegyedik alkotmánykiegészítésre hivatkozott, holott a Kongresszus által hozott törvény megtámadása esetén az ötödikre kellett volna. A Supreme Court erre nem tér ki, valószínüleg nyilvánvaló elírásként kezelték a tévedést.

664190 U. S. 175

665191 U. S. 207
} 
napi nyolc órára szükítette, emellett minden közmunka elvégzésére irányuló, az állam és magánszemélyek között létrejött szerződés teljesítése során ezt az időtartamot jelölte meg irányadóként. A tizennegyedik alkotmánykiegészítés első szakaszának sérelmét állító indítványt a Supreme Court elutasította, abból a megfontolásból, hogy az állami társaságok az állam teremtményei, melyeket az államhatalom gyakorlása céljából hoztak létre, ily módon az állam tetszése szerint szabhatja meg a feladat teljesítésének feltételeit. ${ }^{666}$ Említésre méltó, hogy az indokolásban a testület kifejezetten hangoztatja: nem kívánja eldönteni, alkotmányos-e az olyan munkaidő jogszabályi korlátozása, melyet két magánszemély szerződésben határoz meg. ${ }^{667}$

Az Atkin-ügyben deklaráltan nyitva maradt jogkérdés megválaszolására mindössze két évet kellett várni. 1905-ben egy New York-i kispékség tulajdonosa alkotmányossági alapon megtámadott egy New York-i jogszabályt arra hivatkozva, hogy a jelzett rendelkezés ütközik a munkáltatók és a munkavállalók szerződési szabadságával. Peckham bíró helyt adott a panasznak. Meglátása szerint a kifogásolt törvényhelyben szereplő „require” kitétel ${ }^{668}$ nem jelent egyebet, mint a szerződéses kötelezettség teljesítésére való kötelezést, melynek tilalma azonban sérti a szerződés alkotmányos szabadságát. ${ }^{669} \mathrm{Az}$ általános tétel lefektetése után, miszerint az államnak jogában áll a tulajdonhoz való jogot és a szerződési szabadságot korlátoznia, amennyiben „a köz biztonsága, egészsége, erkölcsei, általános jóléte" (safety, health, morals and general welfare of the public) úgy kívánja, ${ }^{670}$ elhatárolja a jelen szituációt a munkaidőt érintő két korábbi esettől, majd rátér az államhatalom korlátainak hangsúlyozására. A police power csak „méltányosan,

\footnotetext{
${ }^{666} 191$ U. S. 220. Érdekes, hogy indokolásában Harlan az állami társaságokat helyezi középpontba, annak ellenére, hogy a vitatott rendelkezés nem csak az állammal kimutathatóan függő viszonyban álló társaságok, hanem azon magánszemélyek alkalmazottaira is vonatkozik, akik/amelyek az állammal közfeladat elvégzése céljából szerződést kötnek.

${ }_{667}$ „Annak kérdése, vajon alkotmányosnak bizonyulna-e egy hasonló, tisztán magánjellegű munkát végző dolgozókra vagy alkalmazottakra vonatkozó jogszabály, óriási jelentőséggel bír, és itt nem áll módunkban eldönteni, vagy akár csak fontolóra venni.” (,Whether a similar statute applied to laborers or employees in purely private work would be constitutional is a question of very large import which we have no occasion now to determine or even to consider.") 191 U. S. 219

${ }^{668}$ A releváns szöveghely a következö. „Tilos megkövetelni az alkalmazottaktól, avagy engedni az alkalmazottaknak, hogy a keksz-, kenyér- és kalácssütödékben, valamint a cukrászipari létesítményekben többet dolgozzanak heti hatvan, illetve napi tíz óránál, hacsak nem abból a célból, hogy a hét utolsó munkanapját lerövidítsék; továbbá tilos meghaladni azt a heti munkaóraszámot, mellyel átlagosan tíz órányi munka jut minden olyan napra, amelyen az alkalmazott dolgozik.” („No employee shall be required or permitted to work in a biscuit, bread or cake bakery or confectionery establishment more than sixty hours in any one week, or more than ten hours in any one day, unless for the purpose of making a shorter work day on the last day of the week; nor more hours in any one week than will make an average of ten hours per day for the number of days during such week in which such employee shall work.") A vonatkozó jogszabályszöveget néhány további §-sal együtt (110-115. §) mellékelték a döntés szövegéhez, lásd: 198 U. S. 46 (kiemelések tölem).

${ }^{669} 198$ U. S. $52-53$

${ }^{670} 198$ U. S. 53
} 
ésszerüen, megfelelöen" gyakorolható (fair, reasonable and appropriate exercise of the police power), míg az alapjogok „ésszerütlen, szükségtelen, önkényes” (unreasonable, unnecessary and arbitrary) megsértése tilos. ${ }^{671}$ Márpedig a kifogásolt rendelkezés ez utóbbit valósítja meg. A pékek semmilyen szempontból nem gyámoltjai az államnak. ${ }^{672} \mathrm{~A}$ rendelkezés nem egészségügyi rendelkezés, mert a közfelfogás szerint a sütőipari munka nem egészségtelenebb egyéb hétköznapi munkáknál. ${ }^{673}$ És mivel tartalmilag nem sorolható a police power legitim gyakorlásának egyéb aleseteibe, önmagában attól, hogy az állam egészségügyi szabályozásnak minősíti, még nem tekinthető alkotmányosnak. ${ }^{674}$ Ezek mellett egy ad absurdum érvet is olvashatunk: Peckham arra figyelmeztet, hogy ha a tárgyalt szabályozás zöld utat kap, legközelebb az állam - mondvacsinált - egészségügyi okokra hivatkozva a szellemi dolgozók, a tudósok, vagy éppen a sportolók munkaidejét is korlátozhatja, ami pedig nemkívánatos szélsőség. ${ }^{675} \mathrm{E}$ megfontolások alapján a Supreme Court szerény többsége alkotmányellenesnek nyilvánította a Bakeshop Act megtámadott rendelkezését.

A jól ismert indokolást nem kevésbé ismert különvélemények követik. John Marshall Harlan szerint a jogalkotó célja legitim, a szabályozás arányos, nem önkényes: a kor szakirodalma alátámasztja a pékek ${ }^{676}$ munkája és az egészségkárosodás közötti összefüggést, a Bakeshop Act minden tekintetben megállja a helyét egészségügyi szabályozásként. ${ }^{677}$ Álláspontját Edward Douglass White és William Rufus Day is osztotta. Oliver Wendell Holmes pedig azt kifogásolta, hogy a Supreme Court belemagyaráz egy adott gazdaságfelfogást a legkülönfélébb világnézetü emberek számára íródott alkotmányba, és megfosztja New York állam többségét bizonyos társadalmi problémák az alkotmány által szó szerint nem tiltott módon való kezelésétől. ${ }^{678}$

\footnotetext{
${ }^{671}$ Vö. 198 U. S. 56.

672198 U. S. 57

${ }^{673} 198$ U. S. 59

674198 U. S. 61

675198 U. S. 60-61

${ }^{676}$ Az ügy tárgyalásánál általában csak a pékeket említik a szabályozás alanyaiként, jóllehet, mint fentebb láthattuk, az szélesebb személyi körre is kiterjed. Az egyszerúség kedveért, továbbá bizonyos, a Bakeshop Act létrejöttét övezö körülményeket szem elött tartva (melyek részletes taglalásához lásd: Kens: i. m. 49-66. o.!) azonban én is maradok a pékeknél.

${ }^{677}$ Egy 2005-ös tanulmány kimutatta, hogy bár az orvostudomány ma már nem igazolja a századforduló idején dolgozó pékek munkája és az egészségromlás közötti összefüggést, akkori állása szerint valóban szoros kapcsolat állt fenn a kettő között, így ebben az értelemben a testület többsége valóban figyelmen kívül hagyta a - korabeli - valóságot. Vö. Bewig, Matthew S. R.: Laboring in the "Poisonous Gases": Consumption, Public Health and the Lochner Court. In New York University Journal of Law \& Liberty, Vol. 1, 2005, 476-495. o.

${ }^{678} 198$ U. S. 74-76. Holmesnak a társadalom „kísérletezéséről” vallott gondolatai jól kifejezésre jutnak az 1919-es Abrams v. United States-ügyben (250 U. S. 616) a szólásszabadság kapcsán írt különvéleményében. Lásd különösen: 250 U. S. 63.
} 
Az 1907-es Ellis v. United States-ügyben ${ }^{679}$ vizsgált kongresszusi törvény a fizikai munkásokra és szerelők (laborers and mechanics) munkaidejére írt elö napi maximumot. Az indítványozó alkotmányossági kifogásaival szemben a Supreme Court teljes mértékben irányadónak tekintette az Atkin $v$. Kansas-ítéletet az ügy vonatkozásában, a Kongresszusnak ugyanúgy hatalmában áll a közmunkák szabályozása, mint az államoknak. ${ }^{680} \mathrm{Az}$ előadó bíró, Holmes, nyomatékosan kiemelte, merész dolog volna feltételezni, hogy a Kongresszus nem jogosult a neki tetsző módon érvényre juttatni a szerződéseket, amelyeket megtilthat vagy engedélyezhet. ${ }^{681}$

Az 1908-as Muller v. Oregon-ügyben ${ }^{682}$ megtámadott jogszabály Oregon állam 1903-as törvénye volt, mely napi tíz órában maximálta a gépesített létesítményekben, gyárakban, mosodákban dolgozó nők munkaidejét. A szabályozás legitimnek bizonyult, éspedig azon az alapon, hogy az egészséges anyák nélkülözhetetlenek az életerős utódok világrajöttéhez, az asszonyok testi jólléte ennélfogva közérdek, védelme érdekében a tizennegyedik alkotmánykiegészítés sérelme nélkül korlátozható a szerződési szabadság, mely egyébként az általa védett szabadság fontos eleme. ${ }^{683}$ Indokolásban a Supreme Court deklarálja, hogy figyelembe veszi az általánosan ismert tényeket, ${ }^{684}$ ugyanakkor érdemes megjegyezni, hogy valószínüleg kevésbé a köztudomás, mint a jogszabály alkotmányossága mellett érvelő Louis D. Brandeis terjedelmes tényfeltáró melléklete járult hozzá az ügy adott kimeneteléhez. Az egyhangúlag hozott ítélet előadója Brewer bíró volt; az előző fejezetben a róla írottak alapján belátható, mi volt a motivációja, mindazonáltal a tény, hogy álláspontját senki sem vitatta, érzékletesen tükrözi azt a korabeli meggyőződést is, hogy a nő „természetes” társadalmi funkciójánál és gyengeségénél fogva aggálytalanul tárgya lehet a protektív szabályozásnak.

A Muller v. Oregon-ítélet meghozatalának évében született egy másik döntés, amely az előző üggyel ellentétes irányultságot sugall. A korábban már említett Adair v. United States-ügyben támadott jogszabály révén a jogalkotó az ún. „sárga kutya-szerződések” (yellow dog contracts) gyakorlatát kívánta visszaszorítani, vagyis azt a szerződéskötési

\footnotetext{
679206 U. S. 246

680206 U. S. 255

681 ,It would be a strong thing to say that a legislature that had power to forbid or to authorize and enforce a contract had not also the power to make a breach of it criminal[.]" 206 U. S. 255-256. A teljesség kedvéért megjegyezhetjük, hogy az ítélet mellé Moody bíró különvéleményt nyújtott be, melyhez Harlan és Day is csatlakozott. Ez azonban a téma szempontjából csekély jelentőséggel bír, a különvélemény ugyanis csak azt vitatja, kik tartozhatnak bele a „fizikai munkások” kategóriájába.

682208 U. S. 412

683208 U. S. 421

${ }^{684}$ Pontosan idézve: „We take judicial cognizance of all matters of general knowledge.“ Lásd uo.
} 
gyakorlatot, mely szerint a szakszervezeti tagság a munkaviszony automatikus megszűnését eredményezi. Az Adair-üggyel szoros összefüggésben áll az 1915-ben született Coppage v. Kansas-ítélet, ${ }^{685}$ ezért a két döntést együtt tárgyalom.

Az Adair-ügyben a támadott jogszabályt a Kongresszus hozta, így hatálya kiterjedt az összes munkáltatóra, mely az ország területén müködött, feltéve, ha tagállamok közötti kereskedelmi tevékenységet folytatott; az alkotmányossági kifogás elsődleges alapja az ötödik alkotmánykiegészítés volt. A Supreme Court hatfös többsége ennek alapján sérelmesnek tartotta a kérdéses tilalmat, és a munkáltatók és a munkavállalók szabadságára hivatkozott, valamint arra, hogy mindkét félnek alkotmányos joga szabadon eldönteni, milyen feltételek mellett alkalmazza a munkavállalót, illetve vállal munkát, avagy lép ki a munkaviszonyból. Beszédes, egyúttal meglepő, hogy az előadó Harlan e doktrína alátámasztására épp a Lochner-ítéletből idéz egy viszonylag terjedelmes passzust. ${ }^{686}$ Beszédes, mert a Lochner-ítélet emblematikus képviselője annak a felfogásnak, hogy a két fél egyenlőnek tételezett, formális szabadsága elsőbbséget kell, hogy élvezzen a jogalkotónak az esetleges materiális egyenlötlenségek kiküszöbölésére tett lépéseivel szemben; és meglepö, mert a Lochner-ítélet többségi indokolásával szemben megfogalmazott egyik különvéleményt épp Harlan jegyezte. A jelen esetben tett hivatkozása alátámasztja azt a meglátást, hogy a Lochner-ügyben tett különvéleménye voltaképpen a többségével azonos koncepcionális alapokon nyugszik, és csupán a végkövetkeztetés tér el a többségétől.

Az ügyben felmerült annak kérdése, hogy a kereskedelmi klauzula nem hatalmazza-e fel a Kongresszust arra, hogy a tagállamok közötti kereskedelem szabályozásának keretei között ilyen korlátozást foganatosítson. A többség erre egyértelmüen nemmel válaszolt, azon az alapon, hogy a kereskedelmi klauzula nem hatalmazza fel bármire a Kongresszust a tagállamok közötti kereskedelem vonatkozásában. A munkaszerződés tartalma nem áll lényegi összefüggésben a tagállamok közötti kereskedelmi tevékenységgel, így annak szabályozása nem képezheti a kongresszusi hatáskör tárgyát. ${ }^{687}$

A többségi indokolás értékelése meglehetősen nehézzé válik a két alkotmányos rendelkezés együttes érintettsége miatt. Egyfelől megítélésem szerint a Supreme Court túlzásba esett, amikor a megfelelő eljárás követelménye alapján alkotmányellenesnek minősítette a rendelkezést. Ránézésre is kézenfekvő és ésszerű érvek támasztják alá a

\footnotetext{
${ }^{685} 236$ U. S. 1

686208 U. S. $173-174$

687208 U. S. 178
} 
kérdéses szabályozást - ahhoz legalábbis mindenképpen kézenfekvőek és ésszerüek, hogy eloszlassák az alkotmányosságukhoz füzhető mindennemü kételyt. A korban nem mentek ritkaságszámba a sztrájkok, és egyes esetekben erőszakos megmozdulásokra is sor került. Ezek megelőzése legitim jogalkotói cél lehet, és az e cél megvalósítására racionálisan alkalmas szabályozással szemben nem támasztható alkotmányossági kifogás. Holmes hasonló gondolatmenetet felvázoló különvéleményével megítélésem szerint csakis egyetérteni lehet, ${ }^{688}$ és a megfelelő eljárás követelménye alapján a Supreme Court helytelenül minősítette alkotmánysértőnek a kérdéses szabályozást.

Nagyobb problémát jelent a Kongresszus hatáskörének kérdése. A többségi indokolás álláspontja meggyőzőnek tünhet, hiszen a szóban forgó jogszabály valóban legfeljebb közvetett összefüggésben van a tagállamok közötti kereskedelemmel, ráadásul az Egyesült Államok alkotmánykoncepciója a korlátozott központi hatalom eszméjére épül, így az átfogóbb, eszmei megfontolások síkján is megalapozott az az érvelés, miszerint a központi hatalom hatáskörébe csak az tartozhat, amit az alkotmány kifejezett oda utal. Ezeknek az érveknek azonban két körülmény is ellentmond. Egyrészt a Supreme Court a McCulloch v. Maryland-ügy óta - a „megfelelő és szükséges-klauzulára” hivatkozva - meglehetősen széles szabadságot biztosított a jogalkotónak a nem egyértelmü esetekben is. Másrészt - és ez a megfontolás képezi McKenna különvéleményének magvát - a testület más döntéseiben is megerősítette azt az álláspontot, hogy a tagállamok közötti kereskedelem fogalma nem merül ki pusztán a javak vagy személyek mozgásában, ennélfogva a konkrét esetben sem támasztható alkotmányossági kifogás a kérdéses szabályozással szemben. ${ }^{689}$

$\mathrm{Az}$ Adair-döntés esetében a többségi álláspont tehát a megfelelő eljárás követelményén, valamint a Kongresszus hatáskörének egyik legfőbb korlátját képező kereskedelmi klauzulán alapult, és ez utóbbi rendelkezést szem előtt tartva alkalmazhatóságának minden bizonytalansága mellett - akár elfogadhatónak is tekinthető a Supreme Court állásfoglalása. A Coppage v. Kansas-ügyben azonban a testület a tagállamok vonatkozásában, a tizennegyedik alkotmánykiegészítés megfelelő eljárási klauzulája alapján megerősíti a korábbi precedenst. Ebben az esetben megítélésem szerint nincs olyan körülmény, amely tarthatóvá tenné a többség álláspontját, hiszen a törvény alkotmányosságát a Supreme Court által következetesen elismert premisszák támasztották

\footnotetext{
688208 U. S. 191

689208 U. S. 183. Moody bíró nem vett részt a döntéshozatalban, így a hatfös többség által támogatott indokolás mellett két bíró fogalmazott meg különvéleményt.
} 
alá. Day különvéleménye - melyhez Charles Evans Hughes is csatlakozott - helyesen mutat rá ezekre. ${ }^{60} \mathrm{Az}$ indokolásból világosan kiderül, hogy a testület irányadónak tekintette az Adair-döntést, és a következetes gyakorlat fenntartása érdekében tartotta magát az abban kimondottakhoz, ugyanakkor megítélésem szerint már a korábbi ítéletben is téves álláspontra jutott akkor, amikor a megfelelő eljárás követelményével, azon belül a szerződési szabadsággal ellentétesnek tartotta a támadott rendelkezést. Az alkotmányellenességet legfeljebb a kereskedelmi klauzula alapozhatta volna meg - és ez az álláspont is vitatható -, a tagállami szinten azonban a hasonló szabályozásnak nem lett volna alkotmányos akadálya.

Az 1910-es évek elején több egyhangú döntés született, amelyben a Supreme Court láthatóan „könnyü esetként” kezelte az eldöntendő kérdést. 1911-ben, a Baltimore \& Ohio Railroad Co. v. Interstate Commerce Commission-ügy ${ }^{691}$ ítéletében a Supreme Court alkotmányosnak találta a vasúti dolgozók munkaidejét oly módon korlátozó kongresszusi törvényt, hogy tilos bármely alkalmazottnak megengedni, vagy számukra elöírni, hogy tizenhat egymást követő órán keresztül dolgozzanak, tizenhat óráig tartó folyamatos munkavégzést követően pedig legalább tíz egymást követő órára fel kell menteni őket. A testület legitimnek ítélte a szerződési szabadság korlátozását, melyet az alkalmazottak és az utasok biztonságának védelmével, illetve a dolgozók túlterheltségének ezekre való veszélyességével magyarázott. ${ }^{692}$ Azt sem tartotta az alkotmányosság akadályának, hogy a tagállamon belüli és a tagállamok közötti kereskedelem elválaszthatatlanul összefonódik e tevékenység során. ${ }^{693}$ 1913-ban a testület a fentebb ismertetett döntések nyomdokain haladva alkotmányosnak ítélt egy olyan rendelkezést, amely szerint a szénbányáknak meghatározott szélességű bejárattal kell rendelkeznie, ám azok bizonyos típusait kivonta a szabályozás alól. ${ }^{694}$ A testület evidensként kezelte azt is, hogy a jogalkotó megtilthatja a kiskorúak alkalmazását, és az alkalmazottak életkora megállapításának kockázatát a munkáltatókra háríthatja. ${ }^{695}$ A rövid indokolásban az előadó bíró utalásszerủen hivatkozott a Holden- és a Muller-ügyekre, valamint a kötelező védőoltás elrendelését alkotmányosnak

\footnotetext{
690236 U. S. 41-42. Day a hivatkozott helyeken a Holden v. Hardy-, valamint a Chicago, Burlington \& Quincy R. R. Co. v. McGuire-ítéletekre támaszkodik. Megjegyezhetö, hogy Holmes is megfogalmazott egy tömör különvéleményt, melyben röviden megismétli a Lochner-ügyben kifejezésre juttatott álláspontját, mely szerint a bíróság nem kifogásolhatja az olyan szabályozást, amely egy ésszerüen gondolkodó ember számára elfogadható meggyőződésen alapul.

691221 U. S. 612 (1911)

692 221. U. S. 618-619

693221 U. S. 618

${ }^{694}$ Barrett v. Indiana, 229 U. S. 26 (1913)

${ }^{695}$ Sturges \& Burn Manufacturing Co. v. Beauchamp, 231 U. S. 320 (1913)
} 
tartó Jacobson v. Massachusetts-, ${ }^{696}$ illetve az üzemi balesetek miatti sérülésekért való felelősség mértékét korlátozó jogszabályt alkotmányosnak tartó Chicago, Burlington and Quincy Railroad Co. v. McGuire-ügyekre. ${ }^{697}$ A gondolatmenet adottnak vette a tagállam azon hatáskörét, hogy az ifjúságot védje, és a konkrét szabályozást e hatáskör meghatározott alkalmazásaként értékelte. ${ }^{698}$ Végül a Keokee-döntésben a Supreme Court a Knoxville Iron Co. v. Harbison-ügyet alkalmazva megerősíti azon álláspontját, hogy a legitim alapjog-korlátozás körébe tartozik annak megtiltása, hogy a munkáltatók a kizárólag a saját üzleteikben beváltható utalványokkal helyettesítik a készpénzben kifizetett munkabért. ${ }^{699} \mathrm{Ez}$ utóbbi ügyből talán érdemes kiemelni azt, hogy az indokolásban az előadó bíró, Holmes tömören egy homályos, absztrakt „tapasztalatot” jelöl meg olyan tényezőként, ami alkotmányosan indokolhatóvá teszi a jogalkotó aktusát. ${ }^{700}$ Ilyesfajta okfejtés megfigyelhető más esetekben is, így például az előző alfejezetben már tárgyalt - időben ugyanakkor körülbelül egy évtizeddel később elbírált - Ward \& Gow v. Krinsky-ügy indokolásának fontos gondolati szálát képezi - igaz, a Holmesénál nagyobb terjedelemben - a tapasztalatra való hivatkozás. Ez utóbbi esetben az előadó bíró szerint az a tény, hogy a károsult egyáltalán elszenvedte az adott sérülést, igazolja, hogy a jogalkotó által meghatározott foglakozások olyan veszélyekkel járnak, amelyek az üzemi balesetért való kárfelelősséget rendezik. ${ }^{701}$ Azt kell látni, hogy mind a Keokee-, mind a Ward \& Gow-ügyben csupán a szóban forgó veszélyek prima facie életszerü mivolta bizonyult meghatározónak, ám átfogó empirikus adatok nem kerültek egyik indokolásban sem megvitatásra.

Az 1914-es Riley v. Massachusetts-ítélet ${ }^{702}$ rövid indokolása lényegében a Muller v. Oregon központi megfontolását erősítette meg. A Supreme Court megállapítja, hogy a gyárakban dolgozó nők és gyermekek napi munkaidejét tíz órában maximáló massachusettsi törvény ésszerű és nem önkényes. ${ }^{703}$ A Mullerrel szemben az indokolást megfogalmazó McKenna bíró nem a nők helyzetéhez füződő társadalmi érdekre hivatkozik. Gondolatmenetéből két aspektust érdemes kiemelni. Egyfelől ha az állam jogosult bizonyos dolgozói osztály munkaidejének korlátozására, jogosult adminisztratív

\footnotetext{
696197 U. S. 11 (1905)

697219 U. S. 549 (1911)

698231 U. S. 325

${ }^{699}$ Keokee Consolidated Coke Co. v. Taylor, 234 U. S. 224 (1914)

700234 U. S. 227

701259 U. S. 514

702232 U. S. 671

703 „The provision is reasonable, and not arbitrary.” Lásd uo.
} 
lépéseket is tenni a szabályszegés megakadályozása érdekében. ${ }^{704}$ Másfelől pedig az igénybevett eszközök helyessége és törvényessége nem ítélhető meg müködésük egy-egy kirívó esete alapján. $^{705}$

Az Erie Railroad Co. v. Williams-ügyben ${ }^{706}$ a Supreme Court egy olyan törvényi elöírással foglalkozott, amelynek értelmében meghatározott tevékenységet végző vállalatok kötelesek készpénzben kiadni alkalmazottaik bérét, és a jogszabály e körön belül is alcsoportonként eltérő időszakonként tette kötelezővé a bérfizetést. A Supreme Court egyhangúlag alkotmányosnak ítélte a rendelkezést. Az ítélet indokolásának magva az a megfontolás, hogy a fizetés módjának elöírásával a munkáltatónak okozott puszta nehézség nem eredményez alkotmányellenességet. ${ }^{707}$ Az ügyet a testület láthatóan könnyü esetként kezelte, ugyanakkor érdemes az indokolását összevetni azzal a gondolatmenettel, amelyet a Lochner-ítélet megalapozása végett fejtett ki Peckham bíró. Az Erie-ügyben az egyenlő törvényi védelem klauzulájára való hivatkozást azzal hárítják el, hogy az indítványozó mint munkáltató a munkavállalók közötti megkülönböztetést támadja, erre azonban nincs indítványozói jogosultsága. ${ }^{708}$ Ehhez képest a Lochner-ügyben, amikor az előadó bíró a támadott elöírások alapjogsértő jellegét ecseteli, arra mutat rá, hogy „a jelen ügyben vizsgálthoz hasonló előírások, melyek megszabják azt, hogy felnőtt és intelligens emberek hány órában dolgozhatnak a megélhetésükért, csupán terhes korlátai az egyéni szabadságjogoknak". ${ }^{709}$ Vagyis itt Peckham, noha az indítványozó az érintett pékség tulajdonosa volt, a munkavállalók alapjogainak sérelmével foglalkozott. Megítélésem szerint az ítélet ebben a vonatkozásában kirí a többi, hasonló kérdésekkel foglalkozó döntések közül, az általam vizsgált precedensek ugyanis azt mutatják, hogy a Supreme Court igen következetesen tartotta magát ahhoz az elvhez, hogy csak a jogosult indítványozót érintő jogsérelemmel foglalkozik érdemben. Emellett figyelmet érdemel az a körülmény is, hogy míg a Lochner-ügyben a Supreme Court kifejezetten kitér arra, hogy a pékek munkája nem egészségtelenebb számos egyéb foglalkozásnál, ezért indokolatlan annak önálló szabályozása. ${ }^{710}$ Ehhez képest az Erie-ügyben nem kerül szóba annak kérdése, hogy a jogalkotó miért csak bizonyos tevékenységek körében írta elö a készpénzben való bérfizetés kötelezettségét, a testület csupán azt állapítja meg, hogy az

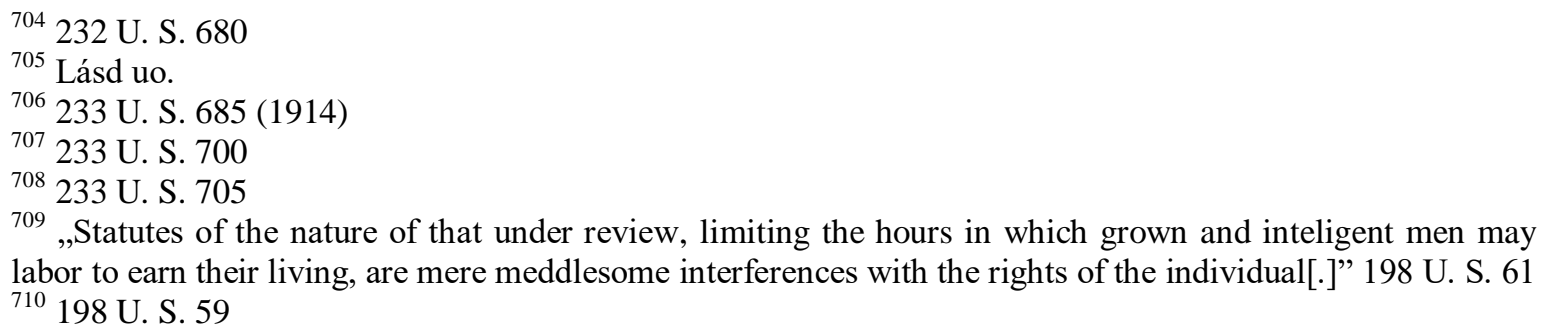


alapjogkorlátozásnak van legitim alapja. Mindez azért érdekes, mert meglátásom szerint a két ügy közötti eltérés sokkal inkább fokozati, nem pedig minőségi. Mindkét esetben egy partikuláris esetcsoportra nézve írt elő szabályozást a jogalkotó, csak a Lochner-ügyben ez sokkal kirívóbb volt, hiszen néhány jól körülírható szakmára korlátozódott a szabályozás, míg az Erie-ügyben sokkal szélesebb spektrumot ölelt fel. Ugyanakkor a szabályozás természetét nézve az figyelhető meg, hogy mind a munkaidő, mind a bérfizetés jellege esetében több, az alkotmányosságot megerösítő precedens is született. A jelen összehasonlítás azt a következtetést engedi levonni, hogy a Lochner-ügyben a szabályozott szakmák szük köre hajlamosabbá tette a Supreme Court többségét a támadott rendelkezés alkotmányellenessé nyilvánítására, míg az Erie-ügyben a szabályozás szélesebb körére tekintettel a testület mintha eltekintett volna attól a lehetséges érvtől, hogy a készpénz helyett egyéb módon - például a munkáltató üzlethelyiségeiben beváltható utalvány formájában - történő bérfizetés nem kevésbé káros jelenség az egyik szakmában, mint a másikban.

A Miller v. Wilson-ügy ${ }^{711}$ ítélete 1915 -ben született. Massachusetts állam napi nyolc vagy heti negyvennyolc órában maximálta bizonyos üzemek női dolgozóinak munkaidejét, míg más munkaköröket explicite kivont a szabályozás alól. A törvény alkotmányosnak bizonyult. Ami a megfelelő eljárás követelménye által védett szerződési szabadságot illeti, a Supreme Court szerint „,[n]yilvánvalóan képtelenség azt állítani, hogy a puszta tény, hogy Kalifornia törvénye nyolc órás munkanapról vagy maximálisan negyvennyolc órás munkahétről rendelkezik, nem pedig tíz órás munkanapról avagy ötvennégy órás munkahétről, kivonja az ügyet a jogalkotói diszkréció köréből." ${ }^{712}$ Az előadó Hughes bíró ugyanakkor megjegyzi, ezt nem azt jelenti, hogy más esetekben ne tolódhatna a szabályozás megengedhetetlen szélsőségekig. ${ }^{713}$ Az ítélettel egy napon a Supreme Court a Bosley v. McLaughlin-ügyben ${ }^{714}$ is ítéletet hozott. A vizsgálat tárgya ugyanazon törvény 1913-as módosítása volt, mely egyebek között a gyógyszerésznők (pharmacists) és ápolónő-tanoncok (student nurses) munkaidejét korlátozta a fent jelzett mértékben, a végzett ápolónőket (graduate nurses) ugyanakkor kizárta személyi hatályából. Az alkotmányosságot fenntartó egyhangú ítélet a szerződési szabadság legitim korlátozásának

\footnotetext{
711 236 U. S. 373

712 „It is manifestly impossible to say that the mere fact that the statute of California provides for an eighthour day, or a maximum of forty-eight hours a week, instead of ten hours a day, or fifty-four hours a week, takes the case out of the domain of legislative discretion." 236 U. S. 382

${ }^{713}$ A teljes mondatot idézve: „This is not to imply that a limitation of the hours of labor of women might not be pushed to a wholly indefensible extreme, but there is no ground for the conclusion here that the limit of the reasonable exertion of protective authority has been overstepped." Lásd uo.

${ }^{714} 236$ U. S. 385
} 
tekinti a jogszabályt, mert közérdek, hogy a kórházakban ne kimerült, túlterhelt ápolók dolgozzanak. Hughes bíró egy tanulmányt idéz, mely a kimerítő munka melletti kemény tanulás hosszú távon káros hatásait vizsgálja, és rámutat, hogy az ápolóképzők felügyelőinek nagy többsége határozottan javasolja a munkaidő napi nyolc órára csökkentését. ${ }^{715} \mathrm{Az}$ indokolásban hivatkozás található a Muller-, a Riley- és a Millerdöntésekre. ${ }^{716}$

Az egyhangú ítéleteket követő, 5:3 arányú ${ }^{717}$ Bunting v. Oregon-ügyben ${ }^{718}$ vizsgált törvény értelmében minden üzem, gyár, termelölétesítmény (mill, factory or manufacturing establishment) dolgozójának tíz órában maximálta a napi munkaidejét bizonyos kivételes esetektől eltekintve, melyek fennállásakor a dolgozókat túlóradíj illeti meg. Az ügy előadója a Lochner-ügyben is a többség mellett döntő Joseph McKenna bíró volt. A törvényt azon az alapon támadták, hogy egészségügyi rendelkezésnek álcázott bérszabályozás. McKenna, fenntartva, hogy puszta nyilatkozatoktól nem válik a jogellenes szabályozás jogszerüvé, ${ }^{719}$ rámutat, hogy a feltételezés elfogadásával azt is feltételeznék, hogy a jogalkotó, rossz kifejezőkészségének köszönhetően, egy dolgot akar, de mást ér el, vagy pedig szándékosan burkoltan jogellenes célt valósít meg. ${ }^{720}$ Erre azonban nincs szükség. A bíróságnak nem dolga pontosan ismerni a jogalkotó megfontolásait vagy meggyőződni a jogalkotói ítélet helyességéről. ${ }^{721}$

Fölöttébb sajnálatos, hogy a testület itt nem foglalkozik az esetnek a Lochner-ügyhöz való hasonlóságaival, illetve az attól való eltéréseivel, miként az is, hogy a többségi döntés ellen szavazó három bíró álláspontját nem ismerhetjük meg részletesen. Az e helyütt bemutatott jogesetek közül talán ennek tárgya mutatja a legtöbb párhuzamot azzal az ítélettel, amely azóta is egyfajta „mumusként” él tovább a szakmai köztudatban. Az ismertetett indítványozói érvelésből kitünik, hogy az indítványozó nagy hangsúlyt fektetett a Lochner-ügyben tekintetbe vett megfontolásokra, és rögtön látható, hogy ezt nem ok nélkül teszi, hiszen mindkét esetben arról van szó, hogy a jogalkotó bizonyos körben megszabja a szerződésben kiköthető munkaidő felső határát. Azonban a Lochner-ügyben ez csak egy egészen szük személyi körre vonatkozott. A Bunting-ügyben ez a kör szélesebb: a megfogalmazás lehetővé teszi, hogy a törvény hatálya alá tartozzon bármilyen

\footnotetext{
715 236 U. S. 393-394

${ }^{716} 236$ U. S. 394

717 Brandeis sem az ügy megvitatásában, sem az ítélethozatalban nem vett részt.

${ }^{718} 243$ U. S. 426 (1917)

719 „Of course, mere declaration cannot give character to a law, nor turn illegal into legal operation, and when such attempt is palpable, this Court necessarily has the power of review." 243 U. S. 435

${ }_{720} 243$ U. S. $435-436$

721 243 U. S. 437
} 
tevékenység, amely a megnevezett létesítményekben valamilyen termék előállítására irányul. Hasonló kérdéssel találkozunk, mint amely a Lochner- és az Erie-ügy kapcsán is felmerült: a vizsgálódás nem minőségi, hanem fokozati, és a Bunting-ügyben az átfogóbb személyi hatály elfogadhatóbbá tette a szabályozást. A Lochner-üggyel szemben a későbbi jogvitában a támadott jogszabály egészségügyi törvényként való minősítése sem jelentett problémát. Mint látható volt, ott azzal érvelt a többség, hogy a pékek munkája semmi olyan rendkívüli egészségügyi kockázatot nem rejt, amely kirívó lenne más hétköznapi munkákhoz képest, és külön szabályozás igényelne. Itt ez már nem volt szempont, és a Supreme Court az alkotmányossági kifogásokkal szemben legitim egészségügyi szabályozásként ismerte el a jogszabályt.

A Bunting- és a Lochner-ítélet viszonyának problémája a joglogikai maximák nyelvére is lefordítható: a későbbi ügyben a jogalkotó a szélesebb jelentéstartalmú ,üzem, gyár, termelőlétesítmény" kifejezést alkalmazta. Ha ebbe beleérthető a pékség is, akkor lehet úgy érvelni, hogy a Lochner-ügyben vizsgálthoz hasonló jogszabályok már nem bizonyulnának alkotmánysértőnek, elvégre a lex posterior derogat legi priori elve alapján a később született precedens irányadó az ilyen szabályozás megítélésénél. Valószínűleg hasonlóra gondolt Taft is, amikor később, az Adkins-ítélethez füzött különvéleményében a Lochner-döntés hallgatólagos felülbírálatát feltételezte. Ha azonban a Lochner-ítéletet speciális esetként fogjuk fel, akkor a lex specialis derogat legi priori elve alapján nem szünik meg annak érvénye, és a hasonlóan specifikus törvények továbbra sem biztos, hogy megállnák az alkotmányosság próbáját. ${ }^{722}$

Az 1917-es Wilson v. New-ügy ${ }^{723}$ tárgya egy 1916-os kongresszusi törvény, mely nyolc órás munkanapot és - átmeneti jelleggel - minimálbért biztosít az államközi és idegen nemzetekkel történő kereskedelemben érintett szállítók alkalmazottjainak. A jogszabály egy munkaügyi vitát követő általános vasutassztrájk keretében született, melynek során az elnök közvetíteni próbált a felek között, s a helyzet oldására javaslatot tett a Kongresszusnak az említett törvény létrehozására. A munkáltatói szervezetek azonban pert indítottak a vasutasok vezetői ellen, megkérdőjelezve, hogy a Kongresszusnak jogában állna efféle szabályozást alkotni. Az 5:4 arányú döntés 724

\footnotetext{
${ }^{722}$ A két ítélet viszonyának problémájához lásd: Molnár, András: Some Brief Remarks on Lochner Era Constitutionalism from the Aspect of the Theory of Precedent. In Studia Iuridica Caroliensia 5, Károli Gáspár Református Egyetem Állam- és Jogtudományi Kar, Budapest, 2010, 65. o.

${ }^{723} 243$ U. S. 332

${ }^{724}$ A „,többségi véleményhez” tulajdonképpen négyen csatlakoztak, McKenna bíró párhuzamos véleményt adott be. Day, Pitney és McReynolds önálló különvéleményt írt, ezek közül Van Devanter Pitneyéhez csatlakozott.
} 
középpontjában a kereskedelmi klauzula és a megfelelö eljárás követelménye állt. Az előadó White szerint az ügy két kulcskérdése: van-e a Kongresszusnak hatalma beleszólni a törvénnyel rendezett viszonyokba, és ha van, tekinthetö-e oly mértékü visszaélésnek az intézkedés, hogy egészében alkotmányellenesnek kell nyilvánítani? ${ }^{725}$

Azt, hogy a munkaidő szabályozása belefér a Kongresszus hatáskörébe, White a fent említett Baltimore \& Ohio-, valamint a Missouri, Kansas \& Texas Railway Company v. United States-ügy ${ }^{726}$ alapján magától értetődőnek véli. Leszögezi azt is, hogy amennyiben a jogalkotónak hatáskörébe tartozik bizonyos életviszonyok szabályozása, annak terjedelme a szabályozás tárgyának természetétől, jellegétől függ, valamint attól, mi a megfelelő szabályozás. ${ }^{727}$ A vasúti szállításhoz füződő közérdek megléte régóta nem vitás. E körbe tartozik a vasúti szállítás folytonosságához füződő közérdek is, ebből pedig egyenesen következik a Kongresszus szabályozási jogosultsága. ${ }^{728}$ E jogosultság a vasúti szállítás legkülönfélébb aspektusait érintheti, beleértve akár a munkáltatók és munkavállalók egymás közötti viszonyait. Következésképp mind a vasúttársaságok tulajdonhoz való joga, mind az alkalmazottak szerződési szabadsága szabályozás tárgyát képezheti. $^{729}$

A megfelelő eljárás követelménye White meglátása szerint azért sem sérült, mert szemben a munkáltatók állításaival - nincs szó a szolgáltatás és ellenszolgáltatás piaci értékének megváltoztatásáról: bár a munkaidő és a bér adott, az előírható teljesítmény szabad alku tárgya. ${ }^{730}$ Másrészt a felek nem is bírtak egyezségre jutni - éppen e végből született a kifogásolt rendelkezés. ${ }^{731}$ Harmadrészt nem önkényes a rendelkezés, hiszen bizonyos ésszerü idő elteltével megszünik, ezzel teljes mértékben a felekre bízva a bérben való megegyezést. ${ }^{732}$

Érdemes rövid kitérőt tenni a különvéleményekre is. Day bíró felhívja rá a figyelmet, hogy noha tartalmát soha nem írták körül precízen, az ötödik alkotmánykiegészítés korlátozza a jogalkotó hatalmat, amennyiben gátat szab az önkényes törvényhozásnak,

\footnotetext{
${ }^{725}$ Vö. 243 U. S. 343

726231 U. S. 112 (1913) Az ítélet alig háromoldalas indokolásában Holmes úgy ítéli, hogy a Baltimore \& Ohio-ügyben megtámadott törvény alapján minden egyes tizenhat óránál tovább dolgozó alkalmazottért önálló felelösség terheli a munkáltatót. Az ügyben nem merül fel alkotmányossági kérdés.

727 „It is equally certain that, where a particular subject is within such authority, the extent of regulation depends on the nature and character of the subject and what is appropriate to its regulation." 243 U. S. 347

${ }^{728} 243$ U. S. $347-349$

729243 U. S. $352-353$

${ }^{730} 243$ U. S. 356

731243 U. S. 357

732 243 U. S. 358
} 
mely ellen a bíróságoknak kötelessége fellépni. ${ }^{733}$ A szóban forgó rendelkezések pedig önkényesek: a bér rögzítésével ugyanazért a munkáért többet kapnak a munkavállalók, a Kongresszus pedig megengedhetetlen módon a munkáltatókra hárította az ezzel járó többletköltségek (vagyis a régi munkabér feletti, a minimálbér-rendelkezéseknek megfelelő összeg) kifizetését, ami azonban az alkotmányosan védett tulajdonjog sérelme. ${ }^{734}$ Később egy ad absurdum érvet alkalmazva Day arra hívja fel a figyelmet, hogy ha a köz szükségletei miatt fel lehetne áldozni az alapjogokat, az azokat védő alkotmányos rendelkezéseknek vajmi csekély gyakorlati értékük lenne. ${ }^{735}$

Mahlon Pitney vitatja, jogosult volt-e egyáltalán a Kongresszus a törvény megalkotására. Bár címében szerepel a „nyolc órás munkanap kitétel”, a törvény nem szankcionálja ennek túllépését, ráadásul olyan látványosan tér el a tizenhat órás munkanapról szóló törvénytől, hogy aligha feltételezhető, hogy a jogalkotó valódi célja a munkaidő szabályozása lett volna. ${ }^{736}$ A törvény valójában nem a kereskedelem szabályozása, mert nem áll azzal lényeges kapcsolatban. ${ }^{737}$ Emellett Pitney is hangoztatja ellenvetését a szolgáltatás-ellenszolgáltatás piaci egyensúlyának minimálbér miatti természetellenes felborításával szemben. ${ }^{738}$ Végül ex cathedra kijelenti, hamis a feltételezés, miszerint a bérnövekedés növelné a munkavállalók elégedettségét, ezzel munkájuk hatékonyságát, s végső soron a kereskedelem intenzitását. ${ }^{739}$ Álláspontjához Van Devanter is csatlakozik.

James Clark McReynolds rövid különvéleményében vitatja, hogy a Kongresszusnak hatalmában állna a törvény meghozatala, továbbá egy - meglátásom szerint némi sértődött

\footnotetext{
733243 U. S. $365-367$

${ }^{734} 243$ U. S. $368-369$

735 „I cannot agree that constitutional rights may be sacrificed because of public necessity, nor taken away because of emergencies which might result in disaster or inconvenience to public or private interests. If this be not so, the constitutional limitations for the protection of life, liberty and property are of little value, and may be taken away whenever it is supposed that the public interest will be promoted by the sacrifice of rights which the framers of the Constitution intended should be forever protected from governmental invasion by any branch of the government." 243 U. S. 372

${ }^{736} 243$ U. S. 373-374

737 „I am convinced, in the first place, that the act cannot be sustained as a regulation of commerce, because it has no such object, operation, or effect. It removes no impediment or obstruction from the way of traffic or intercourse, prescribes no service to the public, lays down no rule respecting the mode in which service is to be performed, or the safeguards to be placed about it, or the qualifications or conduct of those who are to perform it. In short, it has no substantial relation to or connection with commerce, no closer relation than has the price which the carrier pays for its engines and cars or for the coal used in propelling them." 243 U. S. 376

${ }^{738}$ 243. U. S. 375

739 „The suggestion that an increase in the wages of trainmen will increase their contentment, encourage prompt and efficient service, and thus facilitate the movement of commerce is altogether fanciful." 243 U. S. 380
} 
hangvételt sem nélkülöző - bekezdésben utal a rendelkezés kereskedelemre káros hatására. ${ }^{740}$

Az 1923-as Adkins v. Children's Hospital-ügyben ${ }^{741}$ a Supreme Court 5:3 $\operatorname{arányban}^{742}$ alkotmányellenesnek nyilvánította a kongresszusi törvényt, mely felhatalmazott egy háromfös bizottságot, hogy Washington D. C. területén ellenőrizze a nők és kiskorúak béreit, foglalkozásonként megszabva a megfelelő minimálbér mértékét. ${ }^{743} \mathrm{Az}$ eset ismertetése után Sutherland kijelenti, hogy a testület gyakorlata értelmében a Kongresszus által hozott jogszabályok érvényességét minden lehetséges módon vélelmezni kell, a mondatot azonban úgy zárja: „amíg nem merül fel az ésszerü mértékünél komolyabb kétely." Ha pedig nyilvánvalóan és kétségbevonhatatlanul bebizonyosodott a jogszabály alkotmányellenessége, a Supreme Court nem tehet mást, mint hogy kimondja azt. ${ }^{744}$ Hangsúlyozza és precedensek sorával támasztja alá, ${ }^{745}$ hogy a szerződési szabadság része a megfelelő eljárás követelménye által védett szabadságnak. ${ }^{746}$ Kiemelve, hogy e jog természetesen nem abszolút, leszögezi, hogy a szerződési szabadság a fószabály, míg a korlátozás a kivétel. Illusztrációként négy nagyobb csoportba sorolja az addigi Supreme Court-ítéleteket: 1. A közérdekkel érintett vállalatok árait, díjszabását rögzítő jogszabályokkal foglalkozó ítéletek. 2. A közmunkák teljesítéséhez kapcsolódó szerződéseket szabályozó jogszabályokkal foglalkozó ítéletek. 3. A bérfizetés jellegét, módját, idejét megállapító jogszabályokkal foglalkozó ítéletek. 4. A munkaidőt rögzítő jogszabályokkal foglalkozó ítéletek. ${ }^{747}$ Míg az 1. és a 2 . esetekben a szabályozás alkotmányos volt, a 3. csoportról ez egyáltalán nem mondható el, és a 4.-ről is csak azzal a fenntartással, hogy még nem került olyan jogszabály a Supreme Court elé, mely általános

\footnotetext{
740243 U. S. $388-389$

741261 U. S. 525

${ }^{742}$ Brandeis sem az ügy megvitatásában, sem az ítélethozatalban nem vett részt.

${ }^{743}$ A bizottság feladata egyfelöl annak megállapítása volt, mikor elégtelen bármely foglalkozást végző nők bére ahhoz, hogy biztosítsa a szükséges létfenntartási költségeket egészségük és erkölcsük megőrzése céljából, másfelől pedig annak megállapítása, mikor ésszerütlenül alacsony bármely foglalkozást végzö kiskorúak bére. (A Supreme Courtot idézve: „By § [9], the board is authorized ... 'to ascertain and declare, in the manner hereinafter provided, the following things: /a/, Standards of minimum wages for women in any occupation within the District of Columbia, and what wages are inadequate to supply the necessary cost of living to any such women workers to maintain them in good health and to protect their morals, and $/ \mathrm{b} /$, standards of minimum wages for minors in any occupation within the District of Columbia, and what wages are unreasonably low for any such minor workers."') 261 U. S. 540

744 „This Court, by an unbroken line of decisions from Chief Justice Marshall to the present day, has steadily adhered to the rule that every possible presumption is in favor of the validity of an act of Congress until overcome beyond rational doubt. But if, by clear and indubitable demonstration, a statute be opposed to the Constitution, we have no choice but to say so.” 261 U. S. 544

${ }^{745}$ Melyek között a minket érintö körből ott szerepel a Lochner- és a Muller-ügy is.

746261 U. S. 545

747261 U. S. $546-548$
} 
jelleggel maximálta volna a napi munkaidőt. A leírtakon túl Sutherland felidézte a Lochner-ügy indokolásából azt az érvet, hogy a cím önmagában nem tesz alkotmányossá egy törvényt, valamint az elnyomó állam veszélyére figyelmeztető ad absurdum érvet.

A későbbiekben Sutherland arra hívja fel a figyelmet, hogy a tisztességes bér megállapítására alkalmazott szempontok elfogadhatatlan mértékben bizonytalanok. ${ }^{748}$ Maga a törvény csak az egyik oldal igényeit veszi figyelembe, hatásában ugyanakkor nem csak a nagy, erős munkaadókat sújtja, hanem a kisebb, gyengébb alkupozícióban lévőket is. ${ }^{749}$ A munkáltatónak egyébként sem erkölcsi kötelessége a megélhetéshez elegendő bér nyújtása. ${ }^{750}$

Különvéleményében, melyhez Edward Terry Sanford is csatlakozott, Taft úgy érvel, nem a bíróság dolga elbírálni egy kongresszusi törvény mögötti gazdaságfelfogás helyességét. ${ }^{751}$ A Muller-ügyet teljes mértékben irányadónak vélve - és érdekes módon kiemelve, hogy nem kíván állást foglalni a felnőtt férfiakra alkalmazható minimálbértörvény alkotmányosságáról - amellett érvel, hogy a jogalkotónak hatalmában állt a kérdéses törvény megalkotása.

Holmes különvéleménye a bírói önmegtartóztatásra helyezi a hangsúlyt. Úgy véli, a bíróságnak nem tiszte felülbírálni a jogalkotó ítéletét olyan kérdésben, mellyel amaz jóval alaposabban foglalkozott, ${ }^{752}$ és élesen elválasztja az alkotmányosság kérdését a helyességétől. ${ }^{753}$ Továbbá arra is felhívja a figyelmet, hogy az Alkotmányban nem szerepel szó szerint a szerződési szabadság - az csak egy példája a szabadságnak, a jog azonban szinte mindig megtilt valamilyen magatartást, a szerződéskötés pedig e szempontból nem különbözik egyéb magatartásoktól. ${ }^{754}$ Emellett pedig cáfolja a többség azon nézetét, hogy a törvény bárkire bármiféle fizetési kötelezettséget ró: egyszerüen megtiltja az adott mérték alá eső bér ellenében történő alkalmazást. ${ }^{755}$

A két Chas. Wolff-ügyben ${ }^{756}$ a Supreme Court olyan szabályozással foglalkozott, amely vita esetén arbitrációs eljáráson való részvételt írt elő a munkáltatóknak és a munkavállalóknak, és az ezen eljárást lebonyolító szerv kötelező jelleggel állapíthatta meg

\footnotetext{
748261 U. S. 556

749261 U. S. 557

750261 U. S. 558

751261 U. S. 562

752261 U. S. 568

753 „The criterion of constitutionality is not whether we believe the law to be for the public good." 261 U. S. 570

754261 U. S. $568-569$

755261 U. S. 570

${ }^{756}$ Chas. Wolff Packing Co. v. Court of Industrial Relations of the State of Kansas 262 U. S. 522 (1923); 267 U. S. 552 (1925)
} 
a munkaszerződés egyes feltételeit, mindenekelőtt a munkabér és a munkaidő mértékét, illetve eltilthatta a munkavállalókat a sztrájktól. A szabályozást a jogalkotó bizonyos szolgáltatások zavartalan biztosítására hivatkozva alakította ki. A Supreme Court alkotmányellenesnek ítélte azt, mondván, nem áll fenn olyan krízishelyzet, amely az ilyen mértékü korlátozást indokolná, emellett csak akkor lehet arra kötelezni a vállalatokat, hogy bizonyos, a „közt széles körben érintő” (affected with a public interest) tevékenységet meghatározott feltételek mellett folytassanak, ha ezt még a tevékenység megkezdése előtt előre tudhatják. ${ }^{757}$ Mivel a jelen esetben ez a követelmény nem valósult meg, a szabályozásnak nincs alkotmányos indoka.

Látni kell, hogy ezekben az ügyekben, szemben a fentebb tárgyalt Adkins-üggyel, ugyanakkor a Wilson v. New-ügyhöz hasonlóan, az elsődleges kérdés nem maga a minimálbér szabályozásának alkotmányossága, hanem az, hogy a közt széles körben érintő tevékenységek milyen mértékben szabályozhatók. Erre nézve a Supreme Court a Munn v. Illinois-döntésben nyilvánította ki az irányadó doktrínát, ${ }^{758}$ melyet később meg is erősített, ${ }^{759}$ és a testület ennek alkalmazhatósági határát vonta meg, amikor deklarálta, hogy csak a tevékenység végzésére való kötelezés előfeltételezésének vélelmezhetősége mellett igazolható a munkaszerződés tartalmának állami meghatározása. A Wilson v. Newés a Chas. Wolff-ügyeket összevetve megfigyelhető, hogy ebben a vonatkozásban fontos szempontot jelentett a korlátozások átmeneti jellege is: az előbbi esetben ez a körülmény az alkotmányosság kimondását eredményezte, az utóbbiakban pedig a testület nem találta elfogadhatónak, hogy a jogalkotó hosszú távra szánta a szabályozást. Ezek az ügyek azonban mindenképpen speciálisnak tekinthetők a munkaviszony feltételeit érintő ügyek többségéhez képest, amelyek hosszú távú szabályozással álltak összefüggésben.

Az 1924-es Radice v. New York-ügy ${ }^{760}$ tárgya egy olyan tagállami törvény volt, amely bizonyos korlátokat írt elő a nagyvárosi éttermekben alkalmazott nők munkaidejére nézve. Az indítványozó két vonatkozásban támadta a szabályozást, az előadó bíró, Sutherland mindkét vonatkozásban elutasította az indítványt. A szerződési szabadság kapcsán a nők és férfiak közötti eltérésekre tekintettel leszögezte, hogy a korlátozást az előbbiek gyengébb fizikai természete indokolja; emellett hangsúlyozta, hogy a testület nem jogosult a jogalkotó tényítéletének felülbírálatára. ${ }^{761}$ Ami a kisebb és nagyobb városok

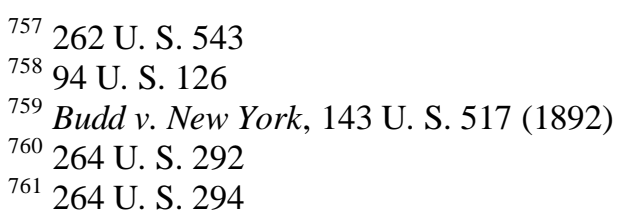


közötti különbségtételt, valamint a bizonyos munkaköröket ellátó nők szabályozás alóli kivonását illeti, Sutherland megállapítja, hogy a törvény egy jól elkülöníthető munkavállalói csoportra vonatkozik, melynek következtében alkotmányellenes diszkriminációról nem lehet szó. ${ }^{762}$

Az 1926-os Connally v. General Construction Co. - ügy $^{763}$ csak röviden érdemel említést: noha a Supreme Court alkotmányellenesnek ítélte a rendelkezést, amelynek értelmében a tagállammal szerződő munkáltatók büntetéssel sújtandók, amennyiben nem az adott környéken elfogadott napibért fizetik munkavállalóiknak. Az egyhangú döntés indokolása értelmében az ilyen rendelkezés túl általános, és nem tartalmaz követhető magatartásmintát a címzettek számára. ${ }^{764}$ Ebben az eseten tehát nem a szabályozás tartalma került vizsgálat alá, hanem csupán annak értelmezhetősége, és a vizsgált precedensek alapján elmondható, hogy a Supreme Court következetesen tartotta magát a szóban forgó jogvitában is alkalmazott doktrínához. ${ }^{765}$

A Carter v. Carter Coal Co.-ügyben ${ }^{766}$ a Supreme Court egy komplex szövetségi szabályösszesség alkotmányosságával foglalkozott. A kérdéses jogszabály - egyebek között - létrehozott egy bizottságot, amely a széntermelés egyes körülményeit, így a munkaidőt, munkabért és egyéb munkakörülményeket is szabályozhatta. A testület a kereskedelmi klauzulával és az ötödik alkotmánykiegészítéssel ellentétesnek ítélte ezt a jogalkotói megoldást. A fó problémát abban látta, hogy a bizottság tagjai mindig a megelőző év szénkészletének kétharmadát kitermelő vállalatokból, illetve az alkalmazott bányászok feléből tevődtek össze, ez pedig jogalkotó hatalom delegálása magánszemélyek részére, ami ahhoz vezethet, hogy a bizottsági döntések szempontjait magánérdekek határozzák meg. ${ }^{767}$

Cardozo különvéleményének a jelen tanulmány szempontjából releváns szakasza arra helyezi a hangsúlyt, hogy a Kongresszus beavatkozása indokolt, mivel a szénkitermelést olyan kiélezett verseny és elmérgesedett konfliktusok jellemezték, amelyek károsan befolyásolták az ország gazdaságát. A hivatkozott precedensekből azokat a gondolatokat emeli ki, amelyek az ötödik alkotmánykiegészítésben foglalt alapjogok

\footnotetext{
762264 U. S. 296-297

763269 U. S. 385

764 Vö. 269 U. S. 391

${ }^{765}$ Vö. pl. International Harvester Co. of America v. Kentucky, 234 U. S. 216 (1914); Collins v. Kentucky, 234 U. S. 634 (1914); American Seeding Machine Co. v. Kentucky, 236 U. S. 660 (1915)

766298 U. S. 238 (1936)

767298 U. S. 311
} 
korlátozhatóságára vonatkoznak. ${ }^{768}$ Egyúttal arra is rámutat, hogy nem ér el alkotmánysértő mértéket a jogalkotó hatalom delegálása, ugyanis az általa alkalmazandó standardok kellöen meghatározottak. ${ }^{769}$

Ugyanebben az évben a Morehead v. New York ex rel. Tipaldo-üggyel gyakorlatilag a tagállamok vonatkozásában ismétlődött meg mindaz, ami tizenhárom évvel korábban szövetségi vonatkozásban történt. New York állam ,,a szolgáltatással vagy annak típusával tisztességes és ésszerü arányban álló" bért elöíró törvénye elbukott a Supreme Court mércéjén. Butler bíró, az ötfös többség álláspontjának megfogalmazója, gyakorlatilag egy az egyben az Adkins-döntést veszi alapul, és leszögezi, hogy - legalábbis e kérdés vonatkozásában - a tizennegyedik alkotmánykiegészítés ugyanolyan korlátokat szab az államok, mint az ötödik alkotmánykiegészítés a Kongresszus számára. ${ }^{770} \mathrm{~A}$ két ügy tényállása nem indokolja azok egymástól való elkülönítését. A szóban forgó törvény semmivel sem konkrétabb az Adkinsben tárgyaltnál, ${ }^{771}$ így megítélésük sem különbözhet. Felidézve Sutherland kategóriáit, Butler rámutat, hogy csak a munkaidő szabályozásánál volt elfogadható a közérdekre vagy a nők és a férfiak fizikai eltérésére való hivatkozás. Kijelentve, hogy nem jogosult felülbírálni egy állam jogszabály-értelmezését, ${ }^{772}$ a Supreme Court helyben hagyta a New York-i bíróság alkotmányellenességet kimondó ítéletét.

A West Coast Hotel Co. v. Parrish-ügy tétje Washington tagállam munkaügyi törvényének alkotmányossága volt. Ez egyebek közt bizottságot állított fel, melynek jogában állt a munkáltatók és a munkavállalók képviselőiből álló egyeztető tanácskozást összehívni, amennyiben úgy találja, hogy valamely foglalkozáson belül a nöknek fizetett bér ,elégtelen arra, hogy a létfenntartáshoz szükséges költségeket biztosítsa számukra, valamint hogy a dolgozókat egészségben tartsa."773 A törvény öt szavazattal négy

\footnotetext{
768298 U. S. $330-332$

769298 U. S. 333

770298 U. S. 610

771 A New York-i törvény az „elnyomó és ésszerütlen” (oppressive and unreasonable) bérek két elemét határozza meg: 1. Kevesebb, mint a nyújtott szolgáltatás tisztességes és ésszerű ellenértéke („,less than the fair and reasonable value of the services rendered"). 2. Nem éri el az egészséges élethez szükséges minimális költségeket (less than sufficient to meet the minimum cost of living necessary for health). Vö. 298 U. S. 606! 772 „Az indítványozó állítása, miszerint a [New York-i] Fellebbviteli Bíróság helytelenül értelmezte a törvényt, nem fogadható el. E bíróságnak nincs hatalma egy állami rendelkezést az állam legföbb bírói fórumától eltérő módon értelmezni. Nem áll módunkban a kérelmező olyan értelmezésen nyugvó érvét figyelembe venni, melyet az a bíróság elvetett.” („Petitioner's contention that the Court of Appeals [of New York] misconstrued the Act cannot be entertained. This Court is without power to put a different construction upon the state enactment from that adopted by the highest court of the State. We are not at liberty to consider petitioner's argument based on the construction repudiated by that court.") 298 U. S. 609

773 ,[I]nadequate to supply them necessary cost of living and to maintain the workers in health[.]" $300 \mathrm{U}$. S. 387
} 
ellenében alkotmányosnak találtatott. A többségi véleményt megfogalmazó Hughes a következő érvekkel támasztotta alá álláspontját.

Az alkotmány nem tartalmazza szó szerint a „szerződési szabadság” kitételt - csak az általános szabadság szerepel benne. Az általános szabadság sokféleképpen korlátozható az emberek egészségét, biztonságát, erkölcseit, jólétét fenyegető veszélyek elhárítása céljából. Ez alól a szerződési szabadság, a szabadság különös esete sem kivétel. ${ }^{774}$ A szabadság garanciája nem tiltja meg az államnak, hogy akár korlátozó jellegü védintézkedéseket tegyen. E megfontolás szolgáltatta a Holden-ügy rációját is, mely különösen érvényes a nők vonatkozásában. A testület számos döntéssel megerősítette, hogy a nők egészségének védelme a nemzet életereje szempontjából legitim állami cél. ${ }^{775}$

A többségi vélemény végén érintőlegesen bírói önmegtartóztatás érvével találkozhatunk: ha valami, akkor a nők védelme a munkáltatói túlkapásokkal szemben melyeknek a férfiaknál egyébként is jobban ki vannak szolgáltatva - biztos, hogy közérdek, vagyis az államhatalom gyakorlásának legitim célja, a jogalkotó pedig minden további nélkül ítélheti úgy, hogy a minimálbér-szabás a cél elérésének alkalmas eszköze. De ha a megfontolás helyessége esetleg kétségbevonható, akkor is a jogalkotót jogosult annak megítélésére. ${ }^{776}$

Az indokolást Hughes egy gazdasági jellegü érvvel zárja. Arra hívja fel a figyelmet, hogy a különbözetet, mely a bér és a létminimum között fennáll, végső soron a társadalomnak kell megfizetnie. A társadalom ennek fizetésére nem köteles, és megteheti, hogy jogalkotó hatalmán keresztül orvosolja a közérdekkel nem törődő munkáltatók okozta károk következményeit. ${ }^{777}$

Különvéleményében, melyhez Van Devanter, McReynolds és Butler is csatlakozott, Sutherland lényegében egy „originalista krédót” fejt ki viszonylag hosszan. „[A]z Alkotmány jelentése nem változik a gazdasági események árapályával”, írja. ${ }^{778}$ Voltaképpen - korábbi álláspontjának megfelelően - posztulálja a „szabadság” kifejezés szerződési szabadságként való értelmezésének szöveghü jellegét, leszögezve, hogy a bíróságok feladata a jogot kinyilatkoztatni úgy, ahogyan az írva van. ${ }^{779} \mathrm{E}$ helyütt azt a Thomas McIntyre Cooley-t is idézi, aki a megfelelő eljárás követelményének szubsztantív

\footnotetext{
774300 U. S. $391-392$

775300 U. S. $394-395$

776300 U. S. $398-399$

777300 U. S. $399-400$

778 ,[T] $[$ he meaning of the Constitution does not change with the ebb and flow of economic events.” 300 U. S. 402

779300 U. S. 404
} 
értelmezésének elméleti alapjait szolgáltatta az 1870-es-80-as években. ${ }^{780}$ A különvélemény hátralevő részében amellett érvel, hogy a Supreme Court előtti tényállás lényegében hasonlít az Adkins-ügyéhez, így az utóbbiban felsorolt érvek a jelen esetre is vonatkoznak. Ennek megfelelően felidézi az Adkins-ügyben kidolgozott kategóriákat, ${ }^{781}$ a gyenge alkuképességű munkáltatók igazságtalan megterhelésének veszélyét, ${ }^{782}$ valamint annak a feltételezésnek téves voltát, miszerint a munkáltatót a munkavállaló létfenntartásáról való gondoskodásra irányuló erkölcsi kötelezettség terhelné. ${ }^{783}$

Összesen 32 döntés került áttekintésre a jelen szakaszban, amelyből 22-ben a Supreme Court a támadott rendelkezés alkotmányosságát állapította meg, az arány tehát 22:10 az alkotmányosságot kimondó döntések javára. Ez feltünően elüt a fellow servant rule-lal kapcsolatos esetcsoportban megfigyelhető értékektől, ahol a többség egyszer sem döntött az alkotmányellenesség megállapítása mellett. 15 döntésben mutatkozott valamilyen véleménykülönbség, ${ }^{784}$ akár született az adott ügyben írásos különvélemény, akár csak ellentétesen szavaztak a többségi állásponttal egyet nem értő bírák, ehhez képest 17 döntés lett egyhangú. ${ }^{785}$ E két csoportban éles tábormegoszlások mutathatók ki. Brewer és Peckham, a vizsgált időszak első évtizedeinek két leginkább konzervatívnak tekintett bírája öt olyan esetben jelzi tartózkodását a többségi döntéstöl, amikor az a támadott rendelkezés alkotmányosságát állapítja meg. Ennek fordítottjára a Lochner-, valamint az Adair-ügy szolgáltat példát, amelyben jelentős tábormegoszlás mellett e két bíró az alkotmányellenesség mellett voksoló többséghez tartozott. Az 1920-as-30-as évek négy konzervatív bírája, valamint a rendszeresen az alkotmányellenesség megállapítása ellen szavazók közötti szembenállás négy esetben mutatható ki, ebböl három esetben a többség a támadott rendelkezés alkotmányellenességét állapította meg, a negyedikben, a vizsgált

\footnotetext{
${ }^{780}$ Vö. Kens: i. m. 98-101. o., illetve Cooley, Thomas M.: Treatise on the Constitutional Limitations which Rest upon the Legislative Power of the States of the American Union. Little, Brown and Company, Boston, 1868, különösen 572-597. o.

781300 U. S. $406-407$

782300 U. S. 409

783300 U. S. 410

${ }^{784}$ Ezek a következők: Holden v. Hardy, Knoxville Iron Co. v. Harbison, Dayton Coal and Iron Co. v. Barton, Atkin v. Kansas, Lochner v. New York, Ellis v. United States, Adair v. United States, McLean v. Arkansas, Coppage v. Kansas, Wilson v. New, Bunting v. Oregon, Adkins v. Children's Hospital, Carter v. Carter Coal Co., Morehead v. New York ex rel. Tipaldo, West Coast Hotel Co. v. Parrish.

${ }^{785}$ Ezek a következők: St. Louis Consolidated Coal Co. v. Illinois, Cotting v. Kansas City Stock Yards Co. and the State of Kansas, Patterson v. Bark Eudora, Muller v. Oregon, Baltimore \& Ohio Railroad Co. v. Interstate Commerce Commission, Barrett v. Indiana, Sturges \& Burn Manufacturing Co. v. Beauchamp, Keokee Consolidated Coke Co. v. Taylor, Riley v. Massachusetts, Erie Railroad Co. v. Williams, Miller v. Wilson, Bosley v. McLaughlin, Booth v. Indiana, Chas Wolff Packing Co. v. Court of Industrial Relations of the State of Kansas, Chas Wolff Packing Co. v. Court of Industrial Relations of the State of Kansas, Radice $v$. New York, Connally v. General Construction Co. A számolás során idevettem azt az egy esetet is, amelyben egy bíró párhuzamos indokolás írása nélkül jelzi, hogy a döntéssel egyetért, de más indokok alapján.
} 
időszakot záró West Coast-döntésben pedig ennek fordítottja történt. Ezek mellett beszédes tábormegoszlást tükröz a Bunting-ügy is, az írásos különvélemény hiánya azonban nem teszi lehetővé természetének pontos megismerését.

Az imént ismertetett két tendenciózus tábormegoszlást összevetve a következő megállapítások tehetők. Az első csoportba tartozó ügyek tárgya túlnyomórészt a munkaidő szabályozása, és a Supreme Court mindenkori többsége azt általában alkotmányosnak itélte, ${ }^{786}$ ezzel szemben a második csoportba tartozó ügyekben a munkabér szabályozását alkotmányellenesnek. Annak ellenére, hogy mindkét tárgykör a munkaviszony bizonyos feltételeivel kapcsolatos, feltűnő a különbség azok alkotmányosságának megítélésében.

A munkaidő-szabályozást alkotmányosnak tartó döntések sehol nem mondják ki általános érvénnyel azt, hogy ez a fajta korlátozás akkor is alkotmányos lenne, ha a jogalkotó annak hatályát minden piaci szereplöre általánosan kiterjesztené. A korlátozáshoz mindig szükség volt legitim, ésszerü indokra. A releváns döntések két csoportra bonthatók. Egy részükben a szabályozás indokoltságát az adta, hogy az érintettek nők voltak. A férfiak és nők közötti természetes különbségek léte abban az időben magától értetődőnek számított, megkérdőjelezésük fel sem merült, és a nőkre vonatkozó protekcionista rendelkezéseket megfelelően igazolni lehetett egyrészt a nők gyengébb fizikumával, másrészt anyai szerepük össztársadalmi jelentőségével. ${ }^{787}$ Az esetek másik részében a munkavégzéshez kapcsolódó speciális veszélyek indokolták a szabályozást: ez a Holden v. Hardy-ügyben kerül kifejtésre, de a vizsgálódást kiterjesztve látható, hogy ezek az érvek legitimálták a különféle biztonsági intézkedéseket előíró rendelkezéseket is, a Lochner-ítéletben pedig éppen az bizonyult perdöntő körülménynek, hogy a Supreme Court többsége a pékek tevékenységét a veszélyesség tekintetében nem találta lényegesen eltérőnek egyéb „hétköznapi” foglalkozásoktól. 1917-re azonban ezt az elvet mintha a testület látványosan fellazította volna azáltal, hogy a Bunting v. Oregon-döntésben egy igen széles személyi hatályú törvény alkotmányosságát erősítette meg. Taft úgy fogalmaz 1923-as különvéleményében, hogy meglátása szerint a Bunting-döntéssel a Supreme Court hallgatólagosan felülbírálta a Lochner-döntést. Ez az álláspont első ránézésre megalapozottnak tünik, azonban amellett is lehet érvelni, hogy a testület azért fogadta el a

\footnotetext{
${ }^{786}$ A vizsgált esetek közül tulajdonképpen csak a Lochner-ítélet volt az, amelyben a munkaidő-szabályozás vonatkozásában alkotmányellenességet állapítottak meg.

${ }^{787}$ A jelen vizsgálódás nem elsősorban erre irányul, ezért csak mellékesen jegyezhető meg, hogy természetesen a XX. század utolsó harmadában felfutó feminista jogkritika képviselői ezeket a maguk korában progresszívnak felfogott protekcionista jogszabályokat, illetve az azokat alkotmányosnak minősítő bírói döntéseket élesen bírálták, mivel álláspontjuk szerint az ilyen megkülönböztető előírások csak megerösítik a társadalmilag konstruált és káros nemi sztereotípiákat.
} 
későbbi szabályozást, mert az nem szemelt ki néhány meghatározott foglalkozást. Ennek alapján a Lochner- és a Bunting-döntés között nem szükséges ellentétet feltételezni. De bármelyik álláspontot is fogadjuk el, a Bunting-döntéssel a Supreme Court egyértelmüvé tette, hogy az általános munkaidő-korlátozás alkotmányos alapokon nem kifogásolható.

Ezen előzményekhez képest meglepő, hogy a minimálbér szabályozásának kérdésében a testület markánsan elutasító álláspontot képviselt. A jelen tanulmányban tárgyalt, minimálbér-szabályozással összefüggő ítéletek az 1923-tól 1937-ig terjedő időszakban születtek. Érdekes módon azonban a Supreme Court már a Bunting-ügyben sejteni engedte, hogy a bérszabályozás alkotmányosságát szigorúbban ítéli meg: az indokolásban azt tekintette az első eldöntendő kérdésnek, hogy a támadott törvényhely bérszabályozás-e, avagy egészségvédelmi. ${ }^{788}$ A válasz az utóbbi volt, és az okfejtésből arra lehet következtetni, hogy ellenkező esetben a rendelkezés nem ment volna át az alkotmányosság próbáján. Az indítványismertetés alapján csak gyanítható, hogy ennek oka abban rejlik, hogy a minimálbér előírása egy személy vagyonától való jogellenes megfosztását és a vagyon más részére átadását jelentené, ami a Supreme Court gyakorlata alapján egyértelmüen az ötödik, illetve a tizennegyedik alkotmánykiegészítés által megfogalmazott tilalomba ütközik. Az Adkins-döntés indokolásában, a szerződési szabadság terjedelmének meghatározása során nyíltan előkerül ez az álláspont: Sutherland szerint míg a munkaidővel kapcsolatos precedenseknél a felek szabadok alkudhatták ki a munkavégzés ellenértékét, itt elvész ennek lehetősége, mert a törvény csak az egyik fél érdekeit veszi figyelembe, és arra kötelezi a másikat, hogy a munka értékére tekintet nélkül fizesse ki az előírt összeget. ${ }^{789}$

Nehéz belátni, hogy a munkaidő-szabályozáshoz képest ez az esetcsoport miért részesült ennyire eltérő megítélésben. Az Adkins-, illetve az azt lényegében mechanikusan alkalmazó Morehead-döntést olvasva úgy tűnik, a minimálbér esetében sajátos dilemma merült fel. Egyrészt valóban igaz az, hogy a minimálbér előírása súlyosabb beavatkozás a munkáltatók szabadságába, másfelől azonban - mint arra Taft és Holmes is rámutattak különvéleményükben ${ }^{790}$ - a munkáltatók számára nem volt kötelező belépni a szerződésbe. A testület előtt két út állt ezen esetcsoport megítélése során: vagy az addigi precedensekben vizsgáltaktól eltérő kategóriaként kezeli a minimálbér elöírását, vagy azt is az alkotmányos szabadságjogok egy megengedhető, indokolható korlátozásaként értelmezi

\footnotetext{
788243 U. S. 435

789261 U. S. 557

790261 U. S. 564, illetve 570
} 
- miként egy sor más piacszabályozó intézkedést. Mint láthattuk, 1937-ig az első felfogás diadalmaskodott. A Supreme Court korabeli többsége az alkotmányos és az alkotmányellenes közötti határvonal meghúzására törekedett, és a minimálbér-elöírásokat kézenfekvő sarkalatos pontnak tünt e kontextusban, ha elfogadjuk azt az érvet, hogy az ilyen szabályozás az ellenszolgáltatás értékén felüli bérfizetésre köteles, és ezért a tulajdonhoz való jogot sérti. Azonban ki kell emelni, hogy a Supreme Court többsége nem a tulajdonhoz való jog sérelmét emeli középpontba indokolásában, hanem a szerződési szabadságot. Az Adkins-ügyben a jogszabály alkotmányosságát támadó felek túláradó bőséggel hivatkoznak a tulajdonhoz való jogra, ${ }^{791}$ és Sutherland is foglalkozik általánosságban annak tartalmával, ${ }^{792}$ utána azonban a konkrét rendelkezést kizárólag a szerződési szabadsággal veti össze. Meglátásom szerint azonban pusztán a szerződési szabadságra való hivatkozás elégtelen a szabályozás alkotmányellenességének megállapítására, és ezen összefüggésben a különvéleményt megfogalmazó bírák helyesen kritizálták a többségi álláspontot. Logikusabb lett volna, ha Sutherland a tulajdonhoz való joggal összefüggésben indokolja az alkotmányellenességet. Való igaz, a tulajdonhoz való jog és a szerződési szabadság között általában szoros kapcsolat feltételezhető, ${ }^{793}$ ám a testület ezt nem emelte ki kellőképpen.

Fontos szem előtt tartani azt is, hogy a többi alkotmányellenességet megállapító precedens nem említhető egy lapon az imént elemzett két ítélettel. A két Chas. Wolffügyben a meghatározó tényező az volt, hogy a jogszabály a felekre nézve kötelező szerződési feltételek szabását tette lehetővé, ráadásul bizonyos - a köz szempontjából kiemelkedő jelentőségünek minősített - gazdasági tevékenységek folytatásának megszakítását csak akkor engedte a meghatározott vállalatoknak, ha az elkerülhetetlenül csődhöz vezet. A Connally-ügy esetében tulajdonképpen a jogbiztonság sérelme eredményezte a szabályozás alkotmányellenességét, nem annak tartalma. A Carter v. Carter Coal Co.-ítéletben pedig a megfelelő eljárás követelménye csak mellékes kérdés volt. Ez utóbbit leszámítva a felsorolt döntések egyhangúak lettek, tehát nem volt nézeteltérés a bírák között.

Hogyan értékelhető a fentiek tükrében a West Coast-ügy? Megítélésem szerint szük kontextusban szemlélve a Supreme Court valóban váltást hajtott végre: az Adkins- és a Morehead-ügyekben alkotmányellenesnek tekintettekhez kétségkívül hasonló

\footnotetext{
791261 U. S. $535-538$

792261 U. S. $545-546$

${ }^{793}$ Vö. pl. Téglási András: A tulajdonhoz való jog alkotmányos védelme. Pólay Elemér Alapítvány, Szeged, 2013, 223-224. o.
} 
jogszabályhelyet ezúttal alkotmányosnak minősített. Ha azonban a precedensek némileg szélesebb körére terjesztjük ki a vizsgálódást, az látható, hogy e döntésével a testület „csak” beillesztette a szóban forgó kérdést évtizedes gyakorlatába. A West Coast-ügyben elfoglalt álláspont szilárd megalapozást nyer a korábbi precedensekböl, amelyekben a Supreme Court számos különbözö, a munkavégzéssel kapcsolatos szabályozást nyilvánított alkotmányosnak. 


\section{Konklúzió}

Az alábbiakban két fó pontban ismertetem a fenti fejtegetésekből levonható következtetéseket. E következtetések két irányba mutatnak; egyikük átfogóbb jellegü, és a Supreme Court szélesebb alkotmányértelmezési gyakorlatának jellemzésére irányul annak alapján, amit a megfelelő eljárás követelményének értelmezése kapcsán megismerhettünk. A másik következtetés szükebb jellegü, és kifejezetten annak meghatározására irányul, hogy a Lochner-ítélet hogyan helyezhető el korának precedenskörnyezetében. Az első következtetés levonásának indokoltsága a korabeli alkotmányértelmezési gyakorlat mélyebb megismerésében ragadható meg. A második következtetés létjogosultságát az annak tárgyául szolgáló jogeset emblematikus volta és vitás megítélése szolgáltatja. 1937 után a Lochner-ügy amolyan ,jogtudományi mumusként” kísértette végig a szakmai közvéleményt, nyílt „,rehabilitációját” pedig - legalábbis részben - egy olyan jogelméleti irányzat - a jog gazdasági elmélete - hozta el, mely maga sem mentes bizonyos ideológiai kötődésektől. Meglehetősen túlzó lenne kijelenteni, hogy ebben a dolgozatban pontot tettem a Lochner-ítélet reputációs vitájának végére; a Supreme Court gyakorlatának beható elemzése azonban, úgy gondolom, szilárdan alátámasztja az itt kifejtett álláspontomat.

\section{V.1. A Supreme Court XIX. század végi és XX. század eleji alkotmányértelmezési gyakorlatának jellemzése}

A jelen tanulmányban tárgyalt ügycsoportokból egyértelműen kiviláglik, hogy a Supreme Court az 1890 és 1937 közötti időtartamban tendenciózusan dogmatikus passzivista gyakorlatot folytatott. Érvelését a józan észre alapozott meglátások jellemzők, és okfejtései során nem hivatkozik az érintett problémákkal kapcsolatos külső szakirodalomra.

A puszta számokat tekintve a vizsgált 114 döntésből 13 esetben állapított meg alkotmányellenességet a Supreme Court. ${ }^{794} \mathrm{Ez}$ az összesített adat azonban nem teljes a belső megoszlások ismertetése nélkül: ezeket szemügyre véve az látható, hogy a 13 alkotmányellenességet kimondó döntésből tíz a munkaviszony feltételeit, körülményeit

\footnotetext{
${ }^{794}$ A vizsgált esetek körében a döntési arányokat illetően a Függelék 2., 3. és 4. diagramja is áttekintést ad .
} 
szabályozó jogszabályokra vonatkozott. Ez a tárgykör tehát messze vitatottabb megítélésűnek bizonyult, mint a többi. A Supreme Court gyakorlatát vizsgálva azonban nem látszik indokolhatónak az, hogy itt miért nyilvánított a testület arányaiban több jogszabályt alkotmányellenesnek, mint a többi esetkörben. A testület rendszeresen támaszkodott olyan érvekre, amelyek alapján az alkotmányellenesség megállapításában végződő ügyekben is az alkotmányosságot megállapító döntés születhetett volna. Ehhez képest bizonyos konkrét tárgyú ügyekben a Supreme Court következetesen kimondta a támadott szabályozás alkotmányellenességét; mindenekelőtt a „sárga kutya-szerződések” és a minimálbér elöírása sorolható ebbe a körbe. Ezek az esetek két okból is különösen magyarázhatatlanok.

Egyrészt a Supreme Court legkésőbb 1898-ban, a Holden v. Hardyban felhasználta érvként a munkáltatóval szemben fokozottan alkuképtelen munkavállaló sztereotípiáját, egy olyan ügyben, amelyben egyébként perdöntő jelentőségű volt az a körülmény is, hogy a kérdéses szabályozás közismerten magas kockázati faktorú iparágakat érintett. Ez minden további nélkül felhasználható lett volna akár azokban az esetekben, amikor a munkáltató a kollektív érvényesítés lehetőségétől akarja a munkaszerződés révén elvágni alkalmazottait, akár azokban, amikor az elvégzett munkáért való juttatás elégségessége vitatott.

Másrészt a munkabér-szabályozással összefüggésben nehéz meghatározni, mi az a specifikum, ami miatt a munkaidő még szabályozható alkotmányosan - és nemcsak átmeneti jelleggel -, a munkabér már nem. Mindkét esetben a munkaviszony valamilyen lényeges elemét érinti a szabályozás, és a jogalkotó mindkét esetben rögzíti a munkaszerződés mint alku valamilyen összetevőjét az egyik oldalon úgy, hogy a másik oldalt érintetlenül hagyja.

Első ránézésre természetesen kézenfekvő lenne a testület többségének a laissez-faire, vagy akár a spenceri szociáldarwinizmus számlájára írni ezeket a döntéseket, hiszen azok végeredménye ezekkel a nézetekkel áll összhangban. Ez azonban elhamarkodott következtetés lenne. Egyrészt ha így lett volna, miért épp ezeket a tárgyköröket szemelte volna ki a testület arra, hogy érvényesítse állítólagos meggyőződését? Másrészt ha így volna, akkor miért hivatkozott egyes döntéseinek indokolásában kiszolgáltatott, az állam beavatkozására rászoruló csoportokra? Harmadrészt a személyes meggyőződés és a szakmai követelmények elválaszthatók egymástól, és azt a jogászi szakmák meg is követelik. Egyáltalán nem szükségszerü, hogy a szabadversenyes kapitalista gazdaságfelfogással bármilyen módon összhangban álló eszmét valló személy ezt a 
meggyőződését a szakmájában is érvényesíteni akarja. A legszemléletesebb példa erre éppen Holmes, aki annyira rokonszenvezett a szociáldarwinizmussal, hogy pártolta a nagytőkések beavatkozását a politikába azon az alapon, hogy mivel ők állták ki a legjobban a szabad verseny kihívásait, ezért ők rendelkeznek a legnagyobb rálátással a társadalom szükségleteire, és ők a legalkalmasabbak a vezetésre; ennek ellenére a jogászi érvelés szintjén gyakran semmilyen ellenvetést nem tett azoknak a jogszabályoknak az alkotmányosságával szemben, amelyek - felfogása szerint - a gyengéknek kedveznek az erősekkel szemben.

Megítélésem szerint a probléma magyarázata máshol keresendő. A viszonylag friss szakirodalom szerint a Supreme Court a századforduló környékén következetes elveket érvényesített, amelyek a természetjog eszméiből, valamint a többé-kevésbé hasonló helyzetü és alkuképességü személyekből álló társadalom képén alapultak, amiből az is következett, hogy a testület alkotmányértelmező tevékenysége során fellépett az egyes társadalmi csoportok indokolatlan megkülönböztetése ellen. A testület döntéseit elemezve jól látható, hogy az esetek túlnyomó többségében igazodott a megváltozott társadalmi körülményekhez. A probléma nem abban volt, hogy a Supreme Court nem bírt volna alkalmazkodni a változásokhoz, hanem abban, hogy a változások tendenciáinak határt akart szabni, mert annak veszélyét látta bennük, hogy a jogalkotó minden fék nélkül leszükíti a magánjogi személyek mozgásterét a szerződéskötés terén.

A munkaidő és a munkabér szabályozása megítélésének eltérései ezt szemléltetik, és a Lochner-ítélet indokolásának az a fordulata, miszerint előfordulhat, hogy a dolgozó hosszabb munkaidőben szeretne dolgozni a magasabb bérért, implicite magában foglalja ezt a megfontolást. Látható volt, hogy kisszámú kivételtől eltekintve a Supreme Court nem vitatta a munkaidő maximálásának alkotmányosságát; ennek legfőbb állomása a Bunting $v$. Oregon-ügy volt. Ehhez képest a minimálbér elöírása sokkal komolyabb alkotmányos akadályokba ütközött. A kétféle szabályozás a következő problémát veti fel. Önmagában a munkaidő szabályozása nincs közvetlen hatással a munkabérre, így megeshet, hogy a határok közé fogott munkaidő ellenében a munkáltató ennek megfelelően csökkentett bért fizet. A piaci korlátozások alkotmányossága mellett gyakran elhangzott az az érv, hogy az alku egyik oldalának törvényi keretek közé utalása nem eredményezi az érintett személyek szabadságának korlátozását, hiszen a csökkentett munkaidő mellett nem voltak kötelesek a korábbi összegü munkabért fizetni. A fizetéscsökkenés felveti annak problémáját, mennyire elegendő az így fizetett bér a létminimumhoz, ez pedig potenciálisan maga után vonhatja a minimálbér előírásának lehetőségét. A Lochner-ítélet indokolásában olvasható 
egy olyan megfontolás, miszerint a kérdéses szabályozás alkotmányossá nyilvánításával a Supreme Court rengeteg abszurd korlátozásnak engedne szabad utat. Ez a gondolat egy konzekvencialista felfogást tükröz, és bár az ismertetett gyakorlatot tekintve ez a megfontolás, ha egyáltalán megjelent, csak elvétve sarkallta a testületet a jogalkotó mozgásterének korlátozására, az mindenképp látható, hogy volt egy véglet, amitől a

Supreme Court óvni akarta a jogrendszert és a társadalmat. Elképzelhető, hogy a minimálbér szabályozásának bevezetésében a testület az e véglethez való közelítést észlelte, és ezért helyezkedett arra az álláspontra, hogy itt a jogalkotó túllépte az alkotmányosság határát. E döntések precedenskörnyezetét szem előtt tartva elmondható, hogy ez az álláspont téves. A magyarázat azonban pusztán a testület korabeli alkotmányértelmezési gyakorlatában is fellelhető: megalapozottan lehet amellett érvelni, hogy a minimálbér előírása ésszerü kapcsolatban áll a közjólét előmozdításának alkotmányos céljával. Ehhez szükségtelen foglakozni annak gazdasági hatékonyságával mint ahogy a Supreme Court számtalan egyéb esetben is hangsúlyozta, hogy a jogalkotó aktusainak „bölcsességével” (wisdom), megfontoltságával. Ebből kifolyólag megítélésem szerint nem állítható, hogy a Supreme Court alkotmányértelmezését meghatározó elvek önmagukban alkalmatlanok lettek volna az új társadalmi kihívásoknak való megfelelésre. Az előfordulhat, hogy az alkotmányt értelmező bírák társadalomképe nem állt összhangban a kor valóságával - ámbátor az elemzett ítélkezési gyakorlat nem ezt mutatja -, magáról az értelmezési keretről azonban ez nem mondható el.

\section{V.2. A Lochner-ítélet helye a Supreme Court gyakorlatában}

Paul Kens részletesen elemezte a Lochner-ítéletben vizsgált Bakeshop Act, valamint maga a döntés megszületésének körülményeit, az azokhoz vezető körülmények összjátékát; ennek fontosabb mozzanatai a III.5. szakaszban is ismertetésre kerülnek. Valószínúleg rengeteg más korabeli törvényhez kapcsolódik hasonló, vagy akár még érdekfeszítőbb történet. A Bakeshop Act történetét az az ítélet tette különlegessé, amelyben a támadott rendelkezései megmérettettek és könnyünek találtattak. Egyetlen ítélet önmagában nem sokat árul el az azt meghozó bíróság gyakorlatáról, ezért a jelen értekezésben elsősorban ítélkezési, érvelési tendenciákra, átfogó fejleményekre igyekeztem ráirányítani a figyelmet. A Lochner-ítélet „nimbusza” azonban megkerülhetetlenné teszi, hogy maga a konkrét döntés is elhelyezésre kerüljön az átfogóbb gyakorlatban. 
A Bakeshop Act kritikus pontjának egyrészt az bizonyult, hogy olyan iparágat emelt ki és szabályozott, amely a munkavállalókat érő egészségügyi kockázat tekintetében a közvélemény szerint nem különbözött lényeges mértékben számos más iparágtól; másrészt az, hogy a Lochner-ügyben támadott rendelkezése távoli kapcsolatban állt a törvény deklarált egészségügyi céljával. Ez az egészségügyi cél két vonatkozásban merült fel: a közegészség és az érintett munkavállalók egészsége kapcsán. A tagállam képviselöje szerint az elkészített sütőipari termékek minőségét, ennélfogva a köz egészségét befolyásolja az, mennyire kimerültek vagy kipihentek a dolgozók, maguk a pékek pedig az egészégre ártalmas körülmények között dolgoznak, ezért munkaidejük korlátozása alkotmányos alapokon nyugszik.

Az első kritikus ponttal kapcsolatban két megjegyzés tehető. valószínűleg önmagában még nem lett volna elég az alkotmányellenesség megállapításához; a kenyér mint az egyik legalapvetőbb élelmiszer elóállításának könnyen adódhat olyan vonatkozása, amely ésszerűvé teszi annak szabályozását - és ehhez hozzá kell tenni, hogy a Bakeshop Act higiéniai elöírásait nem is kifogásolták a Lochner-ügyben. Ráadásul a Supreme Court más esetekben is alkotmányosnak nyilvánított olyan szabályokat, amelyek tárgyi hatálya meghatározott számú tevékenységre szükült.

A vita a második pont megítéléséből fakad, vagyis abból a kérdésből tekinthető-e egészségügyinek ez a rendelkezés. A Supreme Court többsége elutasította mindkét érvet, amellyel a tagállam képviselője azt próbálta igazolni, hogy a támadott rendelkezés egészségügyi elöírásnak minősíthető. Ez az állásfoglalása azonban nem olyan kikezdhetetlen, mint amilyennek az előadó bíró igyekezett beállítani. A Supreme Court következetesen tartotta magát ahhoz a mércéhez, hogy a szabályozás és annak célja között ésszerü kapcsolatnak kell fennállnia, a szabályozás adekvátságának („,bölcsességének”) vizsgálatától azonban tartózkodott. Ez a két elv azonban feszültségbe kerülhetett egymással. A Lochner-ügy esetében éppúgy kijelenthető az, hogy a munkaidő és a termék minősége (mint a közegészséget érintő dolog) független egymástól (és ezáltal az „ésszerü összefüggés" hiányára tekintettel alkotmányellenessé nyilvánítható a kérdéses rendelkezés), mint az, hogy van értékelhetö kapcsolat a kettő között például azért, mert a kipihent dolgozó várhatóan nagyobb odafigyelést tanúsít arra, hogy megfelelően készíti el a terméket (és erre tekintettel a bíróság nem foglalkozik a jogalkotó „bölcsességével” és azzal, tényleg a legjobb megoldást választotta-e a probléma kezelésére). Ennek a határvonalnak a képlékenységét jól illusztrálja egy másik korabeli probléma, a szesztilalom. A Supreme Court már a tizennyolcadik alkotmánykiegészítés elfogadása előtt 
következetesen alkotmányosnak nyilvánította a szeszesital-forgalmazás korlátozását vagy akár teljes tilalmát, holott mára már meglehetősen bevett vélekedéssé vált - és ezt épp a tizennyolcadik alkotmánykiegészítés kudarca igazolta -, hogy a tilalom nem vezetett eredményre, alkalmatlan volt céljának elérésére. Mégsem állítható, hogy nincs - legalábbis felszínesen - értékelhető összefüggés a korlátozó rendelkezések és a cél - a csökkenő alkoholfogyasztás és annak egészségügyi előnyei - között. Ennek analógiájára amellett is lehet érvelni, hogy a pékek munkaideje és a termék minősége között fennáll egy olyan felszíni összefüggés, ami az alkotmányosságot megalapozza, még akkor is, ha a gyakorlatban ez az intézkedés nem éri el deklarált célját.

A Supreme Court azonban meg akarta vonni önmegtartóztatásának határát, és a Lochner-ügy lett ennek a határmegvonásnak az állomása. Ez bizonyos szempontból érthető, ugyanis nem lehet említés nélkül hagyni azt a körülményt, hogy a jogalkotó meglehetősen szerencsétlenül választotta meg szabályozásának tárgyát, valamint a szabályozás indokait. A közvélekedés számára a sütőipari munka csak egy volt a sok közül, és - dacára mindazoknak a körülményeknek, amelyekröl Kens beszámol - nem rejtett magában semmilyen kiemelt veszélyforrást, a támadott rendelkezés alkotmányossága mellett felhozott érvek pedig túlságosan univerzálisak voltak ahhoz, hogy kizárólag az érintett iparágak vonatkozásában meghatározóak legyenek. A közvélemény szemében a nyilvánvaló kockázatok hiánya miatt a munkavállalók egészsége nem lehetett meghatározó szempont, hiszen ez alapján bármely szakma szabályozható lenne hasonlóképpen, elvégre minden foglalkozás maga után vonja a saját egészségügyi kockázatait. Hasonló mondható el a köz egészségének érintettségéről is: bármely iparágról elmondható, hogy annak dolgozói kipihenten minőségibb szolgáltatást nyújtanak, illetve termékeket állítanak elö.

Nem szabad megfeledkezni arról, hogy a Supreme Court mindemellett sem törekedett arra, hogy precíz kategorizálásra sarkallja a jogalkotót. A Holden v. Hardyügyben támadott törvény csak a bányászok és az olvasztómunkások vonatkozásában maximálta a munkaidőt, és a Supreme Court (hétfös többsége) ennek semmilyen alkotmányos akadályát nem látta, holott felhozható lenne az az ellenvetés, hogy más iparágak éppúgy jelentős kockázatot hordoznak magukban, mint az említettek, és egy valóban diszkriminációmentes szabályozás ezekre mind egyformán vonatkozna. A Supreme Court korabeli gyakorlatából azonban világosan kitűnik, hogy nem értelmezte ilyen feszesen a diszkrimináció tilalmát. A bányászok és olvasztómunkások vonatkozásában a nyilvánvaló ismeretek körébe tartozott ezeknek a tevékenységeknek az 
egészségre veszélyes jellege, ezért a Supreme Court nem is vette tekintetbe azt, hogy más tevékenységek nem maradtak-e ki diszkriminatív módon a szabályozásból. A Lochnerügyben az egészségkárosodás veszélye nem volt ilyen nyilvánvaló, így a testület azt nem tekintette mérvadó megfontolásnak.

A Bakeshop Act egy tényfeltáró jelentés, az annak nyomán keletkezett széleskörü felháborodás, valamint a problémák orvoslását célzó nagyívü reformtörekvés eredményeképp született meg, és mindezt a belső pártmozgások elősegítették (de legalábbis nem hátráltatták). A szabályozás kézenfekvő volt, és a politika logikáját ismerve természetes, hogy a jogalkotó reagált egy olyan problémára, ami - a média közvetítésének is köszönhetően - széleskörü visszhangot váltott ki. A szabályozás tárgyának megválasztása nem volt szerencsés, mert olyan „határesetet” érintett, ami a kor alkotmányjogi dogmatikájának fényében nagyon bizonytalan megítélésű volt. Ezt már a tagállami bíróságok előtti eljárás is mutatja, ${ }^{795}$ és végül a Supreme Court többsége sem tudott mit kezdeni a kialakult helyzettel. Ebböl azonban nem következik, hogy a Lochnerügyben a többség valamilyen ideológiai meggyőződés alapján nyilvánította a Bakeshop Act támadott szabályát alkotmányellenessé, az meg még kevésbé, hogy a testületet átfogó gyakorlata során ilyen megfontolások mozgatták. Még az sem állítható meggyőzően, hogy a Supreme Court alkotmányértelmezési elvei fölött a progresszív korban, a fokozott állami beavatkozás szükségességének megjelenésével eljárt az idő: látható volt, hogy rengeteg szabályozási megoldást alkotmányosnak nyilvánított a testület, és tekintettel volt kora társadalmi változásaira. E döntéseinek indokolása során rendszerint a vonatkozó tudományos szakirodalom nyílt hivatkozása nélkül, a józan ész alapján feltételezhető belátásokra támaszkodott, ebből kifolyólag összességében a „dogmatikus passzivista” kategóriával jellemezhető a gyakorlata. A Lochner-ügy azonban az általa érintett megfontolások vitathatósága miatt nem fért bele ebbe a passzivista gyakorlatba.

\footnotetext{
${ }^{795}$ Azt, hogy mennyire vitatott volt a Bakeshop Act támadott rendelkezésének megítélése, jól mutatja, hogy a Supreme Court eljárását megelőzően a tagállami bíróságok is komoly szembenállások mellett hoztak döntést. New York állam Legfelsőbb Bíróságának fellebbviteli osztályán (Appellate Division of the Supreme Court) 3:2 arányban született döntés a jogszabály alkotmányossága mellett, a New York Állam Fellebbviteli Bírósága (Court of Appeals of the State of New York) elötti eljárás pedig 4:3 arányban végződött ugyanezen eredménnyel. Vagyis amellett, hogy a tagállami fellebbviteli bíróságok - az elsőfokú eljárás pontos eredményéről nincs adat - alkotmányosnak ítélték a Bakeshop Act vonatkozó passzusát, ez a többség mindig csak egy fön múlt.
} 


\section{Függelék}

1. diagram: A „bírói aktivizmus” (judicial activism) kifejezés előfordulási aránya 1925 és 2008 között a Google Ngram Viewer alapján (https://goo.gl/NdKTDR; 2017. február 25.)

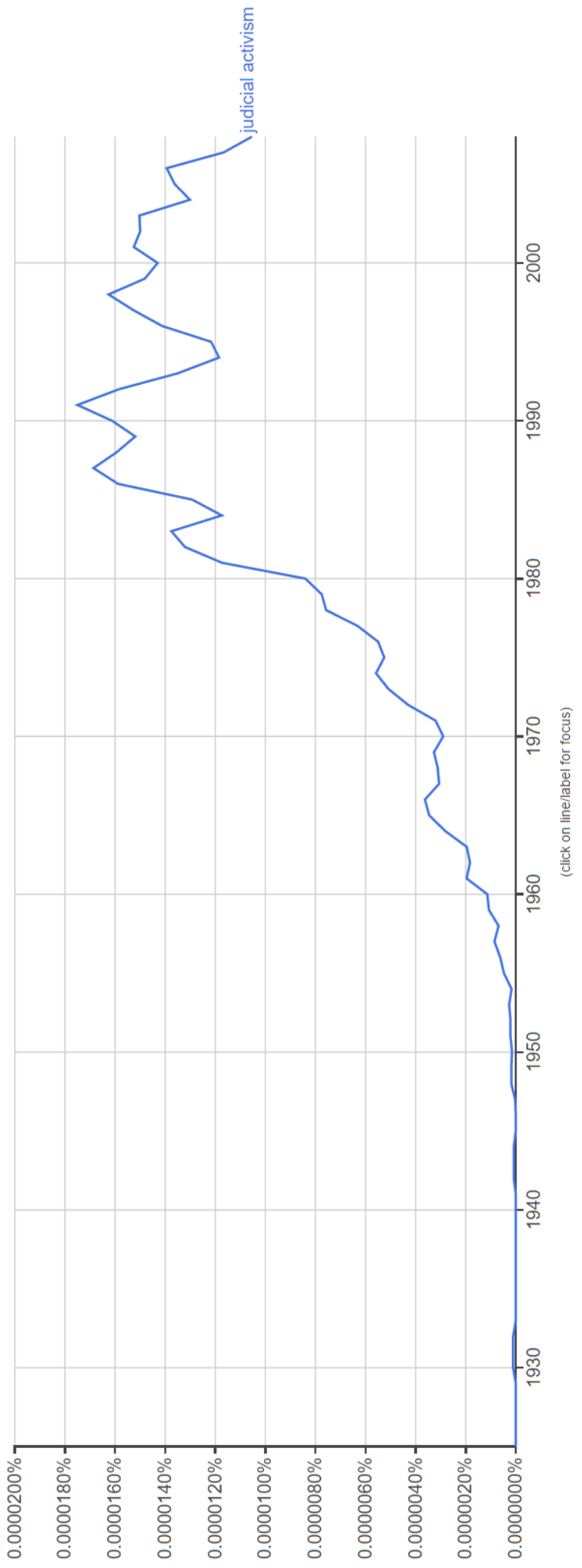


2. diagram: A IV. fejezetben vizsgált tárgykörökben született döntések megoszlása a támadott szabályozás $\underline{\text { megítélése szerint }}$

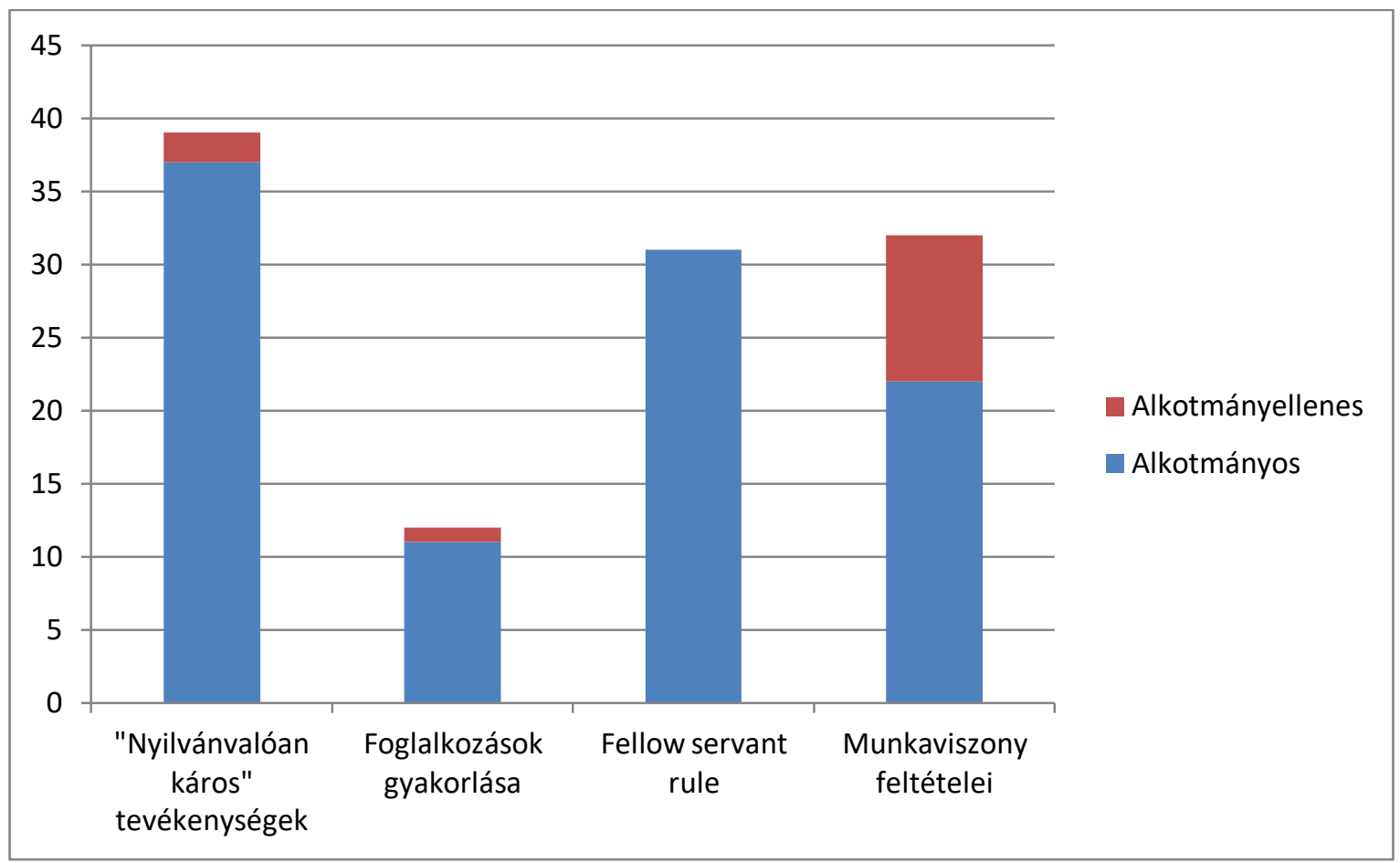

3. diagram: A IV. fejezetben vizsgált, alkotmányosságot megállapító döntések megoszlása tárgykör, valamint az álláspontok megosztottsága szerint

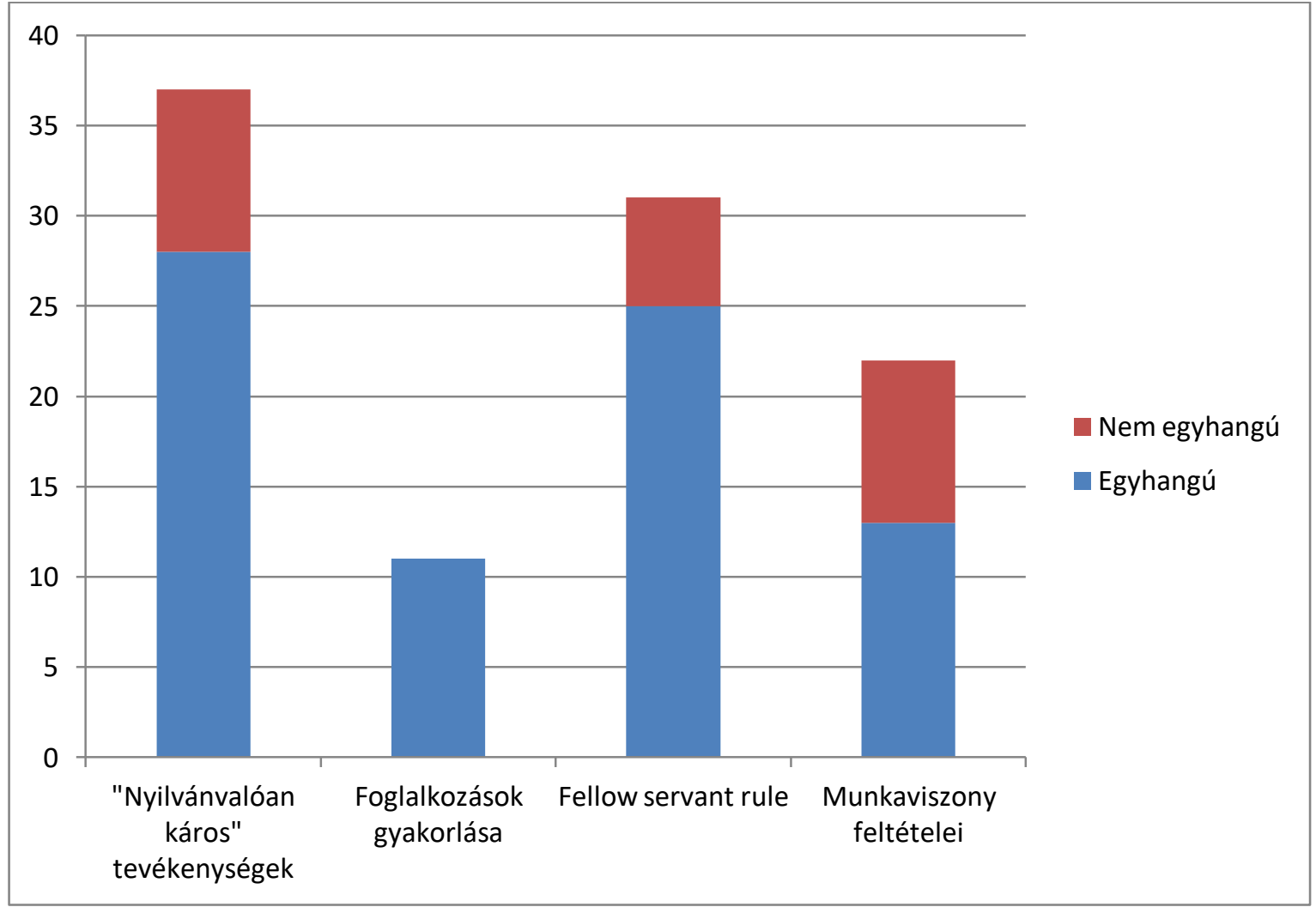


4. diagram: A IV. fejezetben vizsgált, alkotmányellenességet megállapító döntések megoszlása tárgykör, valamint az álláspontok megosztottsága szerint

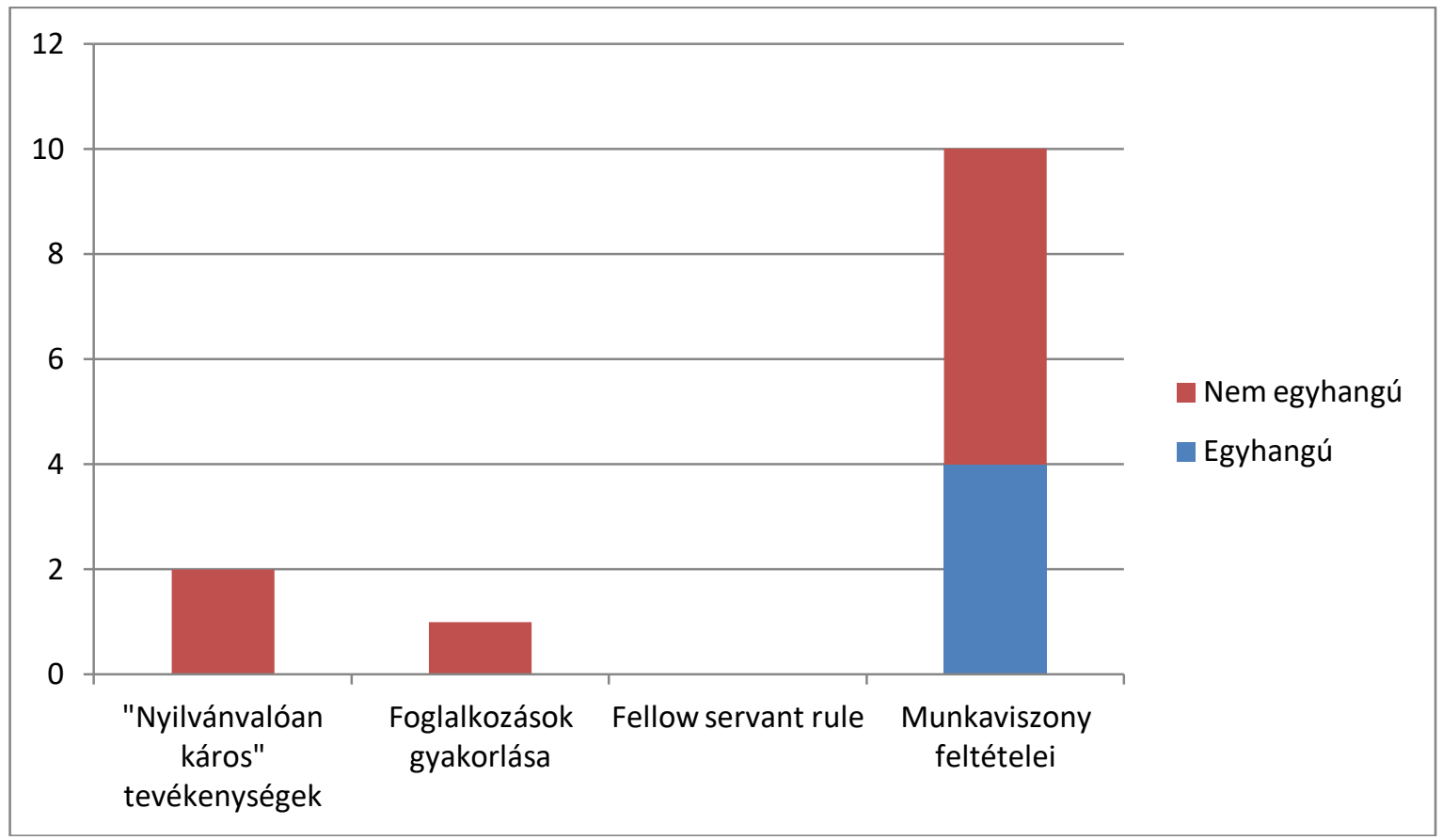




\section{Felhasznált irodalom}

Abramson, Paul R. - Pinkerton, Steven D. - Huppin - Mark: Sexual Rights in America. The Ninth Amendment and the Pursuit of Happiness. New York University Press, New York - London, 2003.

Balkin, Jack M.: "Wrong the Day It Was Decided": Lochner and Constitutional Historicism. In Boston University Law Review Vol. 85, 2005, 677-725. o.

Balkin, Jack M. - Levinson, Sanford: The Canons of Constitutional Law. In Harvard Law Review, Vol. 111, 1998, 964-1022. o.

Balkin, Jack M. - Levinson, Sanford: Thirteen Ways of Looking at Dred Scott. In Chicago-Kent Law Review, Vol. 82, 2007, 49-95. o.

Barnett, Randy E.: Foreword: What's so Wicked About Lochner? In New York University Journal of Law \& Liberty, Vol. 1, 2005, 325-333. o.

Becker, Gary. S.: Crime and Punishment: An Economic Approach. In Journal of Political Economy Vol. 76, 1968, 169-217. o.

Bencze Mátyás: Díszítőelem, álcázóháló vagy tartóoszlop? - A büntetőbírói gyakorlat és az Alkotmány. In Fundamentum, 2007/3. szám, 5-21. o.

Bergan, Francis: Mr. Justice Brewer: Perspective of a Century. In Albany Law Review Vol. 25, 1961, 191-202. o.

Berger, Raoul: Congress v. The Supreme Court. Harvard University Press, Cambridge, 1974

Berger, Raoul: Government by Judiciary: The Transformation of the Fourteenth Amendment. Harvard University Press, Cambridge, 1977

Berger, Raoul: The Ninth Amendment. In Cornell Law Review, Vol. 66, 1980, 1-26. o.

Bernstein, David E.: Rehabilitating Lochner. Defending Individual Rights against Progressive Reform. University of Chicago Press, Chicago, 2011

Bernstein, David E.: You Can't Say That! The Growing Threat to Civil Liberties from Antidiscrimination Laws. Cato Institute, Washington, 2003

Bewig, Matthew S. R.: Laboring in the "Poisonous Gases": Consumption, Public Health and the Lochner Court. In New York University Journal of Law \& Liberty, Vol. 1, 2005, 476-495. o. 
Bickel, Alexander: The Least Dangerous Branch - The Supreme Court at the Bar of Politics. Yale University Press, New Haven, 1986

Bloom, Harold: The Western Canon: The Books and School of the Ages. Harcourt, Brace \& Company, New York, 1994

Bojnár Katinka: Az Alkotmánybíróság határozata a család fogalmáról. A családfogalom szűkítő értelmezésének elfogadhatósága. In Jogesetek Magyarázata 4. évf., 1. szám, 2013, 19-27. o.

Brown, Ray A.: Due Process of Law, Police Power, and the Supreme Court. In Harvard Law Review Vol. 40, 1927, 943-968. o.

Calabresi, Guido: Some Thoughts on Risk Distribution and the Law of Torts. In The Yale Law Journal Vol. 70, 1961, 499-553.

Cantu, Timothy: Virtue Jurisprudence and the American Constitution. In Notre Dame Law Review, Vol. 88, 2013, 1521-1542. o.

Cappelletti, Mauro - Cohen, William: Az alkotmánybíráskodás története és jelenkori elterjedése. In Paczolay Péter (szerk.): Alkotmánybíráskodás - alkotmányértelmezés. Rejtjel Kiadó, Budapest, 2003, 41-51. o.

Chemerinsky, Erwin: The Price of Asking the Wrong Question: An Essay on Constitutional Scholarship and Judicial Review. In Texas Law Review Vol. 62, 1984, 1207-1261. o.

Chemerinsky, Erwin: Substantive Due Process. In Touro Law Review, Vol. 15, 1999, 1501-1534. o.

Chronowski Nóra et al.: Túl az alkotmányon... Az alkotmányvédelem elméleti és európai kontextusa, továbbá magyar gyakorlata 2010-ben, avagy felülvizsgálható-e az alkotmánymódosító törvény az Alkotmánybíróság által. In Közjogi Szemle, 4. szám, 2010, 1-12. o.

Coase, Ronald: The Problem of Social Cost. In Journal of Law and Economics Vol. 3, 1960, 1-44. o.

Commager, Henry Steele: Judicial Review and Democracy. In Levy, Leonard W. (ed.): Judicial Review and the Supreme Court, Harper Torchbooks, New York, 1967, 6473. 0 .

Cooley, Thomas M.: Treatise on the Constitutional Limitations which Rest upon the Legislative Power of the States of the American Union. Little, Brown and Company, Boston, 1868 
Coppedge, Michael et al.: Conceptualizing and Measuring Democracy: A New Approach. In Perspectives on Politics, Vol. 9, 2011, 247-267. o.

Corwin, Edward S.: Marbury v. Madison and the Doctrine of Judicial Review. In Michigan Law Review, Vol. 12, 1913-1914, 538-572. o.

Cox, Archibald: The Role of the Supreme Court in American Government. Oxford University Press, London, 1976

Csink Lóránt - Paczolay Péter: A törvényhozói mulasztás problémái az alkotmánybíráskodásban. In Szabó Imre (szerk.): Ius et legitimatio - Tanulmányok Szilbereky Jenő 90. születésnapja tiszteletére. Pólay Elemér Alapítvány, Szeged, 2008, 185-198. o.

Dabney, Arch'd D.: Abrogation of the Fellow-Servant Doctrine with Reference to Railroad Employees. In Virginia Law Register, Vol. 8, 1902, 245-254. o.

Dahl, Robert A.: Decision-Making in a Democracy: the Supreme Court as a National Policy-Maker. In Levy, Leonard W. (ed.): Judicial Review and the Supreme Court, Harper Torchbooks, New York, 1967, 105-123. o.

Diederichsen, Uwe: Das Bundesverfassungsgericht als oberstes Zivilgericht - ein Lehrstück der juristischen Methodenlehre. In Archiv für die civilistische Praxis, Bd. 198, 1998, 171-260. o.

Dombos Tamás - Polgári Eszter: Zavaros progresszió: Az Alkotmánybíróság a családok védelméről szóló törvényről. In Fundamentum 17. évf., 1. szám, 2013, 55-62. o.

Drinóczi Tímea: Ismét az alkotmányozó, az alkotmánymódosító hatalomról és az alkotmányellenes alkotmánymódosításról - az Alaptörvény alapján. In Jogtudományi Közlöny, 70. évf., 7-8. szám, 2015, 361-378. o.

Drinóczi Tímea: A racionális vagy tényeken alapuló jogalkotás és az Alkotmánybíróság. In Jogtudományi Közlöny, 70. évf., 5. szám, 2015, 229-243. o.

Dworkin, Ronald: Vajon szabályok rendszeréből áll-e a jog? In Varga Csaba (szerk.): Jog és filozófia. Antológia a XX. század jogi gondolkodása köréből. Szent István Társulat, Budapest, 2001, 383-416. o.

Dyevre, Arthur: Technocracy and distrust: Revisiting the rationale for constitutional review. In International Journal of Constitutional Law, Vol. 13, 2015, 32. o.

Easterbrook, Frank H.: Do Liberals and Conservatives Differ in Judicial Activism? In University of Colorado Law Review, Vol. 73, Issue 4, 2002, 1403-1416. o.

Elek Balázs: A hamis beismerő vallomást eredményező befolyásolás a büntetőeljárásban. In Debreceni Jogi Műhely, 2007/2. szám, 
http://www.debrecenijogimuhely.hu/archivum/2_2007/a_hamis_beismero_vallomast_ered menyezo_befolyasolas_a_buntetoeljarasban/ (2012. szeptember 14.)

Ely, John Hart. Democracy and Distrust. A Theory of Judicial Review. Harvard University Press, Cambridge, 1980

Ely, John Hart: The Wages of Crying Wolf: A Comment on Roe v. Wade. In The Yale Law Journal, Vol. 82, 1973, 920-949. o.

Epstein, Richard A.: Beyond Judicial Activism and Restraint. In The Georgetown Journal of Law \& Public Policy, Vol. 1, Issue 1, 2002, 85-91. o.

Epstein, Richard A.: Substantive Due Process by Any Other Name: The Abortion Cases. In Supreme Court Review, 1973, 159-185. o.

Frankfurter, Felix: The Constitutional Opinions of Justice Holmes. In Harvard Law Review Vol. 29, 1916a, 683-702. o.

Frankfurter, Felix: Hours of Labor and Realism in Constitutional Law. In Harvard Law Review, Vol. 29, 1916, 353-373. o.

Frankfurter, Felix: Mr. Justice Holmes and the Constitution. In Harvard Law Review Vol. 41, 1927, 121-173. o.

Friedman, Barry: The History of the Countermajoritarian Difficulty, Part Three: The Lesson of Lochner. In New York University Law Review Vol. 76, 2001, 1383-1455. o.

Gamer, Robert E.: Justice Brewer and Substantive Due Process: A Conservative Court Revisited. In Vanderbilt Law Review Vol. 18, 1965, 615-641. o.

Gillman, Howard: The Constitution Besieged. The Rise and Demise of Lochner Era Police Powers Jurisprudence. Duke University Press, Durham, 1993

Gillman, Howard: De-Lochnerizing Lochner. In Boston University Law Review Vol. 85, 2005, 859-865. o.

Golsong, Heribert: The European Court of Human Rights and the national lawmaker: some general reflections. In Matscher, Franz - Petzold, Herbert: Protecting Human Rights: The European Dimension. Carl Heymanns Verlag KG, Köln, 1990, 239-244. o.

Greene, Jamal: The Anticanon. In Harvard Law Review, Vol. 125, 2011, 379-475. o. Greene, Jamal: The So-Called Right to Privacy. University of California, Davis Law Review, Vol. 43, 715-748. o.

Grimmel, Andreas: 'This is not Life as it is Lived Here': The Court of Justice of the EU and the Myth of Judicial Activism in the Foundational Period of Integration through Law. In European Journal of Legal Studies Vol. 7, 2014, 56-76. o. 
Győrfi Tamás: Az alkotmánybíráskodás politikai karaktere. Értekezés a magyar Alkotmánybíróság első tíz évéről. Indok, Budapest, 2001

Hamilton, Alexander: The Federalist, 78. In Goldman, Lawrence (ed.): The Federalist Papers. Oxford University Press, Oxford, 2008, 379-385. o.

Hart, H. L. A.: A jog fogalma. Osiris Kiadó, Budapest, 1995

Hitchcock, Susan Tyler: Roe v. Wade: Protecting a Woman's Right to Choose. Chelsea House Publishers, New York, 2007

Holmes, Oliver Wendell: The Common Law. Little, Brown, and Company, Boston, 1881

Holmes, Oliver Wendell: Law in Science and Science in Law. In Harvard Law Review Vol. 12, 1899, 443-463. o.

Holmes, Oliver Wendell: Natural Law. In Harvard Law Review Vol. 32, 1918, 4044. 0 .

Holmes, Oliver Wendell: The Path of the Law. In Harvard Law Review Vol. 10, 1897, 457-478. o.

Horwitz, Morton J.: Law and Economics: Science or Politics? In Hofstra Law Review Vol. 8, 1980, 905-912. o.

Horwitz, Morton J.: The Place of Justice Holmes in American Legal Thought. In Gordon, Robert W. (ed.): The Legacy of Oliver Wendell Holmes, Jr. Stanford University Press, Stanford, 1992, 31-71. o.

Horwitz, Morton J.: The Transformation of American Law 1870-1960. Oxford University Press, Oxford, 1992

Hunt, Alan: The Sociological Movement in Law. The Macmillan Press Ltd., London, 1978

Jakab András: Az Alkotmány kommentárjának feladata. In Uő. (szerk.): Az Alkotmány kommentárja I. Századvég Kiadó, Budapest, 2009, 5-80. o.

Jakab András - Fröhlich Johanna: Alkotmányjogi érvelés az Alkotmánybíróság gyakorlatában. In Alkotmánybírósági Szemle, 2. szám, 2014, 83-103. o.

Jakab András: Az európai alkotmányjog nyelve. Nemzeti Közszolgálati Egyetem, Budapest, 2016

Jennings, Robert: Human rights and domestic law and courts. In Matscher, Franz Petzold, Herbert: Protecting Human Rights: The European Dimension. Carl Heymanns Verlag KG, Köln, 1990, 295-300. o. 
Johnson, Frank M.: In Defense of Judicial Activism. In Emory Law Journal Vol. 28, 1979, 901-912. o.

Kelley, Patrick J.: Holmes, Langdell and Formalism. In Ratio Juris, Vol. 15, 2002, 26-51. o.

Kelsen, Hans: General theory of Law and State. Harvard University Press, Cambridge, 1949

Kens, Paul: Lochner v. New York. Economic Regulation on Trial. Kansas University Press, Kansas, 1998

Kmiec, Keenan D.: The Origin and Current Meanings of "Judicial Activism". In California Law Review, Vol. 92, Issue 5, 2004, 1441-1477. o.

Krotoszynski, Ronald J.: The Wages of Crying Wolf Revisited: The Essential Consanguinity of Lochner, Roe, and Eastern Enterprises. In The Georgetown Journal of Law \& Public Policy, Vol. 1, 2002, 133-147. o.

Leishman, Rory: Against Judicial Activism - The Decline of Freedom and Democracy in Canada. McGill-Queen's University Press, Montreal - Kingston, 2006

Lenaerts, Koen: The Court's Outer and Inner Selves: Exploring the External and Internal Legitimacy of the European Court of Justice. In Adams, Maurice et al. (ed.): Judging Europe's Judges. The Legitimacy of the Case Law of the European Court of Justice. Hart Publishing, Oxford, 2013, 13-60. o.

Leuchtenburg, William E.: The Supreme Court Reborn. Oxford University Press, New York, 1995

Levinson, Sanford: Why I Do Not Teach Marbury (Except to Eastern Europeans) and Why You Shouldn't Either. In Wake Forest Law Review, Vol. 38, 2003, 553-578. o.

Levinson, Sanford: Why I Still Won't Teach Marbury (Except in a Seminar). In University of Pennsylvania Law Review, Vol. 6, 2004, 588-603. o.

Levy, Leonard W.: Judicial Review, History, and Democracy: An Introduction. In Levy, Leonard W. (ed.): Judicial Review and the Supreme Court, Harper Torchbooks, New York, 1967, 1-42. o.

Lindquist, Stefanie A. - Cross, Frank B.: Measuring Judicial Activism. Oxford University Press, New York, 2009

Link, Arthur S.: American Epoch - A History of the United States Since the 1890's. Alfred A. Knopf, New York, 1963 
Mahoney, Paul: Judicial Activism and Judicial Self-Restraint in the European Court of Human Rights: Two Sides of the Same Coin. In Human Rights Law Journal Vol. 11, 1990, 57-89. o.

Marshall, William P.: Conservatives and the Seven Sins of Judicial Activism. In University of Colorado Law Review, Vol. 73, Issue 4, 2002, 1217-1255. o.

McGehee, Lucius Polk.: Due Process of Law under the Federal Constitution. Edward Thompson Company, Northport, 1906

Mezei Péter: A joghézag kérdése régen és ma. In Jogelméleti Szemle, 2002/2. szám, http://jesz.ajk.elte.hu/mezei10.html (2012. szeptember 14.)

Michael, Helen K.: The Role of Natural Law in Early American Constitutionalism: Did the Founders Contemplate Judical Enforcement of "Unwritten" Individual Rights? In North Carolina Law Review, Vol. 69, 1991, 421-490. o.

Molnár András: Adalékok az 'alkotmányellenes alkotmánymódosítás' problémájához. In Balogh Elemér (szerk.): Számadás az Alaptörvényröl. Magyar Közlöny Lap- és Könyvkiadó, 2016, 243-264. o.

Molnár András: Az amerikai Supreme Court „konzervatív aktivizmusa” a XX. század első évtizedeiben született precedensek tükrében. In Jogelméleti Szemle, 2013/4. szám, http://jesz.ajk.elte.hu/molnar56.pdf (2014. augusztus 27.)

Molnár András: Érvelési minták a „Lochner-bíróság” munkaidő- és minimálbérszabályozás alkotmányosságát vizsgáló döntéseiben. In Jogelméleti Szemle 2009/4. szám, http://jesz.ajk.elte.hu/molnar40.mht (2013. november 29.)

Molnár András: A magánszférához való jog az amerikai Legfelsőbb Bíróság gyakorlatában. In De iurisprudentia et iure publico, 2011/2. szám, 2011/2 http://dieip.hu/wp-content/uploads/2011-2-11.pdf (2014. augusztus 27.)

Molnár András: Oliver Wendell Holmes jogi gondolkodása. In Jogelméleti Szemle, 2011/4. szám, http://jesz.ajk.elte.hu/molnar48.pdf (2013. november 29.)

Molnár András: Pragmatizmus és legalizmus - Richard Posner és Antonin Scalia a bírói szerepröl. In De iurisprudentia et iure publico, 2009/1, 29-68. o. http://dieip.hu/wpcontent/uploads/2009-1-szam.pdf (2014. január 15.)

Molnár, András: Some Brief Remarks on Lochner Era Constitutionalism from the Aspect of the Theory of Precedent. In Studia Iuridica Caroliensia 5, Károli Gáspár Református Egyetem Állam- és Jogtudományi Kar, Budapest, 2010, 55-67. o.

Molnár András: Szempontok a bírói „aktivizmus” definiálásához. In Jogelméleti Szemle, 2012/3. szám, http://jesz.ajk.elte.hu/molnar51.pdf (2013. november 29.) 
Molnár András - Téglási András - Tóth J. Zoltán: A magánjogi és az alapjogi érvelések együttélése - feszültségek és dilemmák. In Jogelméleti Szemle, 2012/2. szám, http://jesz.ajk.elte.hu/molnar50.pdf (2012. szeptember 14.)

Nagy Tamás: Josef K. nyomában - jogról és irodalomról -. Attraktor, Máriabesnyő Gödöllö, 2010

Nagy Zsolt: Szociológiai jogelmélet vagy jogszociológia? Jhering hatása Amerikában. In Frivaldszky János - Pokol Béla (szerk.): Rudolf von Jhering és jogelméletének hatása. PPKE JÁK, Budapest, 2011, 193-209. o.

Nagyné Szegvári Katalin: Munkajogi szabályozás és a Legfelső Bíróság joggyakorlata Amerikában. In Béli Gábor - Kajtár István - Szekeres Róbert (szerk.): Jogtörténeti tanulmányok VIII. PTE ÁJK, Pécs, 2005, 371-387. o.

Nelson, William E.: Brown v. Board of Education and the Jurisprudence of Legal Realism. In Saint Louis University Law Journal, Vol. 48, 2004, 795-838. o.

Nizsalovszky Endre: Fogalomkutató és érdekkutató jogtudomány, a szabad jogi iskola és a Tiszta Jogtan. In Uö.: Tanulmányok a jogról. Akadémiai Kiadó, Budapest, 1984

Paczolay Péter: Alkotmánybíráskodás a politika és jog határán. In Uő. (szerk.): Alkotmánybíráskodás - alkotmányértelmezés. Budapest, Rejtjel Kiadó, 2003, 9-31. o.

Palmer, Ben W.: Hobbes, Holmes and Hitler. In American Bar Association Journal Vol. 31, 1945, 569-573. o.

Paul, Ellen Frankel: Freedom of Contract and the „Political Economy” of Lochner v. New York. In New York University Journal of Law \& Liberty Vol. 1, 2005, 515-569. o.

Peczenik, Aleksander: On Law and Reason. Springer, 2009

Phillips, Michael J.: The Lochner Court, Myth and Reality, Substantive Due Process from the 1890s to the 1930s. Praeger Publishers, Westport, 2001

Phillips, Michael J.: The Substantive Due Process Decisions of Mr. Justice Holmes. In American Business Law Journal Vol. 36, 1999, 439-477. o.

Plajos Rita: A bírák szerepe és a bírói jogalkotás William Blackstone és Jeremy Bentham elméletében. In Jogelméleti Szemle, 2009/3. szám, http://jesz.ajk.elte.hu/plajos39.mht (2012. szeptember 14.)

Plucknett, Theodore F. T.: Bonham's Case and Judicial Review. In Harvard Law Review, Vol. 40, 1926-1927, 30-70. o.

Pócza Kálmán: Az alkotmánybíráskodás intézménye demokráciaelméleti szempontból. In Berkes Lilla - Csink Lóránt (szerk.): Az ombudsmani rendszer és az 
alkotmánybíráskodás átalakulása. Tanulmányok az alapjogvédelem köréböl. Pázmány Press, Budapest, 2015, 185-225. o.

Pokol Béla: Alkotmánybíráskodás - Szociológiai, politológiai és jogelméleti megközelítésekben. Kairosz Kiadó, Budapest, 2014

Pokol Béla: Autentikus jogelmélet. Dialóg Campus Kiadó, Budapest, 2010

Pokol Béla: Jogelmélet. Századvég Kiadó, Budapest, 2005

Pokol Béla: Szociológiaelmélet. Századvég Kiadó, Budapest, 2004

Popovic, Dragoljub: Prevailing of Judicial Activism over Self-Restraint in the Jurisprudence of the European Court of Human Rights. In Crighton Law Review Vol. 42, 2009, 361-396. o.

Posner, Richard Allen: The Costs of Enforcing Legal Rights. In East European Constitutional Review, Vol. 4, Issue 3, 1995, 71-83. o.

Posner, Richard A.: Economic Analysis of Law. Aspen Law \& Business, New York, 1998

Posner, Richard A.: The Problematics of Moral and Legal Theory. The Belknap Press of Harvard University Press, Cambridge, 1999

Posner, Richard A.: What Has Pragmatism to Offer Law? In Southern California Law Review, Vol. 63, 1990, 1653-1670. o.

Pound, Roscoe: Common Law and Legislation. In Harvard Law Review Vol. 21, 1908, 383-407. o.

Pound, Roscoe: Law in Books and Law in Action. In American Law Review Vol. 44, 1910, 12-36. o.

Pound, Roscoe: Liberty of Contract. In Yale Law Journal, Vol. 18, 1909, 454-487. o.

Pound, Roscoe: Mechanical Jurisprudence. In Columbia Law Review, Vol. 8, 1908a, 605-623. o.

Pound, Roscoe: The Scope and Purpose of Sociological Jurisprudence. In Harvard Law Review, Vol. 25, 1912, 489-516. o.

Powell, Thomas Reed: The Judiciality of Minimum-Wage Legislation. In Harvard Law Review Vol. 37, 1924, 545-573. o.

Ramraj, Victor V.: Four models of due process. In International Journal of Constitutional Law, Vol. 2, 2004, 492-524. o.

Reimann, Mathias W.: Holmes's Common Law and German Legal Science. In Gordon, Robert W. (ed.): The Legacy of Oliver Wendell Holmes, Jr. Stanford University Press, Stanford, 1992, 72-114. o. 
Riggs, Robert E.: Substantive Due Process in 1791. In Wisconsin Law Review, 1990, 941-1005. o.

Riis, Jacob: How The Other Half Lives. Hill and Wang, New York, 1957

Roberts, Caprice L.: In Search of Judicial Activism: Dangers in Qualifying the Quantitative. In Tennesse Law Revire Vol. 74, 2007, 567-621. o.

Rogat, Yosal: Mr. Justice Holmes: A Dissenting Opinion. In Stanford Law Review Vol. 15, 1962, 3-44. o.

Rogat, Yosal: Mr. Justice Holmes: A Dissenting Opinion. In Stanford Law Review Vol. 15, 1963, 254-308. o.

Rosenfeld, Michel: Pragmatism, Pluralism and Legal Interpretation: Posner's and Rorty's Justice without Metaphysics Meets Hate Speech. In Dickstein, Morris (ed.): The Revival of Pragmatism. New Essays on Social Thought, Law, and Culture. Duke University Press, Durham, 1998, 324-343. o.

Rostow, Eugene V.: The Democratic Character of Judicial Review. In Levy, Leonard W. (ed.): Judicial Review and the Supreme Court, Harper Torchbooks, New York, 1967, 74-104. o.

Rublin, Amy: The Role of Social Science in Judicial Decision Making: How Gay Rights Activists Can Learn from Integration and Capital Punishment Case Law. In Duke Journal of Gender Law \& Policy, Vol 19, 2011, 179-222. o.

Sajó András: Az alkotmánybíráskodás a diksurzuselmélet fényében. In Állam- és Jogtudomány, 36. évf., 1994, 11-35. o.

Scalia, Antonin: Common-Law Courts in a Civil-Law System: The Role of United States Federal Courts in Interpreting the Constitution and Laws. In Uö.: A Matter of Interpretation. Federal Courts and the Law. Princeton University Press, Princeton, 1997, 3 47. 0 .

Scalia, Antonin: Originalism: The Lesser Evil. In University of Cincinnati Law Review, Vol. 57, 1989, 849-866. o.

Schauer, Frederick: Precedent. In Stanford Law Review, Vol. 39, Issue 3, 1987, 571 605. o.

Schauer, Frederick: Rules and the Rule of Law. In Harvard Journal of Law and Public Policy, Vol. 14, Issue 3, 1991, 645-694. o.

Schwartz, Bernard: The Reins of Power: A Constitutional History of the United States. Hill and Wang, New York, 1963 
Segall, Eric J.: Why I Still Teach Marbury (and So Should You): A Response to Professor Levinson. In University of Pennsylvania Journal of Constitutional Law, Vol. 6, 2004, 573-587. o.

Selznick, Philip: Jogszociológia. In Sajó András (szerk.): Jog és szociológia. Válogatott tanulmányok. Közgazdasági és Jogi Könyvkiadó, Budapest, 1979, 65-81. o.

Sherry, Suzanna: The Founders' Unwritten Constitution. In The University of Chicago Law Review, Vol. 54, 1987, 1127-1177. o.

Siegel, Jonathan R.: What Statutory Drafting Errors Teach Us About Statutory Interpretation. In George Washington Law Review, Vol. 69, 2001, 309-366. o.

Sonnevend, Pál - Jakab, András - Csink, Lóránt: The Constitution as an Instrument of Everyday Party Politics: The Basic Law of Hungary. In von Bogdandy, Armin Sonnevend, Pál (ed.): Constitutional Crisis in the European Constitutional Area. Theory, Law and Politics in Hungary and Romania. Hart Publishing, Oregon, 2015, 58., valamint 33-109. o.

Stephenson, D. Grier: The Supreme Court and Constitutional Change: Lochner v. New York Revisited. In Villanova Law Review, Vol. 21, 1976, 217-243. o.

Strauss, David A.: Why Was Lochner Wrong? In The University of Chicago Law Review, Vol. 70, 2003, 373-386. o.

Summers, Robert Samuel - Taruffo, Michele: Interpretation and Comparative Analysis. In McCormick, Donald Neil - Summers, Robert Samuel (ed.): Interpreting Statutes. Dartmouth Publishing Co., Aldershot, 1991, 464-474. o.

Sunstein, Cass R.: Burkean Minimalism. In Michigan Law Review, Vol. 105, 2006, 353-408. o.

Sunstein, Cass R.: A Constitution of Many Minds. Why the Founding Document Doesn't Mean What It Meant Before. Princeton University Press, Princeton, 2009

Sunstein, Cass R.: Constitutional Myth-Making: Lessons from the Dred Scott Case. In Occasional Papers of the Law School of the University of Chicago, Vol. 37, 1996, 1-28. 0.

Sunstein, Cass R.: Lochner's Legacy. In Columbia Law Review, Vol. 87, 1987, 873 919. o.

Sunstein, Cass R.: Problems with Rules. In California Law Review, Vol. 83, Issue 4, 1995, 953-1026. o.

Sweet, Alec Stone: Governing with Judges. Constitutional Politics in Europe. Oxford University Press, Oxford, 2000 
Swygert, Luther M.: In Defense of Judicial Activism. In Valparaiso University Law Review, Vol. 16, 1982, 439-458. o.

Szente Zoltán: Érvelés és értelmezés az alkotmányjogban. Dialóg Campus Kiadó, Budapest - Pécs, 2013

Takács Imre: Az alkotmány és az alkotmányosság fogalma. In Kukorelli István (szerk.): Alkotmánytan I., Osiris Kiadó, Budapest, 2010, 19-34. o.

Taylor, Hannis: Due Process of Law and the Equal Protection of the Laws. Callaghan and Company, Chicago, 1917

Téglási András: A tulajdonhoz való jog alkotmányos védelme. Pólay Elemér Alapítvány, Szeged, 2013

Thayer, James Bradley: The Origin and Scope of the American Doctrine of Constitutional Law. In Harvard Law Review, Vol. 7, 1893, 129-156. o.

The Creation of a Common Law Rule: The Fellow Servant Rule, 1837-1860. In University of Pennsylvania Law Review, Vol. 132, 1984, 579-620. o.

Tóth J. Zoltán: Dinamizmus, originalizmus, textualizmus, avagy az aktivista alapjogi bíráskodás és az arra adott neokonstrukcionista jogelméleti reakciók az Egyesült Államokban. In Jogtudományi Közlöny, 2007/4, 143-153. o.

Tóth J. Zoltán: Jogértelmezési módszerek a bírói gyakorlatban. In Jogelméleti Szemle, 2009/4. szám, http://jesz.ajk.elte.hu/tothj40.mht (2012. szeptember 14.)

Tóth Mihály: A „magyar Miranda” első néhány éve. In Erdei Árpád (szerk.): Tények és kilátások - Tanulmányok Király Tibor tiszteletére. Közgazdasági és Jogi Könyvkiadó, Budapest, 1995, 62-77. o.

Treanor, William Michael: Judicial Review Before Marbury. In Stanford Law Review Vol. 58, 2005, különösen 455-562. o.

Tushnet, Mark: Self-Historicism. In Tulsa Law Review, Vol. 38, 2003, 771-777. o.

Varga Zs., András: Constitutional identity and the judgments of the ECtHR. In Pázmány Law Working Papers, No. 16, 2016. http://plwp.eu/evfolyamok/2016/174-2016$\underline{16}$ (2017. február 16.)

Varga Zs. András: Eszményből bálvány? A joguralom dogmatikája. Századvég Kiadó, Budapest, 2015

Varga Zs. András: A jogrendszer és a jogalkalmazás határozatlansága és nemteljessége. In Jogtudományi Közlöny, 68. évf., 3. szám, 2013, 109-119. o. 
Vos, Ellen: The European Court of Justice in the face of scientific uncertainty and complexity. In Dawson, Mark et al. (ed.): Judicial Activism at the European Court of Justice. Edward Elgar Publishing Ltd., Cheltenham, 2013, 142-166. o.

De Waele, Henri - van der Vleuten, Anna: Judicial Activism in the European Court of Justice-The Case of LGBT Rights. In Michigan State Journal of International Law Vol. 19, 2011, 639-666. o.

Waldron, Jeremy: The Core of the Case Against Judicial Review. In The Yale Law Journal, Vol. 115, Issue 6, 2006, 1346-1406. o.

Warren, Charles: The Progressiveness of the United States Supreme Court. In Columbia Law Review Vol. 13, 1913, 294-313. o.

Wechsler, Herbert: Toward Neutral Principles of Constitutional Law. In Harvard Law Review, Vol. 73, Issue 1, 1959, 1-35. o.

White, G. Edward: Justice Oliver Wendell Holmes: Law and the Inner Self. Oxford University Press, New York, 1993

Wilkinson, Harvie J.: Is There a Distinctive Conservative Jurisprudence? In University of Colorado Law Review, Vol. 73, Issue 4, 2002, 1383-1400. o.

Wolfe, Christopher: Judicial Activism. Roman \& Littlefield Publishers, Lanham, 1997

Wolfe, Cristopher: The Rise of Modern Judicial Review. From Constitutional Interpretation to Judge-Made Law. Basic Books, New York, 1986

Wright, J. Skelly: The Judicial Right and the Rhetoric of Restraint: A Defense of Judicial Activism in an Age of Conservative Judges. In Hastings Constitutional Law Quarterly, Vol. 14, Issue 3, 1987, 487-523. o.

Zumbansen, Peer: Lochner Disembedded: The Anxieties of Law in a Global Context. In Indiana Journal of Global Legal Studies, Vol. 20, 2013, 29-69. o. 


\section{A Supreme Court döntései}

Abrams v. United States, 250 U. S. 616 (1919)

Adair v. United States, 208. U. S. 161 (1908)

Adams Express Co. v. Ohio State Auditor, 165 U. S. 194 (1897)

Adams v. Milwaukee, 228 U. S. 572 (1913)

Adkins v. Children's Hospital, 261 U. S. 525 (1923)

Alaska Packers Association v. Industrial Accident Commission of California, 294 U.

S. $532(1935)$

Allgeyer v. Louisiana, 165 U. S. 578 (1897)

American Seeding Machine Co. v. Kentucky, 236 U. S. 660 (1915)

Arizona Employers' Liability Cases, 250 U. S. 400 (1919)

Armour \& Co. v. North Dakota, 240 U. S. 510 (1916)

Armour Packing Co. v. Lacy, 200 U. S. 226 (1906)

Atkin v. Kansas, 191 U. S. 207 (1903)

Aluminium Company of America v. Ramsey, 222 U. S. 251 (1911)

Baccus v. Louisiana, 232 U. S. 334 (1914)

Baker v. Carr, 369 U. S. 186 (1962)

Baltimore \& Ohio Railroad Co. v. Interstate Commerce Commission, 221 U. S. 612 (1911)

Barbier v. Connolly, 113 U. S. 27 (1885)

Barrett v. Indiana, 229 U. S. 26 (1913)

Bell's Gap Railroad Co. v. Pennsylvania, 134 U. S. 232 (1890)

Booth Fisheries Co. v. Industrial Commission of Wisconsin, 271 U. S. 208 (1926)

Booth v. Indiana, 237 U. S. 391 (1915)

Bosley v. McLaughlin, 236 U. S. 385 (1915)

Bountiful Brick Co. v. Giles, 276 U. S. 154 (1928)

Bowers v. Hardwick, 478 U.S. 186 (1986)

Boyd v. United States, 116 U. S. 616 (1886)

Boynton v. Virginia, 364 U.S. 454 (1960)

Bradley v. Richmond, 227 U. S. 477 (1913)

Bratton v. Chandler, 260 U. S. 110 (1922) 
Brown v. Board of Education, 347 U.S. 483 (1954)

Buck v. Bell, 274 U.S. 200 (1927)

Budd v. New York, 143 U. S. 517 (1892)

Bunting v. Oregon, 243 U. S. 426 (1917)

California Reduction Co. v. Sanitary Reduction Works, 199 U. S. 306 (1905)

Capital City Dairy Co. v. Ohio, 183 U. S. 238 (1902)

Carter v. Carter Coal Co., 298 U. S. 238 (1936)

Chas. Wolff Packing Co. v. Court of Industrial Relations of the State of Kansas, 262 U. S. $522(1923)$

Chas. Wolff Packing Co. v. Court of Industrial Relations of the State of Kansas, 267 U. S. $552(1925)$

Chicago, Burlington and Quincy Railroad Co. v. McGuire, 219 U. S. 549 (1911)

Chicago, Indianapolis \& Louisville Railway Co. v. Hackett, 228 U. S. 559 (1913)

Chicago, Kansas and Western Railroad Co. v. Pontius, 157 U. S. 209 (1895)

Chicago, Milwaukee \& St. Paul Railway Co. v. Public Utilities Commission of the State of Idaho, 274 U. S. 344 (1927)

Chicago v. Sturges, 222 U. S. 313 (1911)

Citizens' Telephone Co. v. Fuller, 229 U. S. 322 (1913)

Clark Distilling Co. v. Western Maryland Railway Co. and State of West Virginia, 242 U. S. 311 (1917)

Colegrove v. Green, 328 U. S. 549 (1946)

Collins v. Kentucky, 234 U. S. 634 (1914)

Collins v. Texas, 223 U. S. 288 (1912)

Connally v. General Construction Co., 269 U. S. 385 (1926)

Cook v. Marshall County, 196 U. S. 261 (1905)

Coppage v. Kansas, 236 U. S. 1 (1915)

Corn Products Refining Co. v. Eddy, 249 U. S. 427 (1919)

Corneli v. Moore, 257 U. S. 491 (1922)

Cox v. Texas, 202 U. S. 446 (1906)

Cotting v. Kansas City Stock Yards Co. and the State of Kansas, 183 U. S. 79 (1901)

Crane v. Johnson, 242 U. S. 339 (1917)

Cronin v. Adams, 192 U. S. 108 (1904)

Cronin v. Denver, 192 U. S. 115 (1904)

Crowell v. Benson, 285 U. S. 22 (1932) 
Crowley v. Christensen, 137 U. S. 86 (1890)

Cudahy Packing Co. of Nebraska v. Parramore, 263 U. S. 418 (1923)

Dayton Coal and Iron Co. v. Barton, 183 U. S. 23 (1901)

Douglas v. Noble, 261 U. S. 165 (1923)

Dred Scott v. Sandford, 60 U. S. 393 (1857)

Eberle v. Michigan, 232 U. S. 700 (1914)

Ellis v. United States, 206 U. S. 246 (1907)

Emert v. Missouri, 156 U. S. 296 (1895)

Employers' Liability Cases, 207 U. S. 463 (1908)

Erie Railroad Co. v. Williams, 233 U. S. 685 (1914)

Ex parte Young, 209 U. S. 123 (1908)

Ferguson v. Skrupa, 372 U. S. 726 (1963)

Fischer v. St. Louis, 194 U. S. 361 (1904)

Furman v. Georgia, 408 U. S. 238 (1972)

Gardner v. Michigan, 199 U. S. 325 (1905)

German Alliance Insurance Co. v. Lewis, 233 U. S. 389 (1914)

Giozza v. Tiernan, 148 U. S. 657 (1893)

Graves v. Minnesota, 272 U. S. 425 (1926)

Griswold v. Connecticut, 381 U. S. 479 (1965)

Gundling v. Chicago, 177 U. S. 183 (1900)

Hammer v. Dagenhart, 247 U. S. 251 (1918)

Hammond Packing Co. v. Montana, 233 U. S. 331 (1914)

Hawker v. New York, 170 U. S. 189 (1898)

Hawkins v. Bleakly, 243 U. S. 210 (1917)

Hebe Co. v. Shaw, 248 U. S. 297 (1919)

Hodge v. Muscatine County, 196 U. S. 276 (1905)

Holden v. Hardy, 169 U. S. 366 (1898)

Home Telephone and Telegraph Co. v. Los Angeles, 227 U. S. 278 (1913)

In re Rahrer, 140 U. S. 545 (1891)

International Harvester Co. of America v. Kentucky, 234 U. S. 216 (1914)

Jacobson v. Massachusetts, 197 U. S. 11 (1905)

Jay Burns Baking Co. v. Bryan, 264 U. S. 504 (1924)

Jeffrey Manufacturing Co. v. Blagg, 235 U. S. 571 (1915)

Katz v. United States, 389 U. S. 347 (1967) 
Keller v. United States, 213 U. S. 138 (1909)

Keokee Consolidated Coke Co. v. Taylor, 234 U. S. 224 (1914)

Knoxville Iron Co. v. Harbison, 183 U. S. 13 (1901)

La Tourette v. McMaster, 248 U. S. 465 (1919)

Lake Shore and Michigan Southern Railway Co. v. Smith, 173 U. S. 684 (1899)

Lawrence v. Texas, 539 U.S. 558 (2003)

Lawton v. Steele, 152 U. S. 133 (1894)

Lehmann v. State Board of Public Accountancy, 263 U. S. 394 (1923)

Licence Cases, 46 U. S. (5 How.) 504 (1847)

Lochner v. New York, 198 U. S. 45 (1905)

Lottery Case, 188 U. S. 321 (1903)

Louis Pizitz Dry Goods Co. v. Yeldell, 274 U. S. 112 (1927)

Louisville and Nashville Railroad Co. v. Garrett, 231 U. S. 298 (1913)

Louisville \& Nashville Railroad Co. v. Melton, 218 U. S. 36 (1910)

Lower Vein Coal Co. v. Industrial Board of Indiana, 255 U. S. 144 (1921)

MacDougall v. Green, 335 U. S. 281 (1948)

Madera Sugar Pine Co. v. Industrial Accident Commission of the State of California, 262 U. S. 499 (1923)

Magoun v. Illinois Trust \& Savings Bank, 170 U. S. 283 (1898)

Magnano Co. v. Hamilton, 292 U. S. 40 (1934)

Marbury v. Madison, 5 U. S. (1 Cranch) 137 (1803)

Marvin v. Trout, 199 U. S. 212 (1905)

Mattson v. Department of Labor and Industries of Washington, 293 U. S. 151 (1934)

McCray v. United States, 195 U. S. 27 (1904)

McCulloch v. Maryland, 17 U. S. (4 Wheat.) 316 (1819)

McLean v. Arkansas, 211 U. S. 539 (1909)

McNaughton v. Johnson, 242 U. S. 344 (1917)

Meyer v. Nebraska, 262 U. S. 390 (1923)

Michigan Central Railroad Co. v. Powers, 201 U. S. 245 (1906)

Middleton v. Texas Power \& Light Co., 249 U. S. 152 (1919)

Miller v. Wilson, 236 U. S. 373 (1915)

Minersville School District v. Gobitis, 310 U. S. 586 (1940)

Miranda v. Arizona, 384 U.S. 436 (1966)

Missouri, Kansas \& Texas Railway Company v. United States, 231 U. S. 112 (1913) 
Missouri Pacific Railway Co. v. Castle, 224 U. S. 541 (1912)

Missouri Pacific Railway Co. v. Mackey, 127 U. S. 205 (1888)

Missouri Pacific Railway Co. v. Omaha, 235 U. S. 121 (1914)

Missouri Rate Cases, 230 U. S. 474 (1913)

Mobile, Jackson \& Kansas City Railroad Co. v. Turnipseed, 219 U. S. 35 (1910)

Morehead v. New York ex rel. Tipaldo, 298 U. S. 587 (1936)

Mountain Timber Co. v. Washington, 243 U. S. 219 (1917)

Muller v. Oregon, 208 U. S. 412 (1908)

Munn v. Illinois, 94 U. S. 113 (1877)

Murphy v. California, 225 U. S. 623 (1912)

Murray's Lessee v. Hoboken Land \& Improvement Co., 59 U.S. 272 (1855)

Mutual Loan Co. v. Martell, 222 U. S. 225 (1911)

Myers v. United States 272 U.S. 52 (1926)

Nashville, Chattanooga \& St. Louis Railway Co. v. Wallace, 288 U. S. 249 (1933)

National Prohibition Cases, 253 U.S. 350 (1920)

New York Central Railroad Co. v. Bianc, 250 U. S. 596 (1919)

New York Central Railroad Co. v. White, 243 U. S. 188 (1917)

New York ex rel. Lieberman v. Van de Carr, 199 U. S. 552 (1905)

New York State Railways v. Shuler, 265 U. S. 379 (1924)

North American Cold Storage Co. v. Chicago, 211 U. S. 306 (1908)

Northern Securities Co. v. United States, 193 U. S. 197 (1904)

Obergefell v. Hodges, 135 S. Ct. 2584 (2015)

Ohio ex rel. Lloyd v. Dollison, 194 U. S. 445 (1904)

Olsen v. Smith, 195 U. S. 332 (1904)

Otis v. Parker, 187 U. S. 606 (1903)

Owensboro v. Cumberland Telephone \& Telegraph Co., 230 U. S. 58 (1913)

P. F. Petersen Baking Co. v. Bryan, 290 U. S. 570 (1934)

Packer Corporation v. Utah, 285 U. S. 105 (1932)

Panama Railroad Co. v. Johnson, 264 U. S. 375 (1924)

Patterson v. Bark Eudora, 190 U. S. 169 (1903)

Phillips Petroleum Co. v. Jenkins, 297 U. S. 629 (1936)

Pittsburgh, Cincinnati, Chicago and St. Louis Railway Co. v. Backus, 154 U. S. 421 (1894)

Planned Parenthood of Southern Pennsylvania v. Casey, 505 U.S. 833 (1992) 
Plessy v. Ferguson, 163 U. S. 537 (1896)

Plumley v. Massachusetts, 155 U. S. 461 (1894)

Powell v. Pennsylvania, 127 U. S. 678 (1888)

Price v. Illinois, 238 U. S. 446 (1915)

Public Clearing House v. Coyne, 194 U. S. 497 (1904)

Purity Extract and Tonic Co. v. Lynch, 226 U. S. 192 (1912)

R. E. Sheehan Co. v. Shuler, 265 U. S. 371 (1924)

Radice v. New York, 264 U. S. 292 (1924)

Reetz v. Michigan, 188 U. S. 505 (1903)

Riley v. Massachusetts, 232 U. S. 671 (1914)

Rippey v. Texas, 193 U. S. 504 (1904)

Roe v. Wade, 410 U. S. 113 (1973)

Schmidinger v. Chicago, 226 U. S. 578 (1913)

Second Employers' Liability Cases, 223 U. S. 1 (1912)

Seven Cases of Eckman's Alternative v. United States, 239 U. S. 510 (1916)

Slaughter-House Cases, 83 U. S. (16 Wall.) 36 (1873)

Smith v. Cahoon, 283 U. S. 553 (1931)

South v. Peters, 339 U. S. 276 (1950)

Southwestern Oil Co. v. Texas, 217 U. S. 114 (1910)

St. John v. New York, 201 U. S. 633 (1906)

St. Louis Consolidated Coal Co. v. Illinois, 185 U. S. 203 (1902)

Staten Island Rapid Transit Railway Co. v. Phoenix Indemnity Co., 281 U. S. 98 (1930)

Sturges \& Burn Manufacturing Co. v. Beauchamp, 231 U. S. 320 (1913)

Thompson v. Kentucky, 209 U. S. 340 (1908)

Tullis v. Lake Erie and Western Railroad Co., 175 U. S. 348 (1899)

Tyson \& Brother v. Banton, 273 U. S. 418 (1927)

Union Pacific Railway Co. v. Botsford, 141 U. S. 250 (1891)

United States v. Shreveport Grain \& Elevator Co., 287 U. S. 77 (1932)

Van Oster v. Kansas, 272 U. S. 465 (1926)

Ward \& Gow v. Krinsky, 259 U. S. 503 (1922)

Watson v. Maryland, 218 U. S. 173 (1910)

Weaver v. Palmer Brothers Co., 270 U. S. 402 (1926)

West Coast Hotel Co. v. Parrish, 300 U. S. 379 (1937) 
West Virginia State Board of Education v. Barnette, 319 U.S. 624 (1943)

Western \& Atlantic Railroad v. Henderson, 279 U. S. 639 (1929)

Whipple v. Martinson, 256 U. S. 41 (1921)

Whole Woman's Health v. Hellerstedt, 579 U.S. (2016)

Williams v. Walsh, 222 U. S. 415 (1912)

Wilmington Star Mining Co. v. Fulton, 205 U. S. 60 (1907)

Wilson v. New, 243 U. S. 332 (1917)

Yick Wo v. Hopkins, 118 U. S. 356 (1886) 


\section{A magyar Alkotmánybíróság döntései}

8/1990. (IV. 23.) AB határozat, $\mathrm{ABH}$ 1990, 42.

1350/B/1992. AB határozat, ABH 1993, 619.

43/2012. (XII. 20.) AB határozat

14/2014. (V. 13.) AB határozat 


\section{Egyéb források}

„Provokatív nézeteim az életről és a halálról elgondolkodásra serkentik az embereket". Peter Singerrel, a Princeton University bioetika professzorával Halmai Gábor beszélget. In Fundamentum, 2001/1. szám, 2001, 61-67. o. 